\title{
Statistical Summaries of Ground-Water Level Data Collected in the Suwannee River Water Management District, 1948 to 1994
}

By J.J. Collins and L.D. Freeman

U.S. GEOLOGICAL SURVEY

Open-File Report 96-352 


\title{
U.S. DEPARTMENT OF THE INTERIOR \\ BRUCE BABBITT, Secretary
}

\author{
U.S. GEOLOGICAL SURVEY \\ Gordon P. Eaton, Director
}

Any use of trade, product, or firm names in this publication is for descriptive purposes only and does not imply endorsement by the U.S. Geological Survey.

For additional information write to:

District Chief U.S. Geological Survey Suite 3015 227 N. Bronough Street Tallahassee, FL 32301
Copies of this report can be purchased from:

U.S. Geological Survey Branch of Information Services Box 25286

Denver, CO 80225 


\section{CONTENTS}

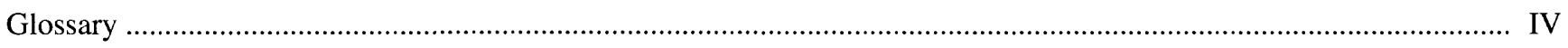

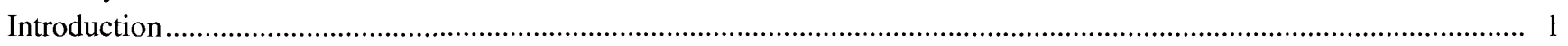

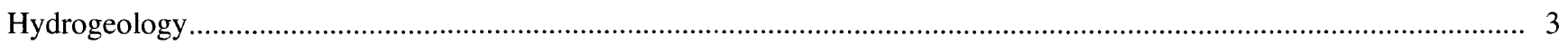

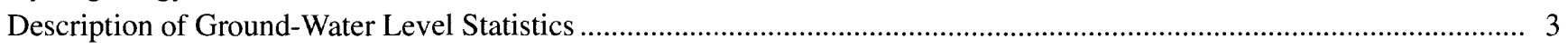

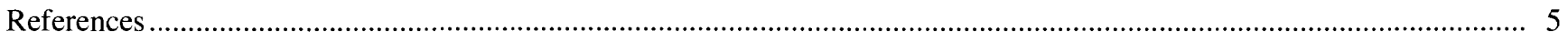

Statistical Summaries of Ground-Water Level Data ......................................................................................6

Appendix I - Location, Aquifer Monitored, and Frequency of Ground-Water Level Measurements .............................. 309

Appendix II - Monthly Maximum, Mean, and Minimum and 75-, 50-, and 25-Percent Quartile Values ........................ 319

\section{FIGURES}

1. Map showing location of Suwannee River Water Management District.......................................................... 2

2-16. Maps showing location of wells in:

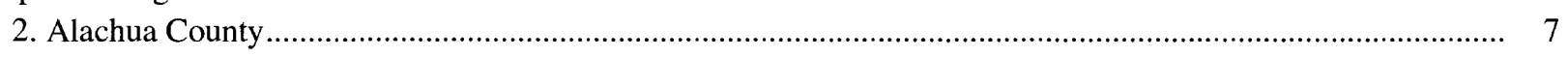

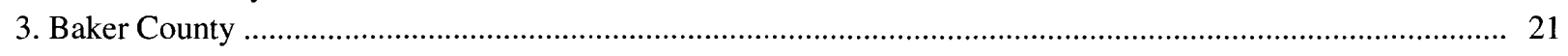

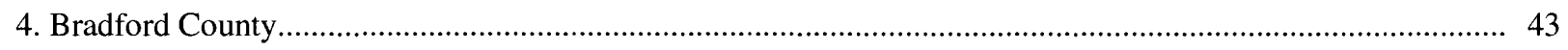

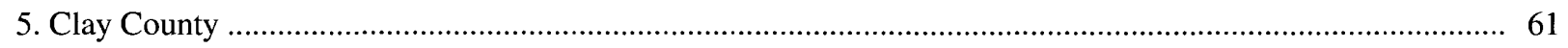

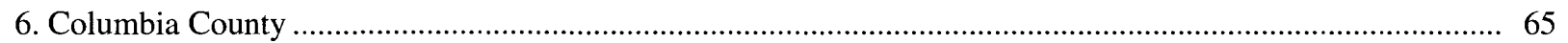

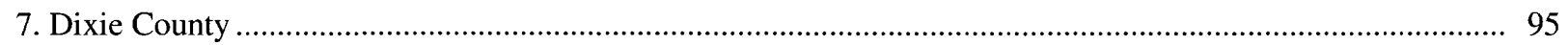

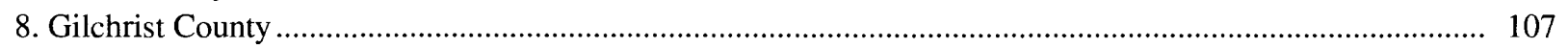

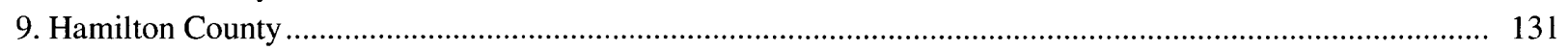

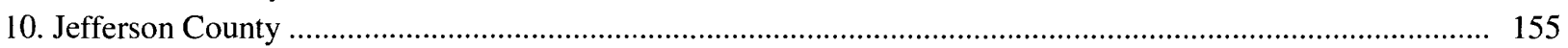

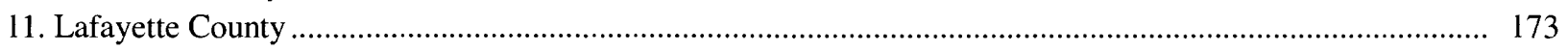

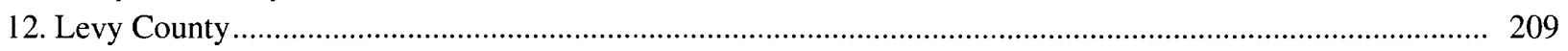

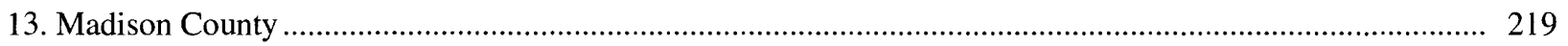

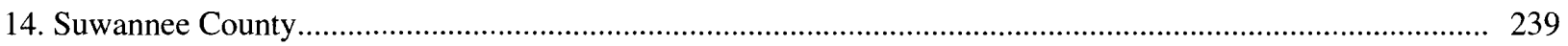

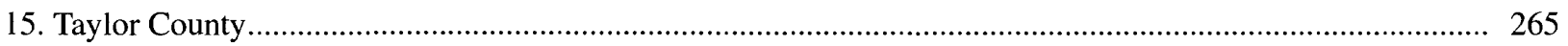

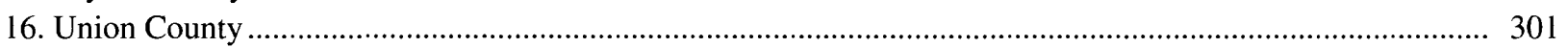


CONVERSION FACTORS AND VERTICAL DATUM

\begin{tabular}{rcl}
\hline Multiply & By & To obtain \\
\hline & Length & \\
\hline inch (in) & 25.4 & millimeter \\
foot (ft) & 0.3048 & meter \\
mile (mi) & 1.609 & kilometer \\
\hline & Area & \\
\hline acre & 4,047 & square meter \\
square foot $\left(\mathrm{ft}^{2}\right)$ & 0.0929 & square meter \\
square inch $\left(\mathrm{in}{ }^{2}\right)$ & 6.452 & square centimeter \\
square mile $\left(\mathrm{mi}^{2}\right)$ & 2.590 & square kilometer \\
\hline & Volume & \\
\hline gallon $(\mathrm{gal})$ & 3.785 & liter \\
gallon $(\mathrm{gal})$ & 0.003785 & cubic meter \\
\hline cubic foot $\left(\mathrm{ft}{ }^{3}\right)$ & 3,785 & cubic meter \\
& 0.028317 & cubic meter \\
\hline million gallons $(\mathrm{Mgal})$ & Flow & \\
\hline cubic foot per second $\left(\mathrm{ft}{ }^{3} / \mathrm{s}\right)$ & 0.02832 & cubic meter per second \\
cubic foot per day $\left(\mathrm{ft}^{3} / \mathrm{d}\right)$ & 0.02832 & cubic meter per day \\
gallon per minute $\left(\mathrm{gal} / \mathrm{min}^{2}\right)$ & 0.06309 & liter per second \\
gallon per day $(\mathrm{gal} / \mathrm{d})$ & 0.003785 & cubic meter per day \\
million gallons per day $(\mathrm{Mgal} / \mathrm{d})$ & 0.04381 & cubic meter per second \\
\hline & 25.4 & millimeter per year \\
\hline & &
\end{tabular}

Sea level: In this report, "sea level" refers to the National Geodetic Vertical Datum of 1929 (NGVD of 1929)--a geodetic datum derived from a general adjustment of the first-order level nets of the United States and Canada, formerly called Sea Level Datum of 1929.

Altitude, as used in this report, refers to distance above or below sea level.

\section{GLOSSARY}

Terms related to ground water, wells, and measuring water levels, and other hydrologic data, as used in this report, are defined below. Refer to the chart for converting English units to International System (SI) Units on page IV of this report.

AQUIFER: A formation, or group of formations, or part of a formation of rocks, consolidated or unconsolidated, that is water bearing and will yield significant quantities of water to wells and springs. An aquifer may be confined or unconfined. Confined aquifers are overlain by sediments with significantly lower permeability. Unconfined aquifers have no confining bed between the zone of saturation and the surface.
CONFINING UNIT: A formation that is above, or below, or adjacent to one or more aquifers and has a permeability that is low in relation to the permeability of the aquifers.

CASING: A section of pipe typically between land surface and the well screen or open hole that allows access to a water bearing unit and keeps the well open through primarily unconsolidated material.

CASING DIAMETER: The diameter of the casing, in inches.

CASING DEPTH: The depth (length) of the casing, in feet.

DRAINAGE BASIN: A part of the surface of the earth that is occupied by a drainage system, which consists of a surface stream or body of impounded 
surface water together with all tributary surface streams and bodies of impounded surface water.

ELEVATION: As used in this report, refers to the distance above or below the NGVD of 1929, that is, the height above or below mean sea level.

GEOLOGIC UNIT CODE: A system of numbers and letters used to designate the aquifer unit into which a well is finished. In this report, 120FLRD refers to undifferentiated rock of the Tertiary System corresponding to the Floridan aquifer; 122HTRN to undifferentiated deposits of the Tertiary System corresponding to the Hawthorn Group; and 110NRSD to undifferentiated surficial sand deposits of the Quaternary System.

HYDROLOGIC UNIT CODE: A geographic area representing part or all of a surface drainage basin of distinct hydrologic features as delineated by the U.S. Geological Survey Office of Water Data Coordination; on State Hydrologic Unit Maps. Each hydrologic unit is identified by an eight-digit number.

INSTRUMENTATION: As used in this report, instrumentation refers to how the water levels were measured.

LINEAR REGRESSION: A simple model of relating a response $y$ to a single quantitative independent variable $x$ in the form of an equation of a straight line.

MEASURING POINT: The point from which the water levels are measured, measuring point is reported as an elevation in feet above NGVD.

MISCELLANEOUS: The word miscellaneous has two distinct usages in this report. When used in the manuscript description section for each well, it refers to the method of recording the elevation of the water in each well by any method other than by a continuous recorder. In Appendix I, miscellaneous refers to the frequency of measurement of water levels and is any non-repetitive time interval.

NATIONAL GEODETIC VERTICAL DATUM

OF 1929: A geodetic datum derived from a general adjustment of the first-order nets of the United States and Canada, formerly called Sea Level Datum of 1929 and abbreviated as NGVD.

NONPARAMETRIC TEST: Statistical process that compares distributions of data and not the parameters themselves or the form of the distribution.

RECORDER: An instrument used to measure water levels continuously.

TAPE DOWN: A method of measuring water levels in wells using a steel tape.

TOWNSHIP, RANGE, SECTION: A locality placement system of the Bureau of Land Management, and upon which the SRWMD defines their site identification system for wells. It is a grid system beginning with a regional baseline (latitude), and a regional meridian line (longitude). Townships are designated, with increasing numbers, north or south of the regional baseline (T1N, T2N, T1S, T2S, etc.); Ranges are designated, with increasing numbers, east or west of the regional meridian (R1E, R2E, R1W, R2W, etc.). Each Township, Range grid is divided into thirty-six quadrants called Sections, for example Section 17 of T2N, R1E.

WATER LEVEL: The depth below the land surface to water in a well, in feet. In this report, all water levels have been converted to elevations, NGVD, by subtracting the measured water level from the elevation of the measuring point. For example, if the measuring point of a well is $70.50 \mathrm{ft}$., NGVD and a water level for that well is $40.50 \mathrm{ft}$., then the corresponding elevation of water in that well for that measurement, is $30.00 \mathrm{ft}$., NGVD. 


\title{
Statistical Summaries of Ground-Water Level Data Collected in the Suwannee River Water Management District, 1948-1994
}

\author{
By J.J. Collins and L.D. Freeman
}

\section{INTRODUCTION}

Since 1948, ground-water level data have been systematically collected from selected wells in the Suwannee River Water Management District (SRWMD) by the U.S. Geological Survey (USGS), the SRWMD, and other agencies. Records of water levels in the SRWMD (fig. 1), collected by the USGS and SRWMD through 1990, and by the SRWMD from 1990 to 1994, have been published for many years in the USGS annual report series "Water Resources Data for Florida." However, no systematic statistical summaries of water levels in the SRWMD have been previously published.

The need for such statistical summary data for evaluations of drought severity, ground-water supply availability, and minimum water levels for regulatory purposes increases daily as demands for ground-water usage increase. Also, much of the base flow of the Suwannee River is dependent upon ground water. As the population and demand for ground water for drinking water and irrigation purposes increase, the ability to quickly and easily predict trends in ground-water availability will become paramount. In response to this need, the USGS, in cooperation with the SRWMD, compiled this report. Ground-water statistics for 136 sites are presented as well as figures showing water levels that were measured in wells from 1948 through September 1994.

In 1994, the SRWMD and the USGS began a long-term program of cooperative studies designed to better understand minimum and maximum stream flows and ground-water levels in the SRWMD.

Minimum and maximum flows and levels are needed by the district to manage the surface- and ground-water resources of the SRWMD and to maintain or improve the various ecosystems. Data evaluation was a necessary first step in the long-term SRWMD ground-water investigations program, because basic statistics for ground-water levels are not included in the USGS annual data reports such as "Water Resources Data for Florida, Water Year 1994" (Franklin and others, 1995). Statistics included in this report were generated using the USGS computer program ADAPS (Automatic Data Processing System) to characterize normal ground-water levels and departures from normal.

The report has been organized so that the statistical analyses of water levels in the wells are presented following this introductory material, a description of the hydrogeology in the study area, and a description of the statistics used to present the water-level data. Specifically, the report presents statistical analyses for each well, as appropriate, in the following manner:

- Description of the well.

- Hydrographs of ground-water levels for the period of record, for the last 10 years of record, and for the last 5 years of record.

- Graphs of maximum, minimum, and mean of monthly mean ground-water levels for wells with 5 or more years of record.

- Frequency hydrographs $(25,50$, and 75 percent $)$ of monthly mean ground-water levels for wells with 5 or more years of record. 


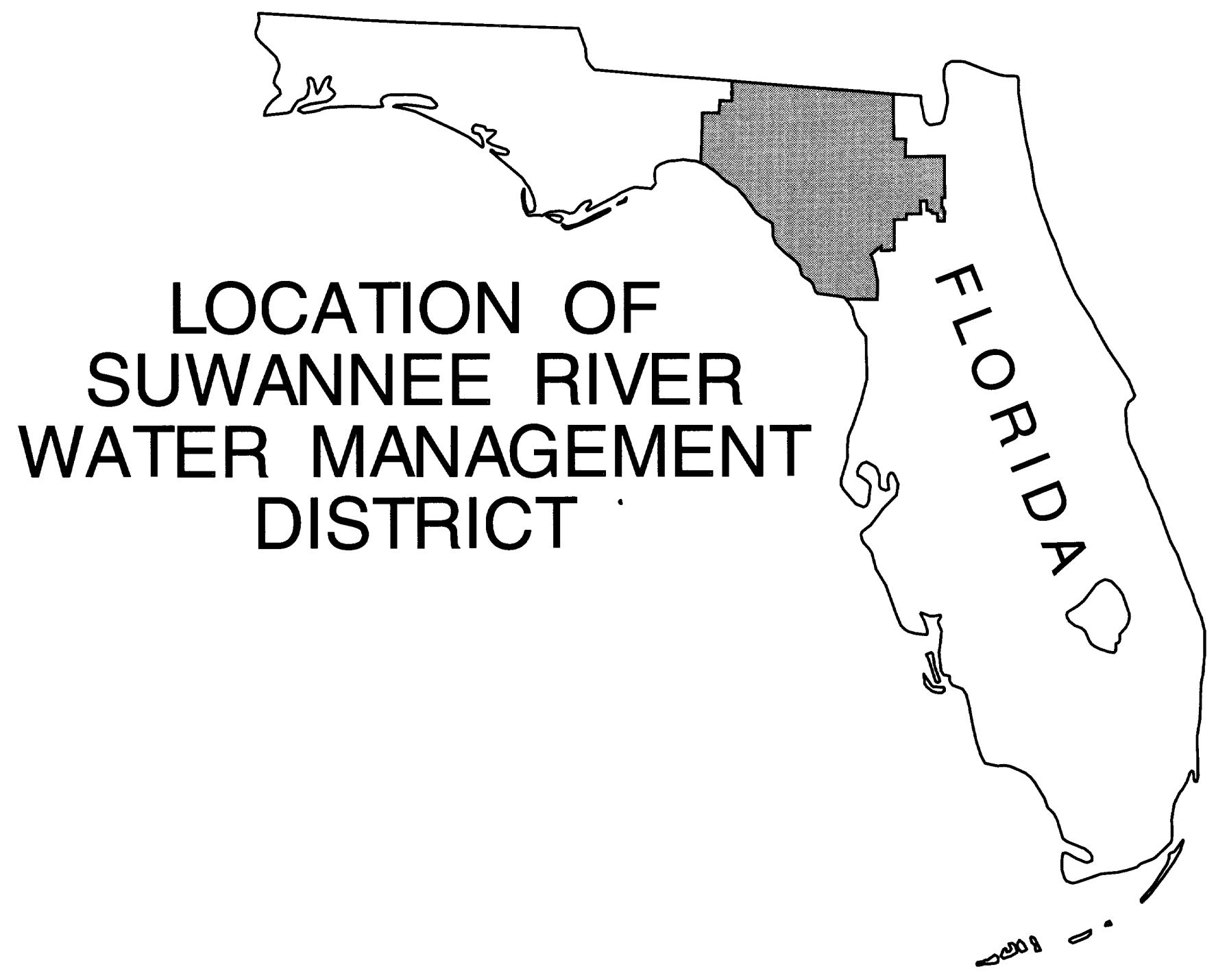

Figure 1. Location of Suwannee River Water Management District. 
Water-level data and statistical plots are grouped by county and sorted within the county by ascending site identification number. Well locations are plotted on county maps preceding the well descriptions and hydrographs.

\section{HYDROGEOLOGY}

The Suwannee River Water Management District is underlain in parts by three general hydrogeologic units: an unconfined surficial aquifer, the upper confining unit of the Upper Floridan aquifer, and the Upper Floridan aquifer (Miller, 1990). The unconfined surficial aquifer consists of undifferentiated silty sands of Pliocene to Pleistocene and Pleistocene age. Surficial aquifers occur in parts of all counties in the SRWMD, except Dixie (Ron Ceryak, Suwannee River Water Management District, oral commun., 1996). The upper confining unit is composed of Miocene age phosphatic clayey sands of the Hawthorn Group. Within the upper confining unit are thin, higher permeability sediments which are referred to as "intermediate aquifers." Intermediate aquifers occur in parts of Alachua, Baker, Bradford, Columbia, Hamilton, Suwannee, and Union Counties. The Upper Floridan aquifer is composed of a thick sequence of carbonate rocks of Eocene to Oligocene age. The rocks of the Upper Floridan are continuous throughout the SRWMD and are at or near the land surface (unconfined) in all counties except Bradford and Clay. In this report, the aquifer named for each well refers to the aquifer into which the well is finished.

\section{DESCRIPTION OF GROUND-WATER LEVEL STATISTICS}

This section provides a description of the summary statistics presented in graphs for each set of water levels measured in the respective wells. Each data set is presented on facing pages. For wells with less than 5 years of record, no statistics were computed, and the graphs have nothing plotted within the axes. Hydrographs for the last 5 and 10 years of record are included for each site so that they can be compared with updated, similar plots in subsequent reports of this type. The scale of the $\mathrm{x}$-axis for the hydrographs shows the year when data was collected. The scale of the y-axis for each graph is the altitude of the water level in feet above mean sea level.
Well information describes location of the well, the aquifer into which it is completed, and the period of record during which water levels have been collected. The well manuscript provides, under various subheadings, the following information as appropriate for each well:

WELL NUMBER.--Each well is given a 15-digit number which consists of a 13-digit number based on the latitude and longitude of the well plus a 2-digit sequential number (for example, 291414082560985) followed by the well name, and the SRWMD well location number (DOF-Cedar Key Tower and -141429001 for the above well). The SRWMD well location number is based on the township, range, and section where the well is located. The well name included in this report is the name used in the SRWMD well data retrieval system.

LOCATION.--Latitude and longitude. This number may differ slightly from the well number. The latitude and longitude is followed by the 8-digit hydrologic unit code (for example, 03110101). These hydrologic units define river basin boundaries.

AQUIFER.--The aquifer name, such as Upper Floridan aquifer of the Tertiary system, followed by the Geologic Unit Code for the Floridan aquifer, such as 120FLRD.

WELL CHARACTERISTICS.--Casing diameter, casing depth, and total well depth.

INSTRUMENTATION.--The elevation of the present Measuring Point for the well. If appropriate, also states that the well has or had a recorder.

DATUM.--The datum to which all ground-water levels are referred. All wells described in this report are referenced to mean sea level.

PERIOD OF RECORD.--The time period for which each well had data collected. An * at the end of this line indicates that this well has a regression curve. $\mathrm{A} \dagger$ at the end of this line indicates that water levels prior to the beginning date of the graph or for periods of no data may be in paper files at the U.S. Geological Survey in Tallahassee, Florida.

EXTREME VALUES.--The maximum and minimum values for the period of record for each well. Used without qualification, the value was taken from a recorder; used with the word observed, the 
value was taken from a tape-down measurement. Dates given are either the only occurrence or the first occurrence, if that value was reached more than once. These are not necessarily the statistical maximum and minimum values shown in the graphs and listed in Appendix II.

Included in this report is information for water levels in 136 wells. A hydrograph of water levels for the period of record is included for each well. Continuous measurements were made by recorders in 26 of these wells. Instantaneous measurements only were made in 72 of the wells, some of these consisting of scheduled monthly measurements of water levels in network wells, by using a steel tape or some other measuring device. The remaining 38 wells were measured by a combination of instantaneous measure-ments and by use of a continuous recorder. Less than 5 years of record are available for 10 of the 136 wells.

On certain period-of-record hydrographs (those designated with an asterisk in figures 2-16 and in the description for the period of record), a linear regression was determined. The line is included with the plot of water-level data in the hydrographs. It should be noted that a linear regression on ground-water time-series data is not the most appropriate method for illustrating possible trends. Linear regression analysis assumes normally distributed data, but ground-water data is typically nonnormal and a nonparametric test provides better results. Linear regression was used for these analyses because the intent of the regression is to supply a graphical aid to illustrate the trend in water levels. If it is necessary to perform a rigorous trend analyses on the data, a different type of statistical analysis should be used.

On the graphs, periods of 6 months or longer of missing data are represented by one of three ways. A solid line is used for all tape-down derived values. A dashed line is used for all recorder derived values. Where a tape-down value occurs as the initial point followed by 5 or more years hiatus to the next value, an " $x$ " is used to represent the initial value with no connecting line. Tape-down derived values will a priori have gaps between values, but a record is maintained, nevertheless; hence, the solid lines between points of 1 to 5 years in duration. Gaps in a recorder record may occur due to either a malfunction of the recorder or for a period of time when no record was maintained-this report does not distinguish between the two. If 5 or more years elapse between an initial measurement and the others, an " $x$ " for an initial tape-down measurement is used with no connecting line between this initial value and the following data. This is done so no erroneous conclusion will be made regarding possible trends.

Monthly mean values of ground-water levels were determined from daily values of water levels measured by the SRWMD and the USGS. The daily water-level values obtained from the SRWMD data base for wells with recorders reflect water levels measured at 12:00 p.m. for that day. Daily water-level values obtained from the USGS data base for wells with recorders reflect the highest value measured for that day. Although there is inconsistency between the SRWMD and the USGS in the way daily values are determined, the differences in values (when comparing values determined by the two methods) are minor, because daily fluctuations in water levels in wells are typically small relative to changes that might occur seasonally or during the period of record.

Monthly mean ground-water levels were also determined for wells without continuous recorders. In wells where instantaneous measurements were made, all water levels measured in a particular month were used to compute the mean for that month. If only one water-level measurement was made in a particular month, that value became the mean for that month.

Graphs showing maximum, minimum, and mean of monthly mean water levels 5 or more years of record were derived from the mean water level computed for each month. For example, all the mean values for a particular month were assembled in a data set. From these monthly values, a maximum and minimum value was selected and a mean value was determined. This type of graph is used to show both the seasonal variations in water levels and extremes which have been encountered during the period of record. The relation of present water levels to long-term conditions can be determined from these statistics. These maximum and minimum values are not necessarily those listed in the extreme values heading.

Frequency hydrographs of daily mean ground-water levels show the percentage of time that indicated values of mean ground-water levels were equaled or exceeded in wells with 5 or more years of data. For example, if a ground-water level of $10 \mathrm{ft}$ corresponds to a value of 25 for the percent of time that the indicated value is equaled or exceeded, this means that a mean elevation of $10 \mathrm{ft}$ was equaled or 
exceeded 25 percent of the entire period of record. Ground-water level duration frequency hydrographs are often used to obtain a general idea of long-term fluctuations in the ground-water levels. Frequency hydrographs may also be used to estimate the percentage of time that the ground-water level in the area adjacent to a well is depressed due to drought or heavy consumption, or elevated due to heavier than normal rainfall. An important limitation of frequency hydrographs is that no information is provided as to whether the values are consecutive or widely scattered in time.

\section{SELECTED REFERENCES}

Franklin, M.A., Giese, G.L., and Mixson, P.R., 1995, Statistical Summaries of Surface-Water Hydrologic Data Collected in the Suwannee River Water Management District, Florida, 1906-93, U.S. Geological Survey Open-File Report 94-709.

Miller, J.A., 1986, Hydrogeologic framework of the Upper Floridan aquifer system in Florida, and in parts of Georgia, Alabama, and South Carolina: U.S. Geological Survey Professional Paper 1403-B, 91 p.

---- 1990, Ground Water atlas of the United States-Segment 6-Alabama, Florida, Georgia, and South Carolina: U.S. Geological Survey Hydrologic Investigations Atlas 730-G, $28 \mathrm{p}$.

U.S. Geological Survey, Water resources data for Florida: U.S. Geological Survey Water-Data Report Series, published annually. 


\section{Statistical Summaries of Ground-Water Level Data}




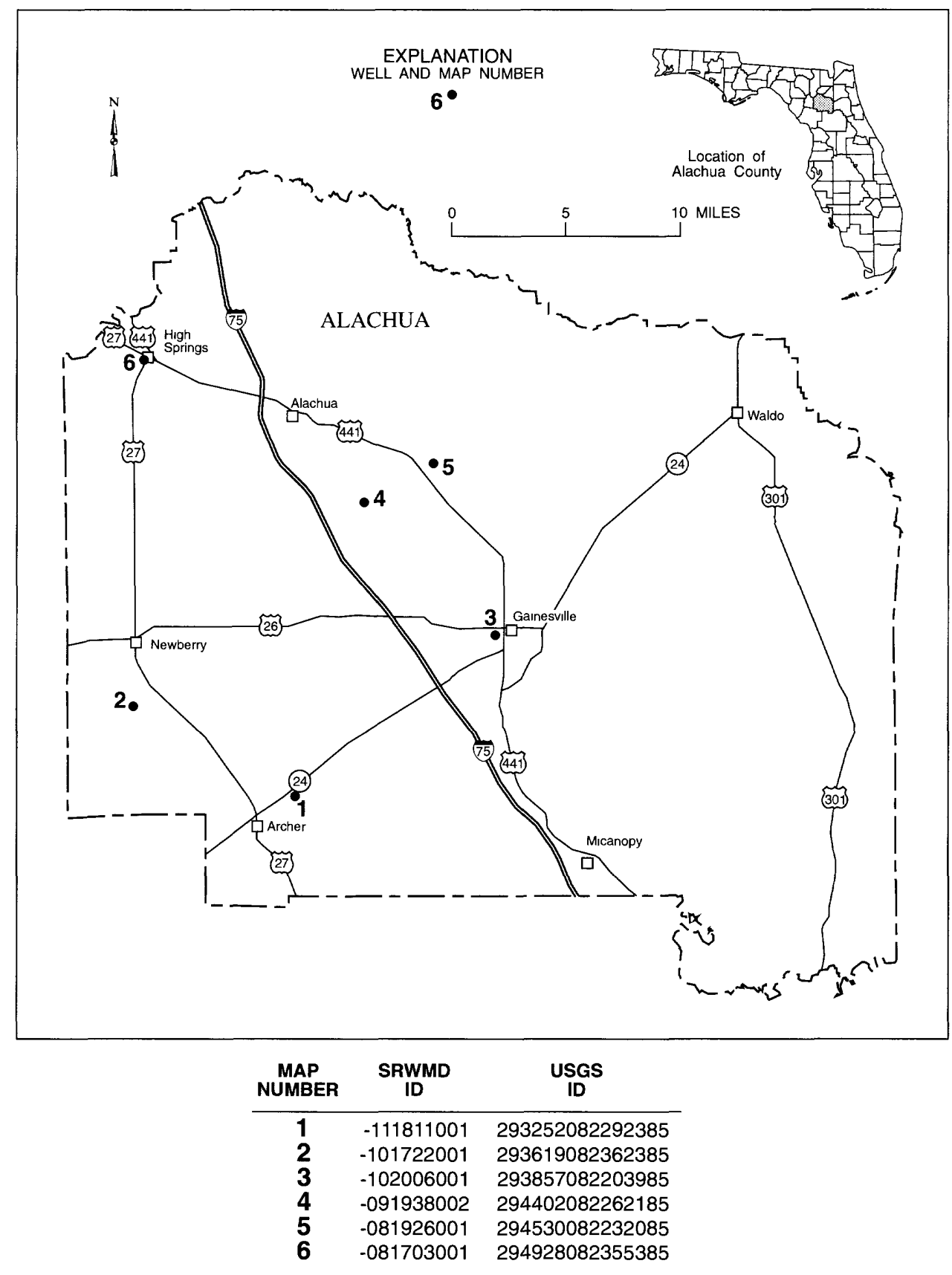

Figure 2. Location of wells in Alachua County. 


\section{Alachua County}

WELL NUMBER.--293252082292385. Alto Straughn. -111811001.

LOCATION.--Lat 29³2'52”, long 82²9’23”, Hydrologic Unit Code 03090102.

AQUIFER.--Upper Floridan aquifer of the Tertiary system, Geologic Unit Code 120FLRD.

WELL CHARACTERISTICS.--Casing diameter 8 in., Casing depth $45 \mathrm{ft}$., Total depth $60 \mathrm{ft}$.

INSTRUMENTATION.--Recorder, set to elevation of the Measuring Point, $77.97 \mathrm{ft}$., NGVD.

DATUM.--The National Geodetic Vertical Datum of 1929.

PERIOD OF RECORD.--09-17-1981 to 09-30-1994.

EXTREME VALUES.--Maximum, 53.47ft. (04-23-1987); minimum, 40.24 ft. (01-13-1982).

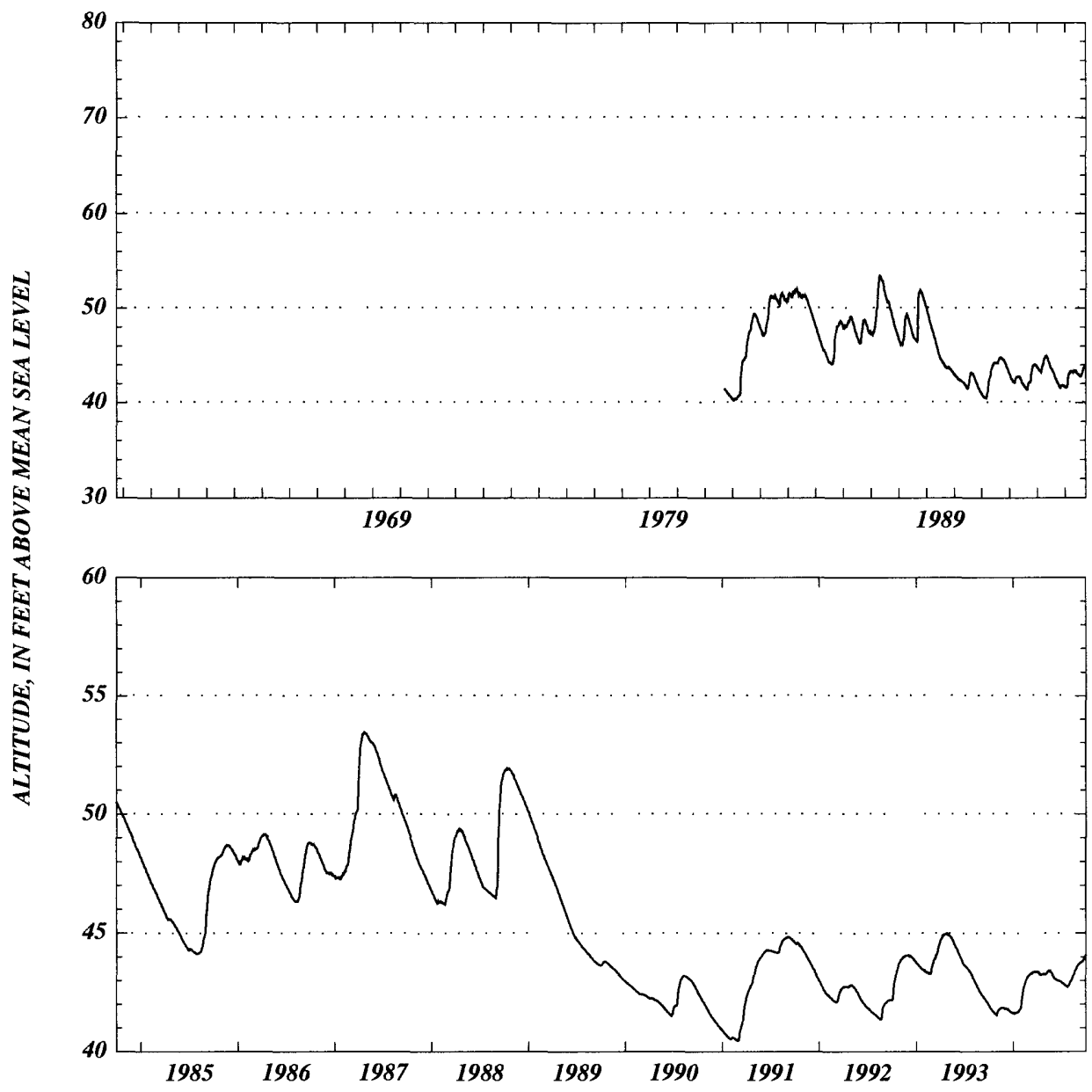



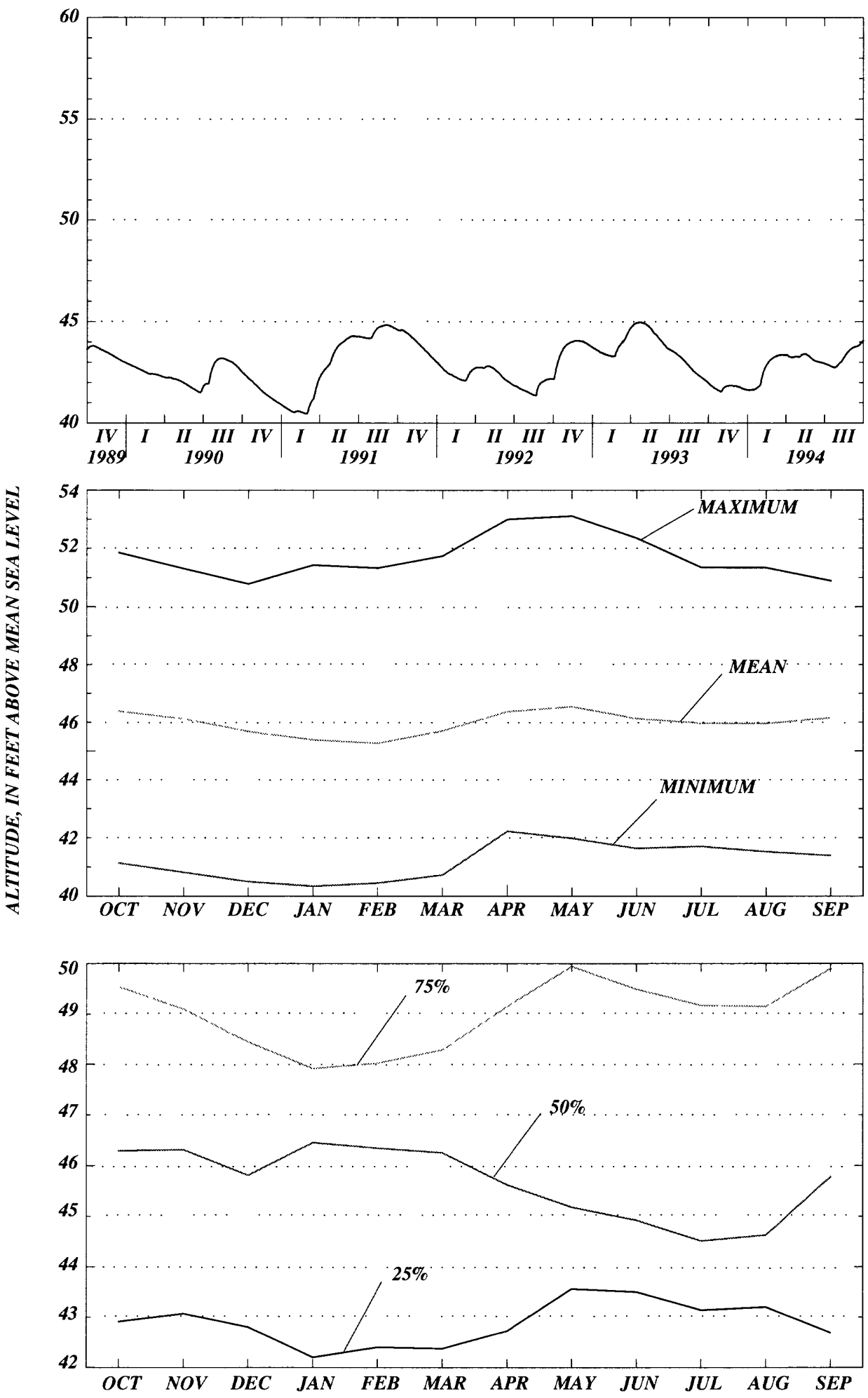


\section{Alachua County}

WELL NUMBER.--293619082362385. USGS - Newberry. -101722001.

LOCATION.--Lat 29³6'23”, long 82³6'23”, Hydrologic Unit Code 03110101.

AQUIFER.--Upper Floridan aquifer of the Tertiary system, Geologic Unit Code 120FLRD.

WELL CHARACTERISTICS.--Casing diameter 8 in., Casing depth $136 \mathrm{ft}$., Total depth $252 \mathrm{ft}$.

INSTRUMENTATION.--Recorder, set to elevation of the Measuring Point, $76.27 \mathrm{ft}$., NGVD.

DATUM.--The National Geodetic Vertical Datum of 1929.

PERIOD OF RECORD.--10-07-1965 to 09-30-1994. *†

EXTREME VALUES.--Maximum, 54.63 ft. (10-07-1965); minimum, 38.00ft. (01-15-1982).

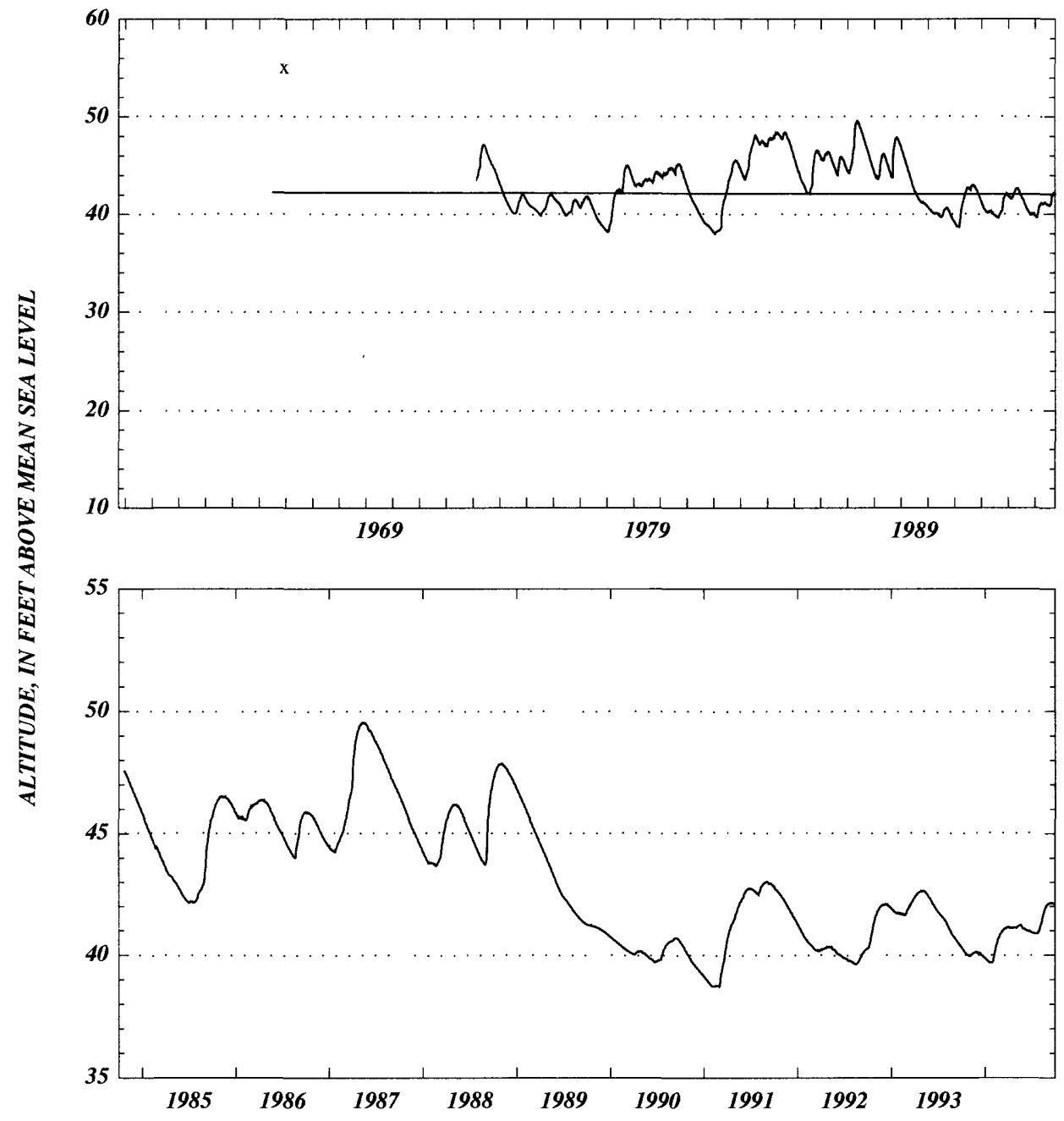



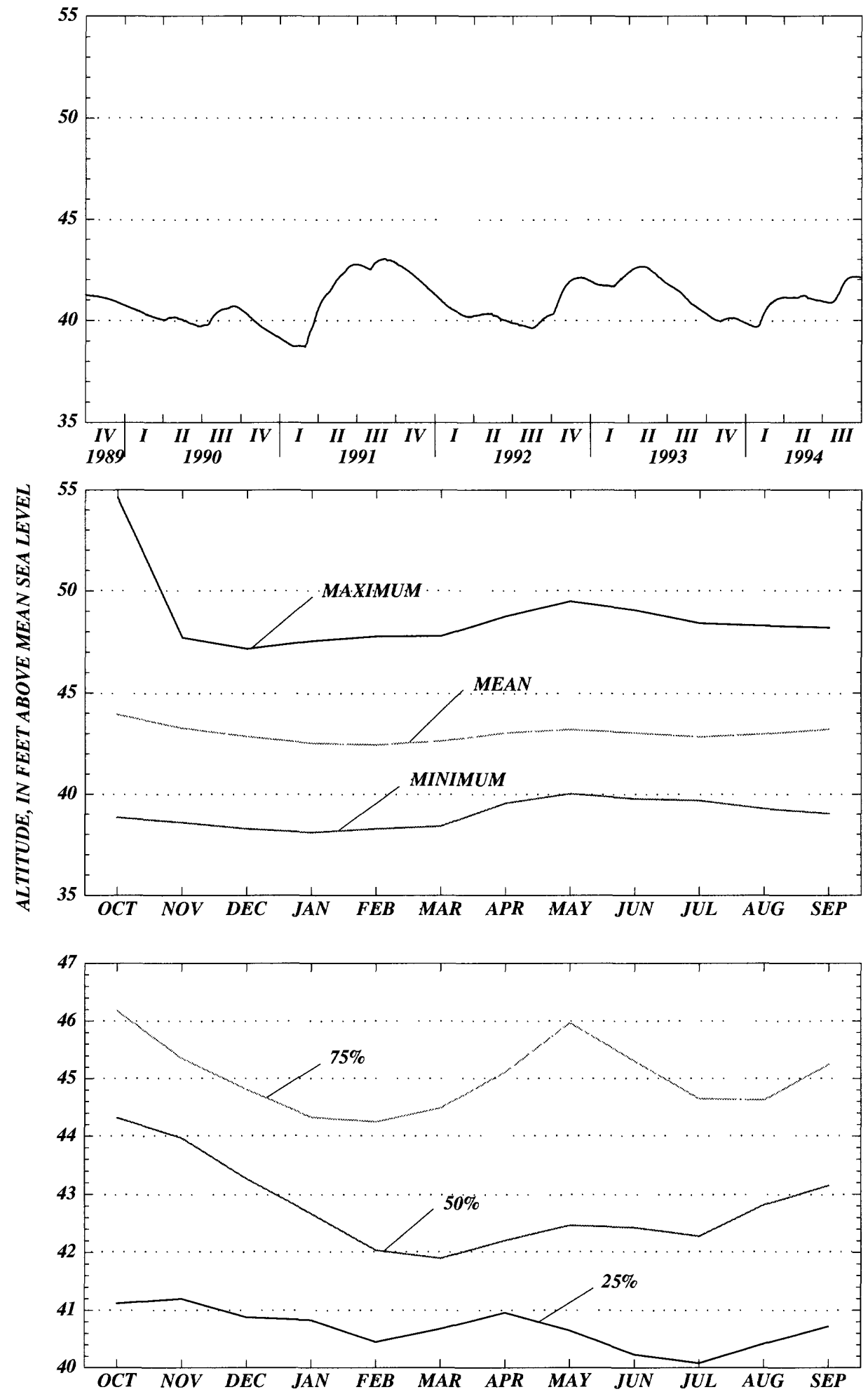


\section{Alachua County}

WELL NUMBER.--293857082203985. University of Florida. -102006001.

LOCATION.--Lat 2938'57”, long 82²0'39”, Hydrologic Unit Code 03090102.

AQUIFER.--Upper Floridan aquifer of the Tertiary system, Geologic Unit Code 120FLRD.

WELL CHARACTERISTICS.--Casing diameter 4 in., Casing depth $142 \mathrm{ft}$., Total depth $406 \mathrm{ft}$.

INSTRUMENTATION.--Miscellaneous measurements from 11-01-1976 to 04-20-1988; recorder from 04-21-1988 to 09-30-1994. Elevation of the Measuring Point, $161.59 \mathrm{ft}$., NGVD.

DATUM.--The National Geodetic Vertical Datum of 1929.

PERIOD OF RECORD.--11-01-1976 to 09-30-1994.

EXTREME VALUES.--Maximum, 53.59 ft. (10-23-1984); minimum, 42.16 ft. (01-23-1991).

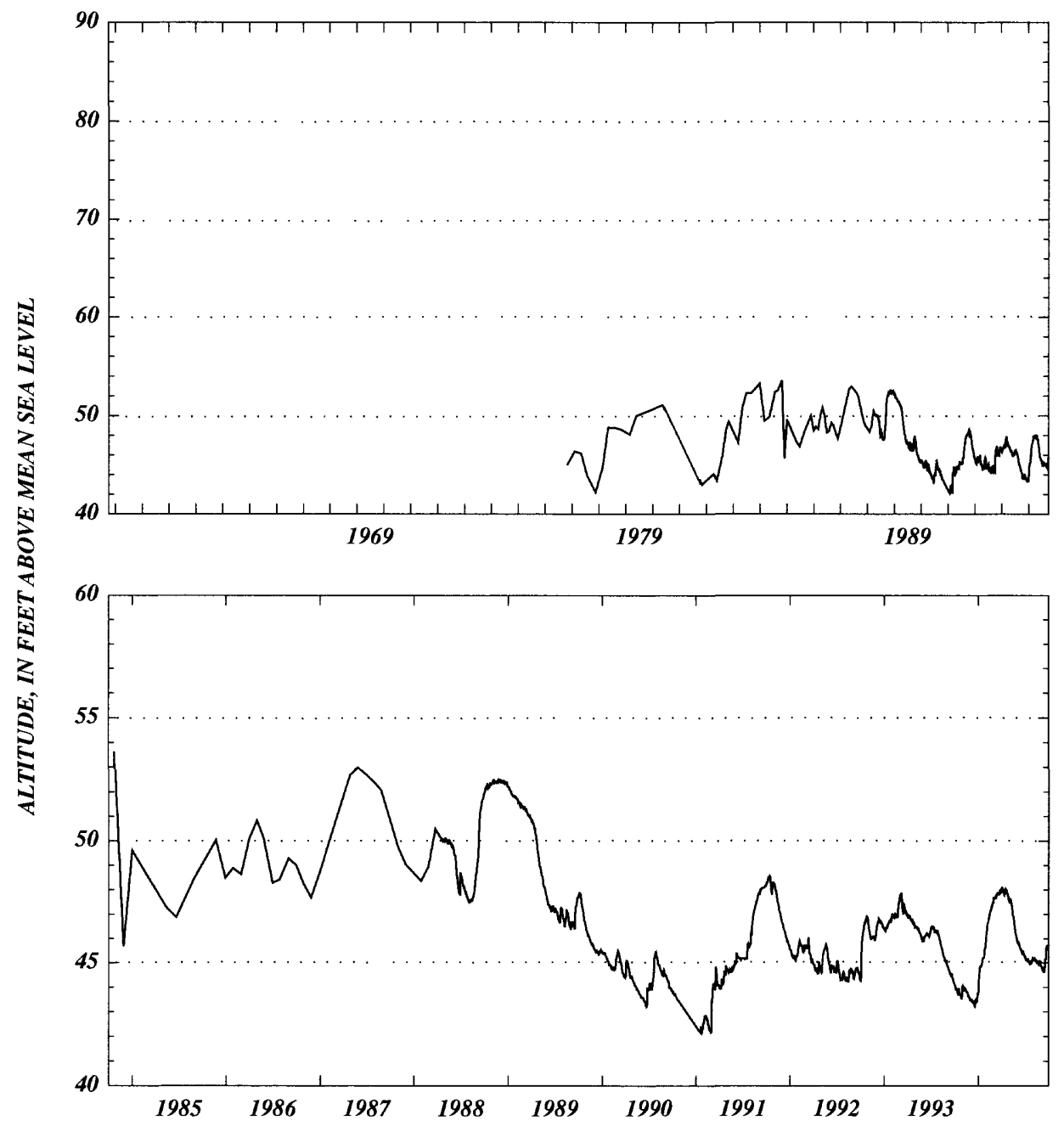



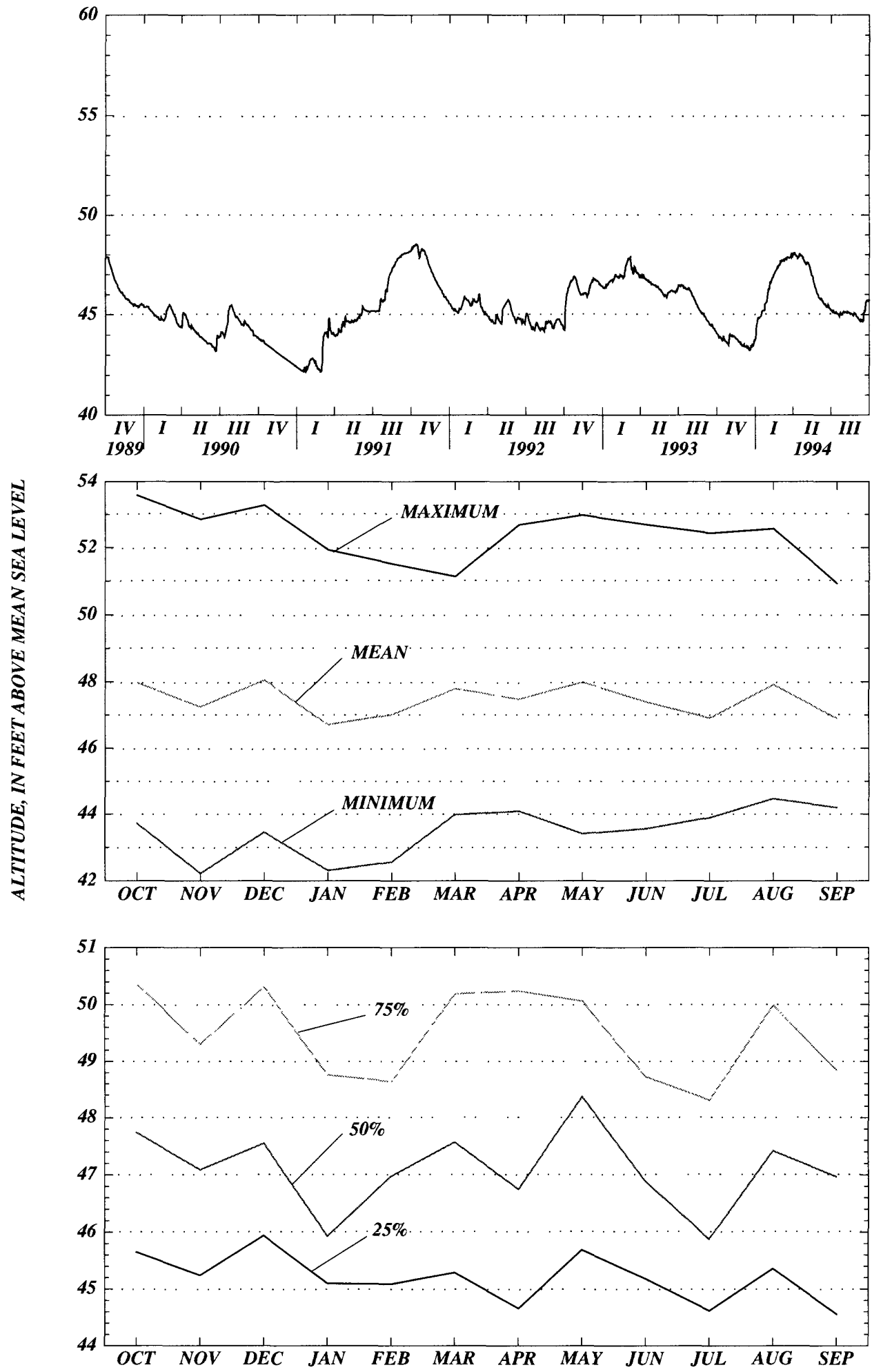


\section{Alachua County}

WELL NUMBER.--294402082262185. DNR - San Felasco Hammock. -091938002.

LOCATION.--Lat 2944'02”, long 82²6'21”, Hydrologic Unit Code 03080102.

AQUIFER.--Upper Floridan aquifer of the Tertiary system, Geologic Unit Code 120FLRD.

WELL CHARACTERISTICS.--Casing diameter 4 in., Casing depth $120 \mathrm{ft}$., Total depth $168 \mathrm{ft}$.

INSTRUMENTATION.--Recorder, set to elevation of the Measuring Point, ft.160.54, NGVD.

DATUM.--The National Geodetic Vertical Datum of 1929.

PERIOD OF RECORD.--08-13-1980 to 09-30-1994.

EXTREME VALUES.--Maximum, 74.98 ft. (09-04-1985); minimum, 43.73 ft. (12-07-1981).

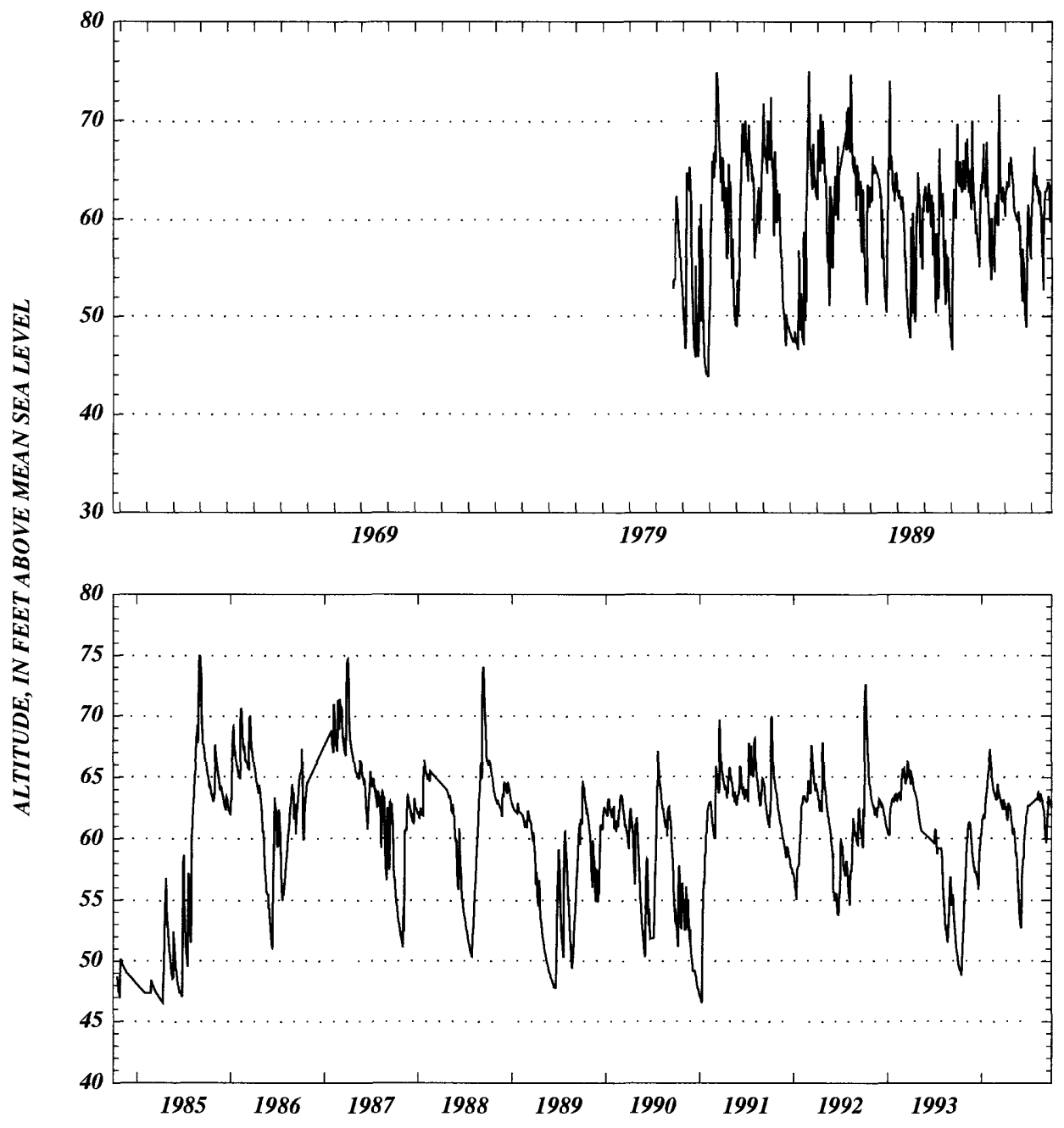




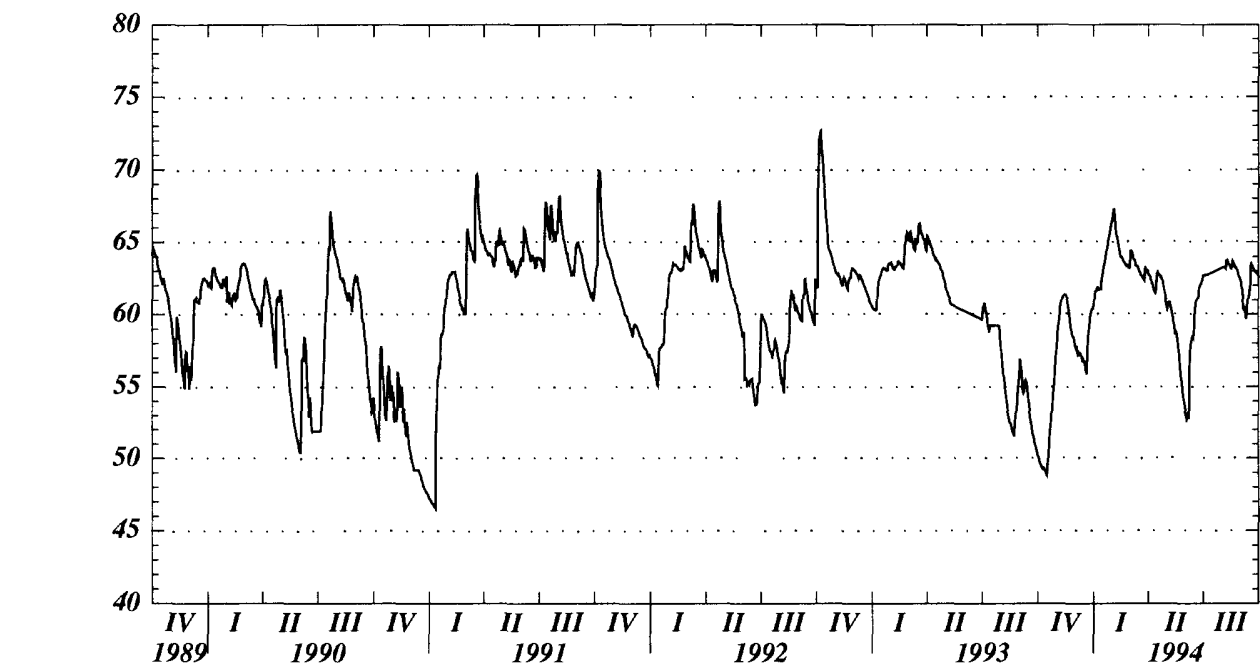

ב⿱
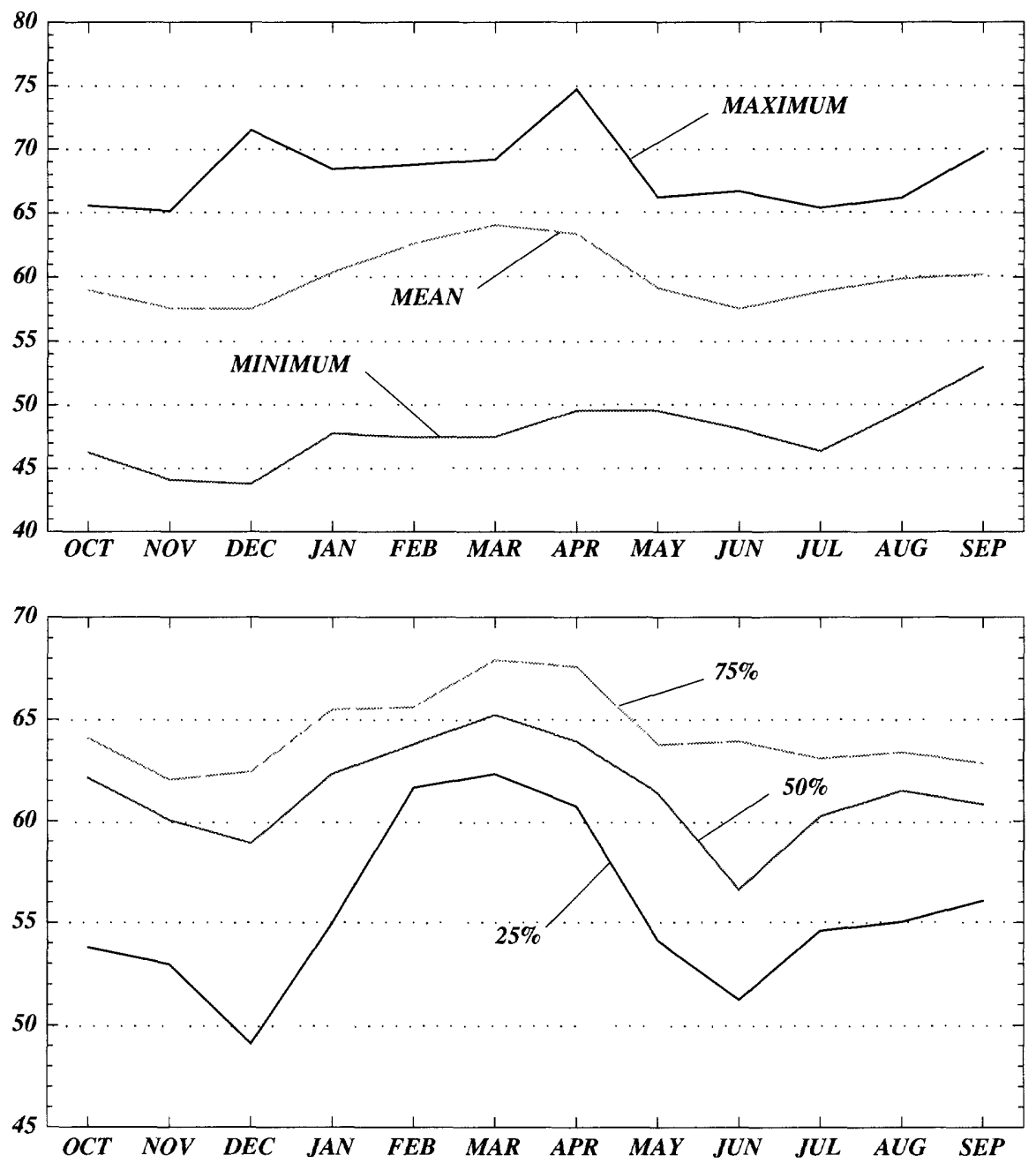


\section{Alachua County}

WELL NUMBER.--294530082232085. City of Gainesville. -081926001.

LOCATION.--Lat 29 45'30”, long 82²3'20”, Hydrologic Unit Code 03110206.

AQUIFER.--Upper Floridan aquifer of the Tertiary system, Geologic Unit Code 120FLRD.

WELL CHARACTERISTICS.--Casing diameter 6 in., Casing depth $139 \mathrm{ft}$., Total depth $284 \mathrm{ft}$.

INSTRUMENTATION.--Miscellaneous: 02-14-1978 to 12-03-1980; then recorder, set to elevation of the Measuring Point, $186.30 \mathrm{ft}$., NGVD.

DATUM.--The National Geodetic Vertical Datum of 1929.

PERIOD OF RECORD.--02-14-1978 to 09-30-1994. *

EXTREME VALUES.--Maximum, 47.47 ft. (06-25-1984); minimum, 39.50 ft. (02-12-1991).

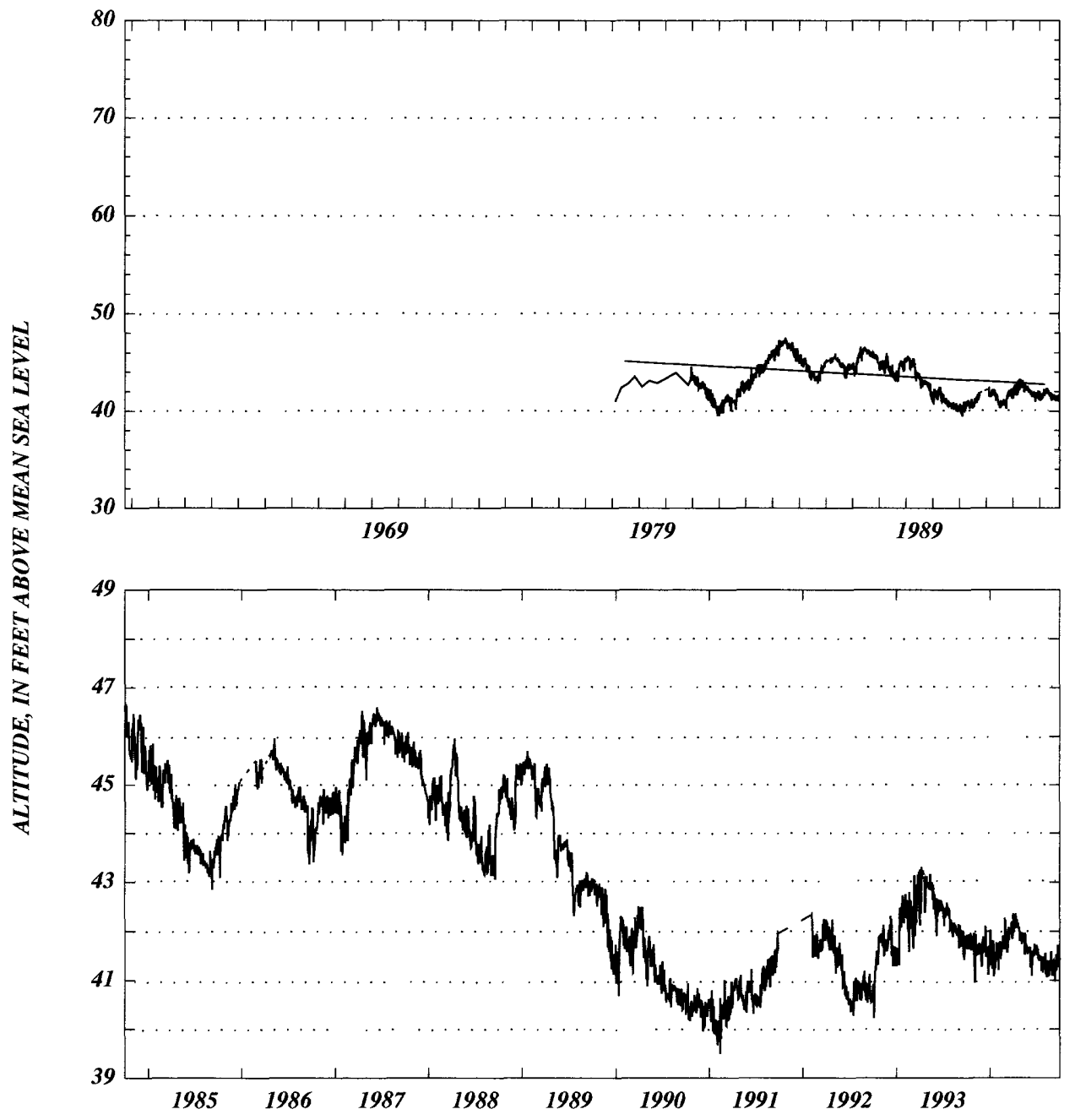



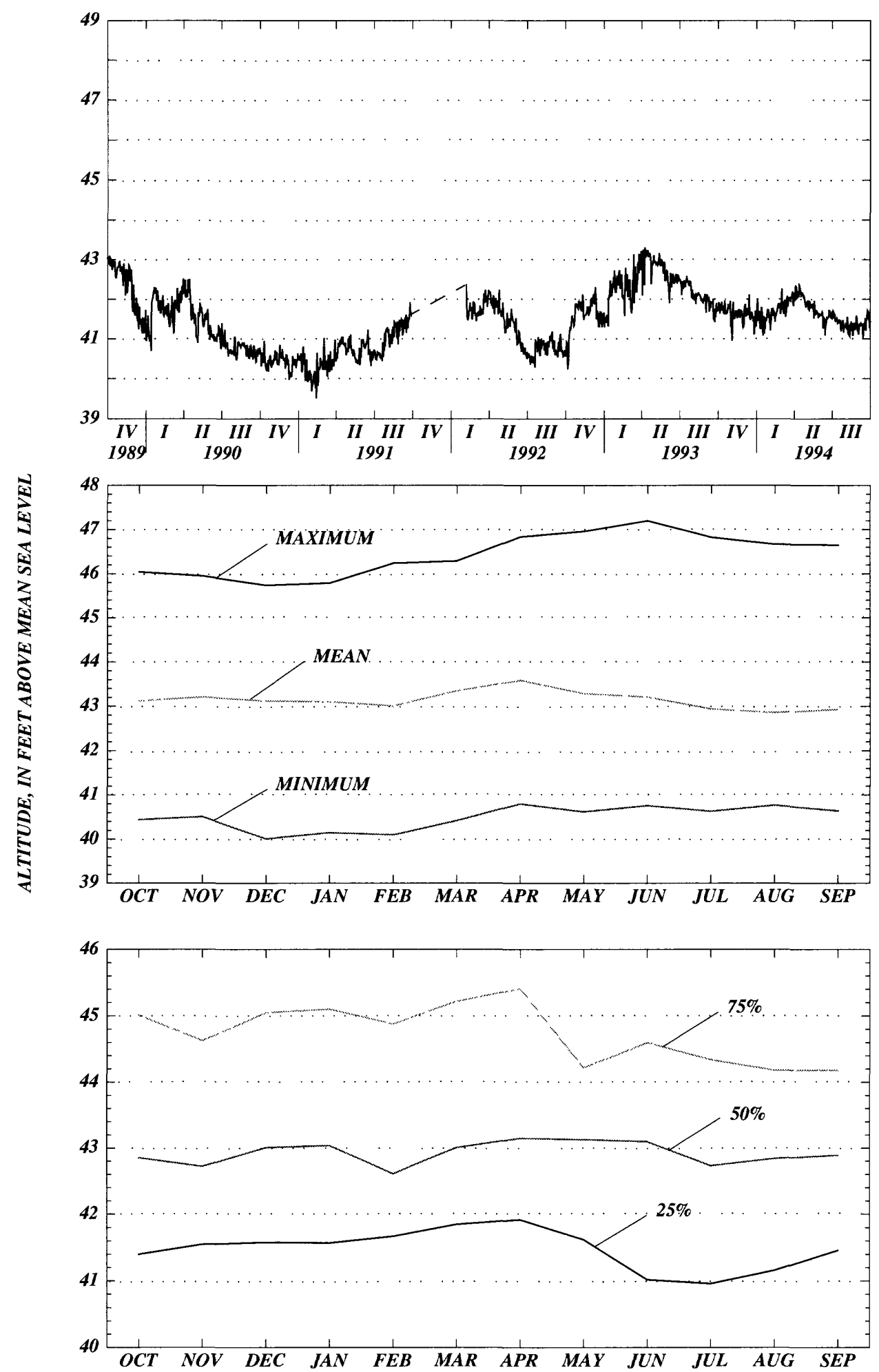


\section{Alachua County}

WELL NUMBER.--294928082355385. City of High Springs. -081703001.

LOCATION.--Lat 2949'28”, long 82³5'53”, Hydrologic Unit Code 03110206.

AQUIFER.--Upper Floridan aquifer of the Tertiary system, Geologic Unit Code 120FLRD.

WELL CHARACTERISTICS.--Casing diameter 10 in., Casing depth $172 \mathrm{ft}$., Total depth $287 \mathrm{ft}$.

INSTRUMENTATION.--Miscellaneous from 07-30-1960 to 09-14-1970; recorder, set to elevation of Measuring Point, $73.00 \mathrm{ft}$., NGVD.

DATUM.--The National Geodetic Vertical Datum of 1929.

PERIOD OF RECORD.--07-30-1960 to 09-30-1994.

EXTREME VALUES.--Maximum, 43.42 ft. (09-17-1964); minimum, 28.07 ft. (05-06-1969).

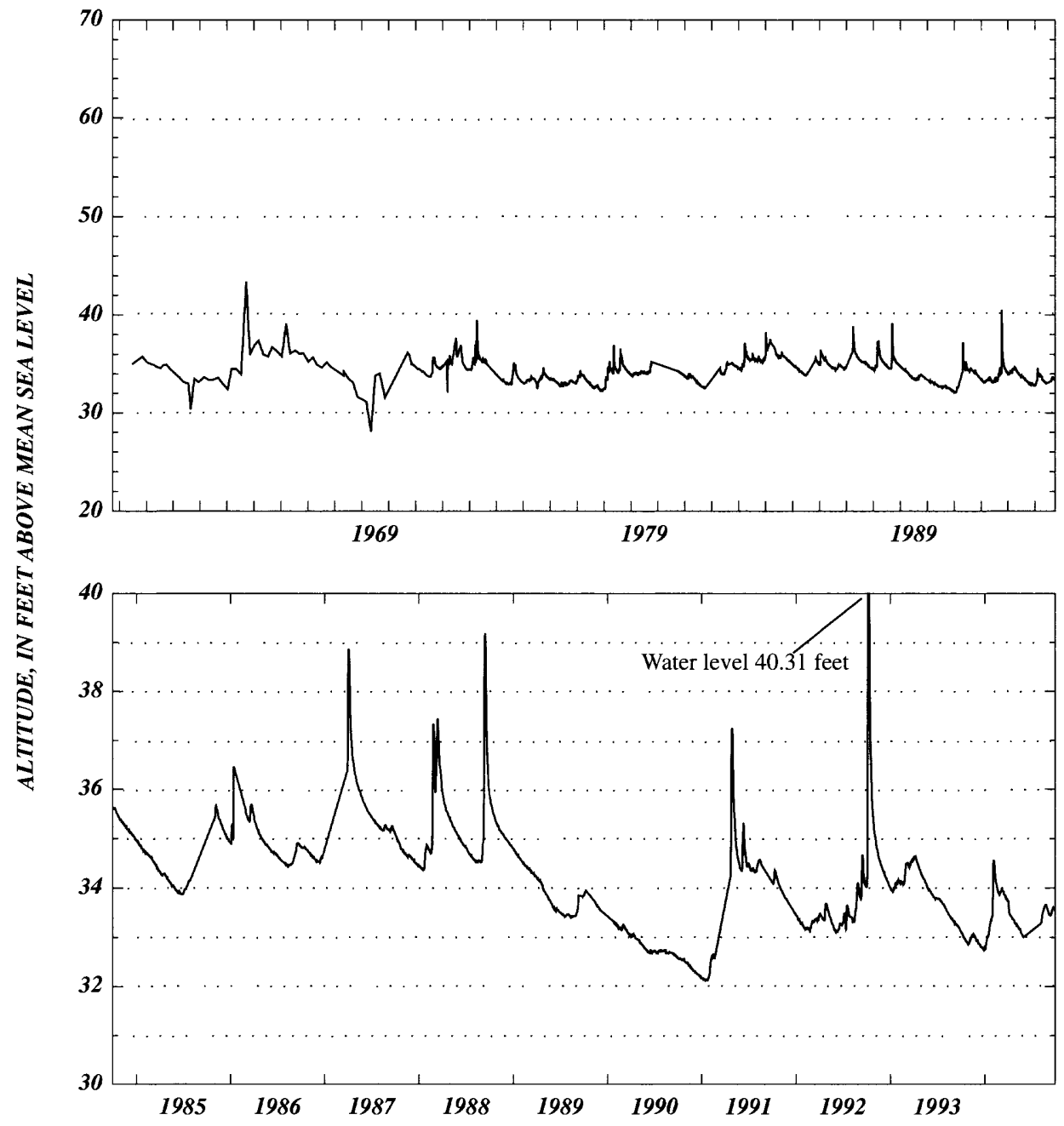



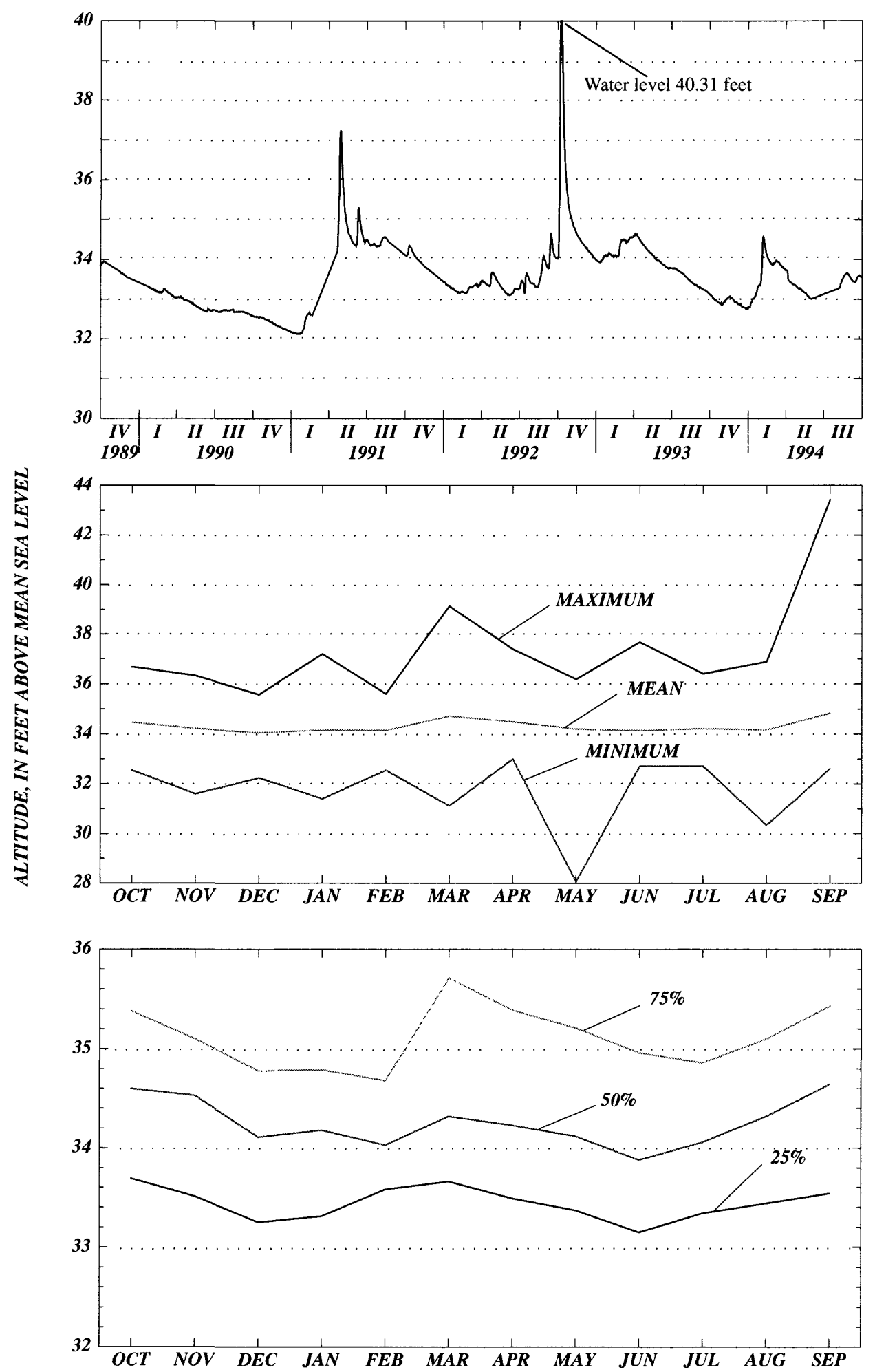


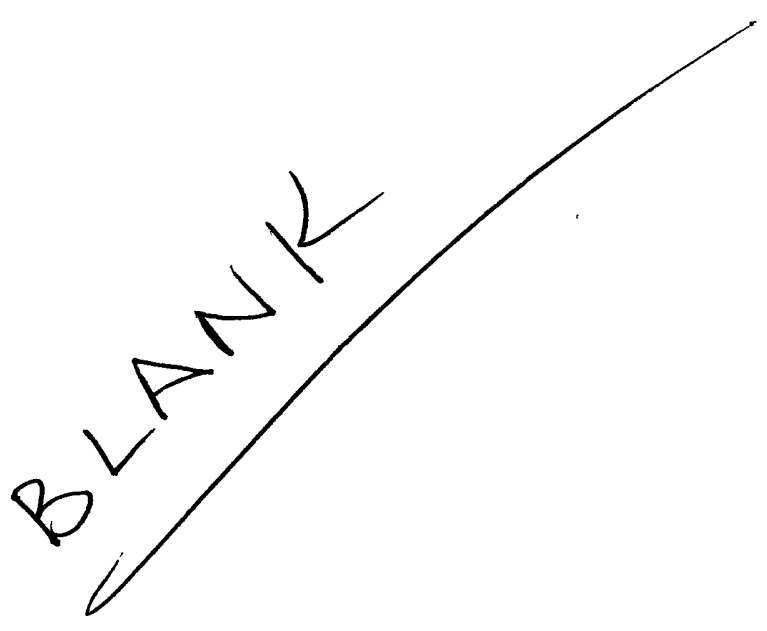

20 Statistical Summaries of Ground-Water Level Data Collected in the Suwannee River Water Management District, 1948-1994 


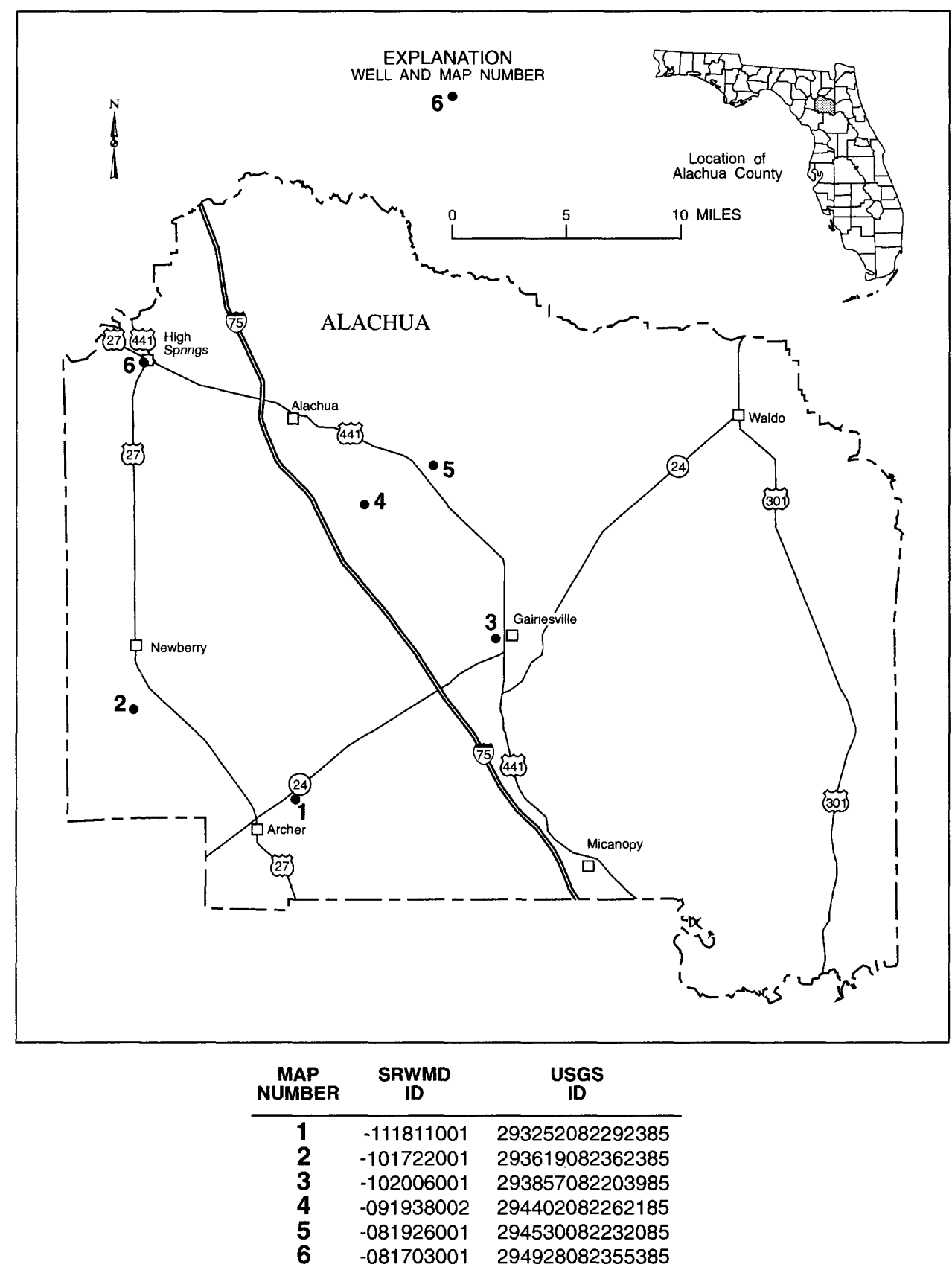

Figure 3. Location of wells in Baker County. 


\section{Baker County}

WELL NUMBER.--301245082233085. USFS - Olustee. -031923004.

LOCATION.--Lat 30¹2’45”, long, 82²3’30”, Hydrologic Unit Code 03070204.

AQUIFER.--Upper Floridan aquifer of the Tertiary system, Geologic Unit Code 120FLRD.

WELL CHARACTERISTICS.--Casing diameter 4 in., Casing Depth $233 \mathrm{ft}$., Total depth $253 \mathrm{ft}$.

INSTRUMENTATION.--Elevation of Measuring Point 181.28 ft., NGVD.

DATUM.--The National Geodetic Vertical Datum of 1929.

PERIOD OF RECORD.--03-25-1988 to 09-30-1994.

EXTREME VALUES.--Maximum observed, 57.99 ft. (03-03-1993); minimum observed, $49.00 \mathrm{ft}$. (11-30-1990).

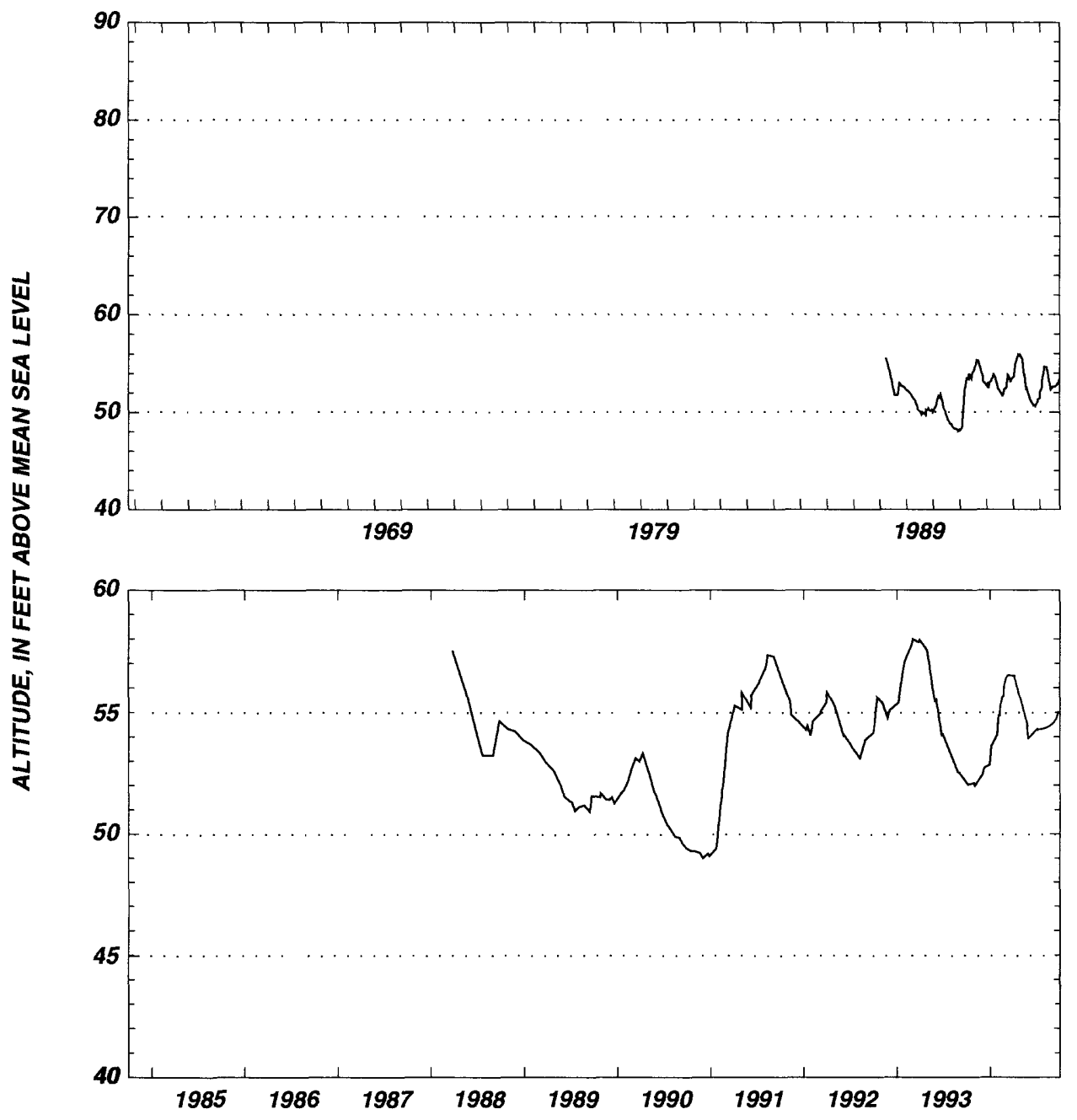



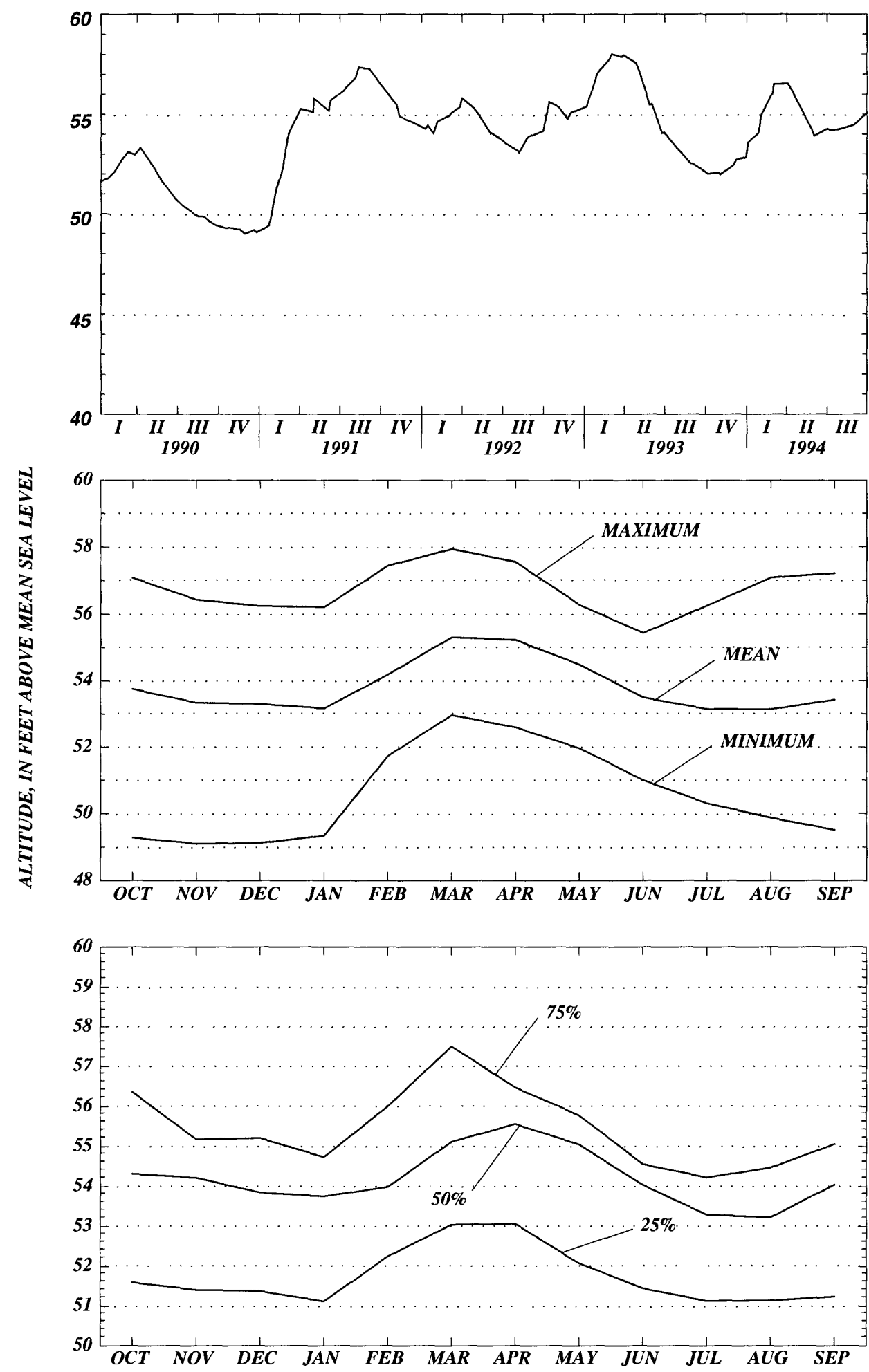


\section{Baker County}

WELL NUMBER.--301246082233085. USFS - Olustee. -031923003.

LOCATION.--Lat 30¹2’46”, long 82²3'30”, Hydrologic Unit Code 03070204.

AQUIFER.--Surficial aquifer, Geologic Unit Code 110NRSD.

WELL CHARACTERISTICS.--Casing diameter 4 in., Casing depth $5 \mathrm{ft}$., Total depth $45 \mathrm{ft}$.

INSTRUMENTATION.--Elevation of Measuring Point $180.73 \mathrm{ft}$., NGVD.

DATUM.--The National Geodetic Vertical Datum of 1929.

PERIOD OF RECORD.--06-05-1989 to 09-30-1994.

EXTREME VALUES.--Maximum observed, 176.97 ft., (03-26-1993); minimum observed, 170.89 ft. (01-14-1991).

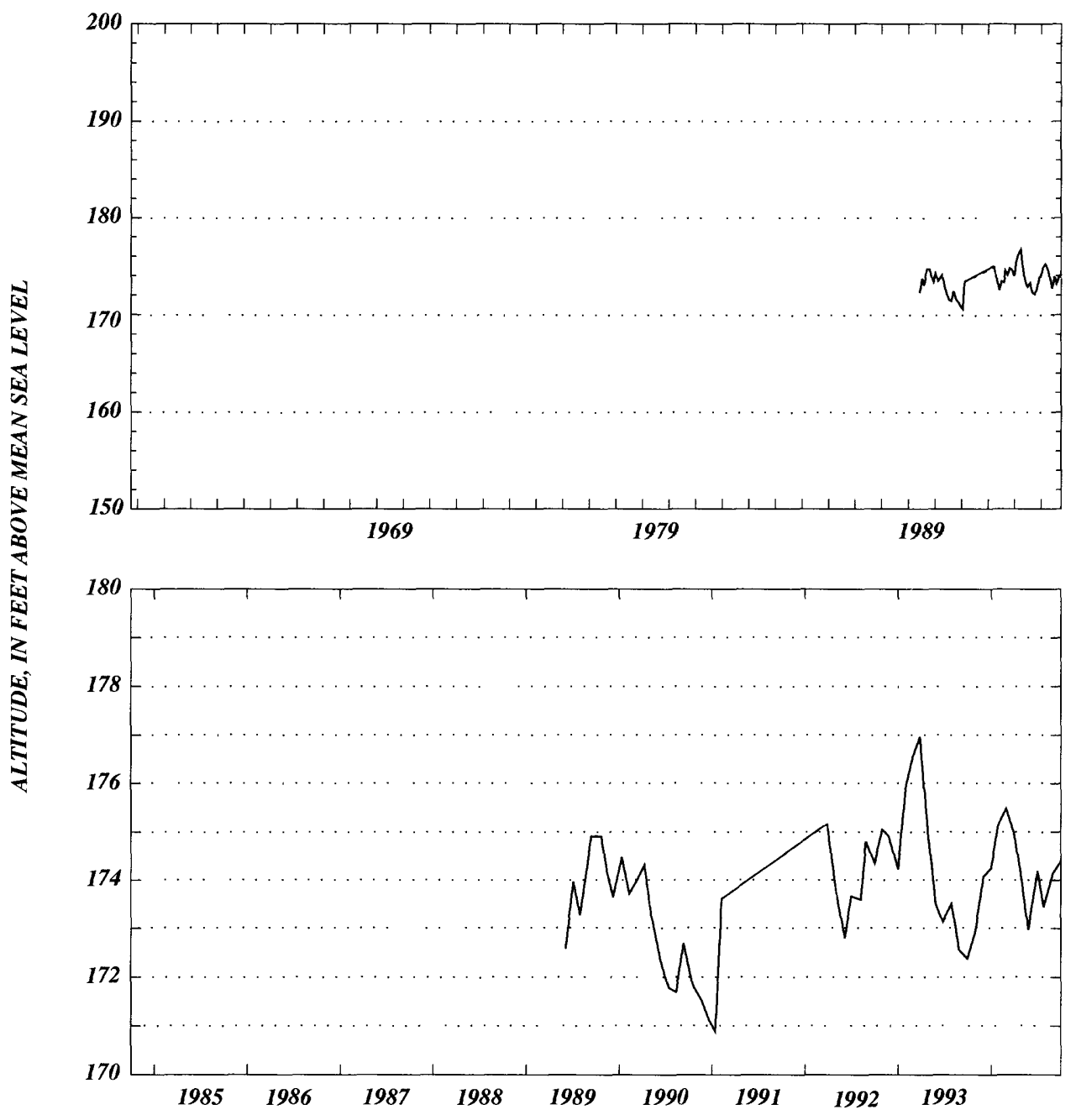



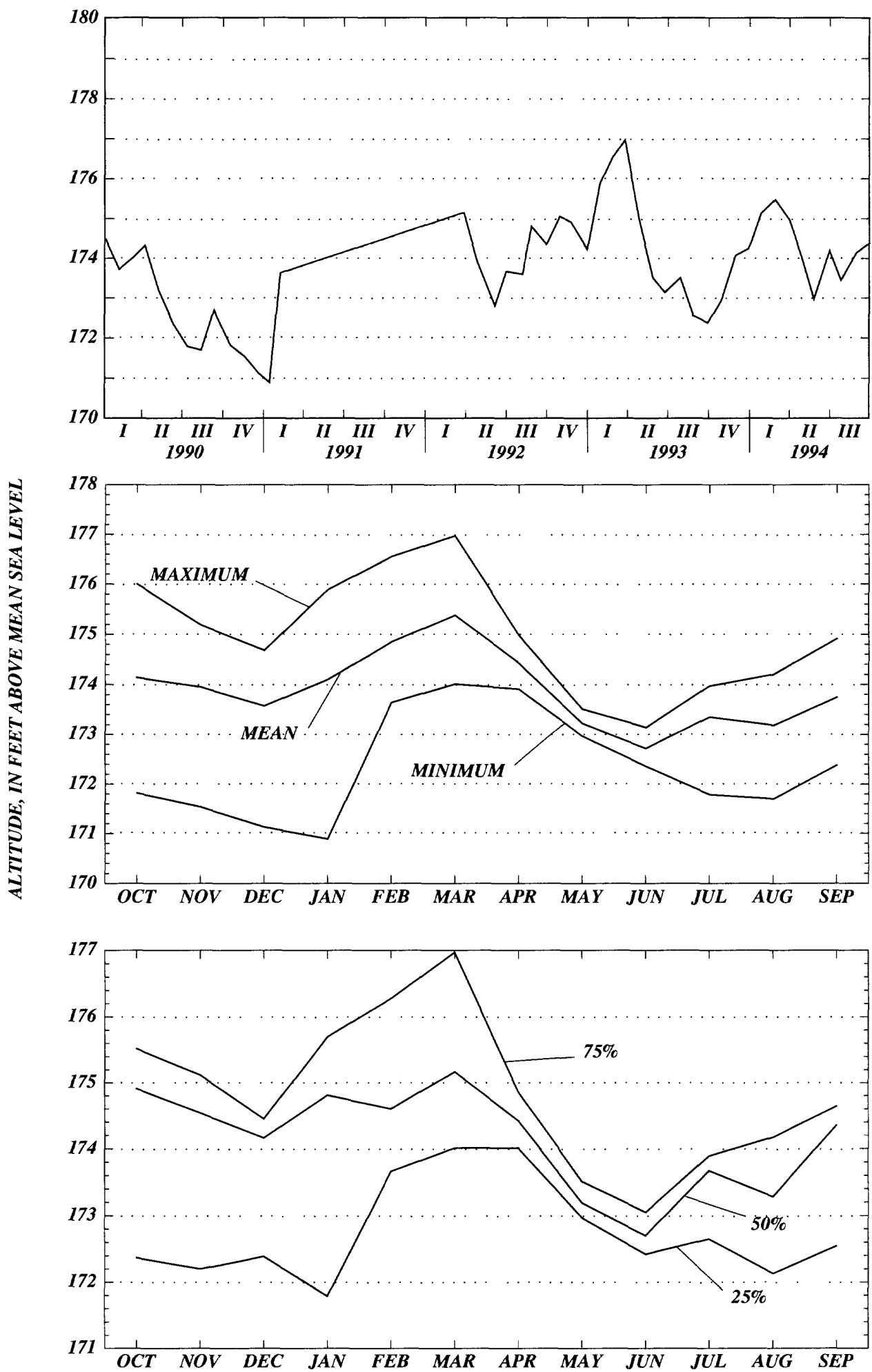


\section{Baker County}

WELL NUMBER.--301423082261185. USGS - Ocean Pond. -031908001.

LOCATION.--Lat 30¹4'23”, long 82²6'11', Hydrologic Unit Code 03070204.

AQUIFER.--Upper Floridan aquifer of the Tertiary system, Geologic Unit Code 120FLRD.

WELL CHARACTERISTICS.--Casing diameter 3 in., Casing depth $134 \mathrm{ft}$., Total depth unknown. INSTRUMENTATION.-Miscellaneous from 12-20-1960 to 06-08-1984; recorder from 06-09-1984 to 09-30-1994. Elevation of Measuring Point, $161.58 \mathrm{ft}$., NGVD.

DATUM.--The National Geodetic Vertical Datum of 1929.

PERIOD OF RECORD.--12-20-1960 to 09-30-1994. *

EXTREME VALUES.--Maximim observed, 67.42 ft. (03-08-1966); minimum, $51.68 \mathrm{ft}$. (10-07-1990).

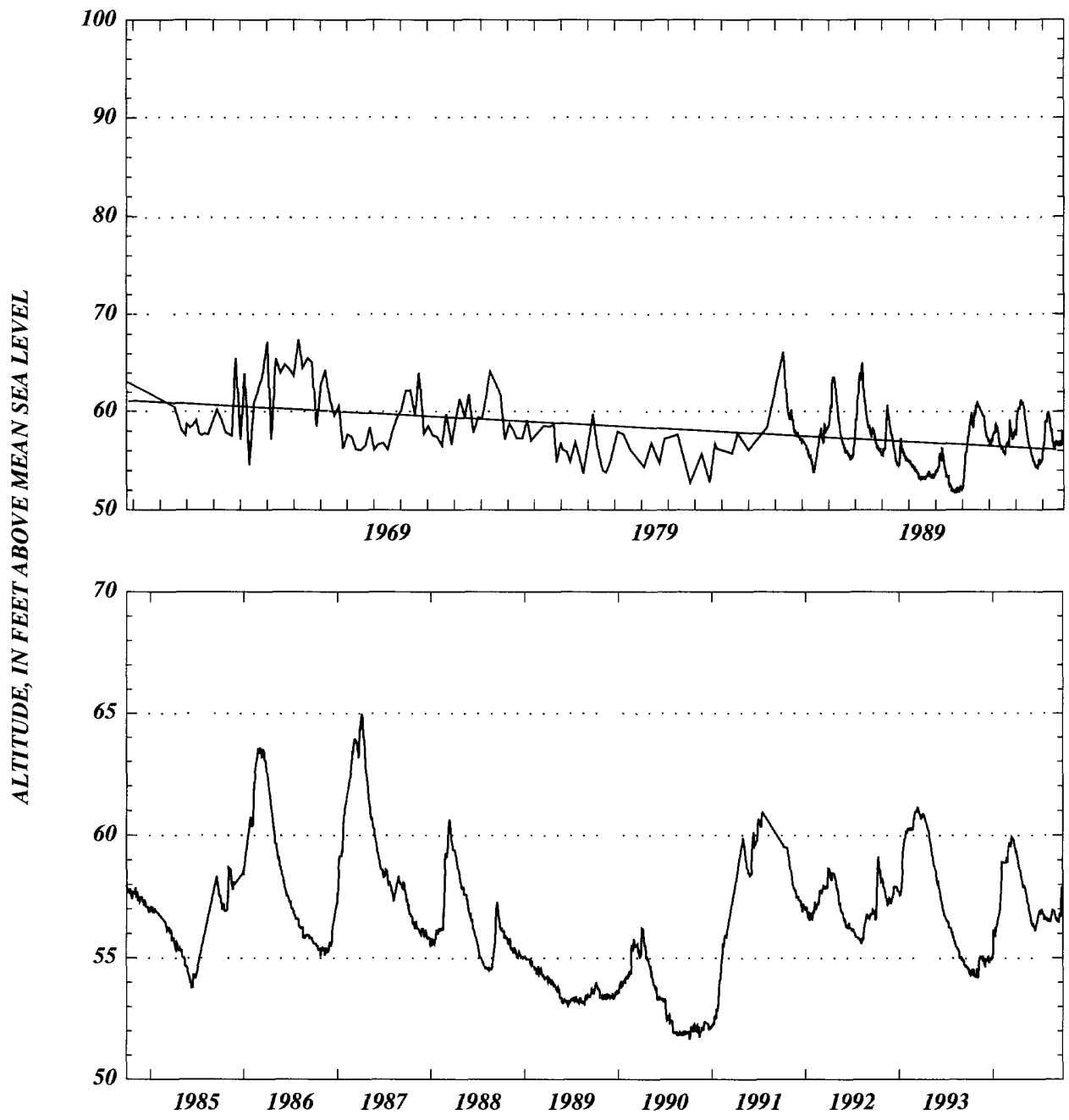



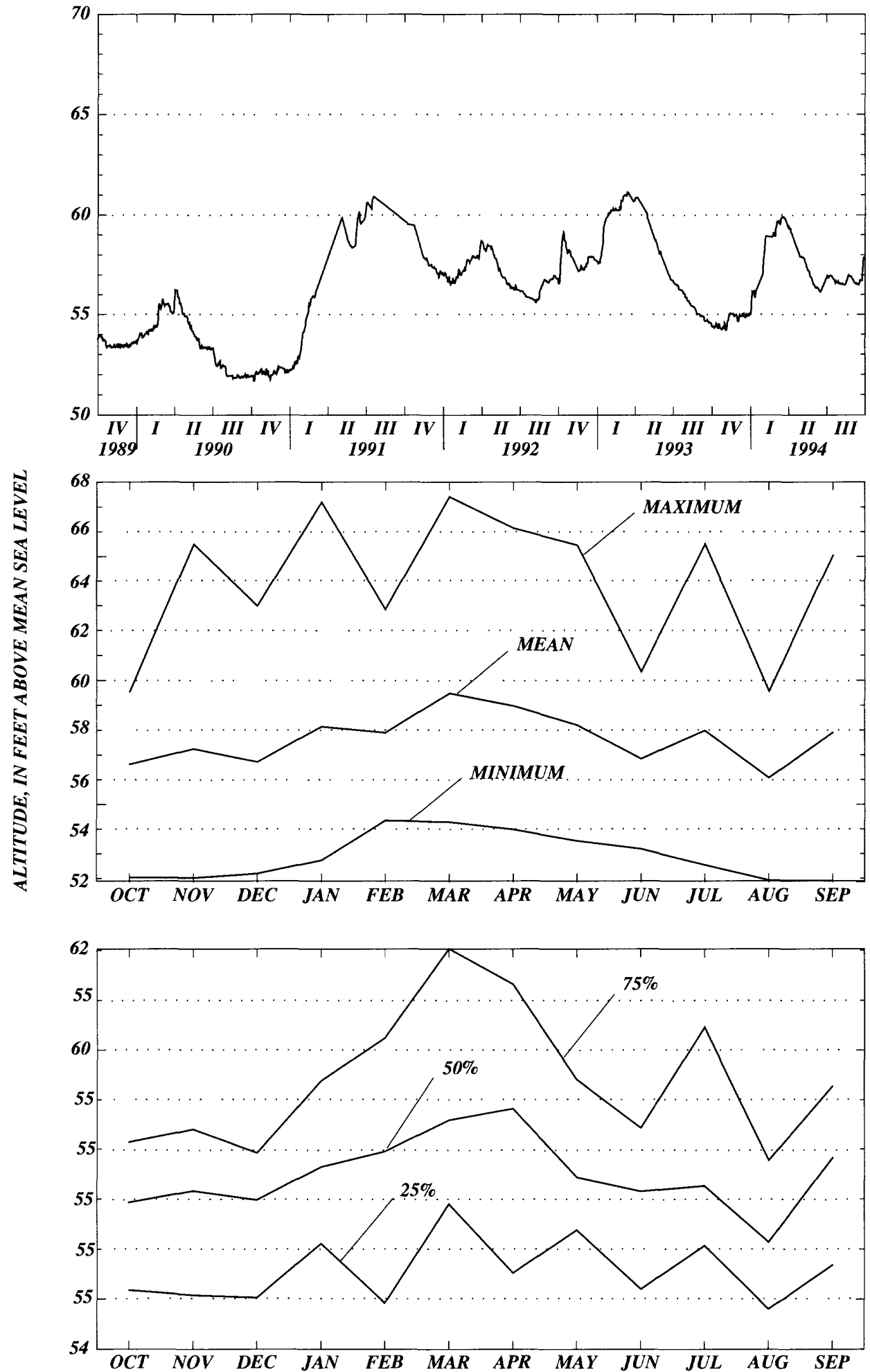


\section{Baker County}

WELL NUMBER.--301535082162085. USGS - Sanderson. -032012001.

LOCATION.--Lat 30¹5'21”, long 82¹6’20’, Hydrologic Unit Code 03070204.

AQUIFER.--Upper Floridan aquifer of the Tertiary system, Geologic Unit Code 120FLRD.

WELL CHARACTERISTICS.--Casing diameter 6 in., Casing depth $283 \mathrm{ft}$., Total depth $720 \mathrm{ft}$.

INSTRUMENTATION.--Elevation of Measuring Point $159.98 \mathrm{ft}$., NGVD.

DATUM.--The National Geodetic Vertical Datum of 1929.

PERIOD OF RECORD.--03-01-1965 to 09-30-1994. $\dagger$

EXTREME VALUES.--Maximum observed, 64.05 ft. (03-01-1965); minimum observed, $47.97 \mathrm{ft}$. (11-30-1990).

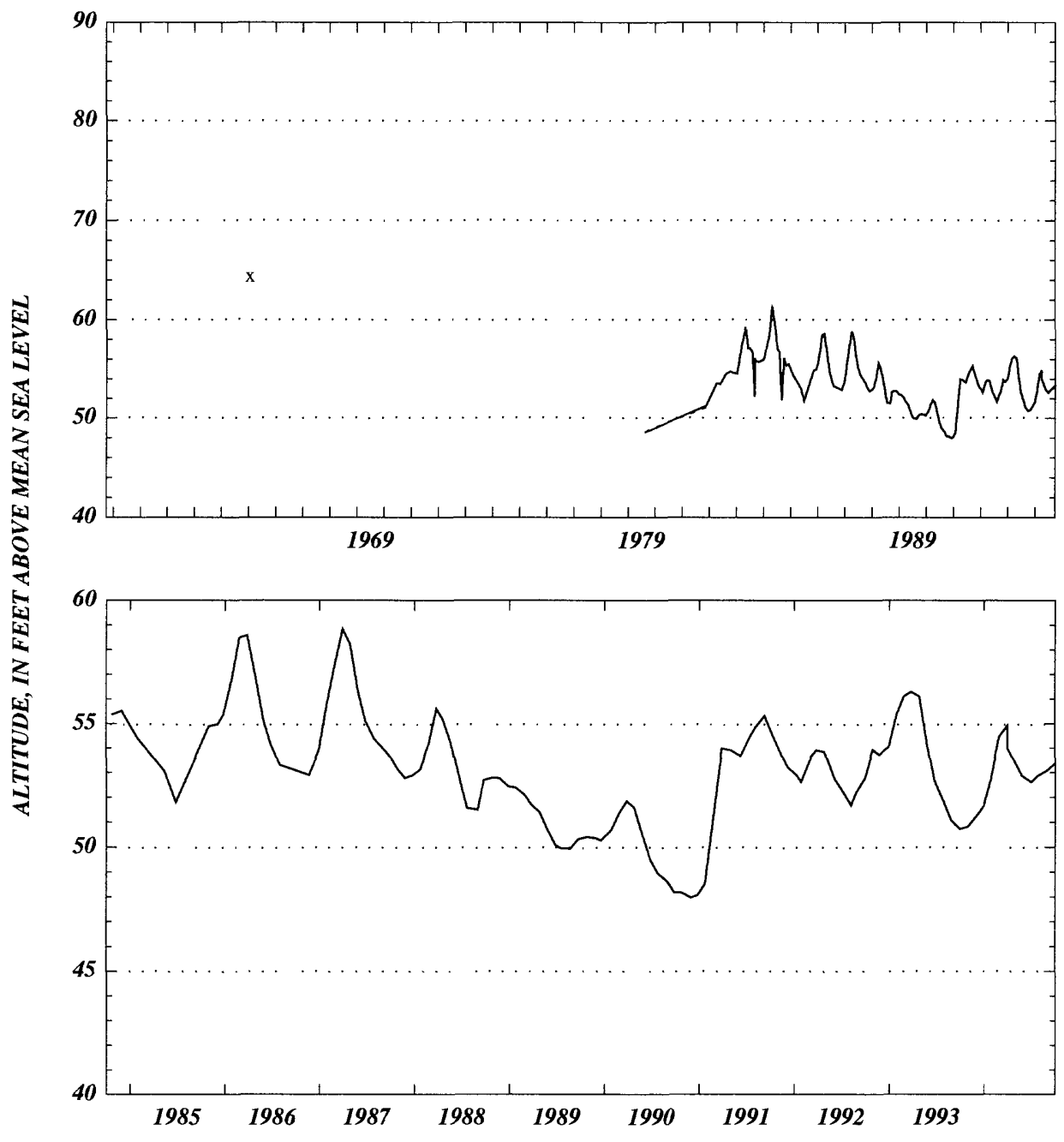



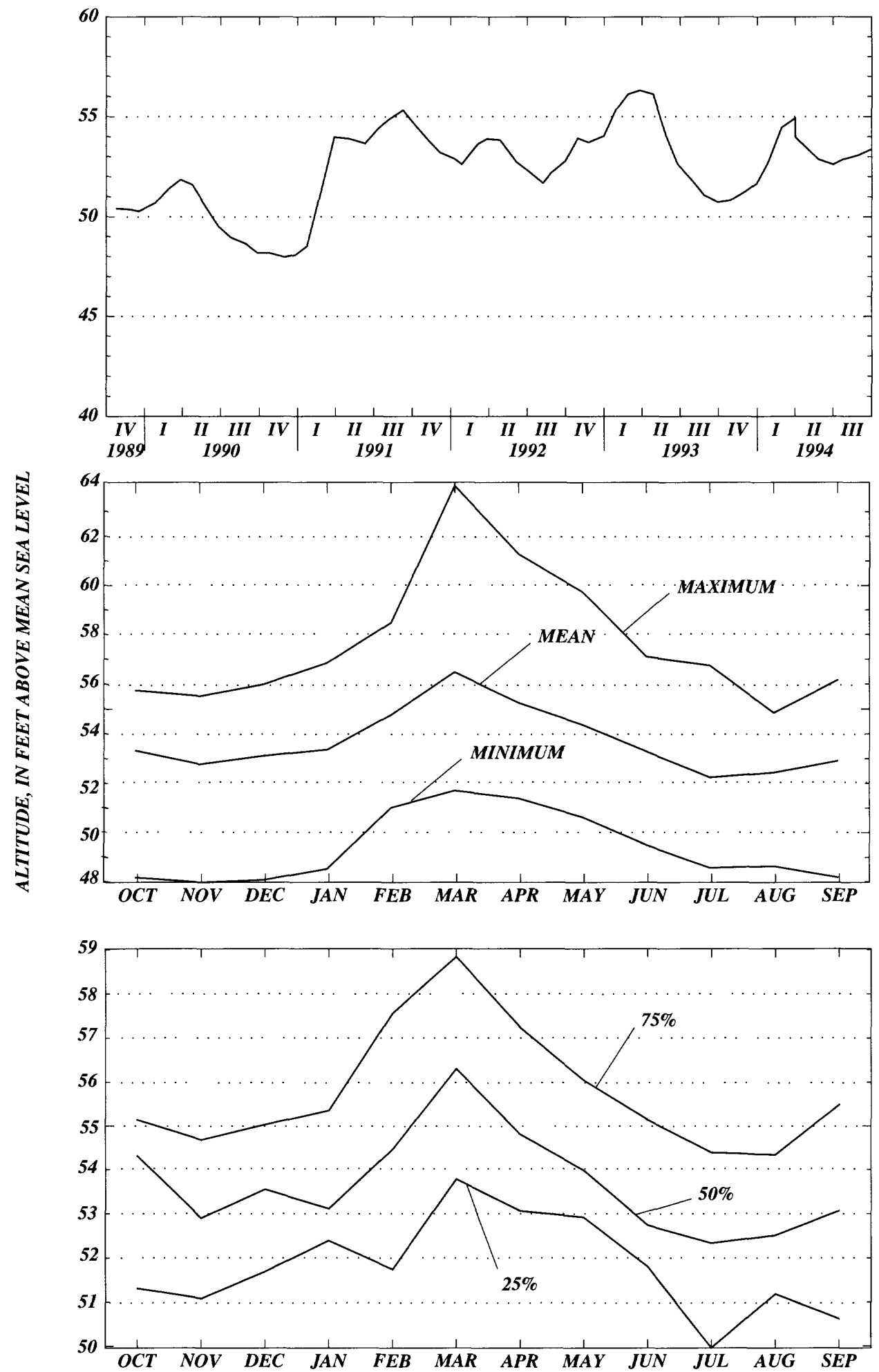


\section{Baker County}

WELL NUMBER.--301635082234085. USGS - ONF 8A. -021934001.

LOCATION.--Lat $30^{\circ} 16^{\prime} 35^{\prime \prime}$, long 82 23'40”, Hydrologic Unit Code 03070204.

AQUIFER.--Upper Floridan aquifer of the Tertiary system, Geologic Unit Code 120FLRD.

WELL CHARACTERISTICS.--Casing diameter 4 in., Casing depth $213 \mathrm{ft}$., Total depth $238 \mathrm{ft}$.

INSTRUMENTATION.--One measurement 08-01-1976; recorder from 09-13-1976 to 03-26-1977, miscellaneous 03-27-1977 to 09-30-1994. Elevation of Measuring Point 155.57 ft., NGVD.

DATUM.--The National Geodetic Vertical Datum of 1929.

PERIOD OF RECORD.--08-01-1976 to 09-30-1994.

EXTREME VALUES.--Maximum observed, $62.90 \mathrm{ft}$. (04-23-1984); minimum observed 48.13, ft. (11-30-1990).

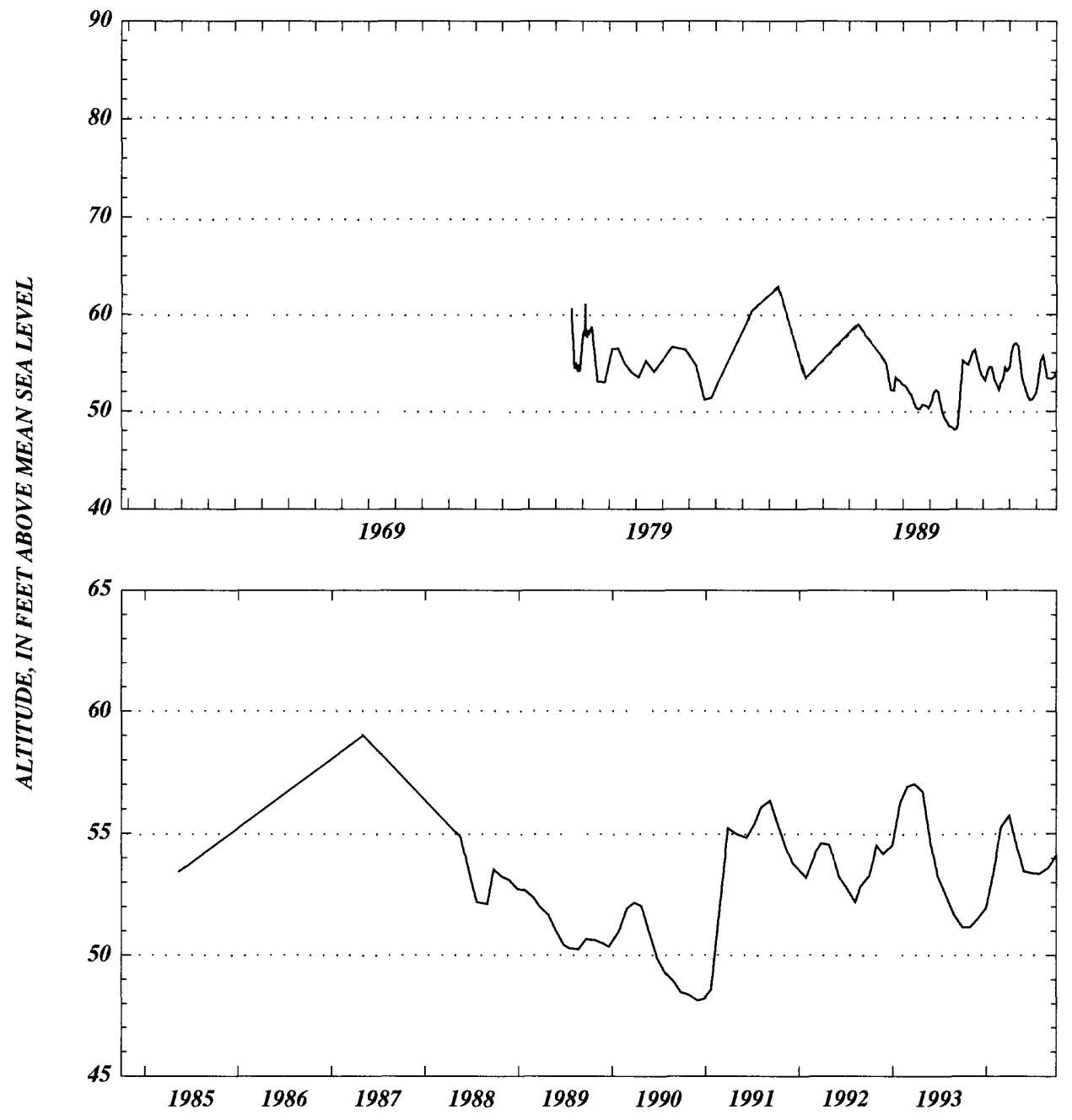



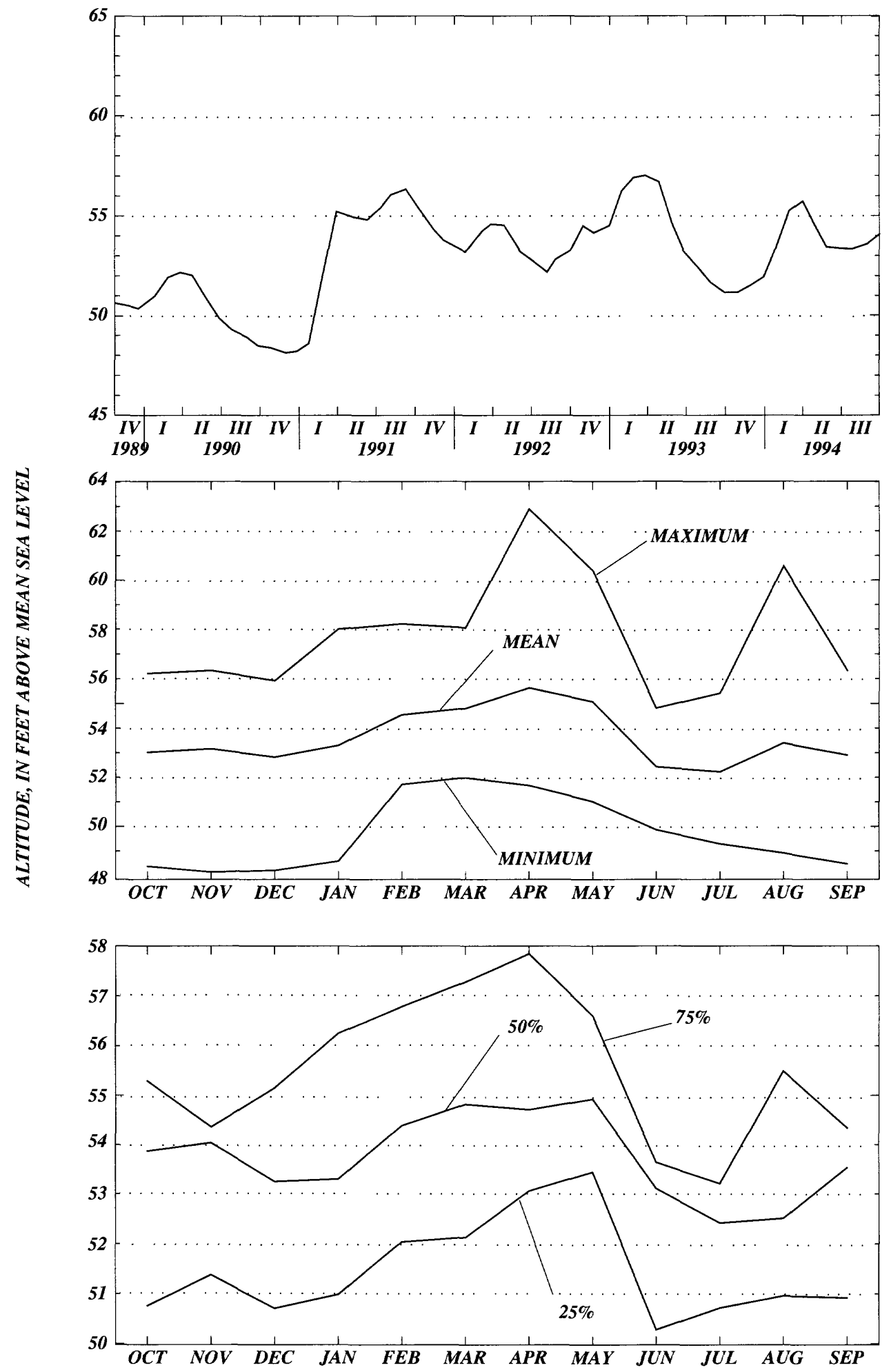


\section{Baker County}

WELL NUMBER.--301702082271585. USGS - ONF 7A. -021930001.

LOCATION.--Lat $30^{\circ} 17^{\prime} 02^{\prime \prime}$, long 82 27'14', Hydrologic Unit Code 03070204.

AQUIFER.--Upper Floridan aquifer of the Tertiary system, Geologic Unit Code 120FLRD.

WELL CHARACTERISTICS.--Casing diameter 4 in., Casing Depth $178 \mathrm{ft}$., Total depth $184 \mathrm{ft}$.

INSTRUMENTATION.--Recorder from 10-21-1976 to 05-05-1977; no record from 05-06-1977 to

05-17-1988; miscellaneous from 05-18-1988 to 09-30-1994. Elevation of Measuring Point $143.48 \mathrm{ft}$., NGVD.

DATUM.--The National Geodetic Vertical Datum of 1929.

PERIOD OF RECORD.--10-21-1976 to 09-30-1994.†

EXTREME VALUES.--Maximum, $60.83 \mathrm{ft}$ (02-09-1977); minimum observed, $48.40 \mathrm{ft}$.

(11-30-1990).

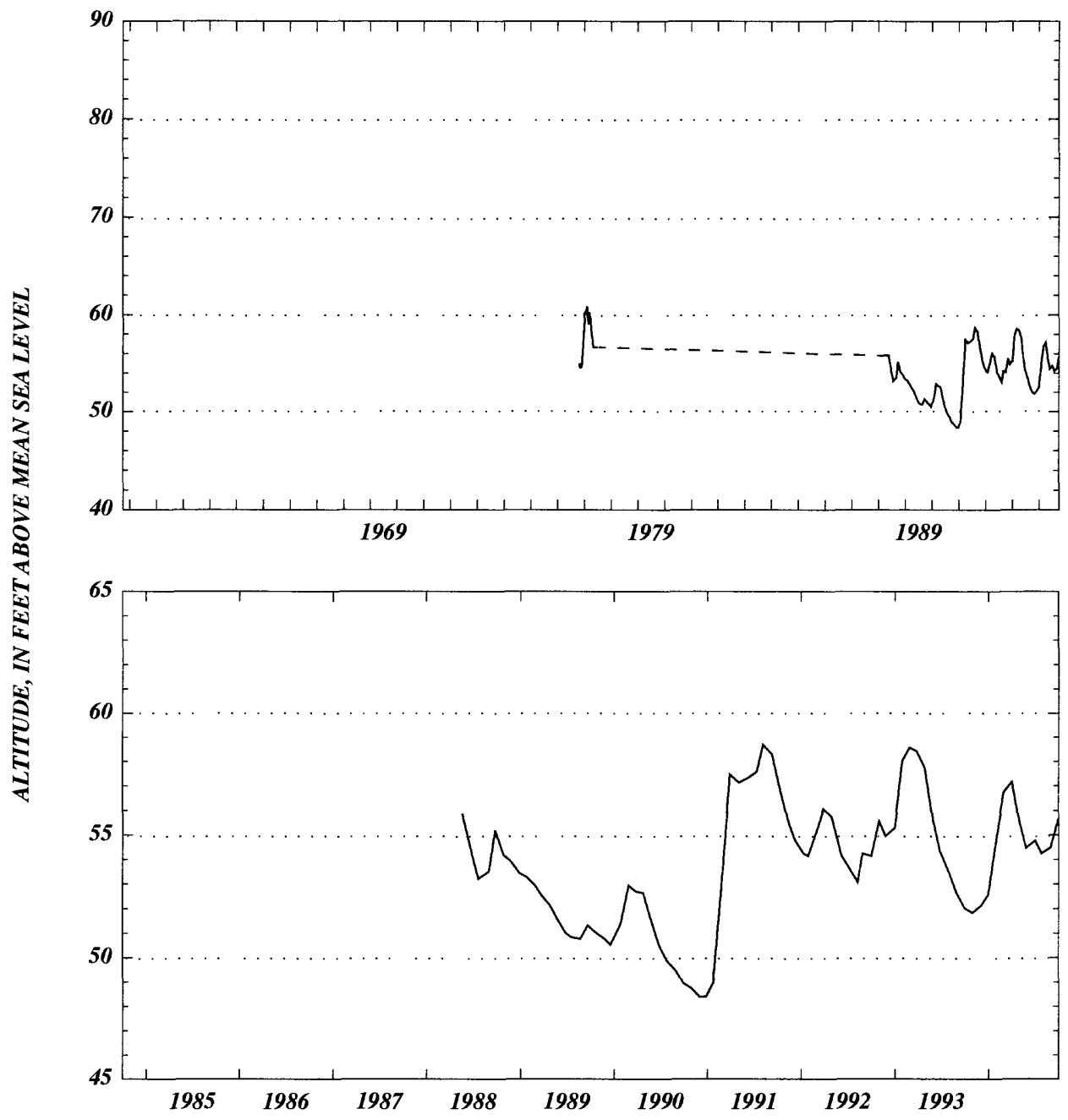



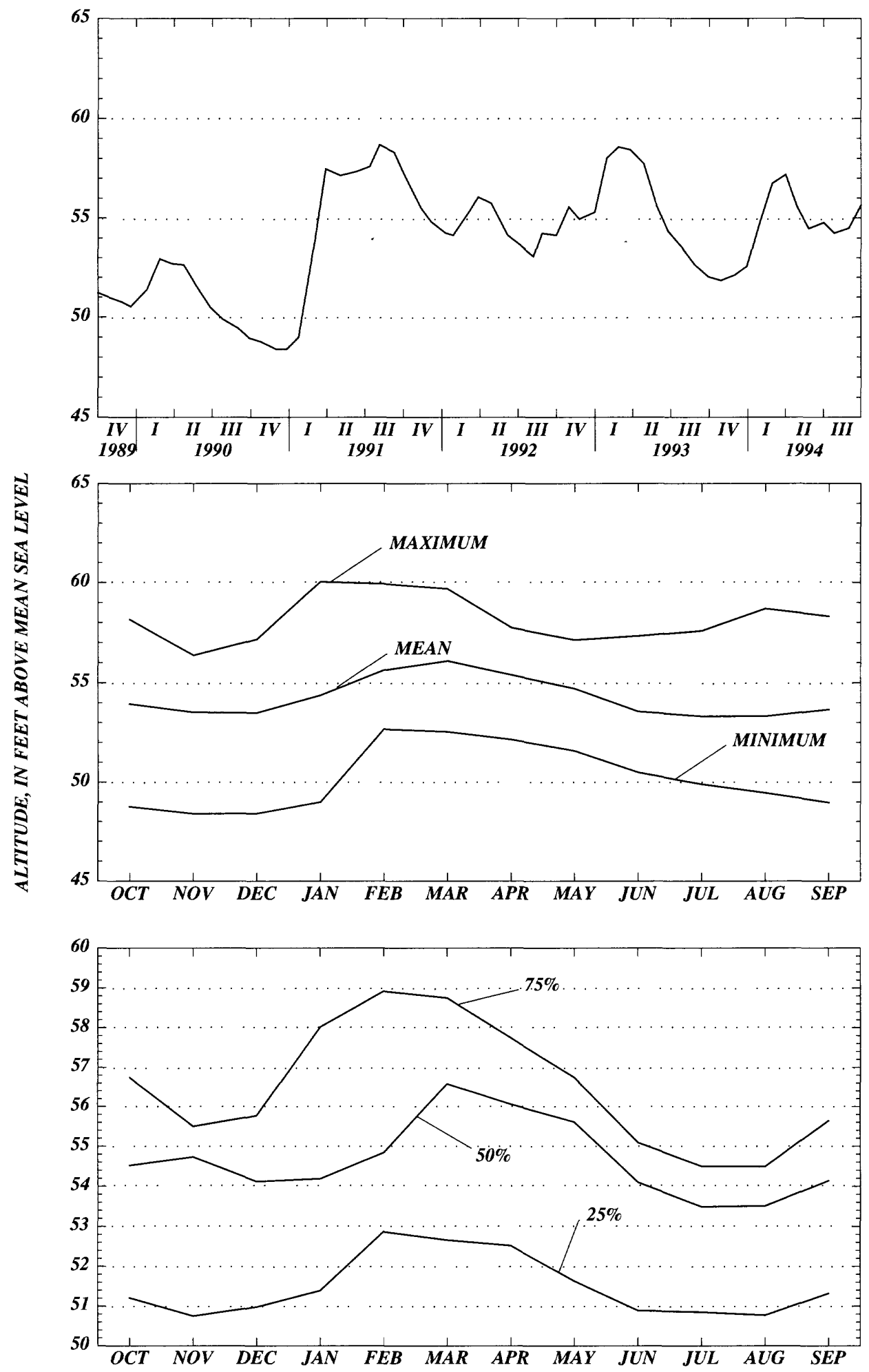


\section{Baker County}

WELL NUMBER.--302115082232285. USGS - ONF 5A. -021902001.

LOCATION.--Lat 30²1'15”, long 82²3'22”, Hydrologic Unit Code 03070204.

AQUIFER.--Upper Floridan aquifer of the Tertiary system, Geologic Unit Code 120FLRD.

WELL CHARACTERISTICS.--Casing diameter 4 in., Casing depth $270 \mathrm{ft}$., Total depth $292 \mathrm{ft}$. INSTRUMENTATION.--Recorder from 08-03-1976 to 09-30-1976; miscellaneous from 11-01 -1976 to 09-30-1994. Elevation of the Measuring Point 134.39ft., NGVD.

DATUM.--The National Geodetic Vertical Datum of 1929.

PERIOD OF RECORD.--08-03-1976 to 09-30-1994.

EXTREME VALUES.--Maximum observed, 60.49 ft. (04-23-1984); minimum observed, $45.98 \mathrm{ft}$. (11-30-1990).

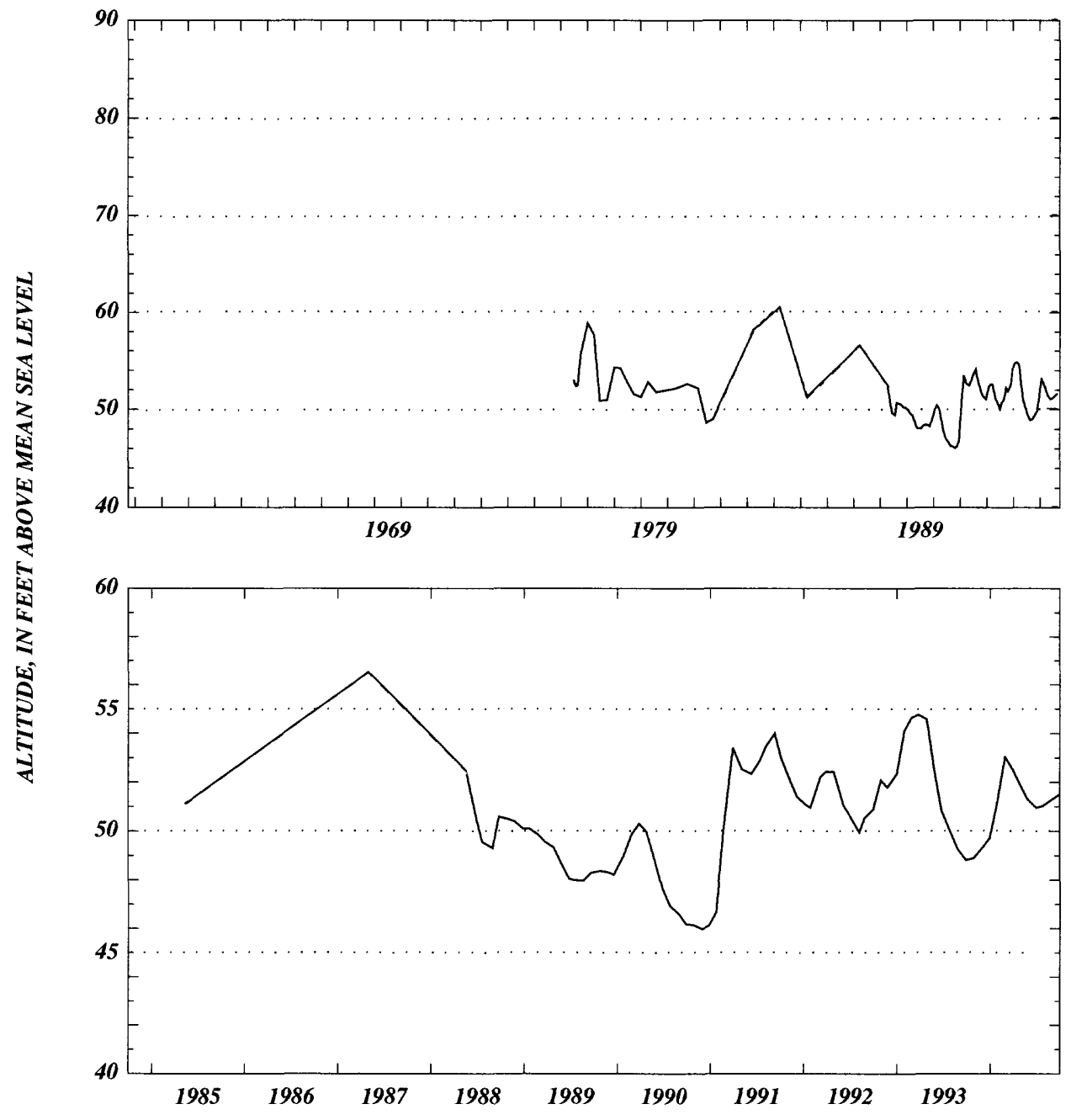



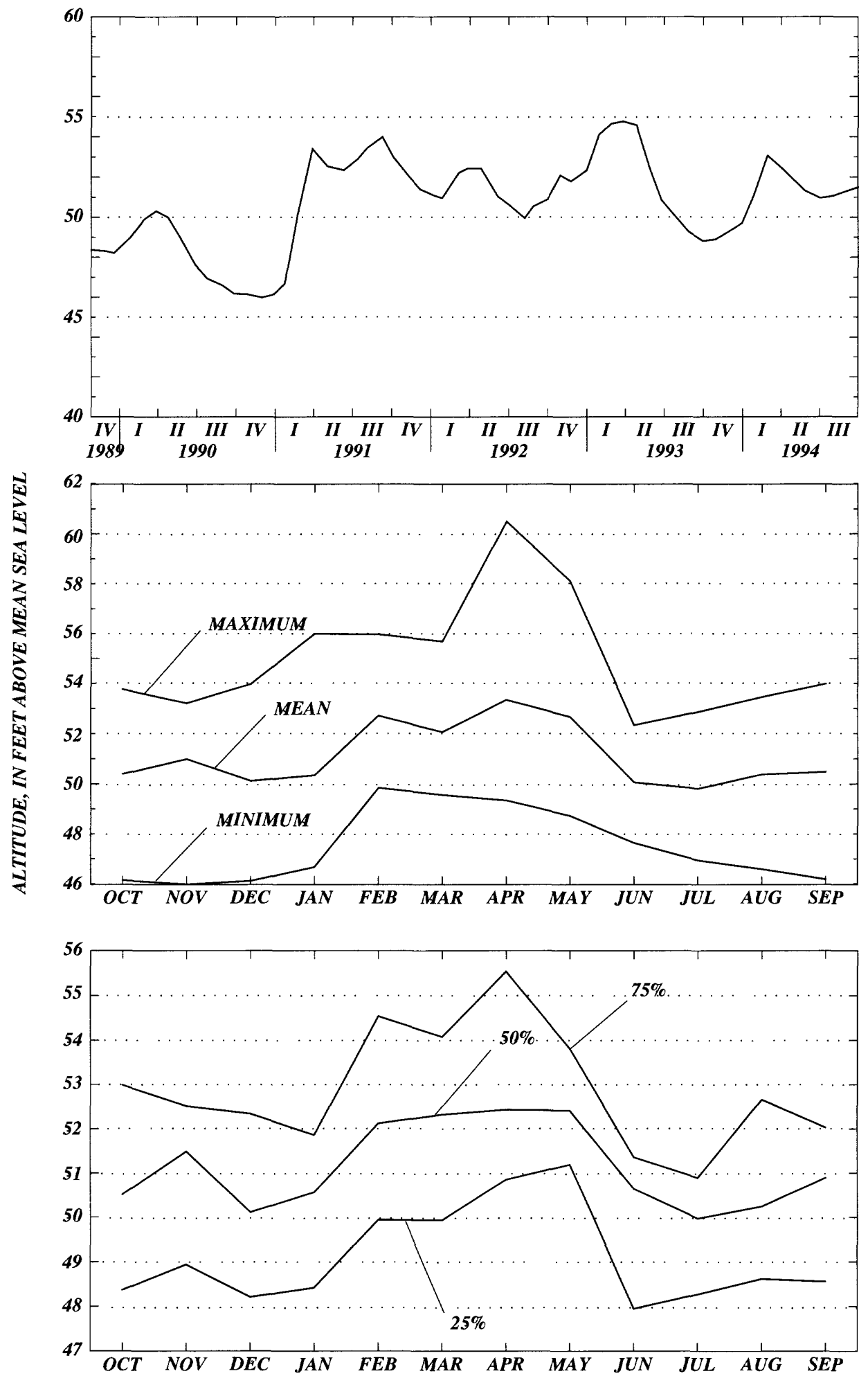


\section{Baker County}

WELL NUMBER.--302251082194985. USGS - ONF 6A. -012029001.

LOCATION.--Lat 30²2'51", long 82¹9'49”, Hydrologic Unit Code 03070204.

AQUIFER.--Upper Floridan aquifer of the Tertiary system, Geologic Unit Code 120FLRD.

WELL CHARACTERISTICS.--Casing diameter 4 in., Casing depth $319 \mathrm{ft}$., Total depth $338 \mathrm{ft}$.

INSTRUMENTATION.--Recorder, set to elevation of Measuring Point, $130.47 \mathrm{ft}$., NGVD.

DATUM.--The National Geodetic Vertical Datum of 1929.

PERIOD OF RECORD.--08-30-1976 to 09-30-1994.

EXTREME VALUES.--Maximum, 60.02 ft. (04-23-1984); minimum, 45.72 ft. (10-03-1990).

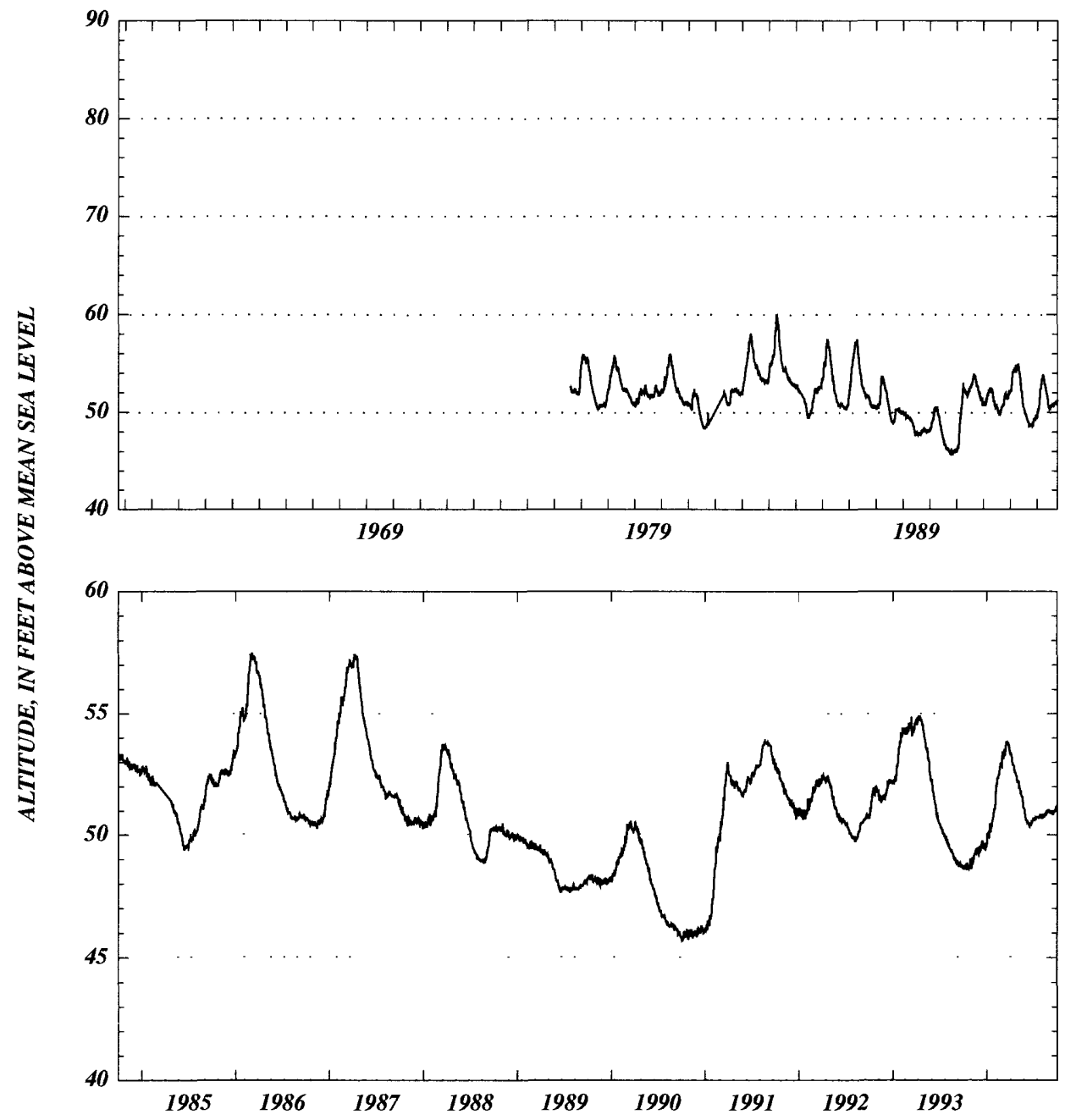



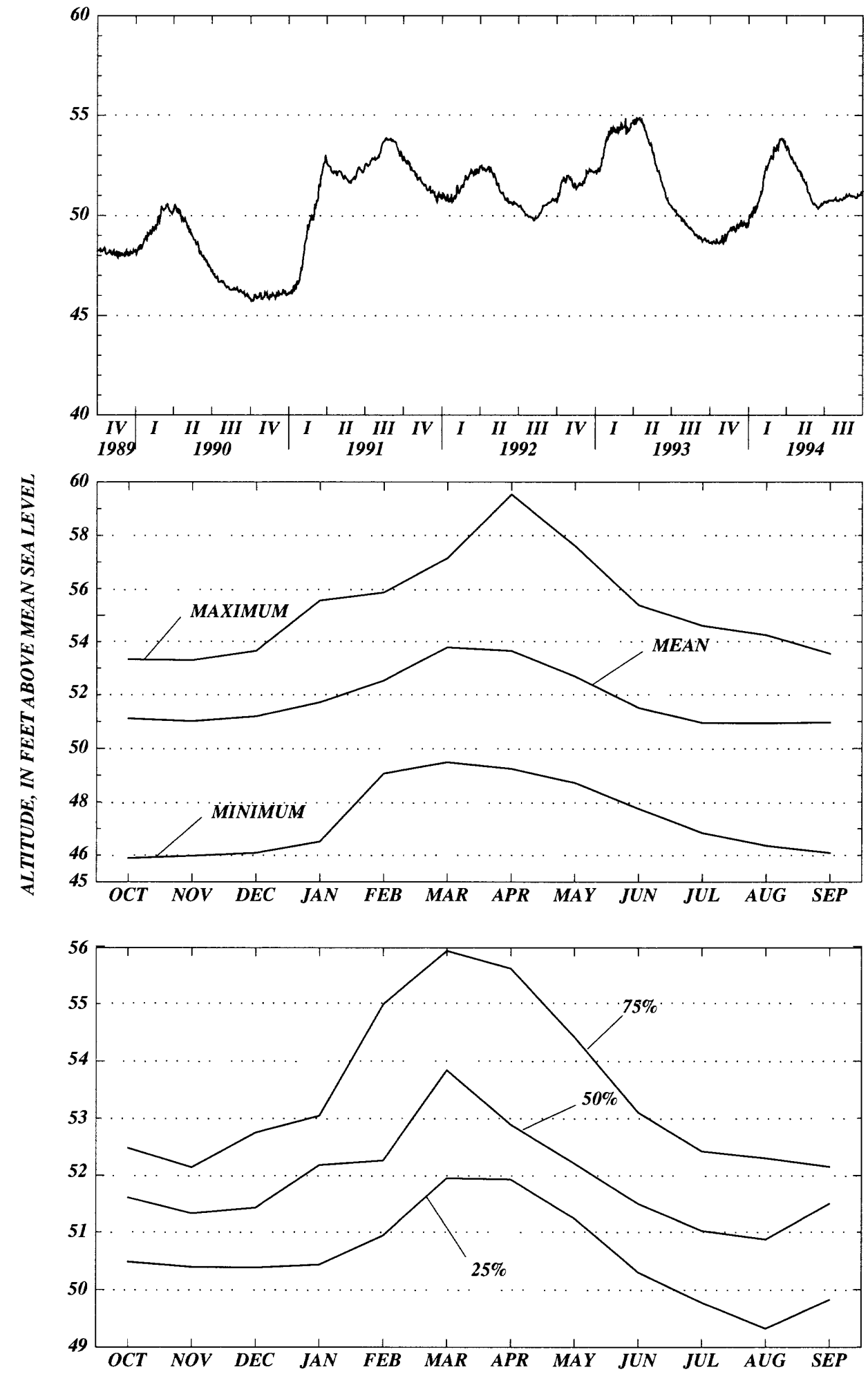


\section{Baker County}

WELL NUMBER.--302251082194986. USGS - ONF 6B. -012029003.

LOCATION.--Lat 30²2'50”, long 82¹9’49”, Hydrologic Unit Code 03070204.

AQUIFER.--Intermediate aquifer, Geologic Unit Code 122HTRN.

WELL CHARACTERISTICS.--Casing diameter 4 in., Casing depth $117 \mathrm{ft}$., Total depth $122 \mathrm{ft}$. INSTRUMENTATION.--Recorder from 08-17-1976 to 04-13-1982; no record from 04-15-1982 to 05-27-1987; miscellaneous from 04-14-1982 to 09-30-1994. Elevation of Measuring Point $131.59 \mathrm{ft}$., NGVD.

DATUM.--The National Geodetic Vertical Datum of 1929.

PERIOD OF RECORD.--08-17-1976 to 09-30-1994. *

EXTREME VALUES.--Maximum, 120.09 ft. (04-08-1980); minimum, 114.06 ft. (12-30-1978).

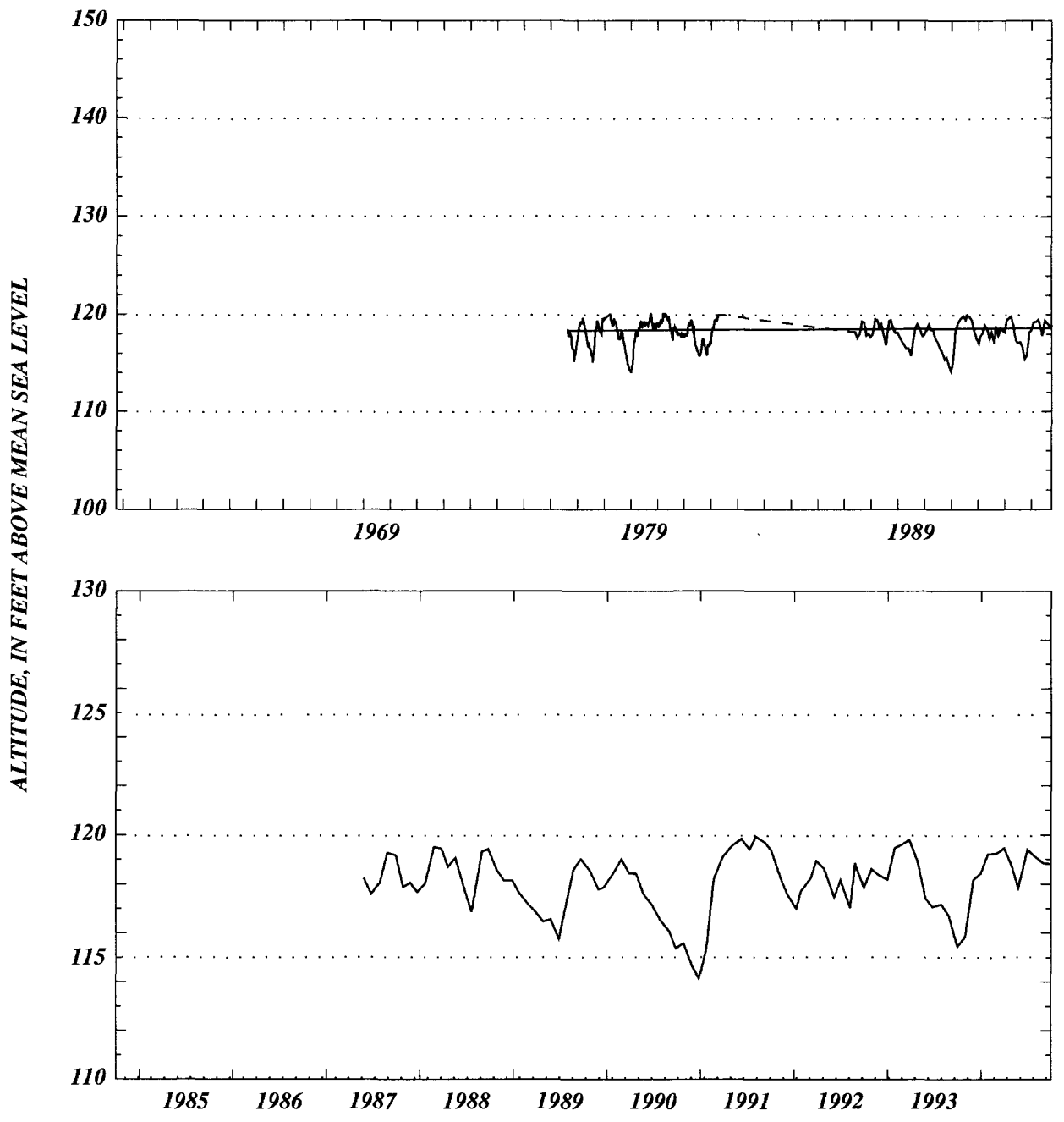



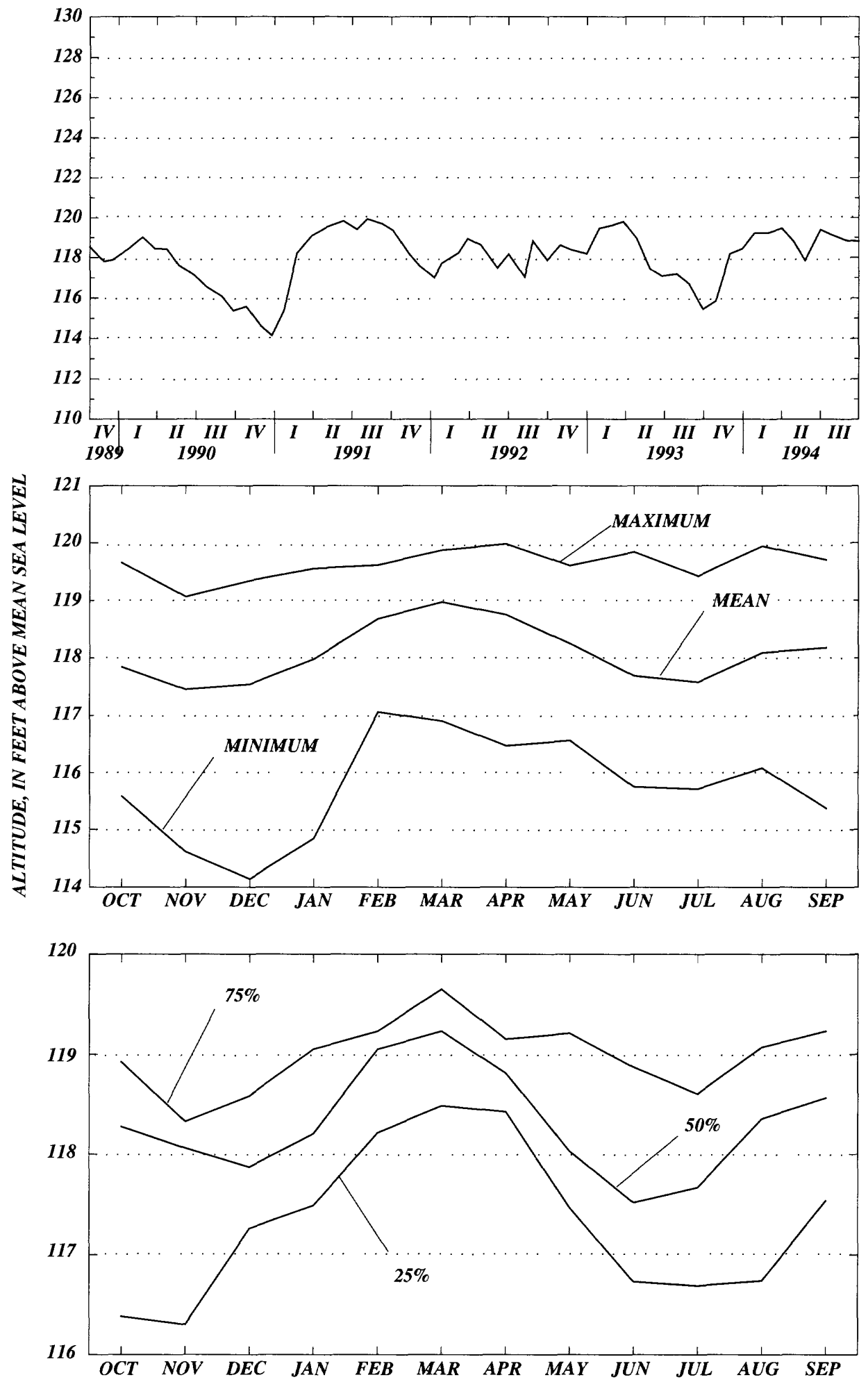


\section{Baker County}

WELL NUMBER.--302620082173585. USGS - Taylor. -012003001.

LOCATION.--Lat 30²6'25”, long 82¹7'20”, Hydrologic Unit Code 03070204.

AQUIFER.--Upper Floridan aquifer of the Tertiary system, Geologic Unit Code 120FLRD.

WELL CHARACTERISTICS.--Casing diameter 6 in., Casing depth $415 \mathrm{ft}$., Total depth $903 \mathrm{ft}$.

INSTRUMENTATION.--Elevation of Measuring Point $118.30 \mathrm{ft}$., NGVD.

DATUM.--The National Geodetic Vertical Datum of 1929.

PERIOD OF RECORD.--01-01-1973 to 09-30-1994. $\dagger$

EXTREME VALUES.--Maximum observed, $62.50 \mathrm{ft}$. (01-01-1973); minimum, $45.40 \mathrm{ft}$. (11-30-1990).

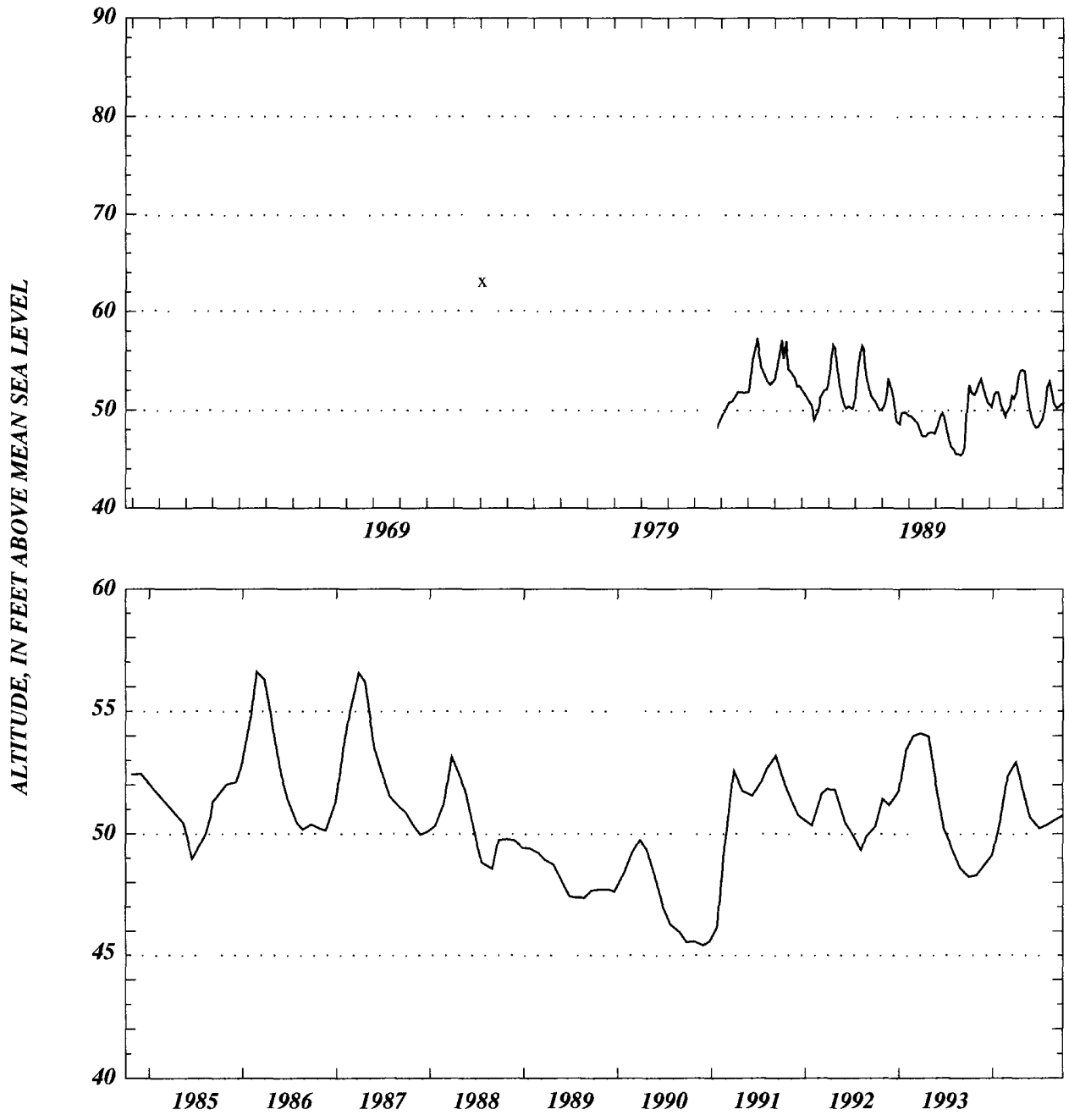



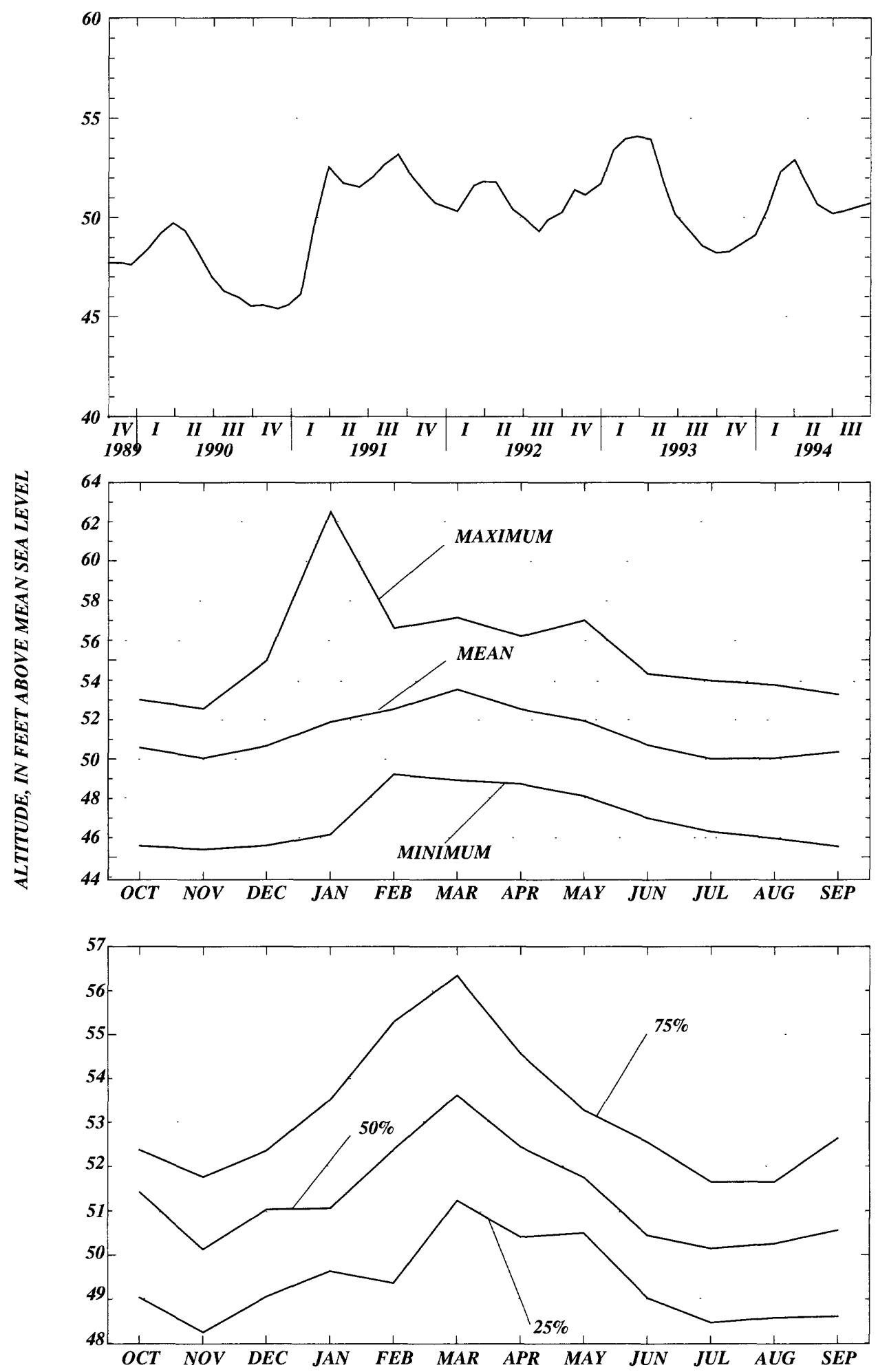


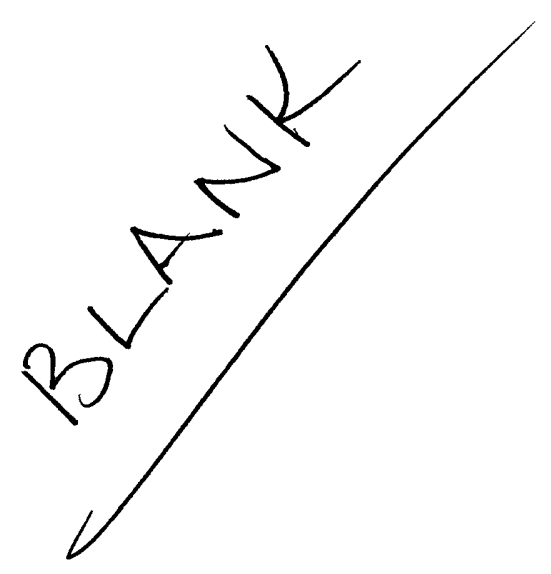




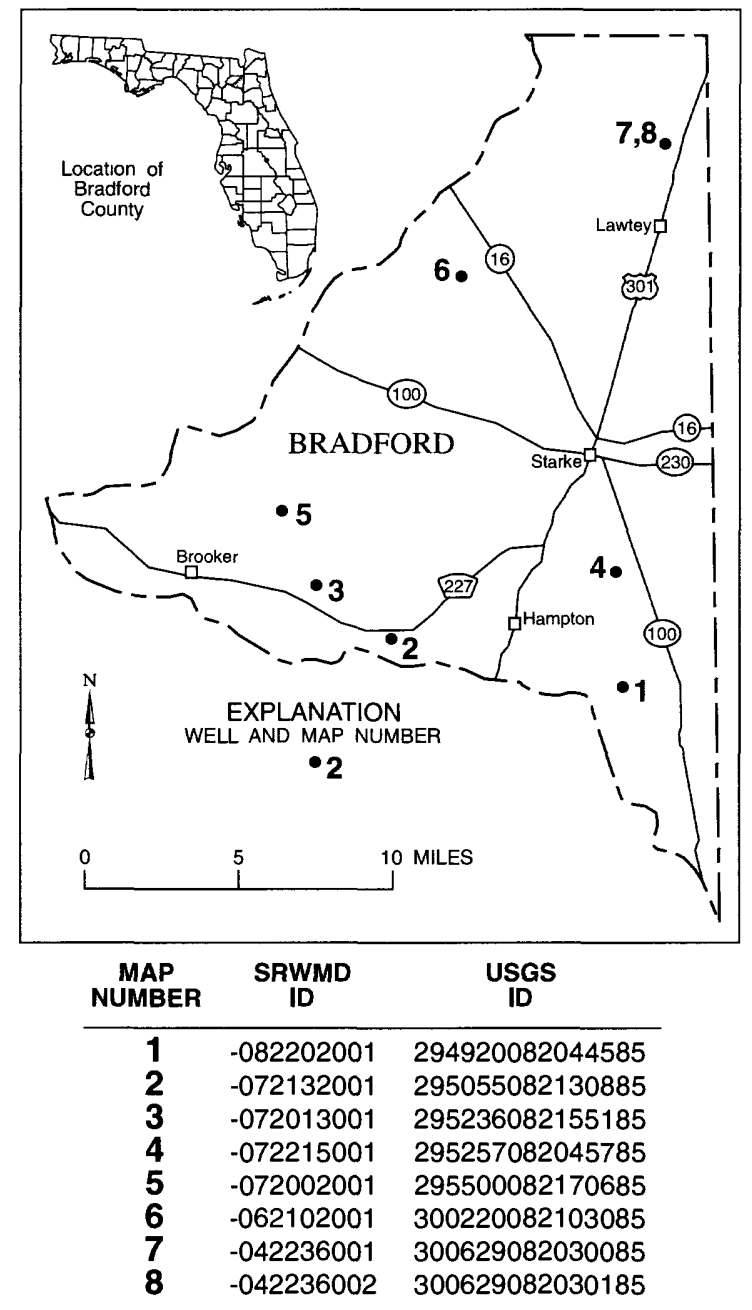

Figure 4. Location of wells in Bradford County. 


\section{Bradford County}

WELL NUMBER.--294920082044585. SRWMD - Santa Fe Swamp. -082202001.

LOCATION.--Lat 2949’20”, long 8204'45”, Hydrologic Unit Code 03110206.

AQUIFER.--Upper Floridan aquifer of the Tertiary system, Geologic Unit Code 120FLRD.

WELL CHARACTERISTICS.--Casing diameter 4 in., Casing depth $168 \mathrm{ft}$., Total depth $208 \mathrm{ft}$.

INSTRUMENTATION.--Recorder, set to elevation of the Measuring Point, 150.42 ft., NGVD.

DATUM.--The National Geodetic Vertical Datum of 1929.

PERIOD OF RECORD.--02-12-1988 to 09-30-1994.

EXTREME VALUES.--Maximum, 78.98 ft. (10-03-1988); minimum, 72.07 ft. (01-23-1990.

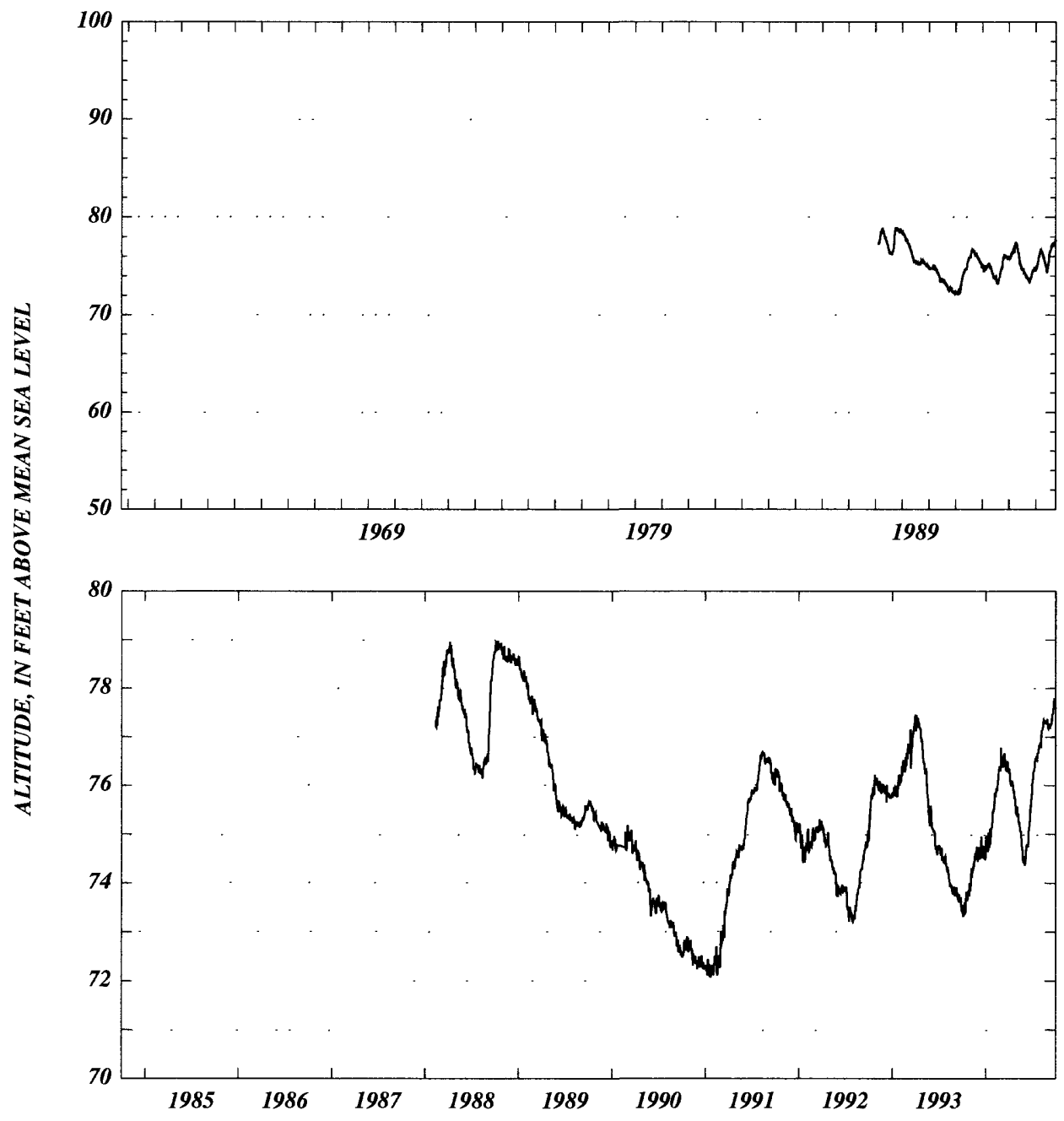



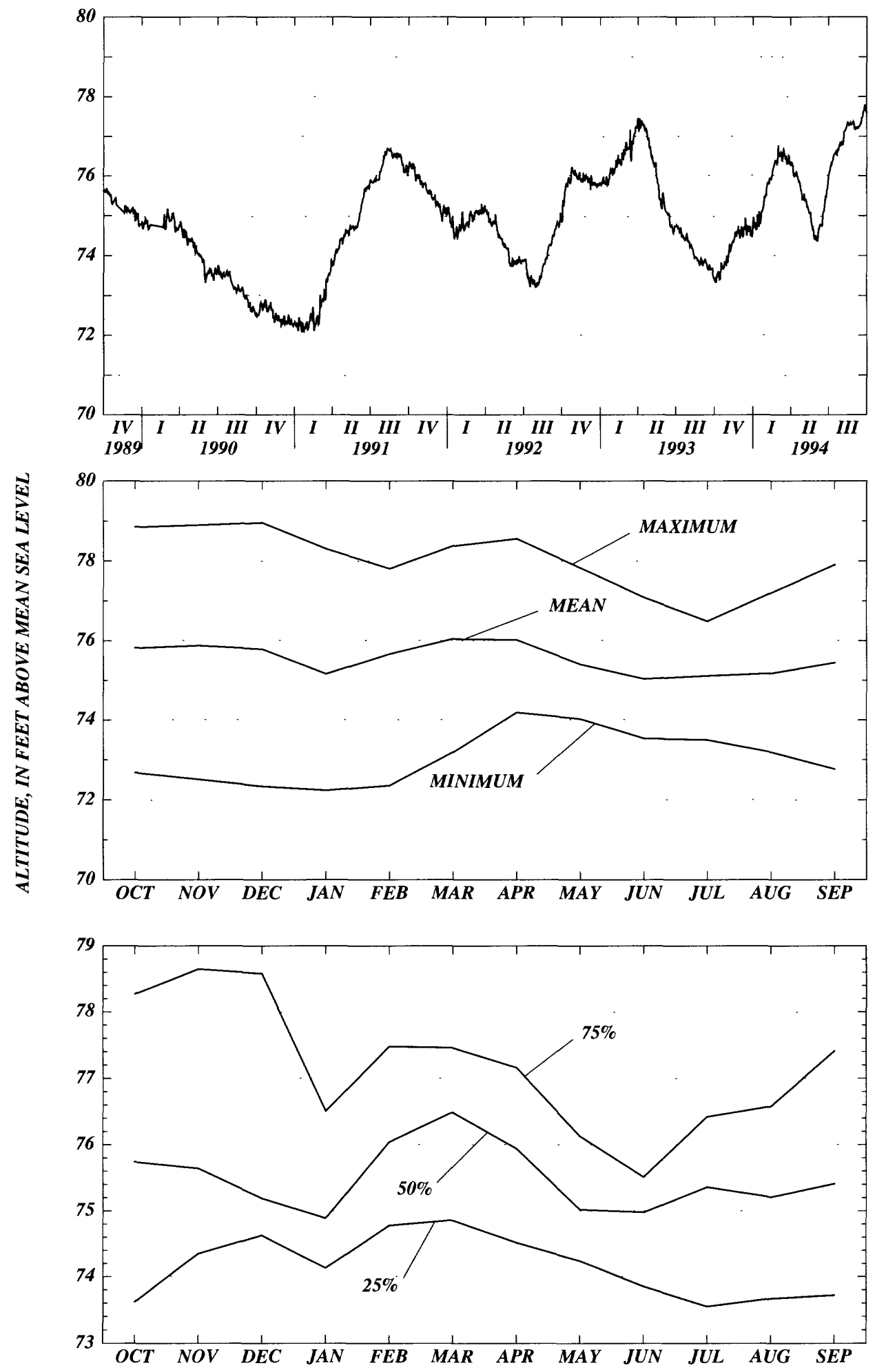


\section{Bradford County}

WELL NUMBER.--295055082130885. USGS - Graham. -072132001.

LOCATION.--Lat 2950'55”, long 82¹3'08”, Hydrologic Unit Code 03110206.

AQUIFER.--Upper Floridan aquifer of the Tertiary system, Geologic Unit Code 120FLRD.

WELL CHARACTERISTICS.--Casing diameter 4 in., Casing depth $172 \mathrm{ft}$., Total depth $206 \mathrm{ft}$. INSTRUMENTATION.--Recorder, set to elevation of the Measuring Point, 141.21 ft., NGVD.

DATUM.--The National Geodetic Vertical Datum of 1929.

PERIOD OF RECORD.--11-01-1976 to 09-30-1994.

EXTREME VALUES.--Maximum, 68.81 ft. (04-23-1984); minimum, 57.58 ft. (11-30-1990)

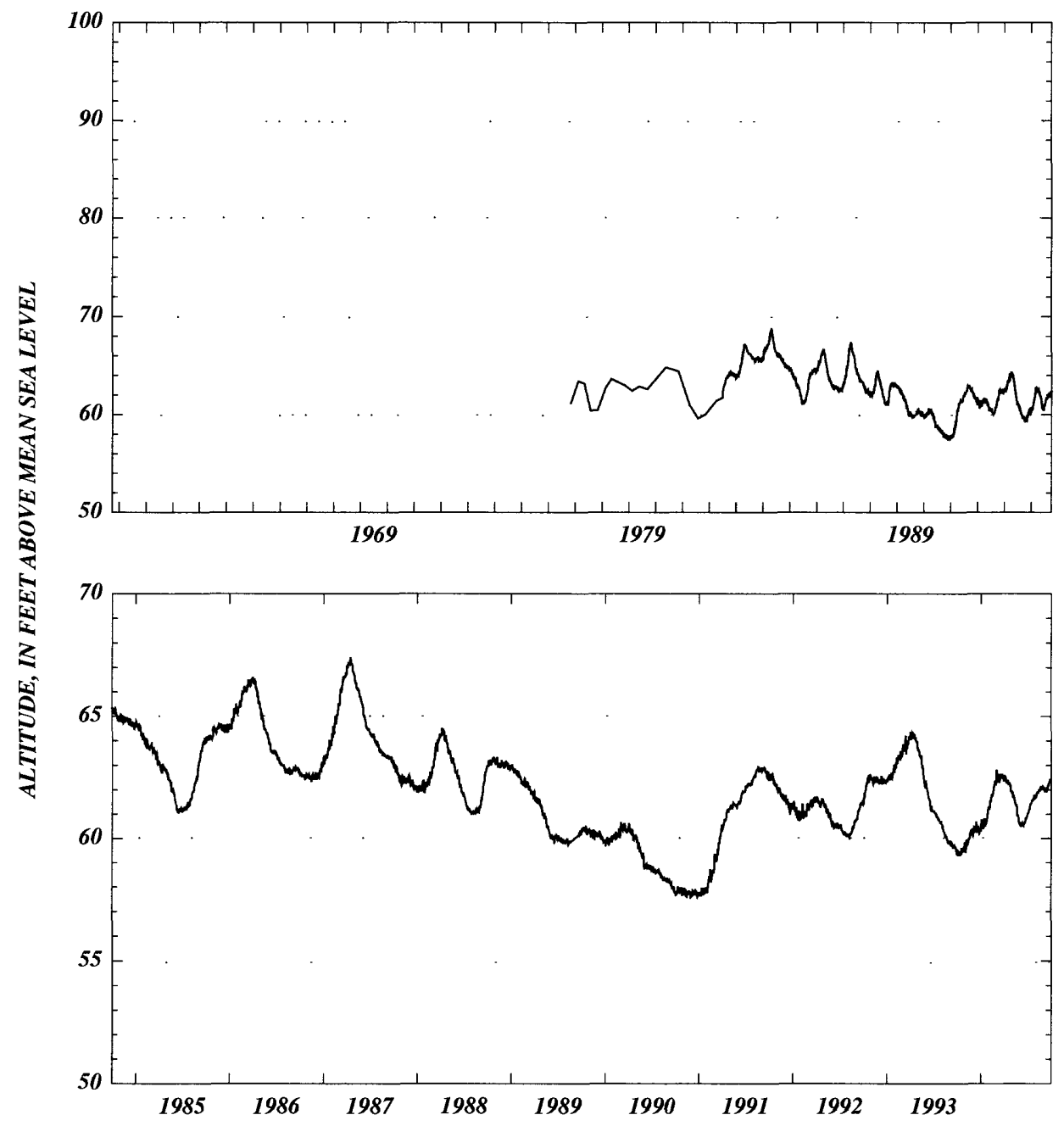



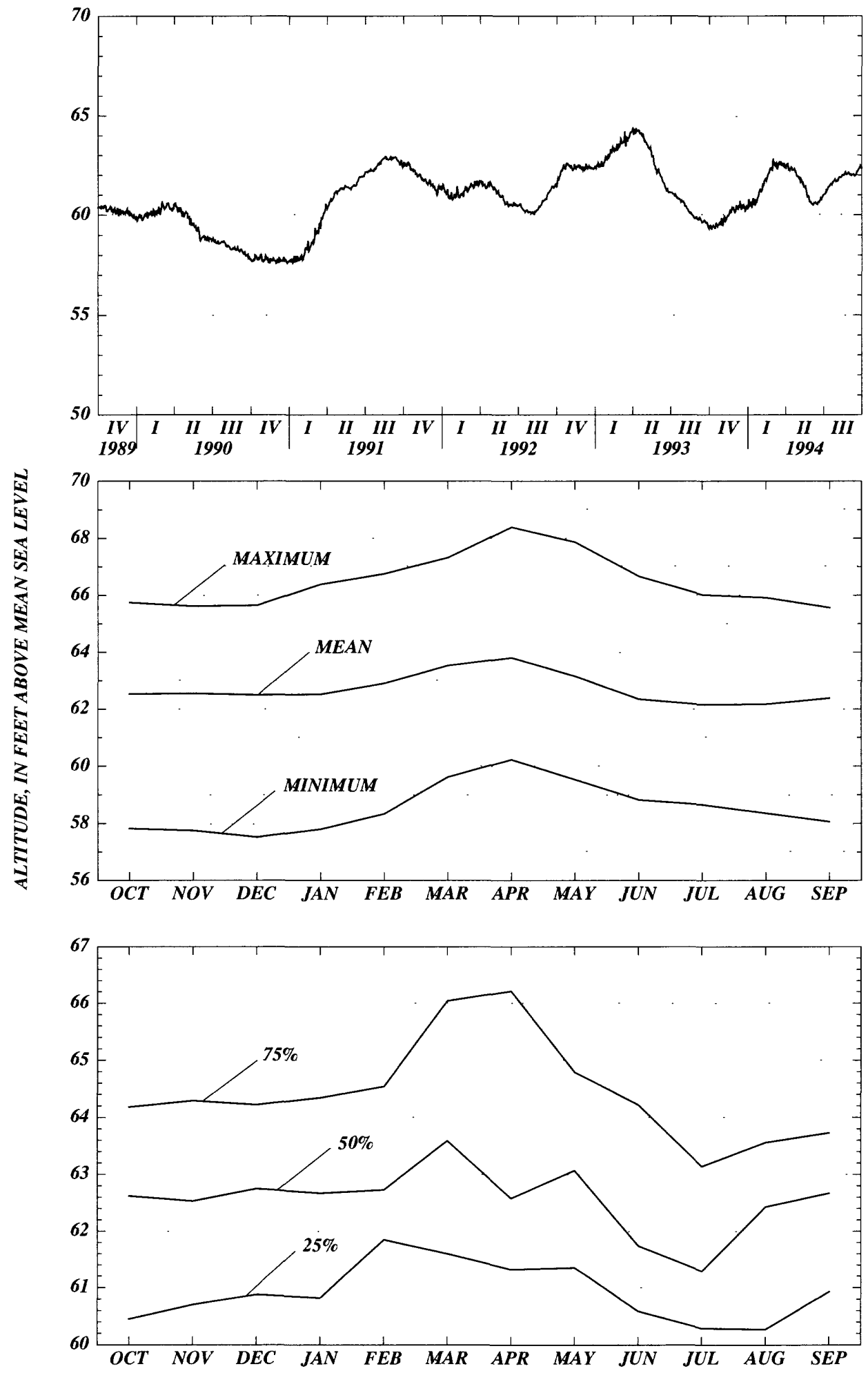


\section{Bradford County}

WELL NUMBER.--295236082155185. Richard Thomason. -072013001.

LOCATION.--Lat 29'52'36”, long, 82¹5'51", Hydrologic Unit Code 03080103.

AQUIFER.--Intermediate aquifer, Geologic Unit Code 122HTRN.

WELL CHARACTERISTICS.--Casing diameter 4 in., Casing depth $48 \mathrm{ft}$. Total depth $65 \mathrm{ft}$.

INSTRUMENTATION.--Elevation of Measuring Point $158.22 \mathrm{ft}$., NGVD.

DATUM.--The National Geodetic Vertical Datum of 1929.

PERIOD OF RECORD.--06-05-1989 to 09-30-1994. *

EXTREME VALUES.--Maximum observed, 140.09 ft. (10-19-1992); minimum observed, 133.34 ft. (10-06-1993).

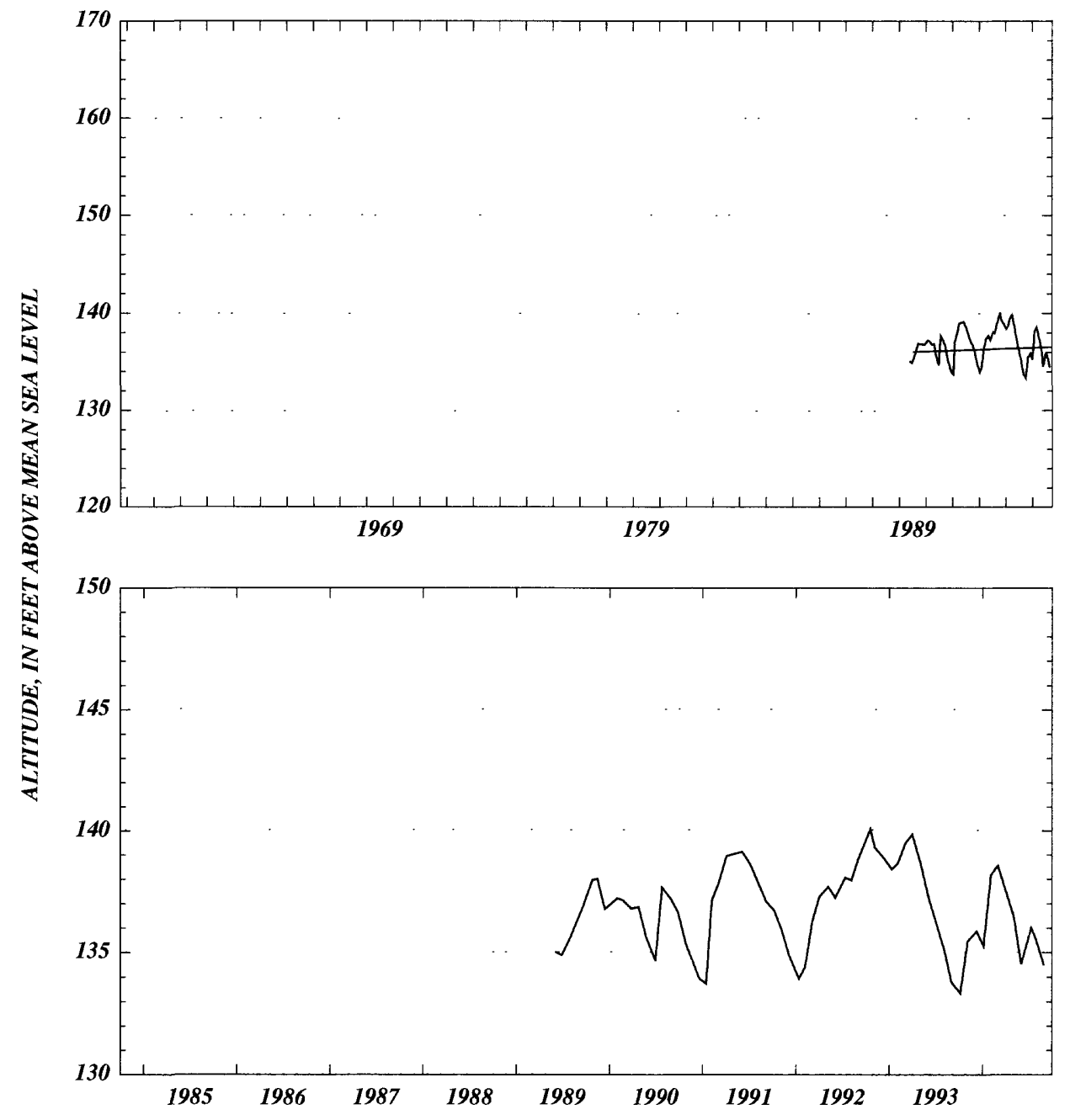



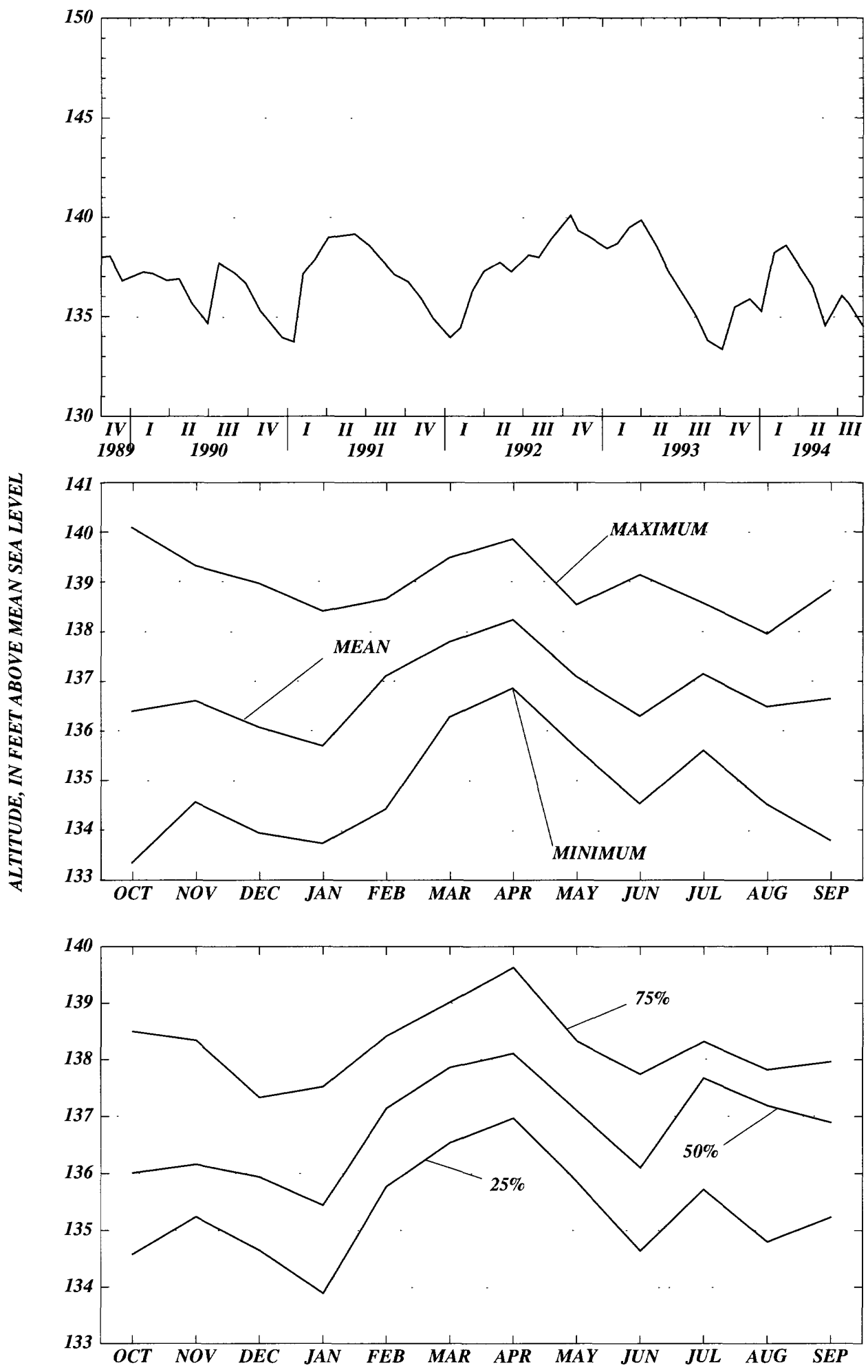


\section{Bradford County}

WELL NUMBER.--295257082045785. USGS - Starke. -072215001.

LOCATION.--Lat 29'52'57”, long 8204'57”, Hydrologic Unit Code 03110206.

AQUIFER.--Upper Floridan aquifer of the Tertiary system, Geologic Unit Code 120FLRD.

WELL CHARACTERISTICS.--Casing diameter 4 in., Casing depth $234 \mathrm{ft}$., Total depth $324 \mathrm{ft}$. INSTRUMENTATION.--Miscellaneous from 11-01-1976 to 08-25-1982, then recorder, set to elevation of the Measuring Point, $176.34 \mathrm{ft}$., NGVD.

DATUM.--The National Geodetic Vertical Datum of 1929.

PERIOD OF RECORD.--11-01-1976 to 09-30-1994.

EXTREME VALUES.--Maximum, 88.50 ft. (05-04-1984); minimum, $79.10 \mathrm{ft}$. (01-10-1990).

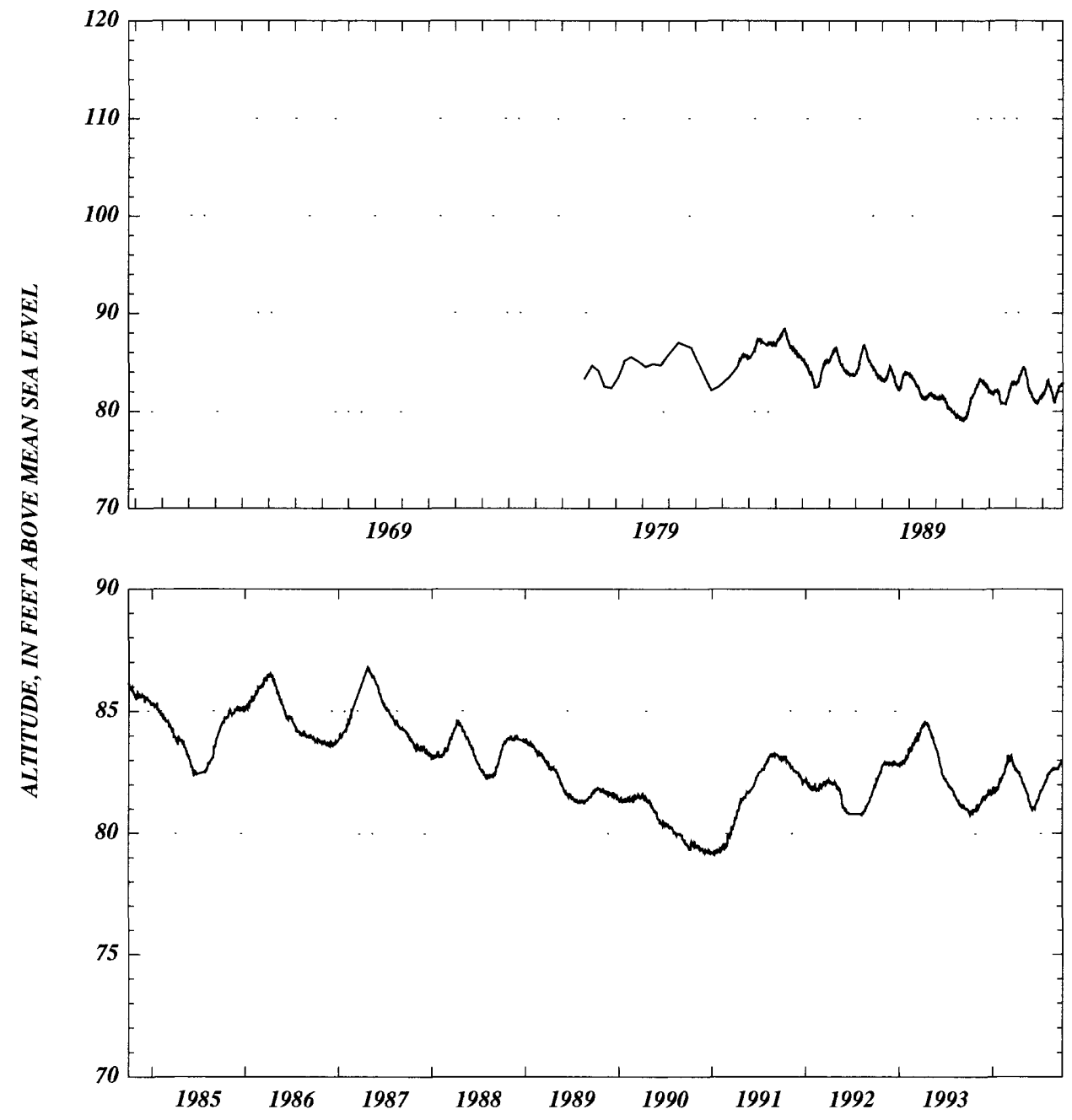



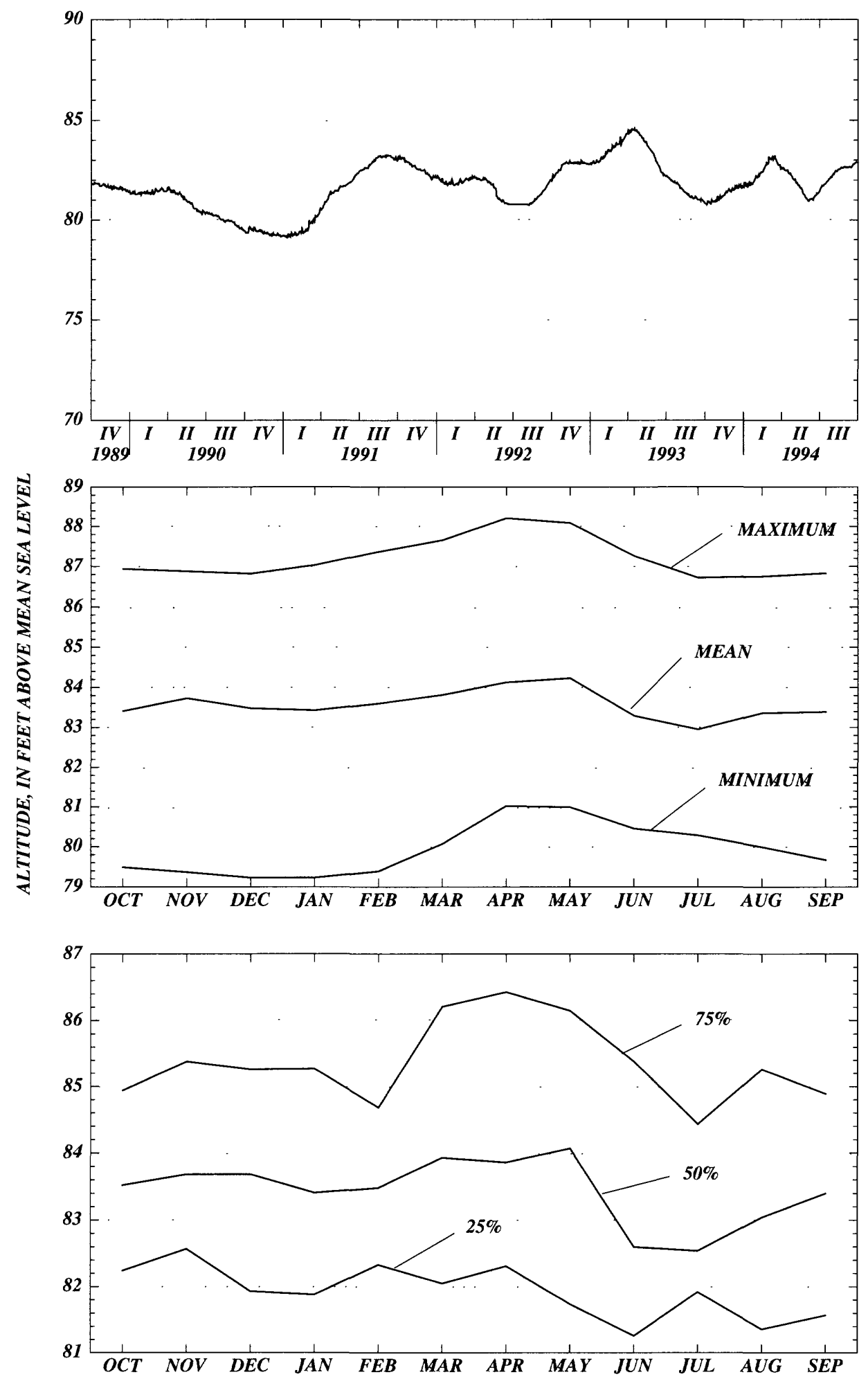


\section{Bradford County}

WELL NUMBER.--295500082170685. Container Corporation. -072002001.

LOCATION.--Lat $29^{\circ} 55^{\prime} 00^{\prime \prime}$, long 82 $17^{\prime} 06^{\prime \prime}$, Hydrologic Unit Code 03110206.

AQUIFER.--Upper Floridan aquifer of the Tertiary system, Geologic Unit Code 120FLRD.

WELL CHARACTERISTICS.--Casing diameter 4 in., Casing depth $182 \mathrm{ft}$., Total depth $202 \mathrm{ft}$.

INSTRUMENTATION.--Elevation of Measuring Point $153.59 \mathrm{ft} .$, NGVD.

DATUM.--The National Geodetic Vertical Datum of 1929.

PERIOD OF RECORD.--02-12-1988 to 09-30-1994.

EXTREME VALUES.--Maximum, 61.47 ft. (04-07-1988); minimum, 53.98 ft. (11-15-1990).

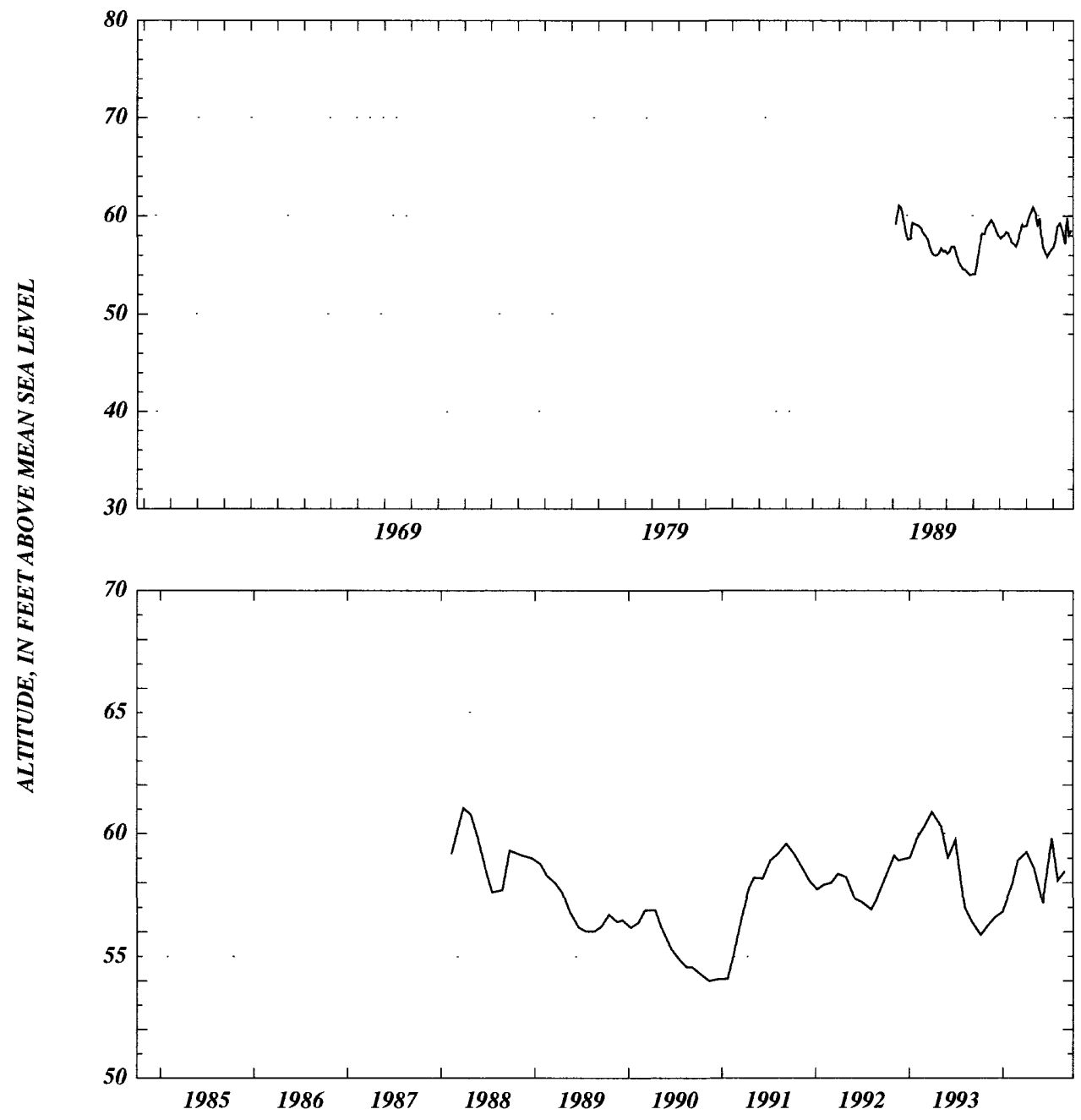



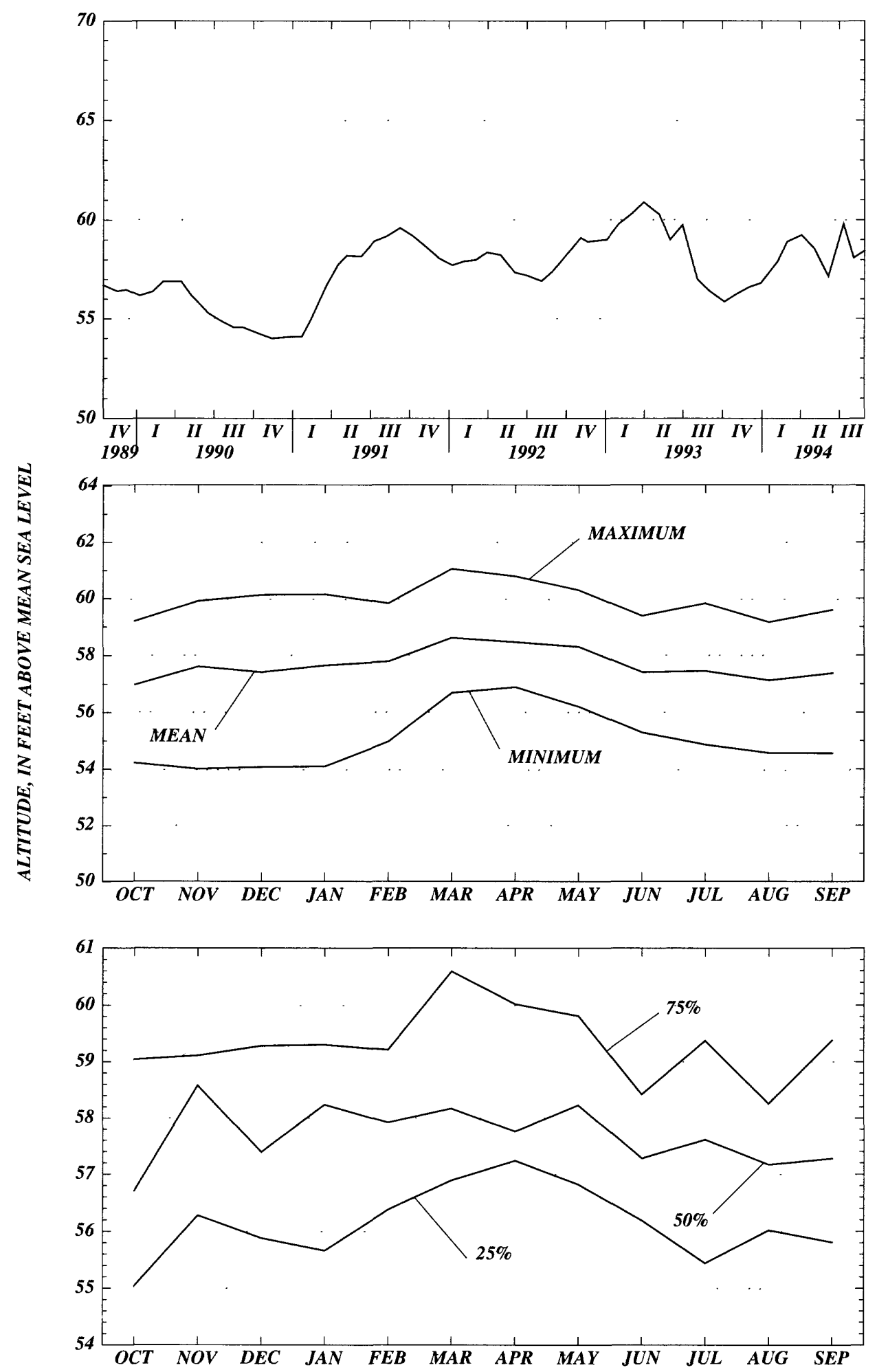


\section{Bradford County}

WELL NUMBER.--300220082103085. USGS - Raiford. -062102001.

LOCATION.--Lat 30 00'20”, long 82¹0'30", Hydrologic Unit Code 03110206.

AQUIFER.--Upper Floridan aquifer of the Tertiary system, Geologic Unit Code 120FLRD.

WELL CHARACTERISTICS.--Casing diameter $4 \mathrm{in}$., Casing depth $247 \mathrm{ft}$., Total depth $294 \mathrm{ft}$.

INSTRUMENTATION.--Recorder, set to elevation of the Measuring Point, $139.16 \mathrm{ft}$., NGVD.

DATUM.--The National Geodetic Vertical Datum of 1929.

PERIOD OF RECORD.--11-12-1959 to 09-30-1994. *

EXTREME VALUES.--Maximum, 68.35 ft. (11-02-1960); minimum, 53.92 ft. (10-03-1990).

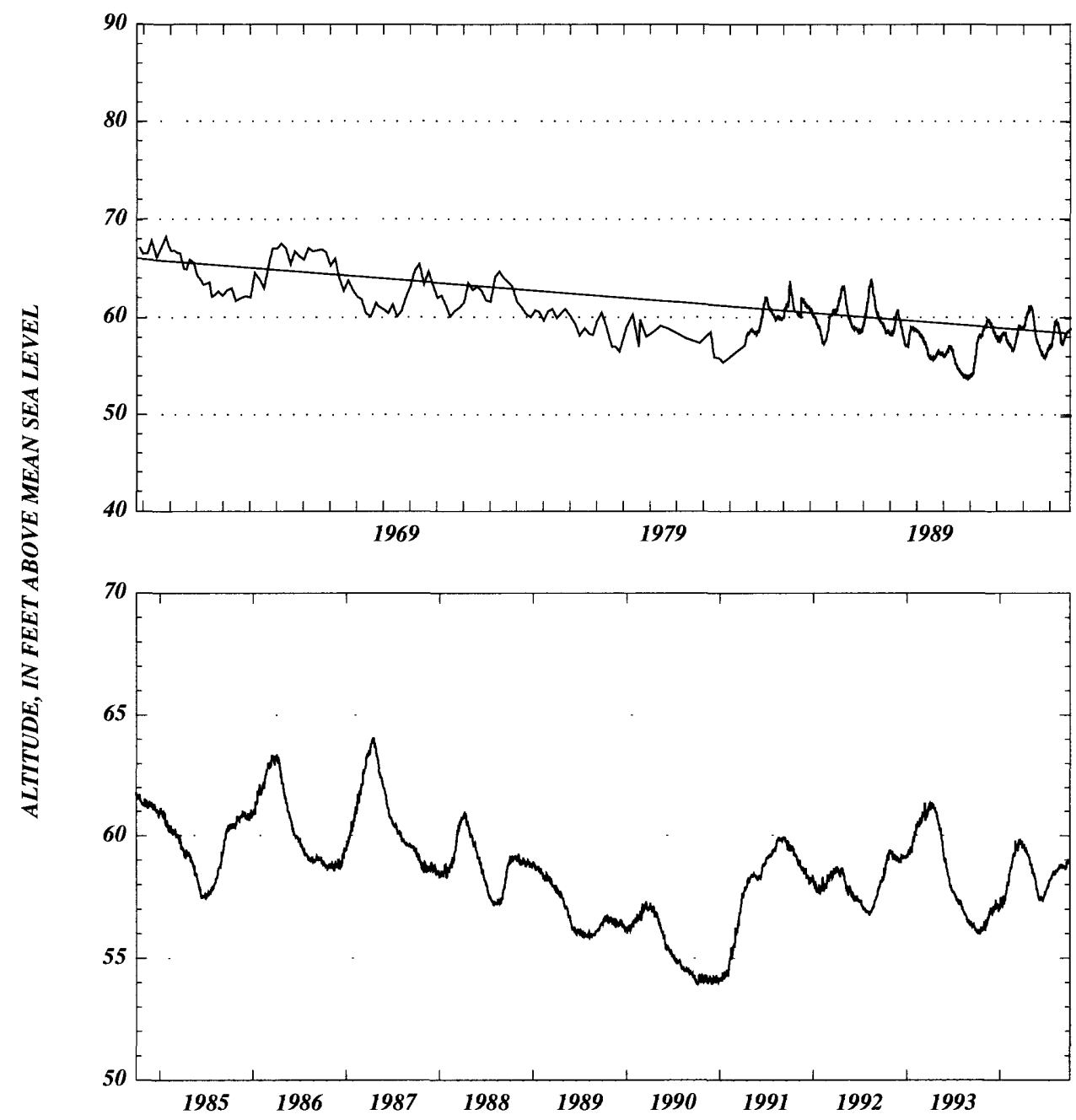



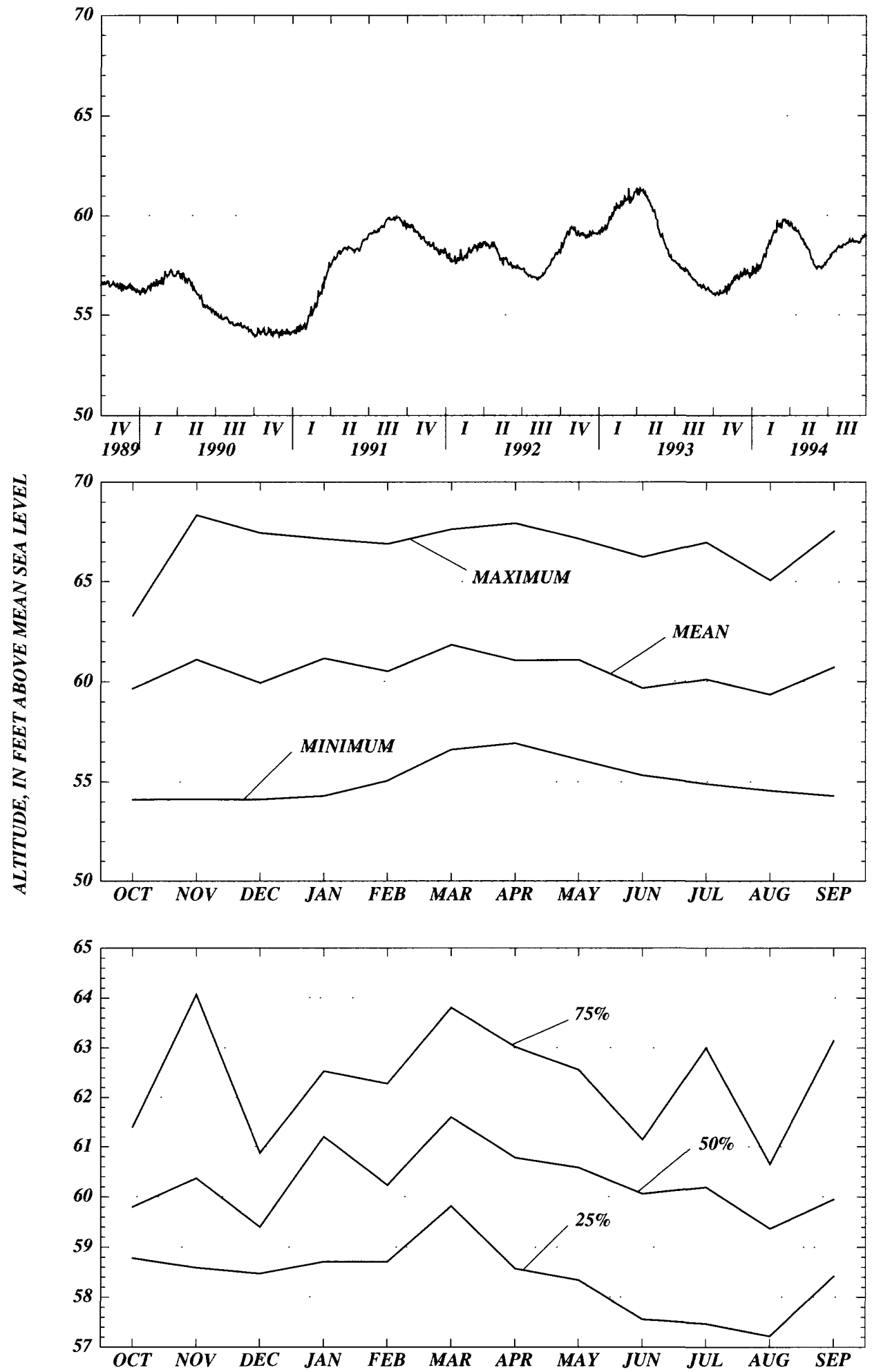


\section{Bradford County}

WELL NUMBER.--300629082030085. DOF - Louis Hill Tower. -042236001.

LOCATION.--Lat 30 06'29”, long 82 03'00”, Hydrologic Unit Code 03110206.

AQUIFER.--Upper Floridan aquifer of the Tertiary system., Geologic Unit Code 120FLRD.

WELL CHARACTERISTICS.--Casing diameter 4 in., Casing depth $418 \mathrm{ft}$., Total depth $438 \mathrm{ft}$.

INSTRUMENTATION.--Recorder from 07-16-1987 to 08-22-1988. Miscellaneous measurements from 09-01-1988 to 09-30-1994; elevation of Measuring Point $210.46 \mathrm{ft}$., NGVD.

DATUM.--The National Geodetic Vertical Datum of 1929.

PERIOD OF RECORD.--07-16-1987 to 09-30-1994.

EXTREME VALUES.--Maxumum observed, $60.03 \mathrm{ft}$ (08-26-1991); minimum observed, $51.20 \mathrm{ft}$. (09-26-1990).

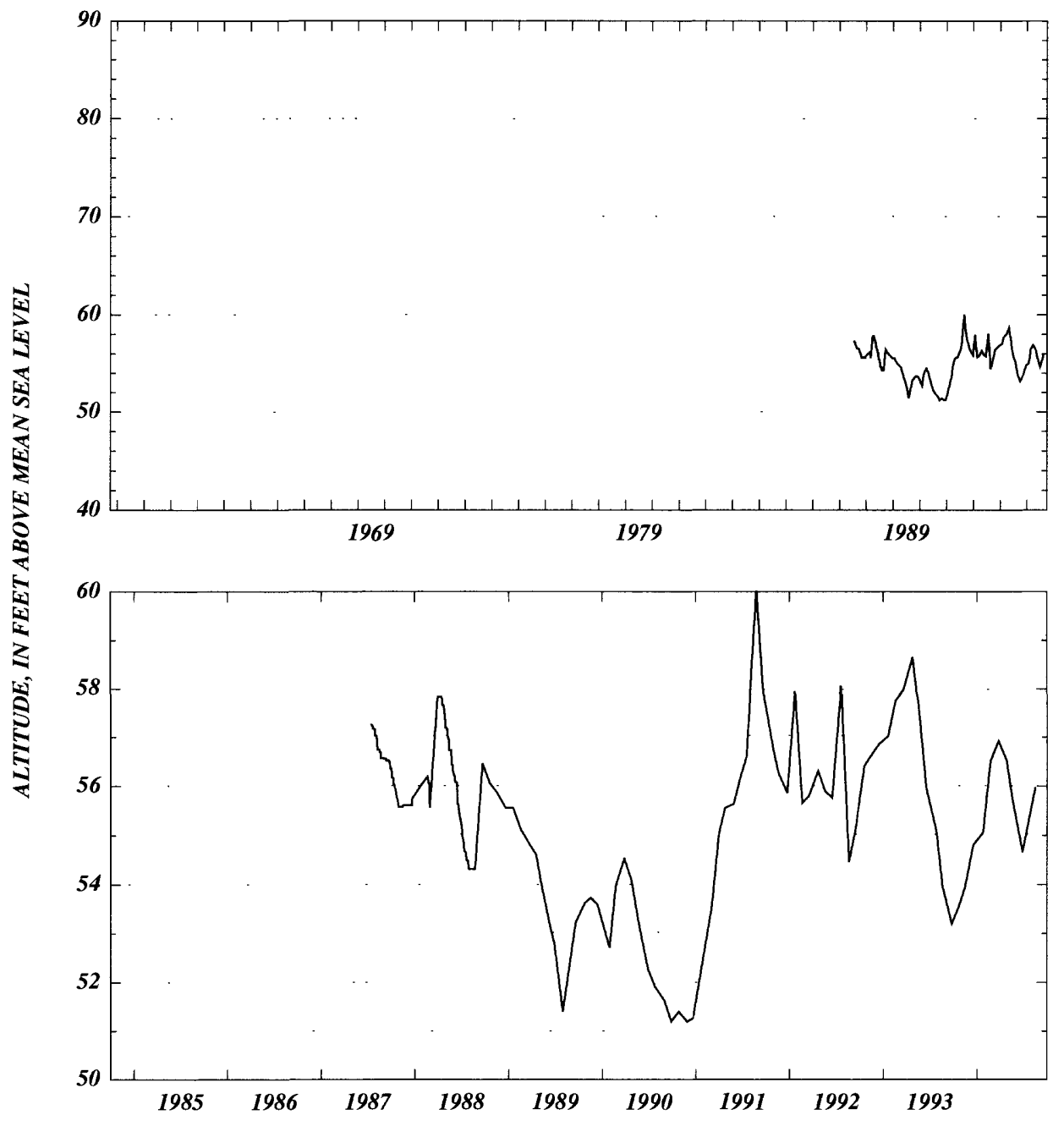



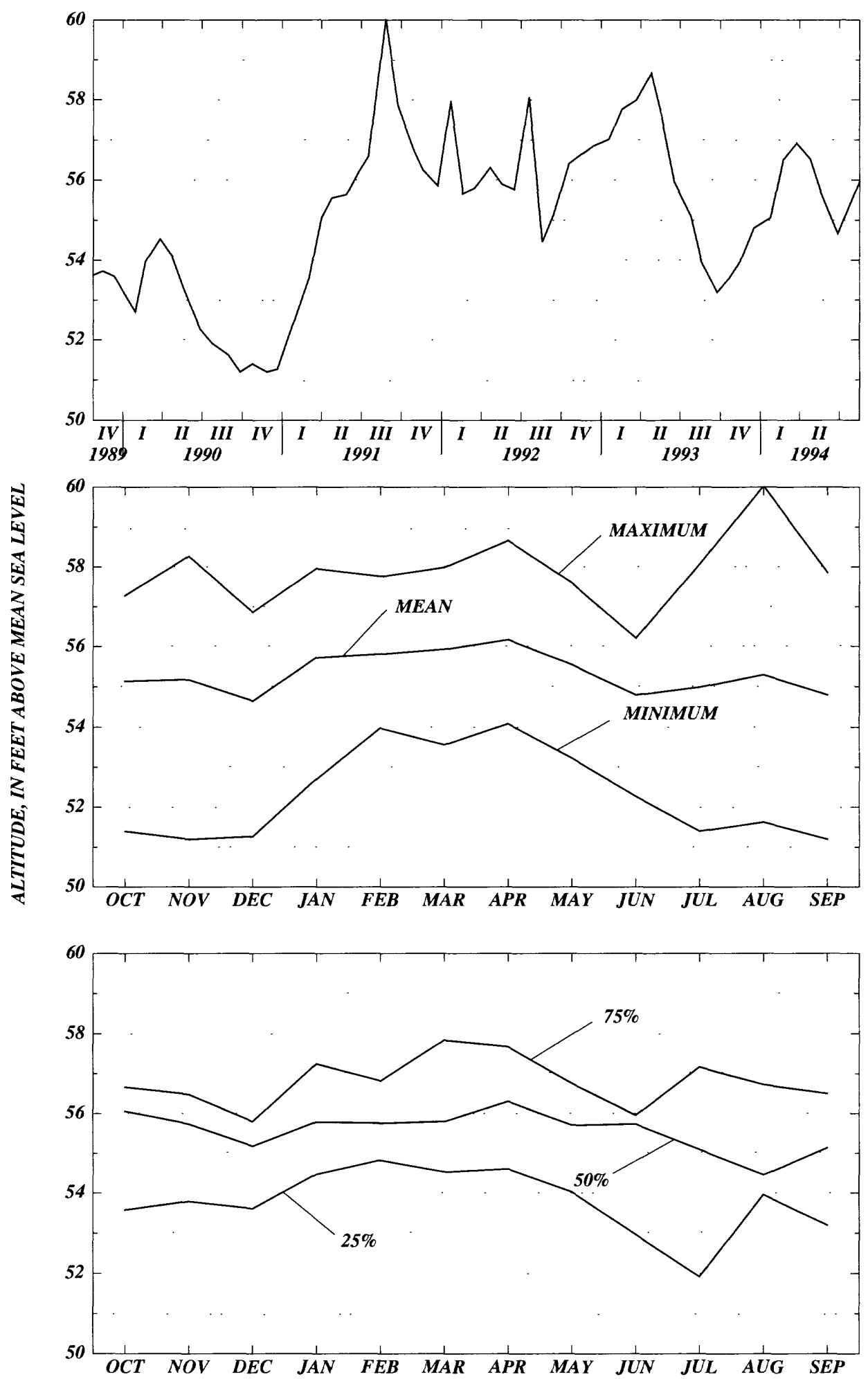


\section{Bradford County}

WELL NUMBER.--300629082030185. DOF - Louis Hill Tower. -042236002.

LOCATION.--Lat 3006'29”, long 82 03'01', Hydrologic Unit Code 03110206.

AQUIFER.--Surficial aquifer, Geologic Unit Code 110NRSD.

WELL CHARACTERISTICS.--Casing diameter 3 in., Casing depth $7 \mathrm{ft}$., Total depth $57 \mathrm{ft}$.

INSTRUMENTATION.--Elevation of Measuring Point $210.29 \mathrm{ft}$., NGVD.

DATUM.--The National Geodetic Vertical Datum of 1929.

PERIOD OF RECORD.--06-28-1989 to 09-30-1994. *

EXTREME VALUES.--Maximum observed, 204.94 ft. (10-19-1992); minimum observed, 197.95 ft. (07-24-1990).

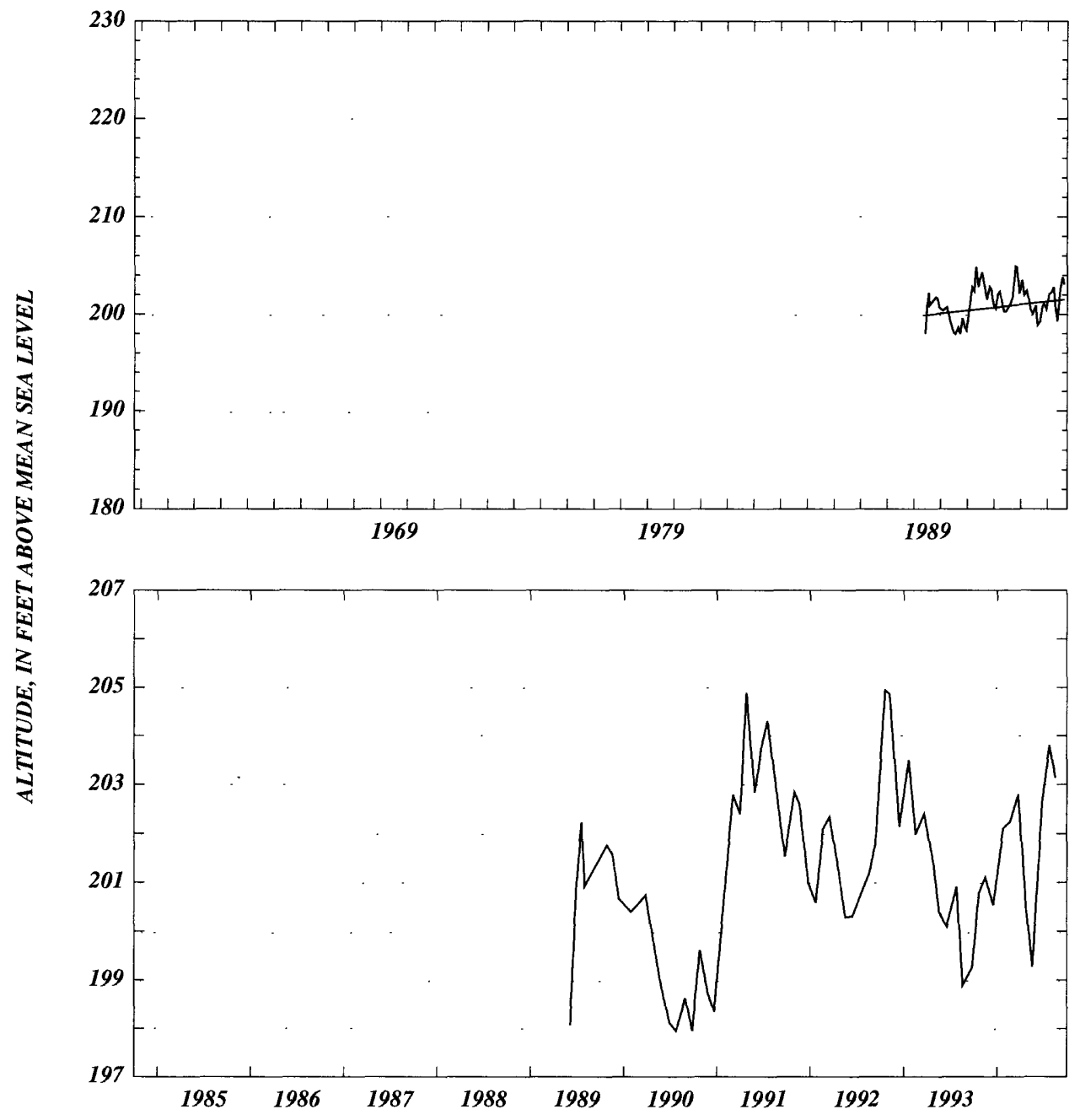



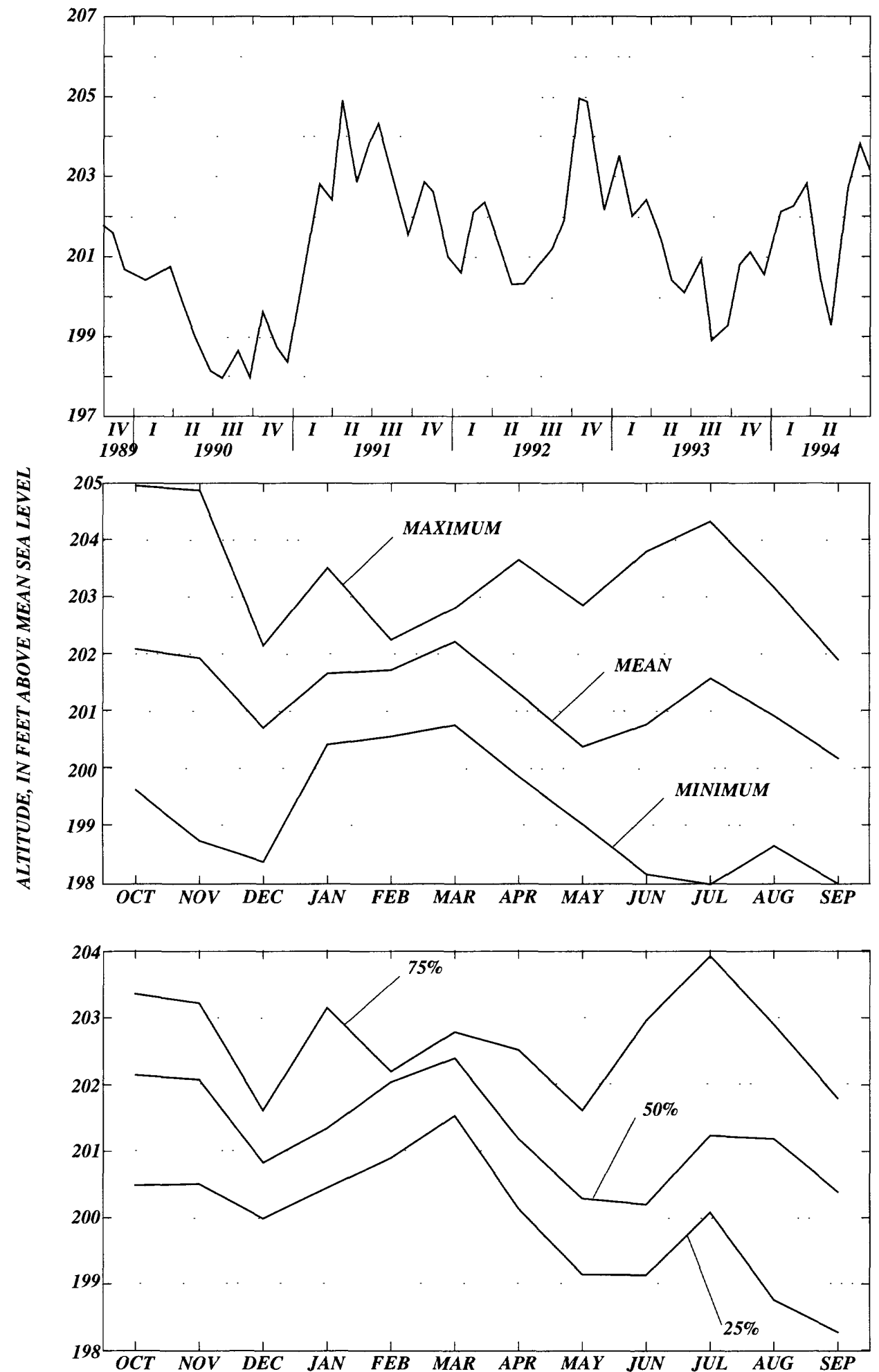


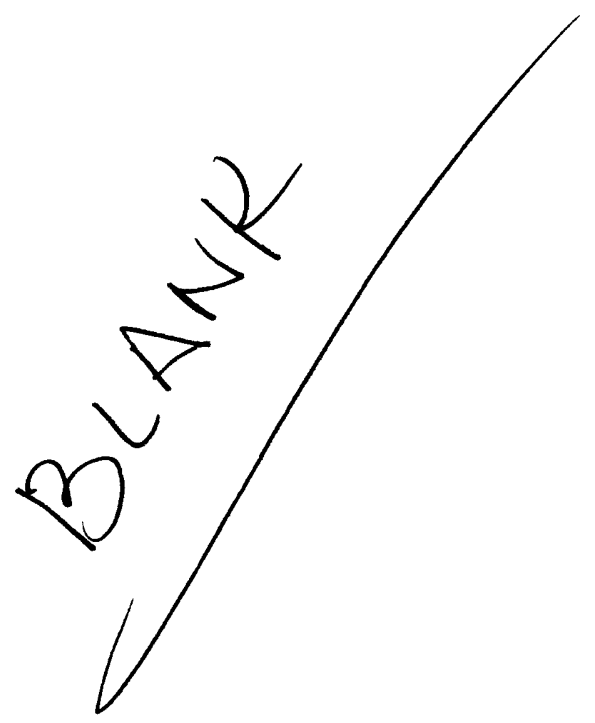




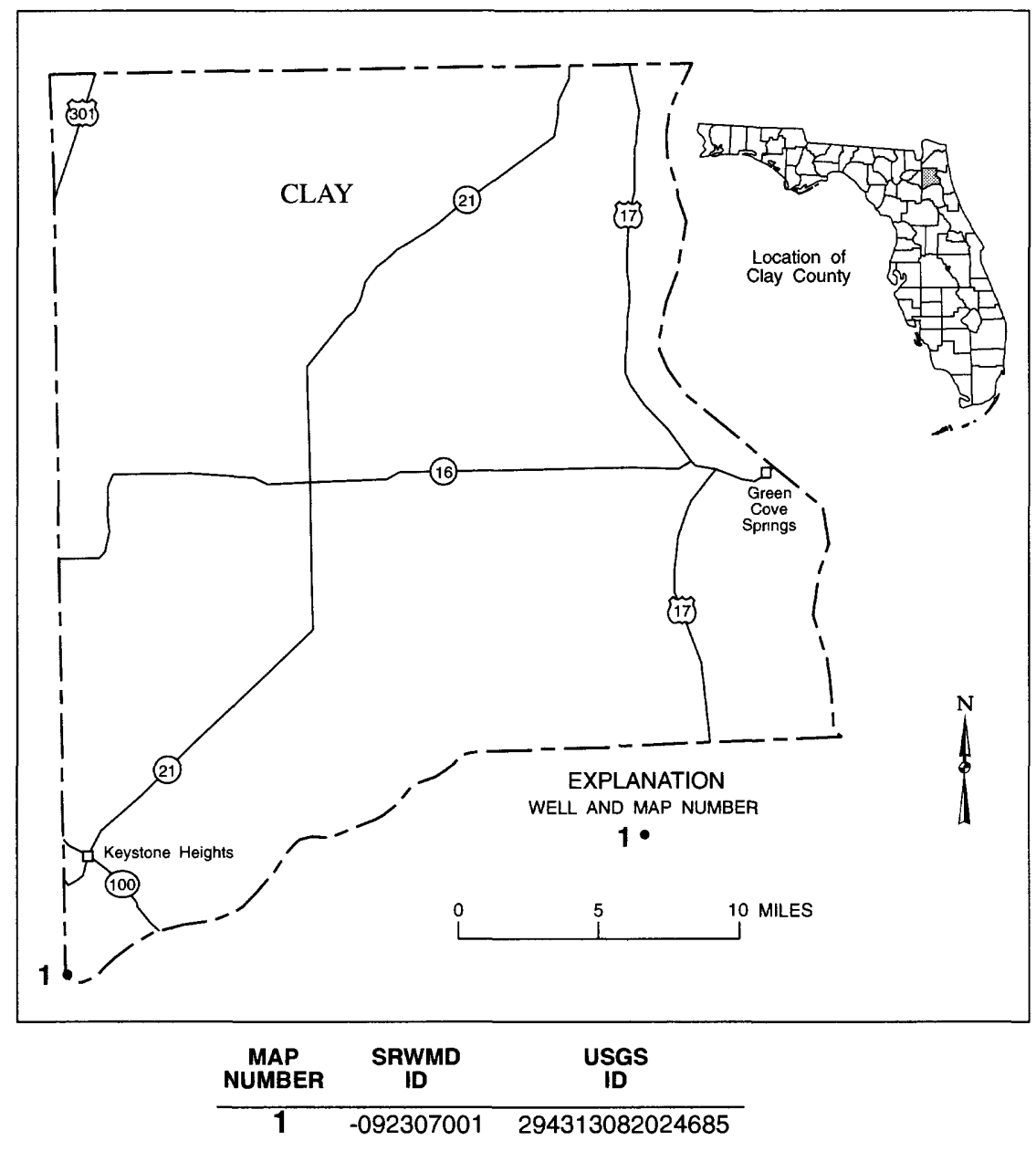

Figure 5. Location of wells in Clay County. 


\section{Clay County}

WELL NUMBER.--294313082024685. USGS - Melrose. -092307001.

LOCATION.--Lat 2943'13”, long 8202'46”, Hydrologic Unit Code 03080103.

AQUIFER.--Upper Floridan aquifer of the Tertiary system, Geologic Unit Code 120FLRD.

WELL CHARACTERISTICS.--Casing diameter 4 in., Casing depth $204 \mathrm{ft}$., Total depth $259 \mathrm{ft}$. INSTRUMENTATION.--Recorder, set to elevation of the Measuring Point, $178.96 \mathrm{ft}$., NGVD.

DATUM.--The National Geodetic Vertical Datum of 1929.

PERIOD OF RECORD.--05-02-1975 to 09-30-1994. *

EXTREME VALUES.--Maximum 89.01 ft (04-10-1984); minimum, 78.04 ft. (02-16-1991).

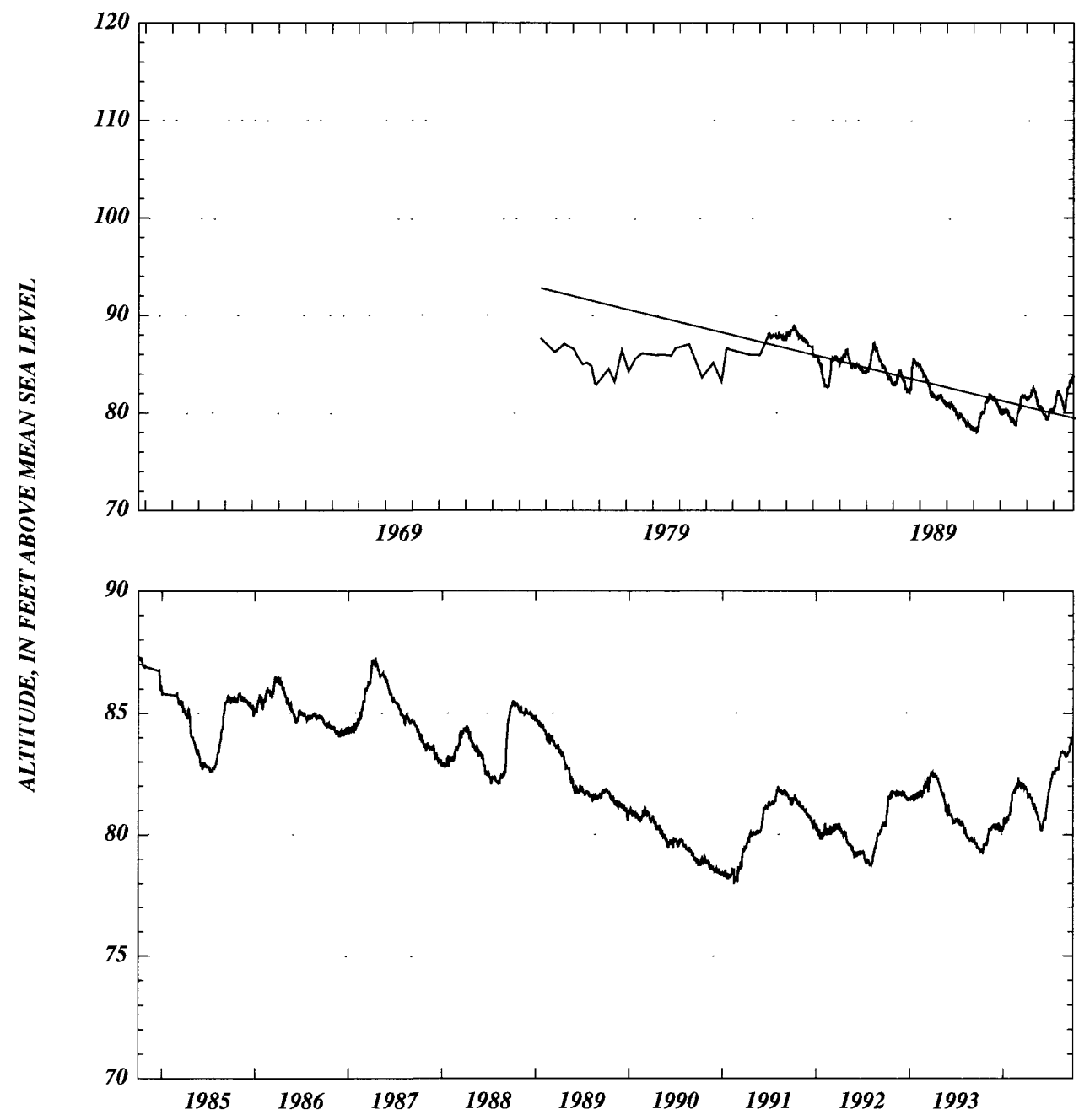



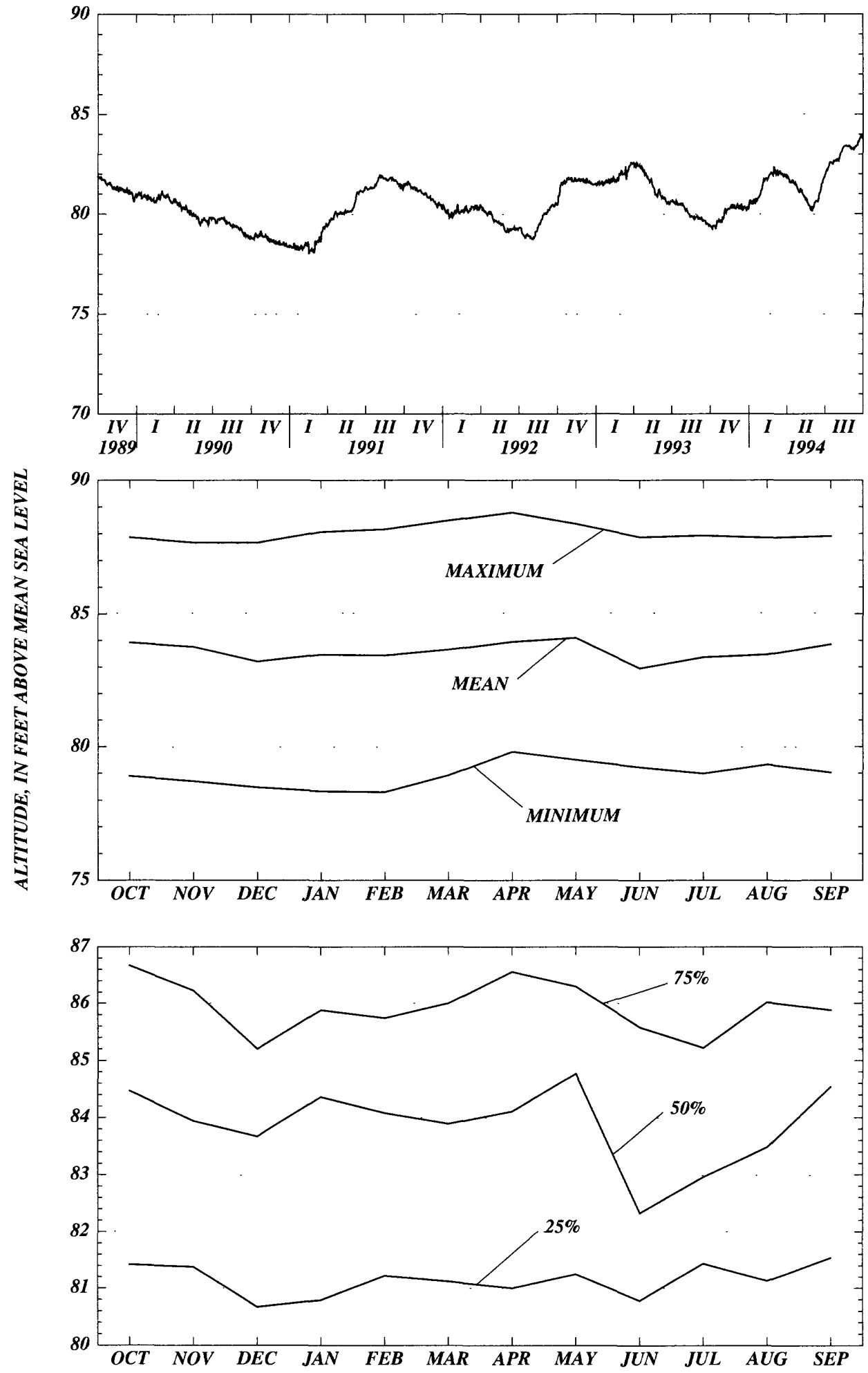


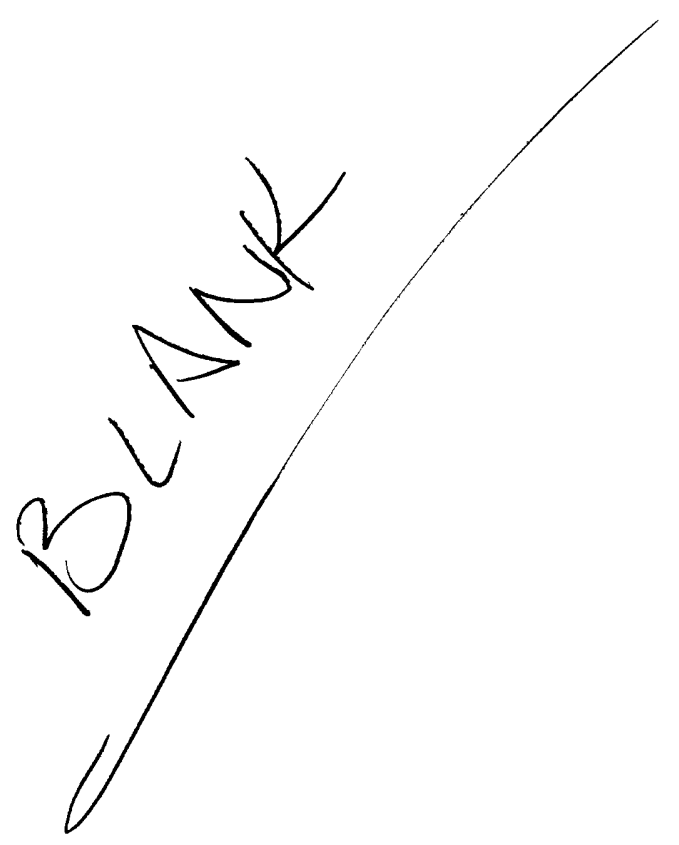




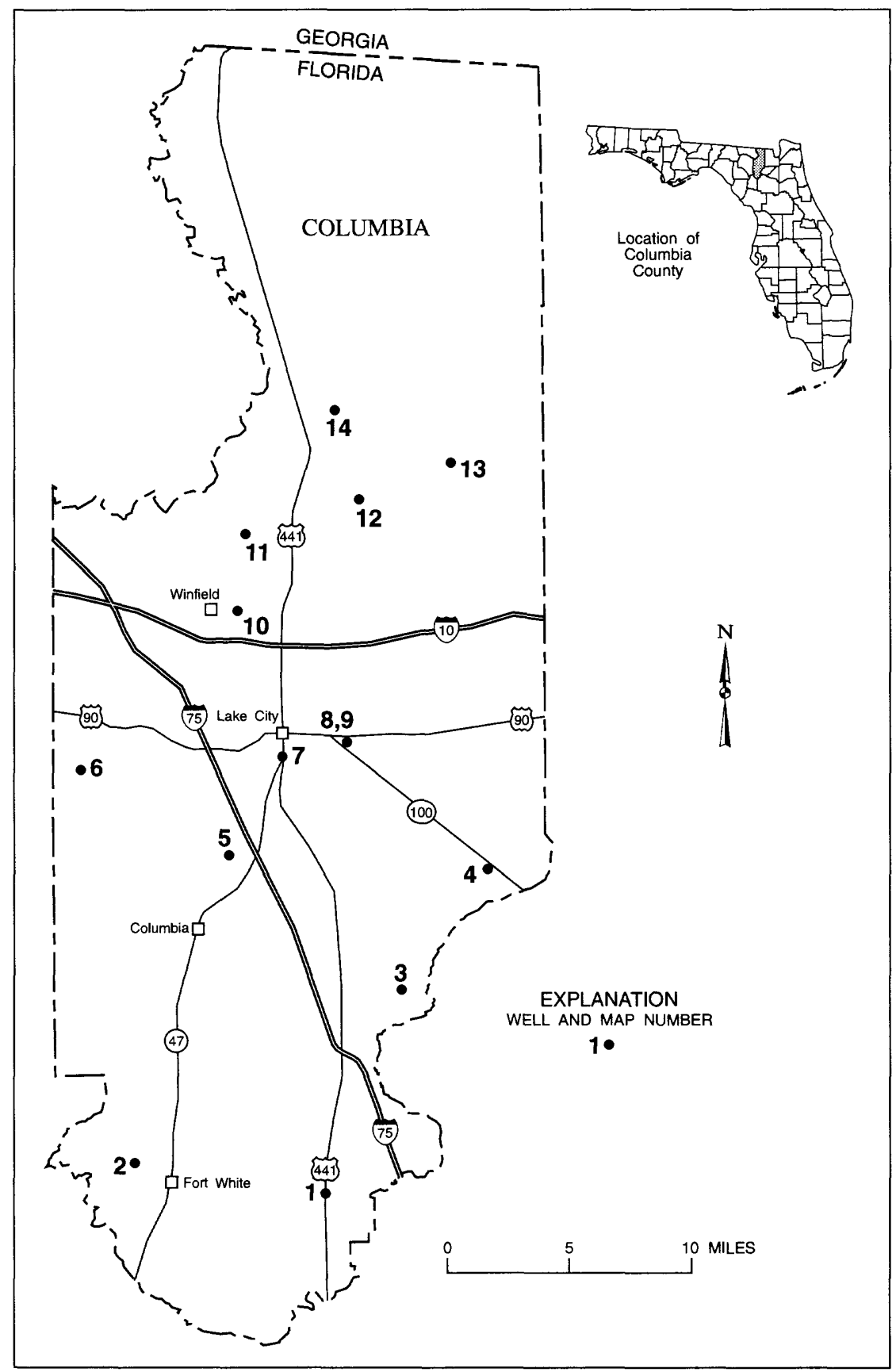

\begin{tabular}{ccc}
$\begin{array}{c}\text { MAP } \\
\text { NUMBER }\end{array}$ & $\begin{array}{c}\text { SRWMD } \\
\text { ID }\end{array}$ & $\begin{array}{c}\text { USGS } \\
\text { ID }\end{array}$ \\
\hline $\mathbf{1}$ & -061734001 & 295513082363085 \\
$\mathbf{2}$ & -061629001 & 295618082440985 \\
$\mathbf{3}$ & -051819001 & 300221082332685 \\
$\mathbf{4}$ & -041827002 & 300635082295985 \\
$\mathbf{5}$ & -041625001 & 300706082402285 \\
$\mathbf{6}$ & -041501001 & 301006082461785 \\
$\mathbf{7}$ & -041705001 & 301031082381085 \\
$\mathbf{8}$ & -031734023 & 301103082353785 \\
$\mathbf{9}$ & -031734011 & 301104082353785 \\
$\mathbf{1 0}$ & -031601003 & 301540082395785 \\
$\mathbf{1 1}$ & -021624001 & 301822082393985 \\
$\mathbf{1 2}$ & -021711003 & 301933082350585 \\
$\mathbf{1 3}$ & -021805001 & $\mathbf{3 0 2 0 5 2 0 8 2 3 1 2 4 8 5}$ \\
$\mathbf{1 4}$ & -011727001 & $\mathbf{3 0 2 2 4 3 0 8 2 3 6 0 2 8 5}$
\end{tabular}

Figure 6. Location of wells in Columbia County. 


\section{Columbia County}

WELL NUMBER.--295513082363085. DOF - Oleno Tower. -061734001.

LOCATION.--Lat 2955'13”, long 82³6’30”, Hydrologic Unit Code 03110206.

AQUIFER.--Upper Floridan aquifer of the Tertiary system, Geologic Unit Code 120FLRD.

WELL CHARACTERISTICS.--Casing diameter 2 in., Casing depth unknown, Total depth $87 \mathrm{ft}$.

INSTRUMENTATION.--Elevation of Measuring Point $78.36 \mathrm{ft} .$, NGVD.

DATUM.--The National Geodetic Vertical Datum of 1929.

PERIOD OF RECORD.--11-01-1976 to 09-30-1994.

EXTREME VALUES.--Maximum observed, $40.36 \mathrm{ft}$. (10-10-1992); minimum observed, $30.54 \mathrm{ft}$. (08-23-1993).

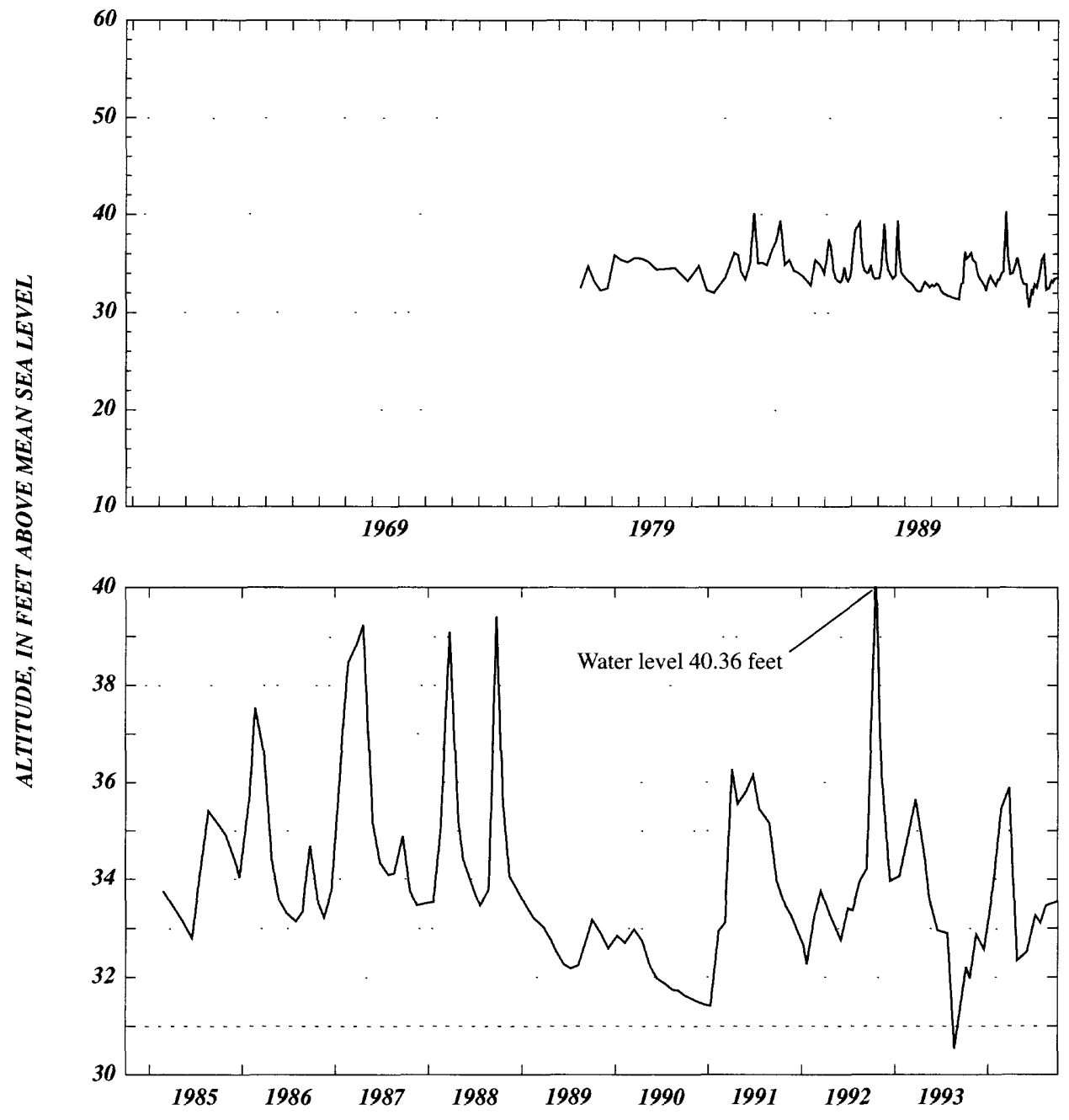



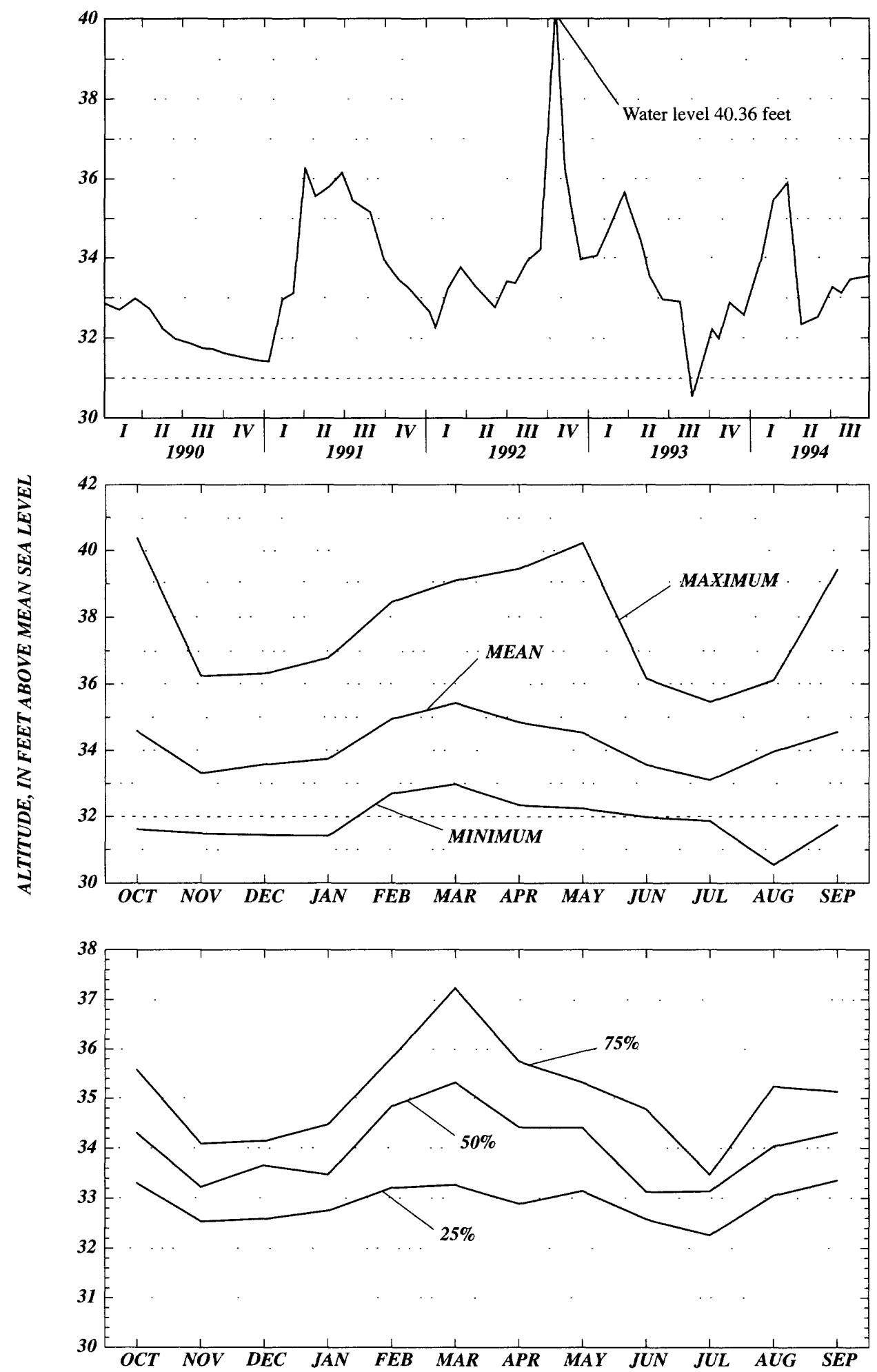


\section{Columbia County}

WELL NUMBER.--295618082440985. Dales Aqua Shack. -061629001.

LOCATION.--Lat 2956'18", long 8244'09”, Hydrologic Unit Code, 03110206.

AQUIFER.--Upper Floridan aquifer of the Tertiary system, Geologic Unit Code, 120FLRD.

WELL CHARACTERISTICS.--Casing diameter 4 in., Casing depth $50 \mathrm{ft}$., Total depth $75 \mathrm{ft}$.

INSTRUMENTATION.--Elevation of Measuring Point, $61.36 \mathrm{ft}$., NGVD.

DATUM.--The National Geodetic Vertical Datum of 1929.

PERIOD OF RECORD.--12-23-1962 to 09-30-1994. *

EXTREME VALUES.--Maximum observed, $32.24 \mathrm{ft}$. (04-26-1984); minimum observed, $18.76 \mathrm{ft}$. (09-17-1990).

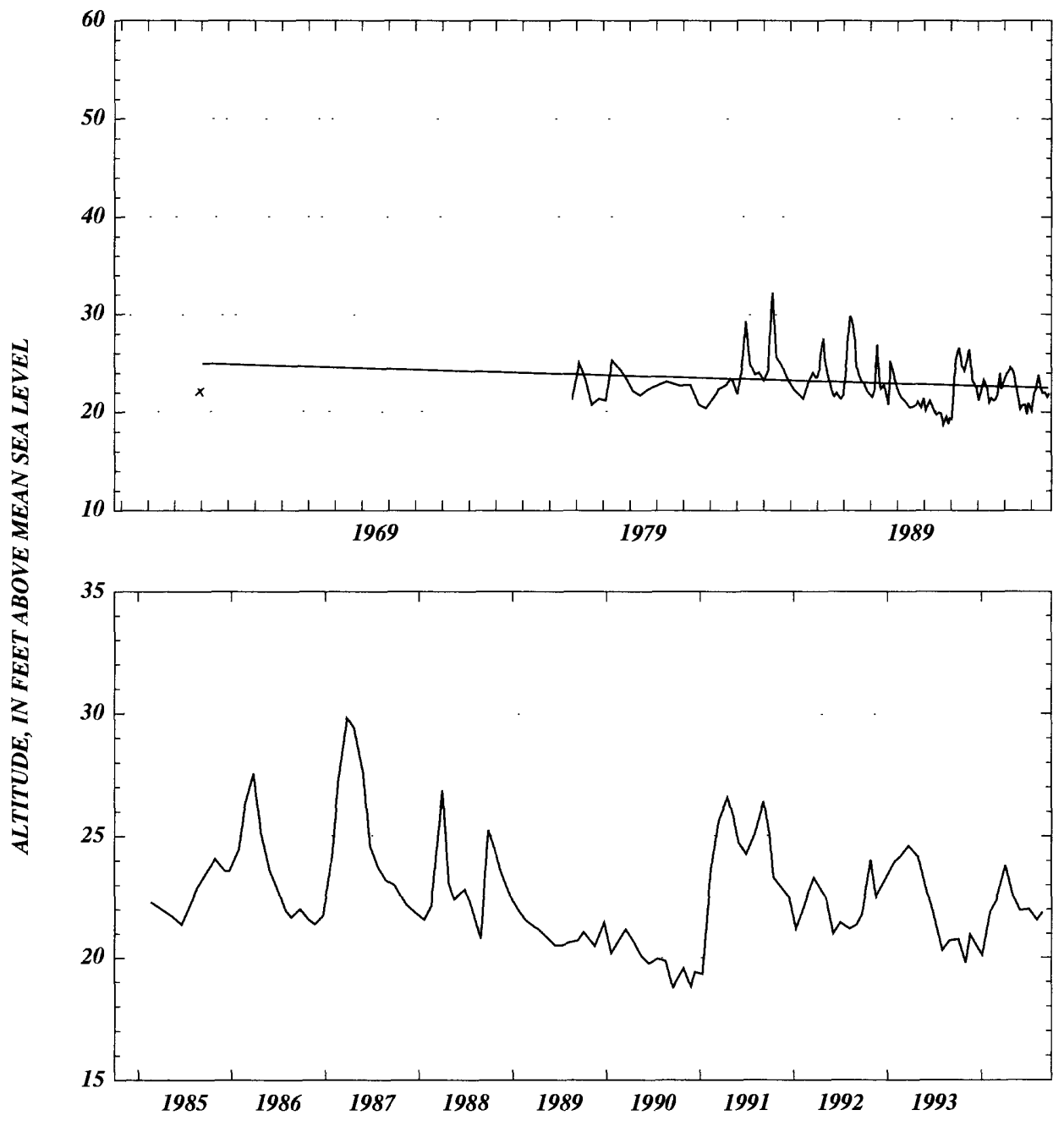



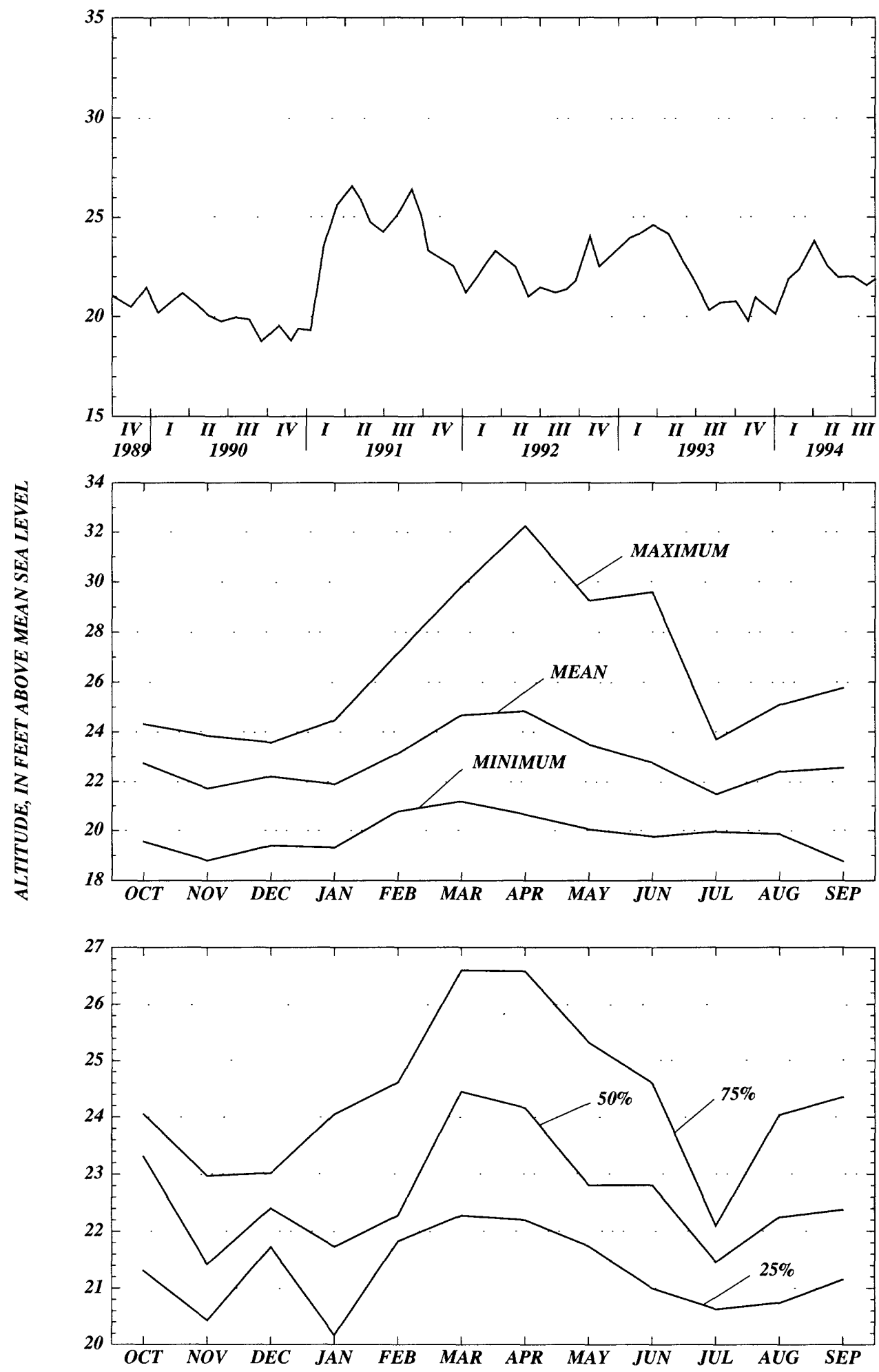


\section{Columbia County}

WELL NUMBER.--300221082332685. Leslie Woods. -051819001.

LOCATION.--Lat 3002'21”, long 82³3'26”, Hydrologic Unit Code 03110206.

AQUIFER.--Upper Floridan aquifer of the Tertiary system, Geologic Unit Code 120FLRD.

WELL CHARACTERISTICS.--Casing diameter 4 in., Casing depth $100 \mathrm{ft}$., Total Depth $120 \mathrm{ft}$.

INSTRUMENTATION.--Elevation of Measuring Point $127.16 \mathrm{ft}$., NGVD.

DATUM.--The National Geodetic Vertical Datum of 1929.

PERIOD OF RECORD.--11-01-1976 to 09-30-1994.

EXTREME VALUES.--Maximum, $48.11 \mathrm{ft}$. (04-26-1984); minimum observed, $38.17 \mathrm{ft}$.

(12-17-1990).

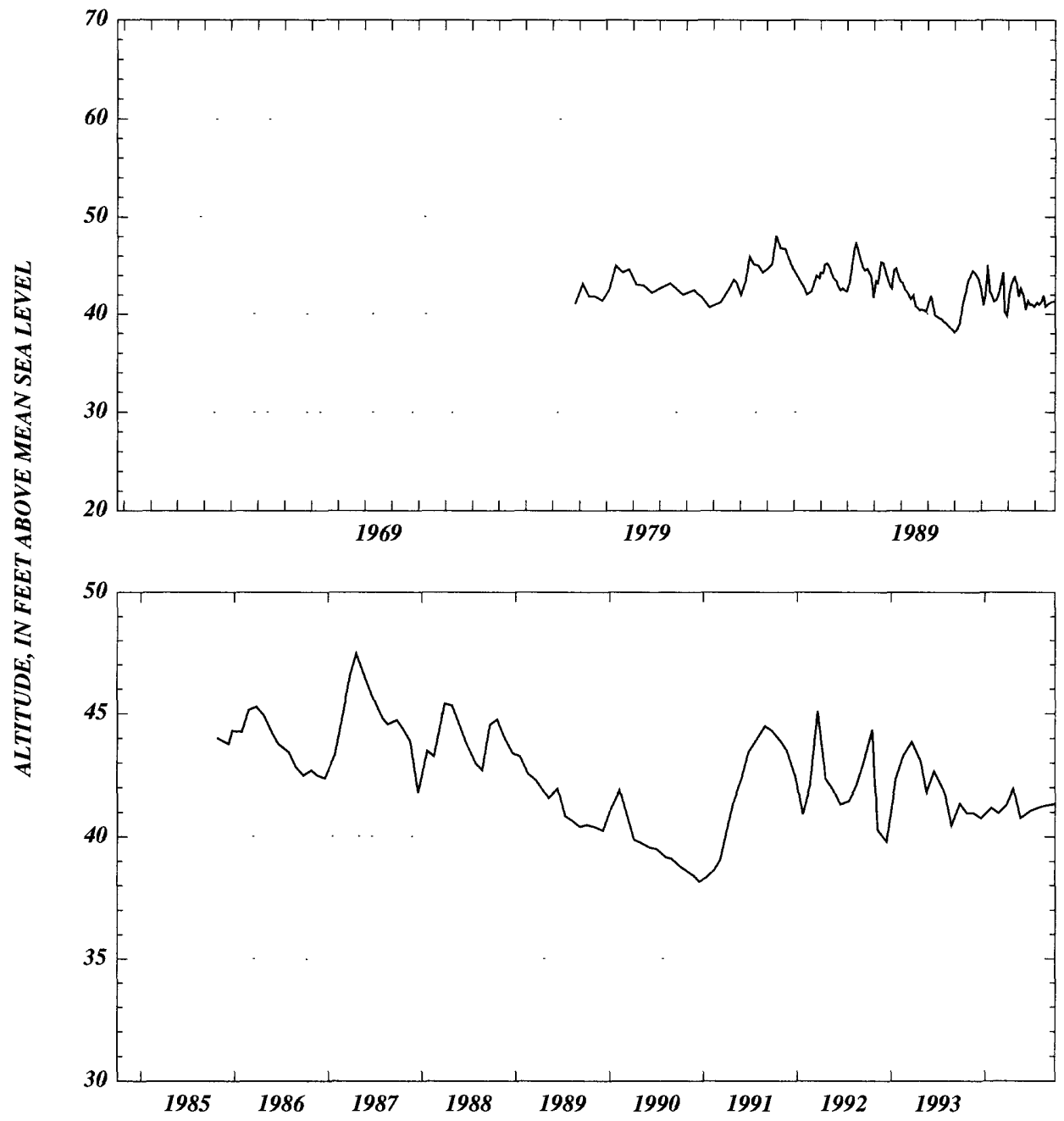



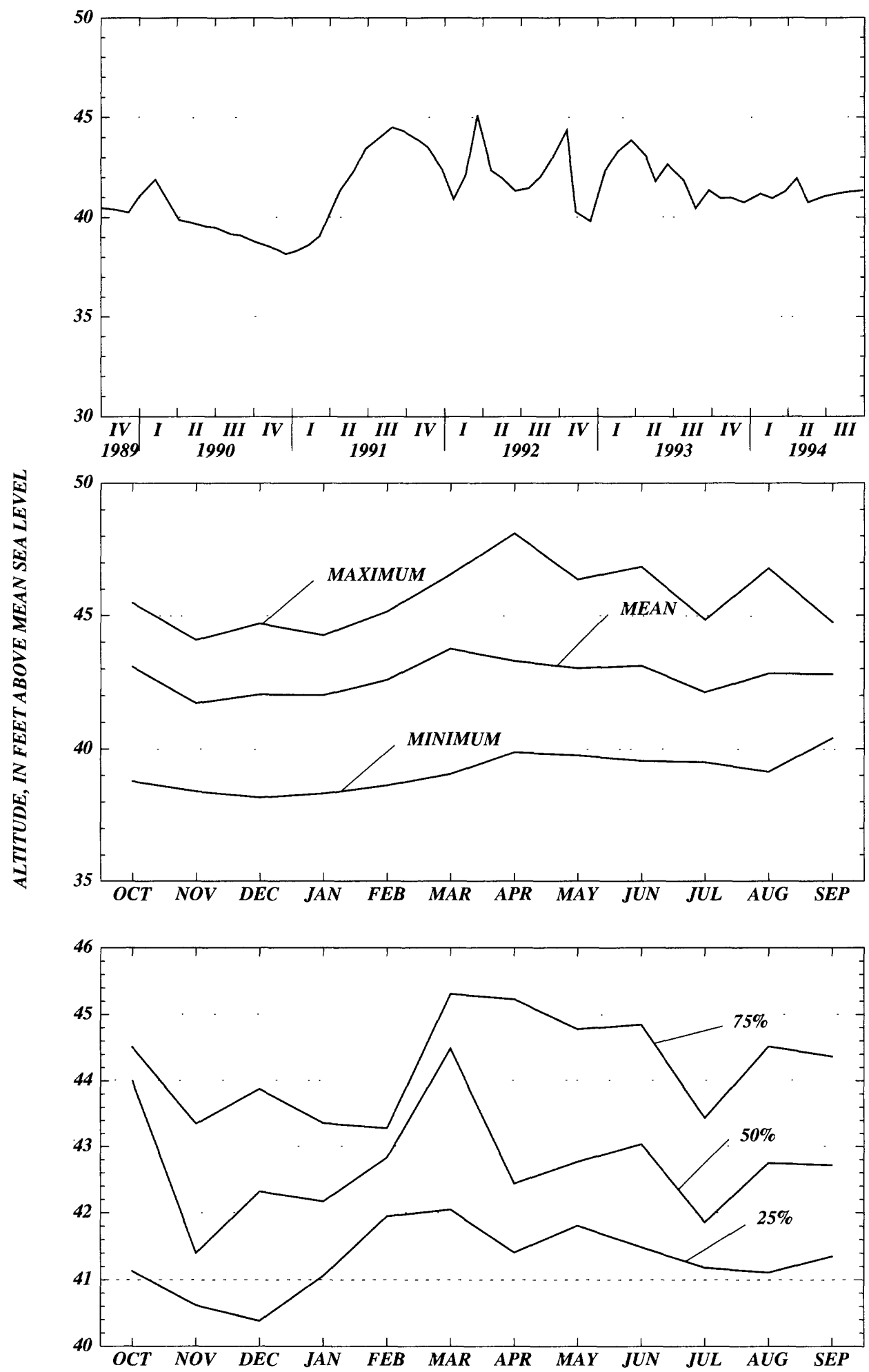


\section{Columbia County}

WELL NUMBER.--300635082295985. Lulu Community Center. -041827002.

LOCATION.--Lat 3006'35”, long 82²9'59”, Hydrologic Unit Code 03110206.

AQUIFER.--Upper Floridan aquifer of the Tertiary system, Geologic Unit Code 120FLRD.

WELL CHARACTERISTICS.--Casing diameter 4 in., Casing depth $174 \mathrm{ft}$., Total depth $214 \mathrm{ft}$.

INSTRUMENTATION.--Recorder, set to elevation of the Measuring Point, $153.32 \mathrm{ft}$., NGVD.

DATUM.--The National Geodetic Vertical Datum of 1929.

PERIOD OF RECORD.--08-19-1988 to 09-30-1994.

EXTREME VALUES.--Maximum, 54.30 ft. (03-13-1993); minimum, 46.34 ft. (12-27-1990).

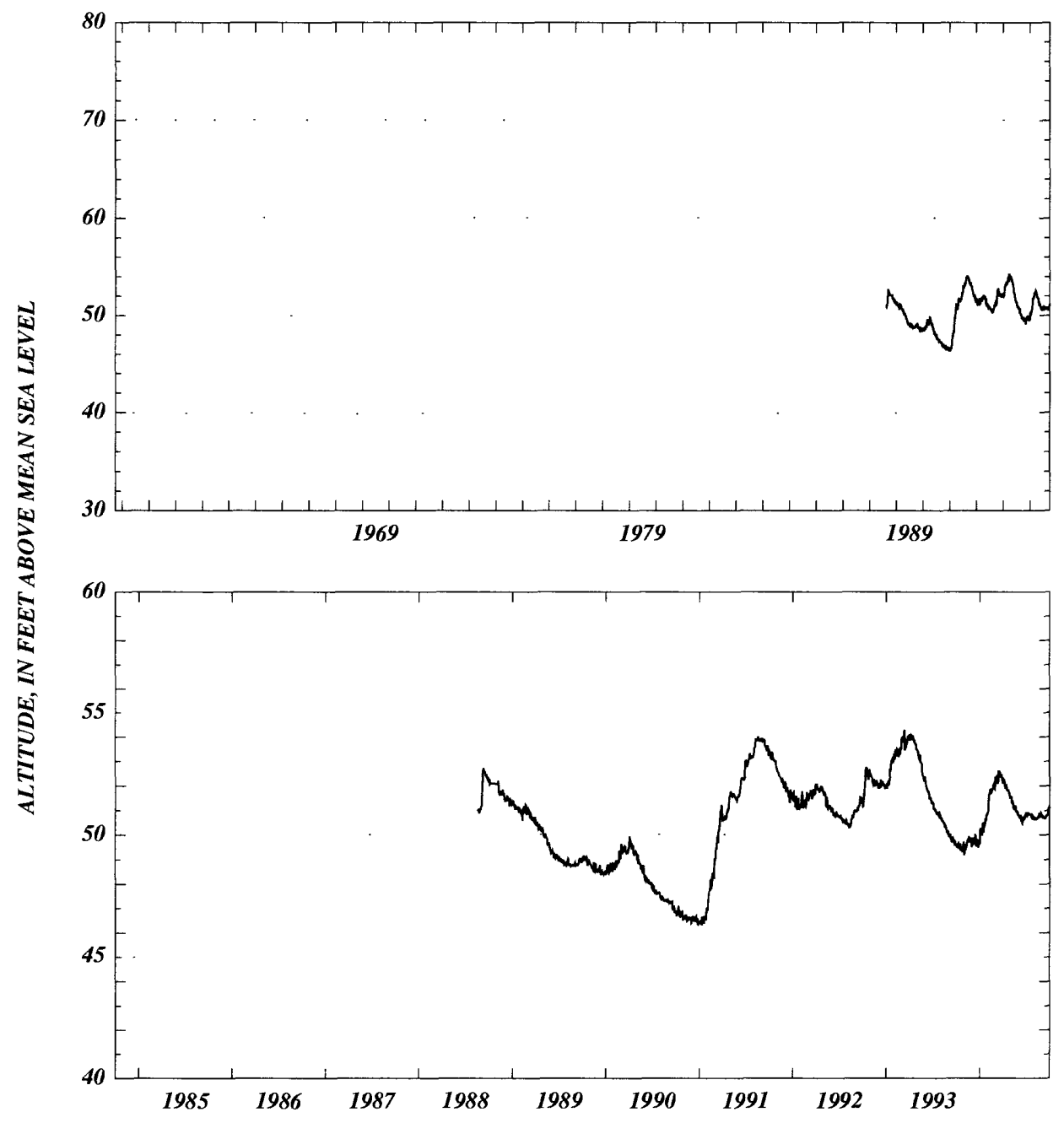



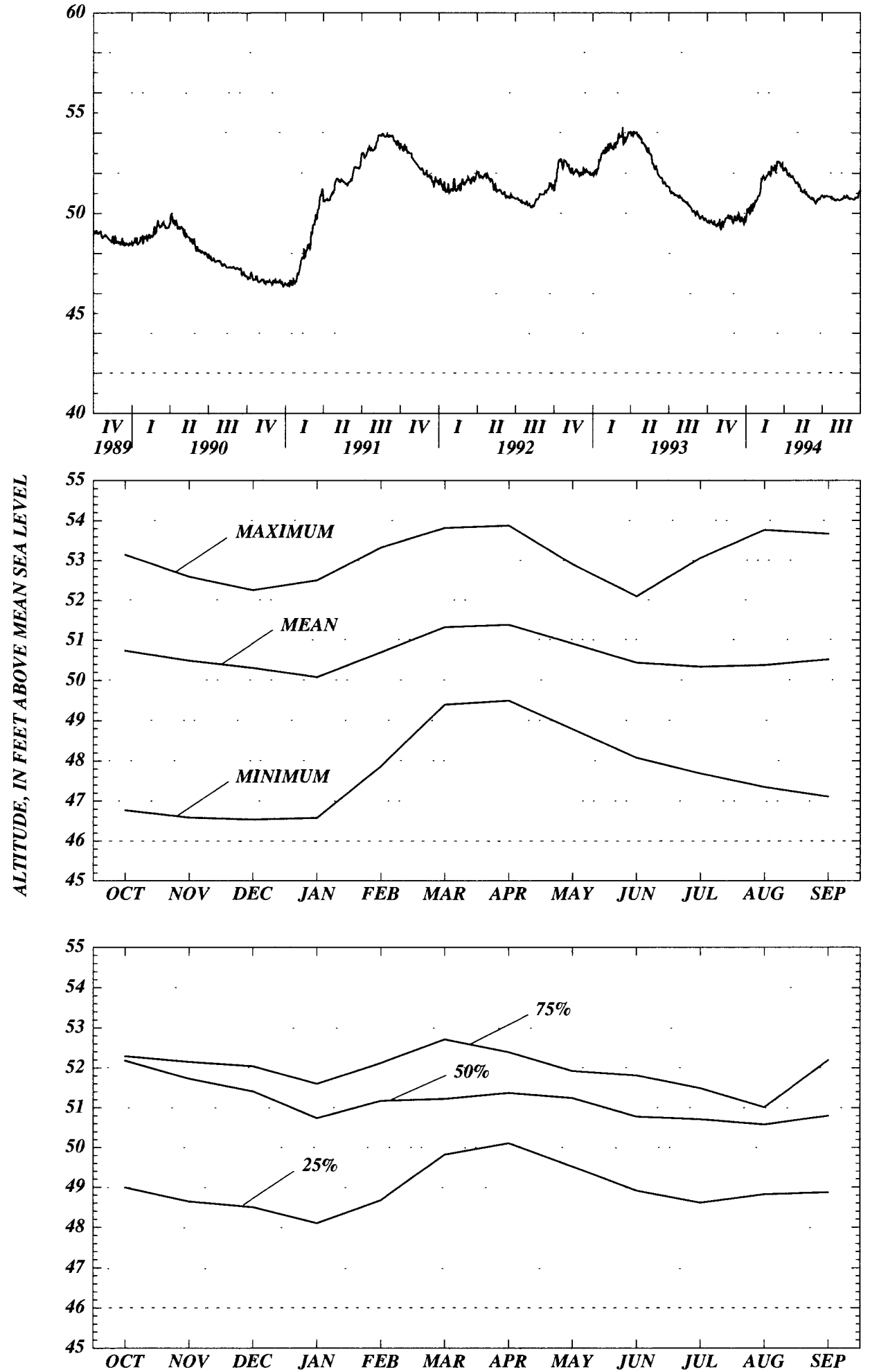


\section{Columbia County}

WELL NUMBER.--300706082402285. Vernon Norton. -041625001.

LOCATION.--Lat 3007'06”, long 8240'22”, Hydrologic Unit Code 03110206.

AQUIFER.--Upper Floridan aquifer of the Tertiary system, Geologic Unit Code 120FLRD.

WELL CHARACTERISTICS.--Casing diameter 6 in., Casing depth $63 \mathrm{ft}$., Total depth $140 \mathrm{ft}$. INSTRUMENTATION.--Miscellaneous from 11-01-1976 to 03-15-1982; then recorder, set to elevation of the Measuring Point, $91.39 \mathrm{ft}$., NGVD.

DATUM.--The National Geodetic Vertical Datum of 1929.

PERIOD OF RECORD.--11-01-1976 to 09-30-1994.

EXTREME VALUES.--Maximum, 48.64 ft. (05-03-1984); minimum, 31.89 ft. (01-25-1991)

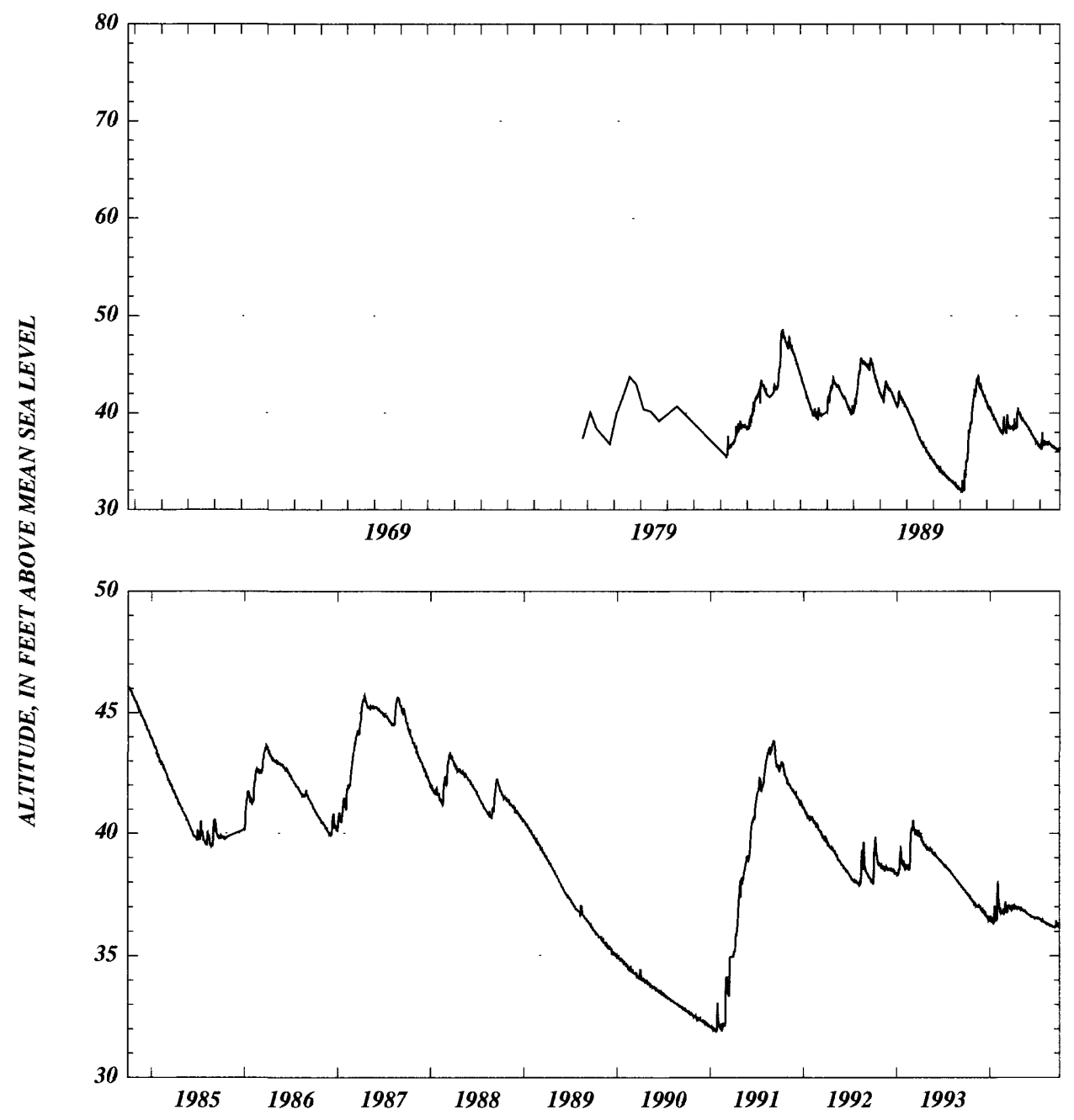



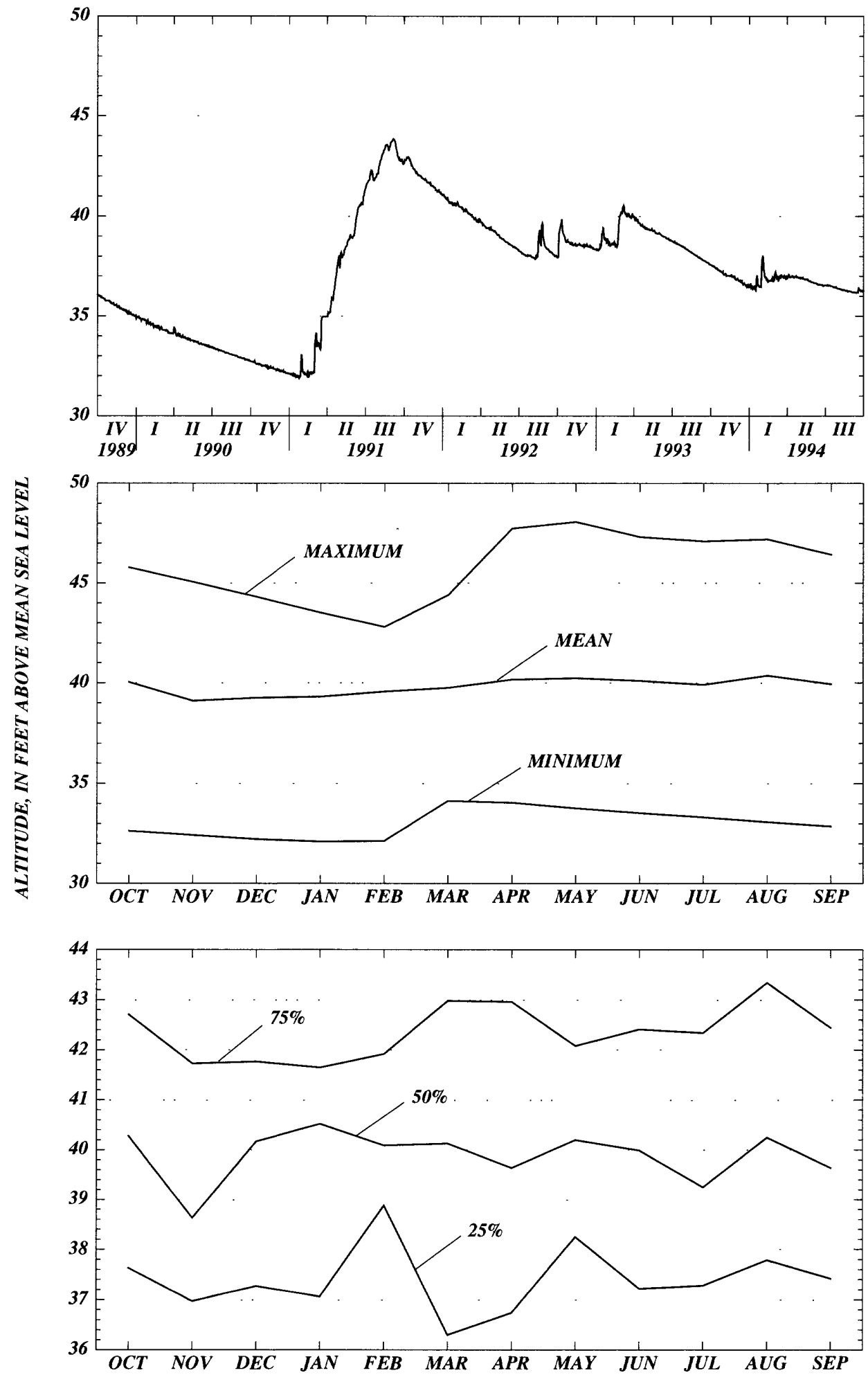


\section{Columbia County}

WELL NUMBER.--301006082461785. St. Regis Paper Company. -041501001.

LOCATION.--Lat 30 10'06”, long 82 46' 17”, Hydrologic Unit Code 03110205.

AQUIFER.--Upper Floridan aquifer of the Tertiary system, Geologic Unit Code 120FLRD.

WELL CHARACTERISTICS.--Casing diameter 8 in., Casing depth $126 \mathrm{ft}$., Total depth $250 \mathrm{ft}$.

INSTRUMENTATION.--Recorder, set to elevation of the Measuring Point, $130.70 \mathrm{ft}$., NGVD.

DATUM.--The National Geodetic Vertical Datum of 1929.

PERIOD OF RECORD.--08-13-1981 to 09-30-1994.

EXTREME VALUES.--Maximum, 46.49 ft. (05-30-1984); minimum, 29.70 ft. (02-01-1991).

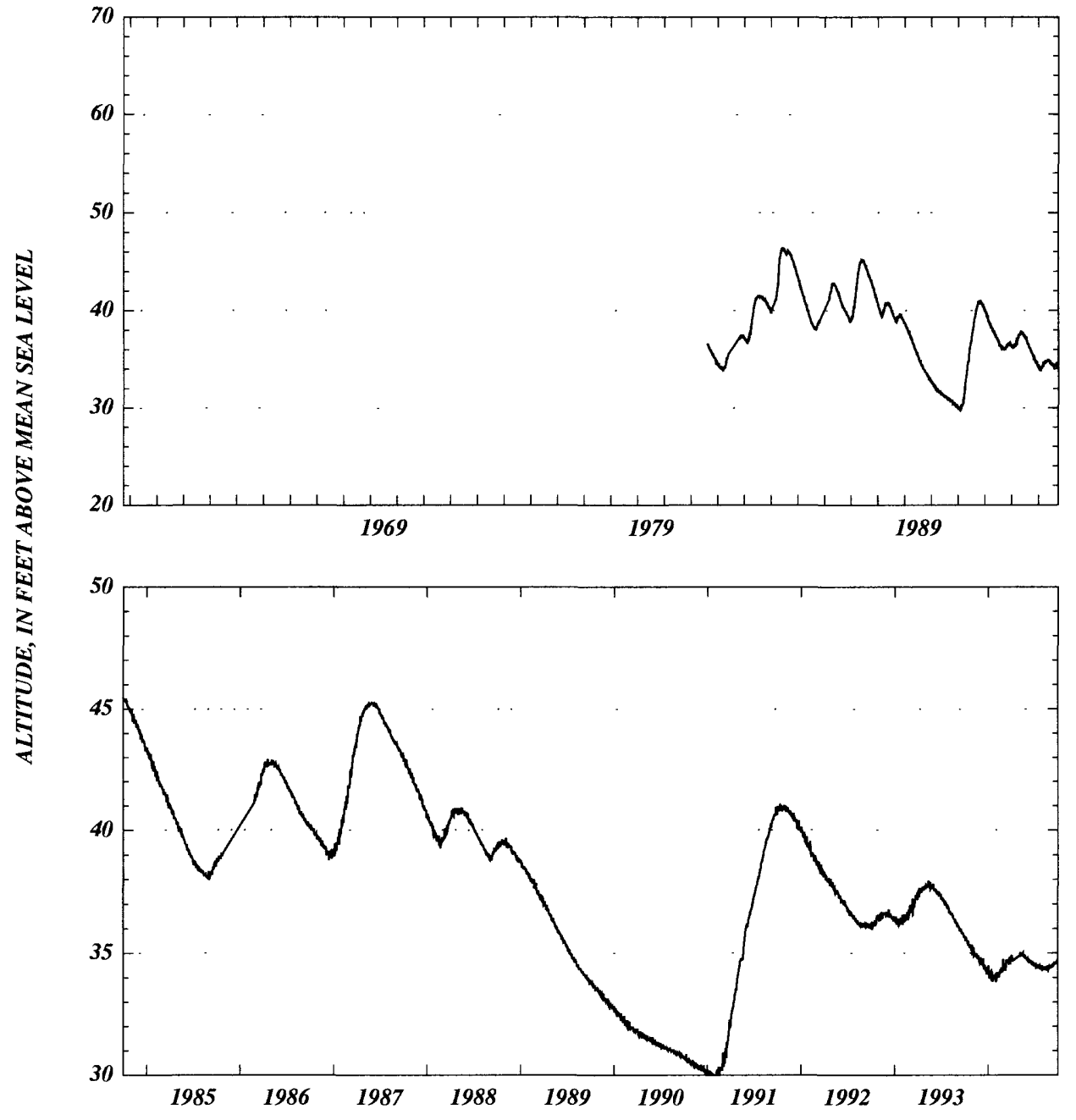



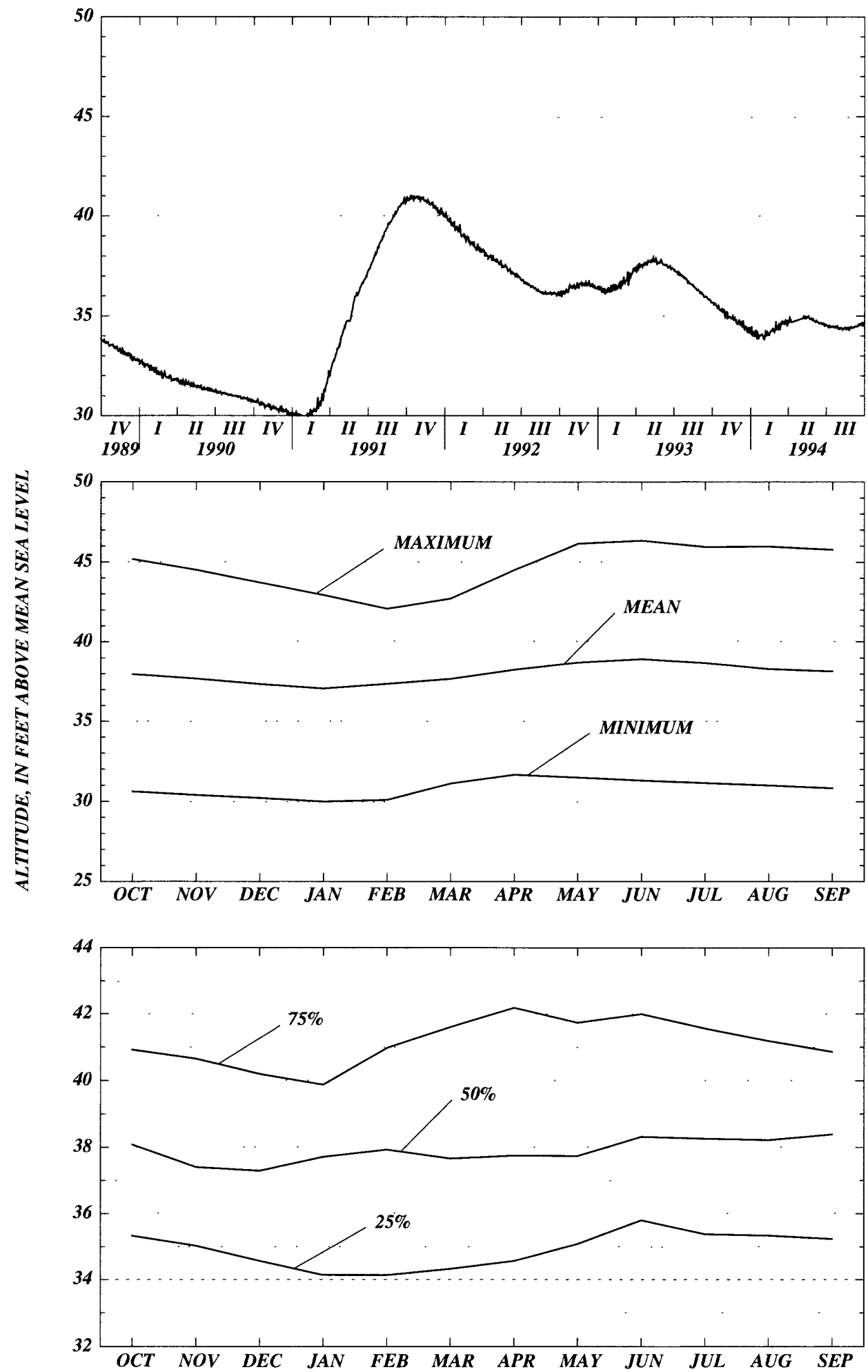


\section{Columbia County}

WELL NUMBER.--301031082381085. DOT - Columbia. -041705001.

LOCATION.--Lat $30^{\circ} 10^{\prime} 31^{\prime \prime}$, long 82³8'10”, Hydrologic Unit Code 03110206.

AQUIFER.--Upper Floridan aquifer of the Tertiary system, Geologic Unit Code 120FLRD.

WELL CHARACTERISTICS.--Casing diameter 12 in., Casing depth $689 \mathrm{ft}$., Total depth $836 \mathrm{ft}$. INSTRUMENTATION.--Recorder, set to elevation of the Measuring Point, $144.69 \mathrm{ft}$., NGVD.

DATUM.--The National Geodetic Vertical Datum of 1929.

PERIOD OF RECORD.--06-05-1948 to 09-30-1994. *

EXTREME VALUES.--Maximum, 64.11 ft. (06-04-1948); minimum, 42.85 ft. (01-09-1991).

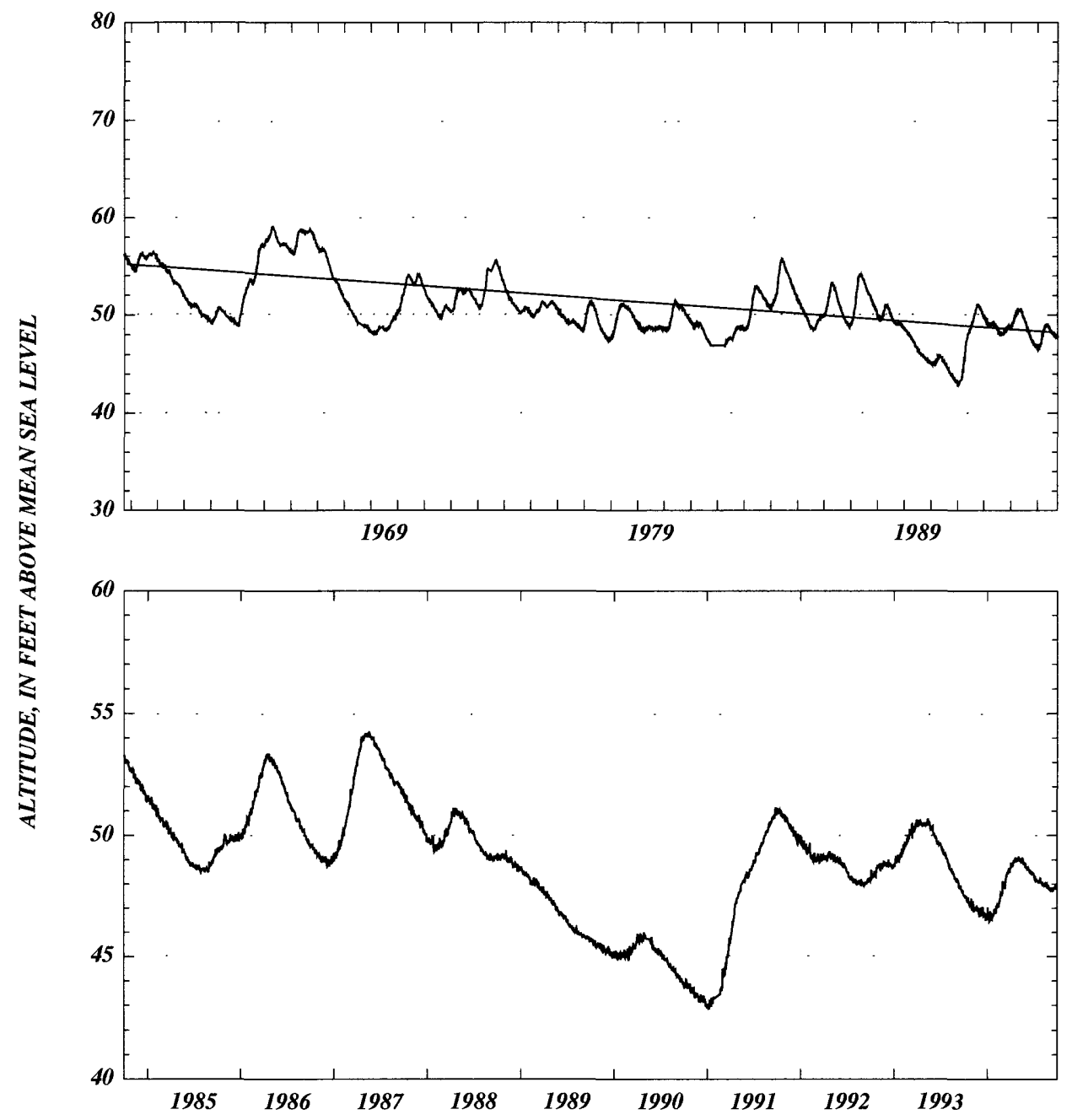



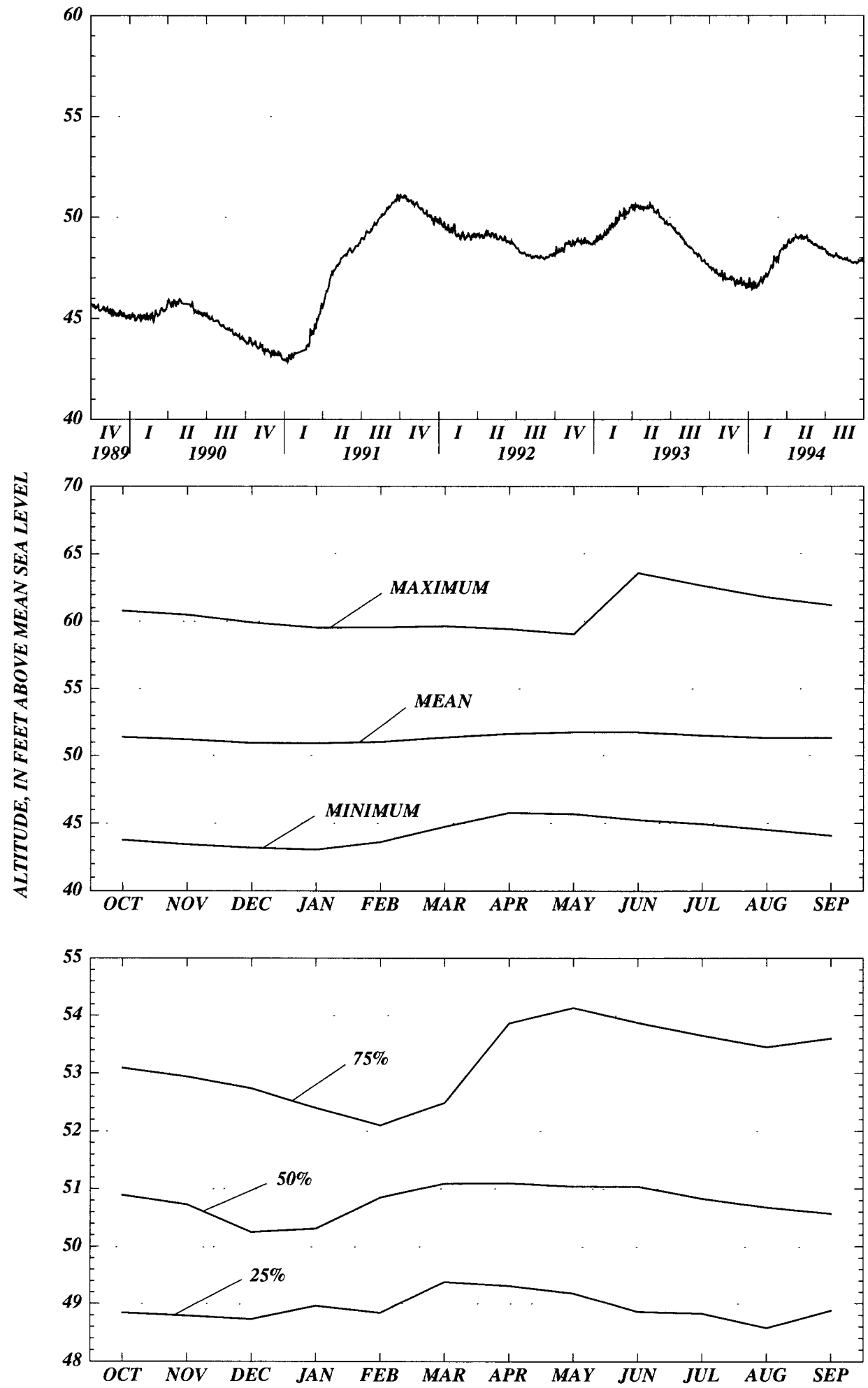


\section{Columbia County}

WELL NUMBER.--301103082353785. DOF - Lake City. -031734023.

LOCATION.--Lat 30 $11^{\circ}$ '03”, long 82³5'37', Hydrologic Unit Code 03110201.

AQUIFER.--Surficial aquifer, Geologic Unit Code 110NRSD.

WELL CHARACTERISTICS.--Casing diameter 3 in., Casing depth $10 \mathrm{ft}$., Total depth $30 \mathrm{ft}$.

INSTRUMENTATION.--Elevation of Measuring Point $197.54 \mathrm{ft}$. NGVD.

DATUM.--The National Geodetic Vertical Datum of 1929.

PERIOD OF RECORD.--06-06-1989 to 09-30-1994. *

EXTREME VALUES.--Maximum observed 194.98 ft. (07-10-1991); minimum observed, $189.21 \mathrm{ft}$. (12-18-1991).

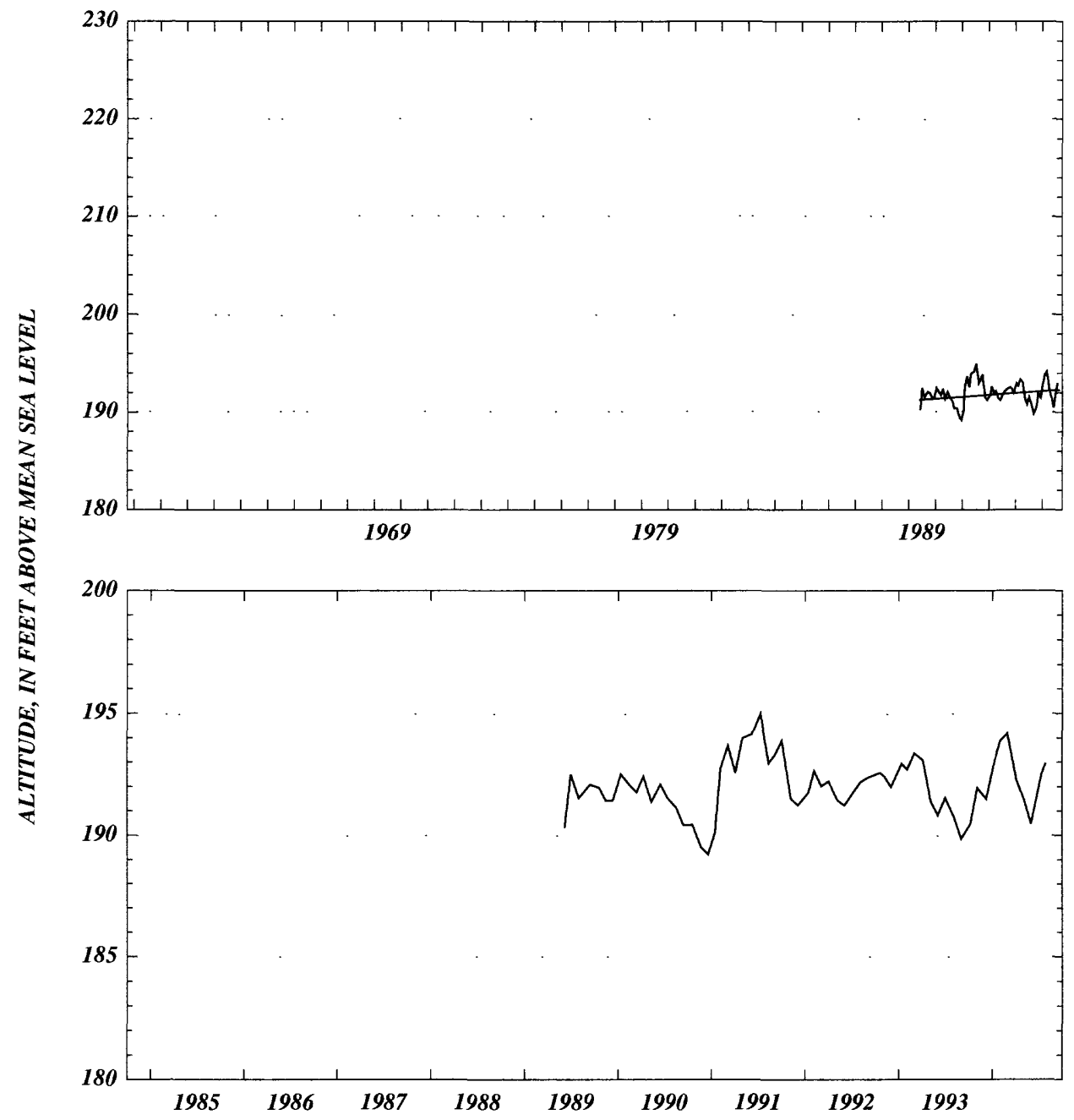



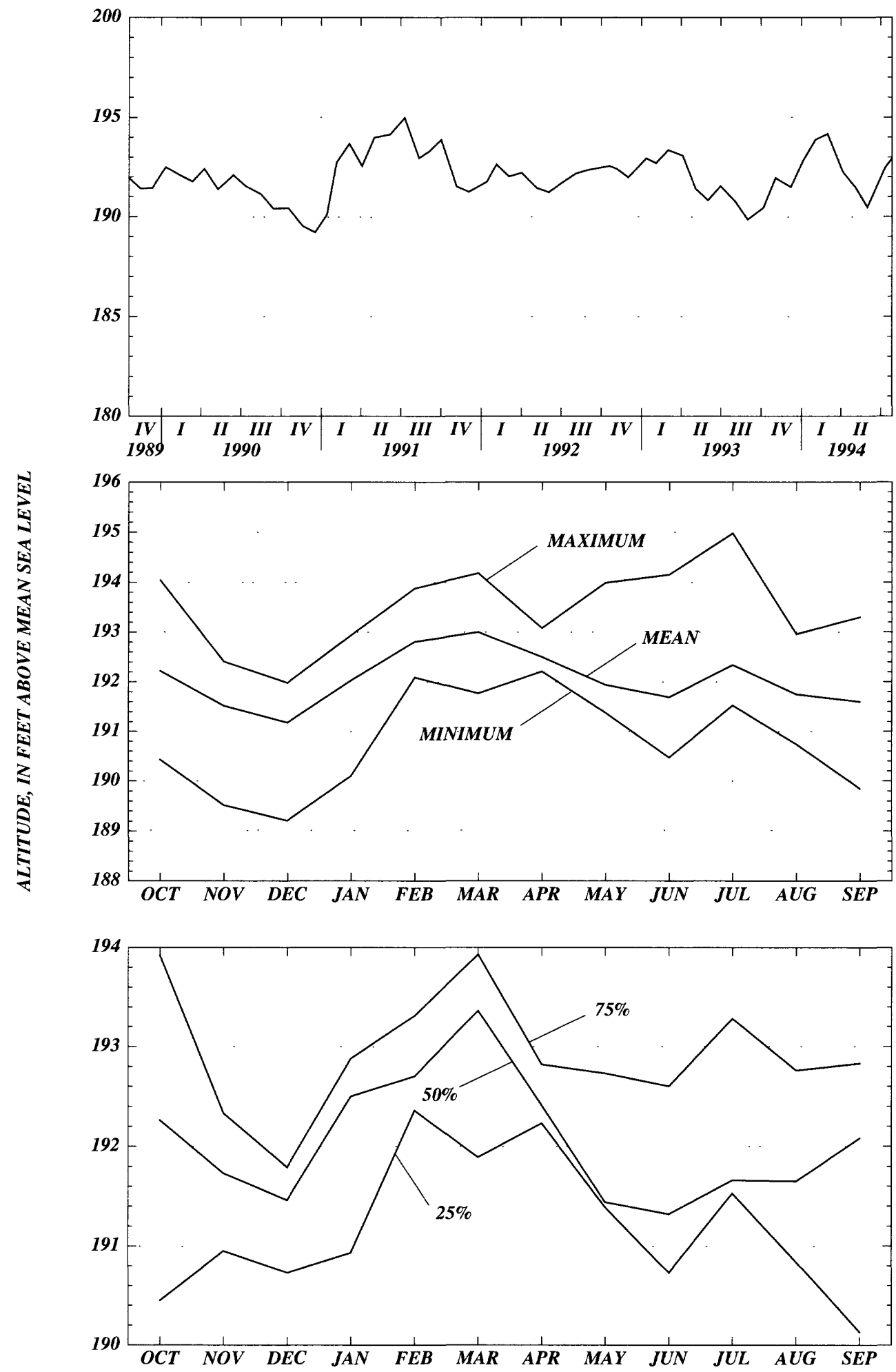


\section{Columbia County}

WELL NUMBER.--301104082353785. DOF - Lake City. -031734011.

LOCATION.--Lat 30¹1'04”, long 82 35'37', Hydrologic Unit Code 03110201.

AQUIFER.--Upper Floridan aquifer of the Tertiary system, Geologic Unit Code 120FLRD.

WELL CHARACTERISTICS.--Casing diameter 4 in., Casing depth $183 \mathrm{ft}$., Total depth $203 \mathrm{ft}$.

INSTRUMENTATION.--Elevation of Measuring Point $197.56 \mathrm{ft} .$, NGVD.

DATUM.--The National Geodetic Vertical Datum of 1929.

PERIOD OF RECORD.--08-05-1992 to 09-30-1994.

EXTREME VALUES.--Maximum observed, 59.55 ft. (03-03-1993); minimum observed, $51.93 \mathrm{ft}$. (11-03-1993).

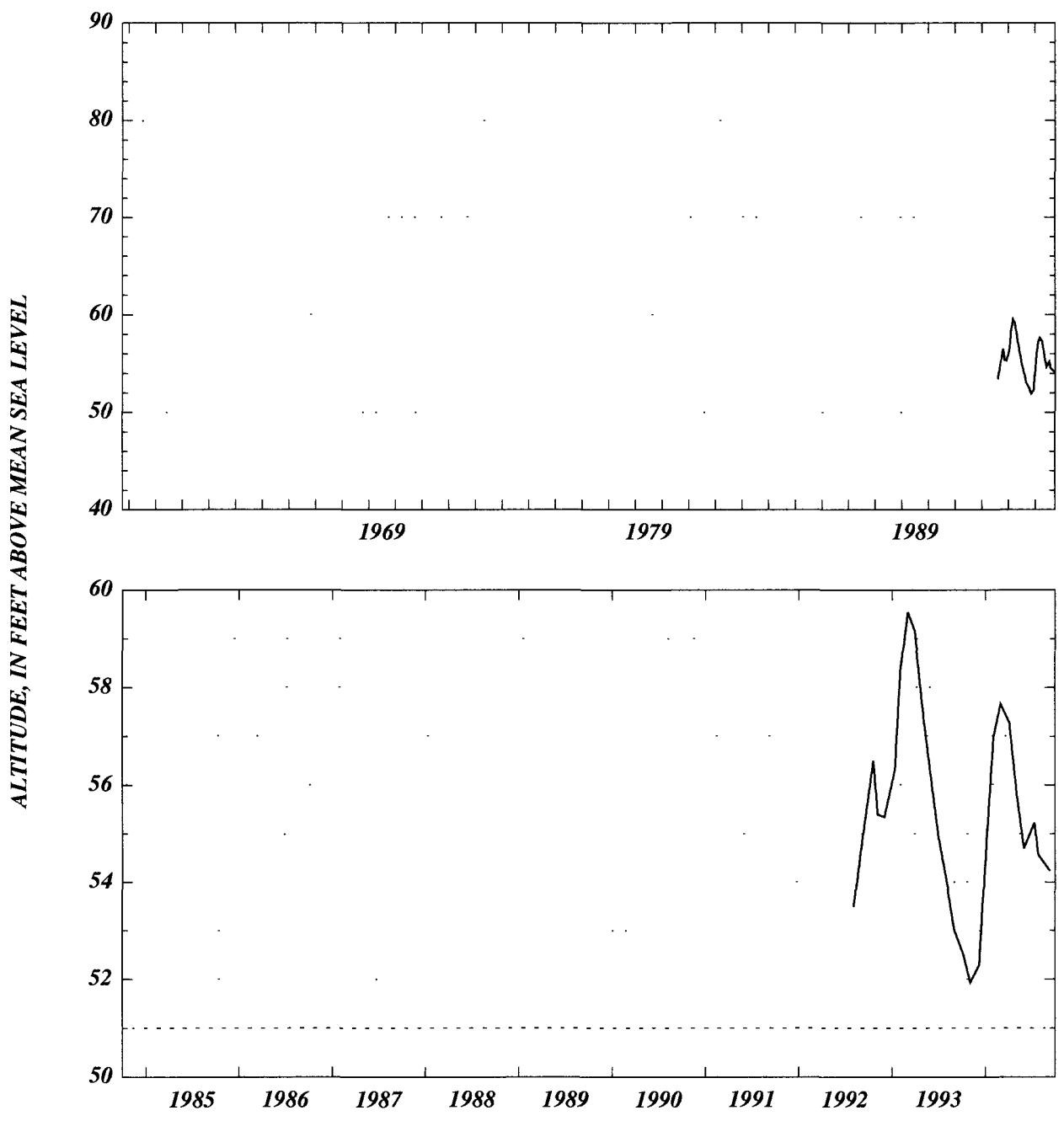



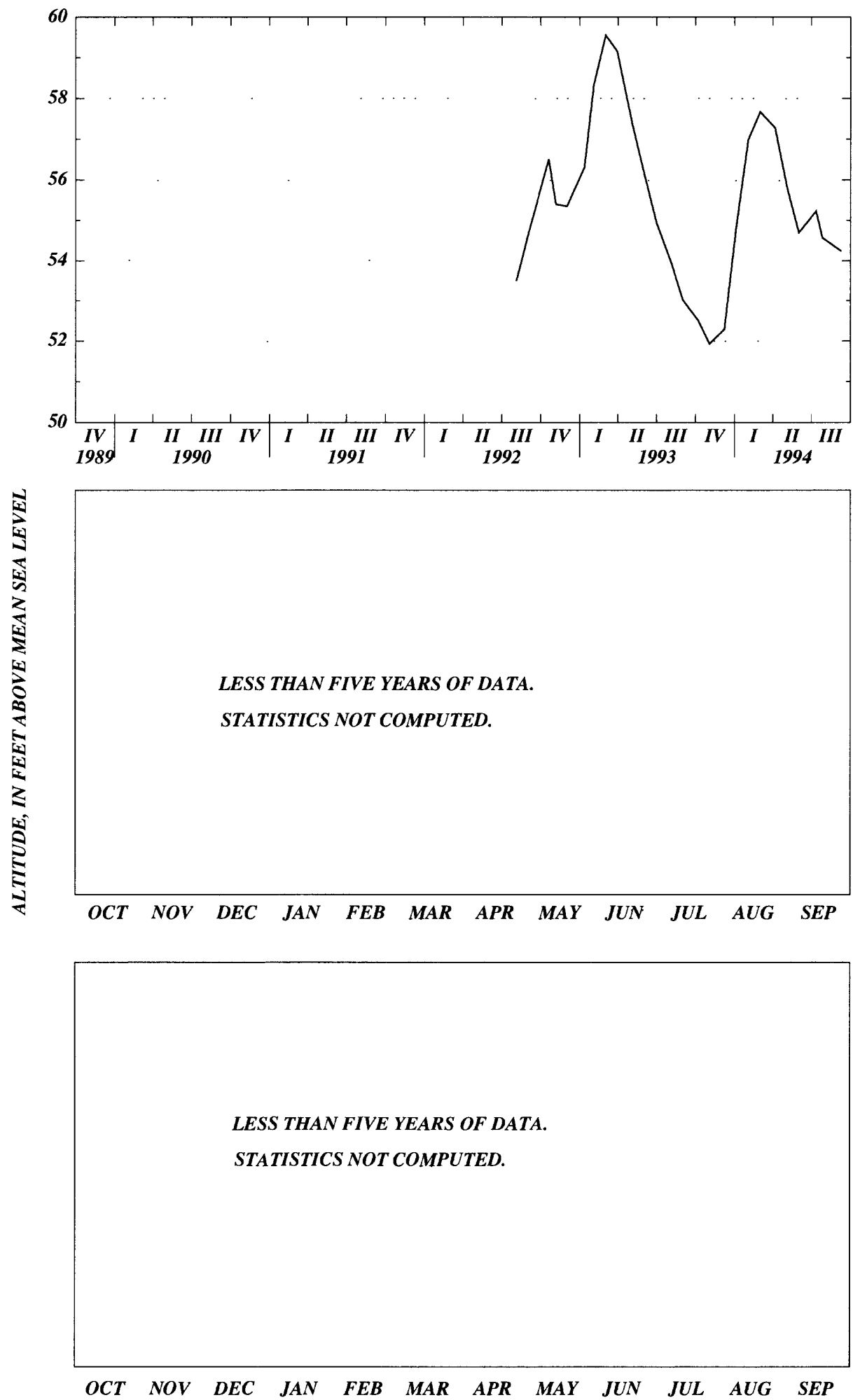


\section{Columbia County}

WELL NUMBER.--301540082395785. George Whittaker. -031601003.

LOCATION.--Lat 30¹5'40”, long 82³9'57’, Hydrologic Unit Code 03110201.

AQUIFER.--Upper Floridan aquifer of the Tertiary system, Geologic Unit Code 120FLRD.

WELL CHARACTERISTICS.--Casing diameter 4 in., Casing depth $117 \mathrm{ft}$., Total depth $120 \mathrm{ft}$.

INSTRUMENTATION.--Recorder from 09-02-1981 to 11-02-1982; then miscellaneous from

01-07-1983 to 09-30-1994. Elevation of Measuring Point $129.40 \mathrm{ft}$., NGVD.

DATUM.--The National Geodetic Datum of 1929.

PERIOD OF RECORD.--09-02-1981 to 09-30-1994.

EXTREME VALUES.--Maximum observed, $83.30 \mathrm{ft}$. (03-30-1987); minimum observed, $48.60 \mathrm{ft}$. (01-04-1991).

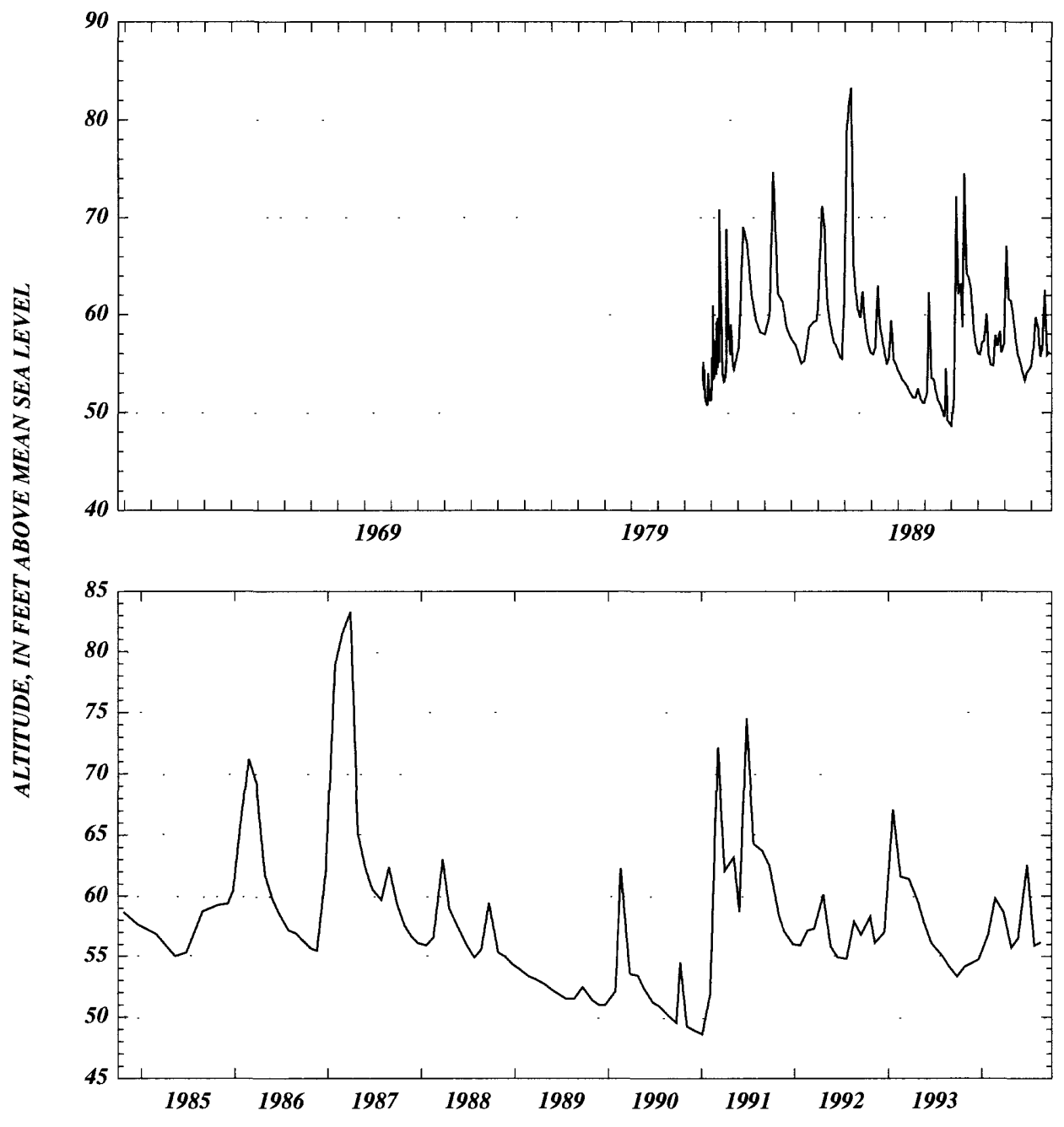



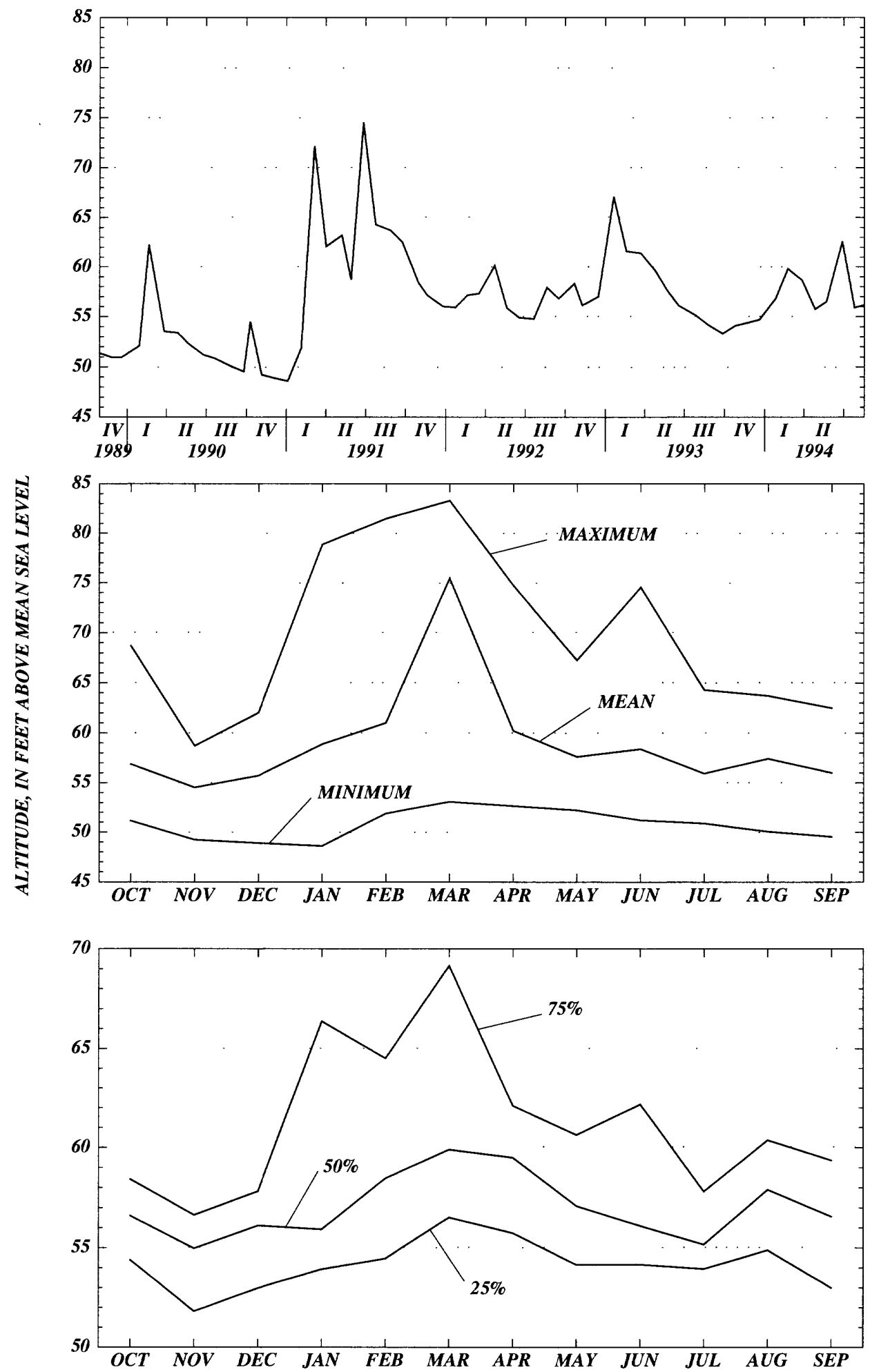


\section{Columbia County}

WELL NUMBER.--301822082393985. A.K. Black. -021624001.

LOCATION.--Lat 30¹8'22”, long 82³9’39”, Hydrologic Unit Code 03110201.

AQUIFER.--Upper Floridan aquifer of the Tertiary system, Geologic Unit Code 120FLRD.

WELL CHARACTERISTICS.--Casing diameter 4 in., Casing depth $75 \mathrm{ft}$., Total depth $167 \mathrm{ft}$.

INSTRUMENTATION.--Recorder from 12-07-1977 to 08-27-1990; miscellaneous measurements from 10-10-1990 to 09-30-1994. Elevation of Measuring Point, $131.91 \mathrm{ft}$., NGVD.

DATUM.--The National Geodetic Vertical Datum of 1929.

PERIOD OF RECORD.--12-07-1977 to 09-30-1994.

EXTREME VALUES.--Maximum 72.78 ft. (04-23-1984); minimum, 49.28 ft. (08-18-1990).

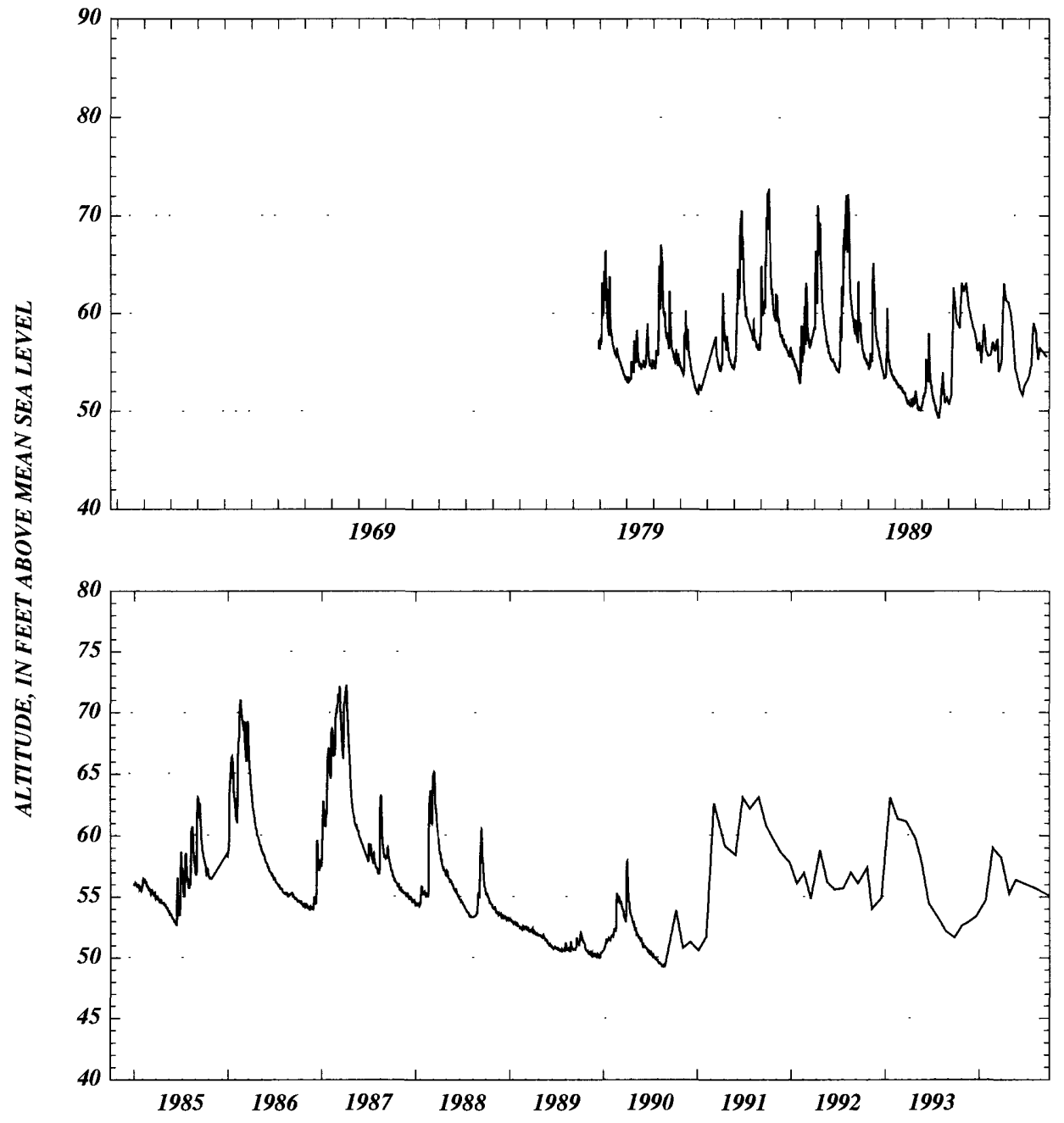



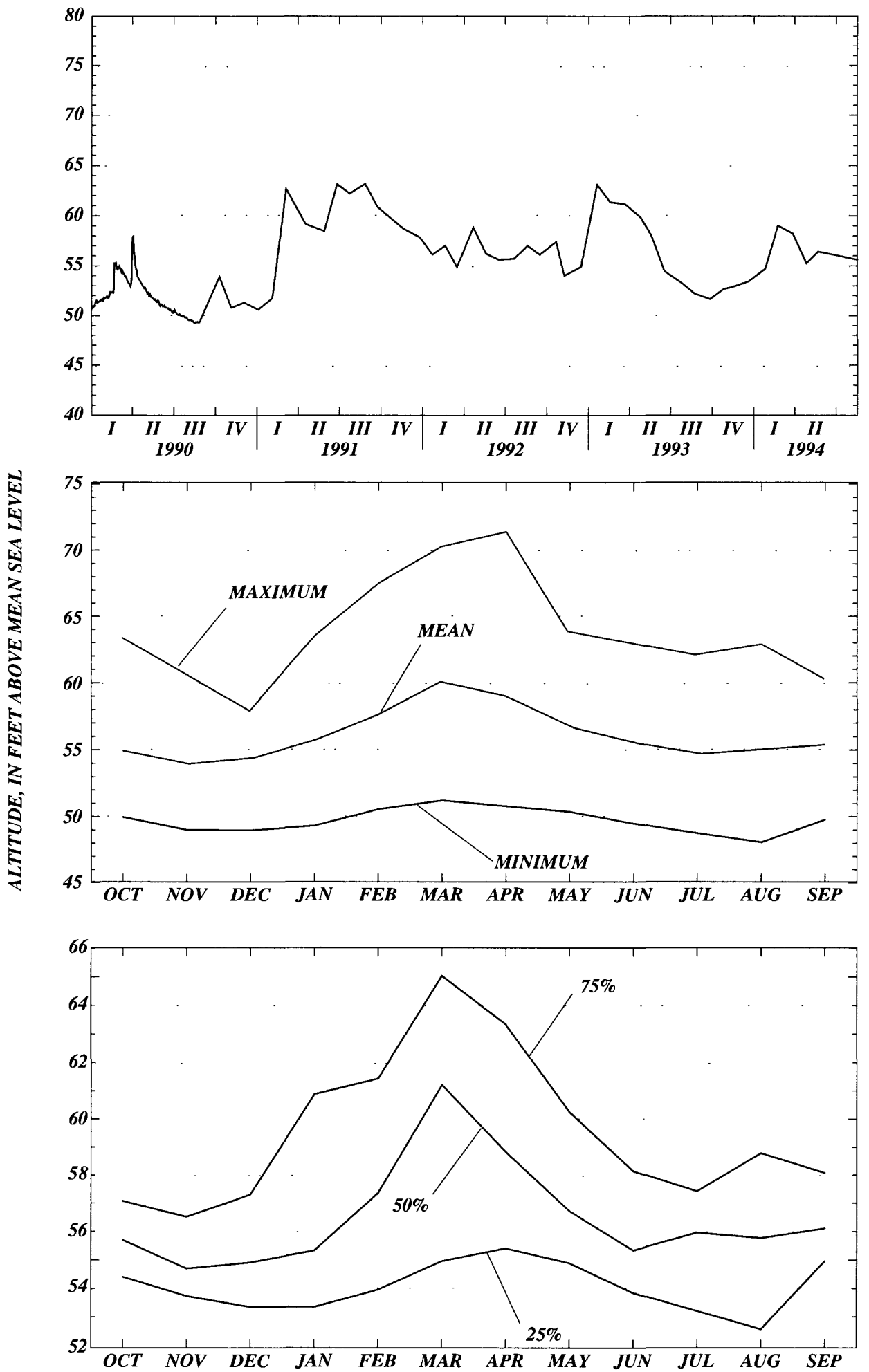


\section{Columbia County}

WELL NUMBER.--301933082350585. USGS - ONF 2V. -021711003.

LOCATION.--Lat 30¹9'39”, long 82³5'26”, Hydrologic Unit Code 03110201.

AQUIFER.--Upper Floridan aquifer of the Tertiary system, Geologic Unit Code 120FLRD.

WELL CHARACTERISTICS.--Casing diameter 18 in., Casing depth $160 \mathrm{ft}$., Total depth $262 \mathrm{ft}$. INSTRUMENTATION.--Recorder, set to elevation of the Measuring Point, $138.18 \mathrm{ft}$., NGVD.

DATUM.--The National Geodetic Vertical Datum of 1929.

PERIOD OF RECORD.--08-05-1976 to 09-30-1994. $\dagger$

EXTREME VALUES.--Maximum, 61.43 ft. (03-23-1991); minimum, 48.20 ft. (01-09-1991).

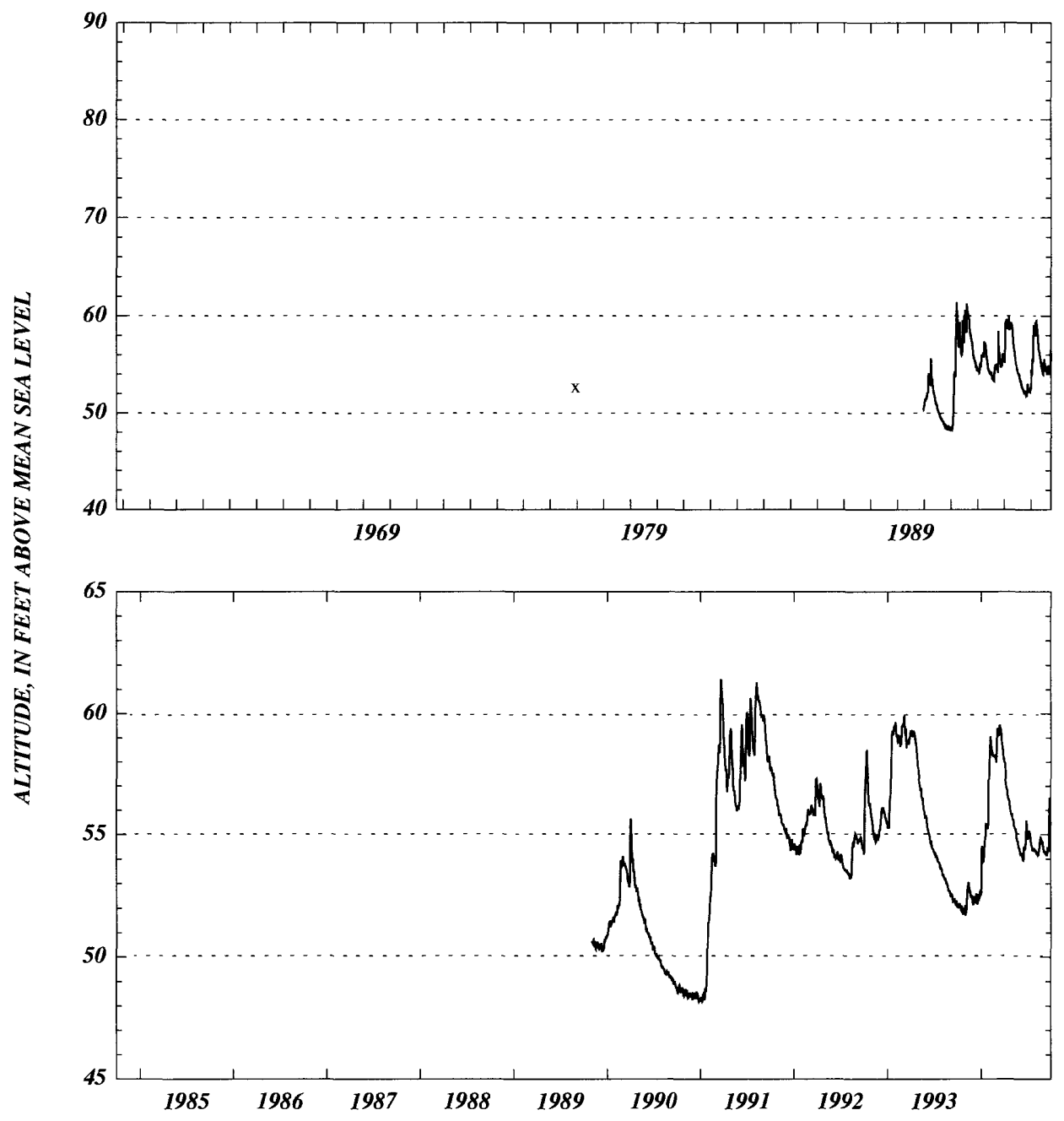



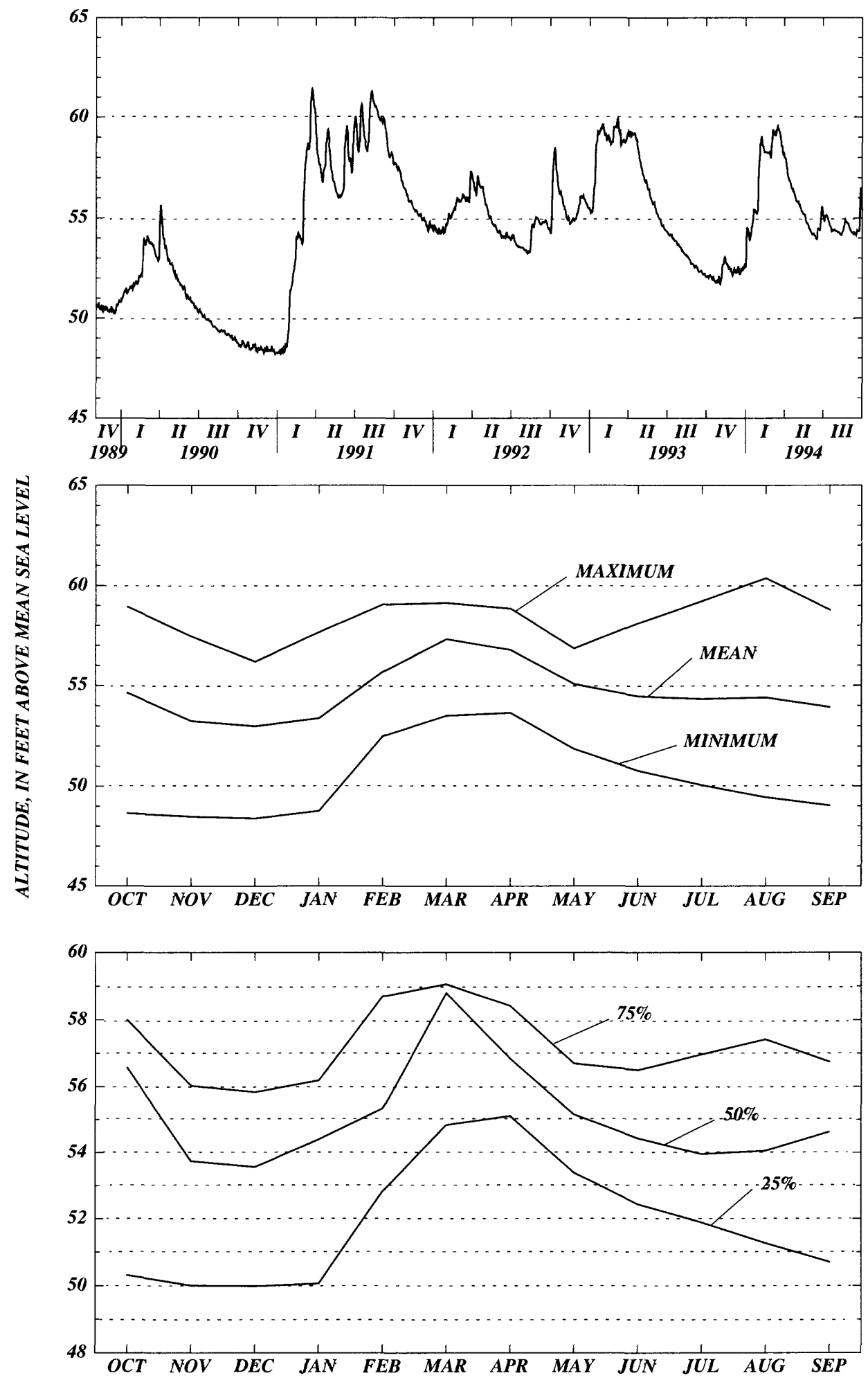


\section{Columbia County}

WELL NUMBER.--302052082312485. USGS - ONF 3A. -021805001.

LOCATION.--Lat 30²0'32”, long 82³1'43”, Hydrologic Unit Code 03110201.

AQUIFER.--Upper Floridan aquifer of the Tertiary system, Geologic Unit Code 120FLRD.

WELL CHARACTERISTICS.--Casing diameter 4 in., Casing depth $195 \mathrm{ft}$., Total depth $220 \mathrm{ft}$.

INSTRUMENTATION.--Recorder from 06-10-1976 to 11-02-1989, miscellaneous measurements from 11-17-1989 to 09-30-1994. Elevation of Measuring Point $131.45 \mathrm{ft}$, NGVD.

DATUM.--The National Geodetic Vertical Datum of 1929.

PERIOD OF RECORD.--06-10-1976 to 09-30-1994. *

EXTREME VALUES.--Maximum, $63.66 \mathrm{ft}$ (04-16-1984); minimum observed, $46.80 \mathrm{ft}$.

(11-16-1990).

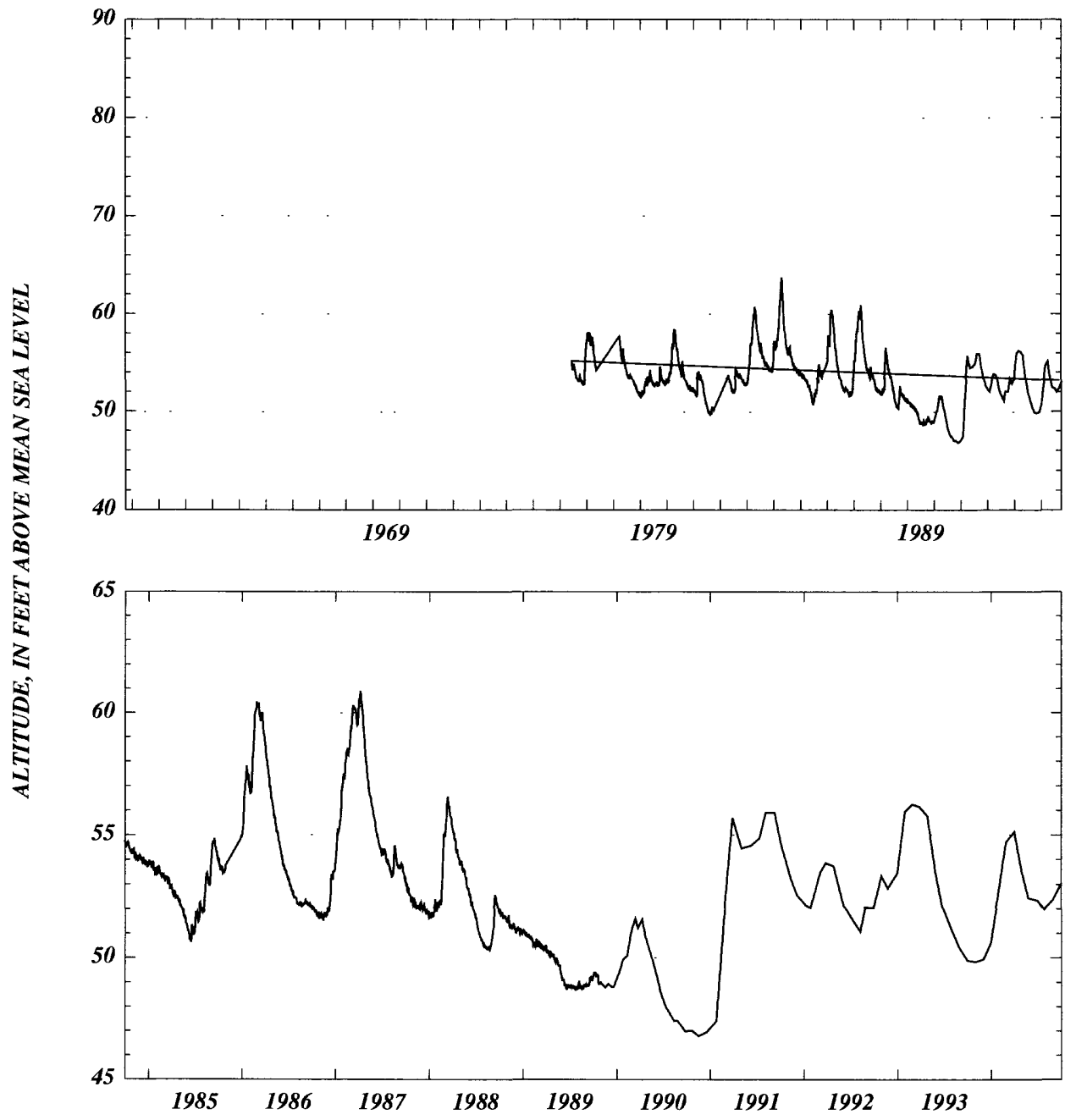



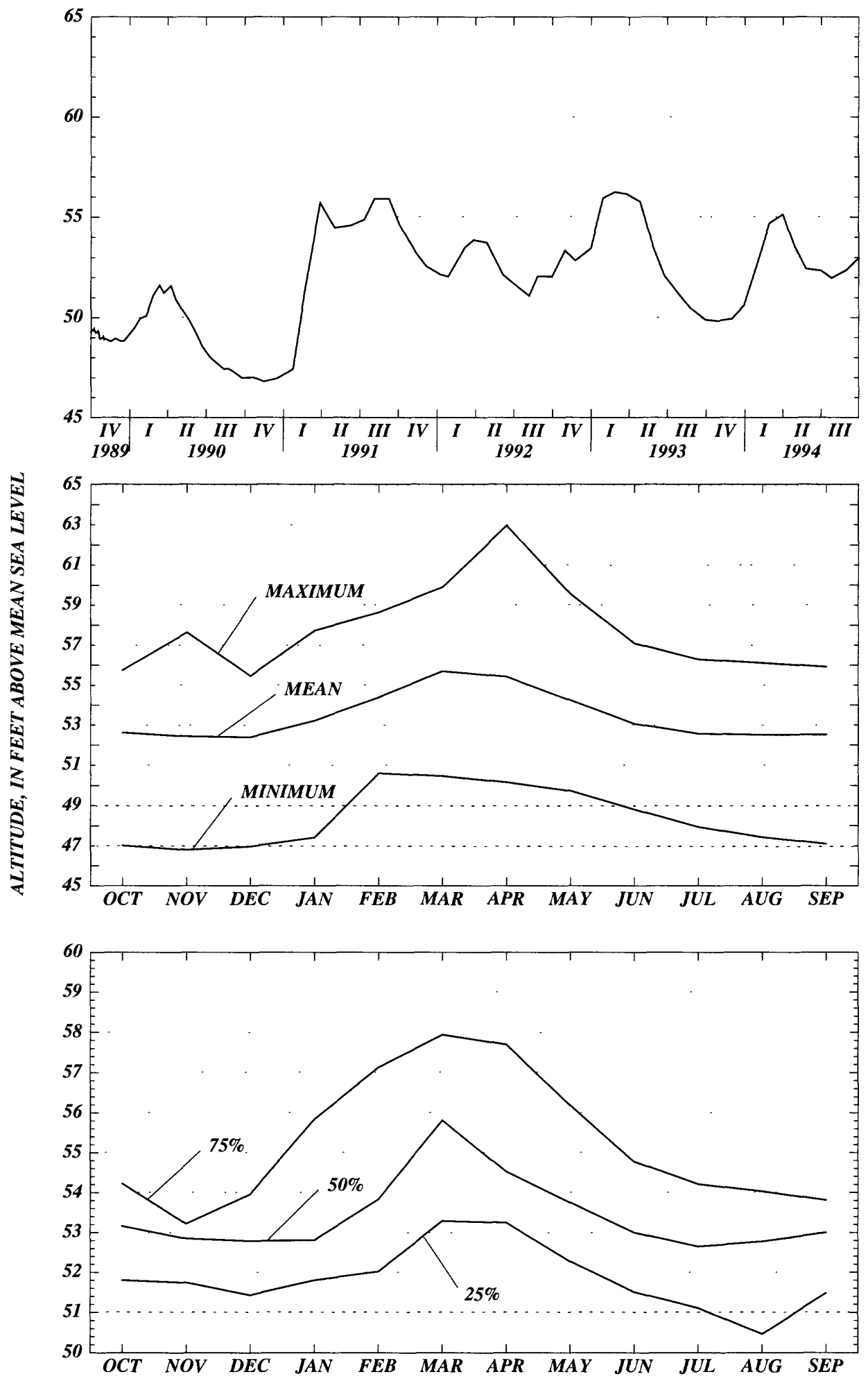


\section{Columbia County}

WELL NUMBER.--302243082360285. USGS - ONF 1A. -011727001.

LOCATION.--Lat 30²2'41”, long 82³6'04”, Hydrologic Unit Code 03110201.

AQUIFER.--Upper Floridan aquifer of the Tertiary system, Geologic Unit Code 120FLRD.

WELL CHARACTERISTICS.--Casing diameter 8 in., Casing depth $192 \mathrm{ft}$., Total depth $228 \mathrm{ft}$. INSTRUMENTATION.--Recorder set to elevation of Measuring Point $122.06 \mathrm{ft}$, NGVD.

DATUM.--The National Geodetic Vertical Datum of 1929.

PERIOD OF RECORD.--06-10-1976 to 09-30-1994.

EXTREME VALUES.--Maximum, 68.03 ft. (04-03-1984); minimum observed, $46.51 \mathrm{ft}$. (10-07-1990).

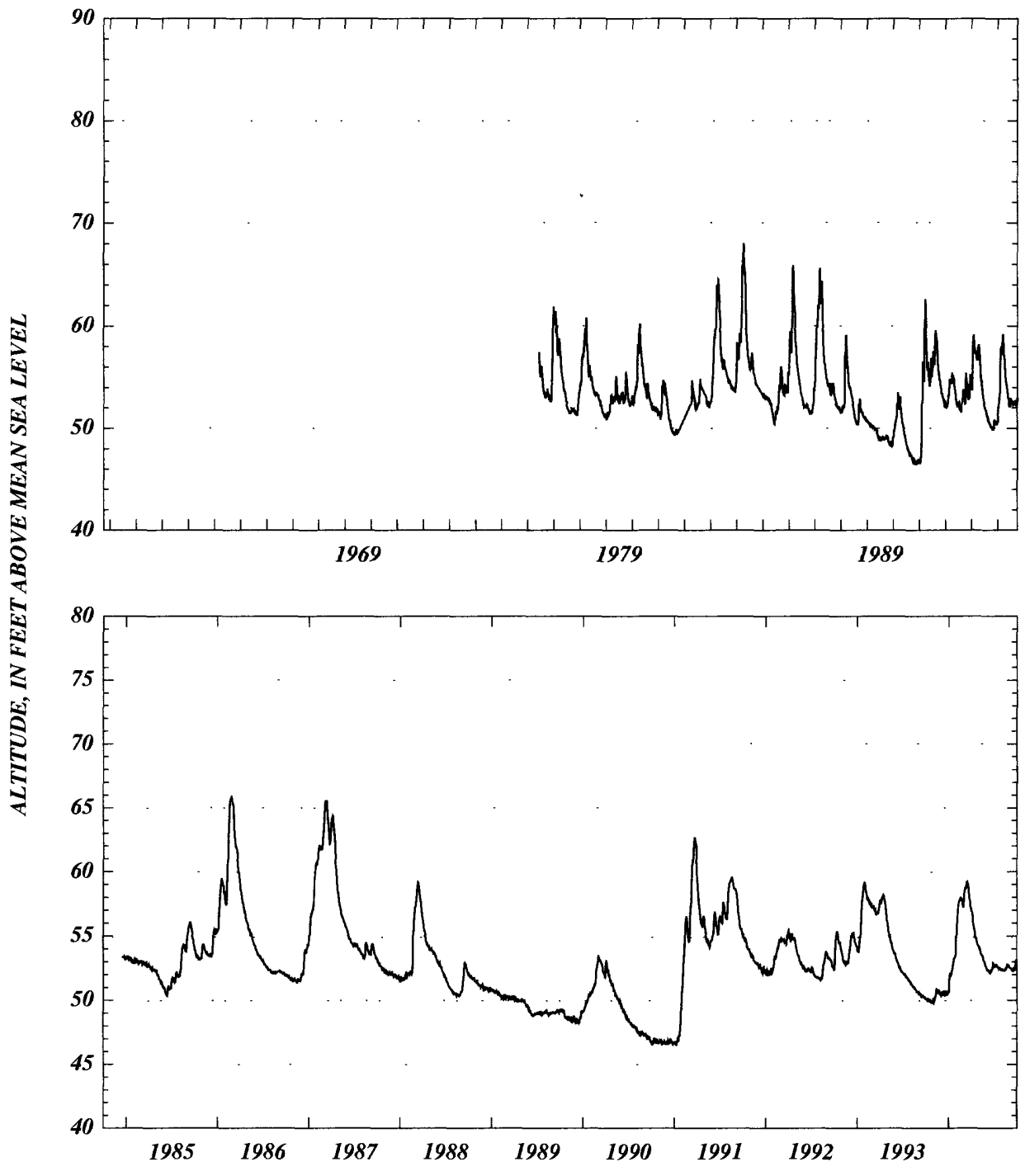



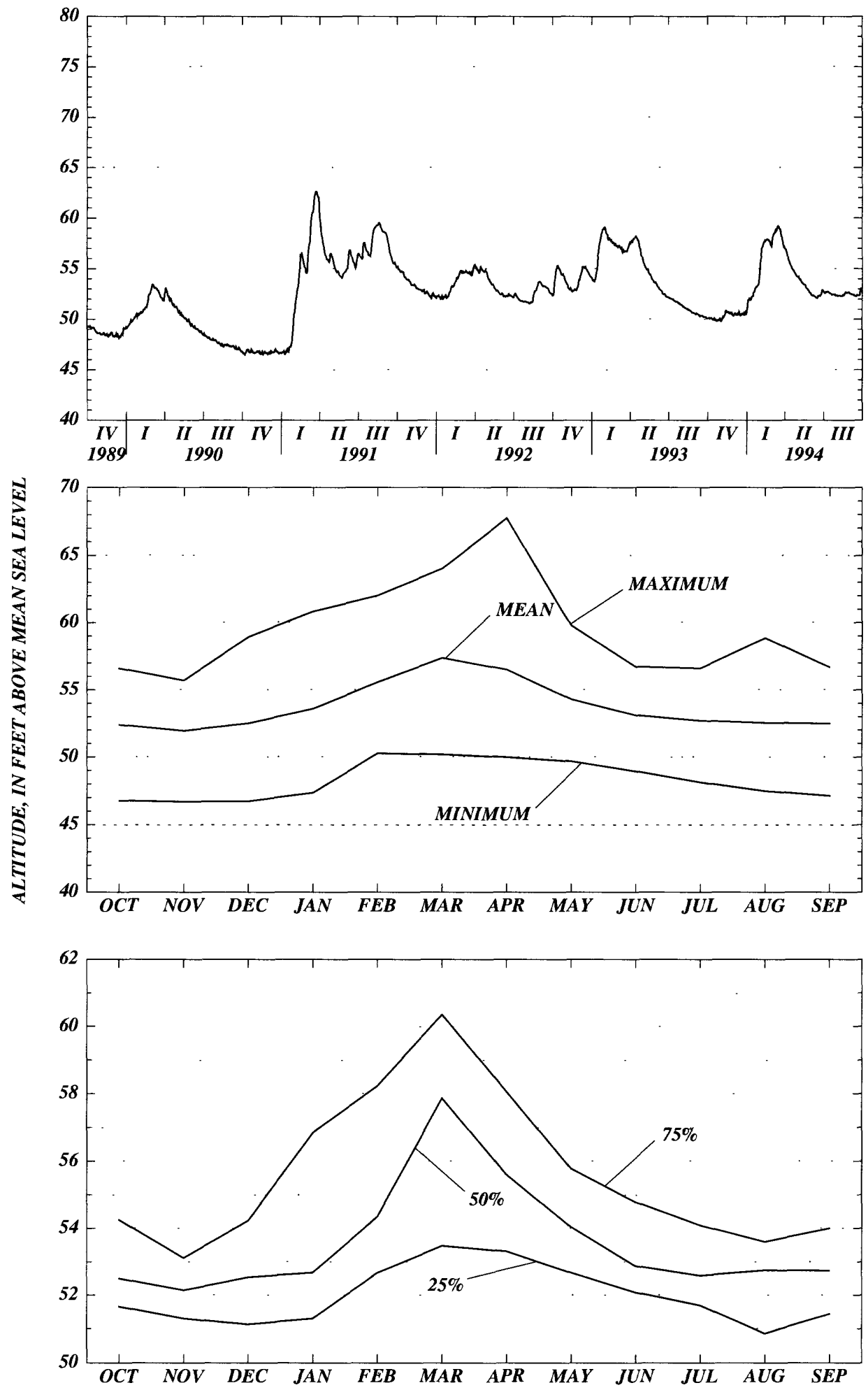


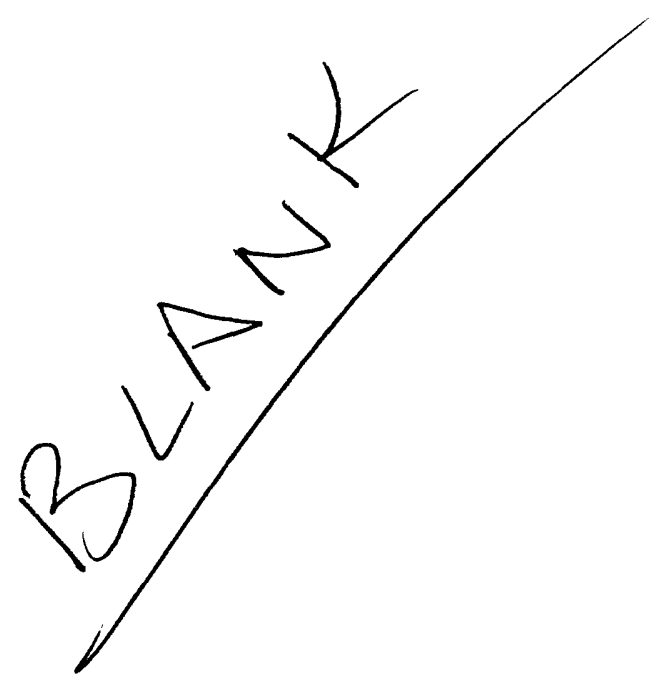

94 Statistical Summaries of Ground-Water Level Data Collected in the Suwannee River Water Management District, 1948-1994 


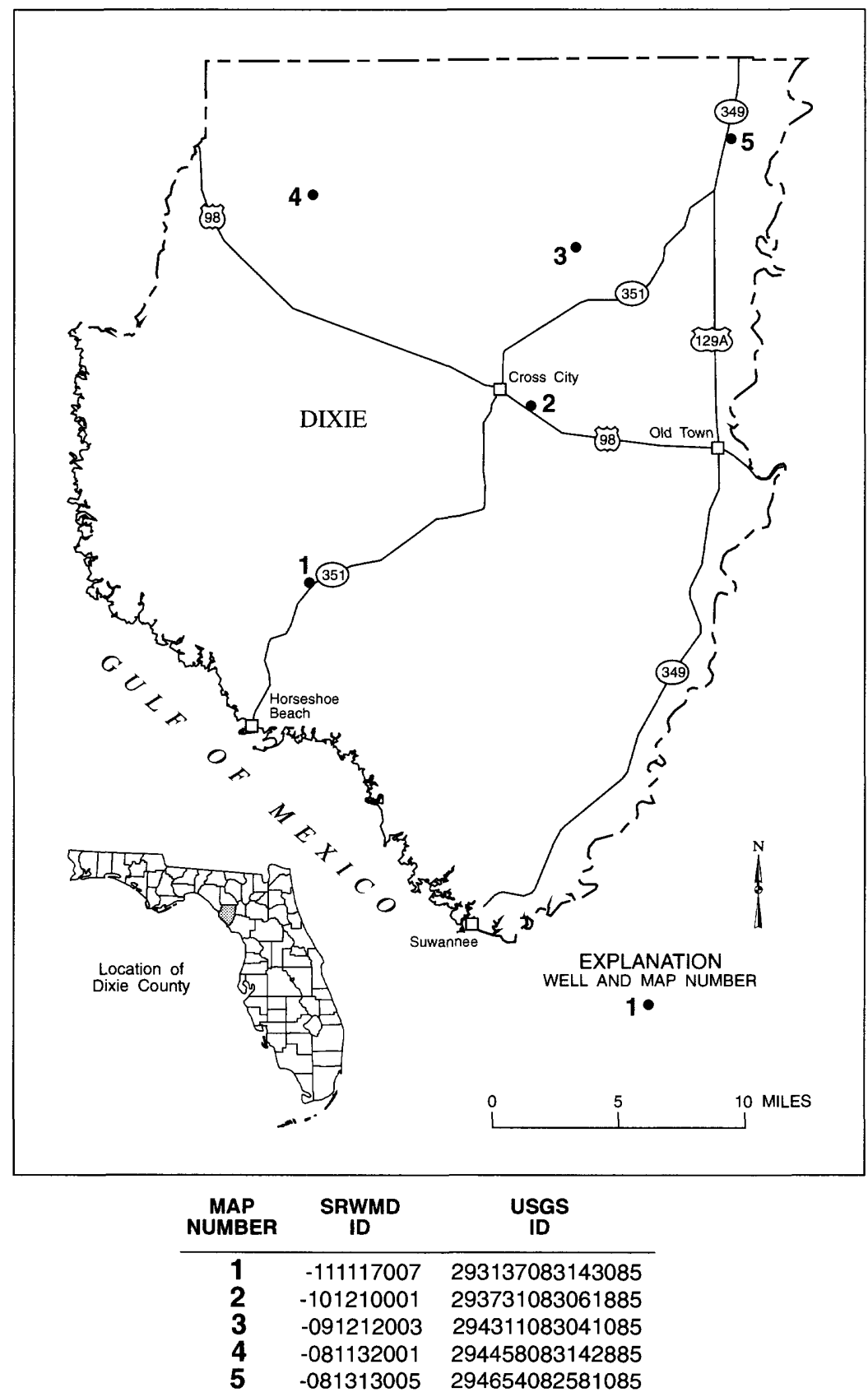

Figure 7. Location of wells in Dixie County. 


\section{Dixie County}

WELL NUMBER.--293137083143085. DOF - Horseshoe Tower, -111117007.

LOCATION.--Lat 29³1'37”, long 83¹4'30”, Hydrologic Unit 03110102.

AQUIFER.--Upper Floridan aquifer of the Tertiary System, Geologic Unit 120FLRD.

WELL CHARACTERISTICS.--Casing diameter 3 in., Casing depth $6 \mathrm{ft}$., Total depth $36 \mathrm{ft}$.

INSTRUMENTATION.--Elevation of Measuring Point $18.43 \mathrm{ft}$., NGVD.

DATUM.--National Geodetic Vertical Datum of 1929.

PERIOD OF RECORD.--06-15-1989 to 09-30-1994.

EXTREME VALUES.--Maximum observed, $16.38 \mathrm{ft}$. (08-15-1991); minimum observed, $11.42 \mathrm{ft}$. (06-15-1989).

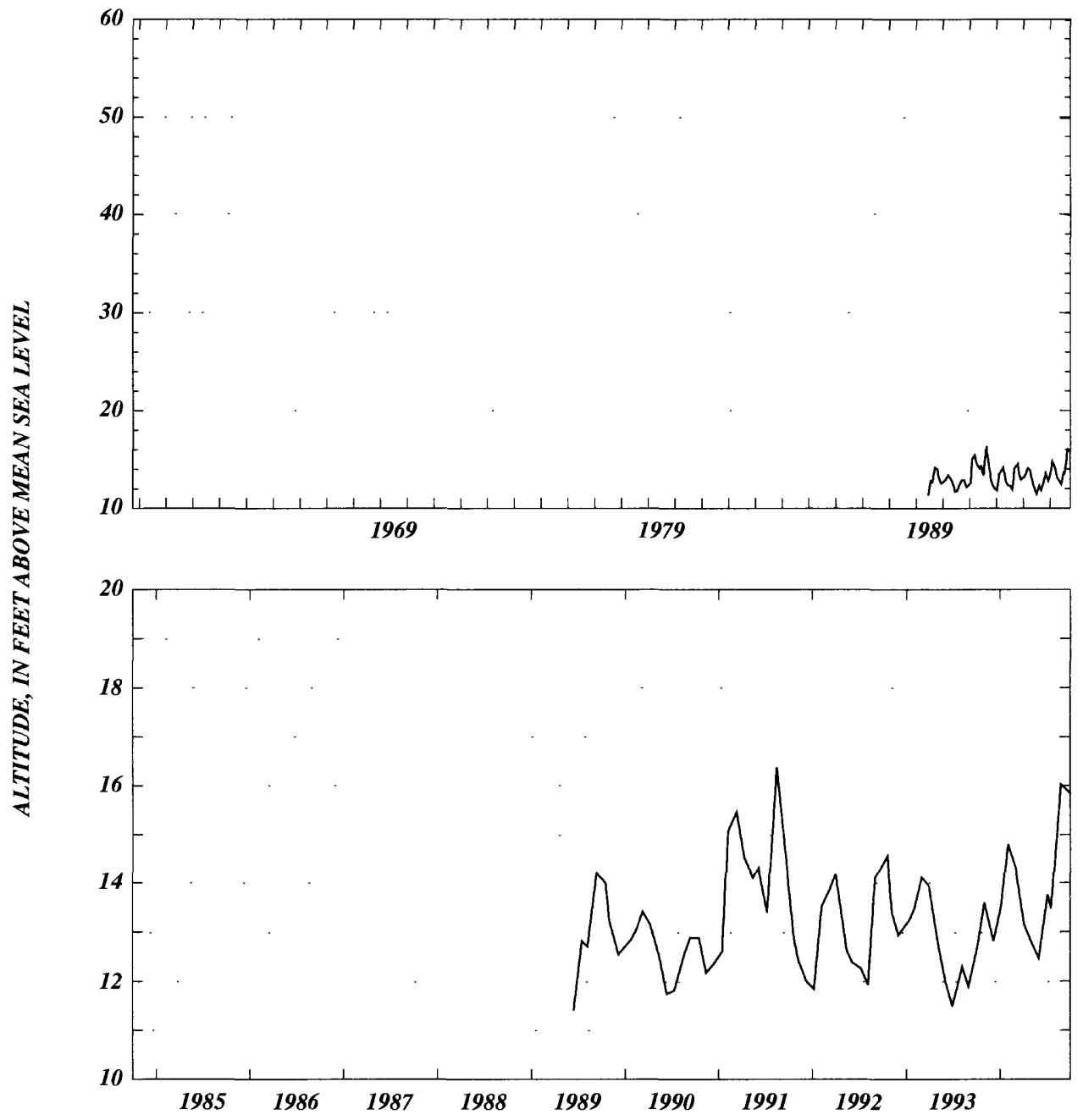



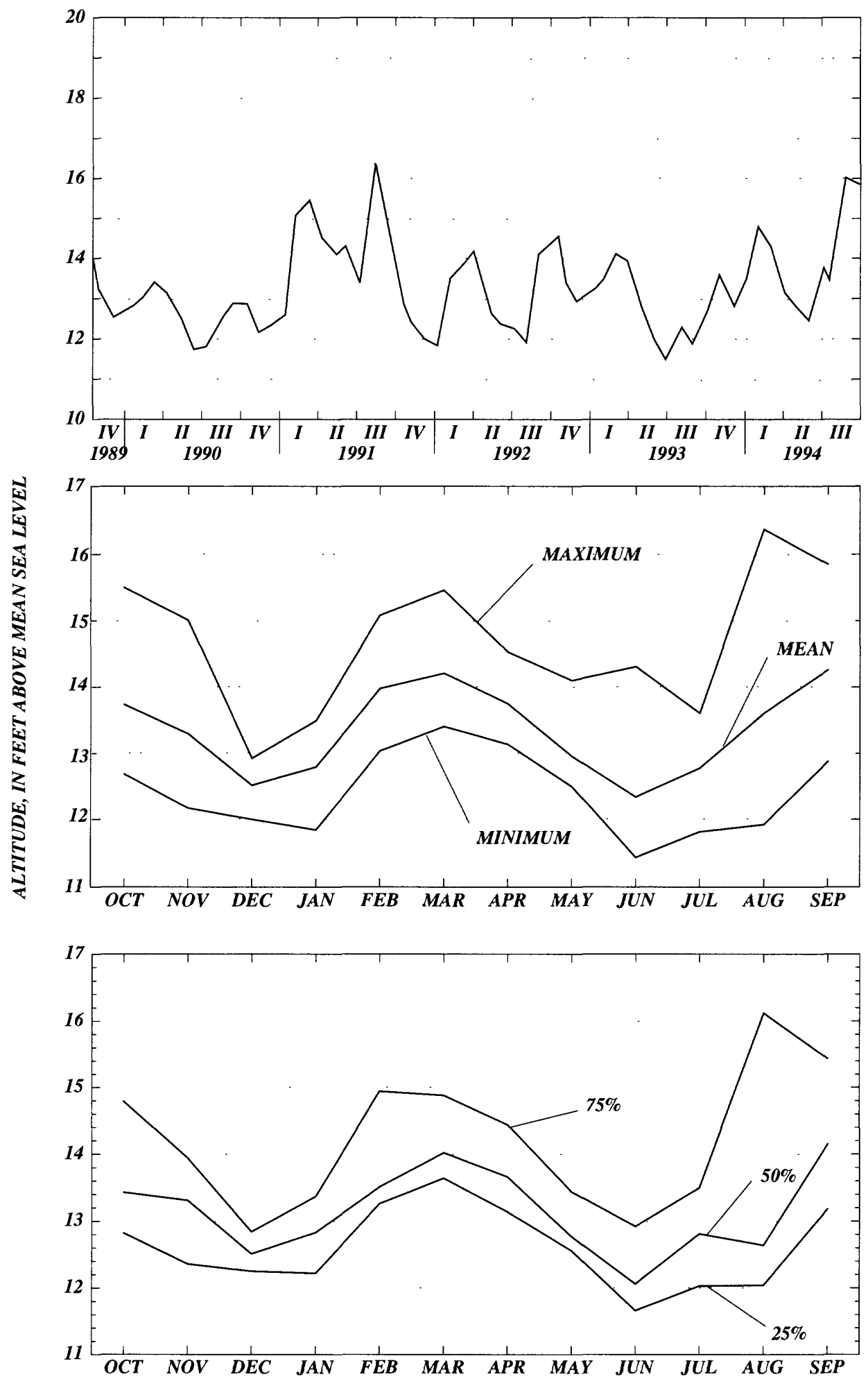


\section{Dixie County}

WELL NUMBER.--293731083061885. City of Cross City. - 101210001.

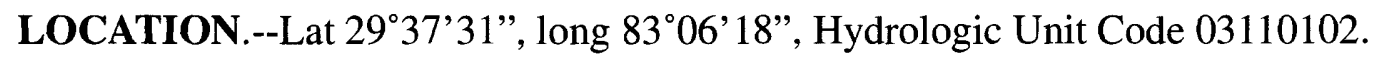

AQUIFER.--Upper Floridan aquifer of the Tertiary system, Geologic Unit Code 120FLRD.

WELL CHARACTERISTICS.--Casing diameter 8 in., Casing depth $106 \mathrm{ft}$., Total depth $215 \mathrm{ft}$.

INSTRUMENTATION.--Recorder from 06-20-1957 to 02-28-1063; no record from 03-01-1963 to 10-12-1974; miscellaneous measurements from 01-03-1974 to 003-19-1980; recorder from 03-20-1980 to 09-30-1994. Elevation of the Measuring Point, $43.90 \mathrm{ft} .$, NGVD.

DATUM.--The National Geodetic Vertical Datum of 1929.

PERIOD OF RECORD.--06-20-1957 to 09-30-1994. * $\dagger$

EXTREME VALUES.--Maximum, 39.80 ft. (09-10-1988); minimum, 30.00 ft. (08-18-1977).

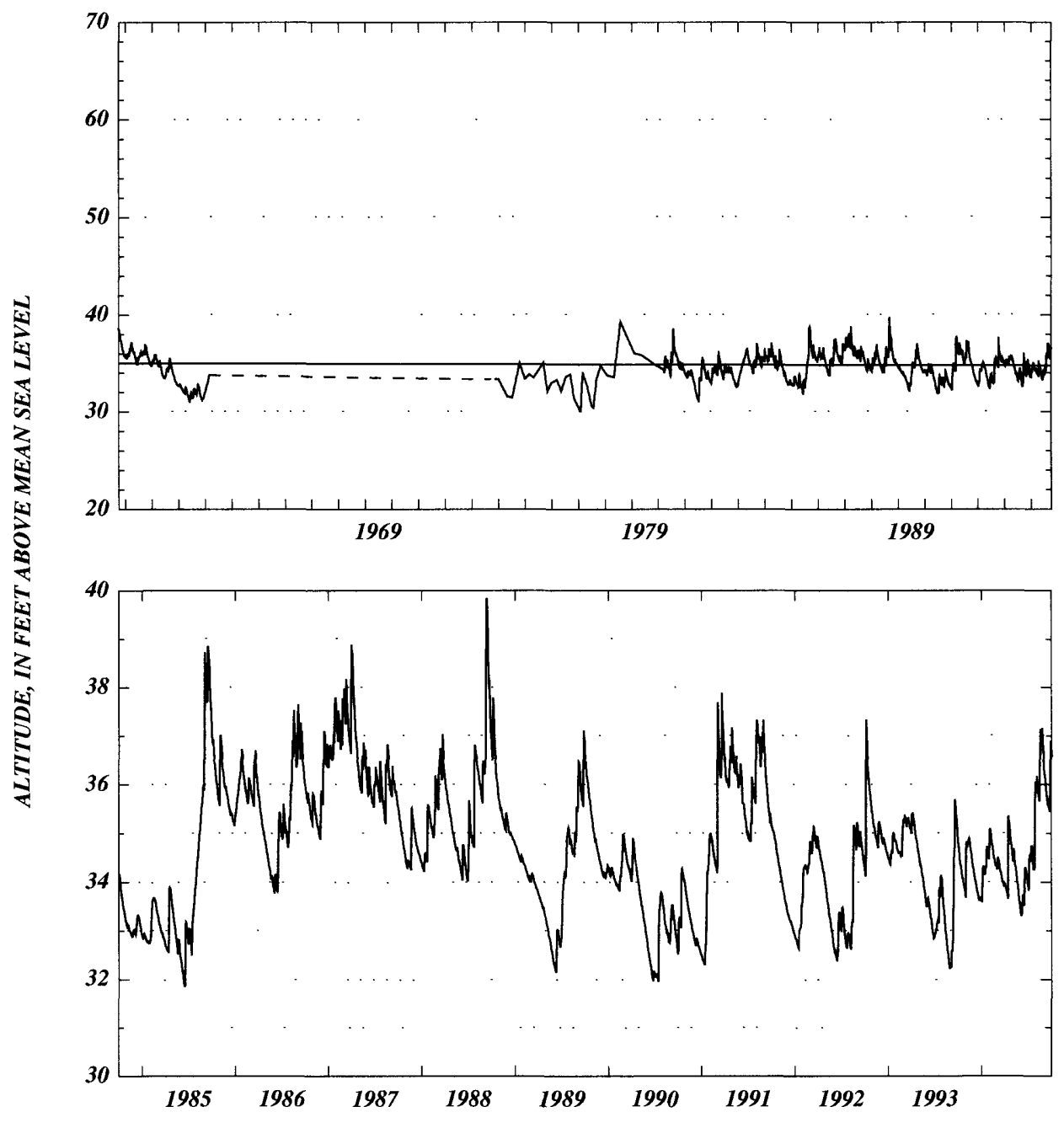



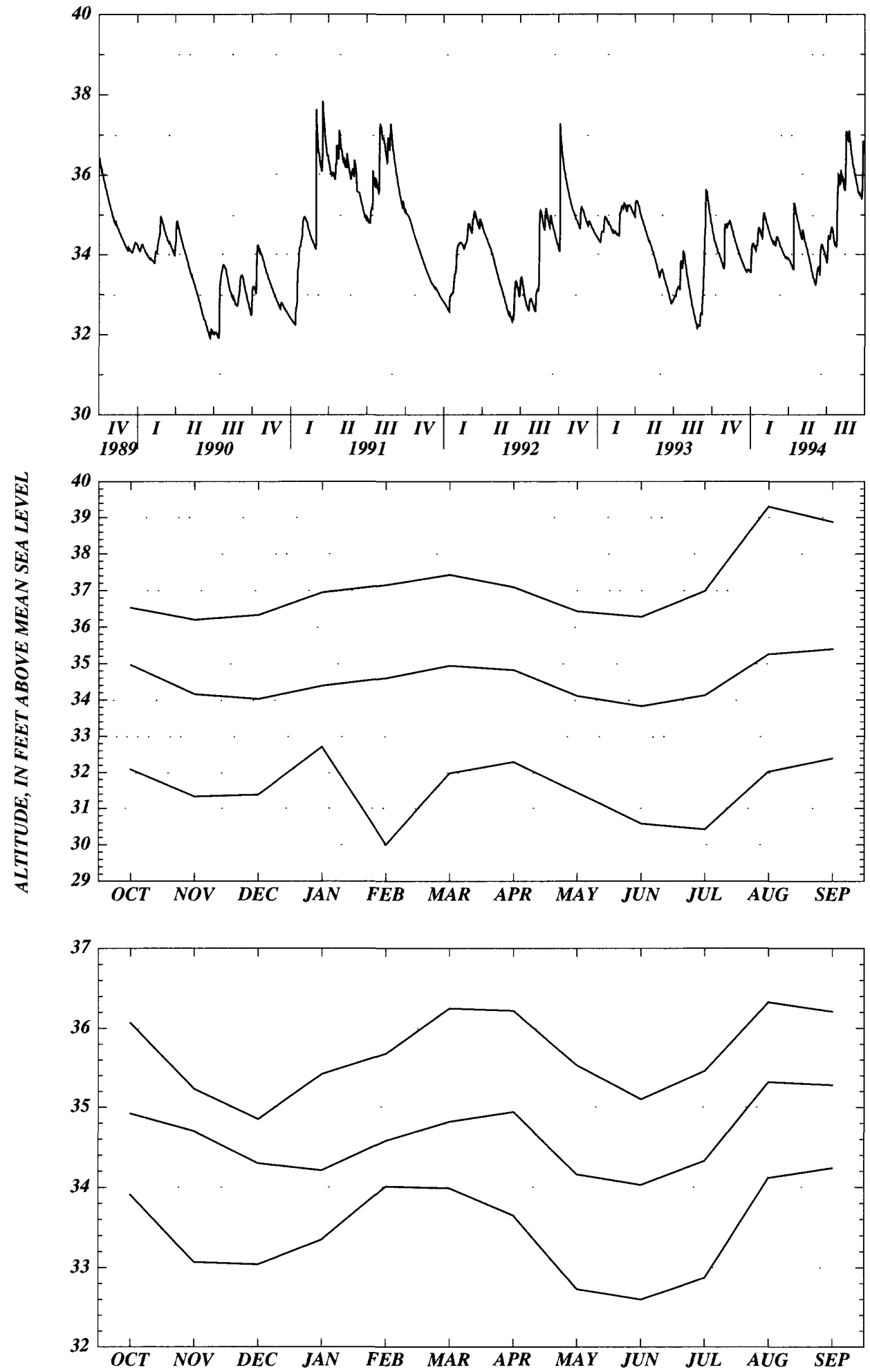


\section{Dixie County}

WELL NUMBER.--294311083041085. DOF - Holly Hill Tower. -091212003.

LOCATION.--Lat 2943'11”, long 8304'10”, Hydrologic Unit Code 03110205.

AQUIFER.--Upper Floridan aquifer of the Tertiary System, Geologic Unit Code 120FLRD.

WELL CHARACTERISTICS.--Casing diameter 3 in., Casing depth $15 \mathrm{ft}$., Total depth $45 \mathrm{ft}$.

INSTRUMENTATION.--Elevation of Measuring Point $71.10 \mathrm{ft}$., NGVD.

DATUM.--The National Geodetic Vertical Datum of 1929.

PERIOD OF RECORD.--06-15-1989 to 09-30-1994.

EXTREME VALUES.--Maximum observed, $49.36 \mathrm{ft}$. (08-26-1994); minimum observed, $44.86 \mathrm{ft}$. (12-05-1990).

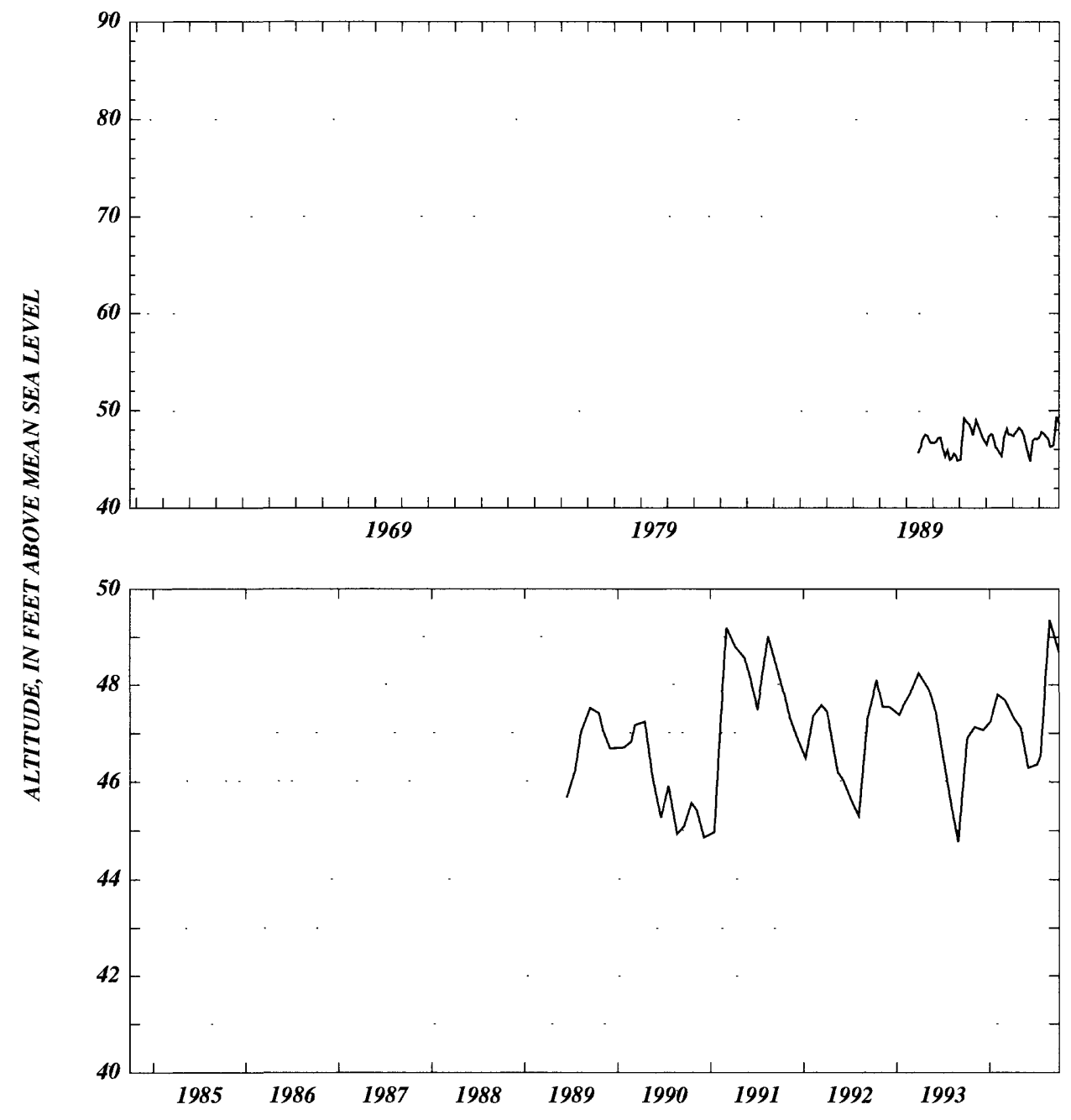



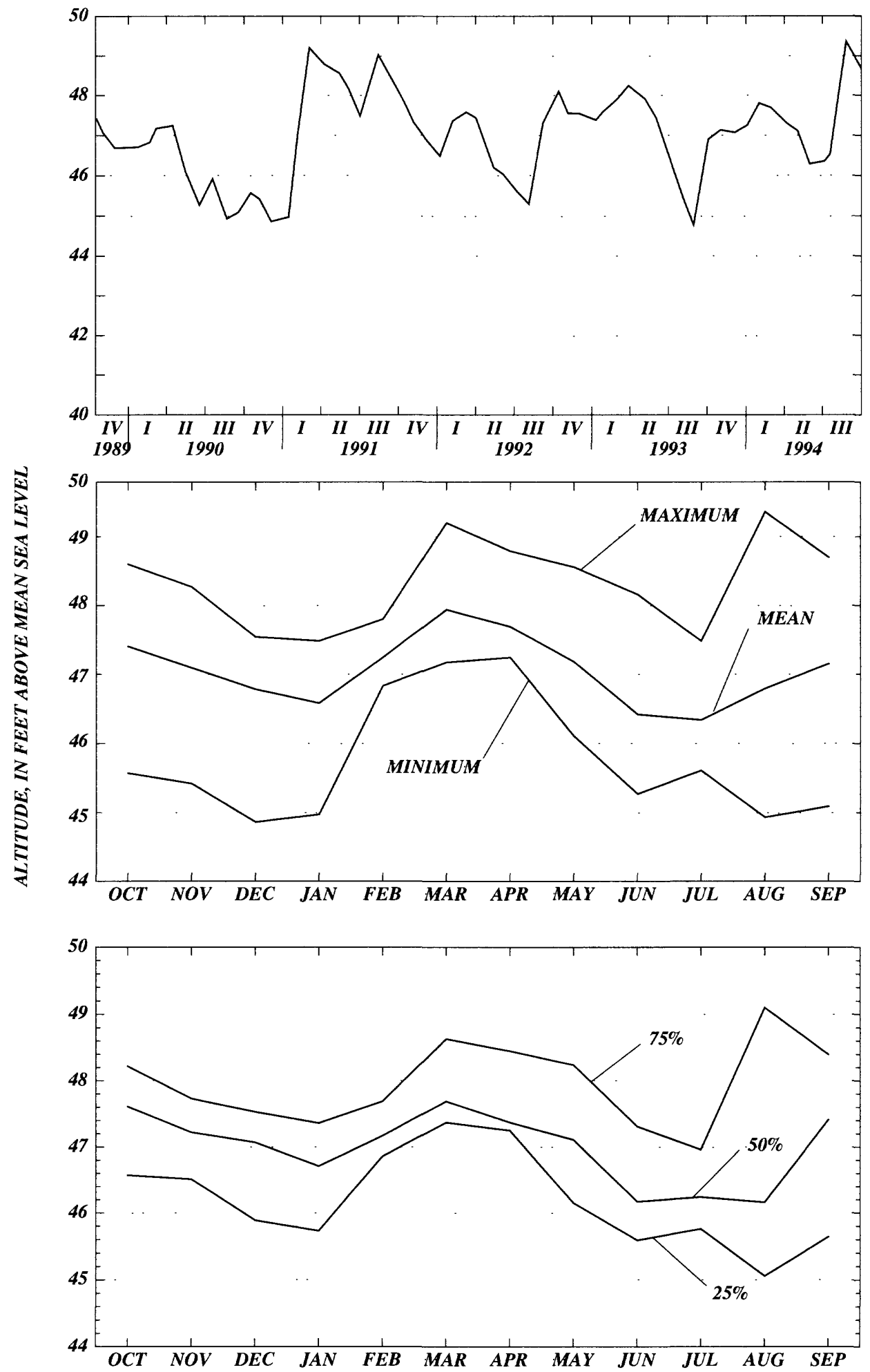


\section{Dixie County}

WELL NUMBER.--294458083142885. DOF - Hines Tower. -081132001.

LOCATION.--Lat 2944'58”, long 8314'28”, Hydrologic Unit Code 03110102.

AQUIFER.--Upper Floridan aquifer of the Tertiary system, Geologic Unit Code 120FLRD.

WELL CHARACTERISTICS.--Casing diameter 4 in., Casing depth $82 \mathrm{ft}$., Total depth $92 \mathrm{ft}$.

INSTRUMENTATION.--Miscellaneous measurements from 02-15-1960 to 11-02-1982; recorder from 11-03-1982 to 09-30-1994. Elevation of the Measuring Point, $42.26 \mathrm{ft}$., NGVD.

DATUM.--The National Geodetic Vertical Datum of 1929.

PERIOD OF RECORD.--12-15-1960 to 09-30-1994.

EXTREME VALUES.--Maximum, 39.69 ft. (09-01-1985); minimum, 34.36 ft. (06-14-1985).

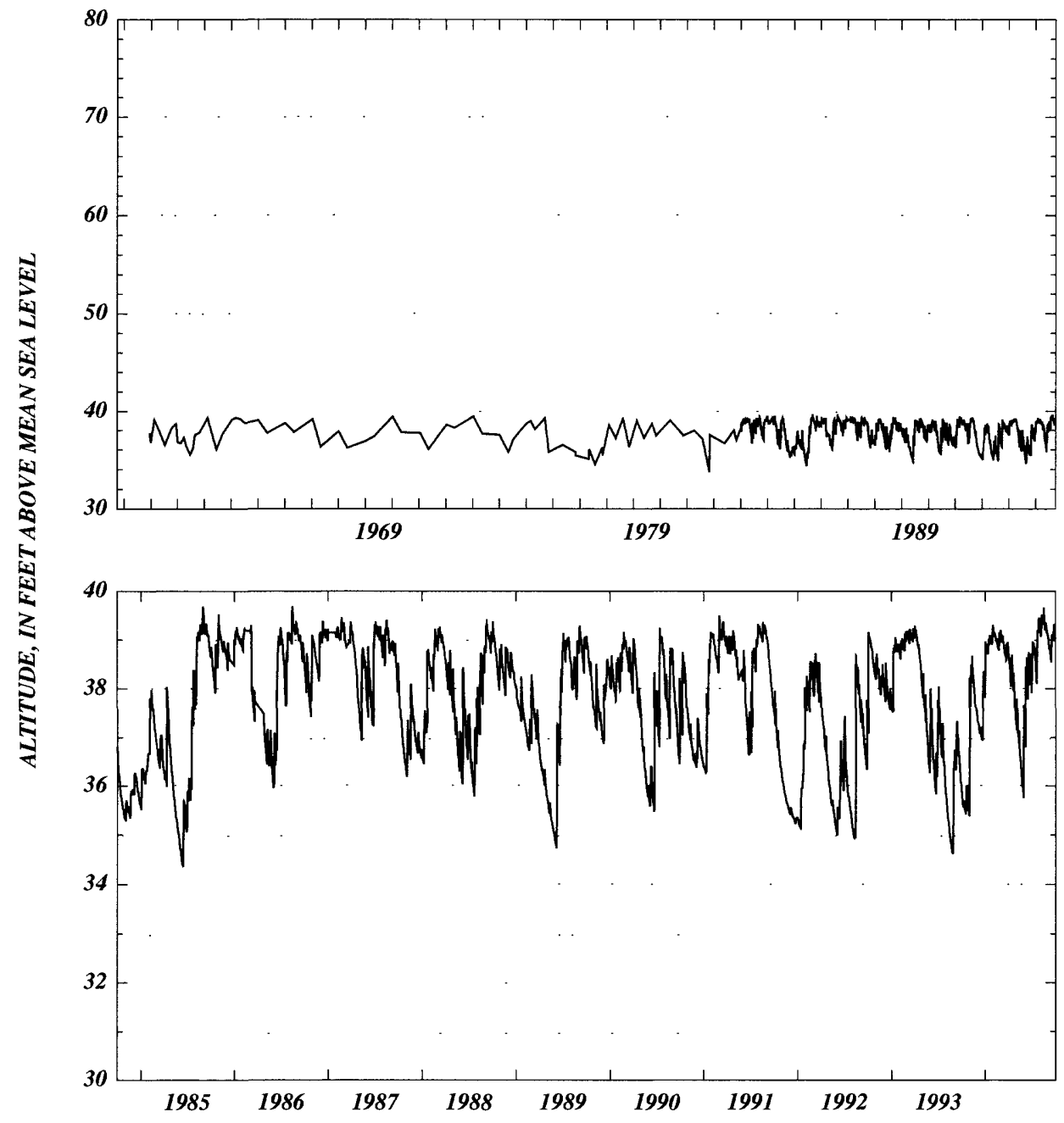



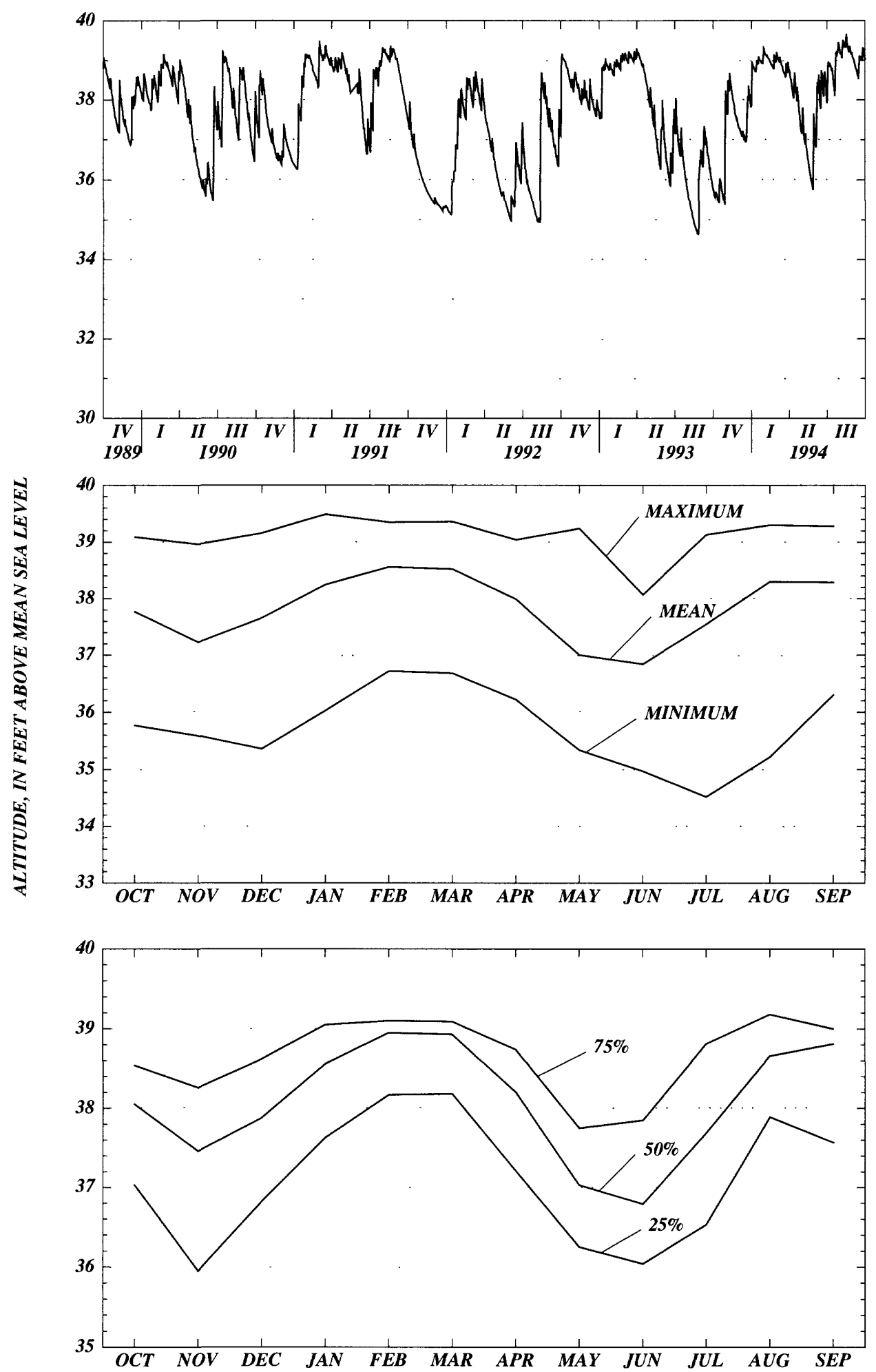


\section{Dixie County}

WELL NUMBER.--294654082581085. Georgia Pacific. -081313005.

LOCATION.--Lat 2946'54”, long 8258'10”, Hydrologic Unit Code 03110205.

AQUIFER.--Upper Floridan aquifer of the Tertiary system, Geologic Unit Code 120FLRD.

WELL CHARACTERISTICS.--Casing diameter 3 in., Casing depth $15 \mathrm{ft}$., Total depth 35ft.

INSTRUMENTATION.--Recorder, set to elevation of the Measuring Point, $40.77 \mathrm{ft}$., NGVD.

DATUM.--The National Geodetic Vertical Datum of 1929.

PERIOD OF RECORD.--03-22-1988 to 09-30-1994.

EXTREME VALUES.--Maximum, 33.66 ft. (08-30-1991); minimum, 19.41 ft. (01-11-1990.)

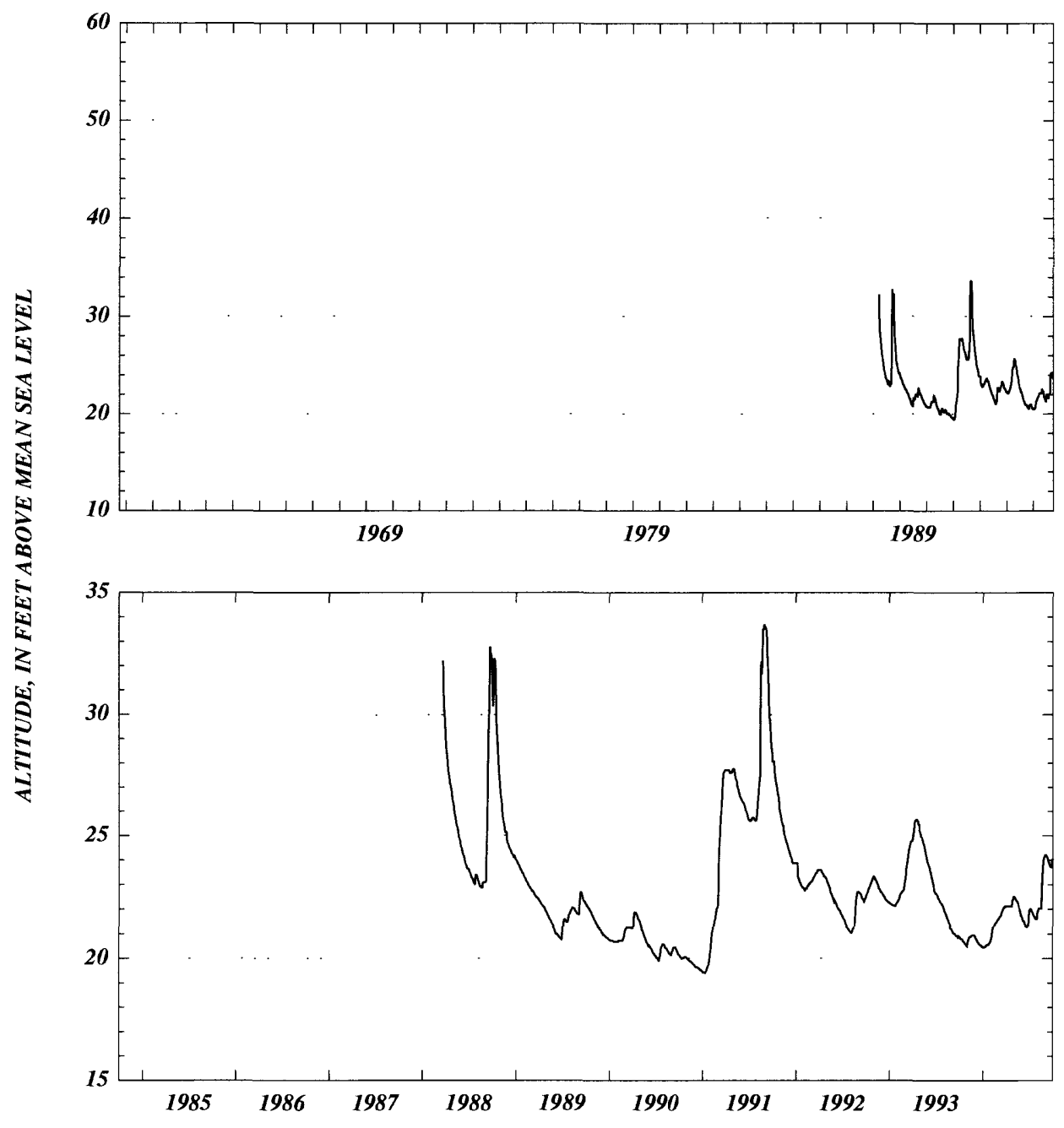



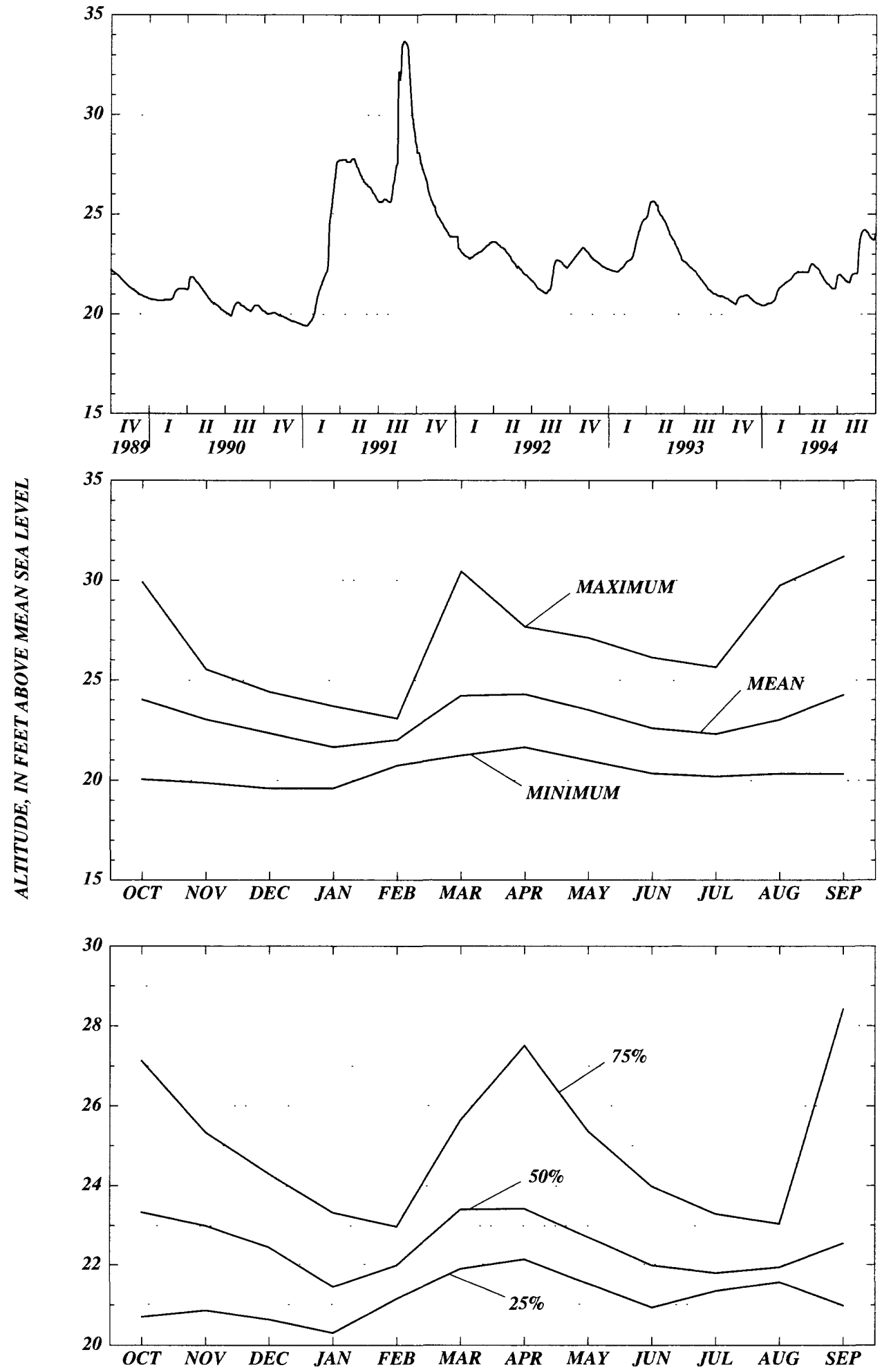


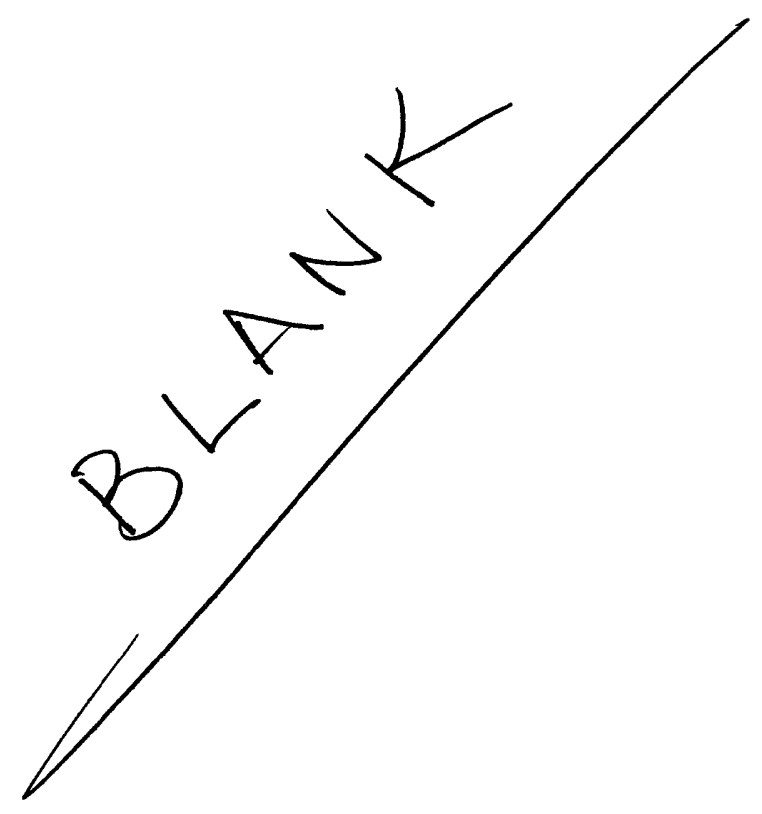




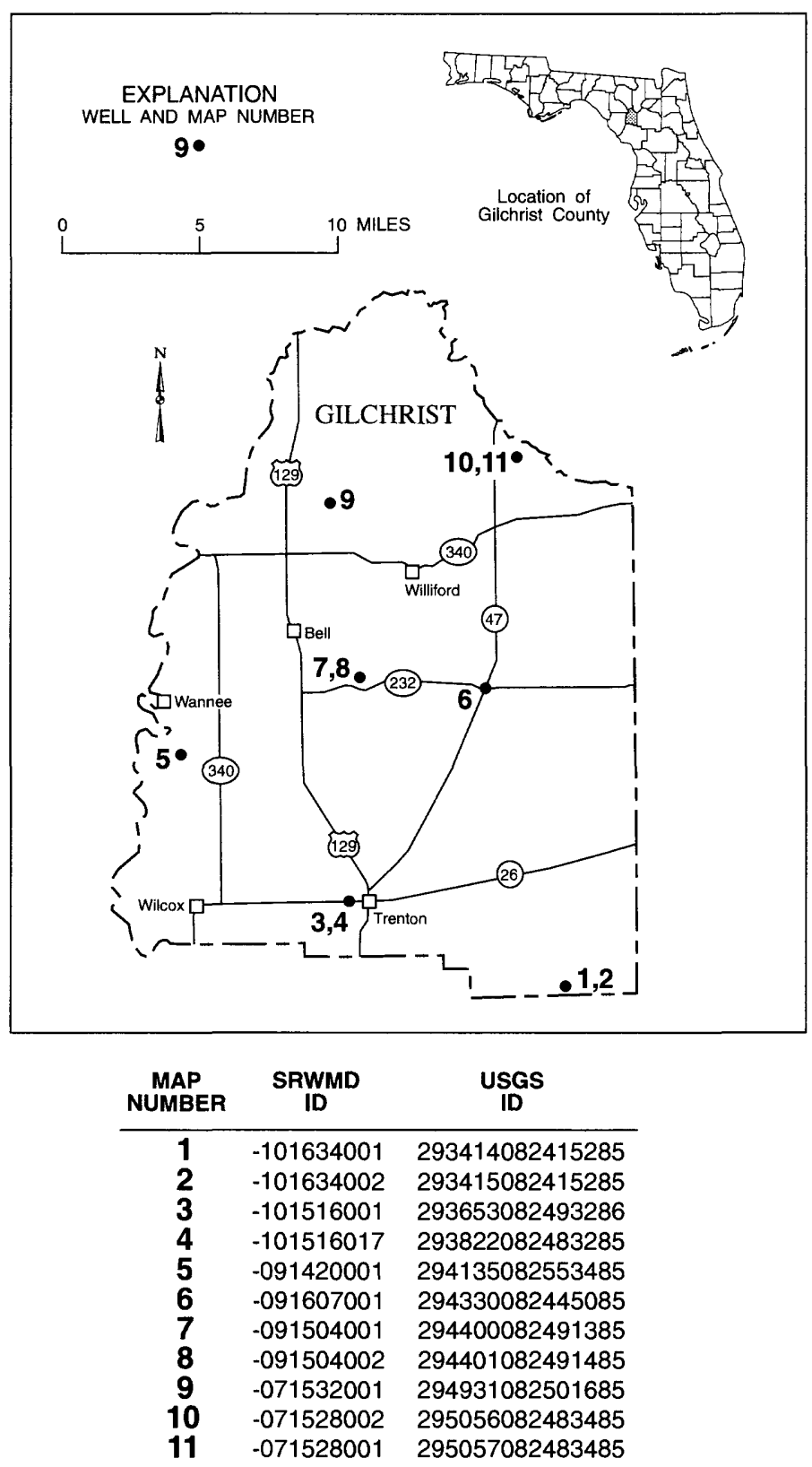

Figure 8. Location of wells in Gilchrist County. 


\section{Gilchrist County}

WELL NUMBER.--293414082415285. Loncala Phosphate Company. -101634001.

LOCATION.--Lat 29³4'14”, long 8241'52”, Hydrologic Unit Code 03110101.

AQUIFER.--Surficial aquifer, Geologic Unit Code 110NRSD.

WELL CHARACTERISTICS.--Casing diameter 4 in., Casing depth $26 \mathrm{ft}$., Total depth $46 \mathrm{ft}$.

INSTRUMENTATION.--Elevation of Measuring Point $69.56 \mathrm{ft}$., NGVD.

DATUM.--The National Geodetic Vertical Datum of 1929.

PERIOD OF RECORD.--06-27-1991 to 09-30-1994.

EXTREME VALUES.--Maximum observed, 65.23 ft. (08-24-1994); minimum observed, $60.41 \mathrm{ft}$. (07-29-1992).

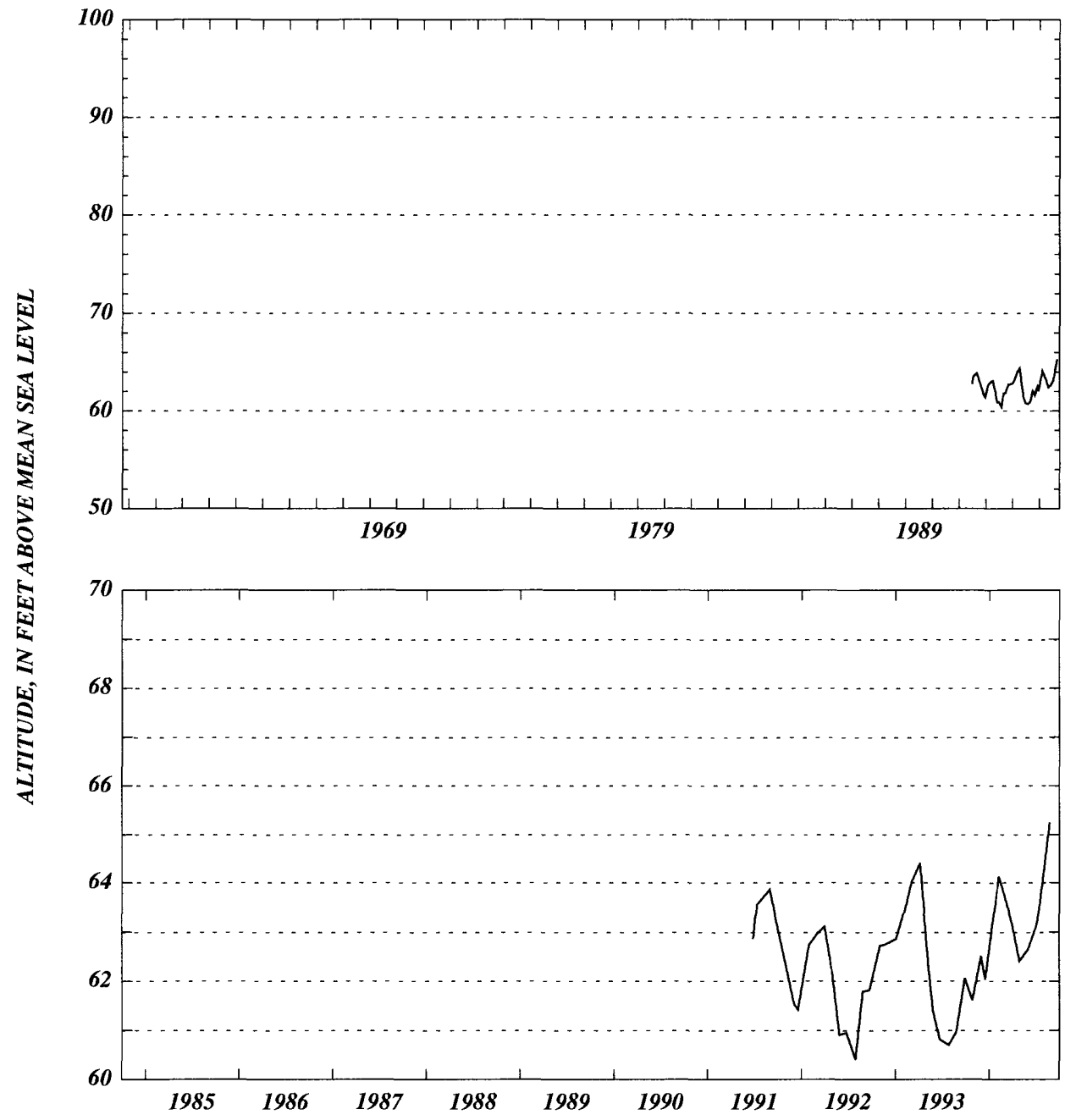



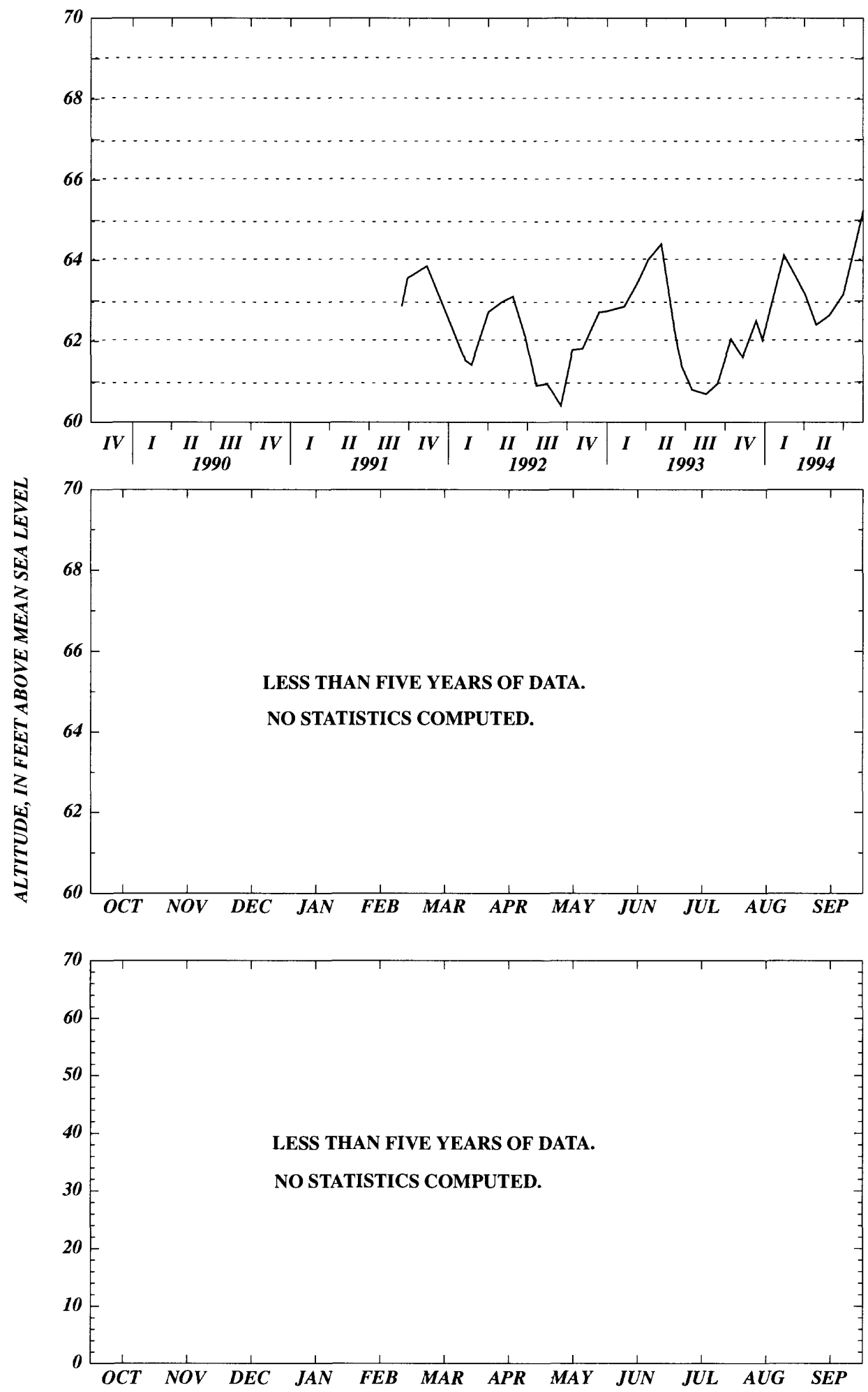


\section{Gilchrist County}

WELL NUMBER.--293415082415285. Loncala Phosphate Company. -101634002.

LOCATION.--Lat 29³4'15”, long 8241'52”, Hydrologic Unit Code 03110101.

AQUIFER.--Upper Floridan aquifer of the Tertiary System, Geologic Unit Code 120FLRD.

WELL CHARACTERISTICS.--Casing diameter 4 in., Casing depth $68 \mathrm{ft}$., Total depth $88 \mathrm{ft}$.

INSTRUMENTATION.--Elevation of Measuring Point $69.92 \mathrm{ft}$., NGVD.

DATUM.--The National Geodetic Vertical Datum of 1929.

PERIOD OF RECORD.--06-27-1991 to 09-30-1994.

EXTREME VALUES.--Maximum observed, 66.37 ft. (08-24-1994); minimum observed, $61.30 \mathrm{ft}$. (07-29-1992).

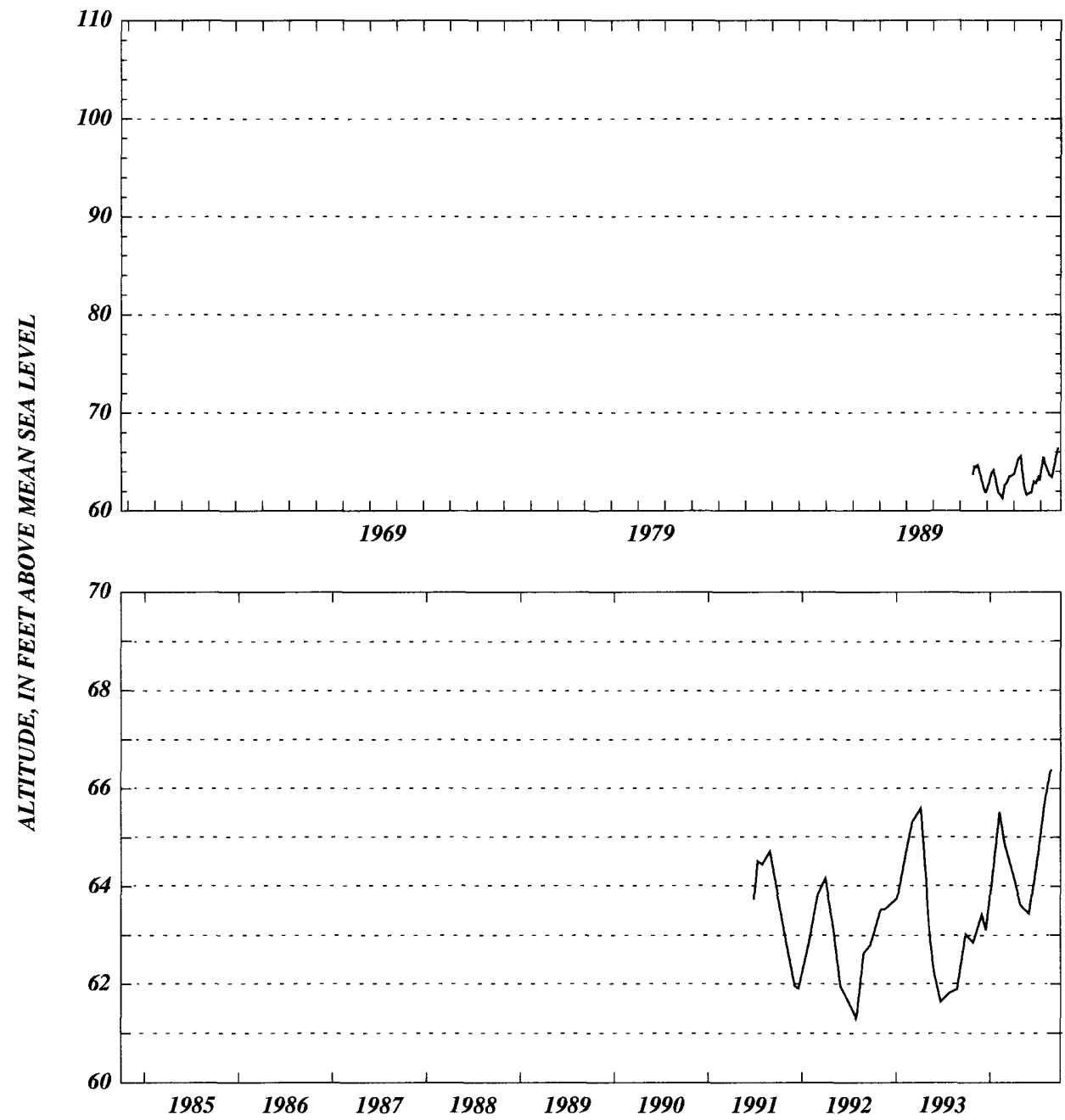



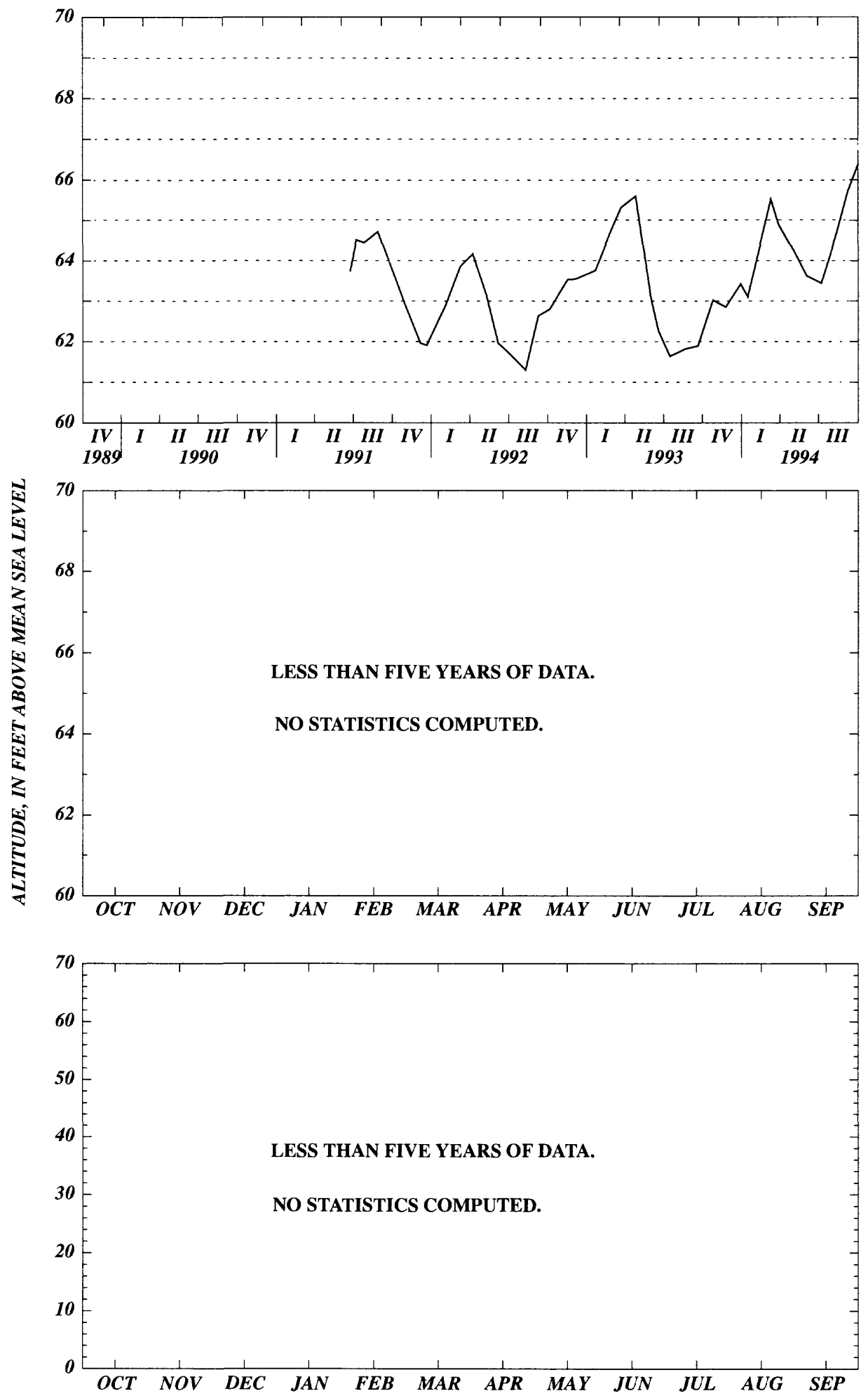


\section{Gilchrist County}

WELL NUMBER.--293653082493286. City of Trenton. -101516001.

LOCATION.--Lat 29³6'49”, long 8249'05”, Hydrologic Unit Code 03110205.

AQUIFER.--The Upper Floridan aquifer of the Tertiary system, Geologic Unit Code 120FLRD.

WELL CHARACTERISTICS.--Casing diameter 12 in., Casing depth $61 \mathrm{ft}$., Total depth $100 \mathrm{ft}$.

INSTRUMENTATION.--Elevation of Measuring Point $55.74 \mathrm{ft} .$, NGVD.

DATUM.--The National Geodetic Vertical Datum of 1929.

PERIOD OF RECORD.--01-23-1961 to 09-30-1994.

EXTREME VALUES.--Maximum observed, 33.39 ft. (08-24-1965); minimum observed, $7.28 \mathrm{ft}$. $(12-17-1990)$.

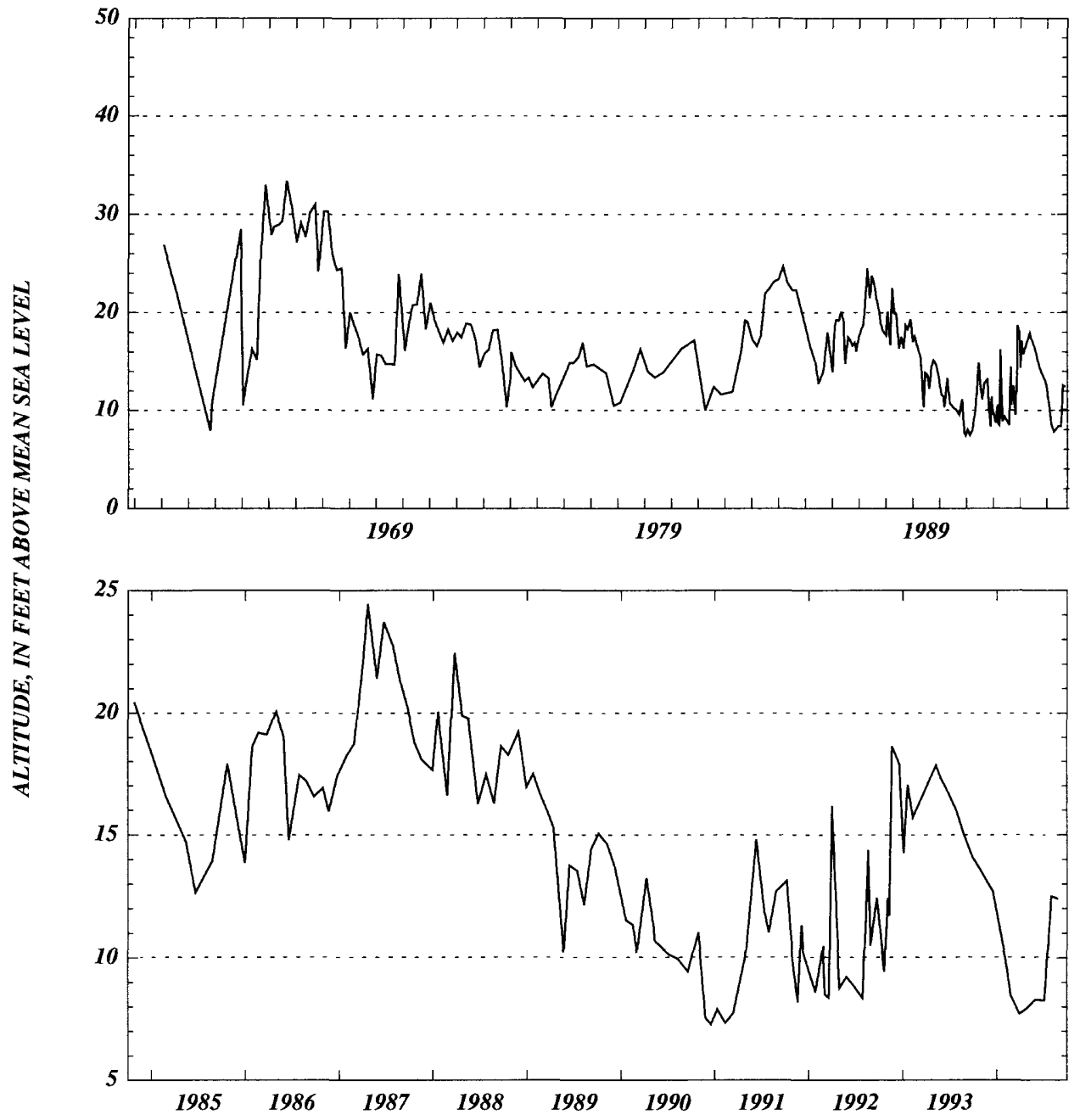



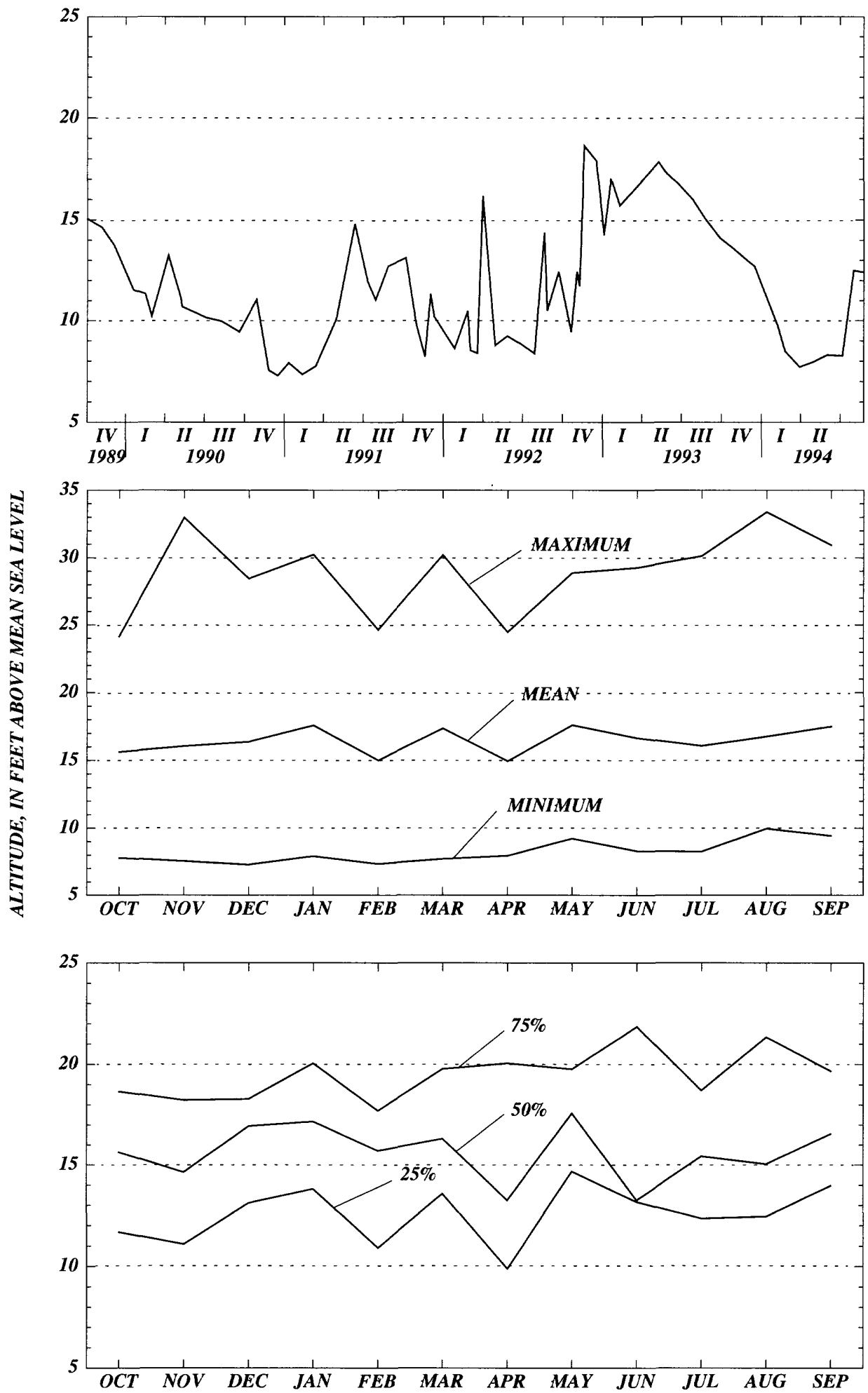


\section{Gilchrist County}

WELL NUMBER.--293822082483285. City of Trenton, new well. -101516017.

LOCATION.--Lat 29³8'22”, long 8248'32”, Hydrologic Unit Code, 03110205.

AQUIFER.--Upper Floridan aquifer of the Tertiary system, Geologic Unit Code, 120FLRD.

WELL CHARACTERISTICS.--Casing diameter 8 in., Casing depth $44 \mathrm{ft}$., Total depth $80 \mathrm{ft}$.

INSTRUMENTATION.--Recorder, set to elevation of the Measuring Point, $58.83 \mathrm{ft}$., NGVD.

DATUM.--The National Geodetic Vertical Datum of 1929.

PERIOD OF RECORD.--01-12-1993 to 09-30-1994.

EXTREME VALUES.--Maximum, 17.93 ft. (04-21-1993); minimum, 11.99 ft. (01-04-1994).

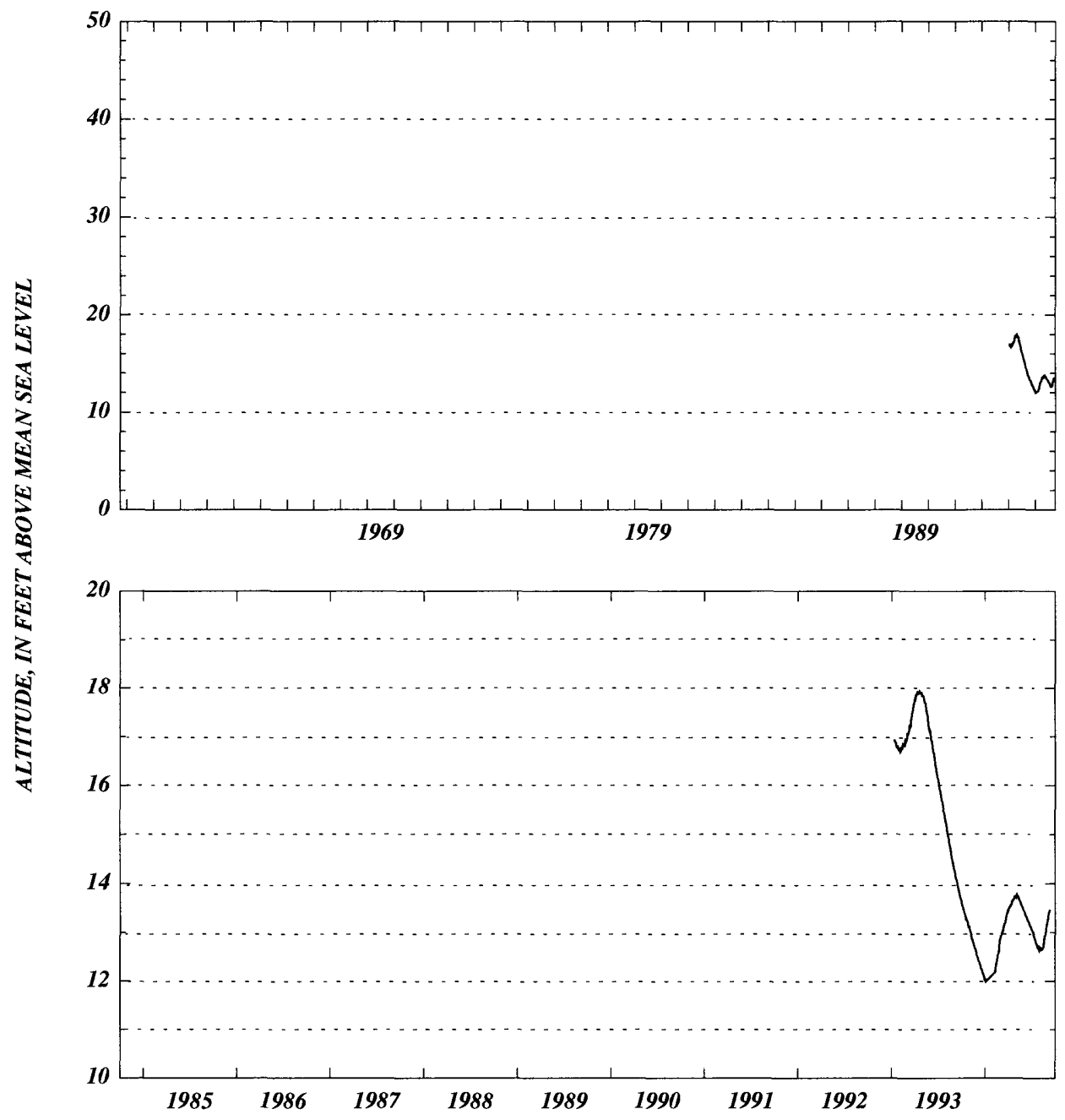



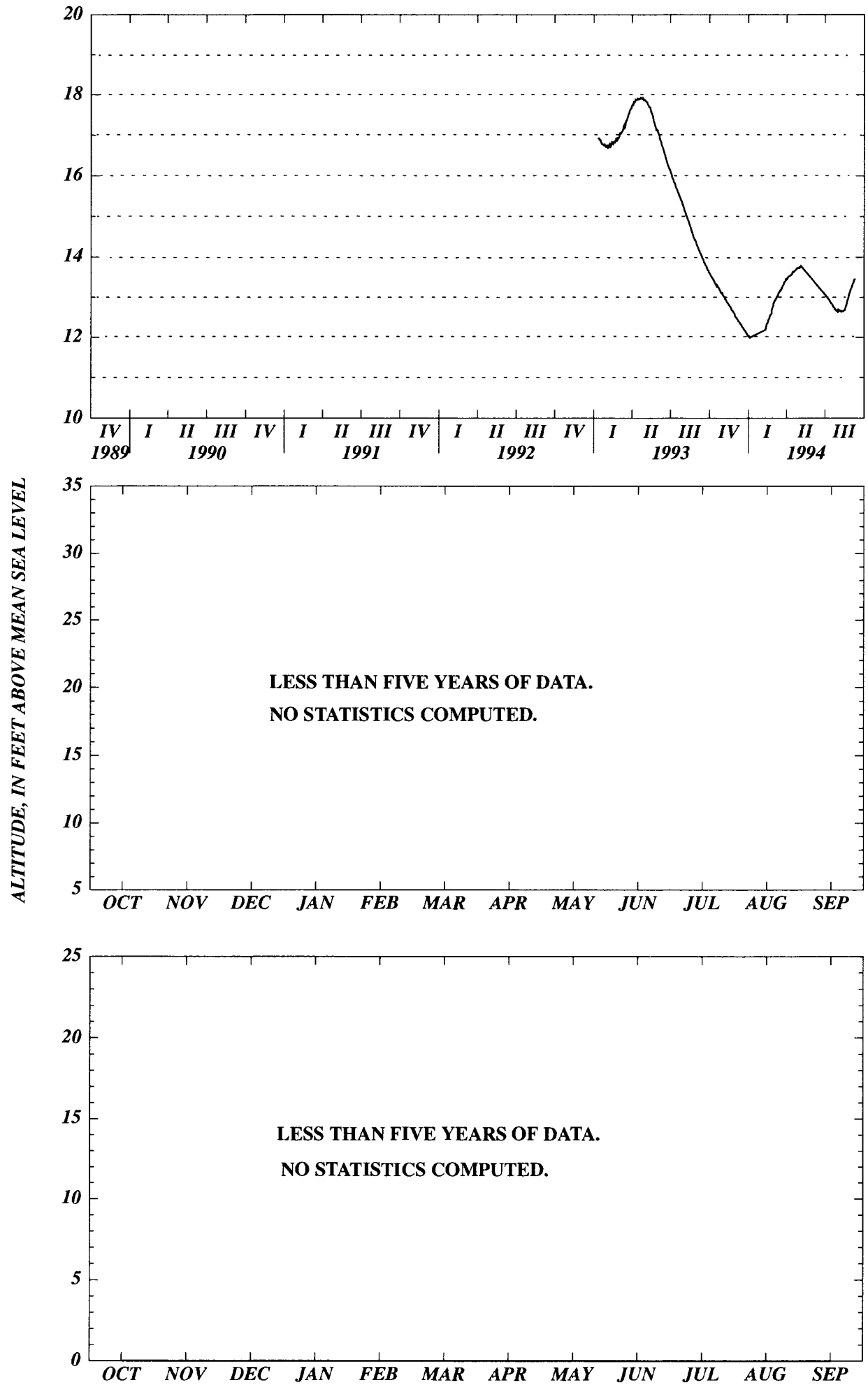


\section{Gilchrist County}

WELL NUMBER.--294135082553485. Clifton Mikel. -091420001.

LOCATION.--Lat 2941'35’, long 8255’30”, Hydrologic Unit Code 03110205.

AQUIFER.--The Upper Floridan aquifer of the Tertiary system, Geologic Unit Code 120FLRD.

WELL CHARACTERISTICS.--Casing diameter 4 in., Casing depth $55 \mathrm{ft}$., Total depth $65 \mathrm{ft}$.

INSTRUMENTATION.--Elevation of Measuring Point $34.26 \mathrm{ft}$., NGVD.

DATUM.--The National Geodetic Vertical Datum of 1929.

PERIOD OF RECORD.--11-01-1976 to 09-30-1994. *

EXTREME VALUES.--Maximum observed, $19.69 \mathrm{ft}$. (04-25-1984); minimum observed, $3.78 \mathrm{ft}$. (11-19-1981

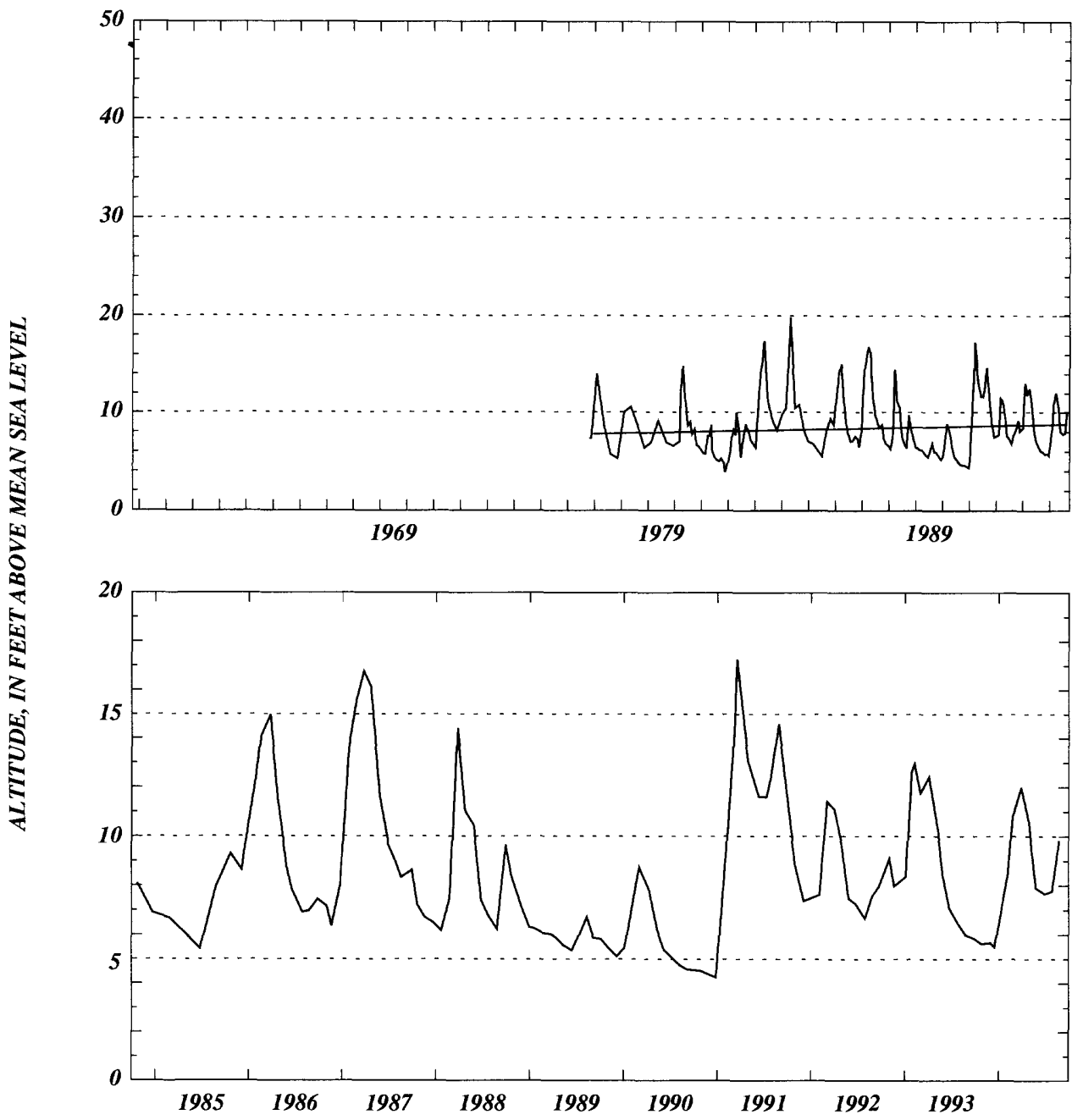



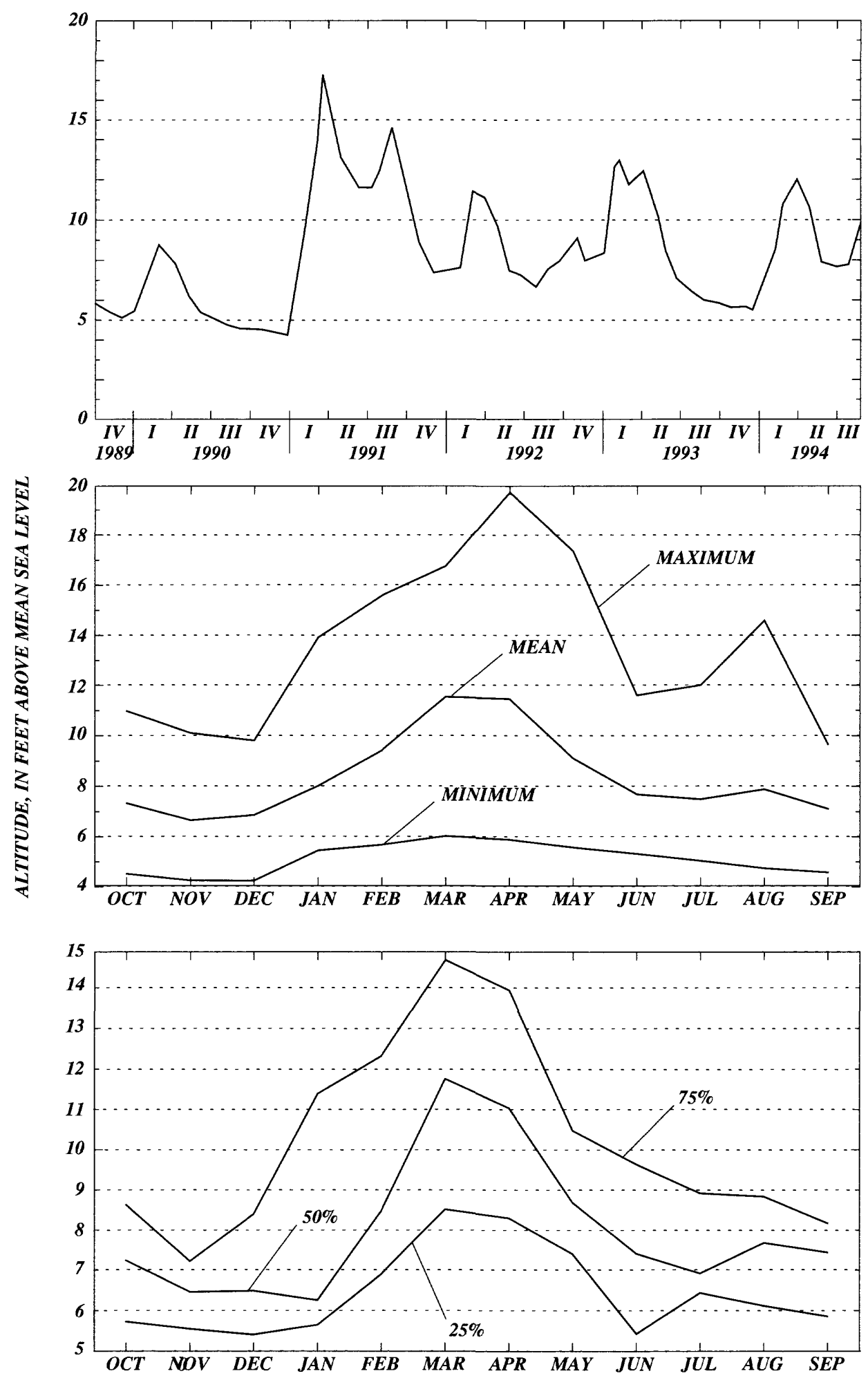


\section{Gilchrist County}

WELL NUMBER.--294330082445085. USGS - near Trenton. -091607001.

LOCATION.--Lat 2943'30”, long 8244'50’, Hydrologic Unit Code 03110206.

AQUIFER.--Upper Floridan aquifer of the Tertiary system, Geologic Unit Code 120FLRD.

WELL CHARACTERISTICS.--Casing diameter 6 in., Casing depth $55 \mathrm{ft}$., Total depth $103 \mathrm{ft}$.

INSTRUMENTATION.--Miscellaneous measurements from 07-10-1964 to 09-30-1965; recorder from 10-01-1965 to 09-30-1994. Elevation of Measuring Point 87.31 ft., NGVD.

DATUM.--The National Geodetic Vertical Datum of 1929.

PERIOD OF RECORD.--07-10-1964 to 09-30-1994. *

EXTREME VALUES.--Maximum 74.68 ft. (10-02-1965); minumum 43.87 ft. (05-04-1976).

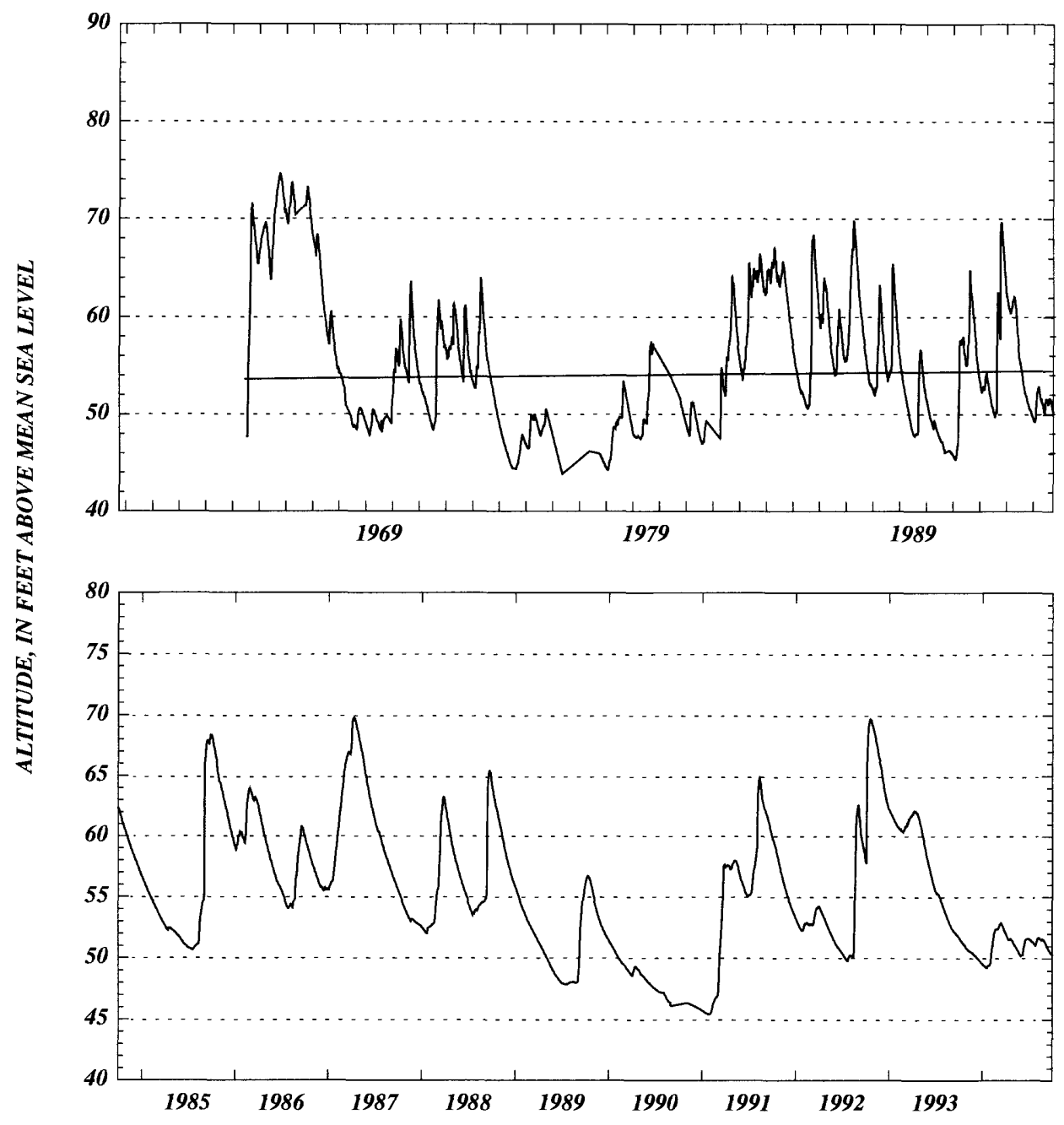



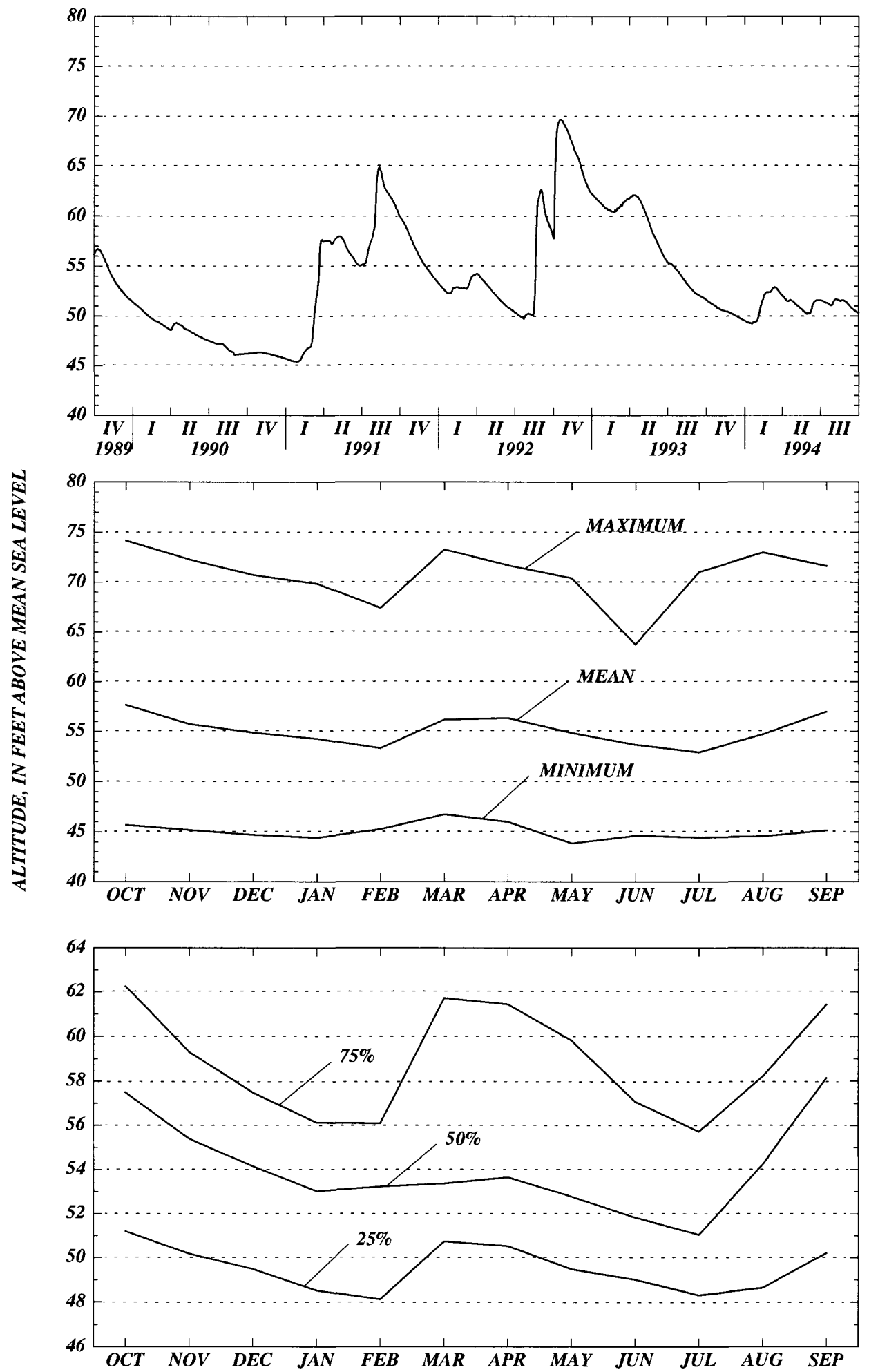
Gilchrist County.

WELL NUMBER.--294400082491385. Wade Investments. -091504001.

LOCATION.--Lat 29 44'00”, long 8249'13”, Hydrologic Unit Code 03110205.

AQUIFER.--Upper Floridan aquifer of the Tertiary system, Geologic Unit Code 120FLRD.

WELL CHARACTERISTICS.--Casing diameter 4 in., Casing depth $41 \mathrm{ft}$., Total depth $51 \mathrm{ft}$.

INSTRUMENTATION.--Elevation of Measuring Point $88.53 \mathrm{ft}$. , NGVD.

DATUM.--The National Geodetic Vertical Datum of 1929.

PERIOD OF RECORD.--04-29-1991 to 09-30-1994.

EXTREME VALUES.--Maximum observed, 84.67 ft. (07-30-1991); minimum observed, $81.56 \mathrm{ft}$. (10-27-1993).

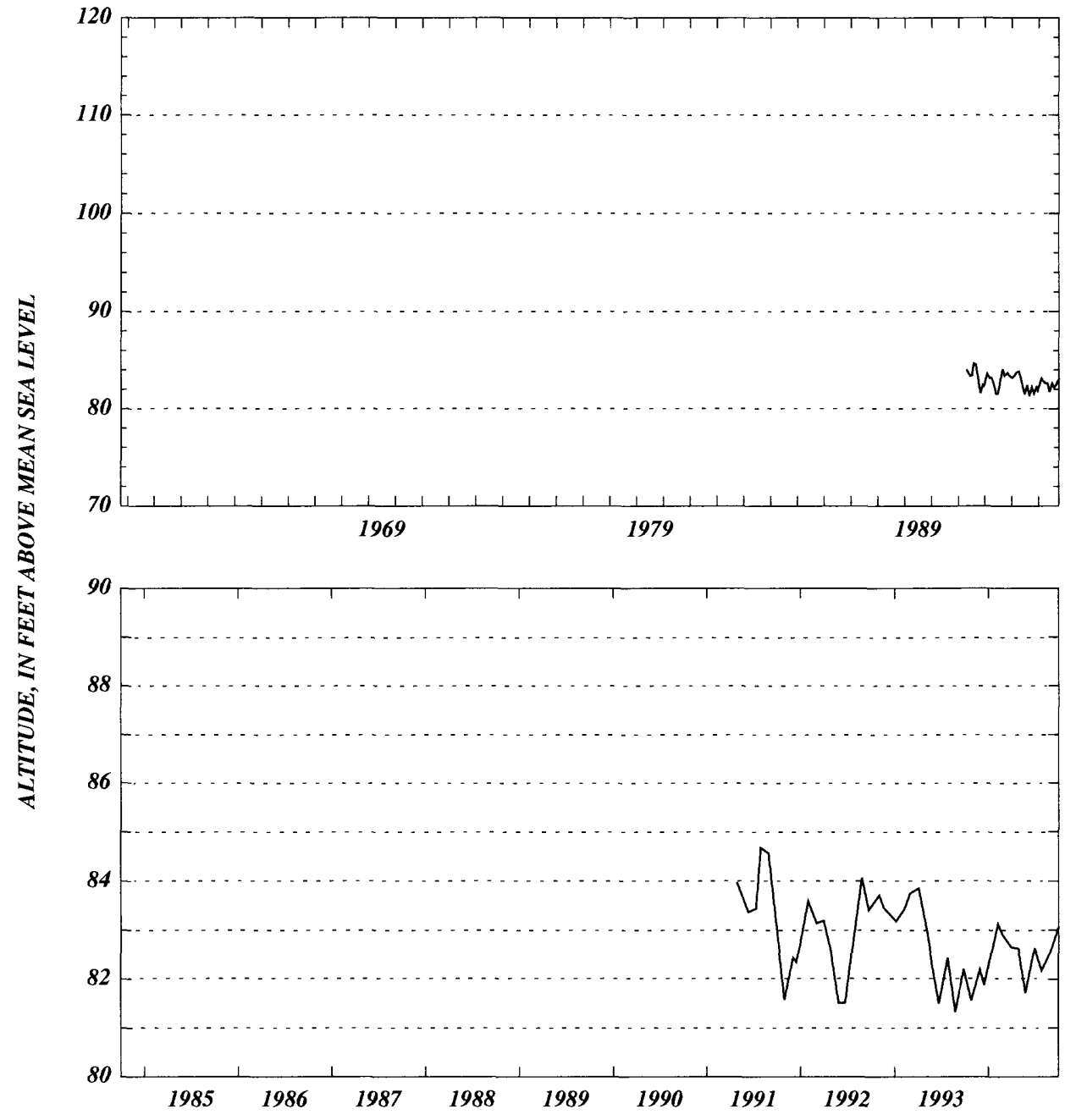



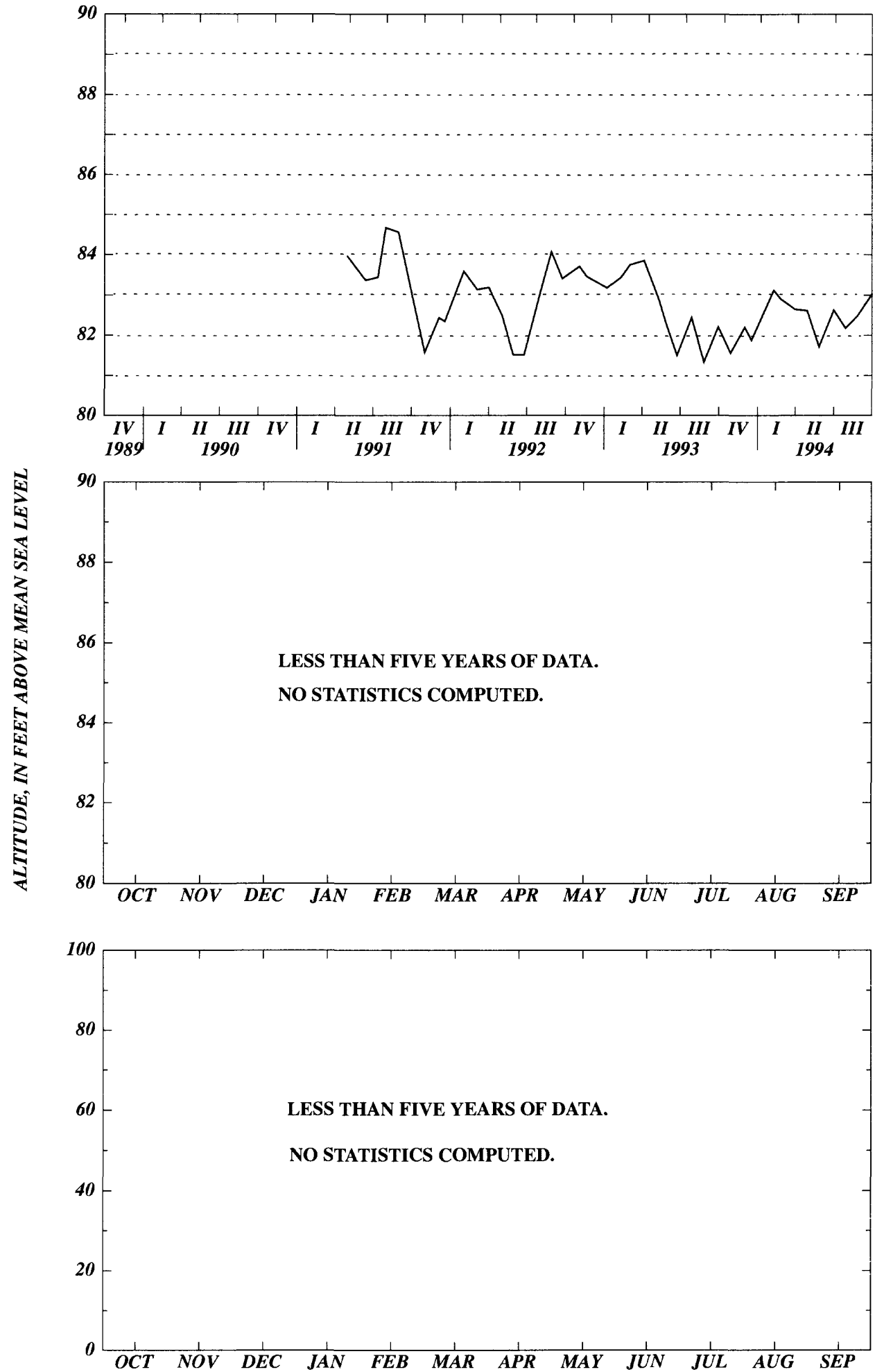


\section{Gilchrist County}

WELL NUMBER.--294401082491485. Wade Investments. -091504002.

LOCATION.--Lat 2944’01”, long 8249’14”, Hydrologic Unit Code 03110205.

AQUIFER.--Surficial aquifer, Geologic Unit Code 110NRSD

WELL CHARACTERISTICS.--Casing diameter 4 in., Casing depth $10 \mathrm{ft}$., Total depth $20 \mathrm{ft}$.

INSTRUMENTATION.--Elevation of Measuring Point $88.12 \mathrm{ft}$., NGVD.

DATUM.--The National Geodetic Vertical Datum of 1929.

PERIOD OF RECORD.--04-29-1991 to 09-30-1994. *

EXTREME VALUES.--Maximum observed, $84.63 \mathrm{ft}$. (07-30-1991); minimum observed, $81.63 \mathrm{ft}$. 06-23-1993).

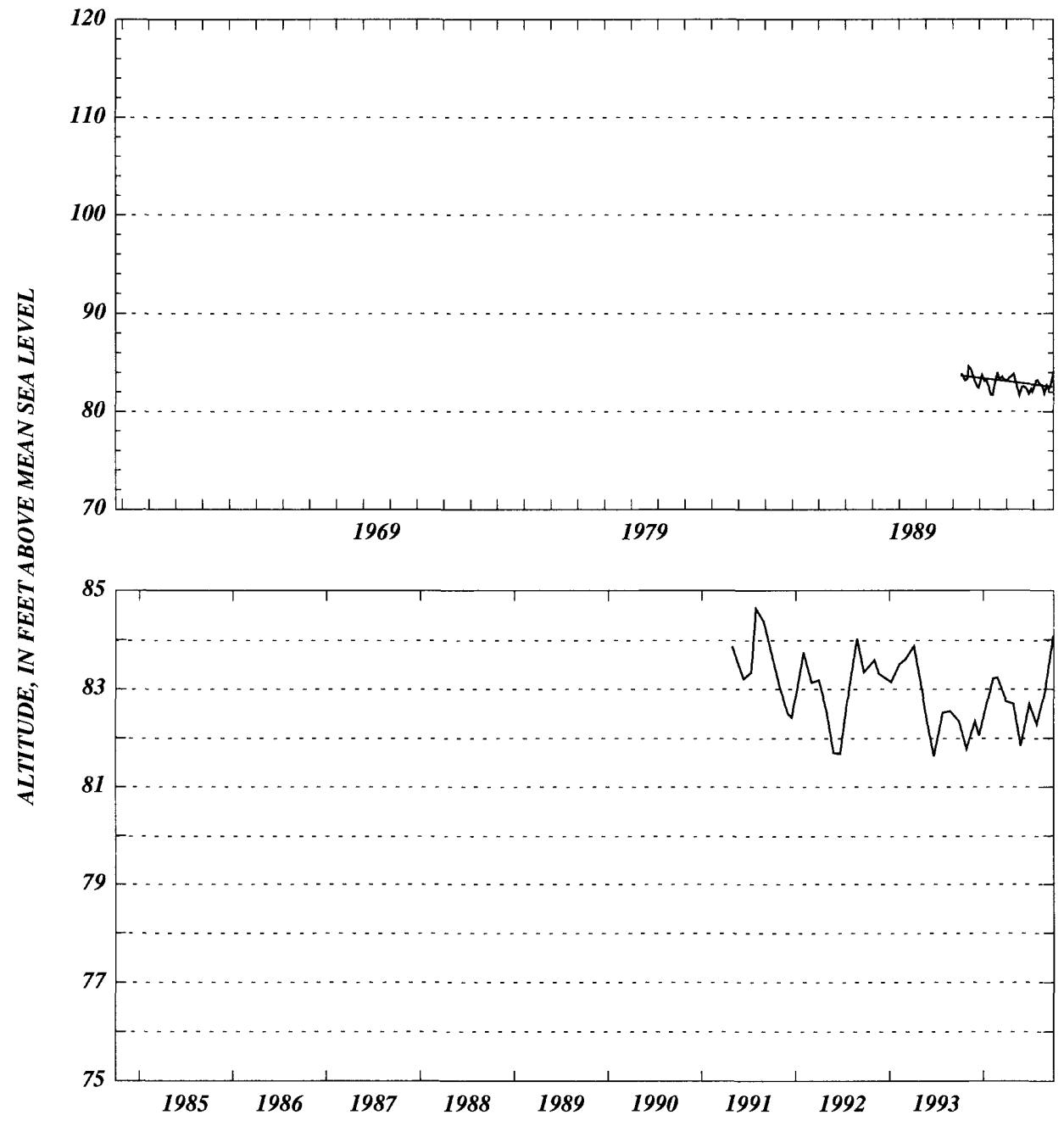



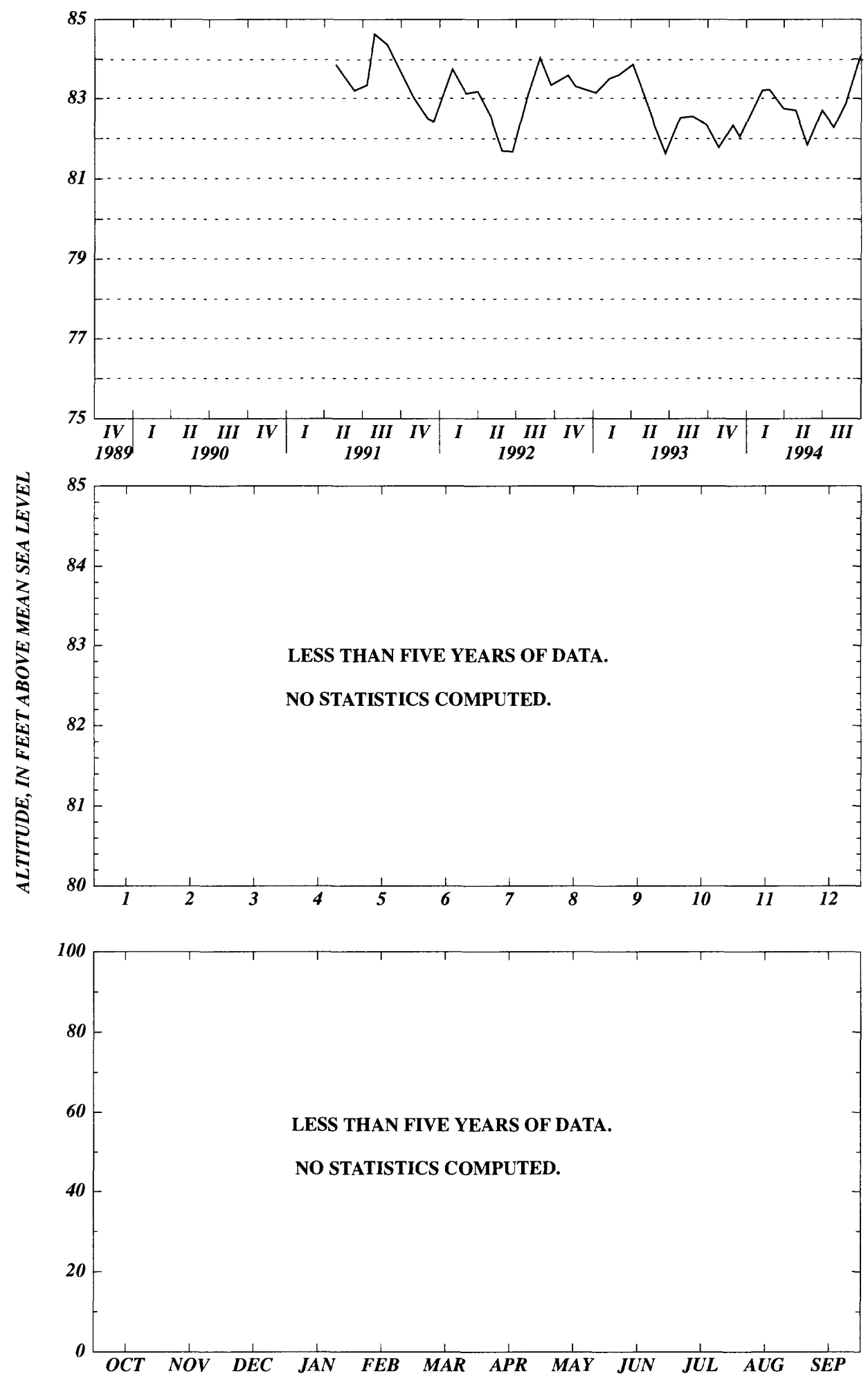


\section{Gilchrist County}

WELL NUMBER.--294931082501685. Ernest M. Sheppard. -071532001.

LOCATION.--Lat 2949'31”, long 8250'16”, Hydrologic Unit Code 03110205.

AQUIFER.--Upper Floridan aquifer of the Tertiary system, Geologic Unit Code 120FLRD.

WELL CHARACTERISTICS.--Casing diameter 4 in., Casing depth $81 \mathrm{ft}$., Total depth $98 \mathrm{ft}$.

INSTRUMENTATION.--Elevation of Measuring Point $70.93 \mathrm{ft} .$, NGVD.

DATUM.--The National Geodetic Vertical Datum of 1929.

PERIOD OF RECORD.--11-01-1976 to 04-01-1994.

EXTREME VALUES.--Maximum observed, $40.00 \mathrm{ft}$. (08-23-1984); minimum observed, $25.43 \mathrm{ft}$. (05-11-1990).

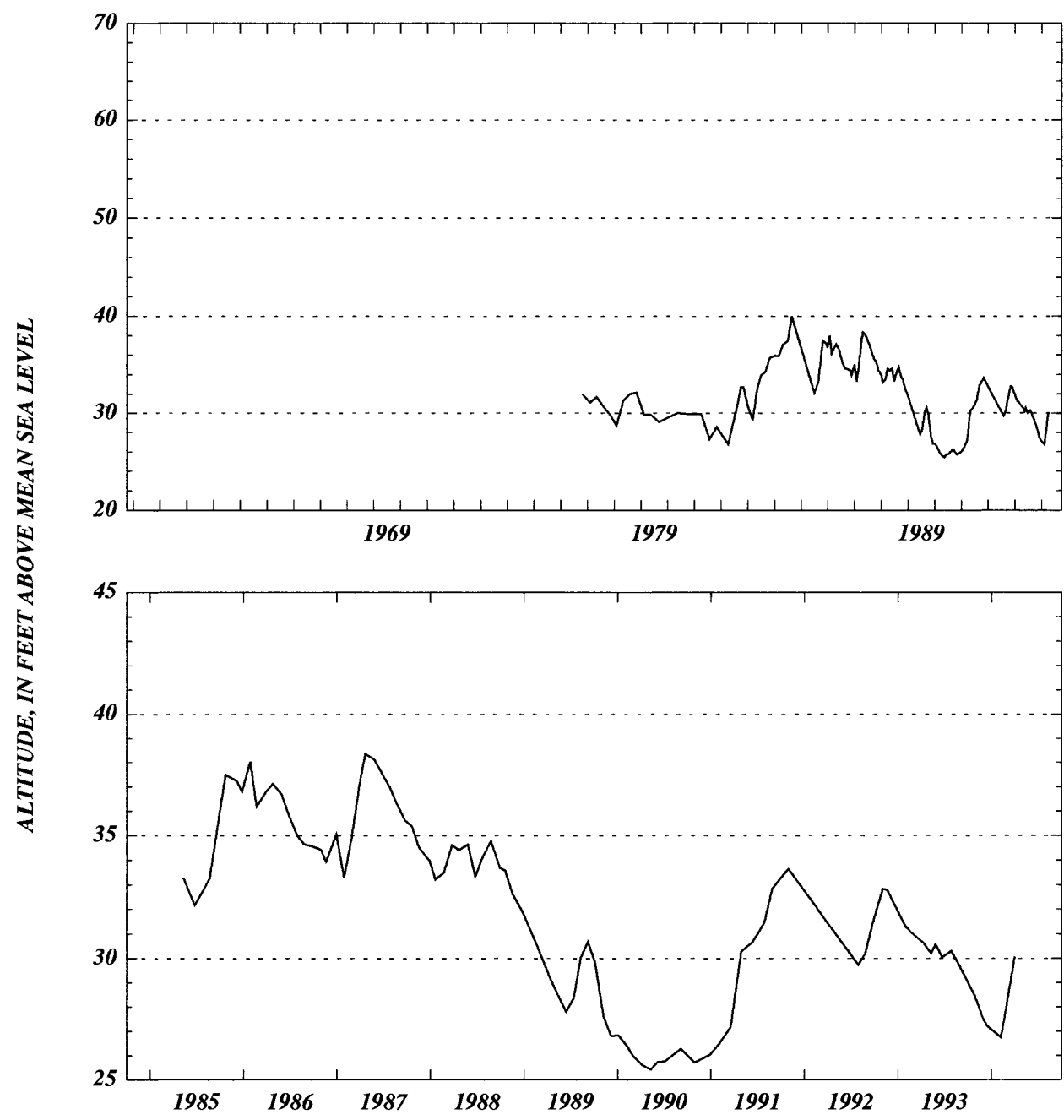



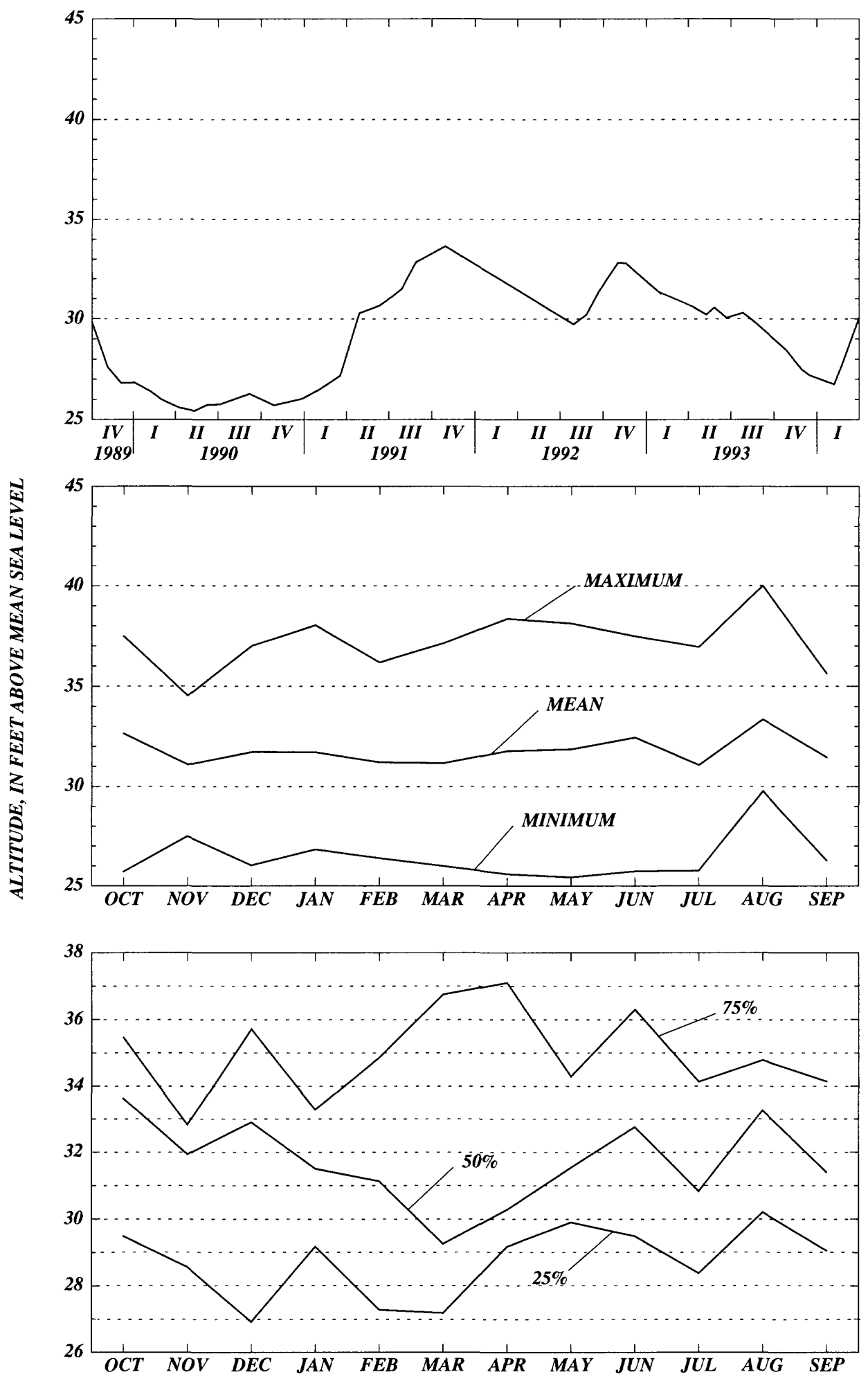

Gilchrist County 
WELL NUMBER.--295056082483485. J. Crayton Pruitt, MD. -071528002.

LOCATION.--Lat 29 50'56”, long 8248’34”, Hydrologic Unit Code 03110205.

AQUIFER.--Surficial aquifer, Geologic Unit Code 110NRSD.

WELL CHARACTERISTICS.--Casing diameter 4 in., Casing depth $5 \mathrm{ft}$., Total depth $55 \mathrm{ft}$.

INSTRUMENTATION.--Elevation of Measuring Point $75.35 \mathrm{ft} .$, NGVD.

DATUM.--The National Geodetic Vertical Datum of 1929.

PERIOD OF RECORD.--08-16-1990 to 09-30-1994.

EXTREME VALUES.--Maximum observed, 71.93 ft. (08-28-1991); minimum observed, $67.19 \mathrm{ft}$. (10-27-1993).

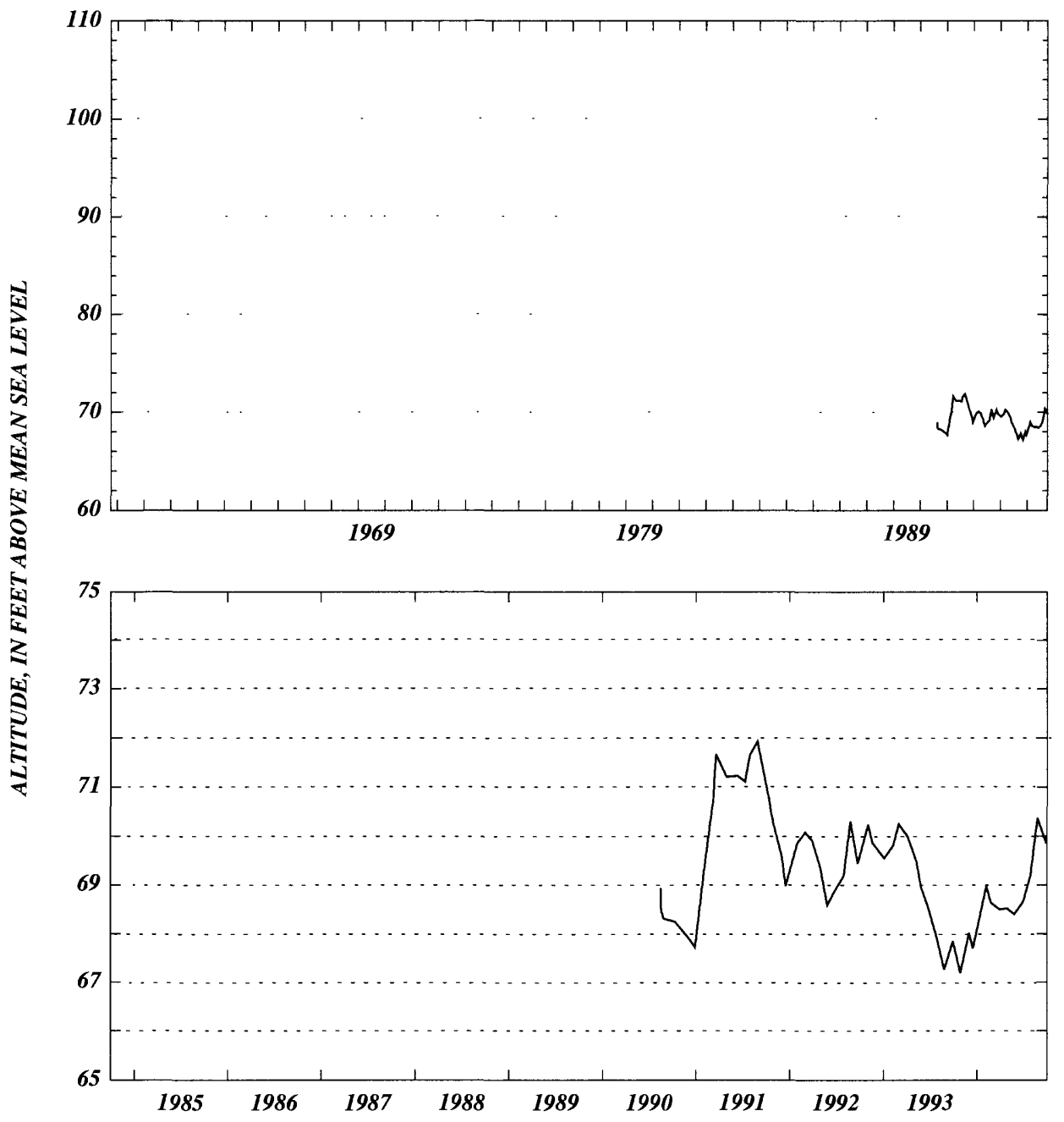



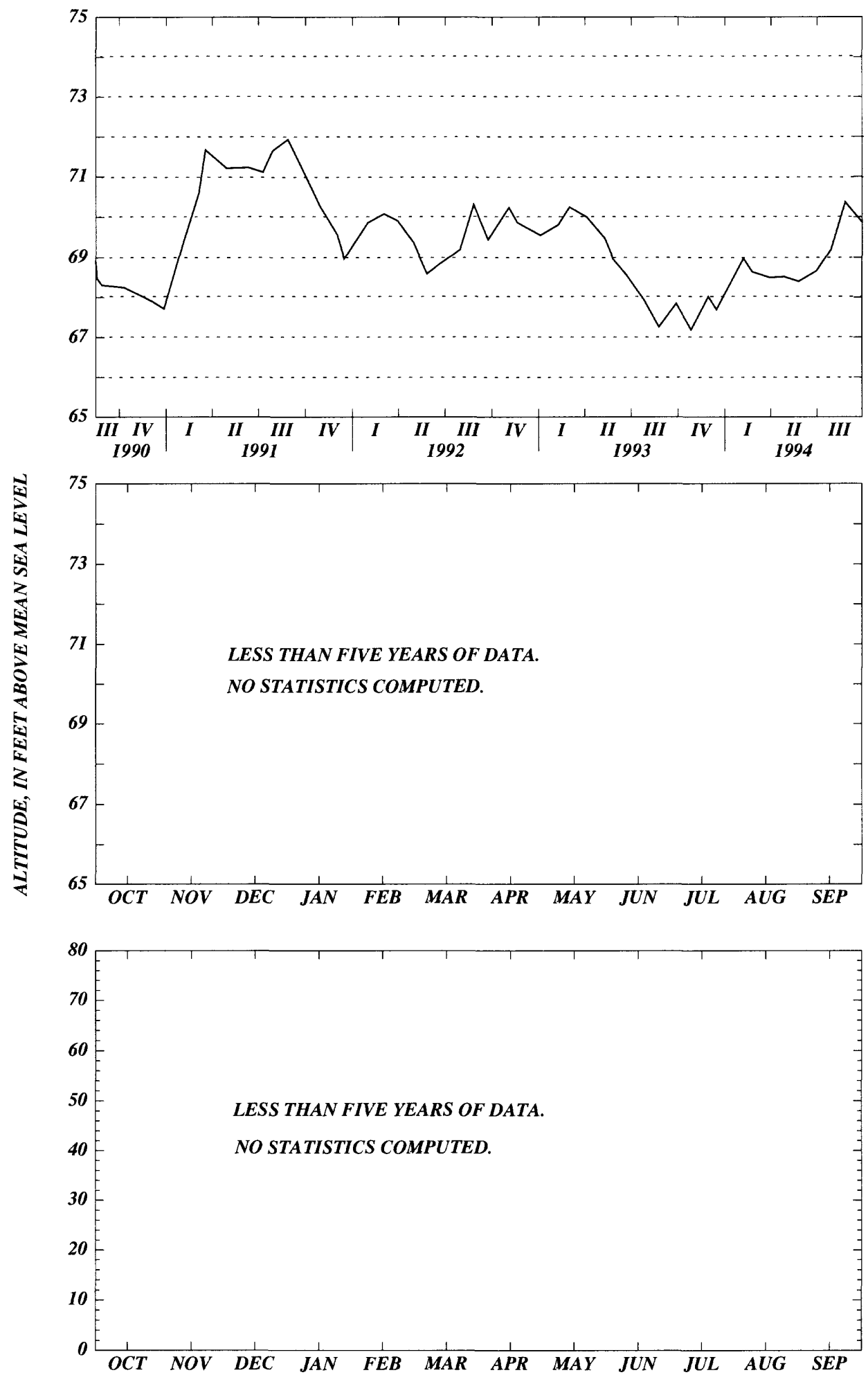


\section{Gilchrist County}

WELL NUMBER.--295057082483485. J. Crayton Pruitt, MD. -071528001.

LOCATION.--Lat 2950'57', long 8248'34", Hydrologic Unit Code 03110205.

AQUIFER.--Upper Floridan aquifer of the Tertiary system, Geologic Unit Code 120FLRD.

WELL CHARACTERISTICS.--Casing diameter 2 in., Casing depth $110 \mathrm{ft}$., Total depth $130 \mathrm{ft}$.

INSTRUMENTATION.--Elevation of Measuring Point $75.35 \mathrm{ft} .$, NGVD.

DATUM.--The National Geodetic Vertical Datum of 1929.

PERIOD OF RECORD.--04-29-1991 to 09-30-1994.

EXTREME VALUES.--Maximum observed, $71.10 \mathrm{ft}$. (08-28-1991); minimum observed $66.76 \mathrm{ft}$. (08-25-1993).

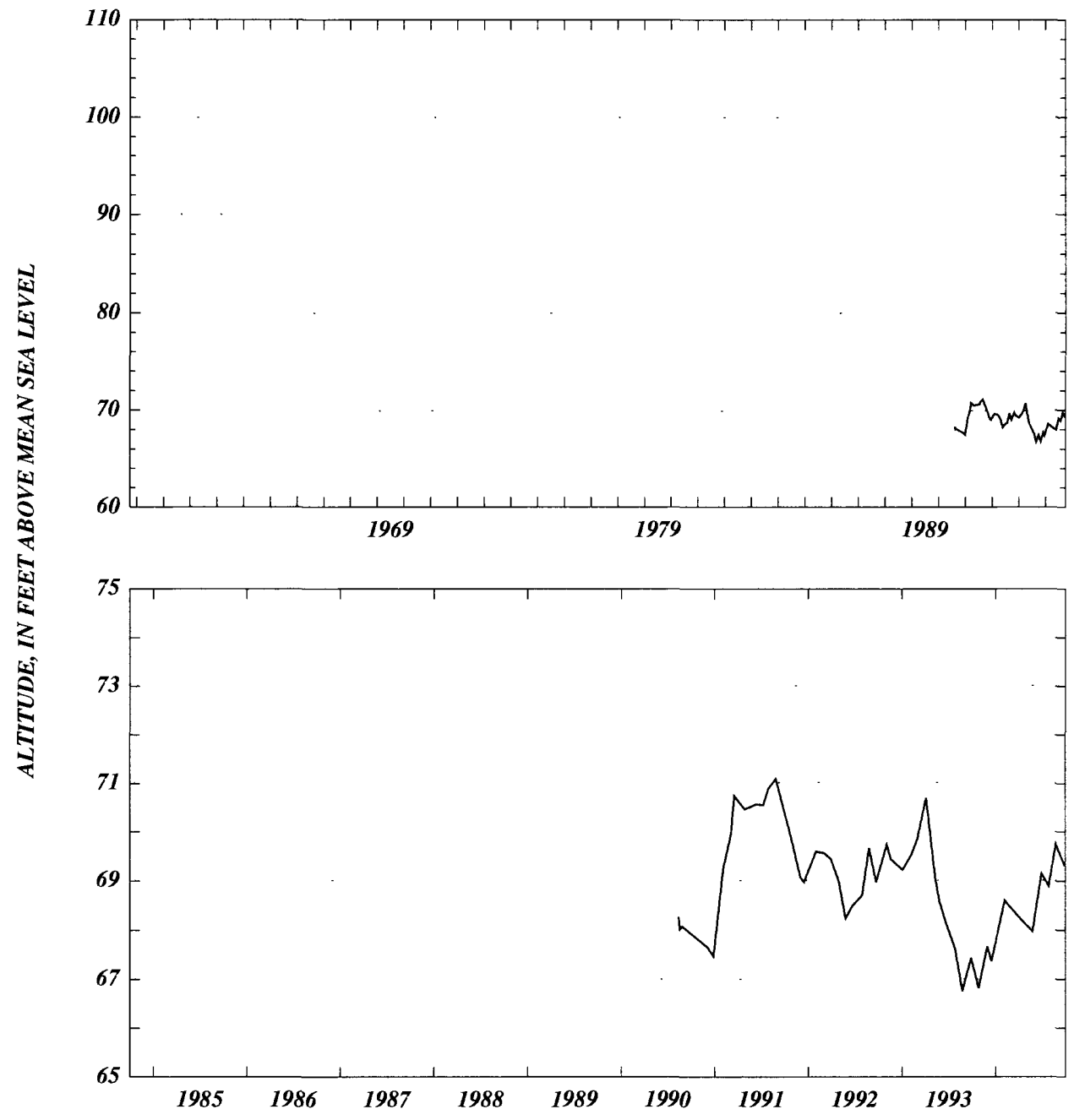



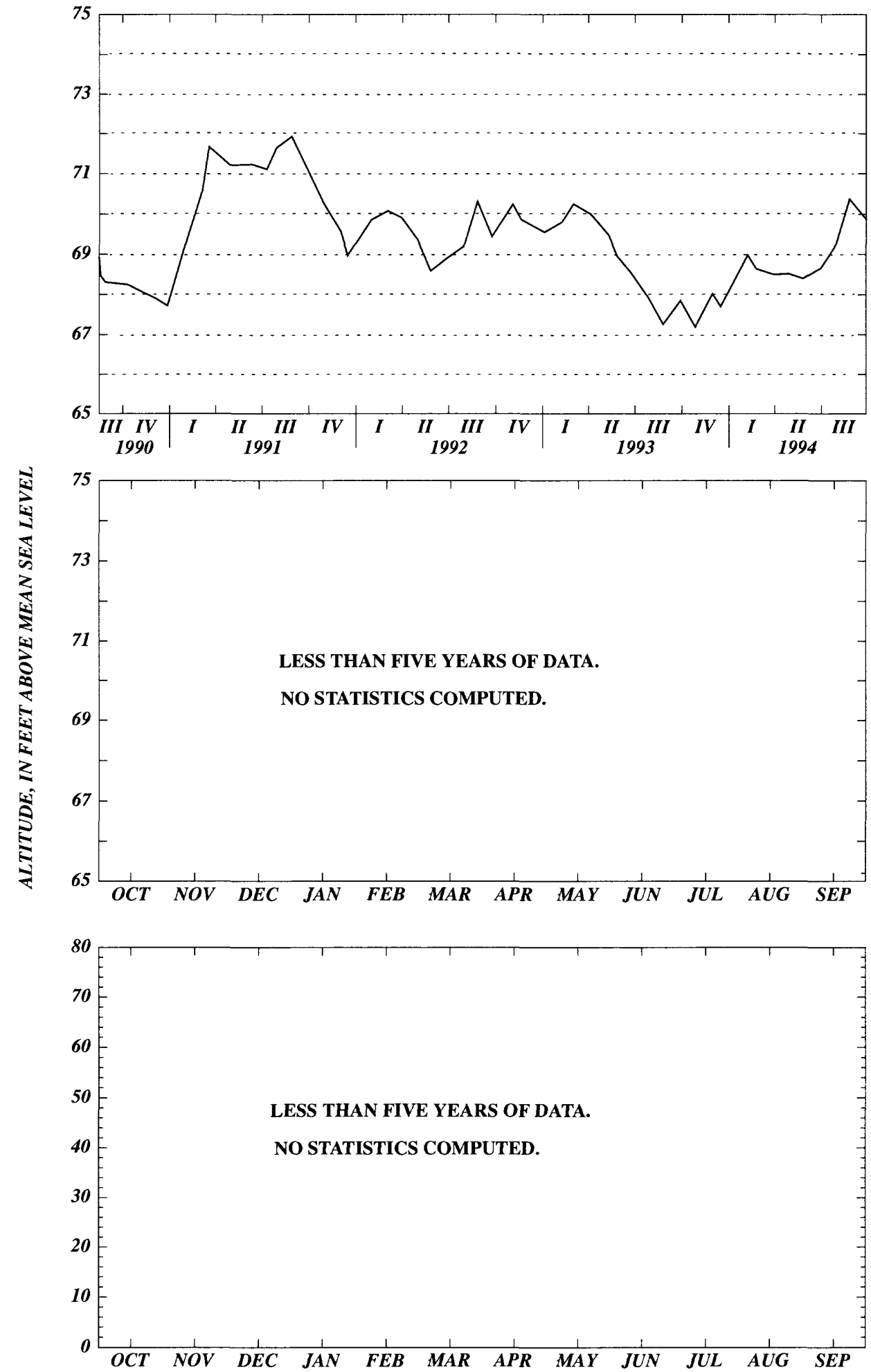


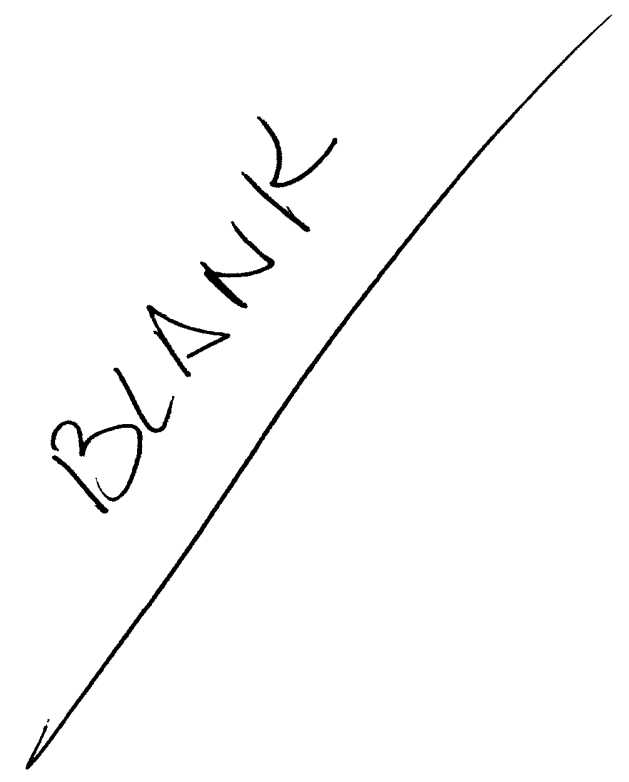




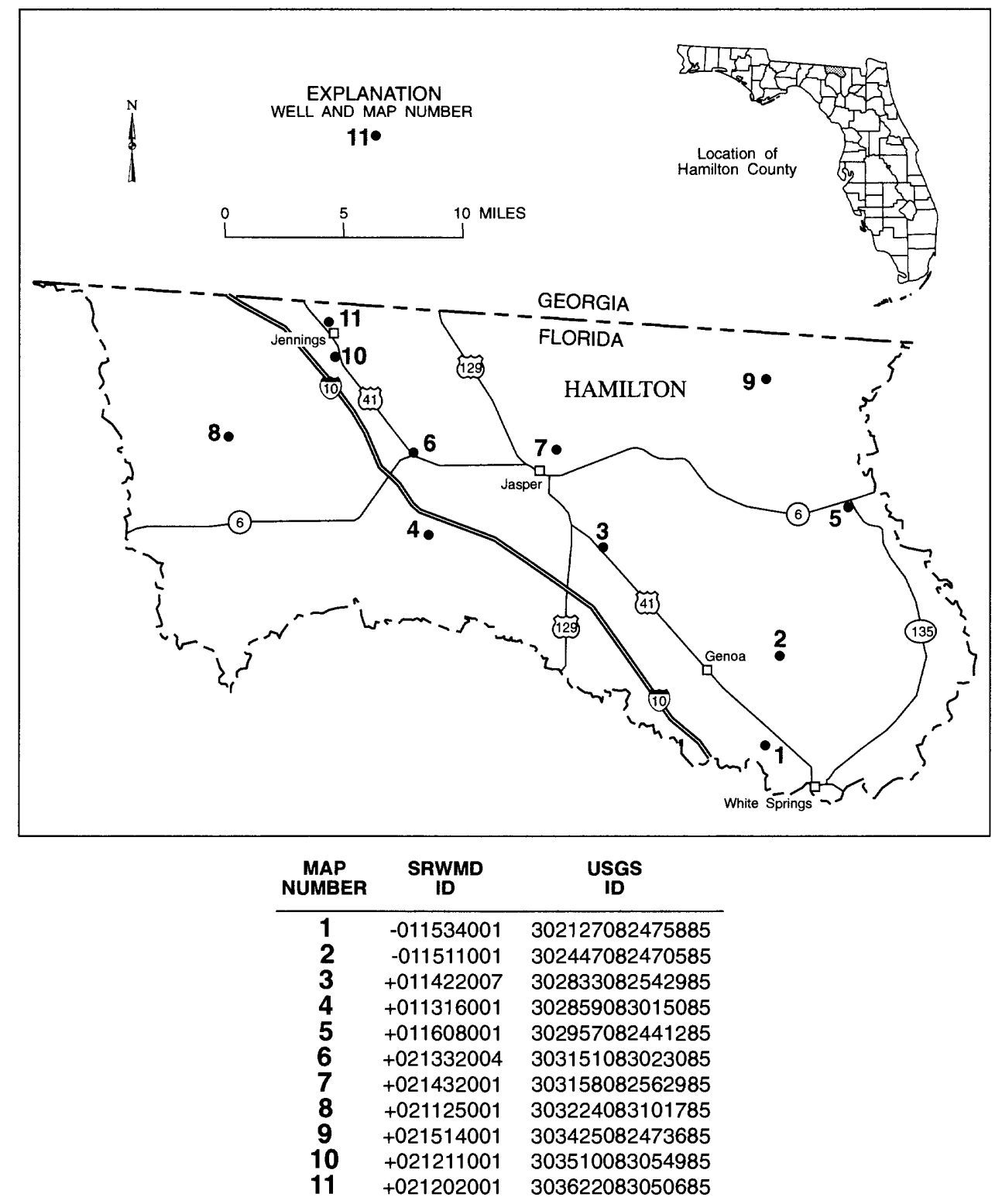

Figure 9. Location of wells in Hamilton County. 
Hamilton County.

WELL NUMBER.--302127082475885. Hilward Morgan. -011534001.

LOCATION.--Lat 30²1'27’, long 8247'58”, Hydrologic Unit Code 03110201.

AQUIFER.--Upper Floridan aquifer of the Tertiary system, Geologic Unit Code 120FLRD.

WELL CHARACTERISTICS.--Casing diameter 6 in., Casing depth $114 \mathrm{ft}$., Total depth $260 \mathrm{ft}$.

INSTRUMENTATION.--Recorder, set to elevation of the Measuring Point, $140.02 \mathrm{ft}$. NGVD.

DATUM.--The National Geodetic Vertical Datum of 1929.

PERIOD OF RECORD.--12-07-1977 to 09-30-1994.

EXTREME VALUES.--Maximum, 78.96 ft. (04-12-1984); minimum, 46.36 ft. (01-09-1991).

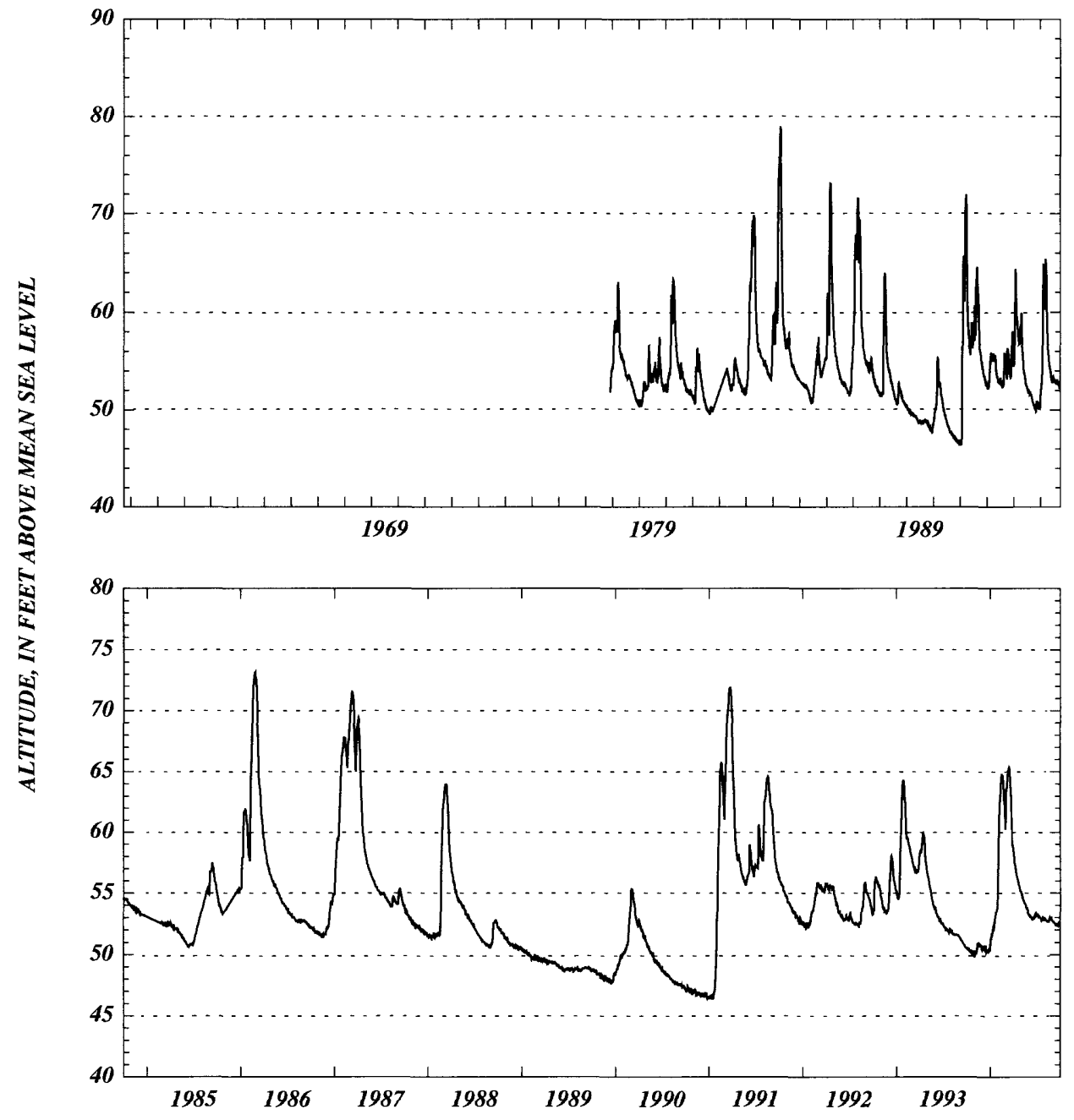



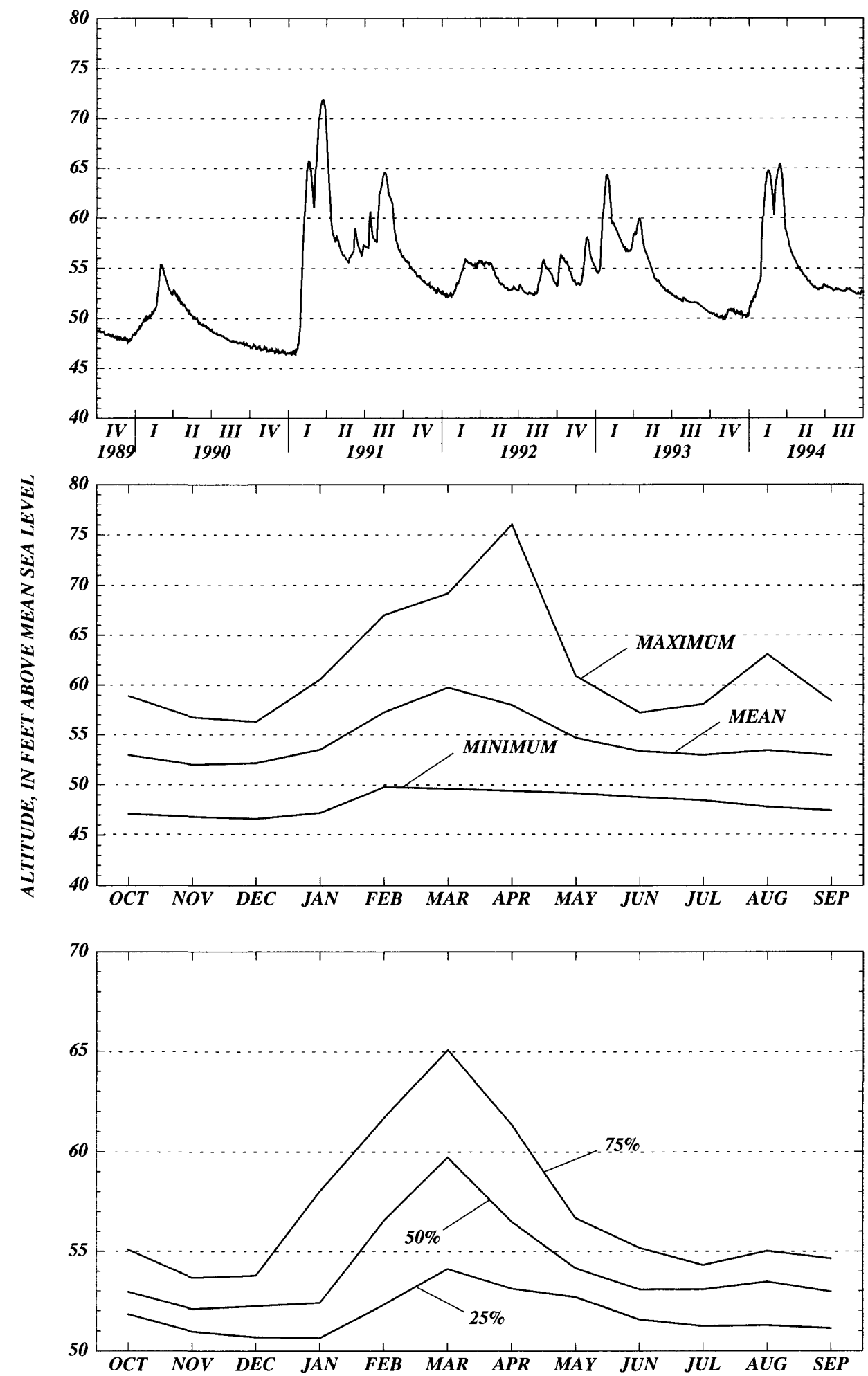
WELL NUMBER.--302447082470585. Occidental Chemical Corporation. -011511001.

LOCATION.--Lat 30 24'47', long 8247'05', Hydrologic Unit Code 03110201.

AQUIFER.--Upper Floridan aquifer of the Tertiary system, Geologic Unit Code 120FLRD.

WELL CHARACTERISTICS.--Casing diameter 6 in., Casing depth $107 \mathrm{ft}$., Total depth $160 \mathrm{ft}$.

INSTRUMENTATION.--Elevation of Measuring Point $120.71 \mathrm{ft}$., NGVD.

DATUM.--The National Geodetic Vertical Datum of 1929.

PERIOD OF RECORD.--05-08-1975 to 09-30-1994.

EXTREME VALUES.--Maximum observed, $71.54 \mathrm{ft}$. (04-24-1984); minimum observed, $47.88 \mathrm{ft}$. (12-20-1993).

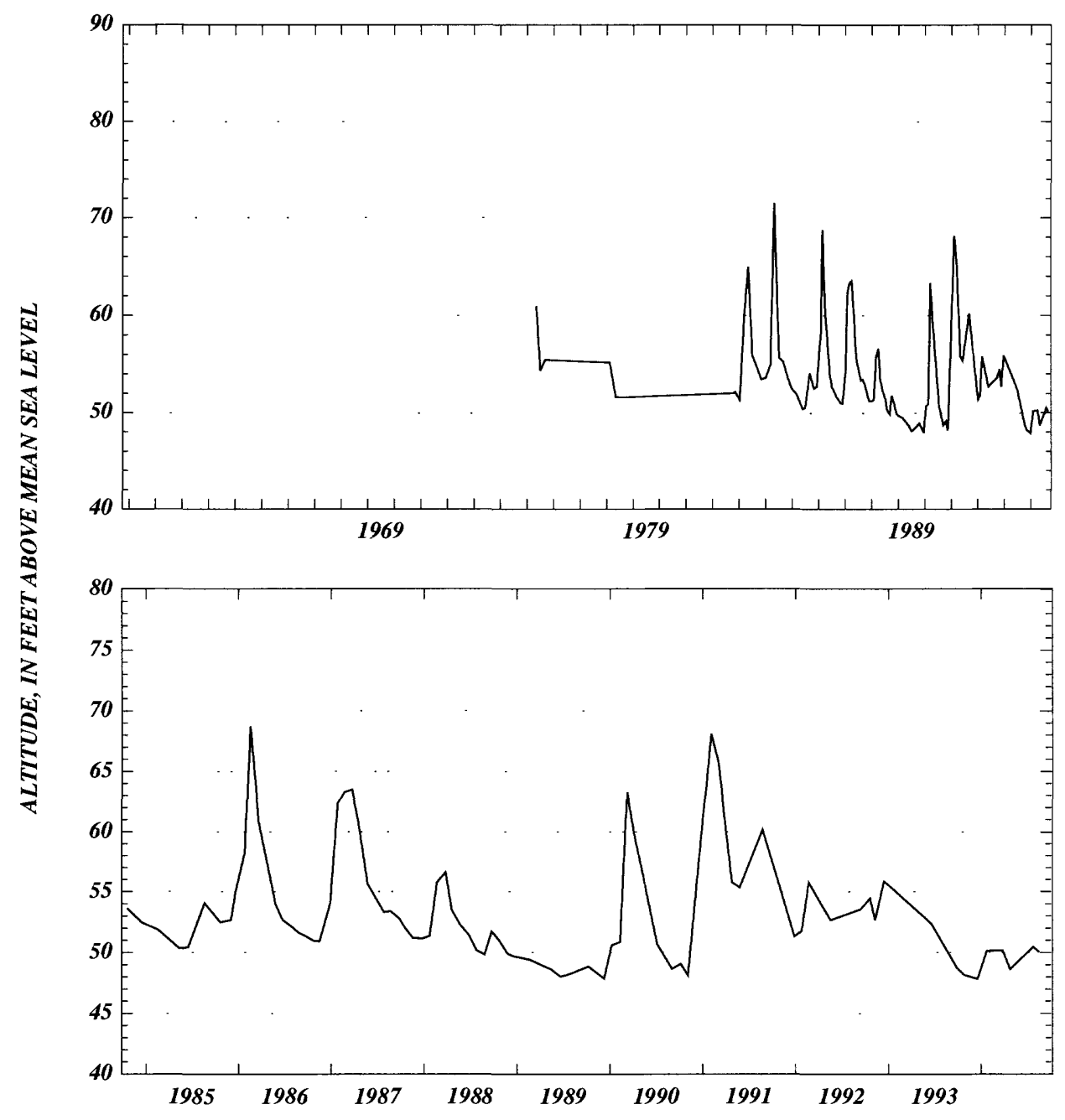



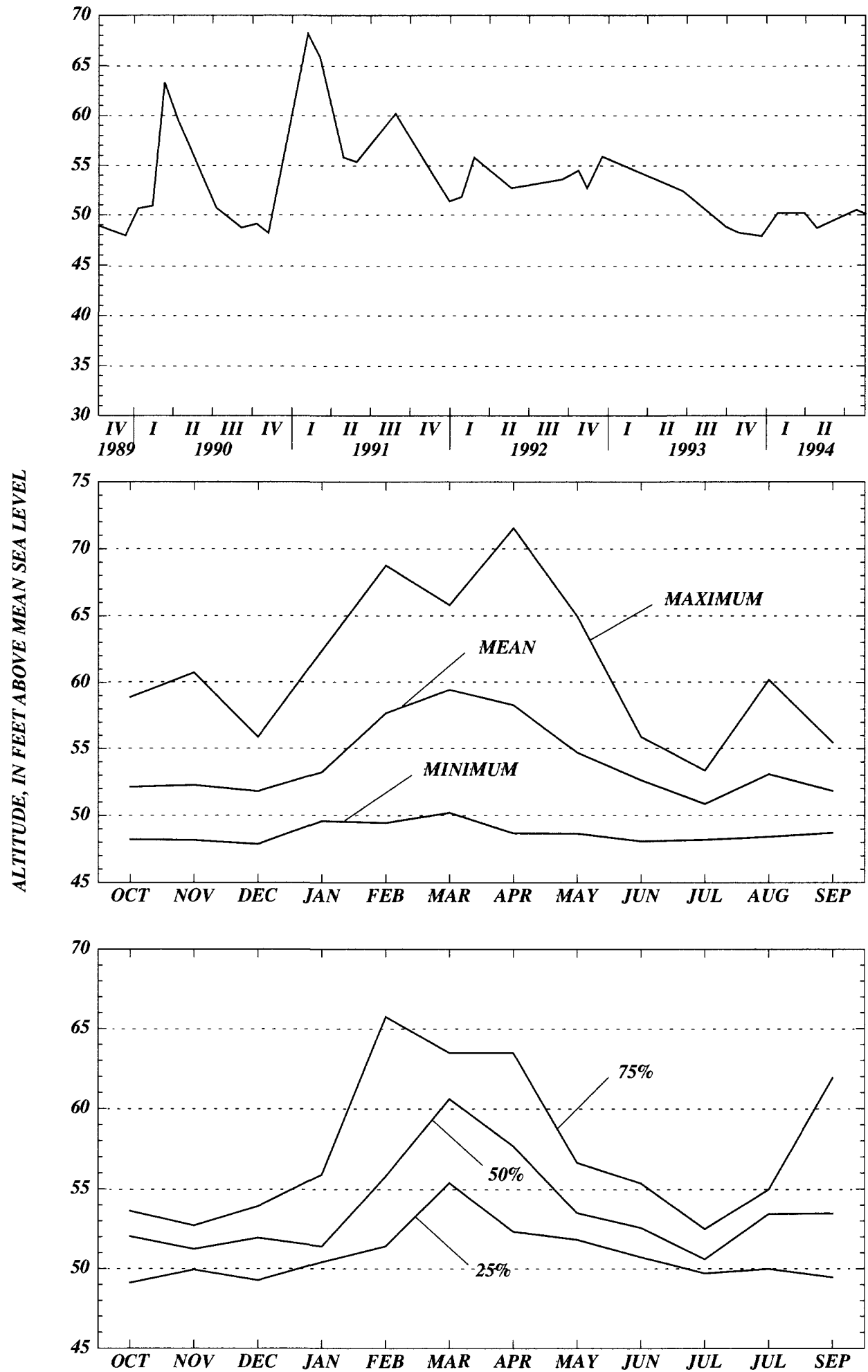


\section{Hamilton County}

WELL NUMBER.--302833082542985. Pete Deas. +011422007.

LOCATION.--Lat 30²8'33”, long 8254'29”, Hydrologic Unit Code 03110201.

AQUIFER.--Upper Floridan aquifer of the Tertiary system, Geologic Unit Code 120FLRD.

WELL CHARACTERISTICS.--Casing diameter 8 in., Casing depth $81 \mathrm{ft}$., Total depth $105 \mathrm{ft}$.

INSTRUMENTATION.--Miscellaneous from 11-01-1976 to 03-10-1981; then recorder, set to elevation of Measuring Point, $139.23 \mathrm{ft}$., NGVD.

DATUM.--The National Geodetic Vertical Datum of 1929.

PERIOD OF RECORD.--03-11-1981 to 09-30-1994.

EXTREME VALUES.--Maximum, 68.68 ft. (04-15-1984); minimum, 39.46 ft. (11-30-1990).

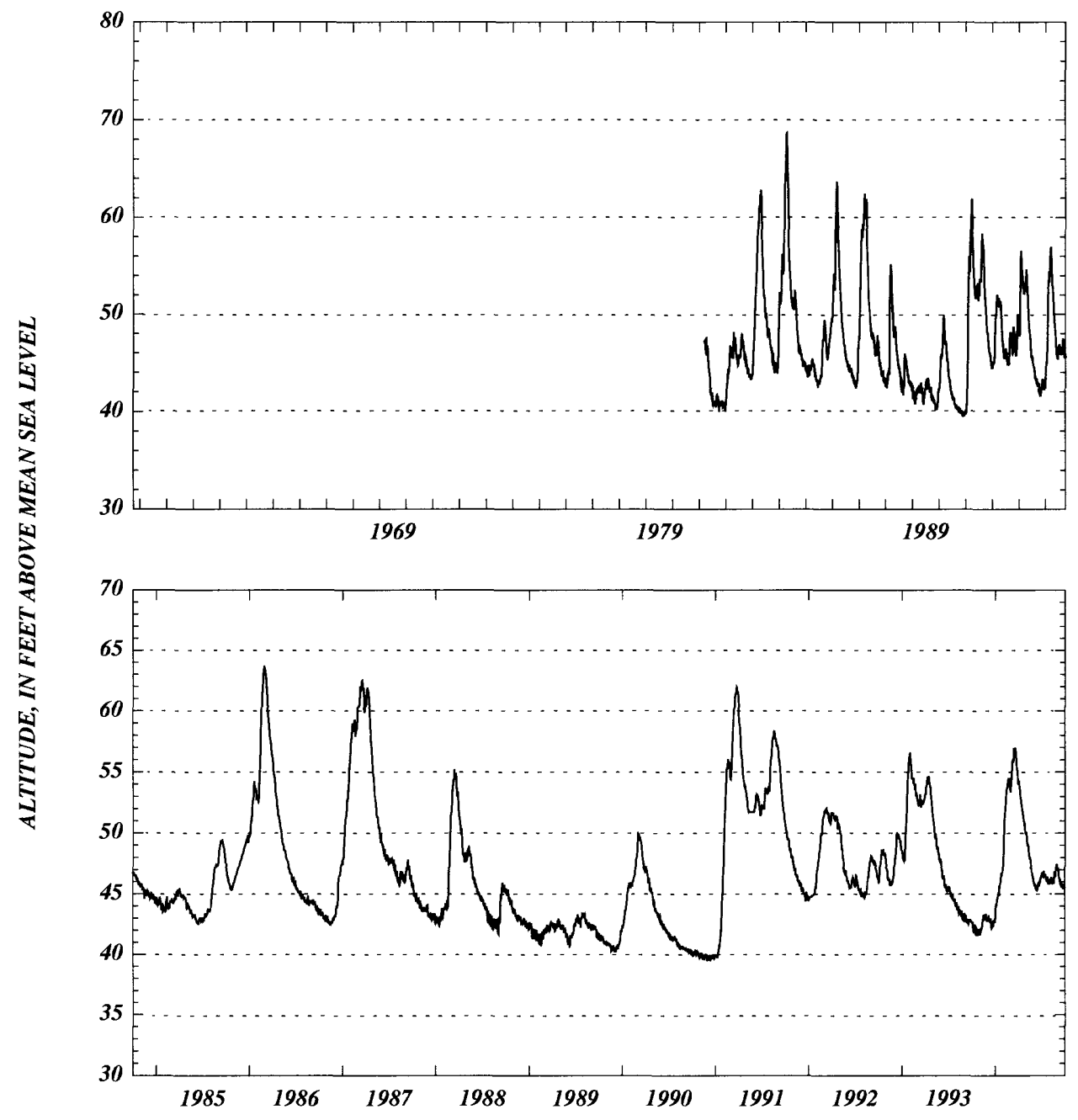



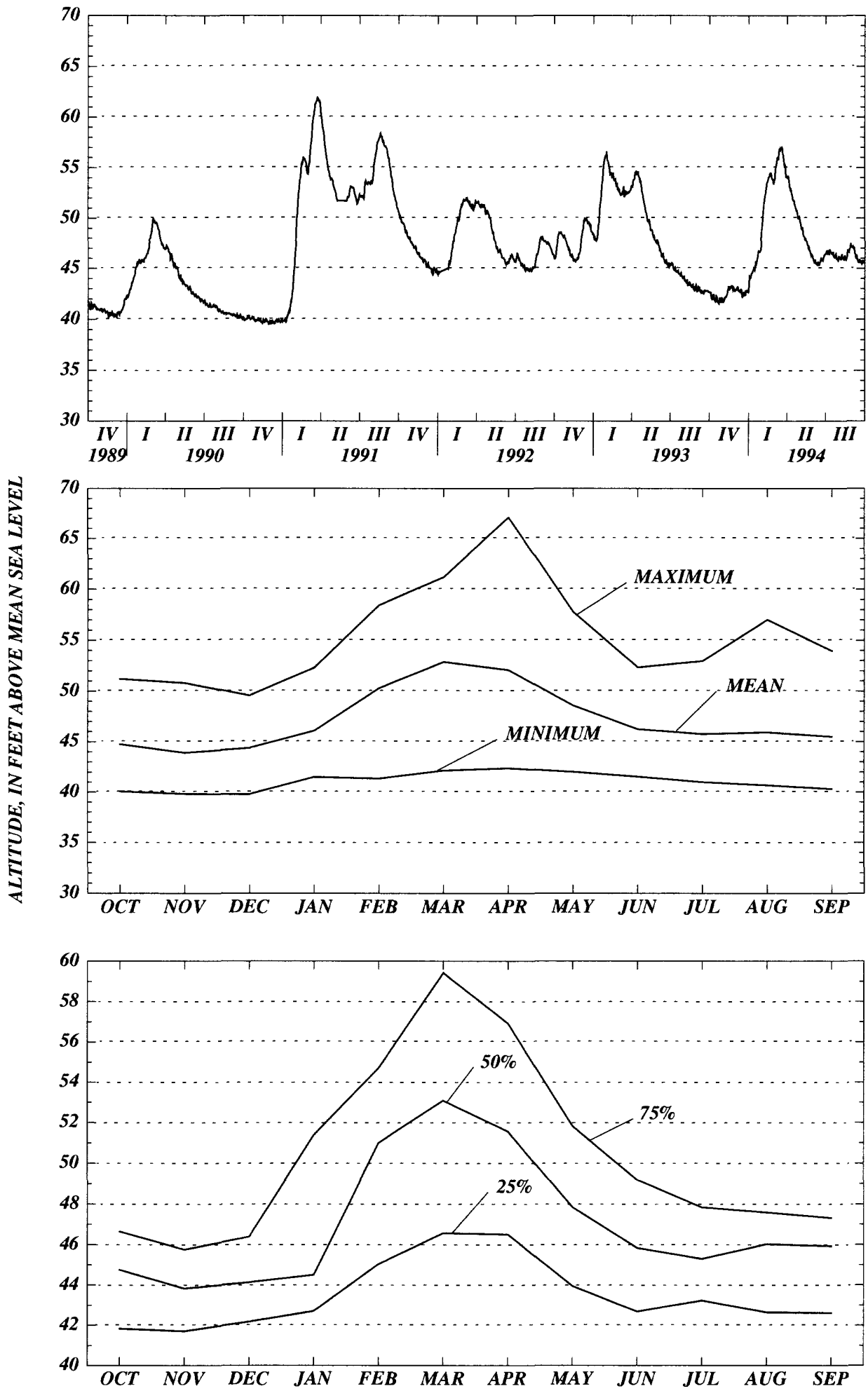


\section{Hamilton County}

WELL NUMBER.--302859083015085. Carl I. Carter. +011316001.

LOCATION.--Lat 30²8'59”, long 8301'50', Hydrologic Unit Code 03110201.

AQUIFER.--Upper Floridan aquifer of the Tertiary system, Geologic Unit Code 120FLRD.

WELL CHARACTERISTICS.--Casing diameter 10 in., Casing depth $100 \mathrm{ft}$., Total depth $167 \mathrm{ft}$.

INSTRUMENTATION.--Miscellaneous from 11-01-1976 to 01-19-1981; then recorder, set to elevation of Measuring Point, $101.06 \mathrm{ft}$., NGVD.

DATUM.--The National Geodetic Vertical Datum of 1929.

PERIOD OF RECORD.--11-01-1976 to 09-30-1994.

EXTREME VALUES.--Maximum, 68.01 ft. (02-19-1986); minimum, 32.59 ft. (10-08-1990).

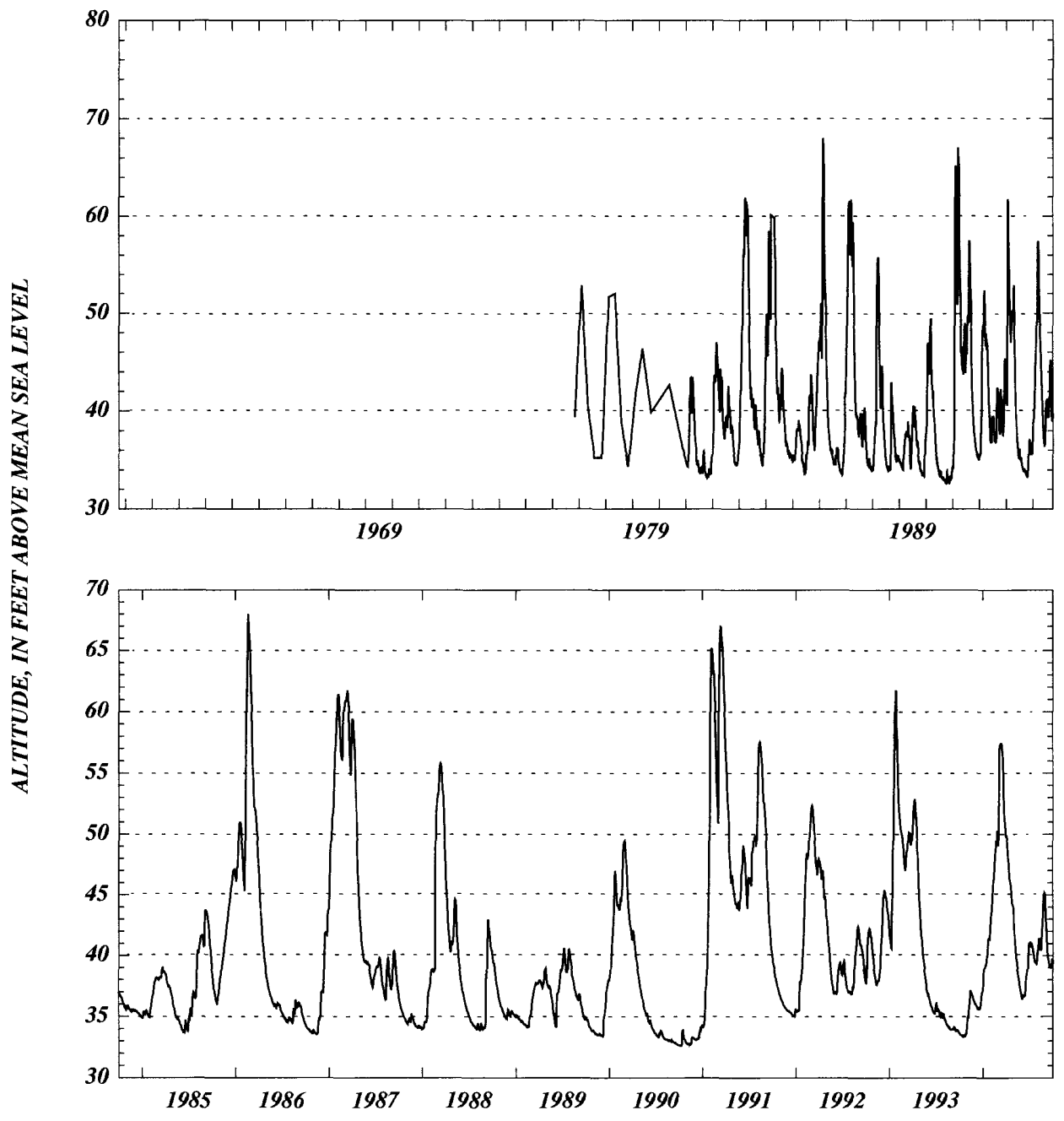



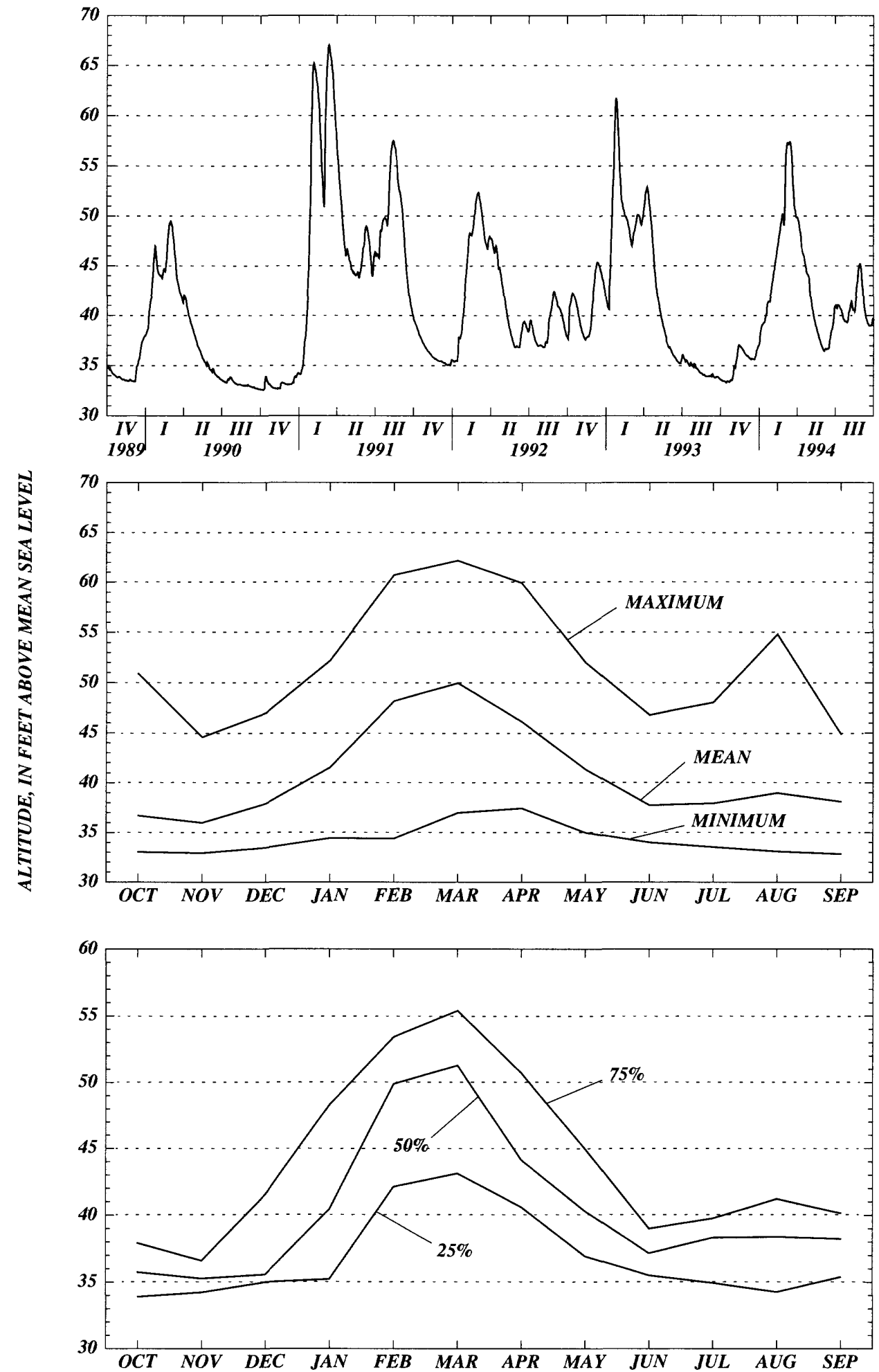
WELL NUMBER.--302957082441285. Irene Morgan - Camp Mallory. +011608001.

LOCATION.--Lat 30²9'57”, long 8244'12", Hydrologic Unit Code 03110201.

AQUIFER.--Upper Floridan aquifer of the Tertiary system, Geologic Unit Code 120FLRD.

WELL CHARACTERISTICS.--Casing diameter 4 in., Casing depth $123 \mathrm{ft}$., Total depth $183 \mathrm{ft}$.

INSTRUMENTATION.--Elevation of the Measuring Point $131.43 \mathrm{ft}$., NGVD.

DATUM.--The National Geodetic Vertical Datum of 1929.

PERIOD OF RECORD.--08-01-1976 to 09-30-1994.

EXTREME VALUES.--Maximum observed, 78.47 ft. (04-20-1984); minimum observed, $52.85 \mathrm{ft}$. (01-08-1991).

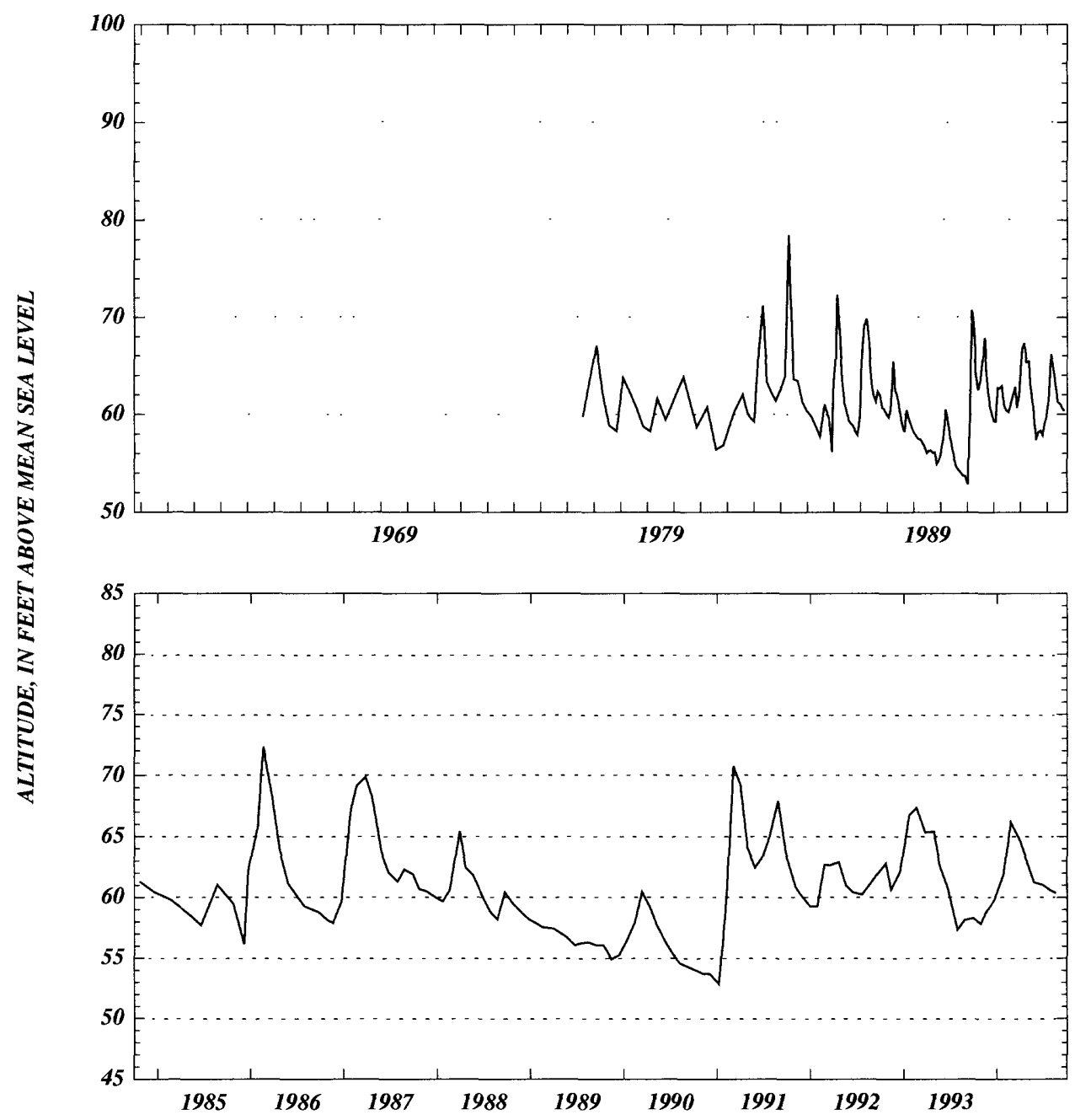



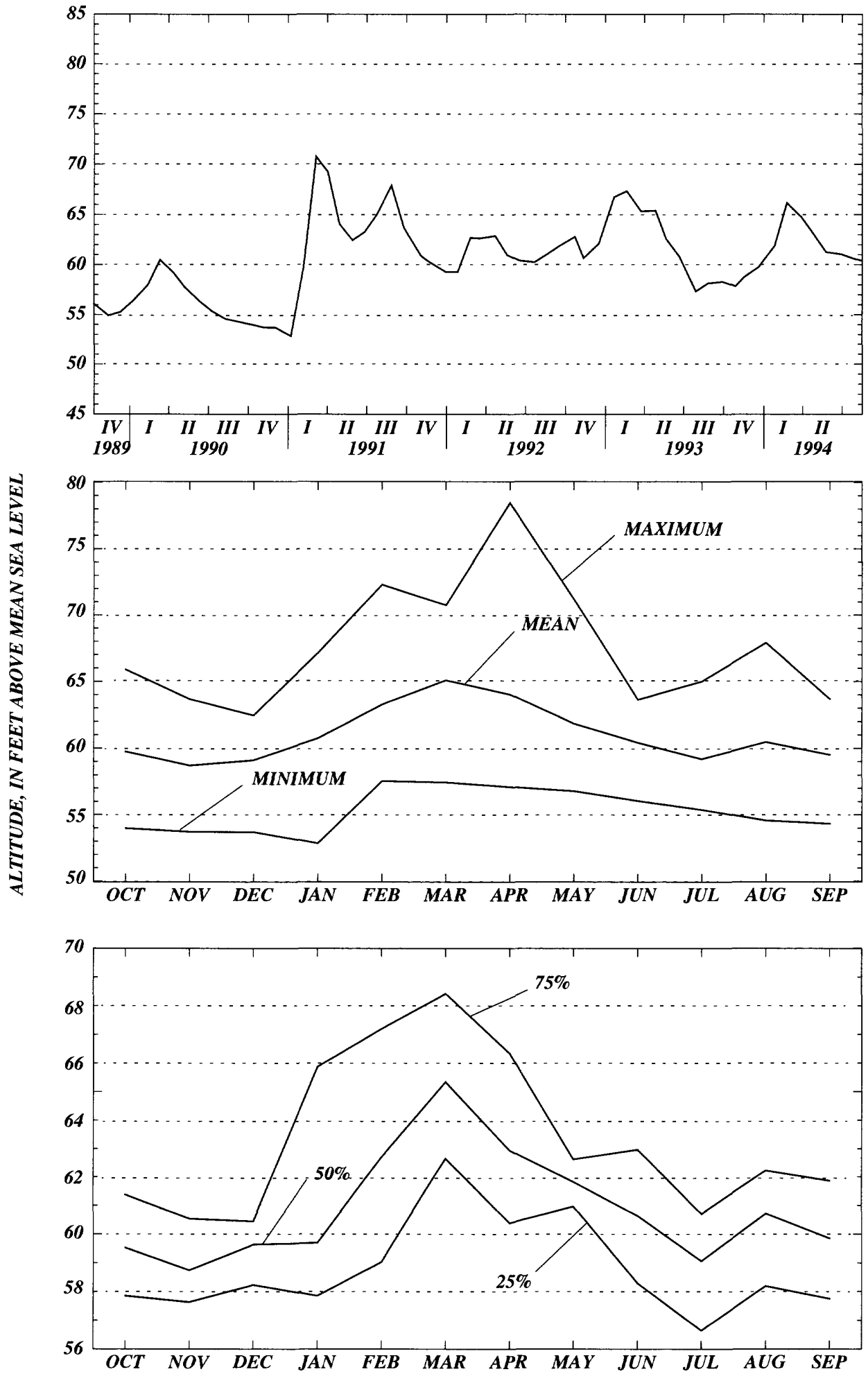


\section{Hamilton County}

WELL NUMBER.--303151083023085. DOF - Alapaha Tower. +021332004.

LOCATION.--Lat 30³1'51”, long 8302’30”, Hydrologic Unit Code 03110202.

AQUIFER.--Upper Floridan aquifer of the Tertiary system, Geologic Unit Code 120FLRD.

WELL CHARACTERISTICS.--Casing diameter 3 in., Casing depth $63 \mathrm{ft}$., Total depth $103 \mathrm{ft}$.

INSTRUMENTATION.--Elevation of Measuring Point $122.94 \mathrm{ft}$., NGVD.

DATUM.--The National Geodetic Vertical Datum of 1929.

PERIOD OF RECORD.--06-12-1989 to 09-30-1994. *

EXTREME VALUES.--Maximum observed, 72.12 ft. (02-07-1991); minimum observed, $32.40 \mathrm{ft}$. (11-13-1990).

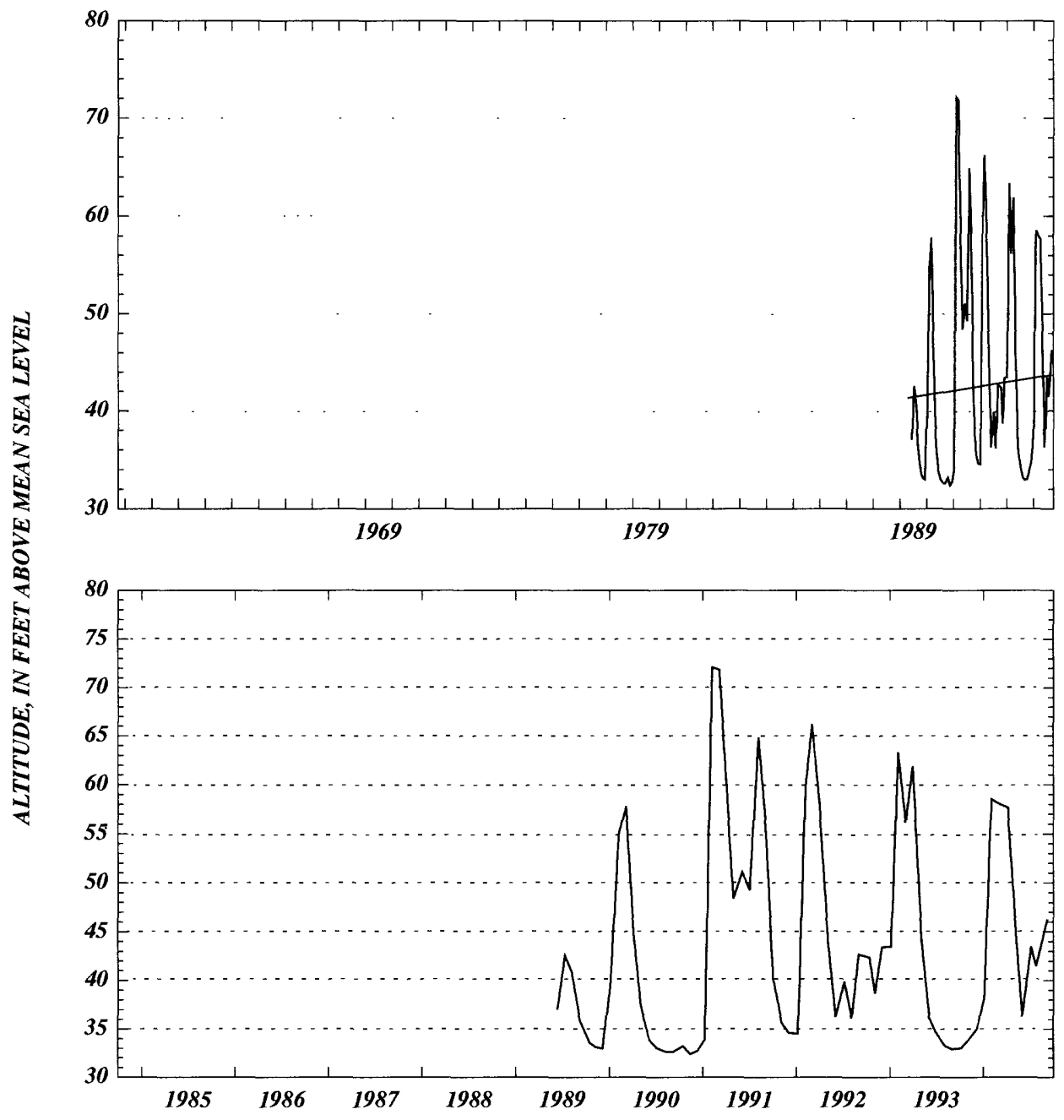



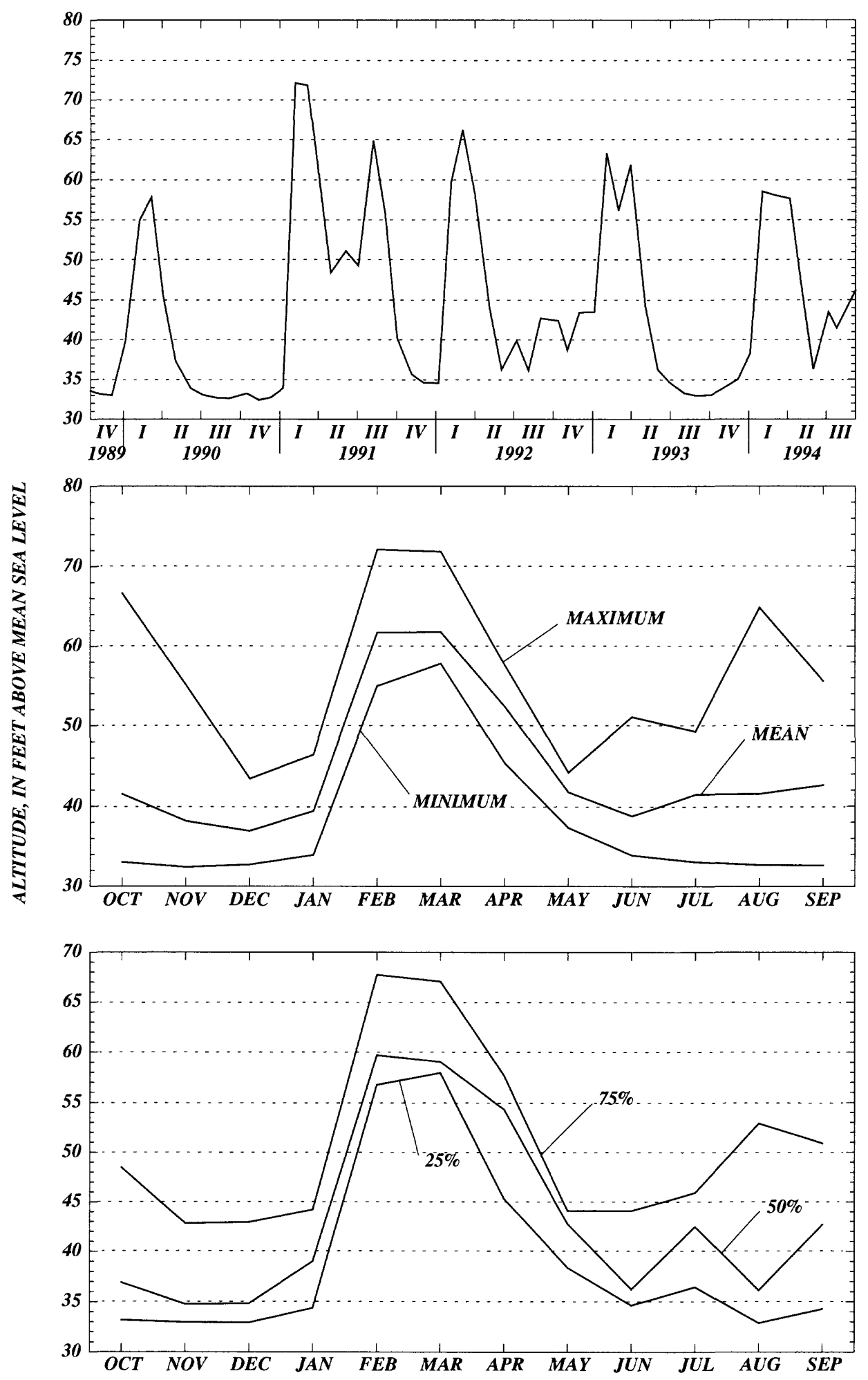
WELL NUMBER.--303158082562985. Stafford Scaff. +021432001.

LOCATION.--Lat 30³1'58”, long 8256'29”, Hydrologic Unit Code 03110205.

AQUIFER.--Upper Floridan aquifer of the Tertiary system, Geologic Unit Code 120FLRD.

WELL CHARACTERISTICS.--Casing diameter $10 \mathrm{in}$., Casing depth $92 \mathrm{ft}$., Total depth $167 \mathrm{ft}$.

INSTRUMENTATION.--Recorder, set to elevation of Measuring Point, $143.62 \mathrm{ft}$., NGVD.

DATUM.--The National Geodetic Vertical Datum of 1929.

PERIOD OF RECORD.--11-15-1975 to 09-30-1994.

EXTREME VALUES.--Maximum, 66.22 ft. (04-10-1984); minimum, 33.83 ft. (11-11-1990).

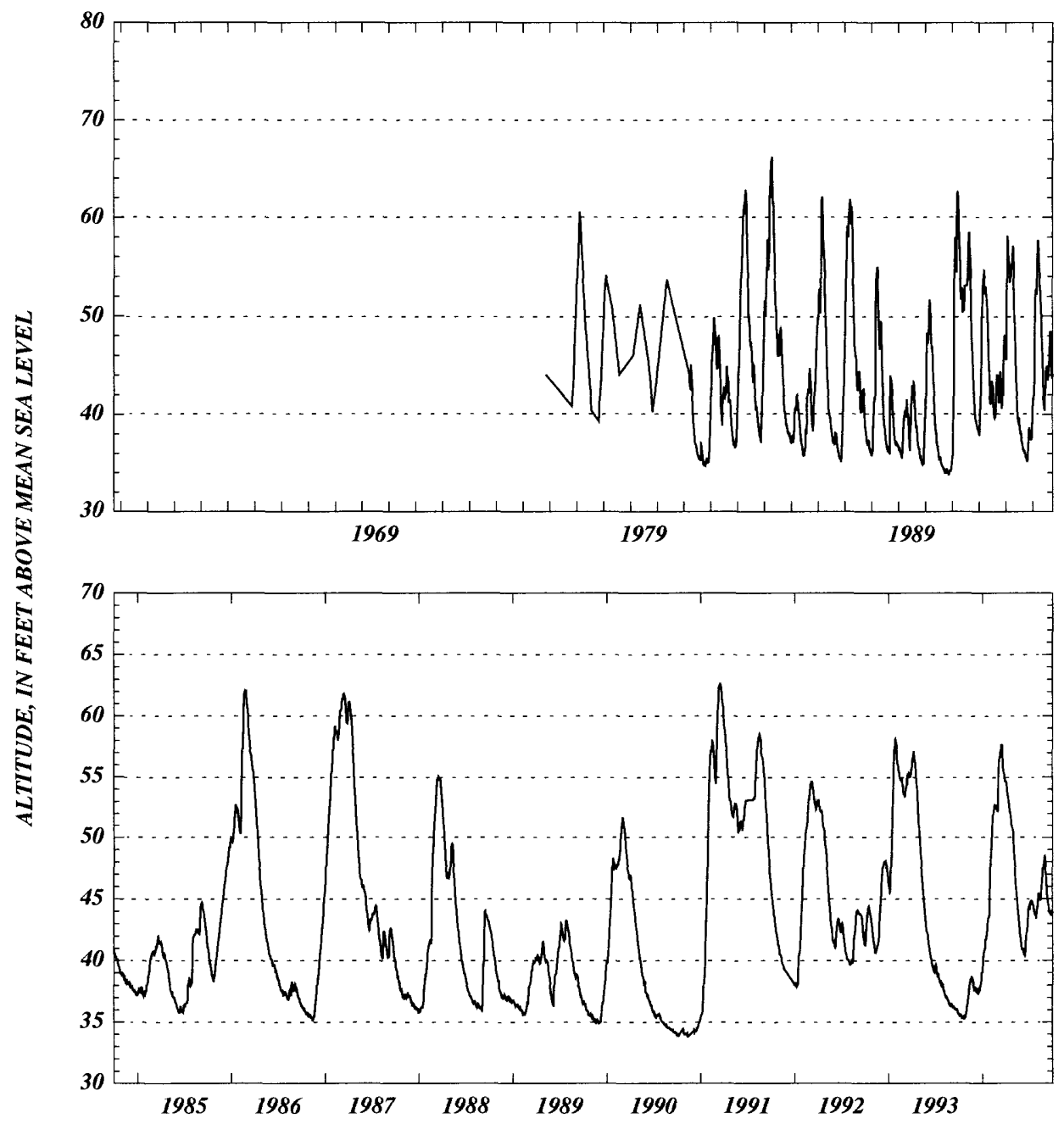



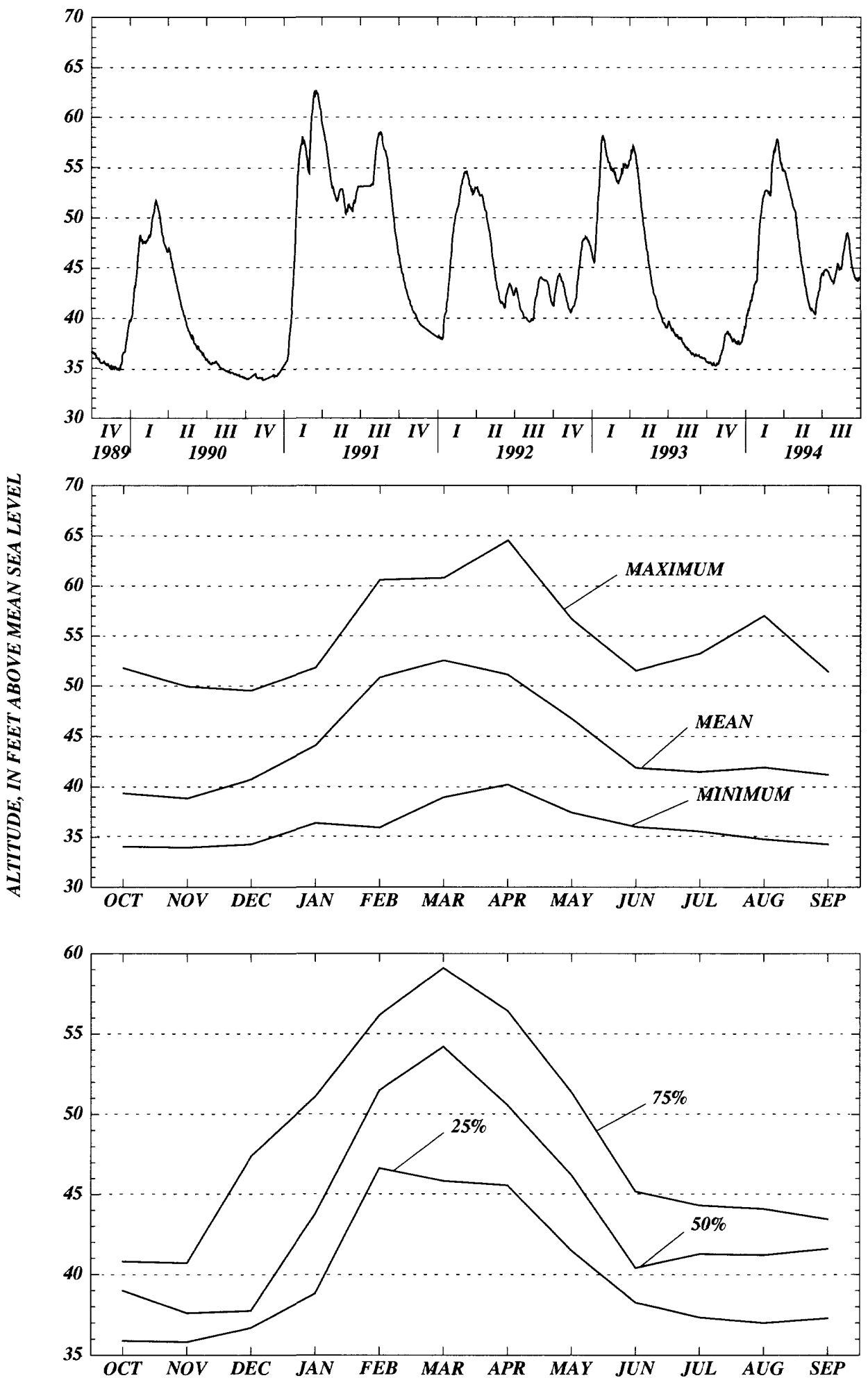


\section{Hamilton County}

WELL NUMBER.--303224083101785. Santa Deas. +021125001.

LOCATION.--Lat 30³2’24”, long 83¹0’17’, Hydrologic Unit Code 03110205.

AQUIFER.--Upper Floridan aquifer of the Tertiary system, Geologic Unit Code 120FLRD.

WELL CHARACTERISTICS.--Casing diameter 8 in., Casing depth $100 \mathrm{ft}$., Total depth $195 \mathrm{ft}$.

INSTRUMENTATION.--Recorder, set to elevation of Measuring Point, $153.72 \mathrm{ft}$., NGVD.

DATUM.--The National Geodetic Vertical Datum of 1929.

PERIOD OF RECORD.--03-10-1981 to 09-30-1994. *

EXTREME VALUES.--Maximum, 69.39 ft. (04-15-1984); minimum, 40.04 ft. (11-11-1990).

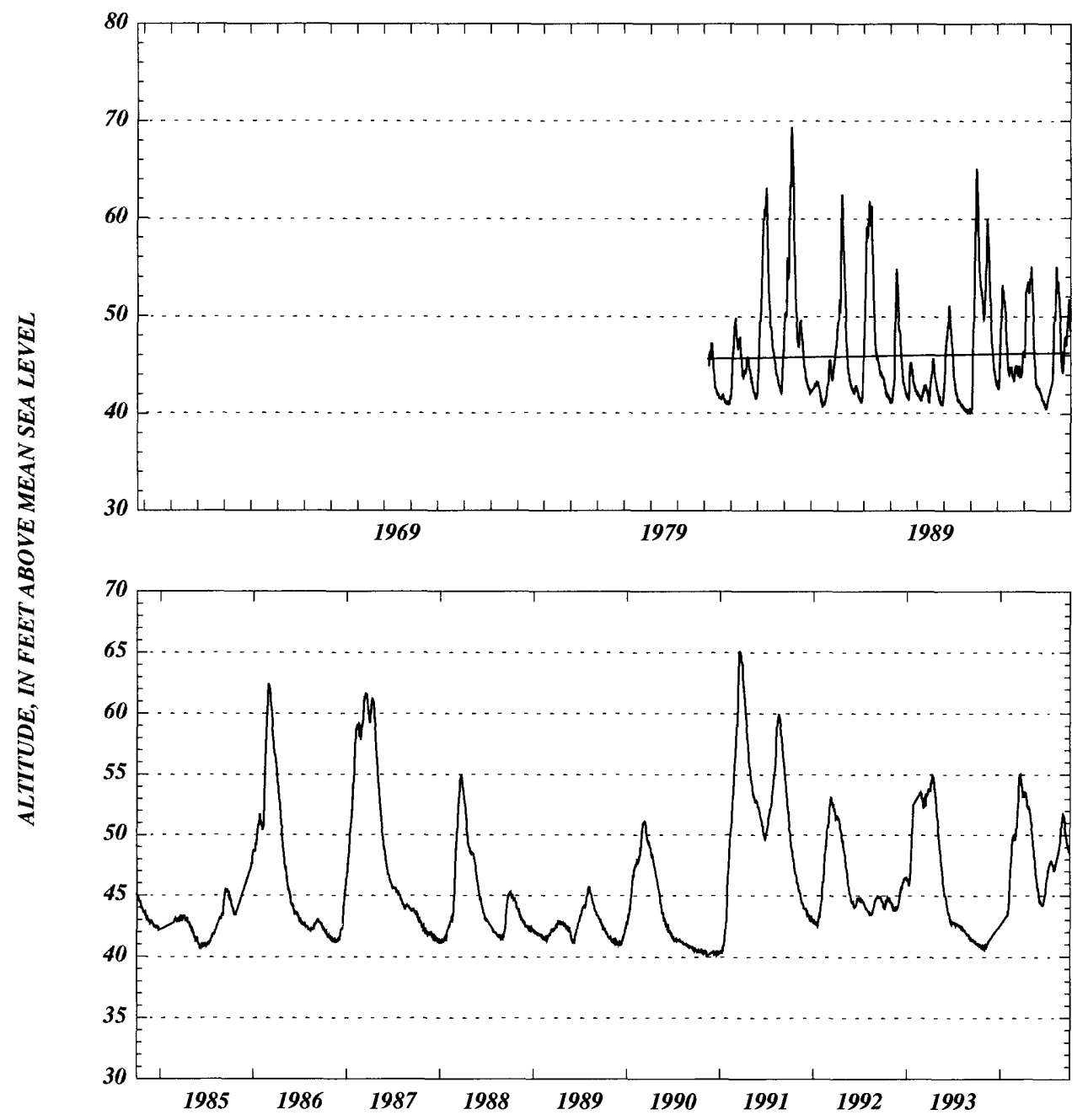



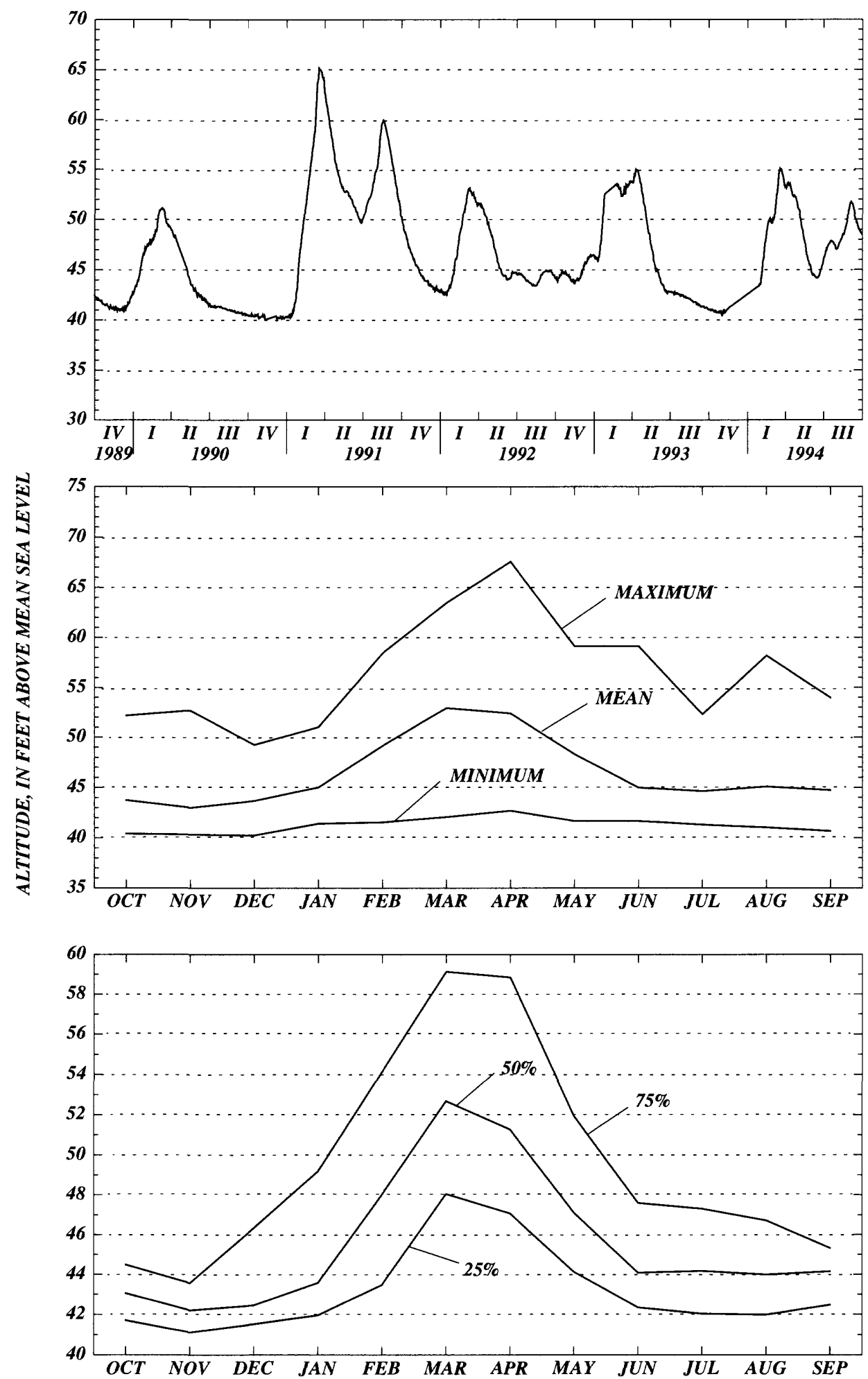
WELL NUMBER.--303425082473685. Cypress Creek Station. +021514001.

LOCATION.--Lat 30³4'25”, long 8247’36”, Hydrologic Unit Code 03110201.

AQUIFER.--Upper Floridan aquifer of the Tertiary system, Geologic Unit Code 120FLRD.

WELL CHARACTERISTICS.--Casing diameter 4 in., Casing depth $192 \mathrm{ft}$., Total depth $220 \mathrm{ft}$.

INSTRUMENTATION.--Miscellaneous from 11-01-1976 to 06-11-1984; then recorder, set to elevation of Measuring Point, $130.76 \mathrm{ft}$., NGVD.

DATUM.--The National Geodetic Vertical Datum of 1929.

PERIOD OF RECORD.--11-01-1976 to 09-30-1994. *

EXTREME VALUES.--Maximum, 69.63 ft. (04-20-1984); minimum, 49.19 ft. (10-08-1990).

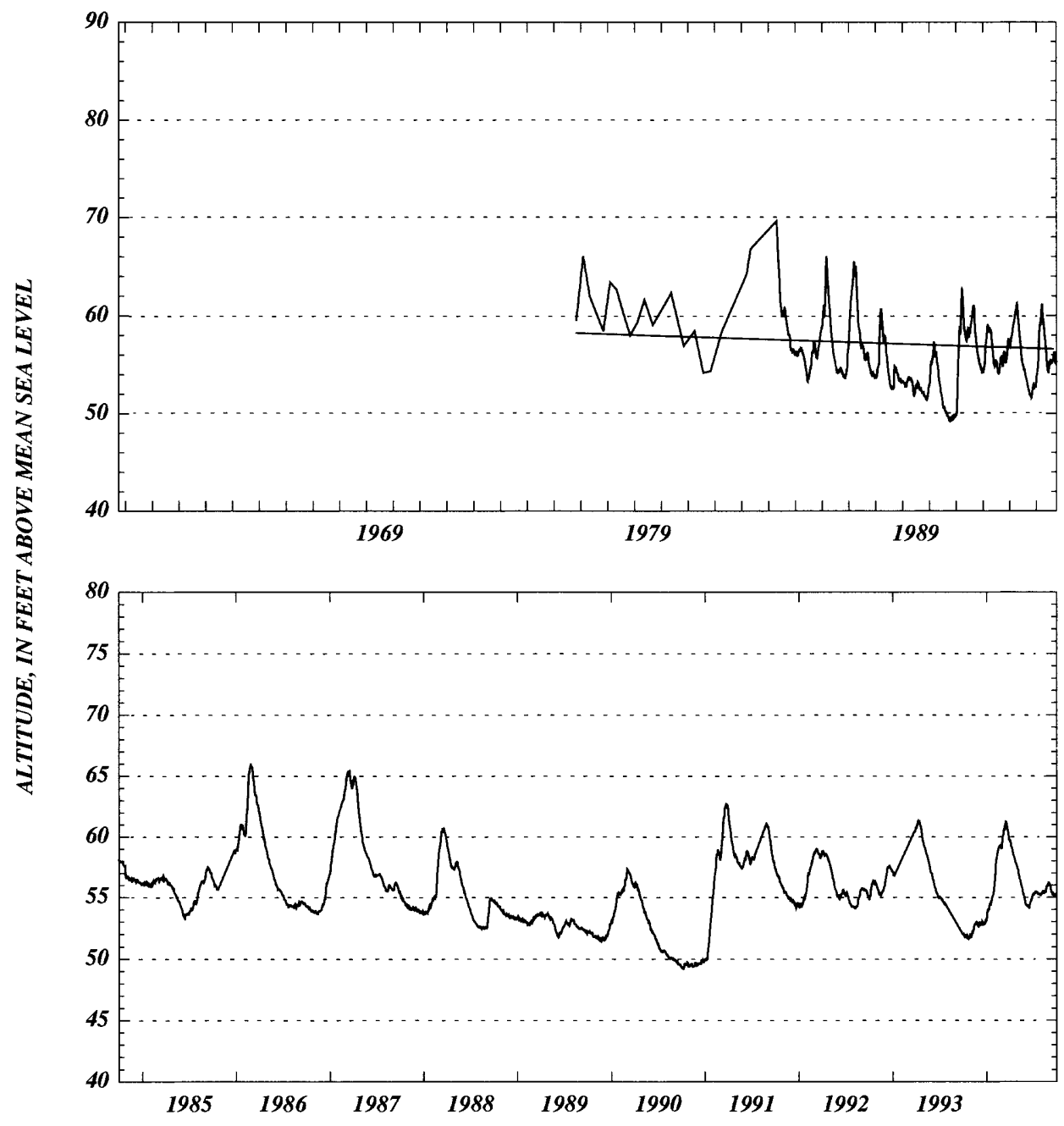



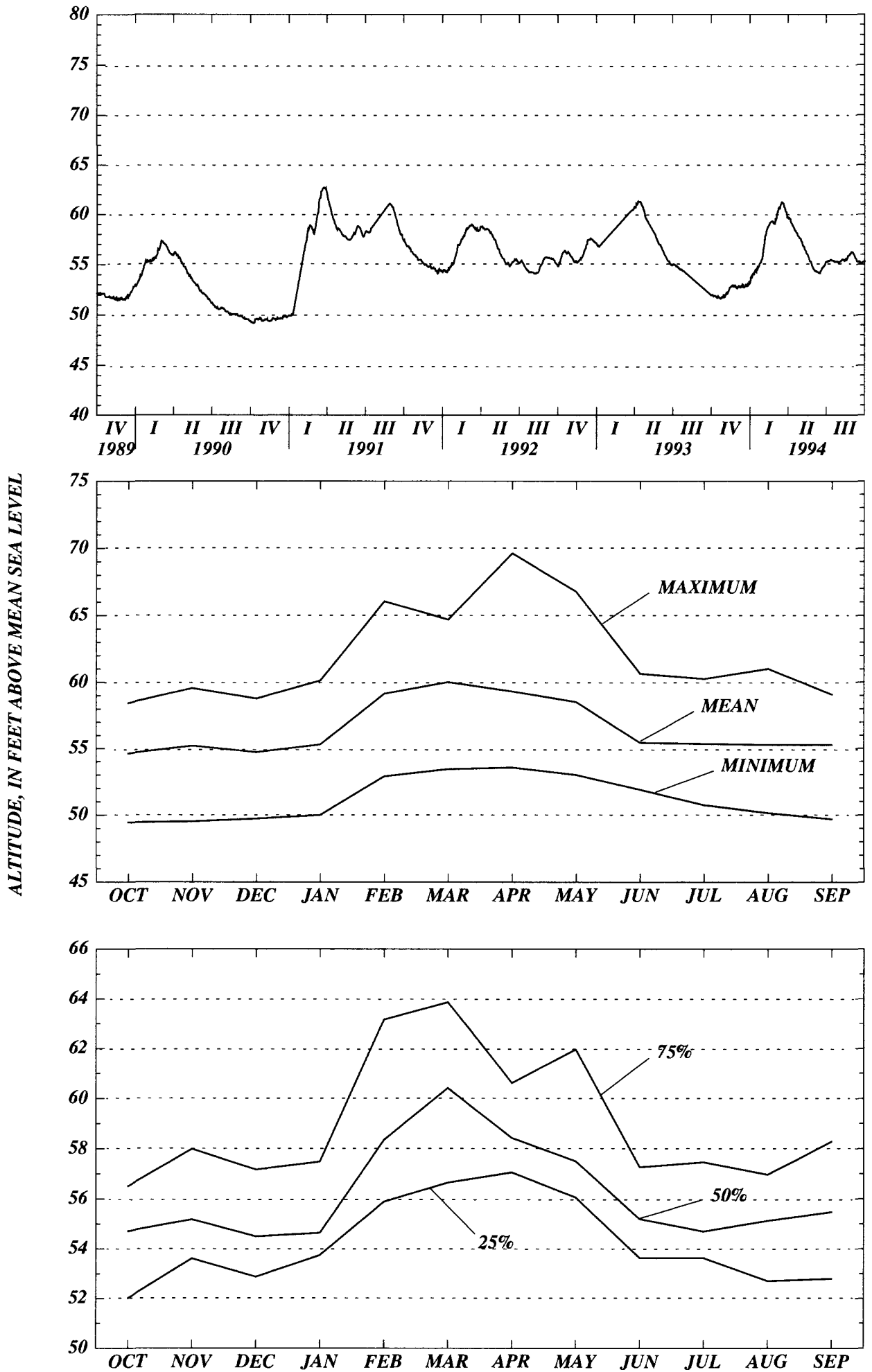


\section{Hamilton County}

WELL NUMBER.--303510083054985. Ivey Prescott. +021211001.

LOCATION.--Lat 30³5'10', long 8305'49', Hydrologic Unit Code 03110205.

AQUIFER.--Upper Floridan aquifer of the Tertiary system, Geologic Unit Code 120FLRD.

WELL CHARACTERISTICS.--Casing diameter 10 in., Casing depth $153 \mathrm{ft}$., Total depth $188 \mathrm{ft}$.

INSTRUMENTATION.--Miscellaneous from 07-26-1977 to 07-11-1980; then recorder, set to elevation of Measuring Point, $155.56 \mathrm{ft}$., NGVD.

DATUM.--The National Geodetic Vertical Datum of 1929.

PERIOD OF RECORD.--07-26-1977 to 09-30-1994.

EXTREME VALUES.--Maximum, 68.72 ft. (03-13-1991); minimum, 35.26 ft. (10-07-1990.)

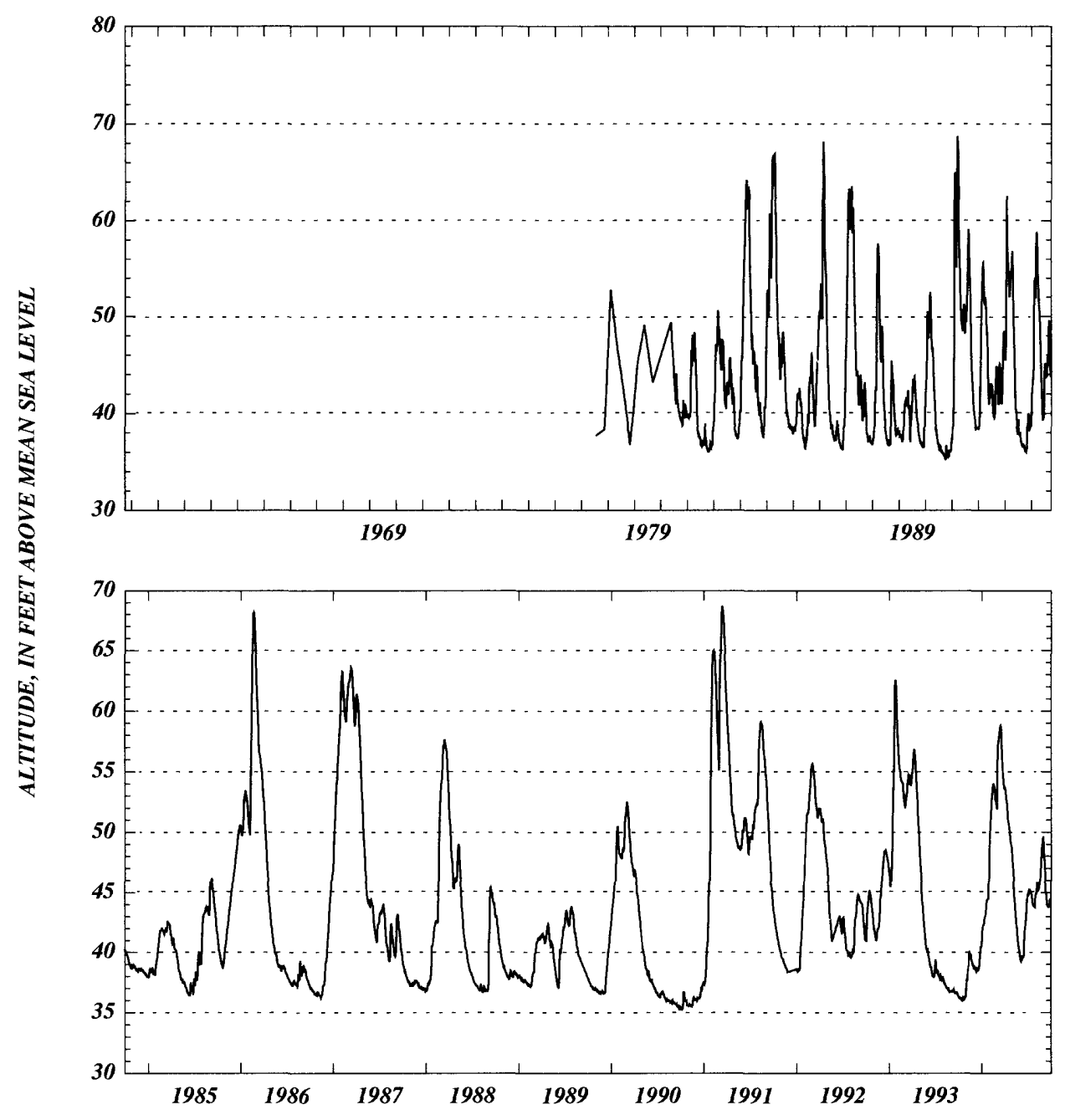



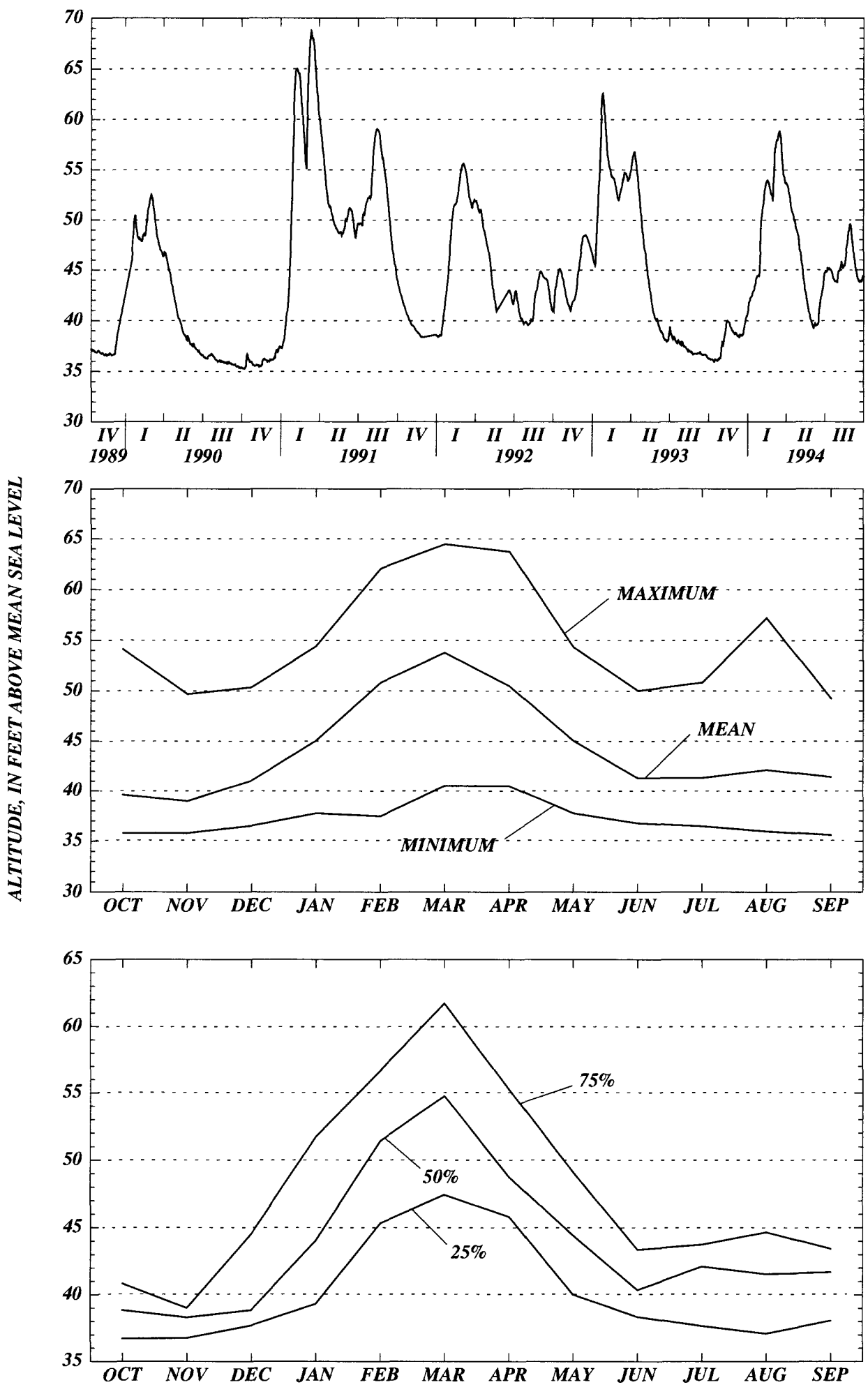


\section{Hamilton County}

WELL NUMBER.--303622083050685. Ben Bates. +021202001.

LOCATION.--Lat 30³6'22”, long 8305'06”, Hydrologic Unit Code 03110202.

AQUIFER.--Upper Floridan aquifer of the Tertiary system, Geologic Unit Code 120FLRD.

WELL CHARACTERISTICS.--Casing diameter 10 in., Casing depth $61 \mathrm{ft}$., Total depth $273 \mathrm{ft}$.

INSTRUMENTATION.--Elevation of Measuring Point $150.70 \mathrm{ft}$., NGVD.

DATUM.--The National Geodetic Vertical Datum of 1929.

PERIOD OF RECORD.--01-24-1961 to 09-30-1994.

EXTREME VALUES.--Maximum observed, 70.85 ft. (05-16-1980); minimum observed, $34.91 \mathrm{ft}$.

(10-31-1978). Water level in the well is measured inside a 4" drop pipe of an irrigation pump. The altitude of the bottom of the drop pipe is 34.91 feet NGVD. The water level drops below the bottom of the drop pipe but cannot be measured.

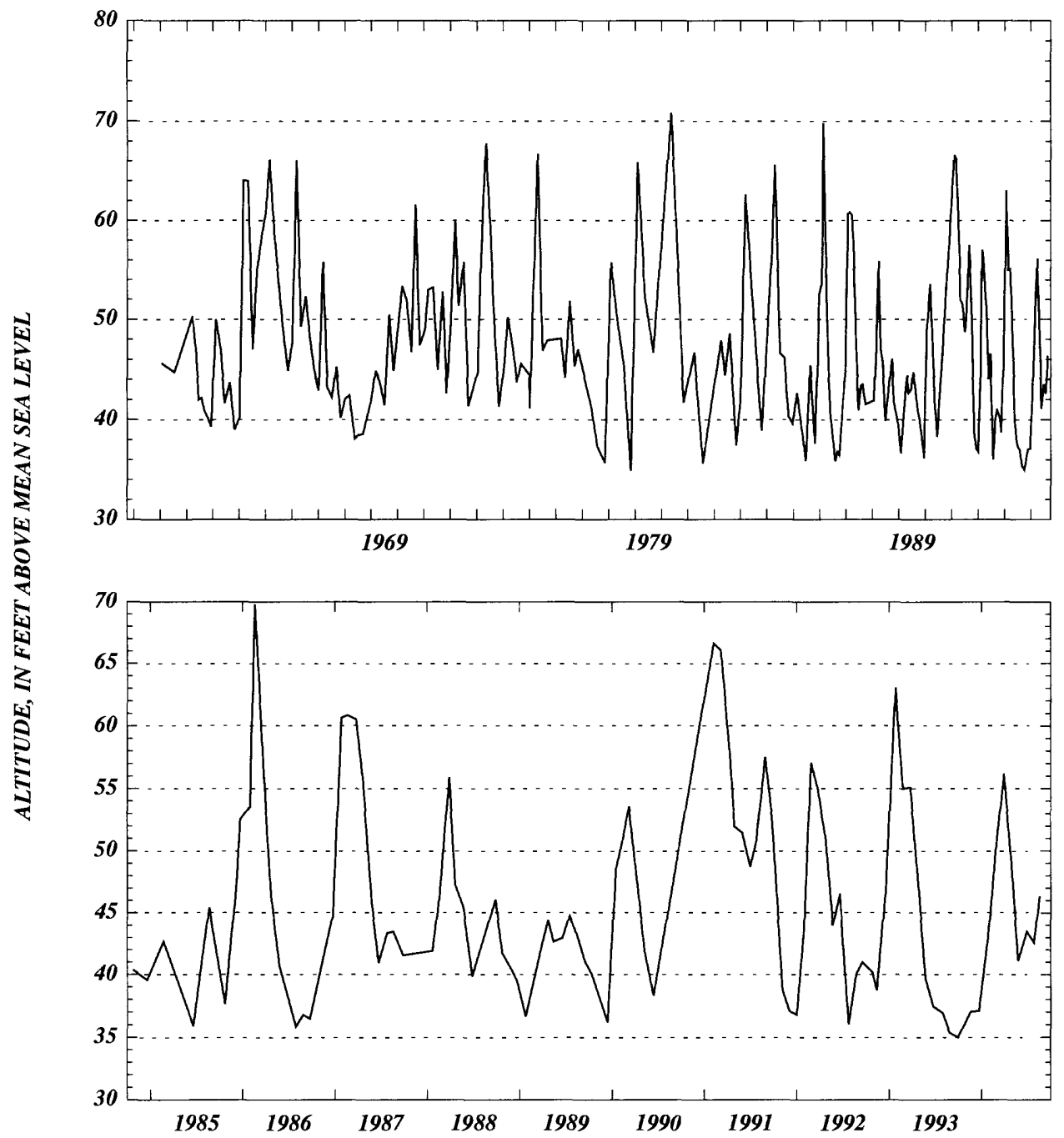



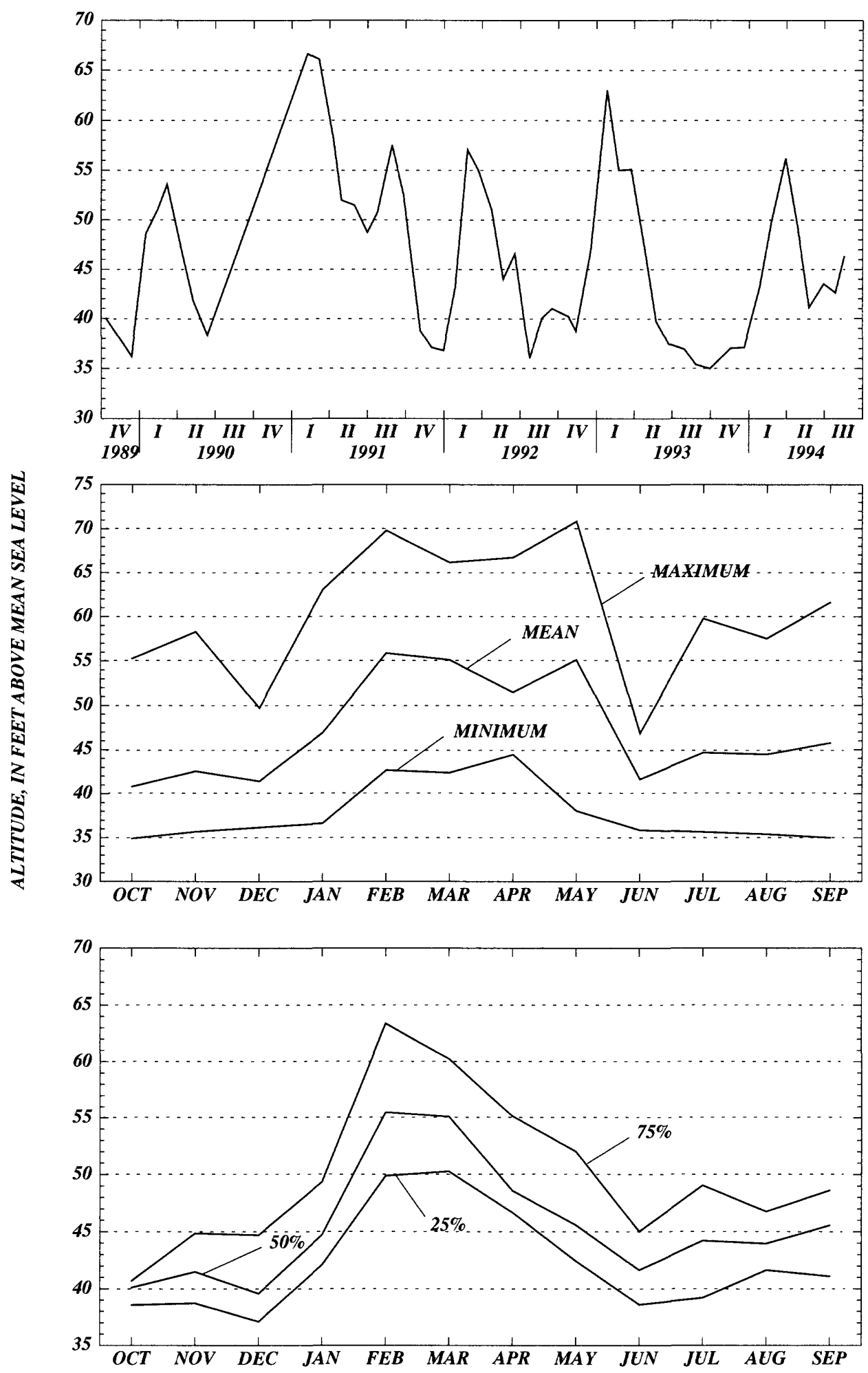


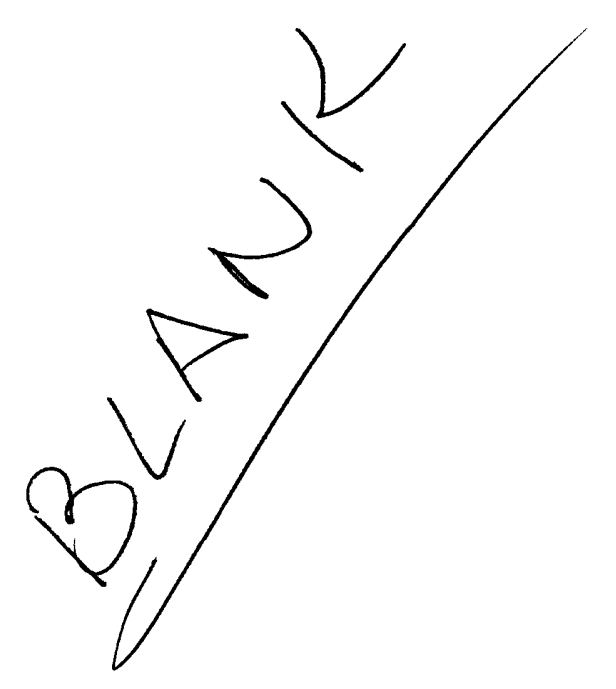

154 Statistical Summaries of Ground-Water Level Data Collected in the Suwannee River Water Management District, 1948-1994 


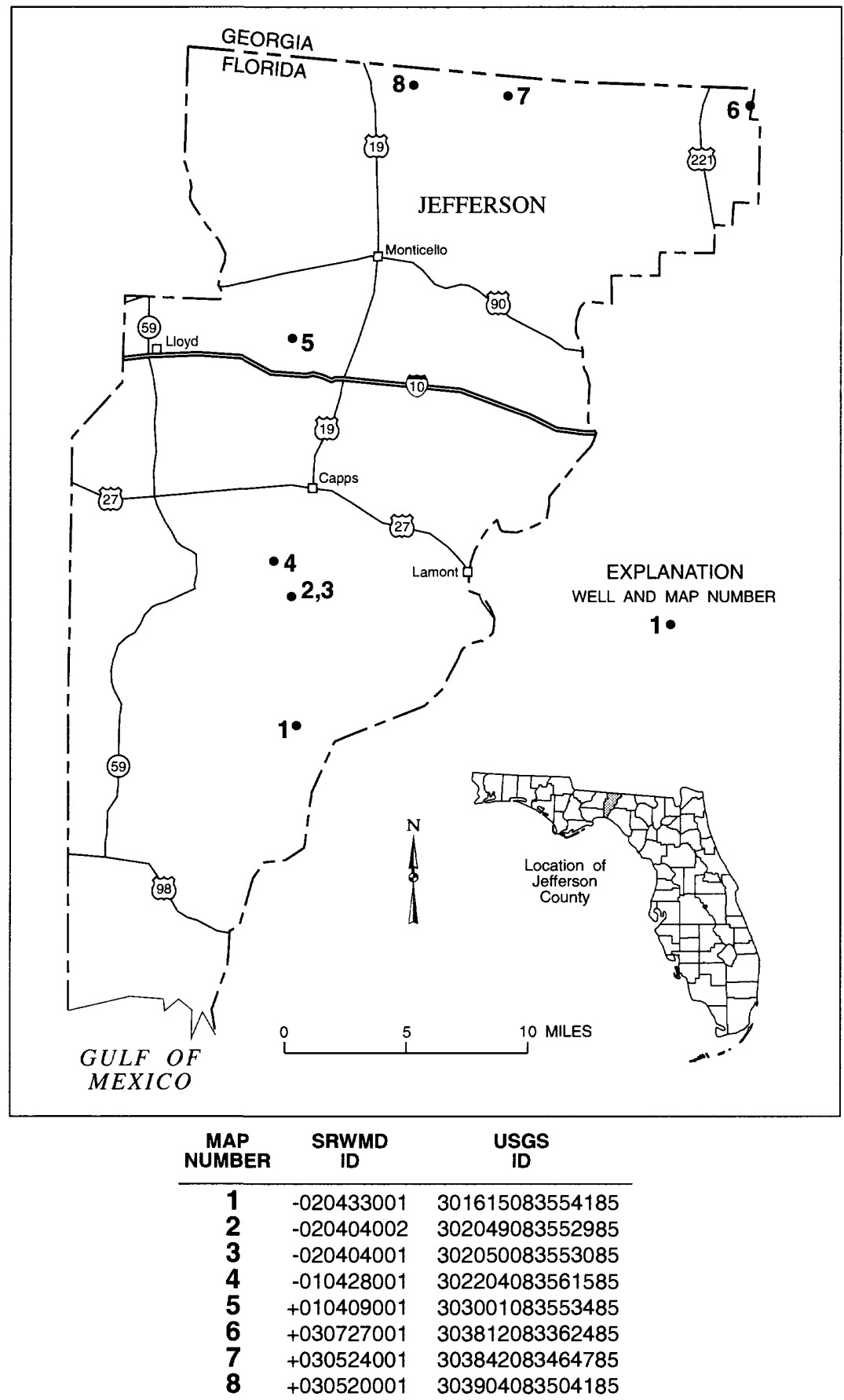

Figure 10. Location of wells in Jefferson County. 


\section{Jefferson County}

WELL NUMBER.--301615083554185. Procter and Gamble. -020433001.

LOCATION.--Lat 30¹6'15”, long 8355'41”, Hydrologic Unit Code 03110103.

AQUIFER.--Upper Floridan aquifer of the Tertiary system, Geologic Unit Code 120FLRD.

WELL CHARACTERISTICS.--Casing diameter 3 in., Casing depth $10 \mathrm{ft}$., Total depth $30 \mathrm{ft}$.

INSTRUMENTATION.--Elevation of Measuring Point $32.20 \mathrm{ft}$., NGVD.

DATUM.--The National Geodetic Vertical Datum of 1929.

PERIOD OF RECORD.--06-06-1989 to 09-30-1994.

EXTREME VALUES.--Maximum observed $29.27 \mathrm{ft}$ (07-26-1994); minimum observed, $23.62 \mathrm{ft}$. (11-07-1990).

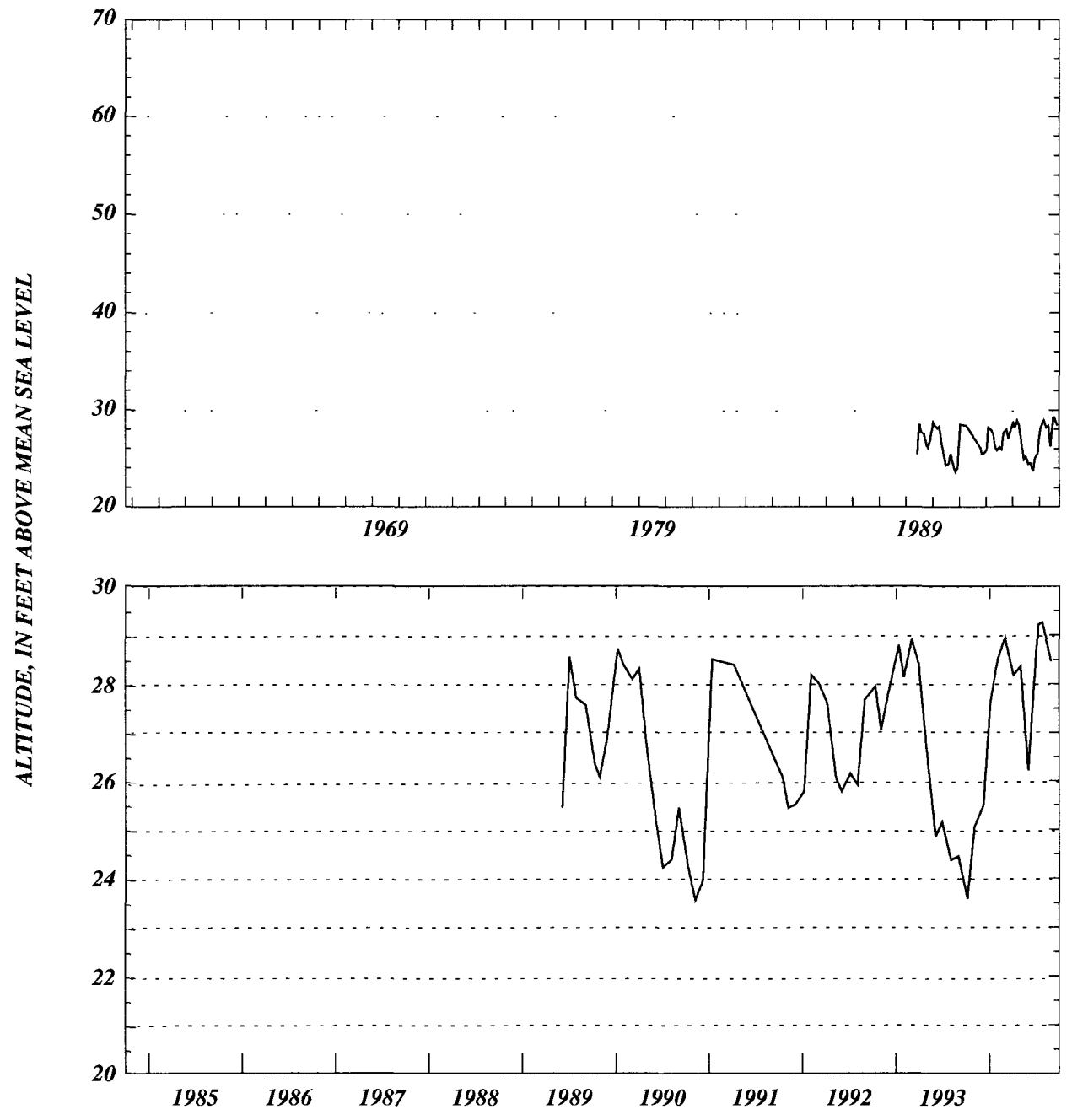



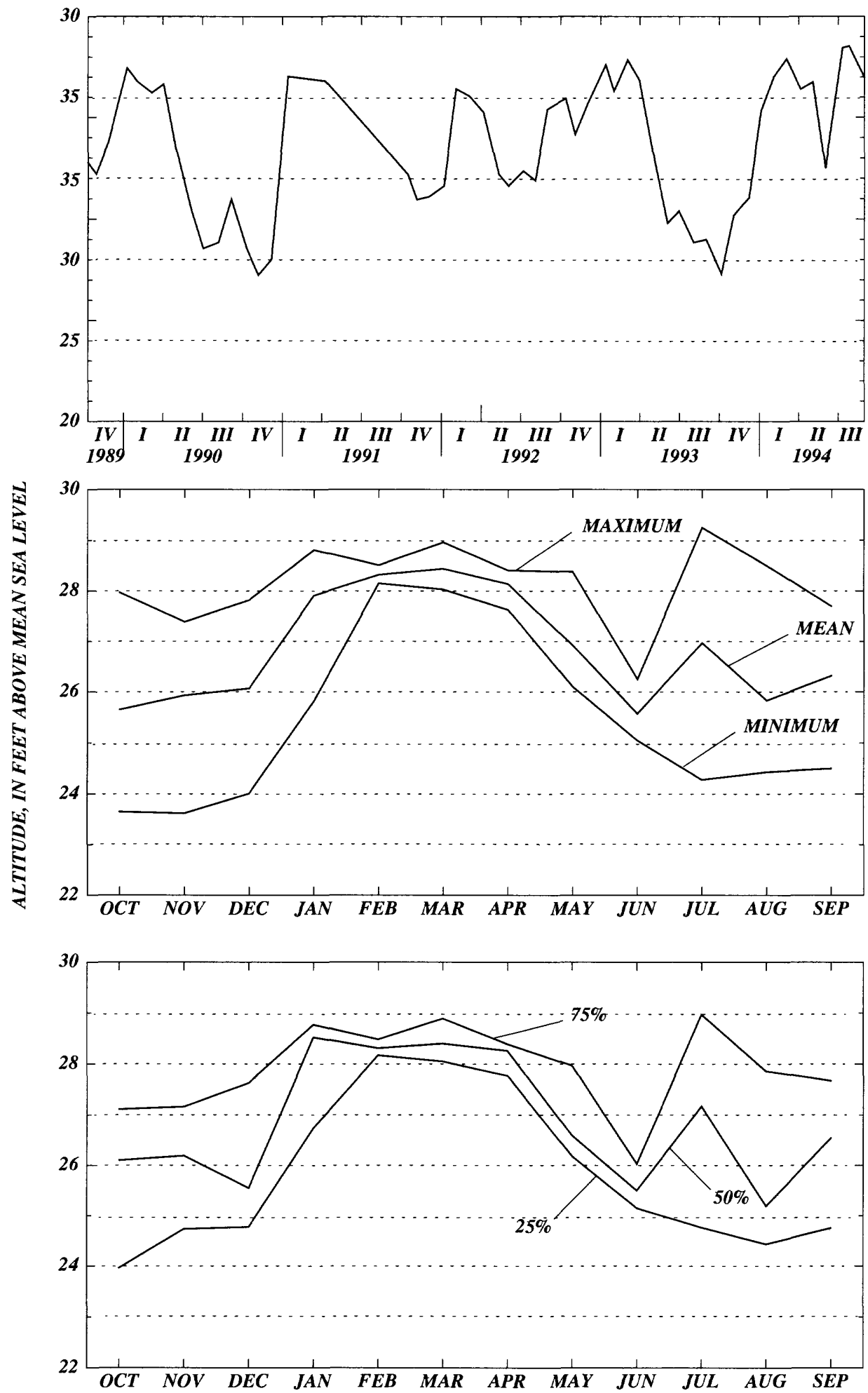


\section{Jefferson County}

WELL NUMBER.--302049083552985. St. Joe Paper Company. -020404002.

LOCATION.--Lat 30²0’49”, long 835'29”, Hydrologic Unit Code 03110103.

AQUIFER.--Upper Floridan aquifer of the Tertiary system, Geologic Unit Code 120FLRD.

WELL CHARACTERISTICS.--Casing diameter 3 in., Casing depth $17 \mathrm{ft}$., Total Depth $37 \mathrm{ft}$.

INSTRUMENTATION.--Elevation of Measuring Point $44.89 \mathrm{ft} .$, NGVD.

DATUM.--The National Geodetic Vertical Datum of 1929.

PERIOD OF RECORD.--07-24-1987 to 09-30-1994. *

EXTREME VALUES.--Maximum observed, 38.57 ft. (03-06-1991); minimum observed, $31.79 \mathrm{ft}$. (12-11-1990).

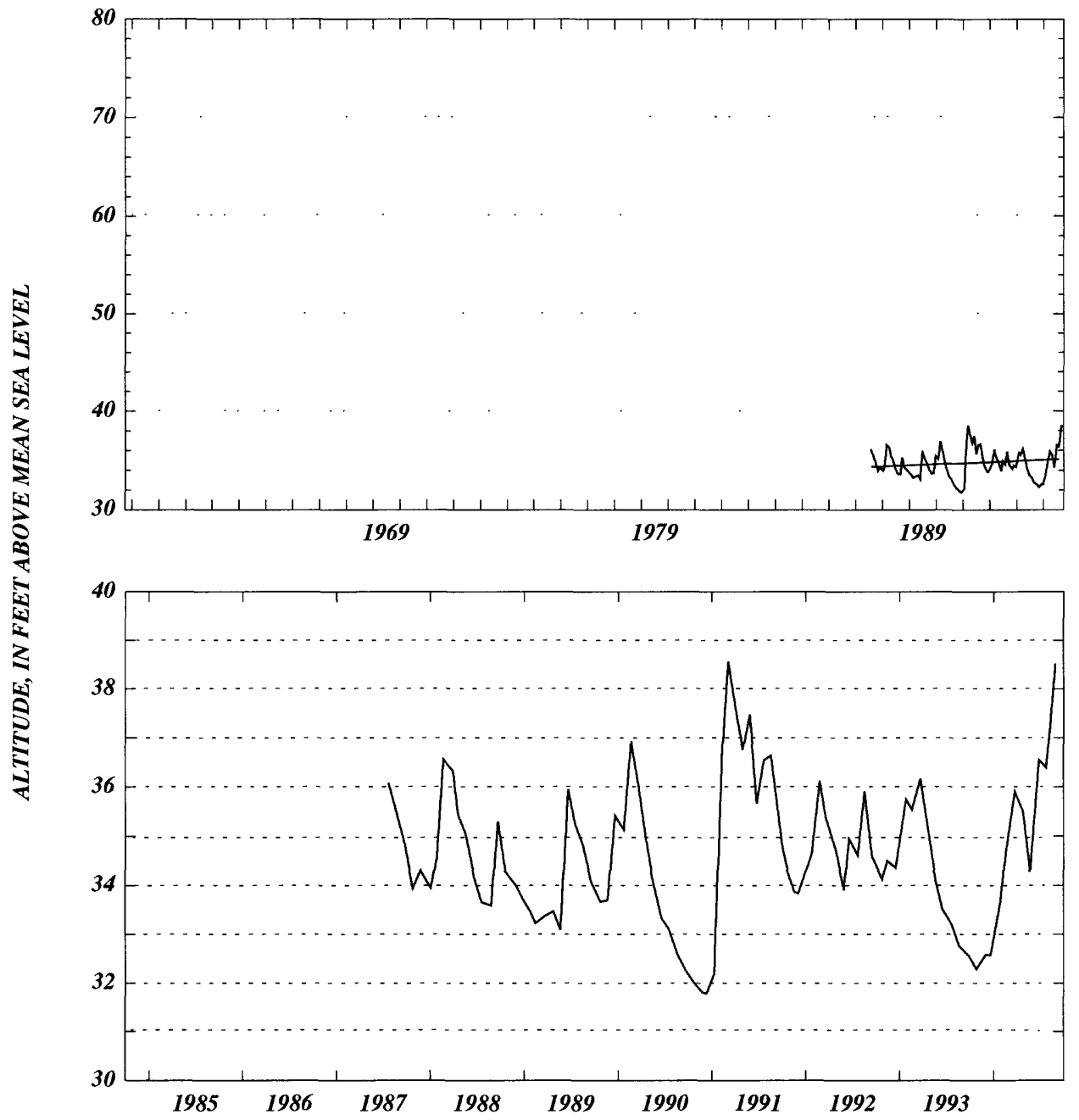



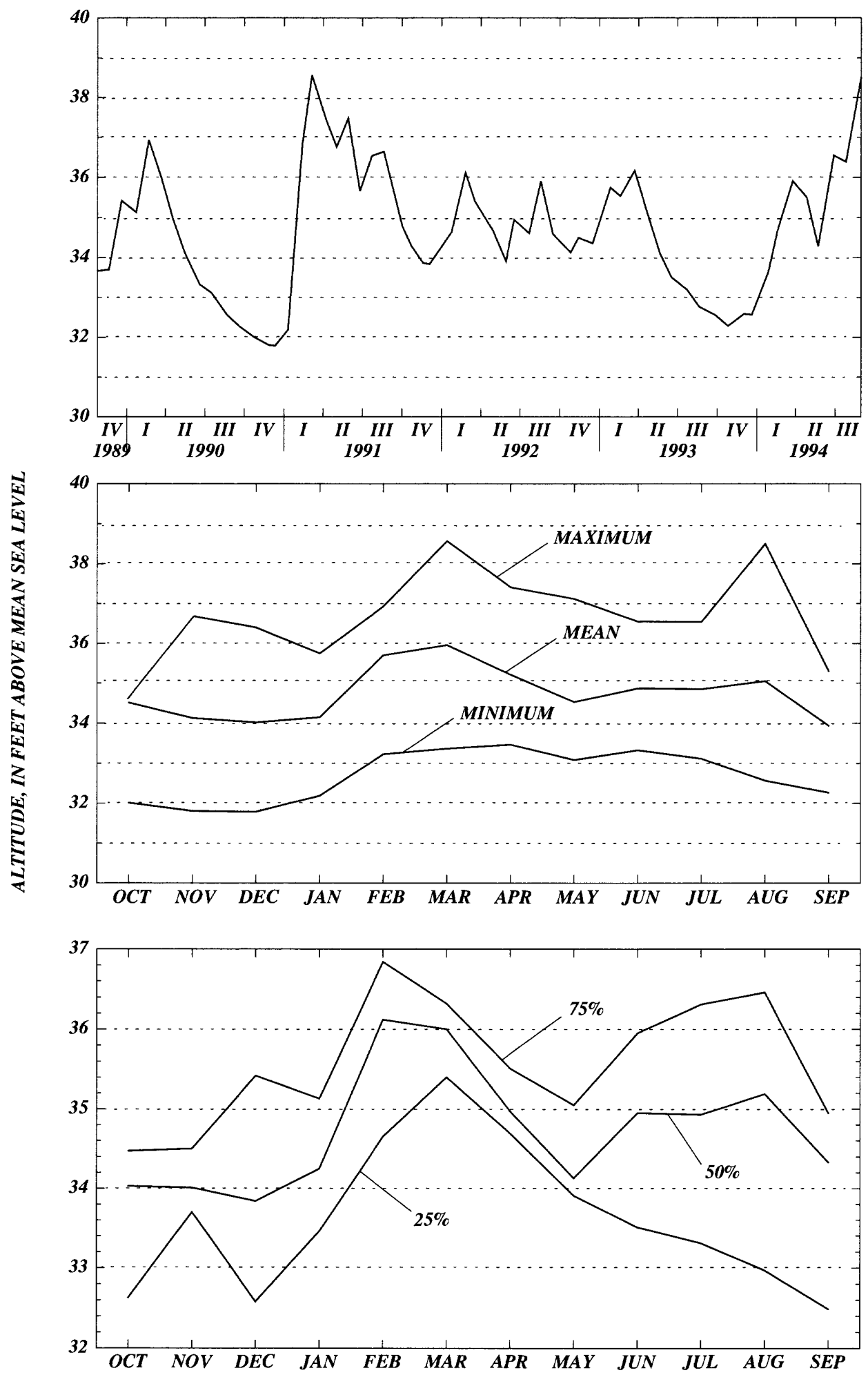


\section{Jefferson County}

WELL NUMBER.--302050083553085. St. Joe Paper Company. -020404001.

LOCATION.--Lat 30²0'50”, long 8355’30”, Hydrologic Unit Code 03110103.

AQUIFER.--Surficial aquifer, Geologic Unit Code 110NRSD.

WELL CHARACTERISTICS.--Casing diameter 3 in., Casing depth $1 \mathrm{ft}$., Total Depth $11 \mathrm{ft}$.

INSTRUMENTATION.--Elevation of Measuring Point $45.20 \mathrm{ft}$., NGVD.

DATUM.--The National Geodetic Vertical Datum of 1929.

PERIOD OF RECORD.--05-18-1987 to 09-30-1994. *

EXTREME VALUES.--Maximum observed, $45.00 \mathrm{ft}$ (08-30-1994); minimum observed, $32.70 \mathrm{ft}$. (12-11-1990).

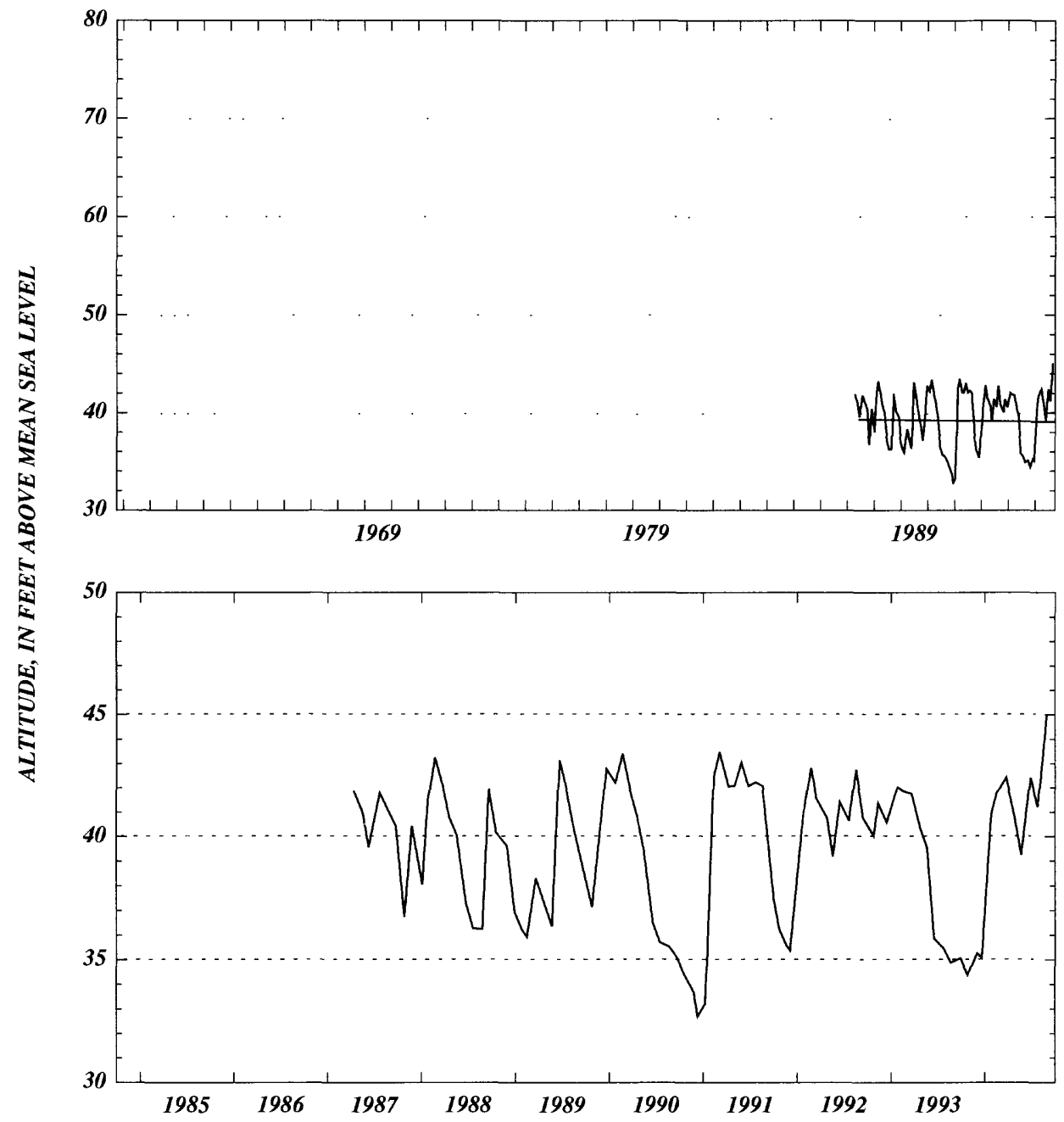



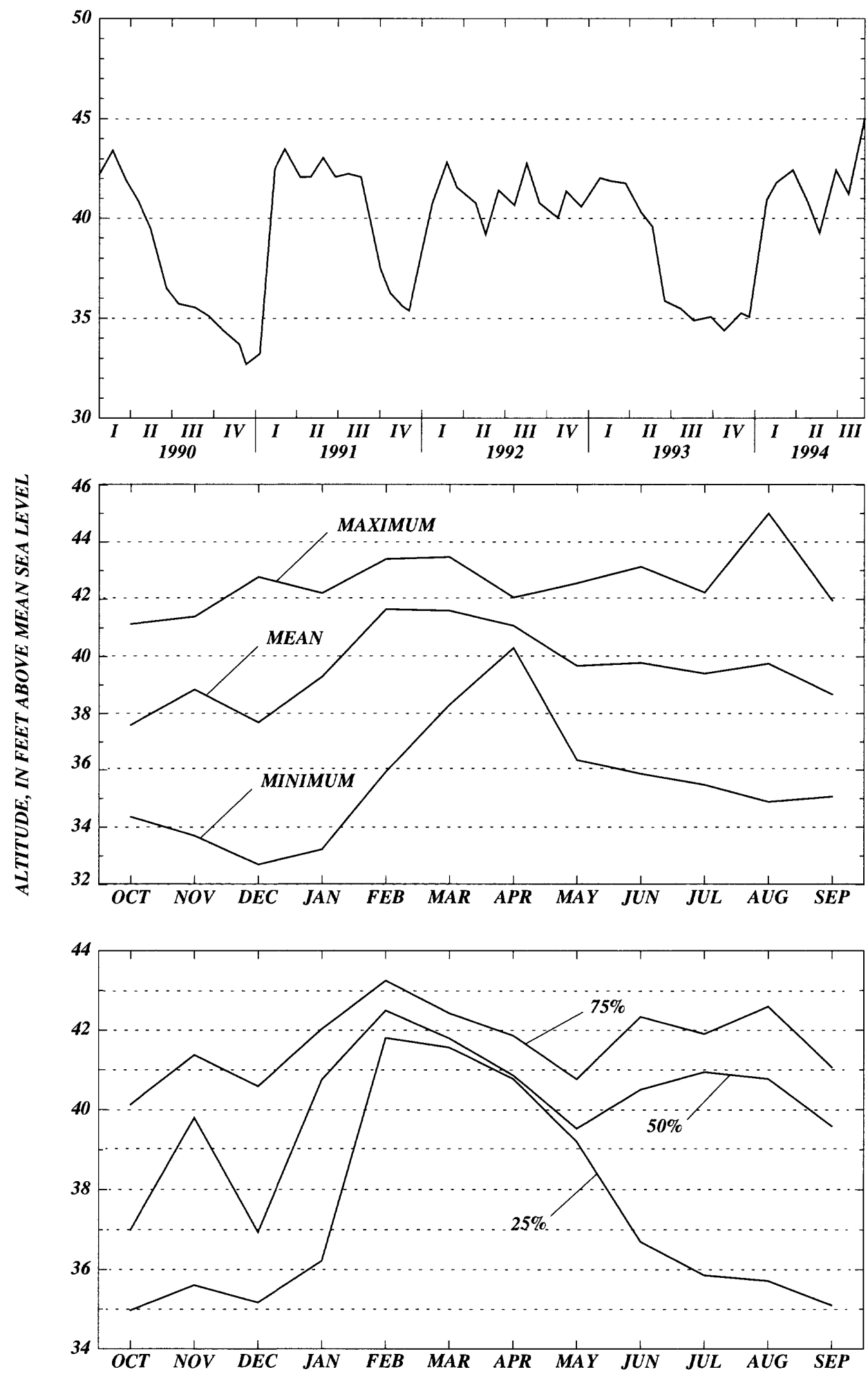


\section{Jefferson County}

WELL NUMBER.--302204083561585. Tungston Plantation. -010428001.

LOCATION.--Lat 30²2'04”, long 8356'15”, Hydrologic Unit Code 03110103.

AQUIFER.--Upper Floridan aquifer of the Tertiary system, Geologic Unit Code 120FLRD.

WELL CHARACTERISTICS.--Casing diameter 8 in., Casing depth $169 \mathrm{ft}$., Total depth $216 \mathrm{ft}$.

INSTRUMENTATION.--Elevation of Measuring Point 180.97 ft., NGVD.

DATUM.--The National Geodetic Vertical Datum of 1929.

PERIOD OF RECORD.--04-30-1960 to 09-30-1994.

EXTREME VALUES.--Maximum observed, $42.71 \mathrm{ft}$. (02-21-1986); minimum observed, $33.04 \mathrm{ft}$. (10-25-1983).

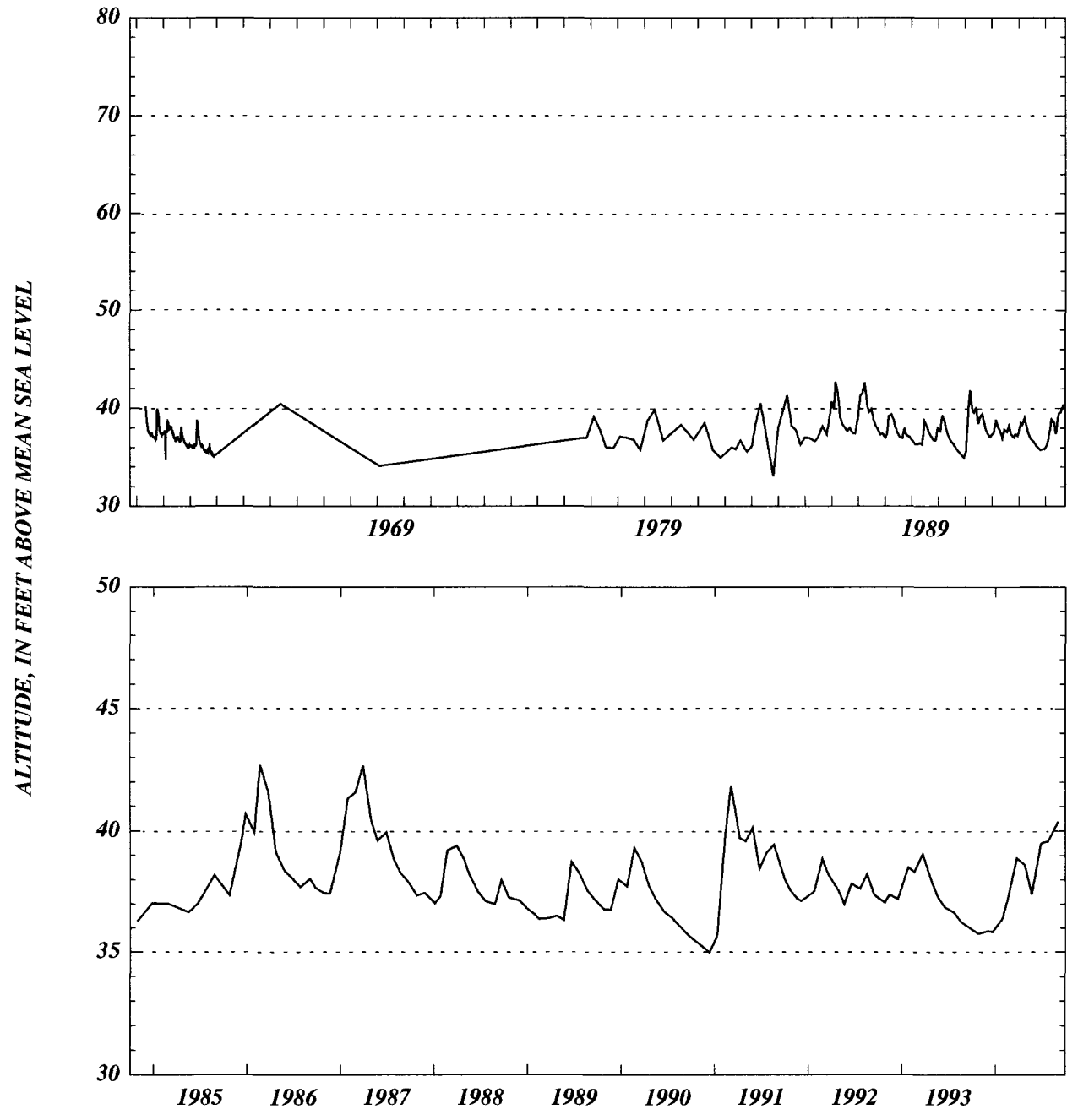



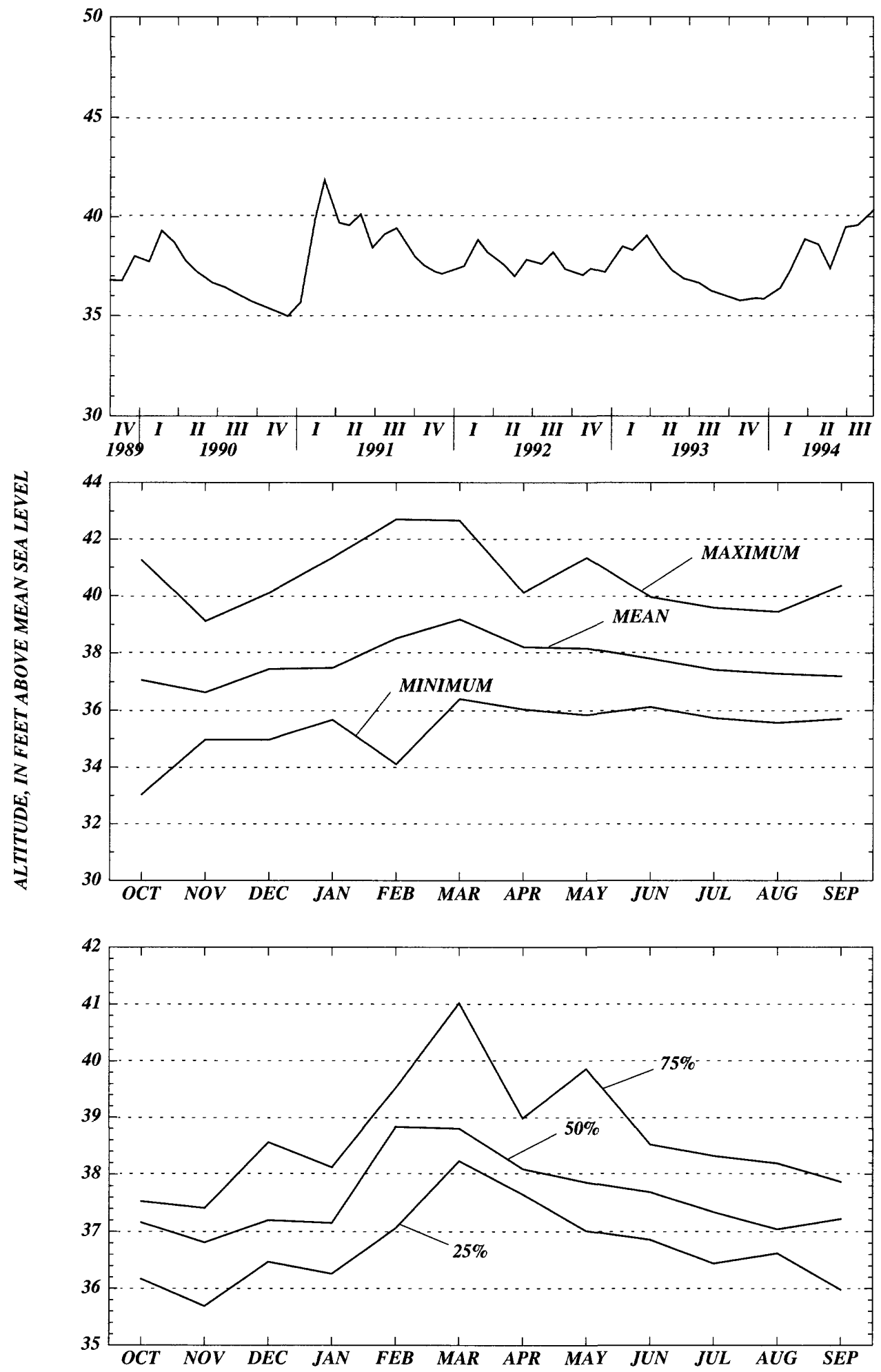


\section{Jefferson County}

WELL NUMBER.--303001083553485. Joseph Bellamy. +010409001.

LOCATION.--Lat 30³0'01”, long 83 55'34”, Hydrologic Unit Code 03120001.

AQUIFER.--Upper Floridan aquifer of the Tertiary system, Geologic Unit Code 120FLRD.

WELL CHARACTERISTICS.--Casing diameter 4 in., Casing depth $140 \mathrm{ft}$., Total depth $185 \mathrm{ft}$.

INSTRUMENTATION.--Elevation of Measuring Point $176.00 \mathrm{ft}$., NGVD.

DATUM.--The National Geodetic Vertical Datum of 1929.

PERIOD OF RECORD.--11-02-1976 to 05-15-1990.

EXTREME VALUES.--Maximum observed, 45.87 ft. (05-03-1984); minimum observed, $30.40 \mathrm{ft}$. (07-25-1977).

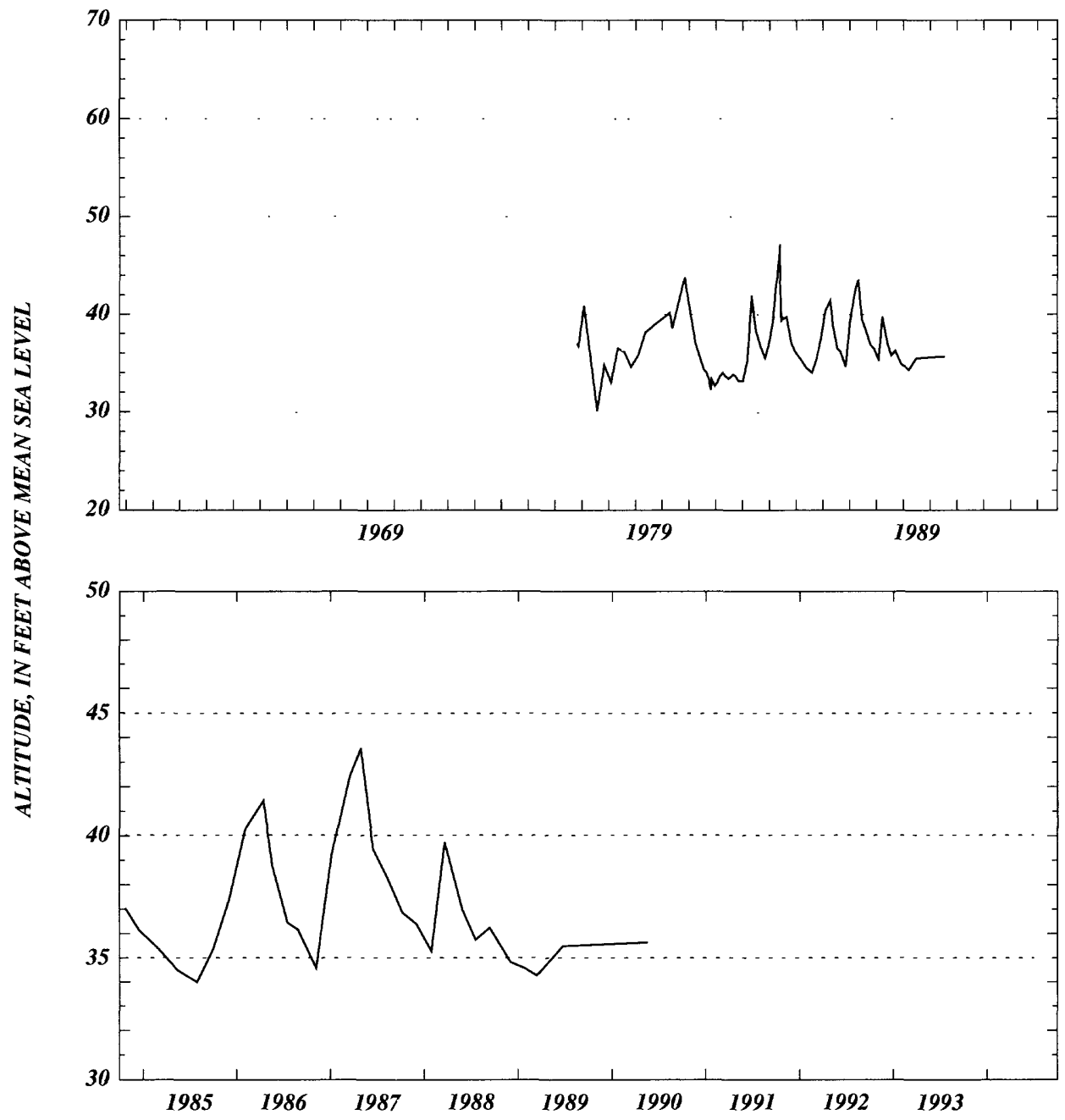



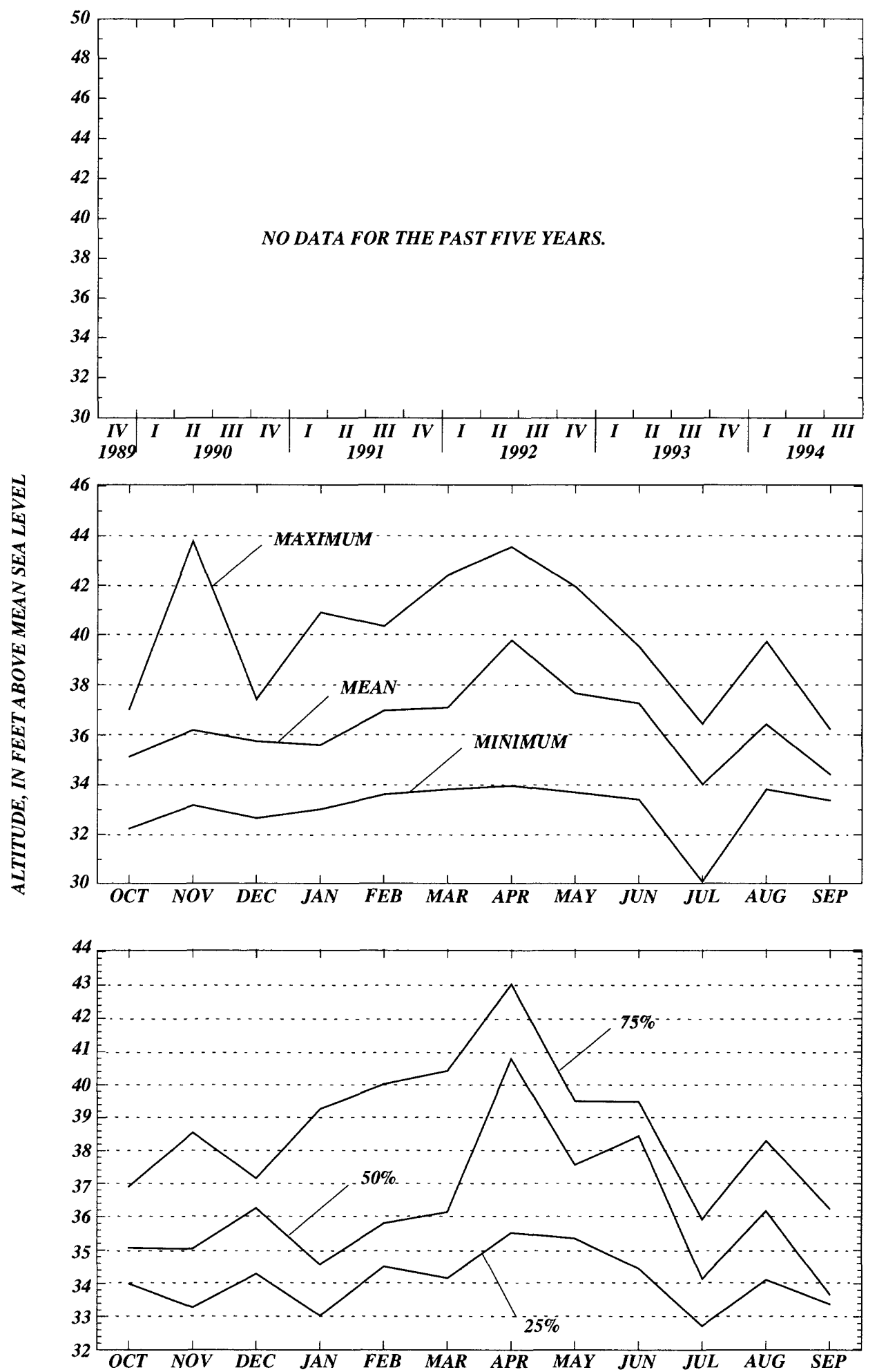


\section{Jefferson County}

WELL NUMBER.--303812083362485. Blackwater Plantation. +030727001.

LOCATION.--Lat 30³8'12”, long 83³6'24”, Hydrologic Unit Code 03110103.

AQUIFER.--Upper Floridan aquifer of the Tertiary system, Geologic Unit Code 120FLRD.

WELL CHARACTERISTICS.--Casing diameter 4 in., Casing depth $144 \mathrm{ft}$., Total depth $161 \mathrm{ft}$.

INSTRUMENTATION.--Recorder from 04-29-1960 to 11-30-1962; miscellaneous from 12-20-1962 to

05-10-1973; no record from 05-10-1973 to 07-24-1984; recorder from 07-25-1984 to 09-30-1994. Elevation of Measuring Point, $99.32 \mathrm{ft}$., NGVD.

DATUM.--The National Geodetic Vertical Datum of 1929.

PERIOD OF RECORD.--04-29-1960 to 09-30-1994. *

EXTREME VALUES.--Maximum observed 84.99 ft. (05-20-1965); minimum observed, $66.47 \mathrm{ft}$. (01-03-1969).

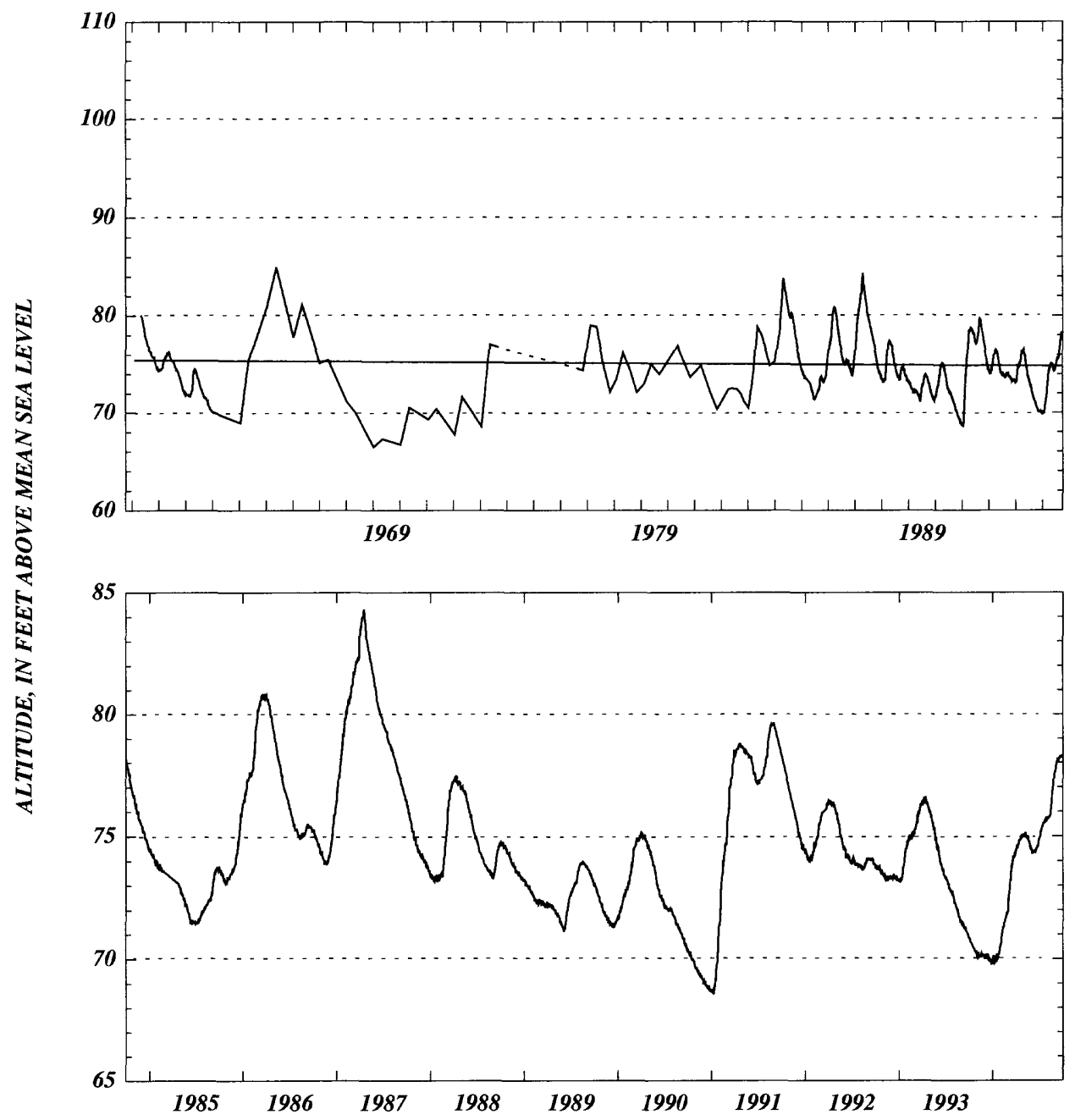



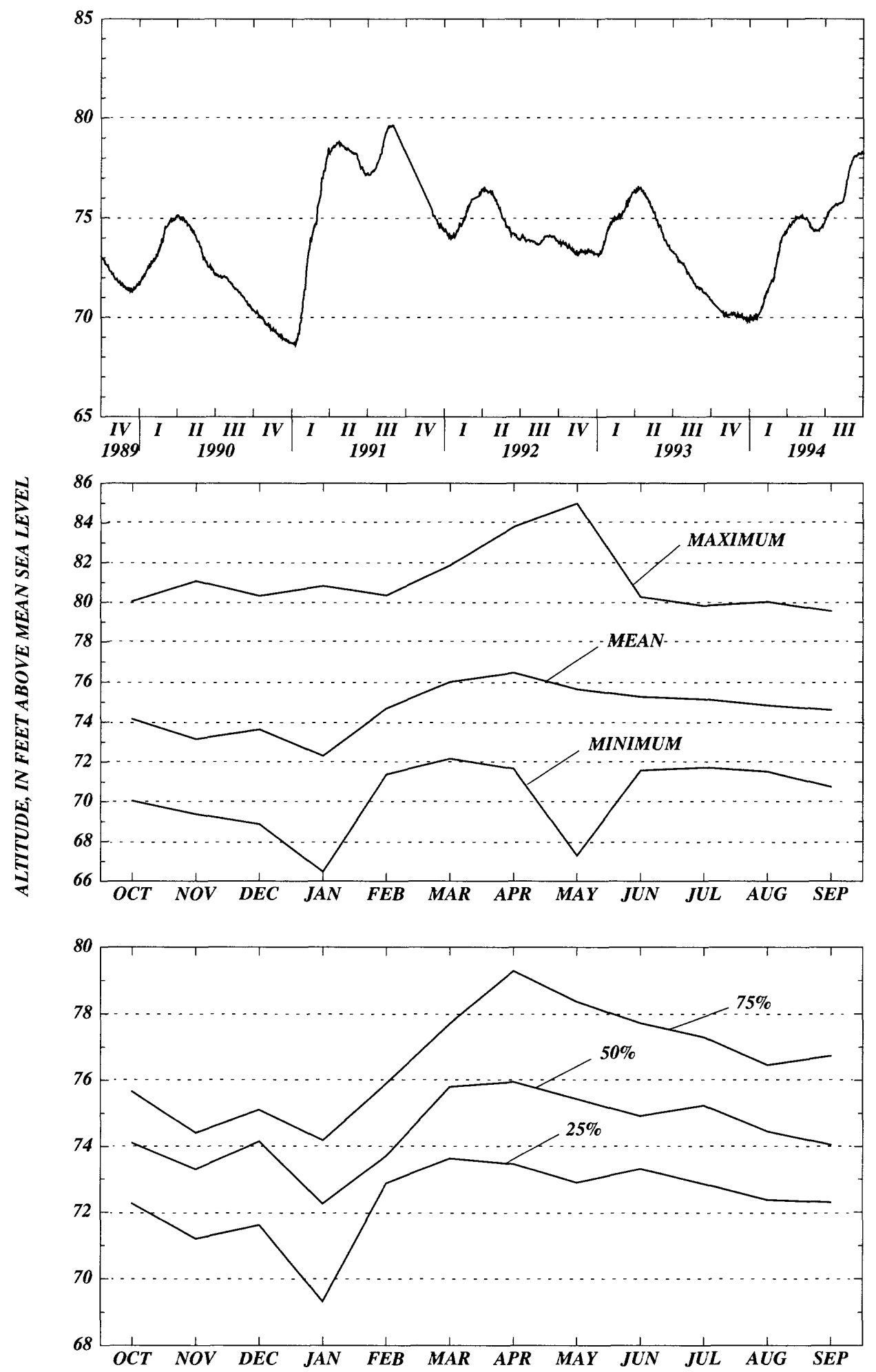


\section{Jefferson County}

WELL NUMBER.--303842083464785. Pinckney Hill Plantation. +030524001.

LOCATION.--Lat 30³8'42”, long 8346’47”, Hydrologic Unit Code 03110103.

AQUIFER.--Upper Floridan aquifer of the Tertiary system, Geologic Unit Code 120FLRD.

WELL CHARACTERISTICS.--Casing diameter 3 in., Casing depth $82 \mathrm{ft}$., Total depth $122 \mathrm{ft}$.

INSTRUMENTATION.--Elevation of Measuring Point $108.08 \mathrm{ft}$., NGVD.

DATUM.--The National Geodetic Vertical Datum of 1929.

PERIOD OF RECORD.--02-22-1988 to 09-30-1994.

EXTREME VALUES.--Maximum observed, 69.98 ft. (09-27-1994); minimum observed, $60.75 \mathrm{ft}$. (01-10-1991).

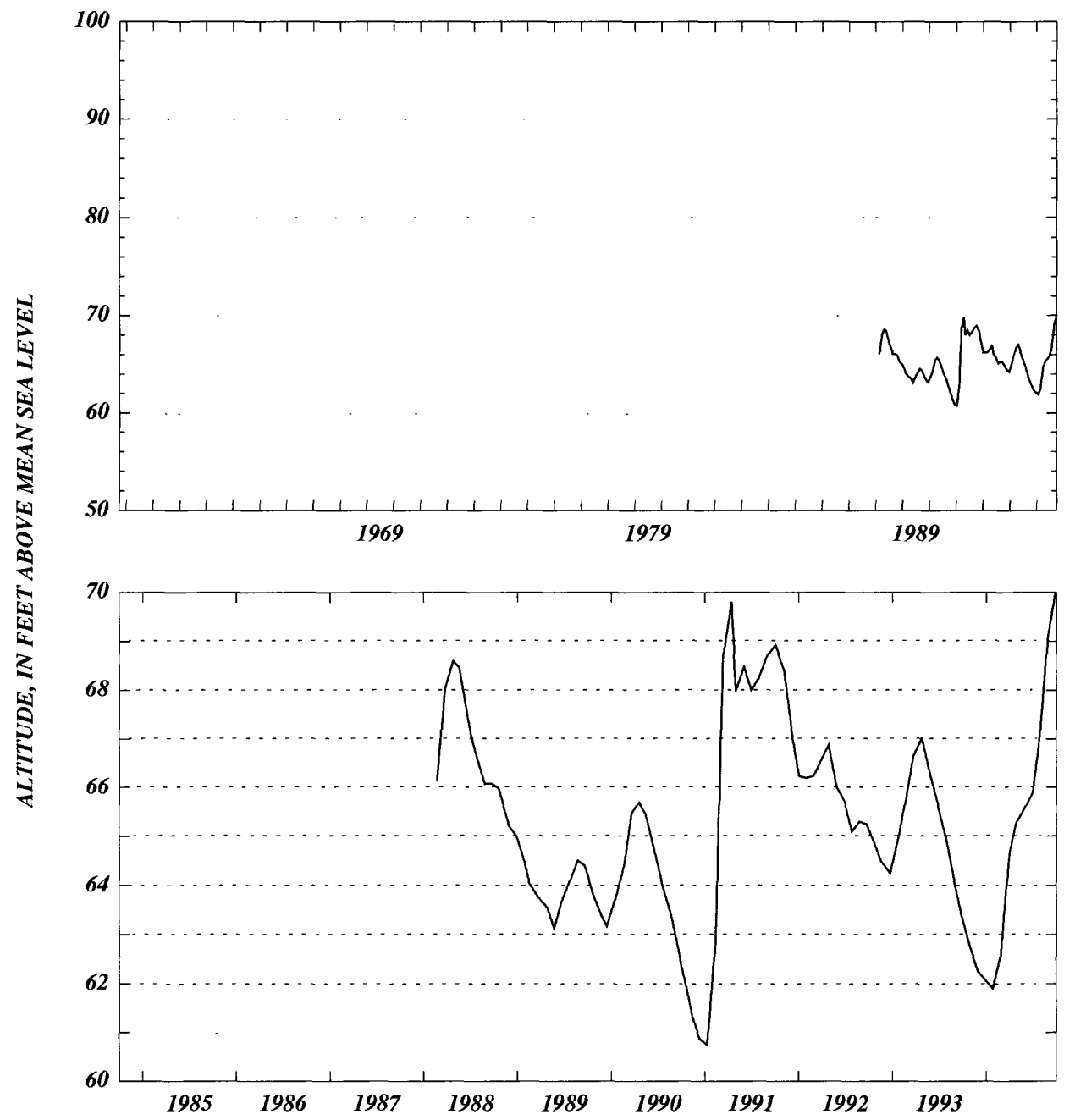



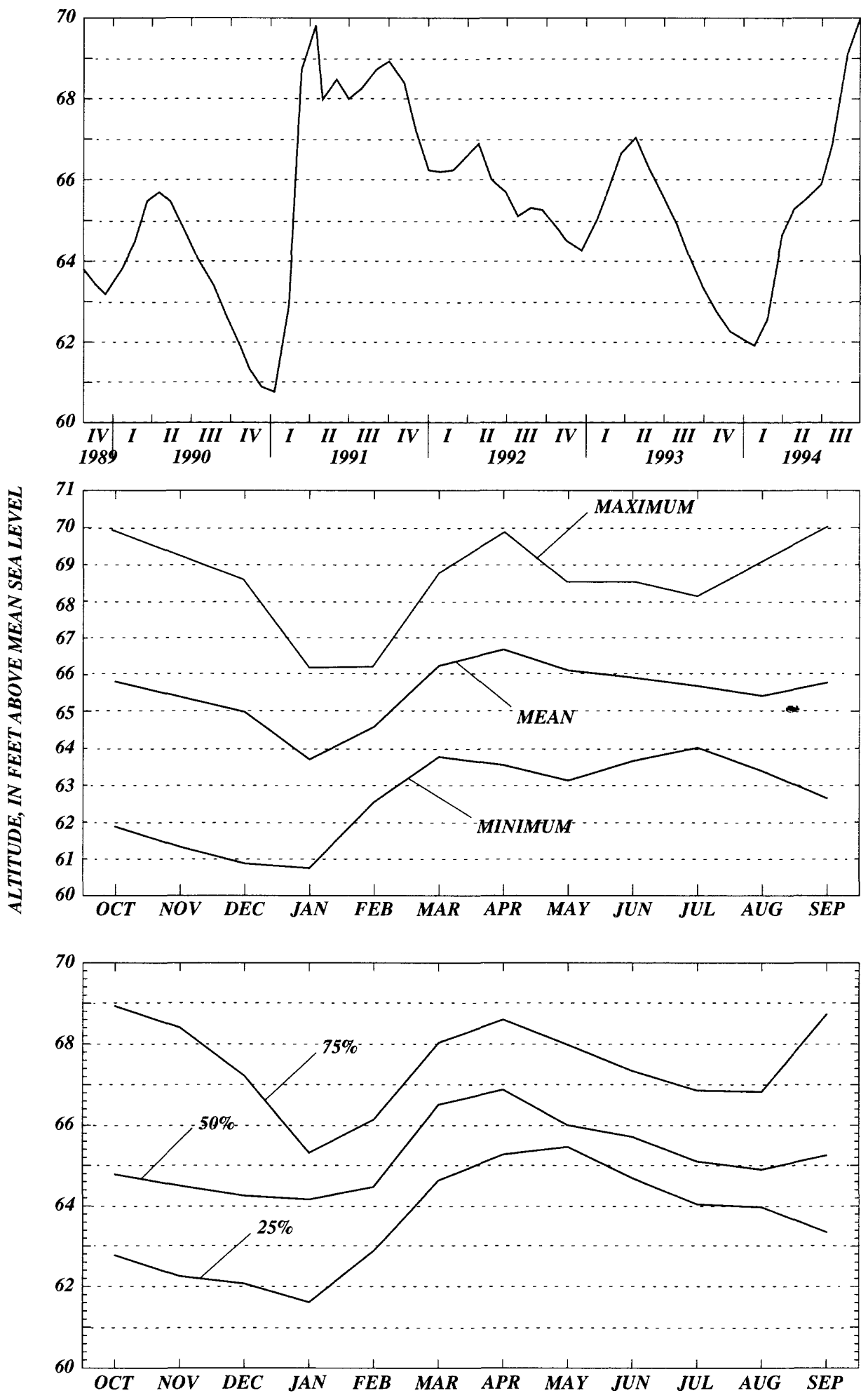


\section{Jefferson County}

WELL NUMBER.--303904083504185. Merrily Plantation. +030520001.

LOCATION.--Lat 30³9'04”, long 8350’41”, Hydrologic Unit Code 03120001.

AQUIFER.--Upper Floridan aquifer of the Tertiary system, Geologic Unit Code 120FLRD.

WELL CHARACTERISTICS.--Casing diameter 8 in., Casing depth unkonwn, Total depth unknown.

INSTRUMENTATION.--Recorder set to the elevation of Measuring Point $190.00 \mathrm{ft}$., NGVD.

DATUM.--The National Geodetic Vertical Datum of 1929.

PERIOD OF RECORD.--08-28-1981 to 04-23-1987.

EXTREME VALUES.--Maximum, 77.40 ft. (04-23-1987); minimum, 65.56 ft. (01-26-1983).

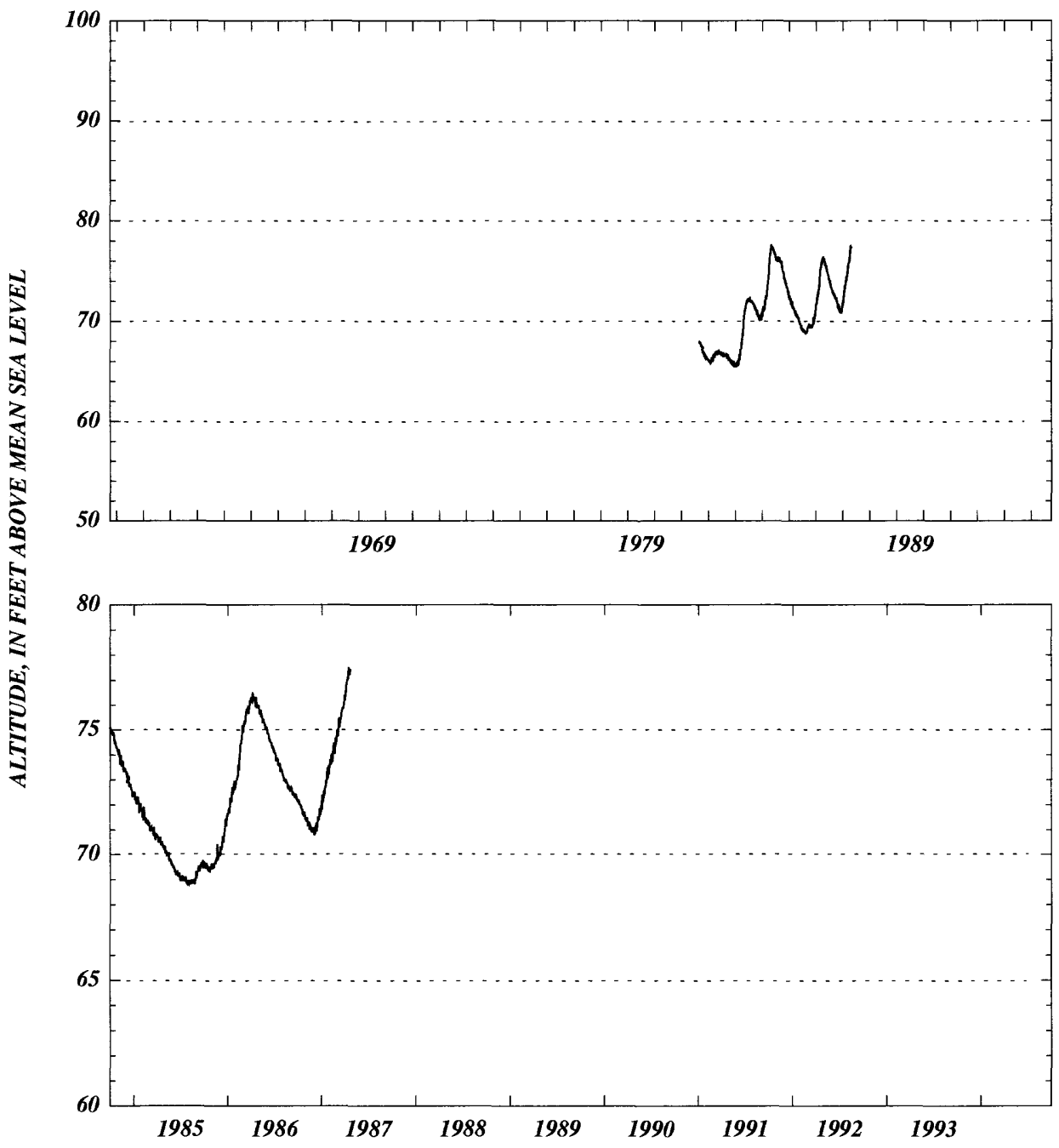



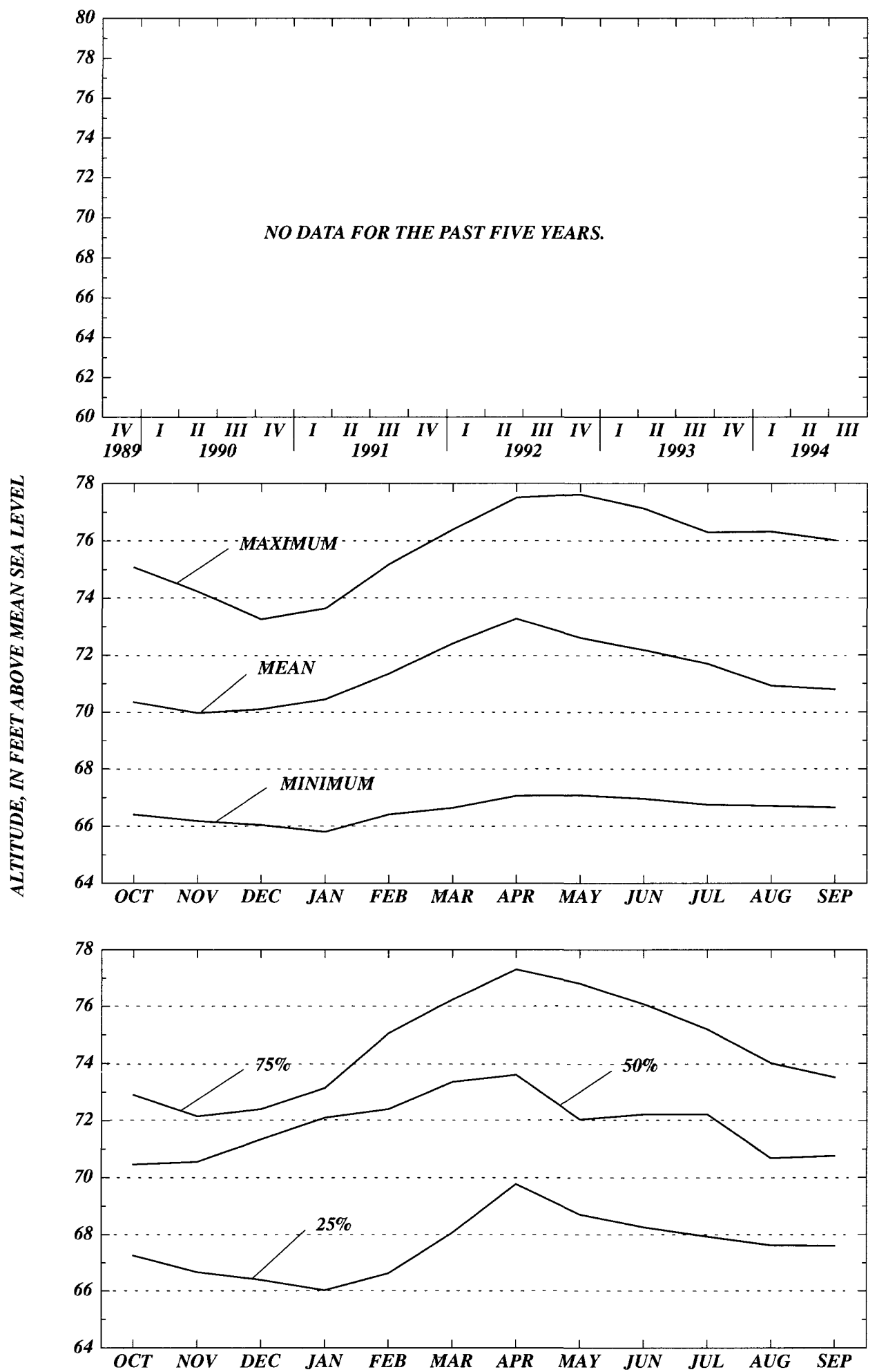


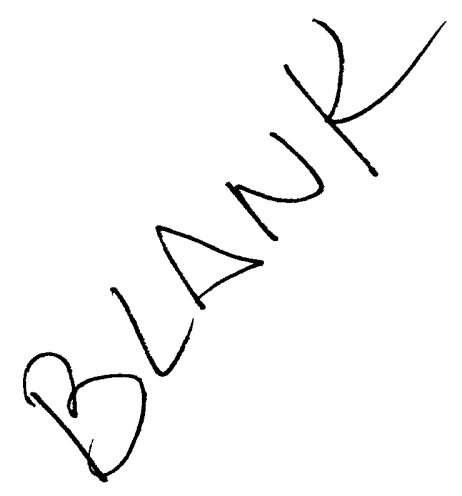




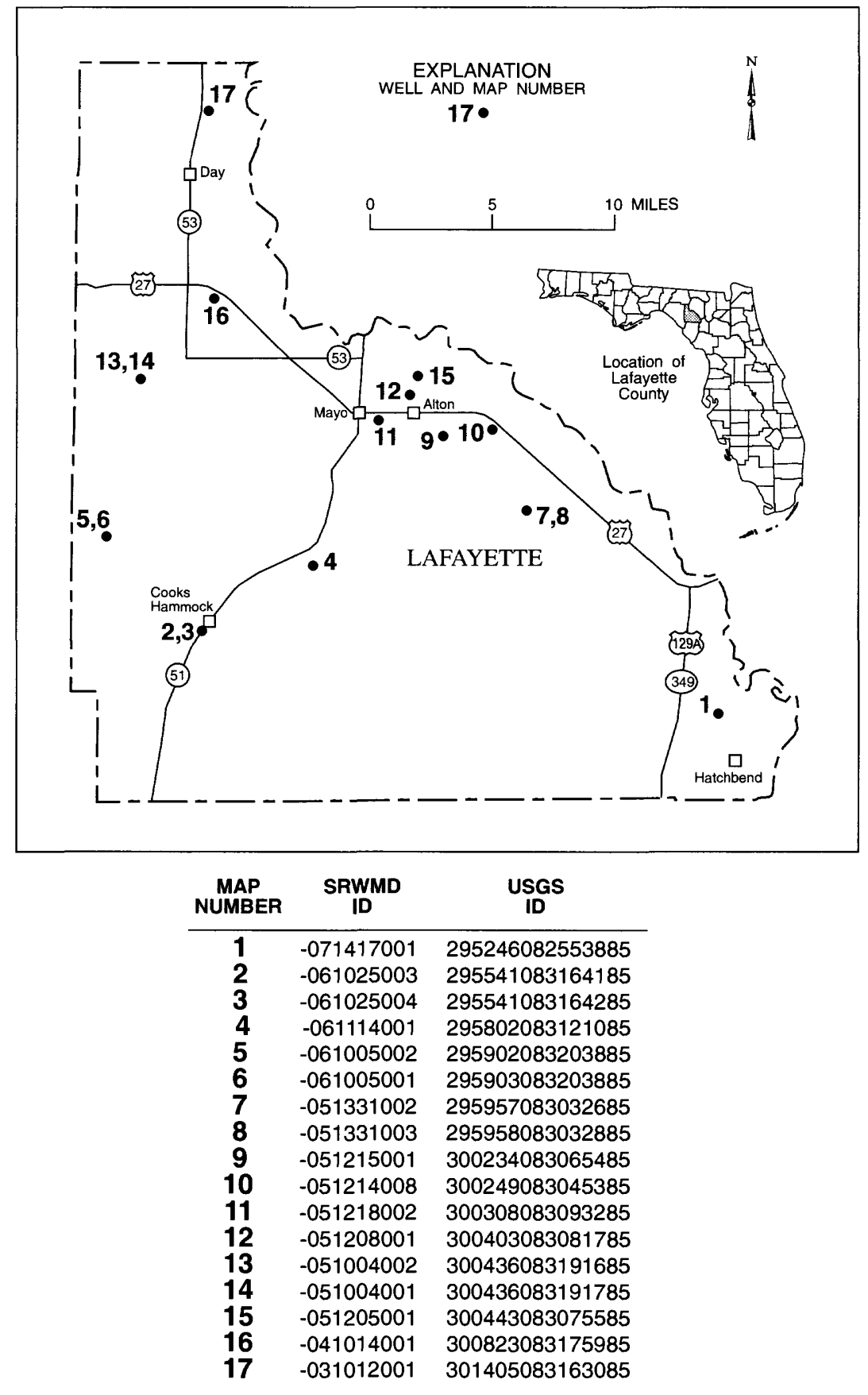

Figure 11. Location of wells in Lafayette County. 


\section{Lafayette County}

WELL NUMBER.--295246082553885. Raymond J. Land. -071417001.

LOCATION.--Lat 29 52'46”, long 8255'38', Hydrologic Unit Code 03110205.

AQUIFER.--Upper Floridan aquifer of the Tertiary system, Geologic Unit Code 120FLRD.

WELL CHARACTERISTICS.--Casing diameter 8 in., Casing depth unknown, Total Depth $100 \mathrm{ft}$.

INSTRUMENTATION.--Elevation of Measuring Point $27.24 \mathrm{ft}$. , NGVD.

DATUM.The National Geodetic Vertical Datum of 1929.

PERIOD OF RECORD.--11-01-1976 to 09-30-1994.

EXTREME VALUES.--Maximum observed, $26.23 \mathrm{ft}$. (05-03-1983); minimum observed, $14.27 \mathrm{ft}$. (01-11-1991).

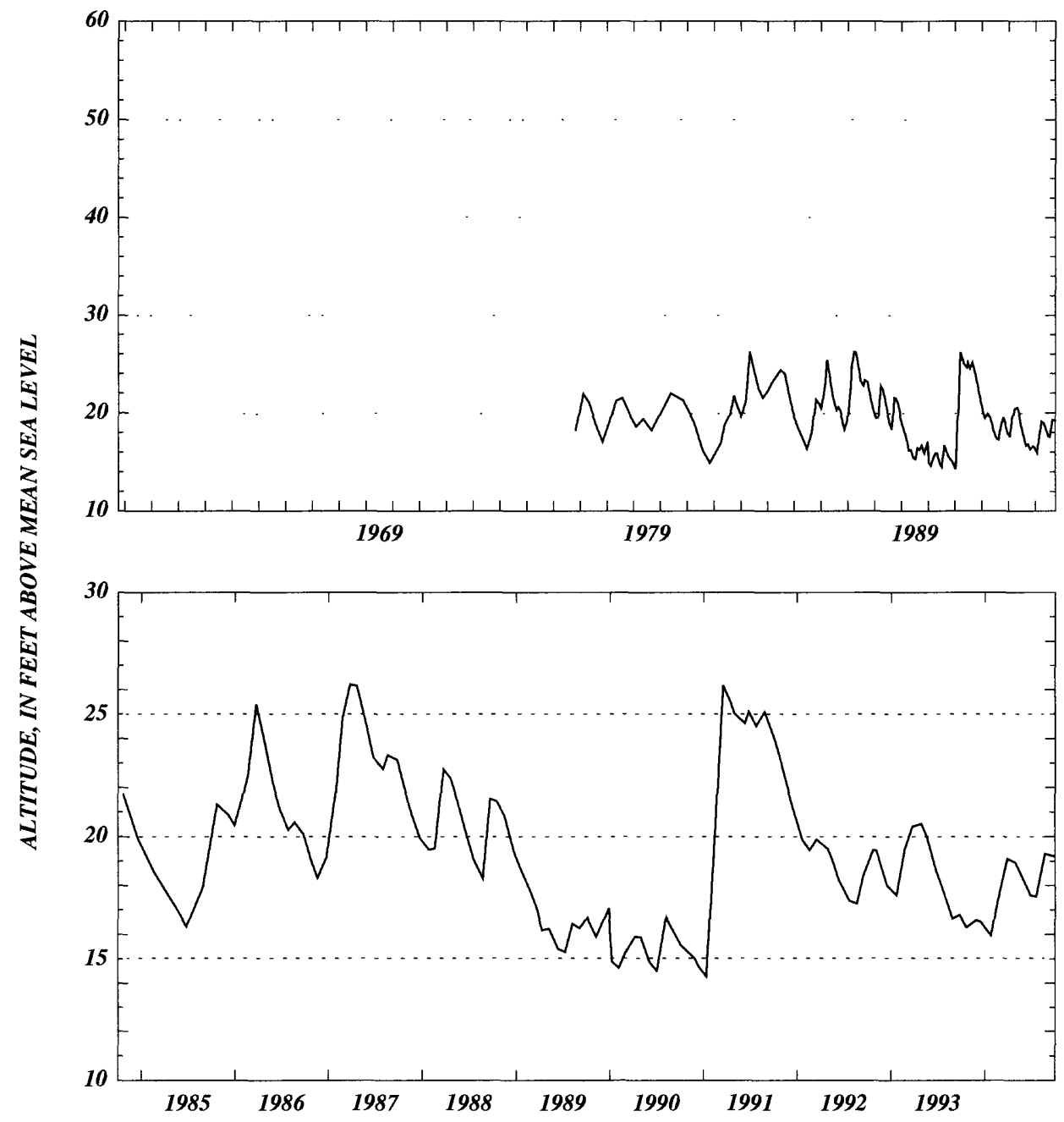



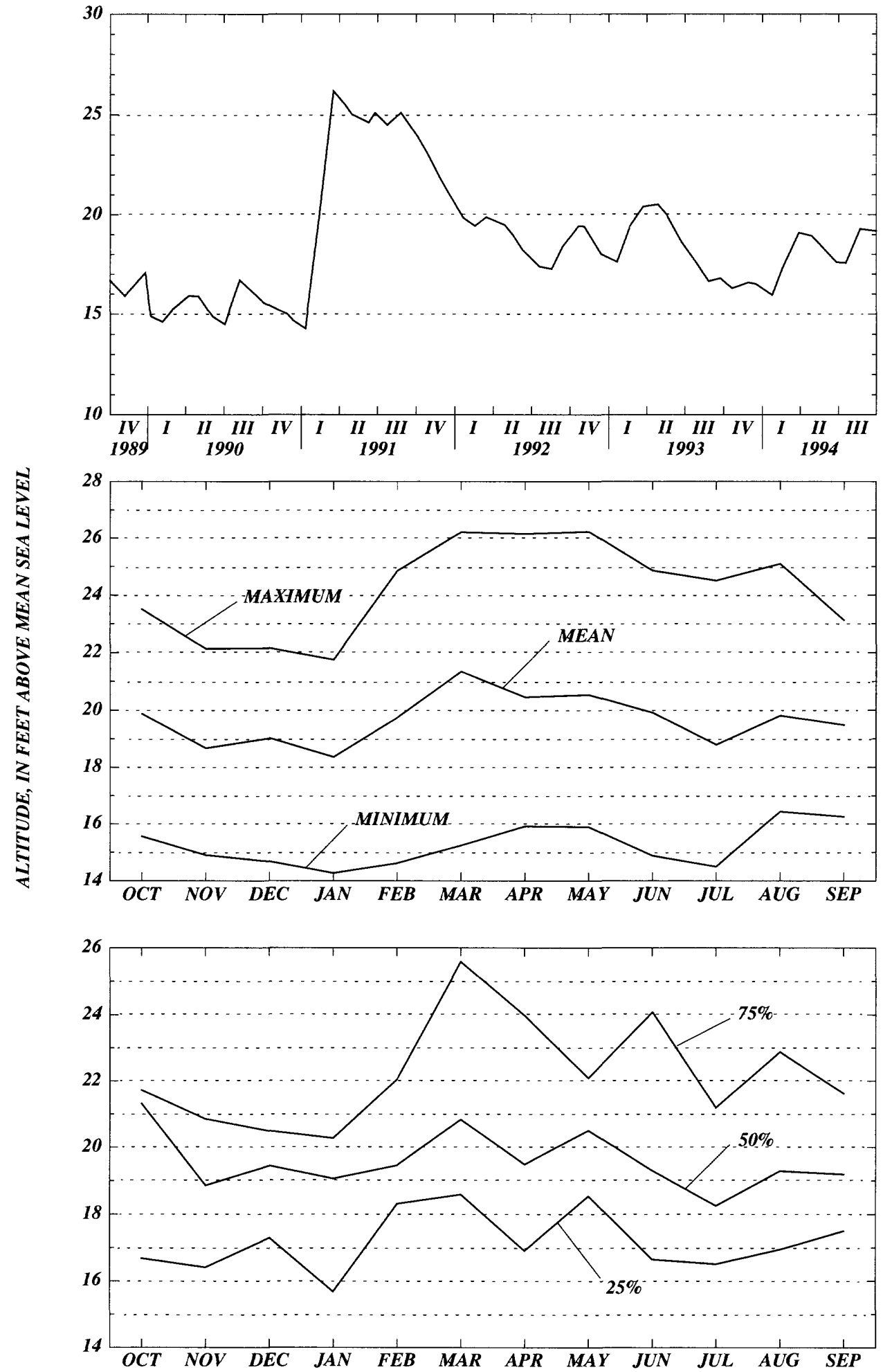
WELL NUMBER.--295541083164185. DOF - Cooks Hammock Tower. -061025003.

LOCATION.--Lat 2955'41”, long 83¹6’41’, Hydrologic Unit Code 03110102.

AQUIFER.--Upper Floridan aquifer of the Tertiary system, Geologic Unit code 120FLRD.

WELL CHARACTERISTICS.--Casing diameter 3 in., Casing depth $41 \mathrm{ft}$., Total depth $61 \mathrm{ft}$.

INSTRUMENTATION.--Elevation of Measuring Point 56.03, ft., NGVD.

DATUM.--The National Geodetic Vertical Datum of 1929.

PERIOD OF RECORD.--07-21-1987 to 09-30-1994.

EXTREME VALUES.--Maximum observed, 52.02 ft. (08-19-1991); minimum observed, $45.59 \mathrm{ft}$. (08-24-1993).

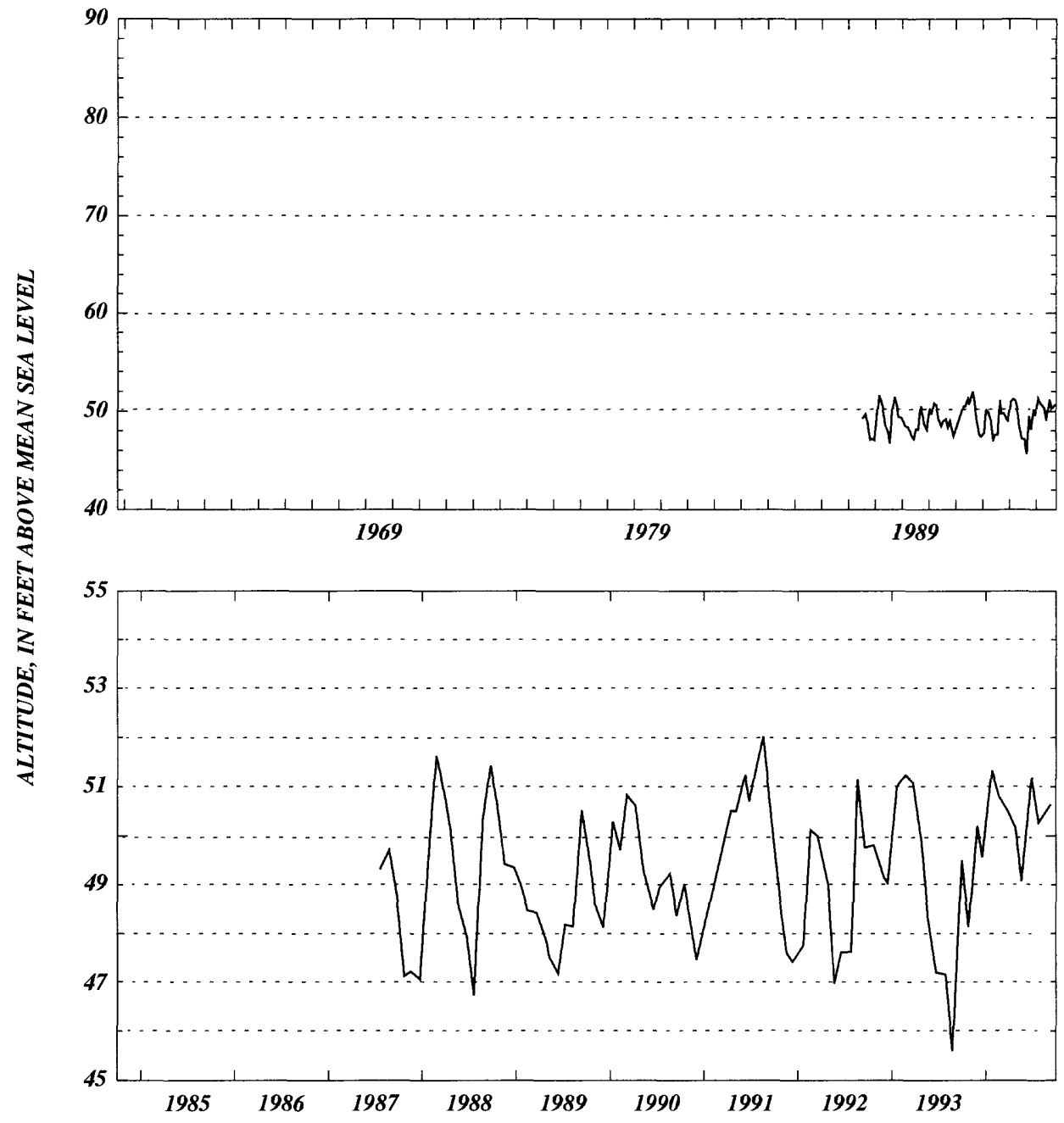



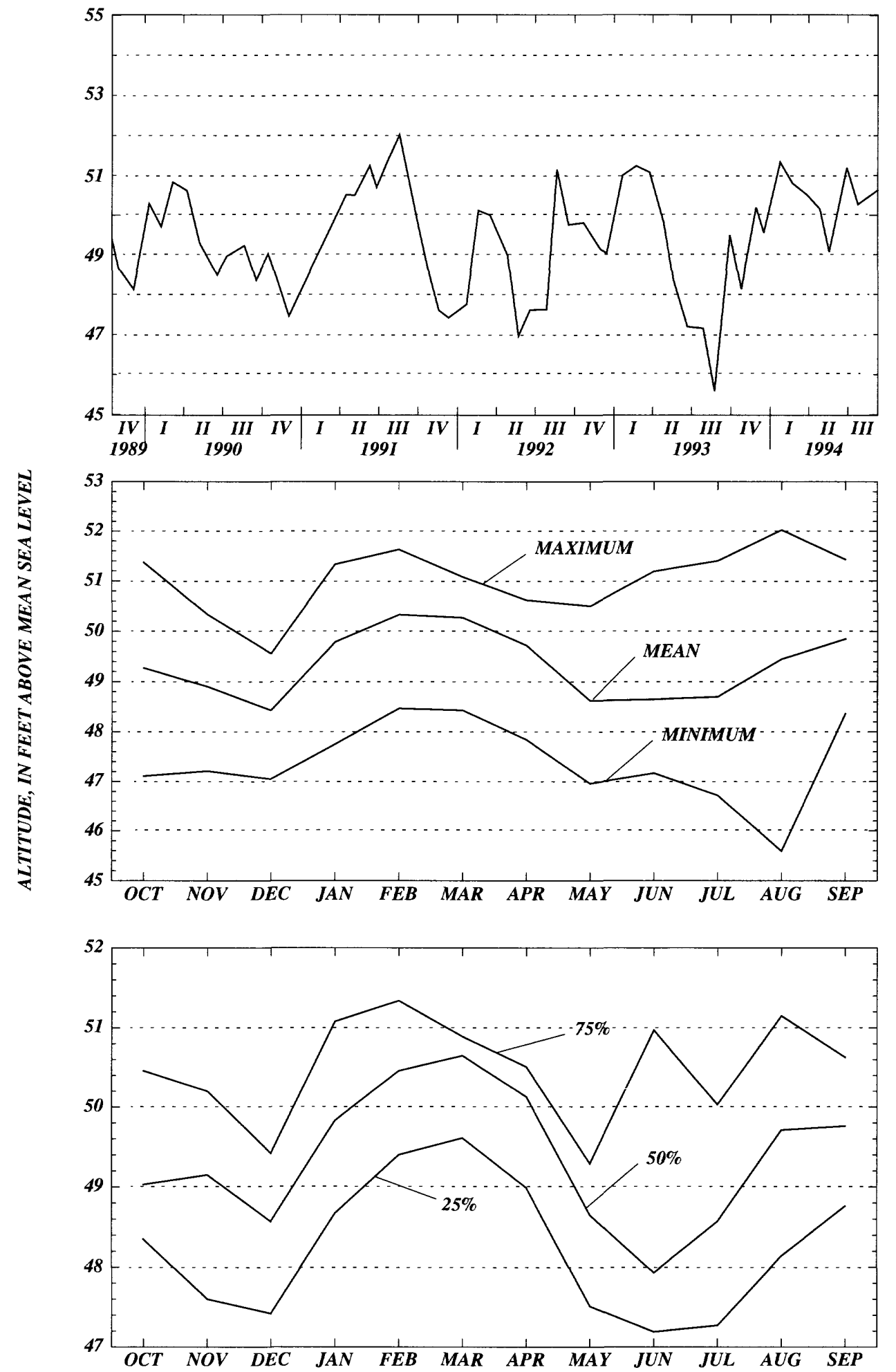


\section{Lafayette County}

WELL NUMBER.--295541083164285. DOF - Cooks Hammock Tower. -061025004.

LOCATION.--Lat 2955'41", long 83¹6’42”, Hydrologic Unit Code 03110102.

AQUIFER.--Surfical aquifer, Geologic Unit Code 110NRSD

WELL CHARACTERISTICS.--Casing diameter 3 in., Casing depth $1 \mathrm{ft}$., Total depth $11 \mathrm{ft}$.

INSTRUMENTATION.--Elevation of Measuring Point $56.18 \mathrm{ft}$., NGVD.

DATUM.--The National Geodetic Vertical Datum of 1929.

PERIOD OF RECORD.--04-14-1987 to 09-30-1994. *

EXTREME VALUES.--Maximum observed, 51.62 ft. (09-22-1988); minimum observed, $45.62 \mathrm{ft}$. (08-24-1993).

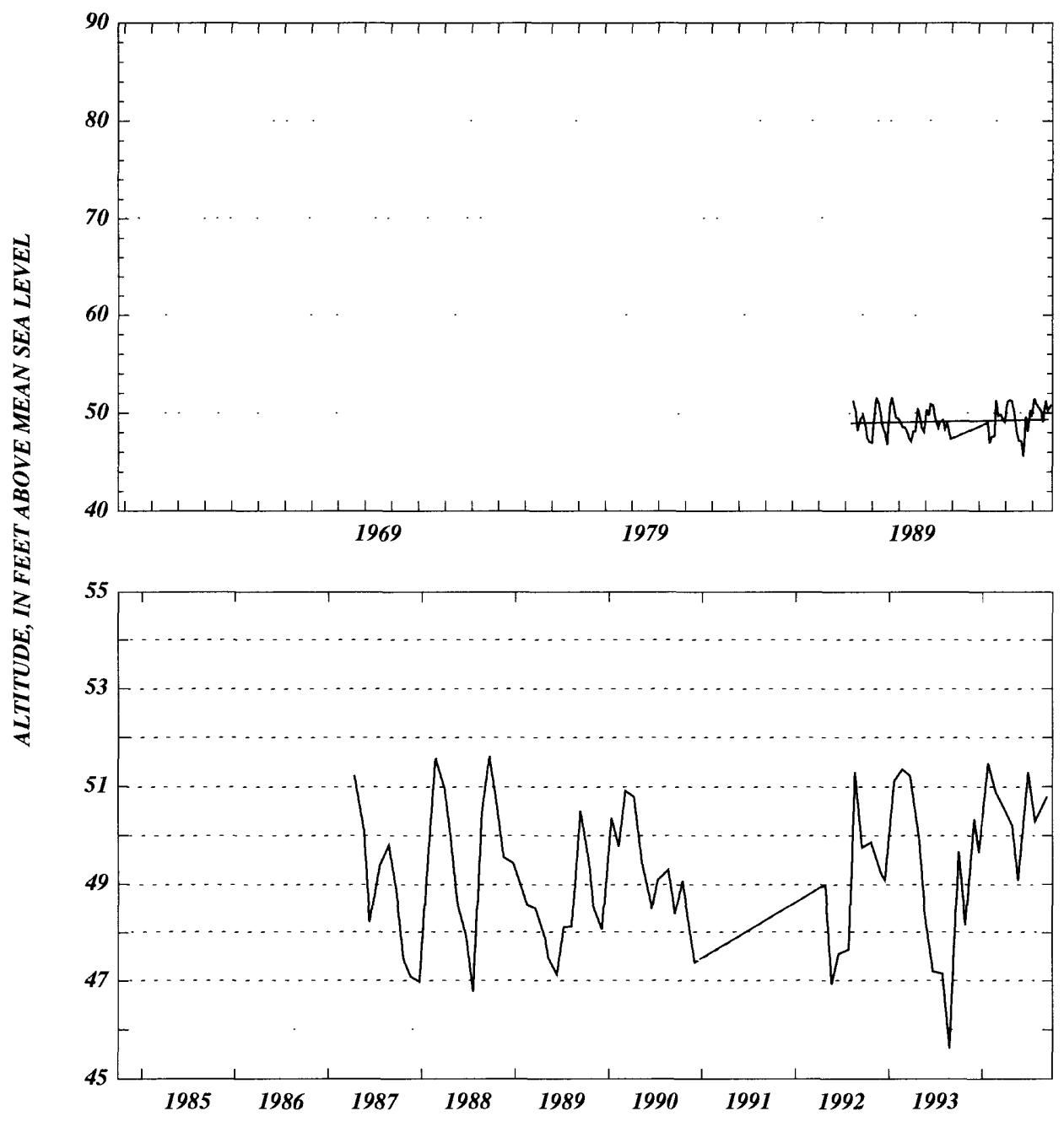



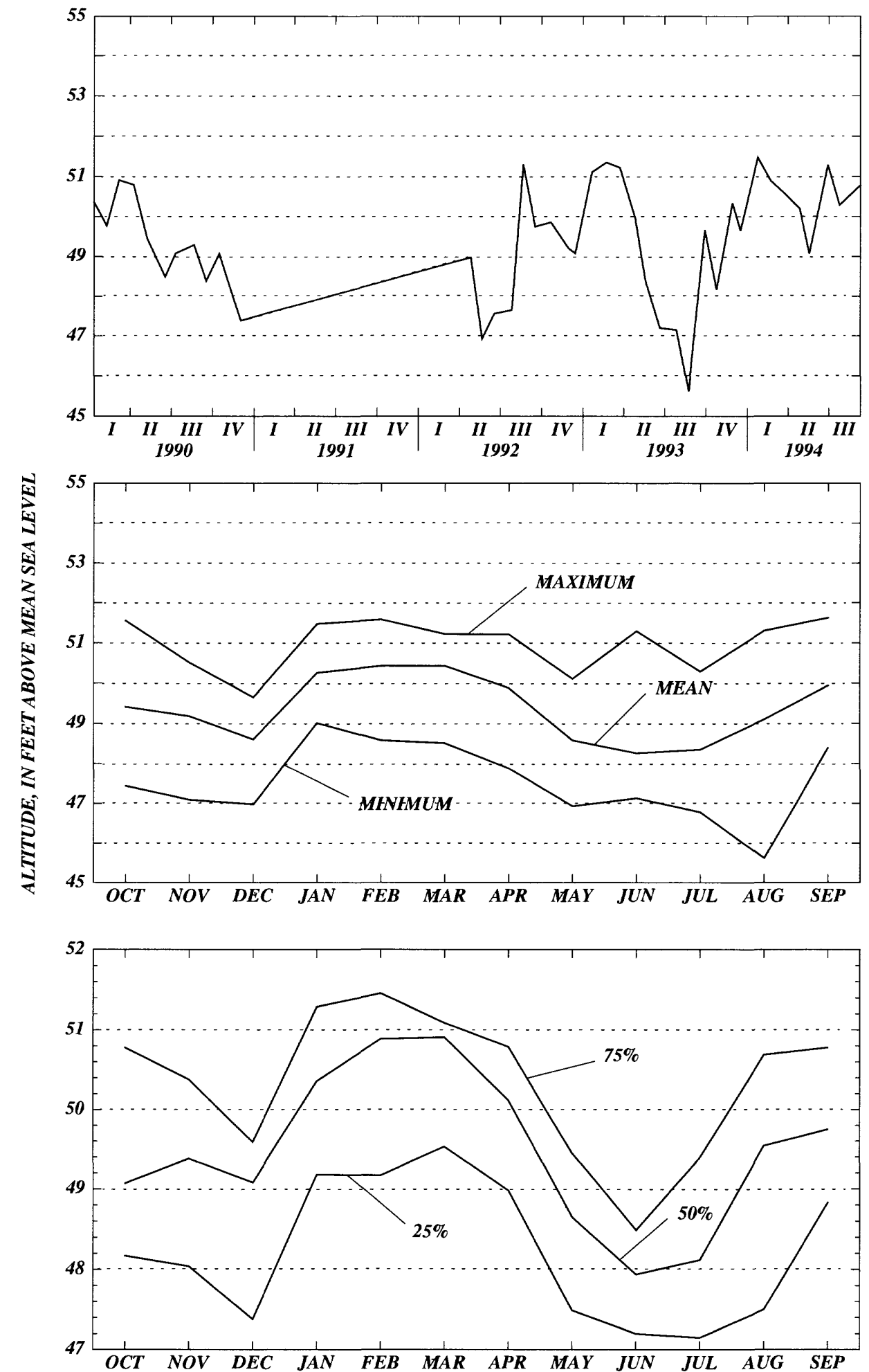
WELL NUMBER.--295802083121085. Lester McCray. -061114001.

LOCATION.--Lat 2958'02”, long 83¹2'10”, Hydrologic Unit Code 03110102.

AQUIFER.--Upper Floridan aquifer of the Tertiary system, Geologic Unit Code 120FLRD.

WELL CHARACTERISTICS.--Casing diameter 6 in., Casing depth $109 \mathrm{ft}$., Total depth $147 \mathrm{ft}$.

INSTRUMENTATION.--Miscellaneous from 10-29-1975 to 05-05-1976; recorder from 05-06-1976 to 11-16-1992; miscellaneous from 11-17-1992 to 09-30-1994. Elevation of Measuring Point 76.51 ft., NGVD.

DATUM.--The National Geodetic Vertical Datum of 1929.

PERIOD OF RECORD.--02-15-1961 to 09-30-1994. *

EXTREME VALUES.--Maximum, 70.71 ft. (04-09-1983), minimum observed, $61.14 \mathrm{ft}$. (10-22-1993).

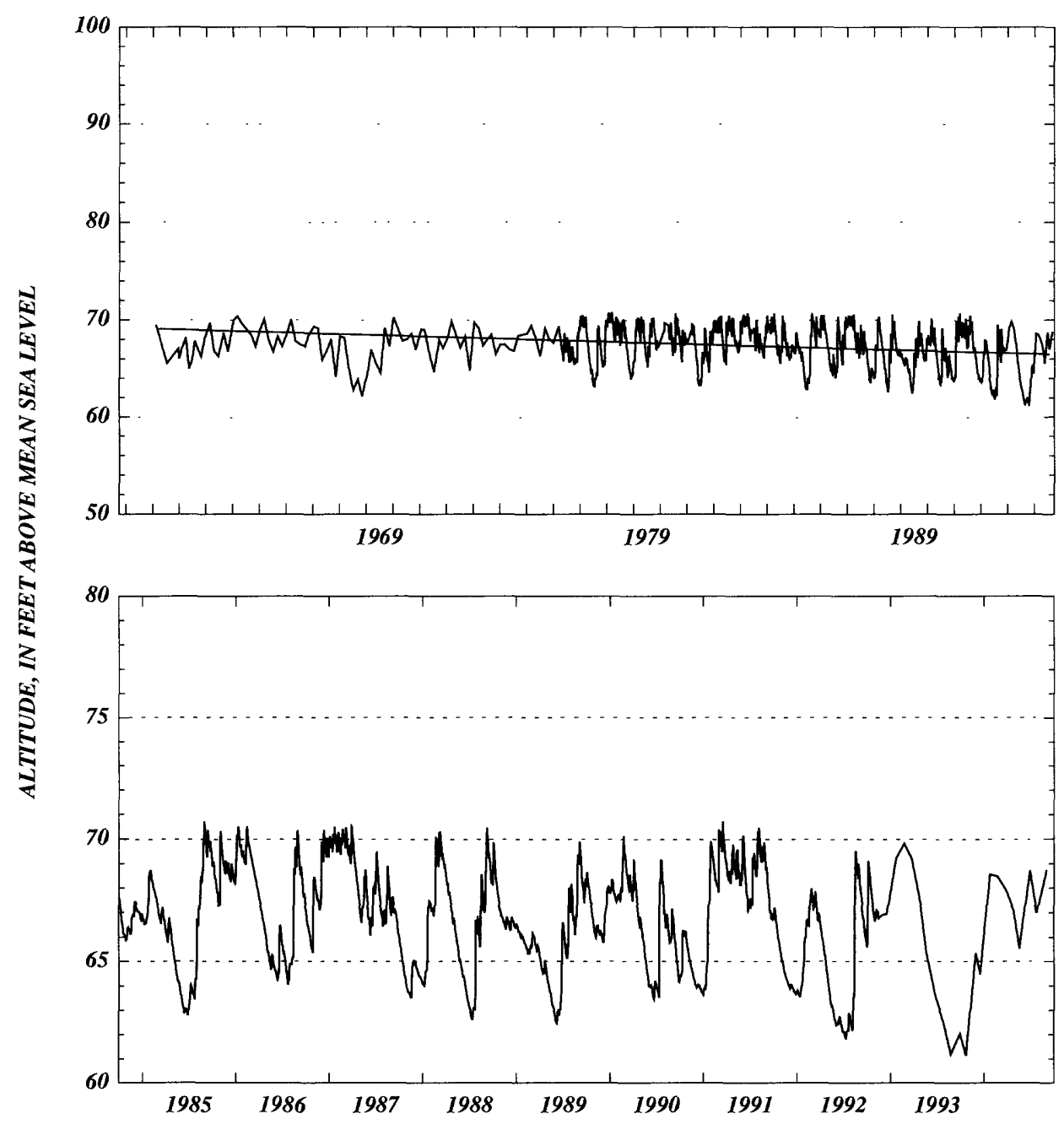



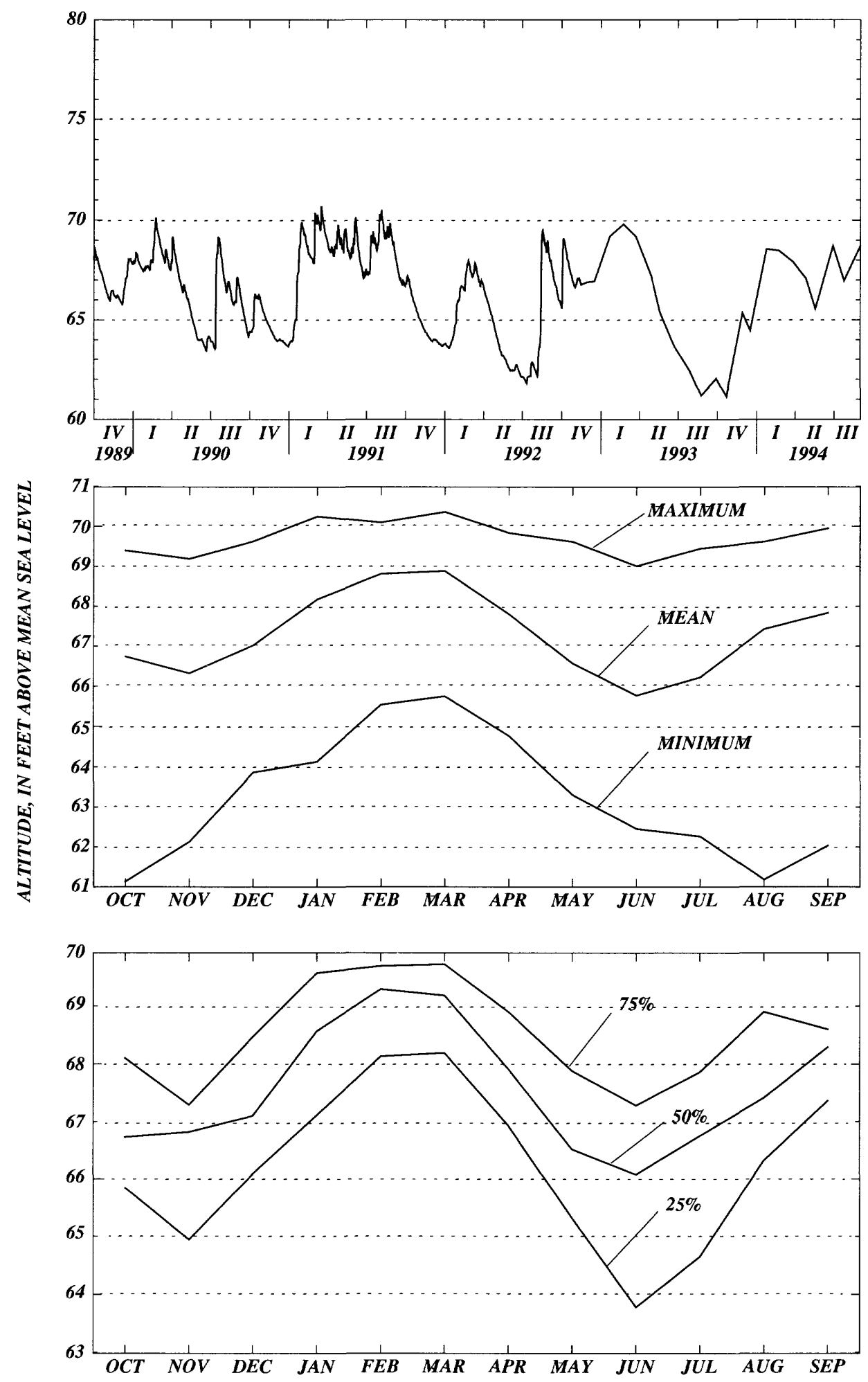


\section{Lafayette County}

WELL NUMBER.--295902083203885. Procter and Gamble. -061005002.

LOCATION.--Lat 2959'02”, long 83²0’38”, Hydrologic Unit Code 03110102.

AQUIFER.--Surficial aquifer, Geologic Unit Code 110NRSD.

WELL CHARACTERISTICS.--Casing diameter 3 in., Casing depth $1 \mathrm{ft}$., Total depth $11 \mathrm{ft}$.

INSTRUMENTATION.--Miscellaneous from 04-14-1987 to 08-15-1988; then; recorder, set to elevation of the Measuring Point $74.29 \mathrm{ft}$., NGVD.

DATUM.--The National Geodetic Vertical Datum of 1929.

PERIOD OF RECORD.--04-14-1987 to 09-30-1994.

EXTREME VALUES.--Maximum, 70.58 ft. (08-16-1994); minimum, 64.37 ft. (06-06-1989).

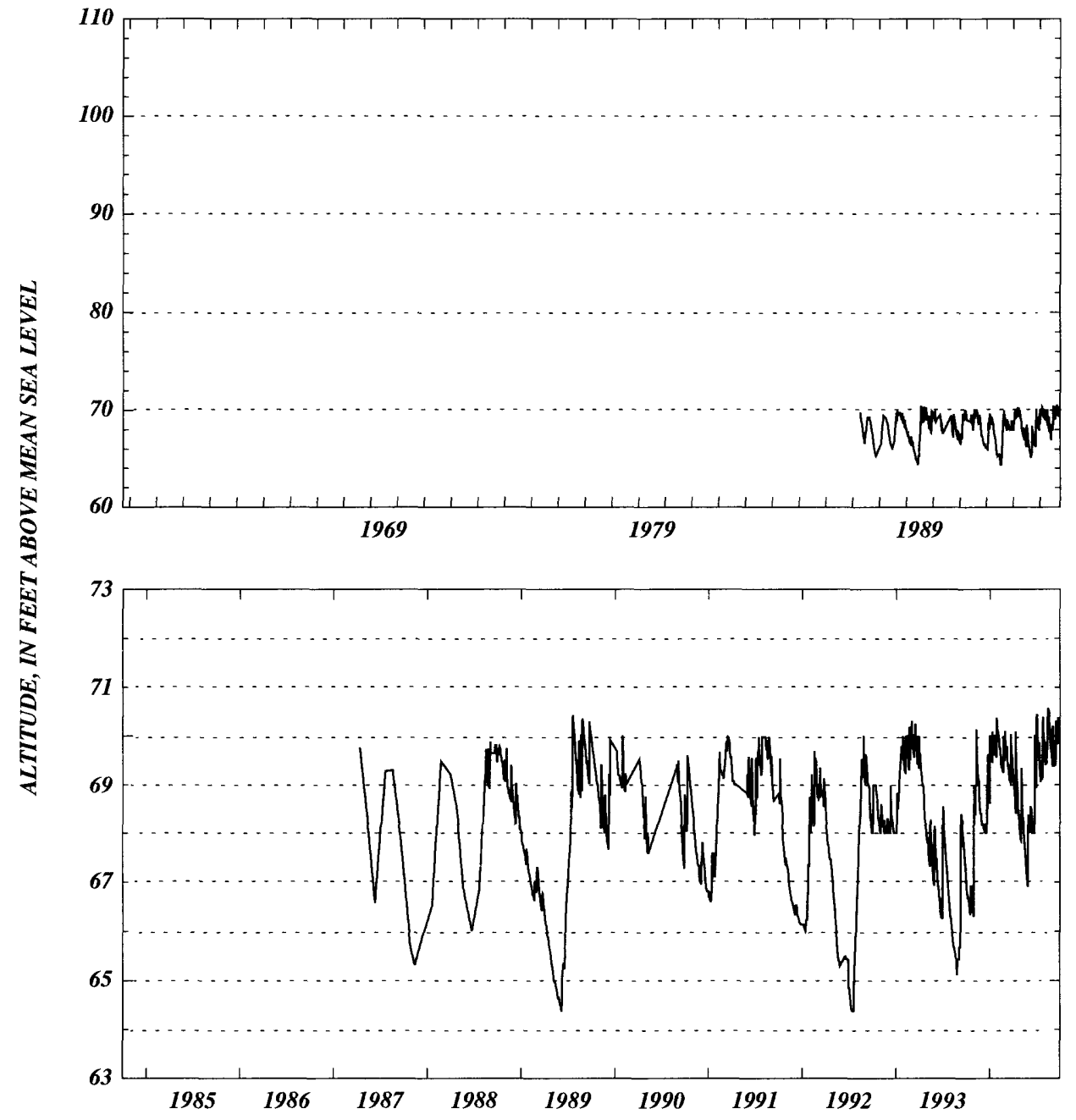



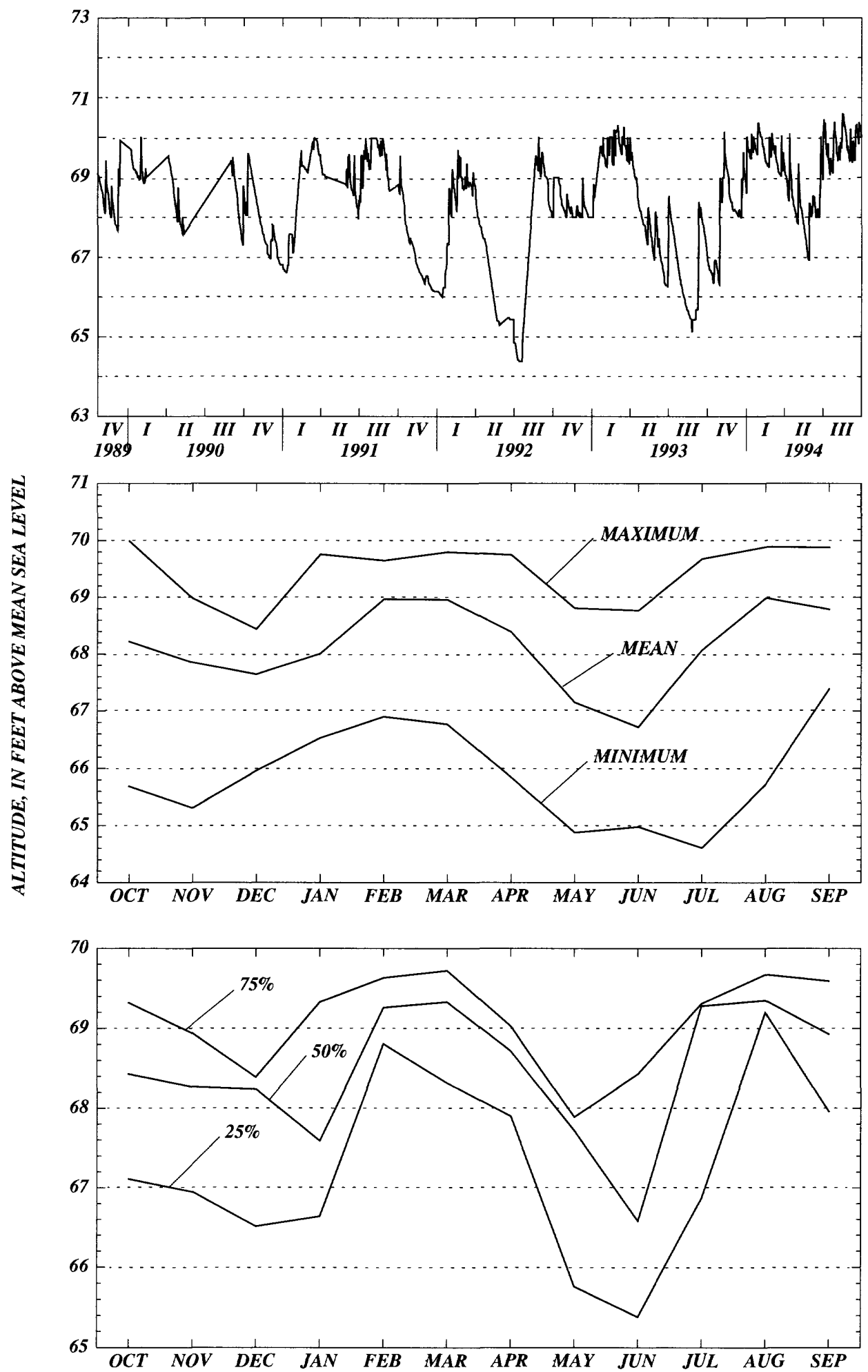


\section{Lafayette County}

WELL NUMBER.--295903083203885. Procter and Gamble. -061005001.

LOCATION.--Lat 2959'03”, long 83²0'38', Hydrologic Unit Code 03110102.

AQUIFER.--Upper Floridan aquifer of the Tertiary system, Geologic Unit Code 120FLRD.

WELL CHARACTERISTICS.--Casing diameter 3 in., Casing depth $23 \mathrm{ft}$., Total depth $43 \mathrm{ft}$.

INSTRUMENTATION.--Miscellaneous from 07-20-1987 to 08-14-1988; then recorder, set to elevation of the Measuring Point $72.35 \mathrm{ft}$., NGVD.

DATUM.--The National Geodetic Vertical Datum of 1929.

PERIOD OF RECORD.--07-20-1987 to 09-30-1994.

EXTREME VALUES.--Maximum, 70.73 ft. (09-06-1988) ‡; minimum 64.03 ft. (07-12-1992).

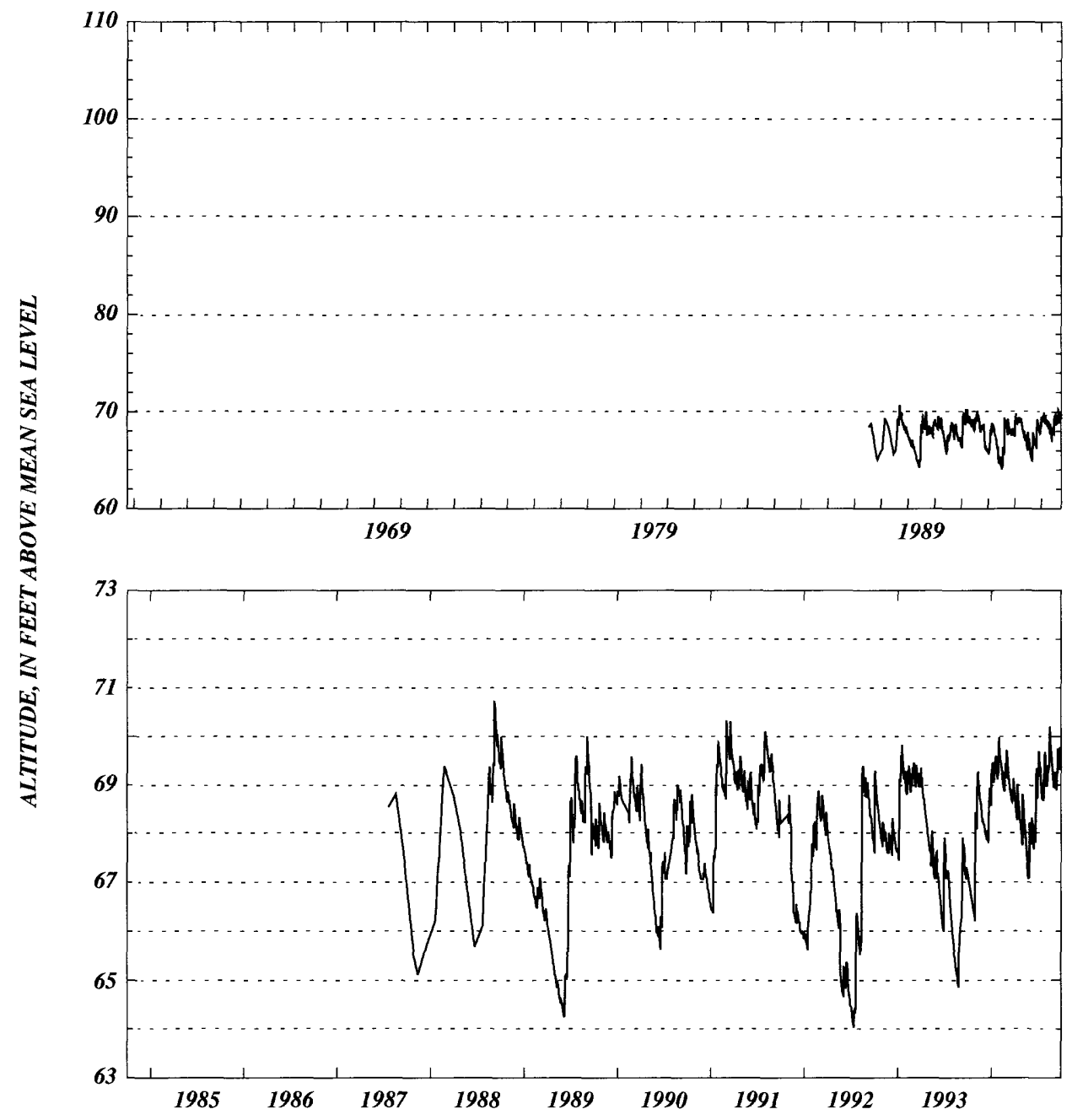



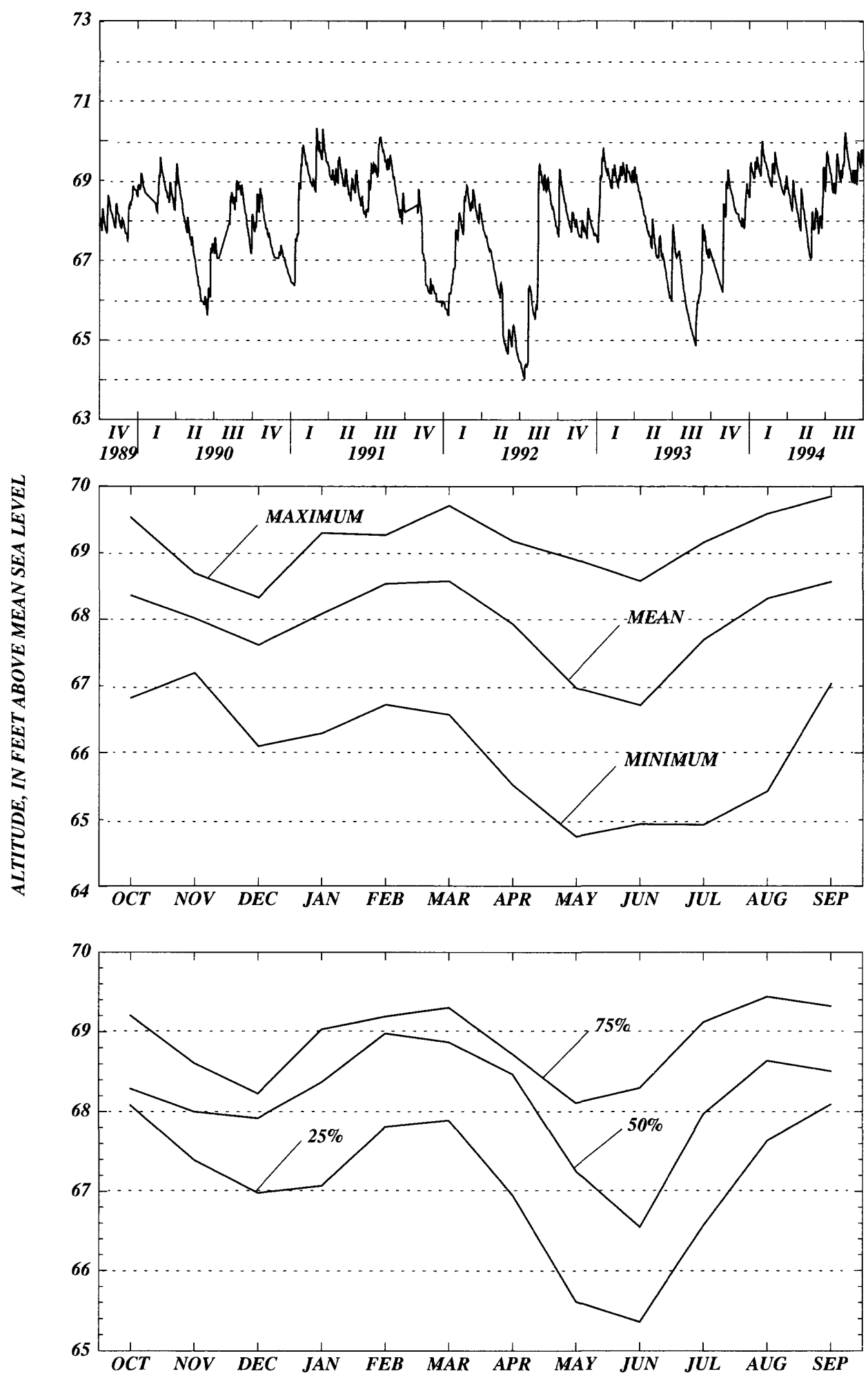
WELL NUMBER.--295957083032685. DOF - Midway Tower. -051331002.

LOCATION.--Lat 2959'57’, long 8303'26”, Hydrologic Unit Code 03110205.

AQUIFER.--Upper Floridan aquifer of the Tertiary system, Geologic Unit Code 120FLRD.

WELL CHARACTERISTICS.--Casing diameter 3 in., Casing depth $36 \mathrm{ft}$., Total depth $56 \mathrm{ft}$.

INSTRUMENTATION.--Elevation of Measuring Point $67.06 \mathrm{ft}$. NGVD.

DATUM.--The National Geodetic Vertical Datum of 1929.

PERIOD OF RECORD.--01-03-1989 to 09-30-1994.

EXTREME VALUES.--Maximum observed, 52.86 ft. (09-03-1991); minimum observed, $36.99 \mathrm{ft}$. (01-29-1991).

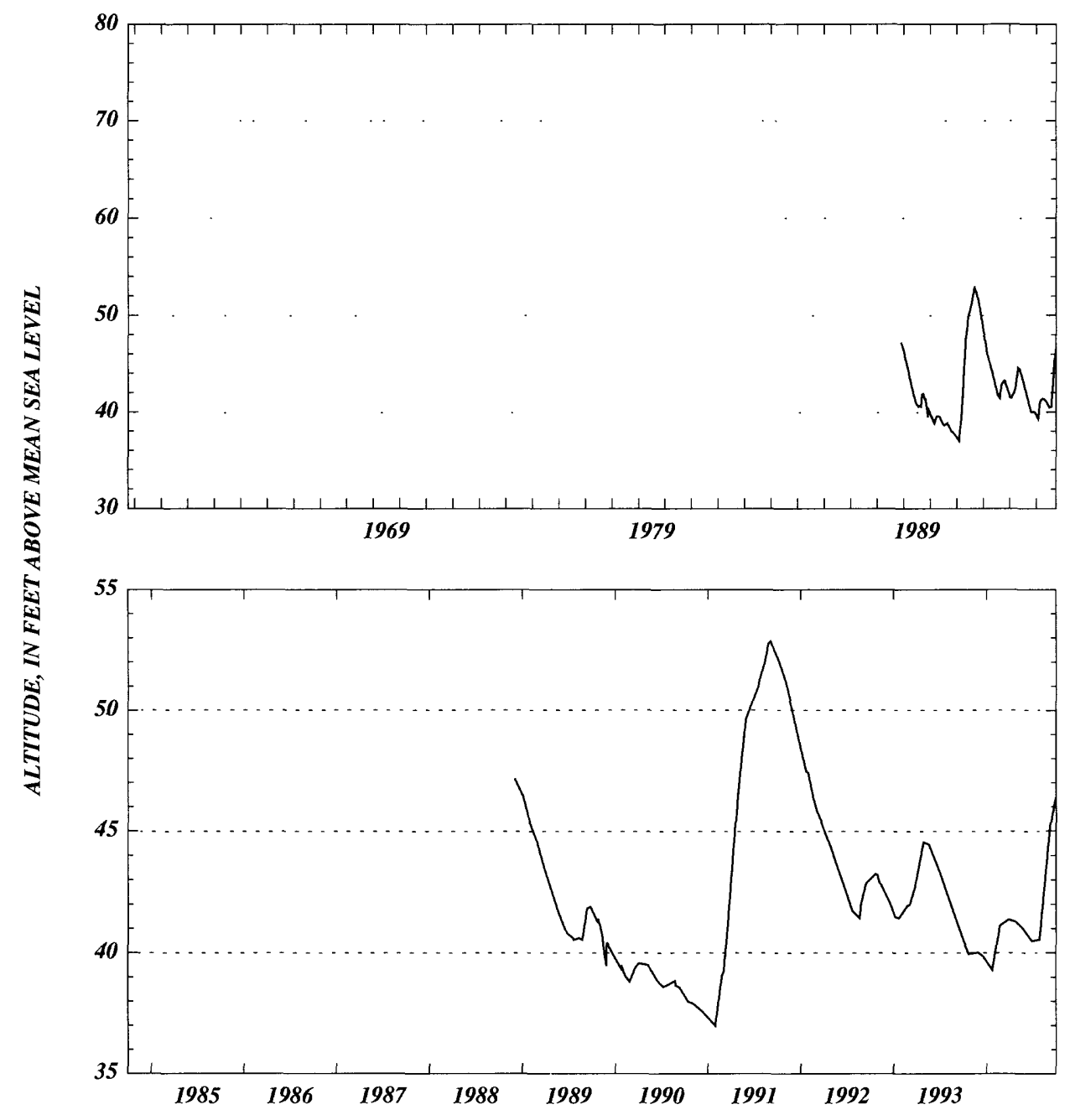



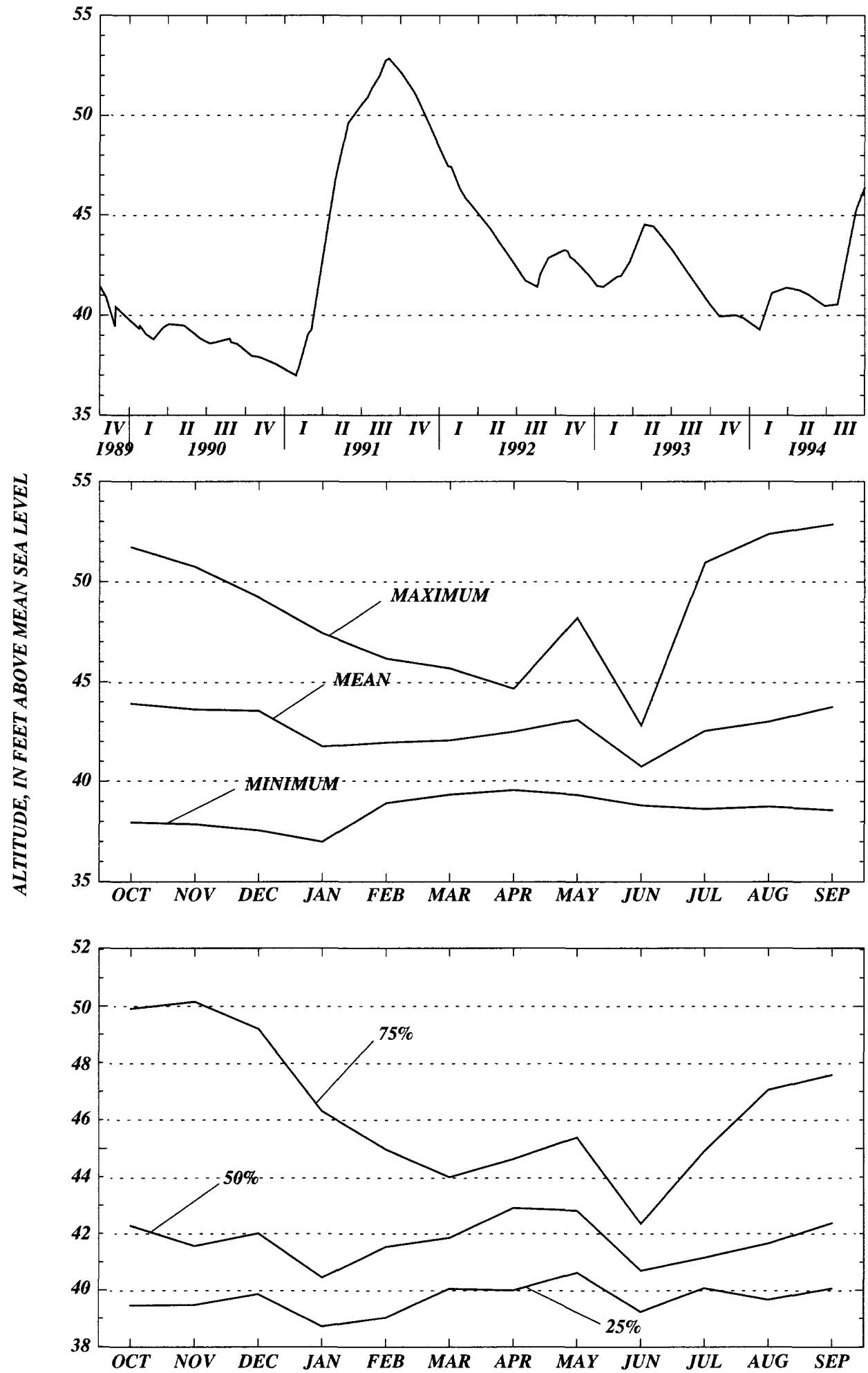
WELL NUMBER.--295958083032885. DOF - Midway Tower. -051331003.

LOCATION.--Lat 2959'58’, long 8303'28”, Hydrologic Unit Code 03110205.

AQUIFER.--Upper Floridan aquifer of the Tertiary system, Geologic Unit Code 120FLRD.

WELL CHARACTERISTICS.--Casing diameter 3 in., Casing depth $24 \mathrm{ft}$., Total depth $44 \mathrm{ft}$.

INSTRUMENTATION.--Recorder, set to elevation of the Measuring Point, $67.68 \mathrm{ft}$., NGVD.

DATUM.--The National Geodetic Vertical Datum of 1929.

PERIOD OF RECORD.--07-08-1993 to 09-30-1994.

EXTREME VALUES.--Maximum, 46.61 ft. (09-30-1994); minimum, 39.52 ft. (01-23-1994).

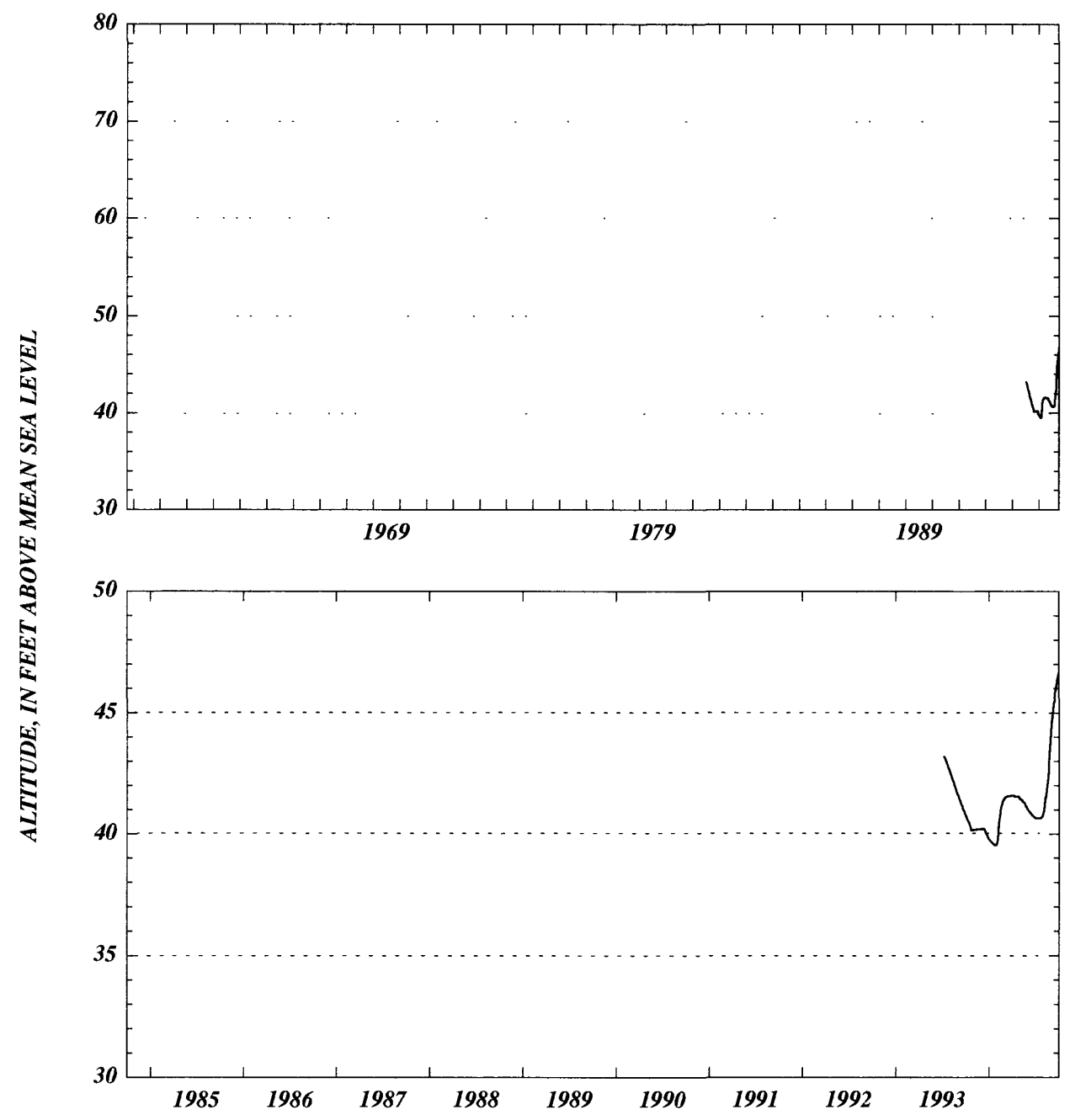



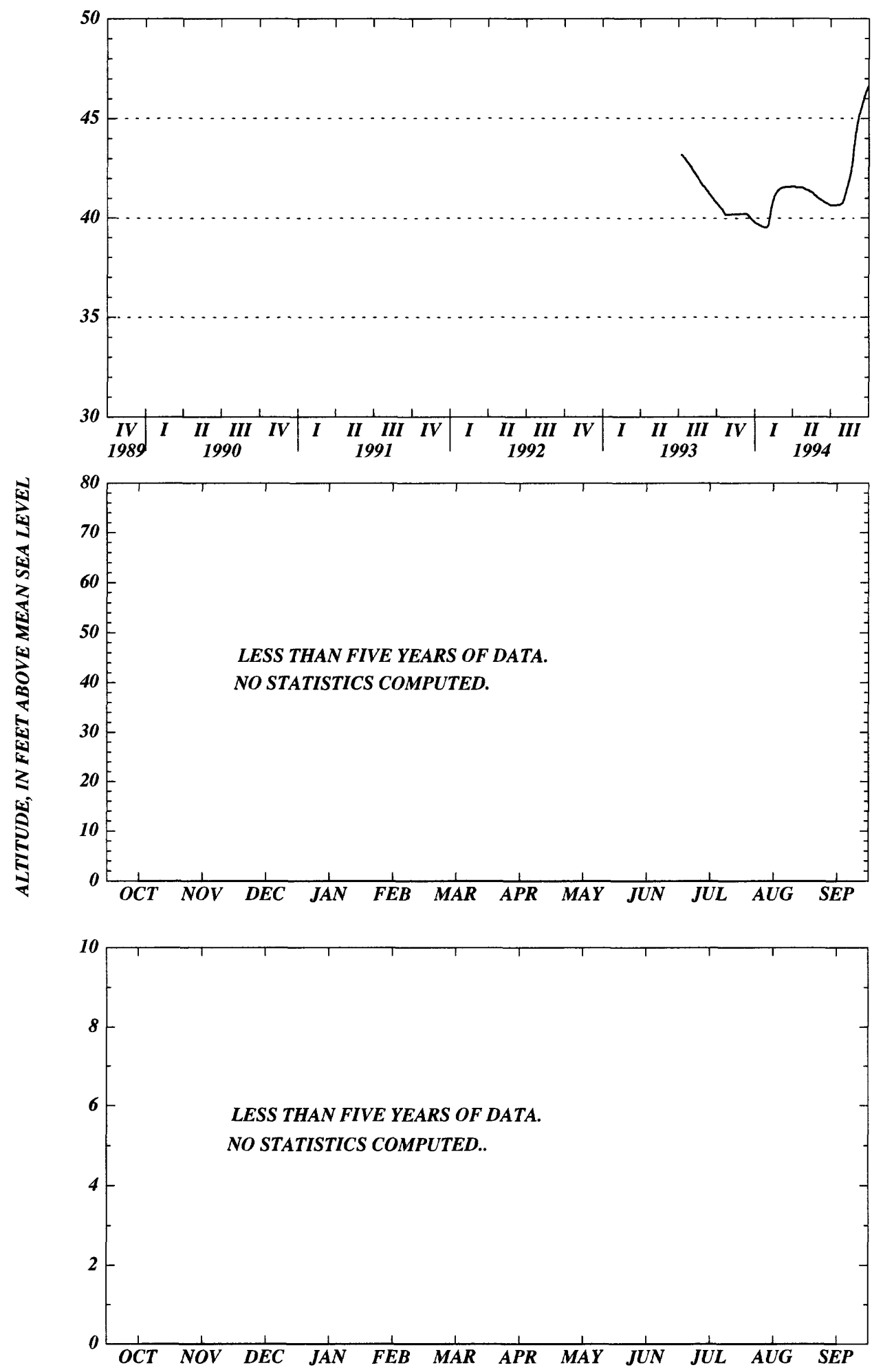
WELL NUMBER.--300234083065485. Visa 6. -051215001.

LOCATION.--Lat 30 02'34", long 8306'54', Hydrologic Unit Code 03110205.

AQUIFER.--Upper Floridan aquifer of the Tertiary system, Geologic Unit Code 120FLRD.

WELL CHARACTERISTICS.--Casing diameter 4 in., Casing depth $60 \mathrm{ft}$., Total depth $80 \mathrm{ft}$.

INSTRUMENTATION.--Elevation of Measuring Point $71.29 \mathrm{ft}$., NGVD.

DATUM.--The National Geodetic Vertical Datum of 1929.

PERIOD OF RECORD.--02-26-1990 to 09-30-1994.

EXTREME VALUES.--Maximum observed, 64.99 ft. (09-04-1991); minimum observed, $59.75 \mathrm{ft}$. (01-29-1991).

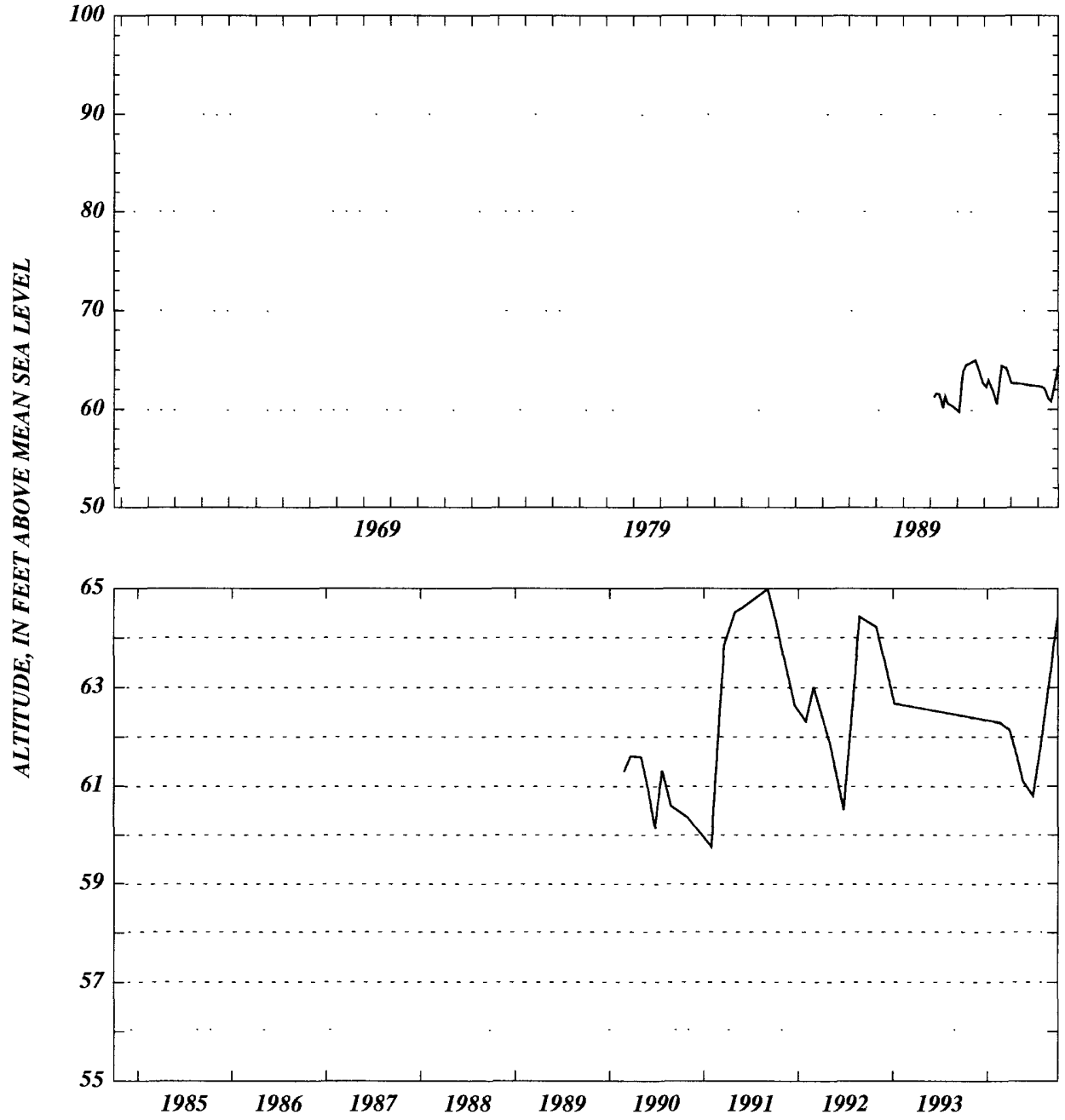



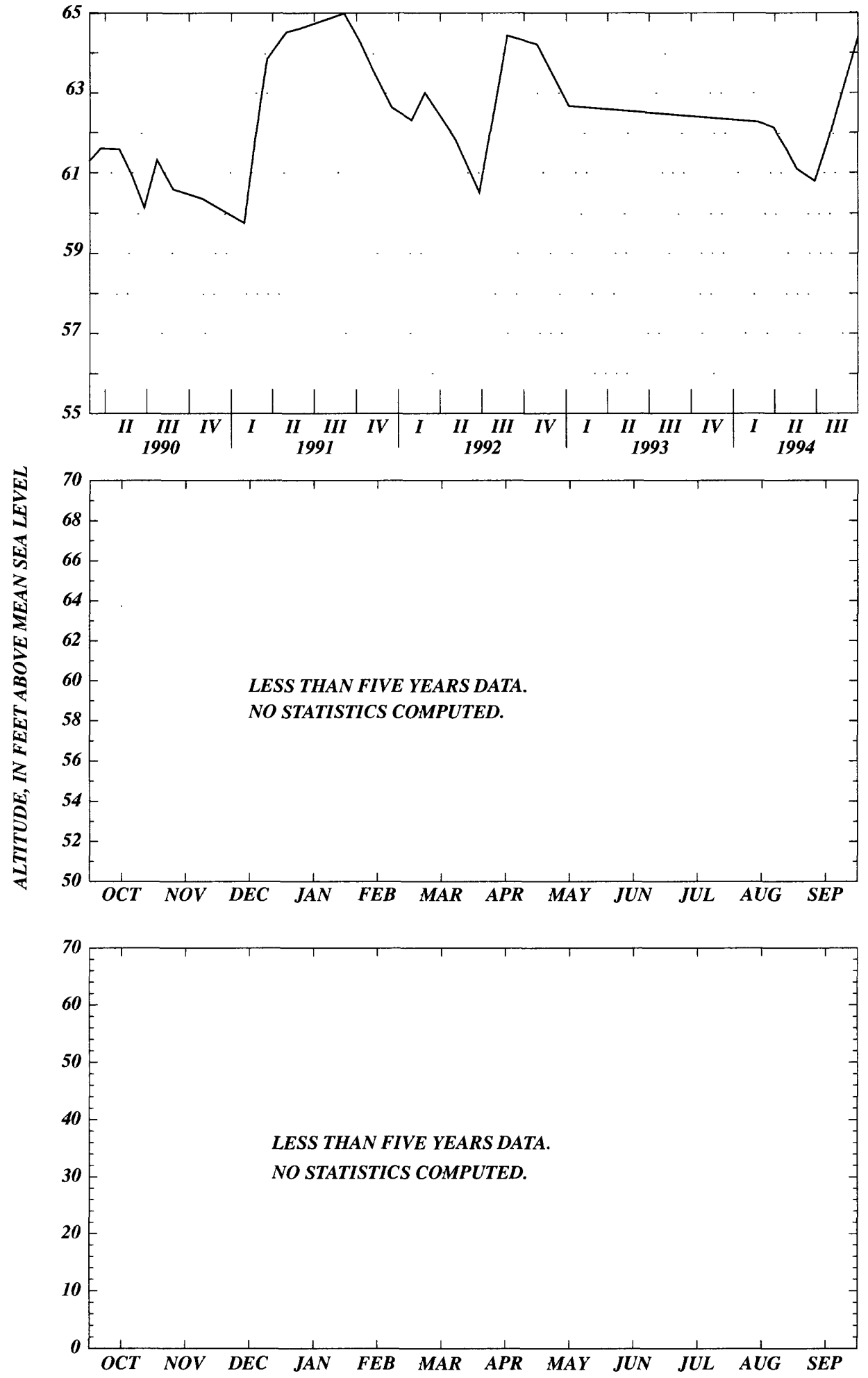


\section{Lafayette County}

WELL NUMBER.--300249083045385. DOT - Visa 8. -051214008.

LOCATION.--Lat 3002'49”, long 8304'53”, Hydrologic Unit Code 03110205.

AQUIFER.--Upper Floridan aquifer of the Tertiary system, Geologic Unit Code 120FLRD.

WELL CHARACTERISTICS.--Casing diameter 4 in., Casing depth $22 \mathrm{ft}$., Total depth $52 \mathrm{ft}$.

INSTRUMENTATION.--Elevation of Measuring Point $49.77 \mathrm{ft}$., NGVD.

DATUM.--The National Geodetic Vertical Datum of 1929.

PERIOD OF RECORD.--02-26-1990 to 09-30-1994.

EXTREME VALUES.--Maximum observed, 33.38 ft. (05-01-1991); minimum observed, $20.40 \mathrm{ft}$. (01-29-1991).

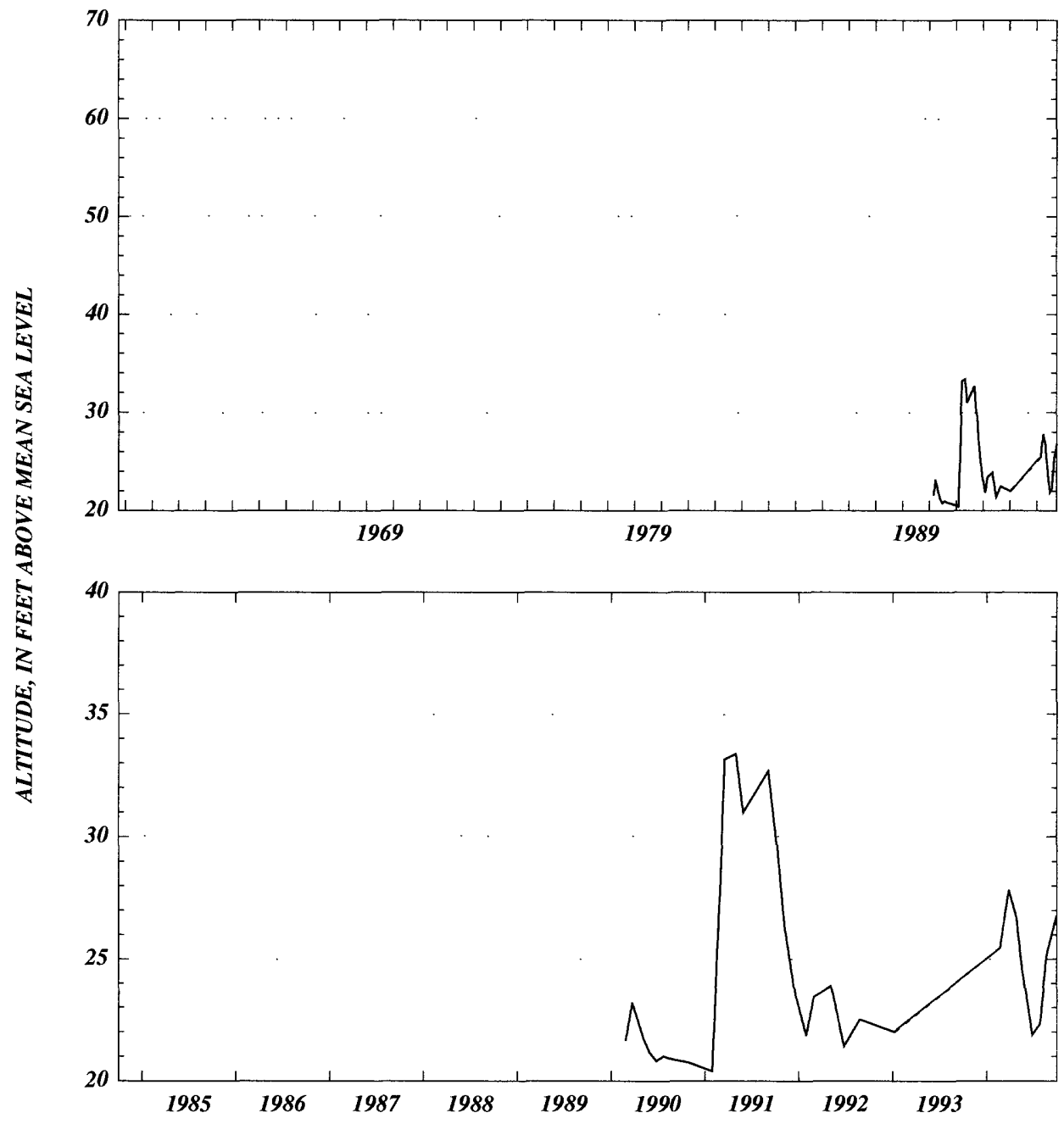



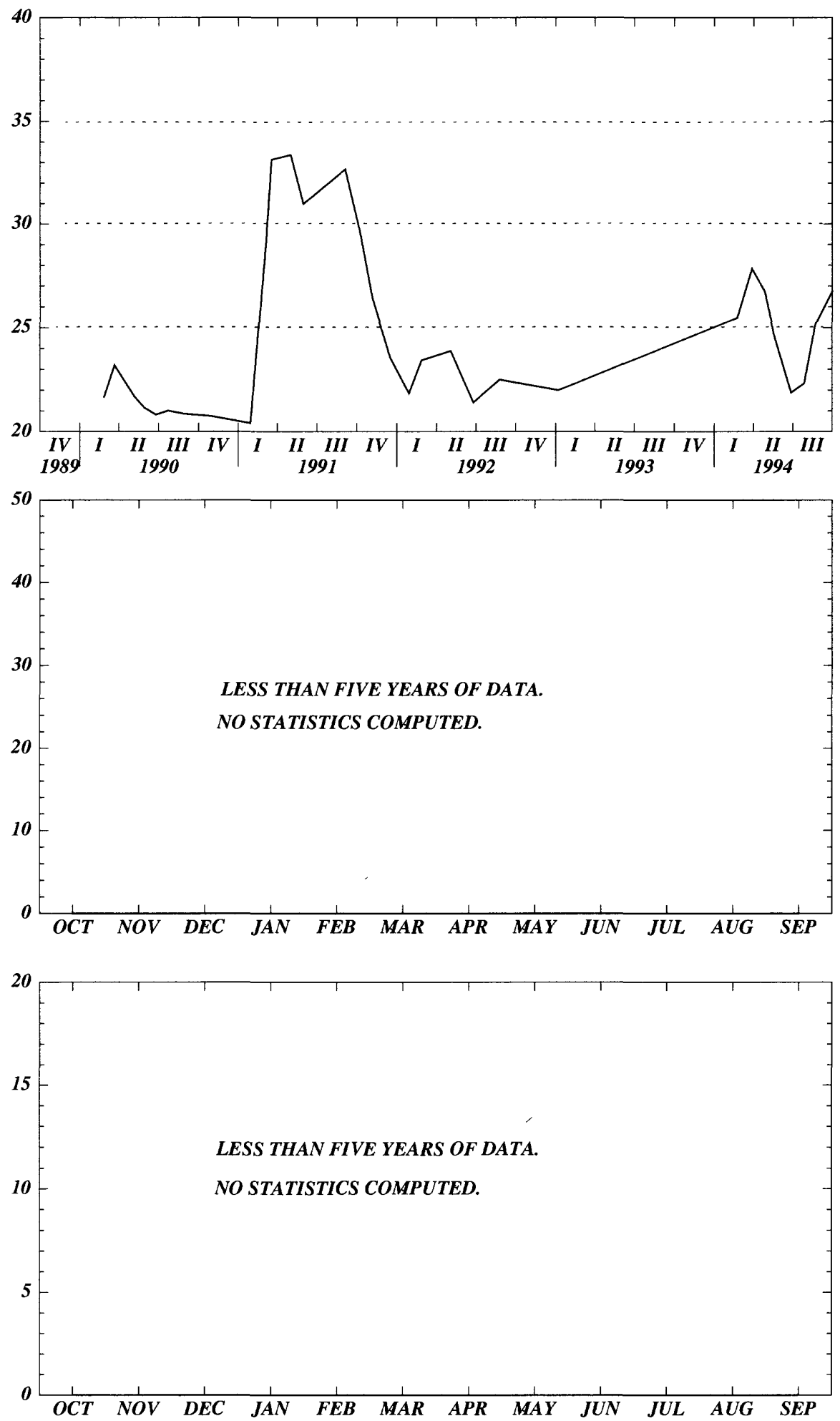


\section{Lafayette County.}

WELL NUMBER.--300308083093285. John Hewitt. -051218002.

LOCATION.Lat 3003'08', long 8309'32', Hydrologic Unit Code 03110205.

AQUIFER.--Upper Floridan aquifer of the Tertiary system, Geologic Unit Code 120FLRD.

WELL CHARACTERISTICS.--Casing diameter 4 in., Casing depth $63 \mathrm{ft}$., Total depth $68 \mathrm{ft}$.

INSTRUMENTATION.--Elevation of Measuring Point $80.57 \mathrm{ft}$. NGVD.

DATUM.--The National Geodetic Vertical Datum of 1929.

PERIOD OF RECORD.--12-02-1988 to 09-30-1994.

EXTREME VALUES.--Maximum observed, 56.34 ft. (09-04-1991); minimum observed, $46.64 \mathrm{ft}$. (07-21-1989).

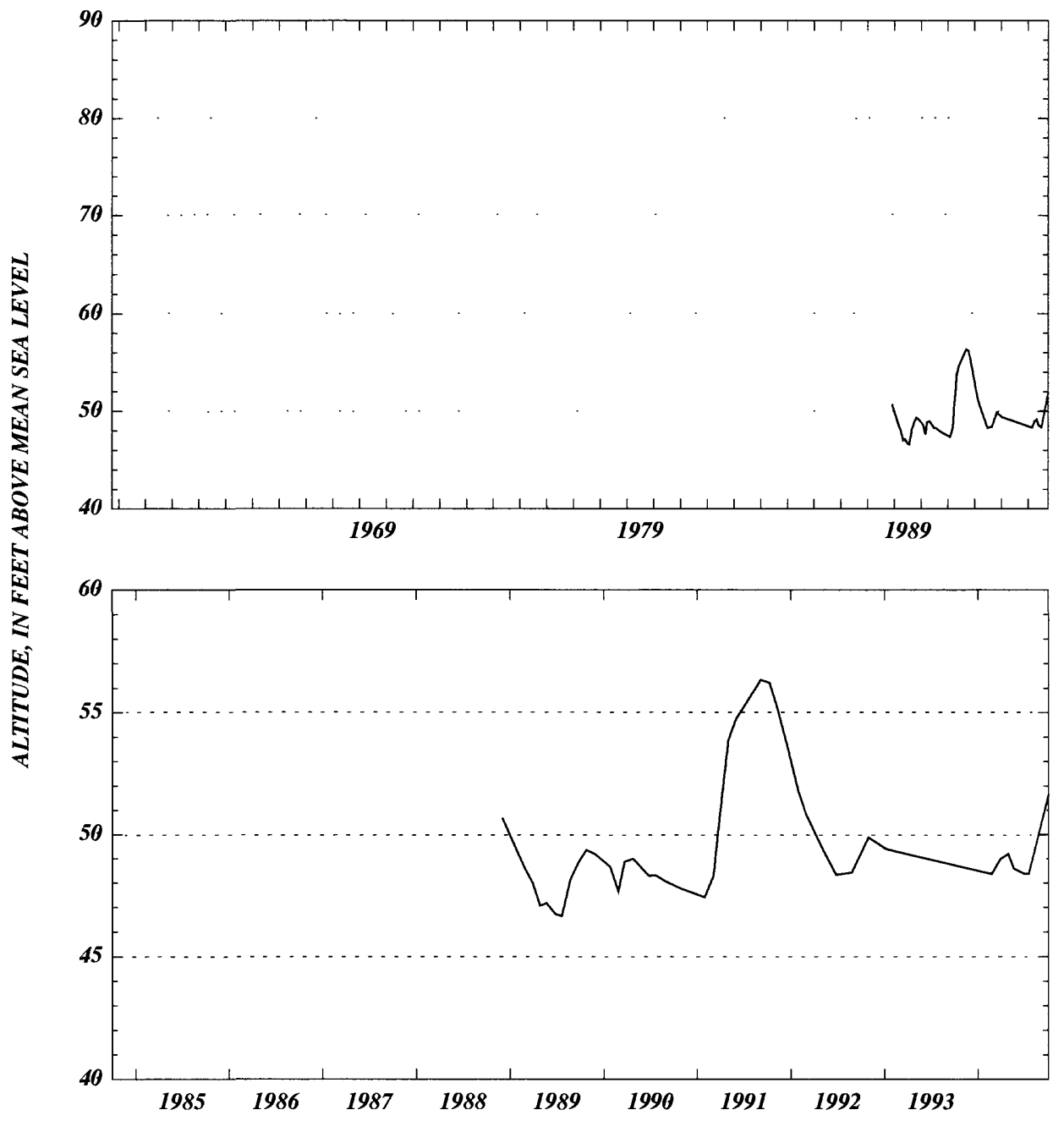



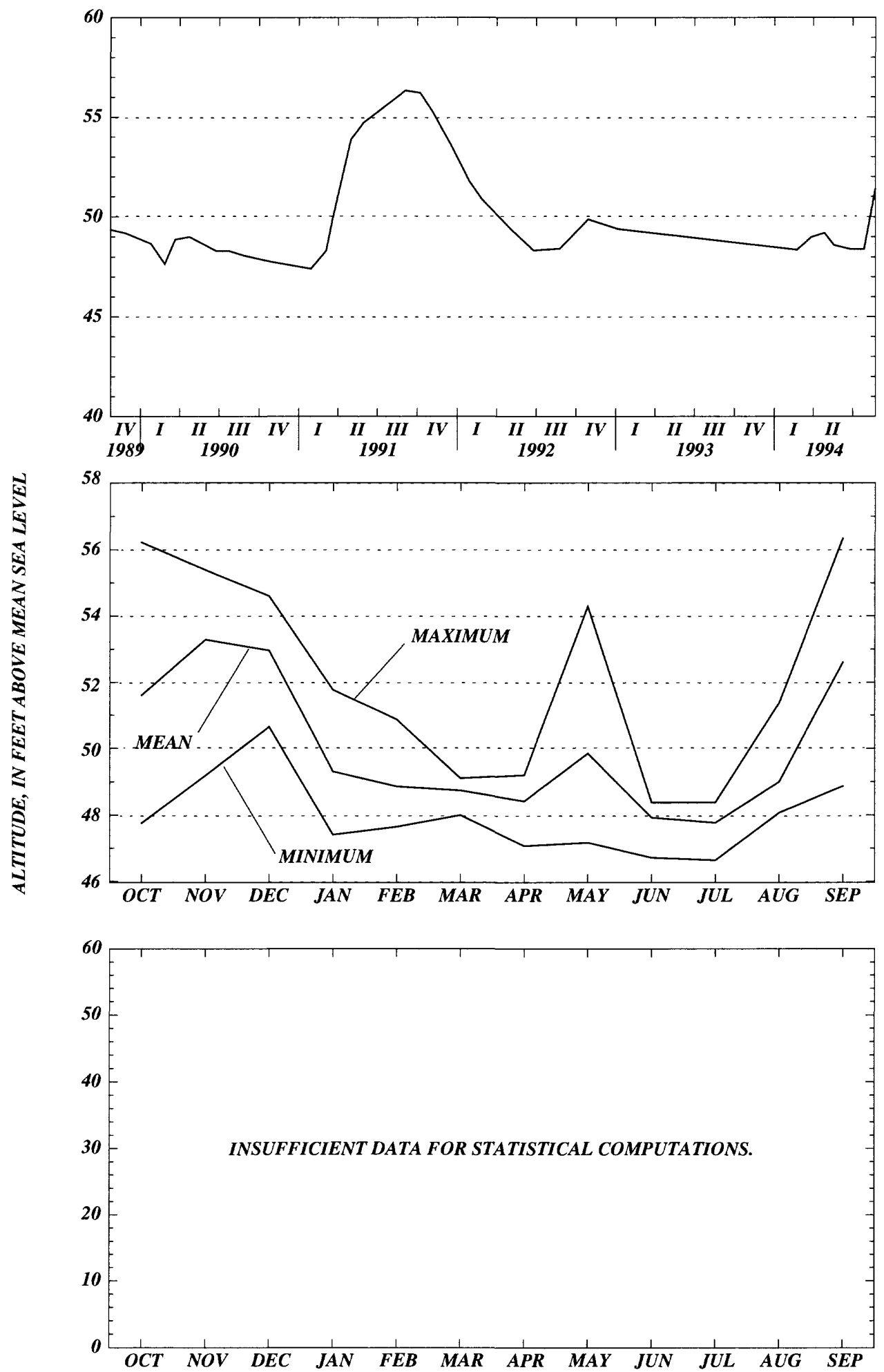


\section{Lafayette County}

WELL NUMBER.--300403083081785. R.L. Koon. -051208001.

LOCATION.--Lat 3004'03', long 8308'17', Hydrologic Unit Code 03110205.

AQUIFER.--Upper Floridan aquifer of the Tertiary system, Geologic Unit Code 120FLRD.

WELL CHARACTERISTICS.--Casing diameter 8 in., Casing depth unknown, Total depth $245 \mathrm{ft}$.

INSTRUMENTATION.--Miscellaneous from 12-02-1988 to 10-25-1989; then recorder, set to elevation of the Measuring Point, $70.17 \mathrm{ft}$., NGVD.

DATUM.--The National Geodetic Vertical Datum of 1929.

PERIOD OF RECORD.--12-02-1988 to 09-30-1994.

EXTREME VALUES.--Maximum, 41.51 ft. (04-09-1991); minimum, 26.22 ft. (11-12-1993).

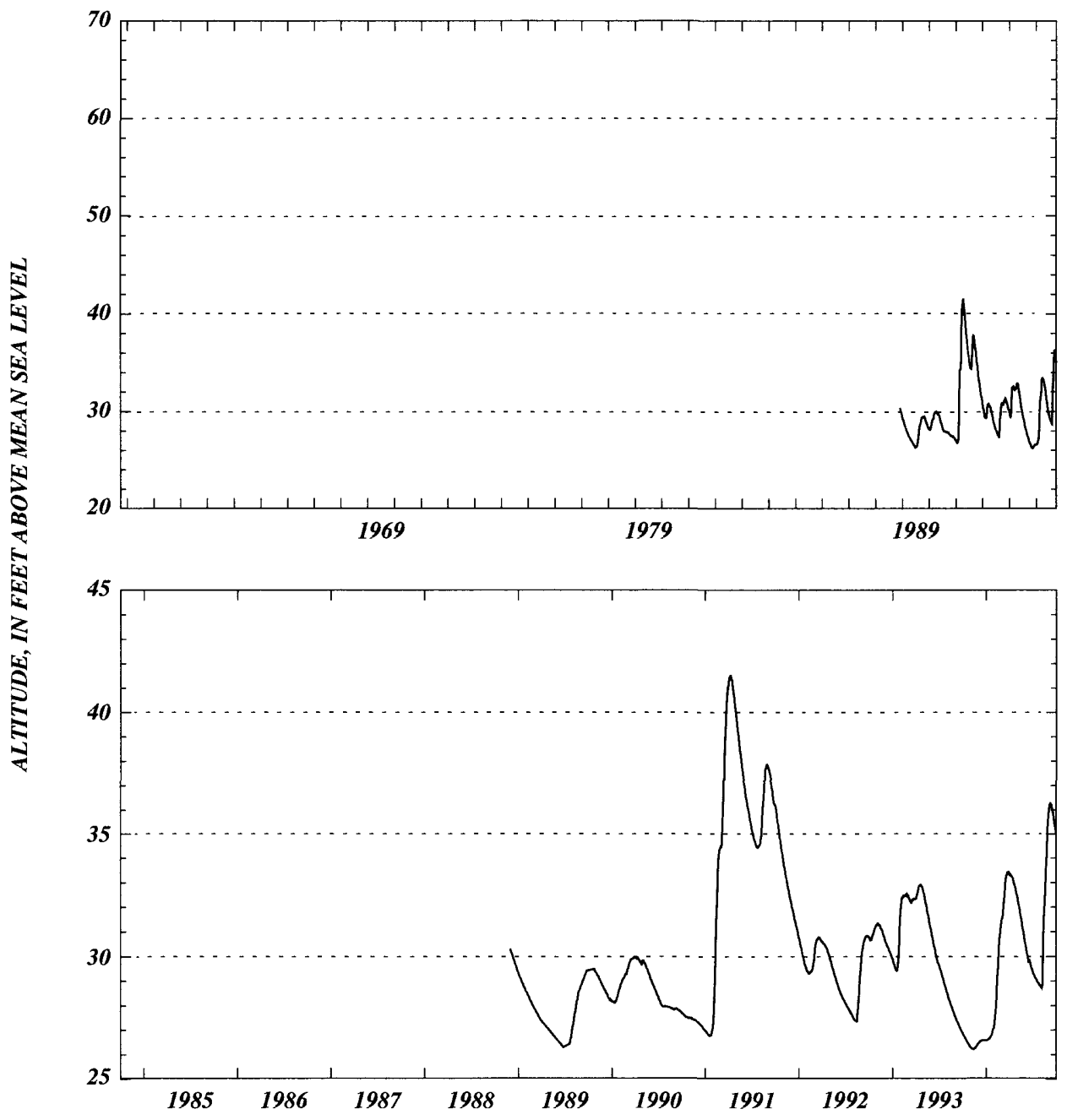



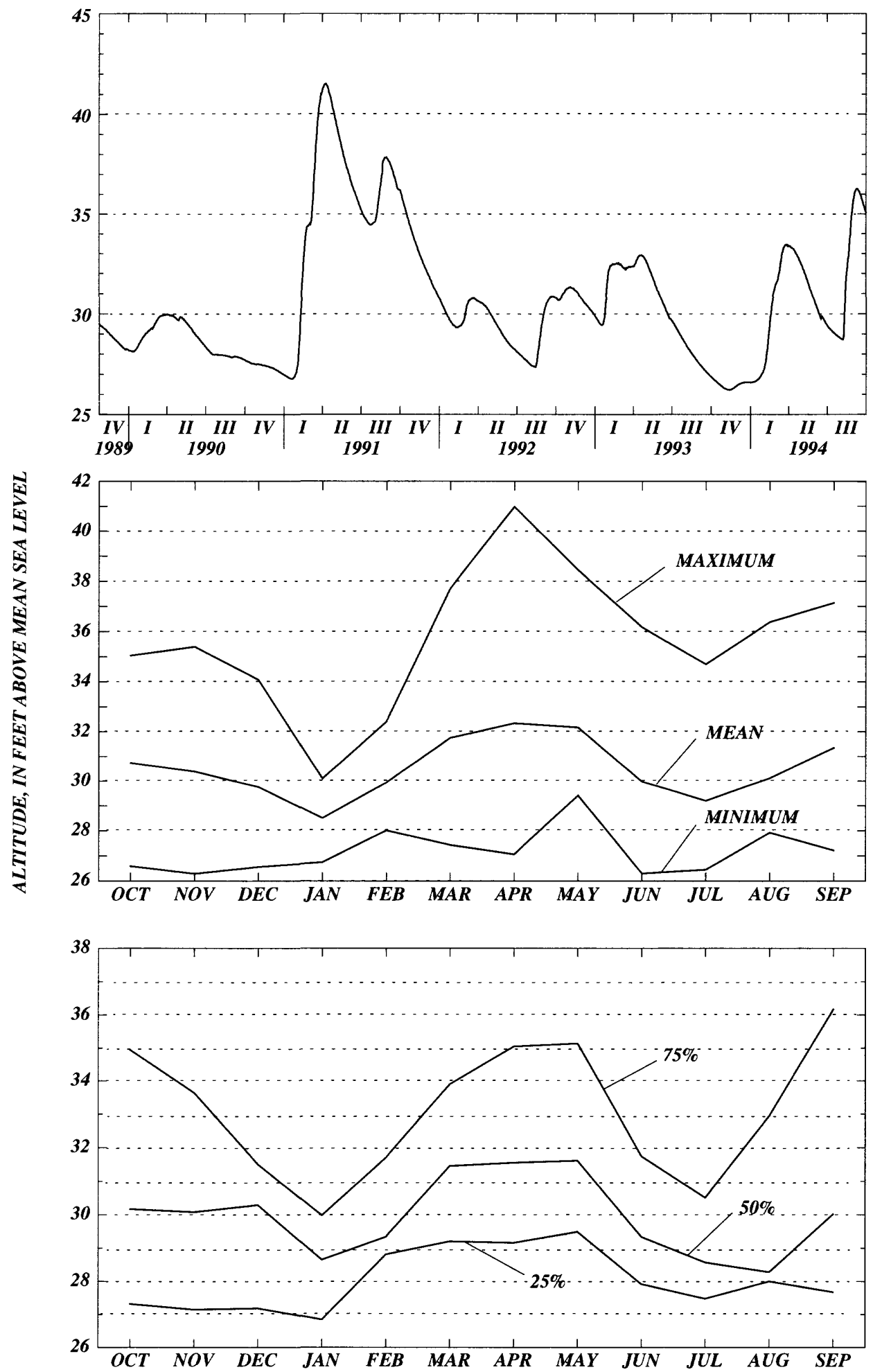


\section{Lafayette County}

WELL NUMBER.--300436083191685. Procter and Gamble. -051004002.

LOCATION.--Lat 3004'36", long 83¹9'16”, Hydrologic Unit Code 03110102.

AQUIFER.--Surficial aquifer, Geologic Unit Code 110NRSD.

WELL CHARACTERISTICS.--Casing diameter 3 in., Casing depth $3 \mathrm{ft}$., Total depth $13 \mathrm{ft}$.

INSTRUMENTATION.--Elevation of Measuring Point $90.14 \mathrm{ft} .$, NGVD.

DATUM.--The National Geodetic Vertical Datum of 1929.

PERIOD OF RECORD.--04-14-1987 to 09-30-1994.

EXTREME VALUES.--Maximum observed, 85.64 ft. (02-02-1994); minimum observed, $80.44 \mathrm{ft}$. (08-03-1992).

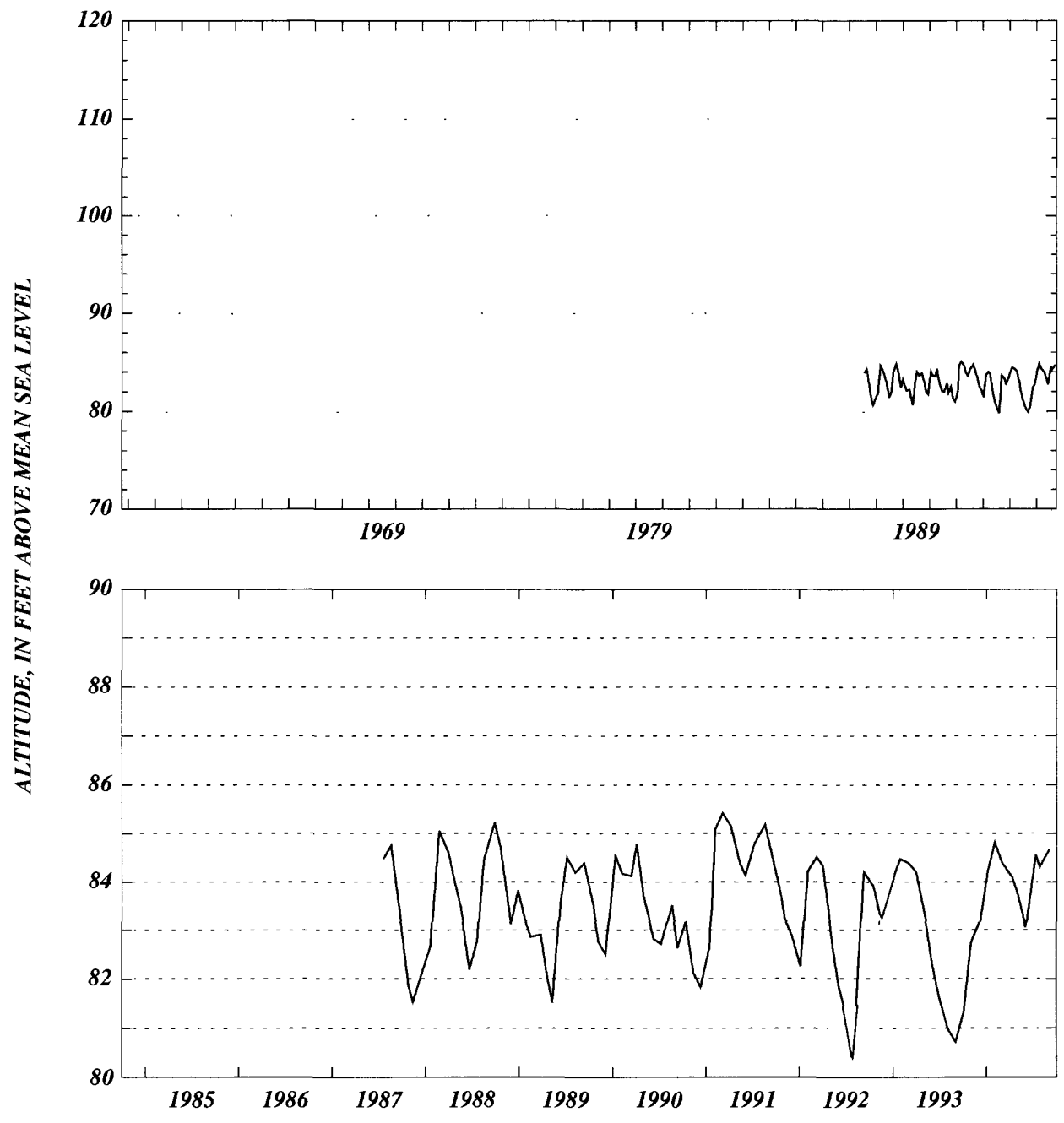



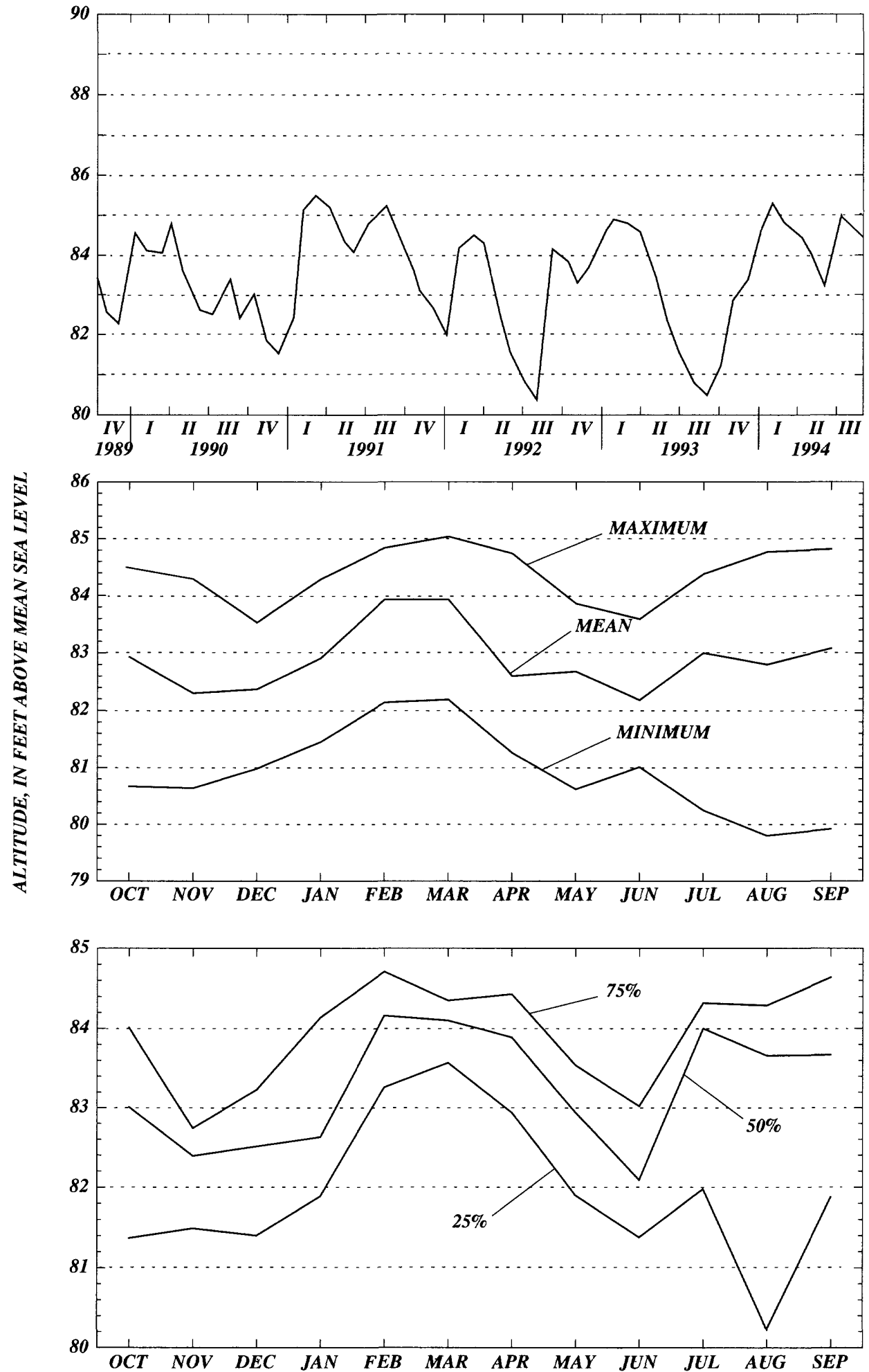
WELL NUMBER.--300436083191785. Procter and Gamble. -051004001.

LOCATION.--Lat 3004'36", long 8319'17', Hydrologic Unit Code 03110102.

AQUIFER.--Upper Floridan aquifer of the Tertiary system, Geologic Unit Code 120FLRD.

WELL CHARACTERISTICS.--Casing diameter 3 in., Casing depth $26 \mathrm{ft}$., Total depth $46 \mathrm{ft}$.

INSTRUMENTATION.--Elevation of Measuring Point $88.44 \mathrm{ft}$., NGVD.

DATUM.--The National Geodetic Vertical Datum of 1929.

PERIOD OF RECORD.--07-22-1987 to 09-30-1994.

EXTREME VALUES.--Maximum observed, 85.04 ft. (03-07-1991); minimum observed, $79.80 \mathrm{ft}$. (08-03-1992).

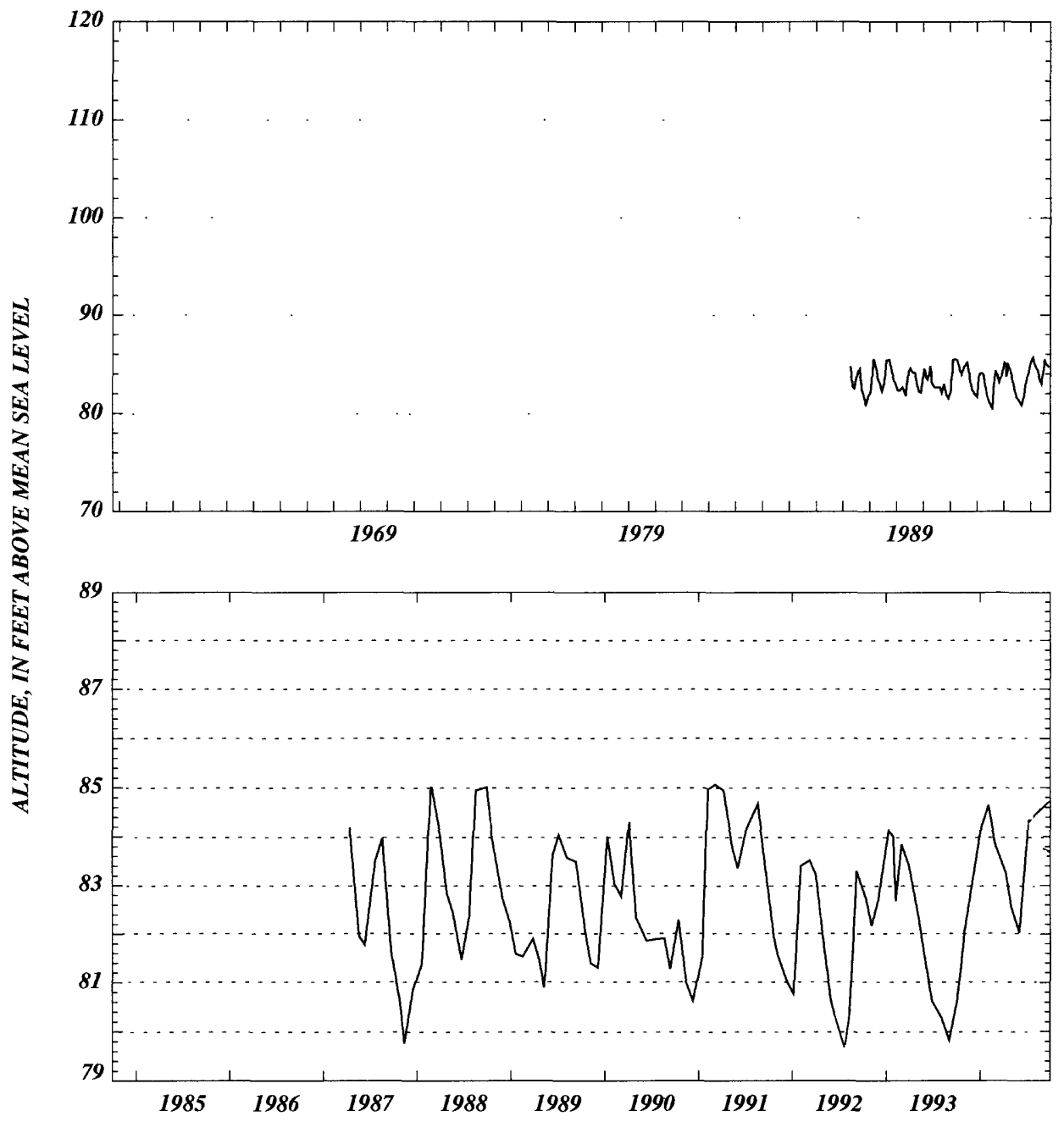



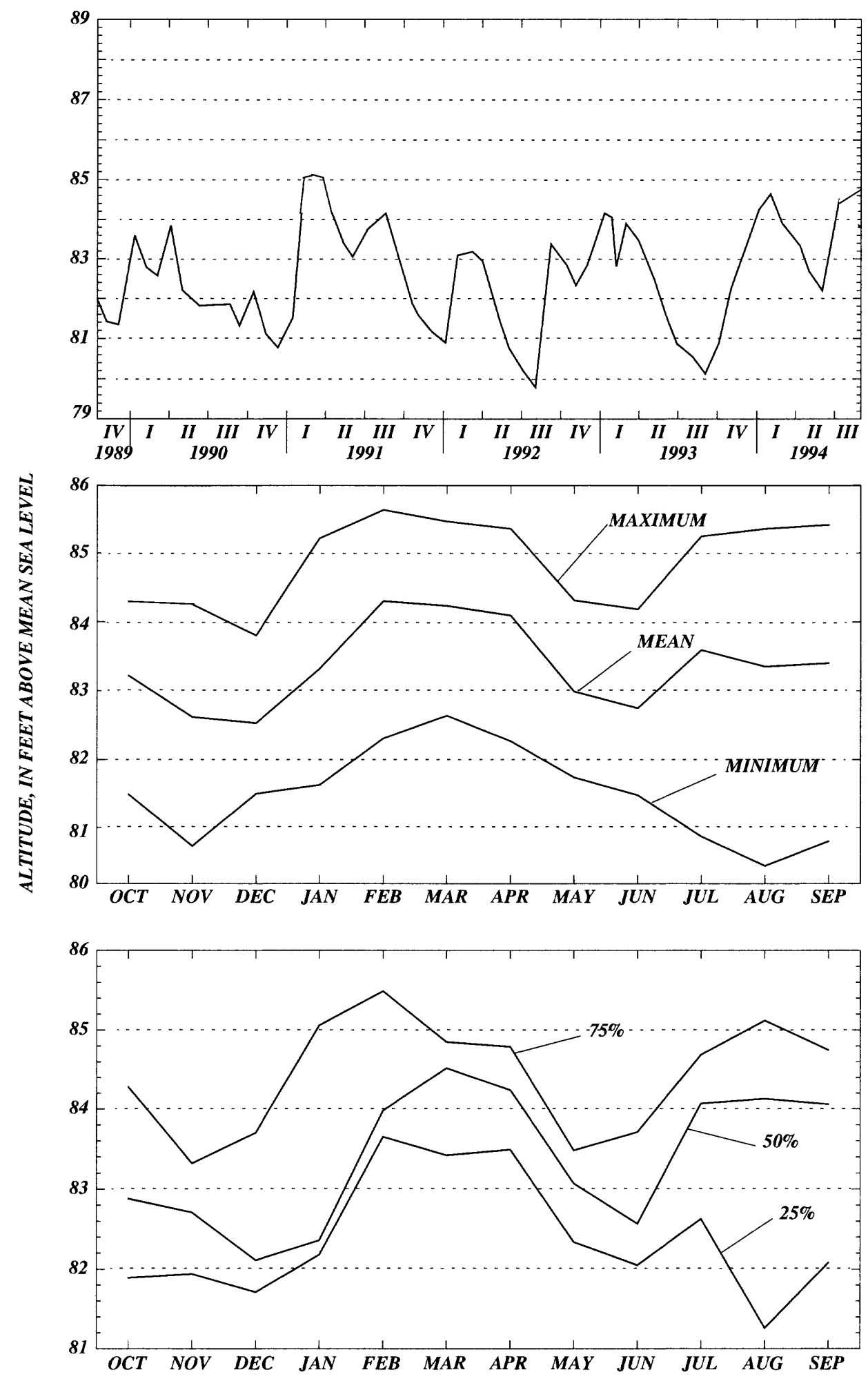


\section{Lafayette County}

WELL NUMBER.--300443083075585. Jeffery Koerner. -051205001.

LOCATION.--Lat 30 04'43”, long 8307'55”, Hydrologic Unit Code 03110205.

AQUIFER.--Upper Floridan aquifer of the Tertiary system, Geologic Unit Code 120FLRD.

WELL CHARACTERISTICS.--Casing diameter 4 in., Casing depth $56 \mathrm{ft}$., Total depth $86 \mathrm{ft}$.

INSTRUMENTATION.--Elevation of Measuring Point $75.71 \mathrm{ft} .$, NGVD.

DATUM.--The National Geodetic Vertical Datum of 1929.

PERIOD OF RECORD.--11-01-1976 to 09-30-1994.

EXTREME VALUES.--Maximum observed, 41.92 ft. (04-24-1984); minimum observed, $15.63 \mathrm{ft}$. $(11-18-1987)$

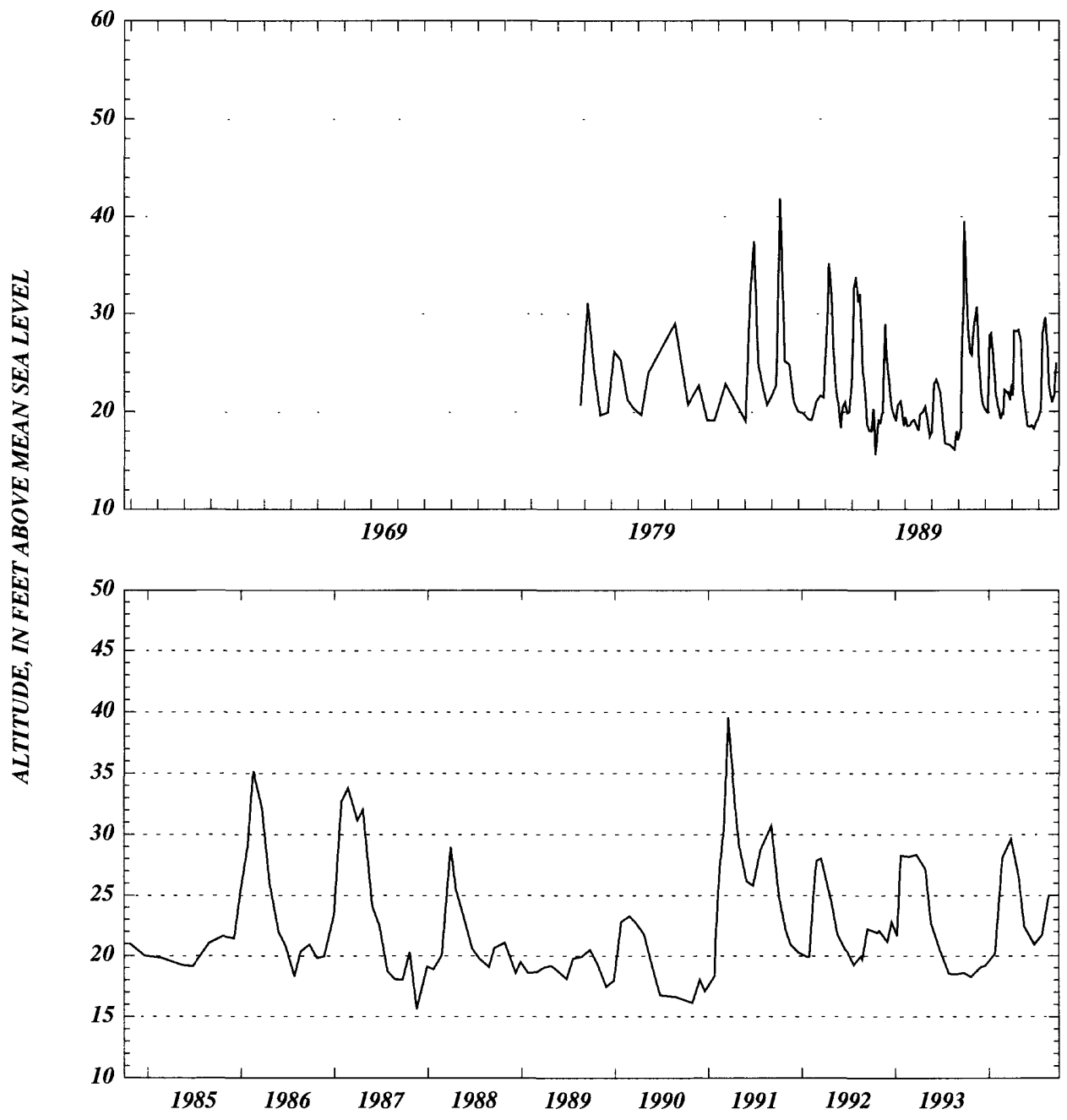



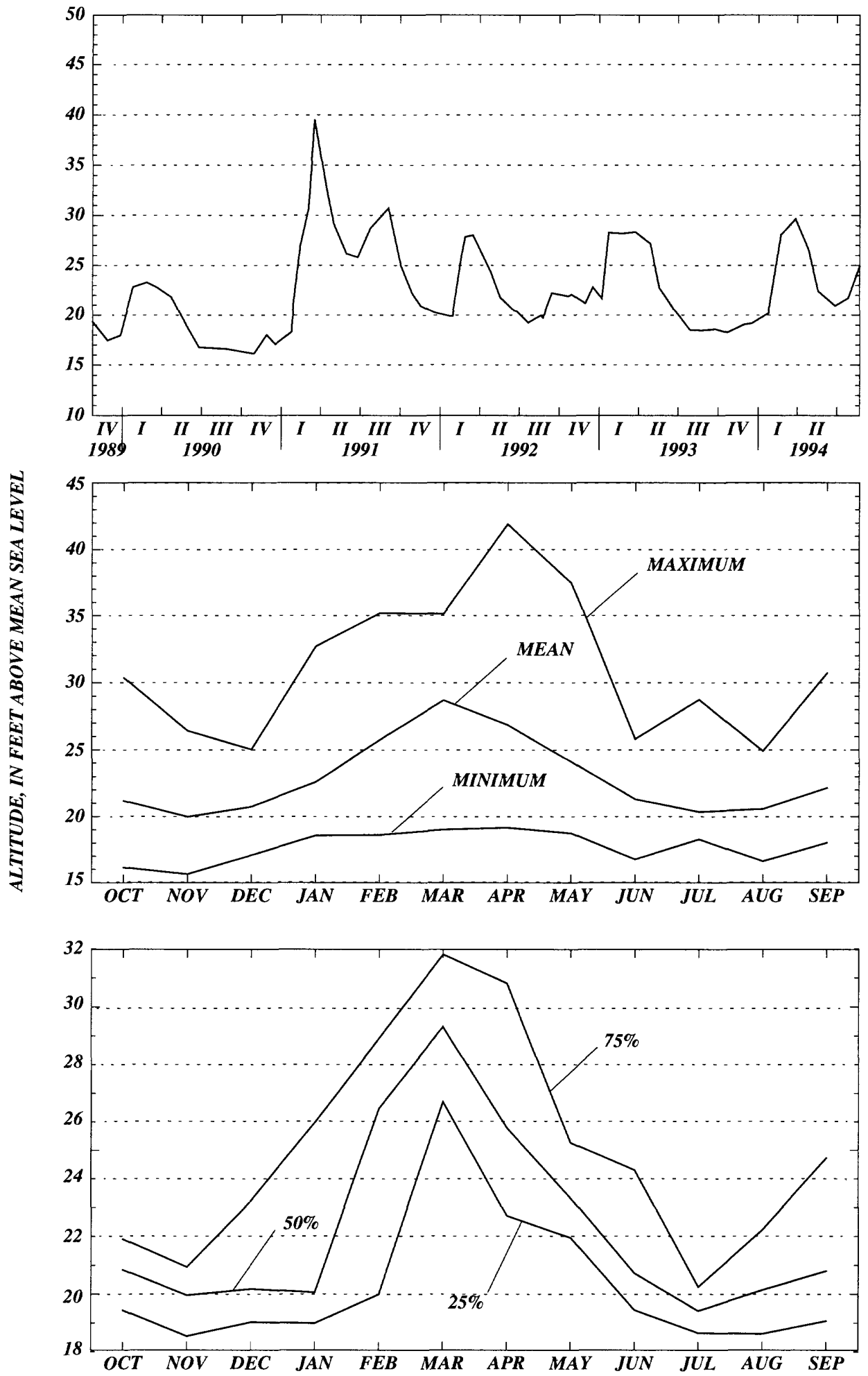


\section{Lafayette County.}

WELL NUMBER.--300823083175985. J.L. Prine. -041014001.

LOCATION.--Lat 3008'23”, long 8317'59”, Hydrologic Unit Code, 03110205.

AQUIFER.--Upper Floridan aquifer of the Tertiary system, Geologic Unit Code, 120FLRD.

WELL CHARACTERISTICS.--Casing diameter 10 in., Casing depth unknown, Total depth $106 \mathrm{ft}$. INSTRUMENTATION.--Elevation of measuring Point, 84.19 ft., NGVD.

DATUM.--The National Geodetic Vertical Datum of 1929.

PERIOD OF RECORD.--11-05-1964 -09-30-1994.

EXTREME VALUES.--Maximum observed, 66.87 ft. (11-05-1964); minimum observed, $35.44 \mathrm{ft}$. (03-05-1969).

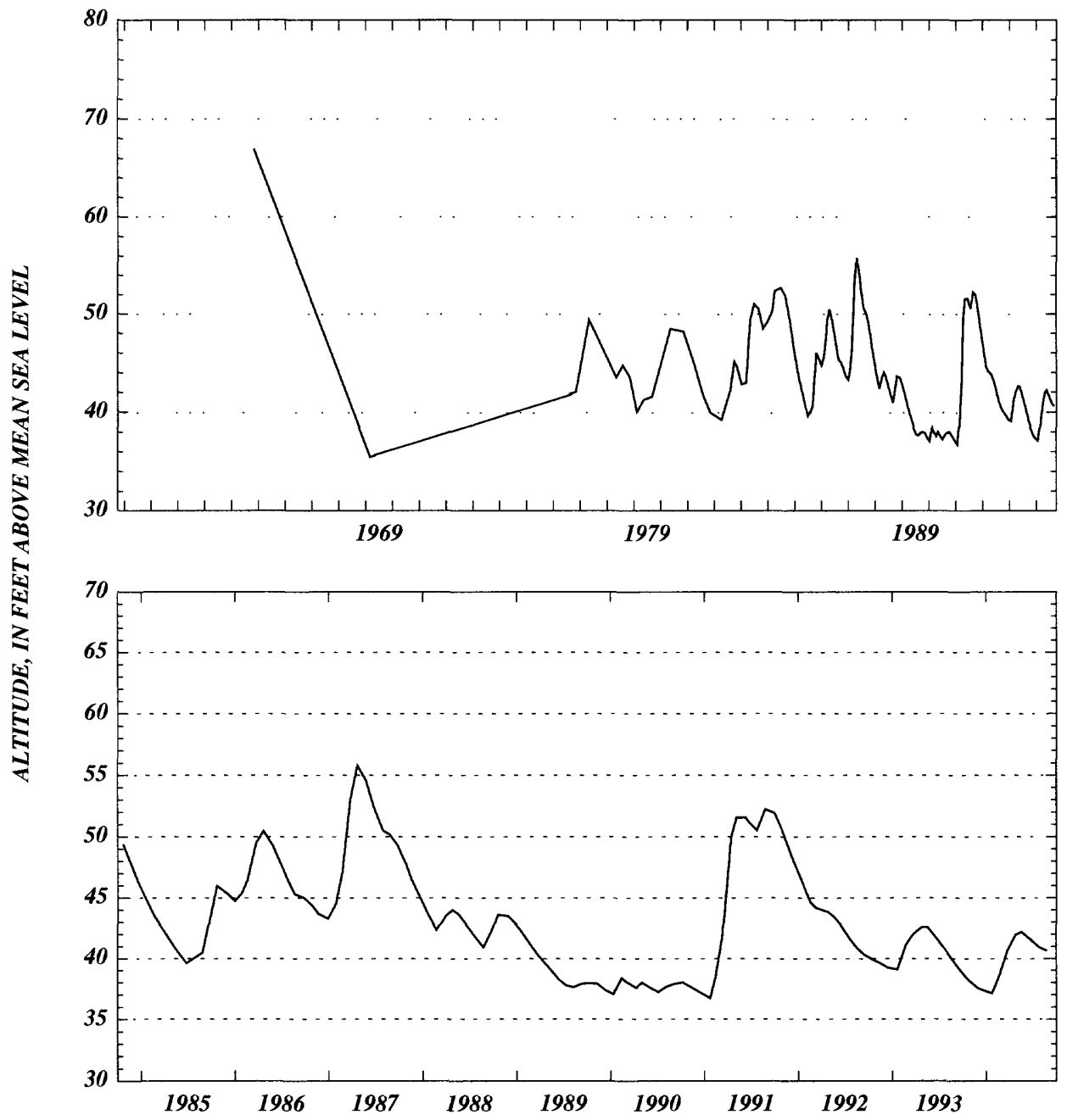




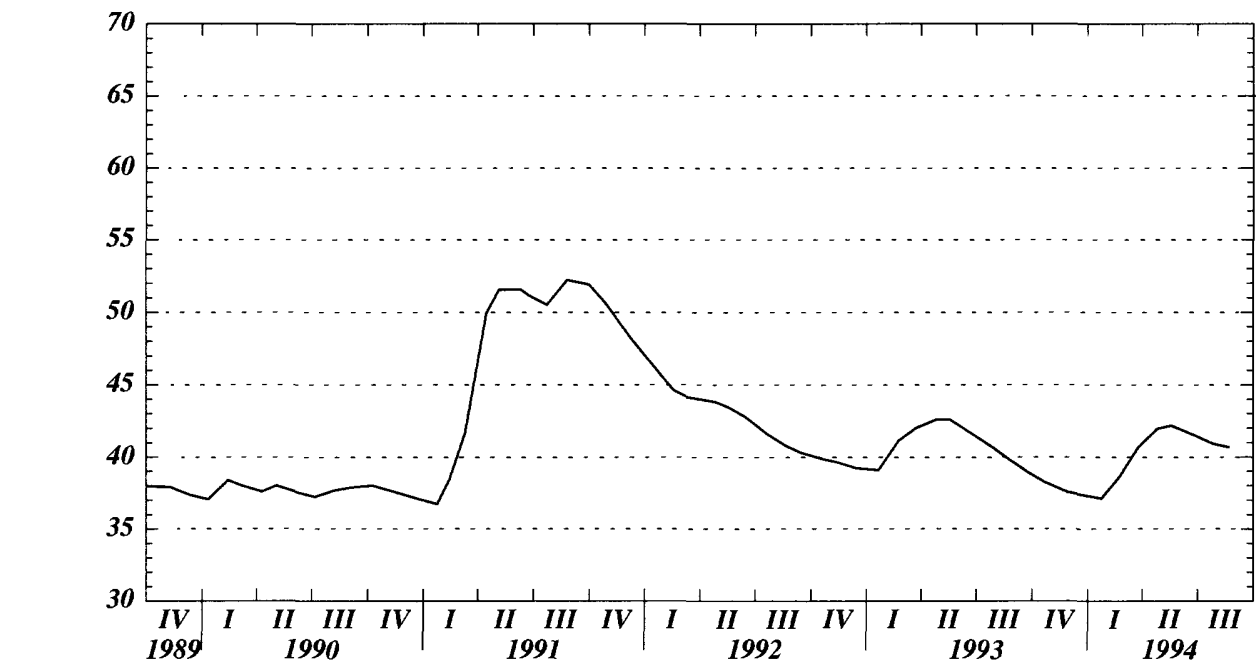

है
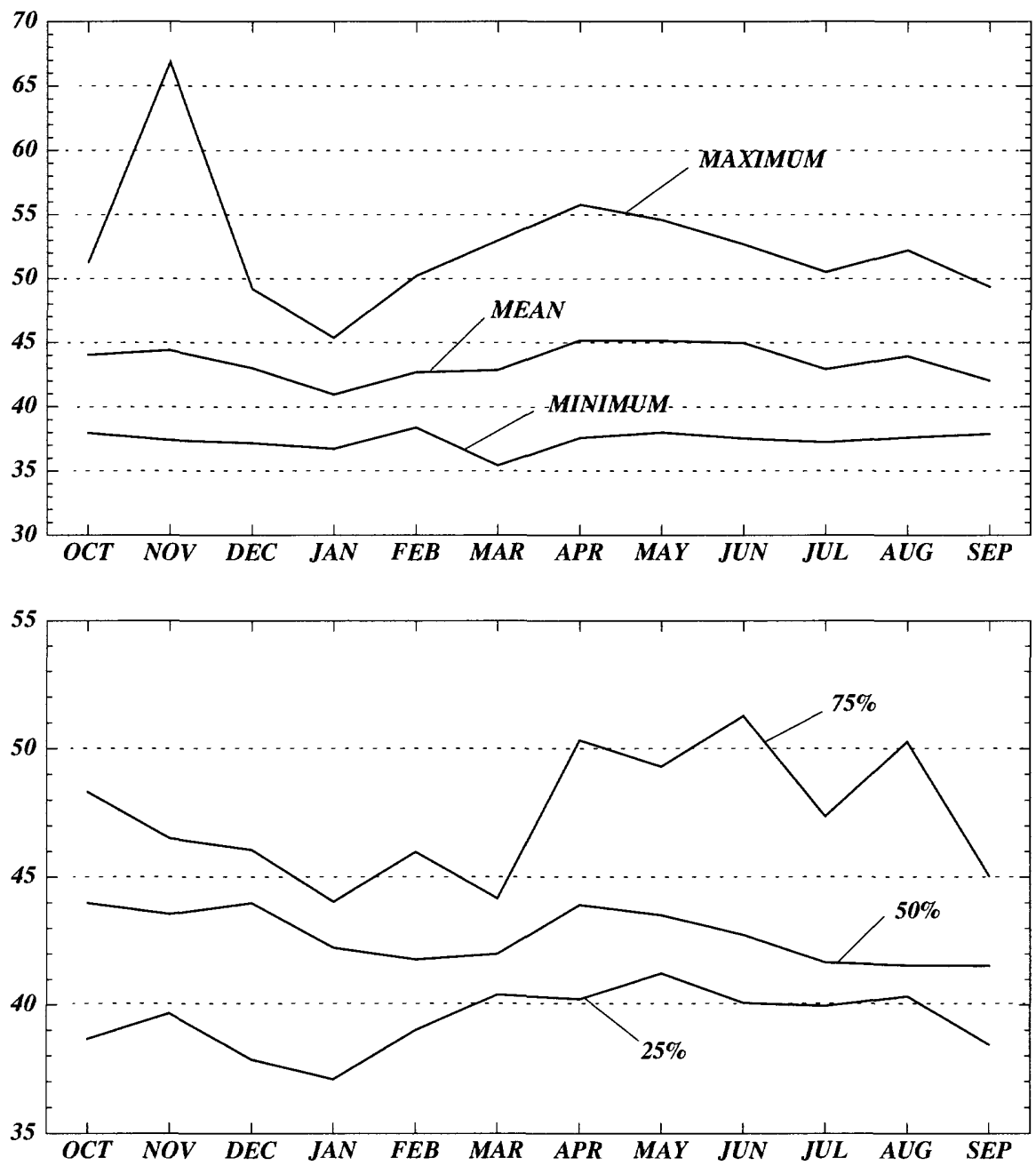


\section{Lafayette County}

WELL NUMBER.--301405083163085. Thedus Deas. -031012001.

LOCATION.--Lat 30 14'05”, long 83¹6'30', Hydrologic Unit Code 03110205.

AQUIFER.--Upper Floridan aquifer of the Tertiary system, Geologic Unit Code 120FLRD.

WELL CHARACTERISTICS.--Casing diameter 6 in., Dasing depth $30 \mathrm{ft}$., Total depth $72 \mathrm{ft}$.

INSTRUMENTATION.--Elevation of Measuring Point $83.02 \mathrm{ft}$., NGVD.

DATUM.--The National Geodetic Vertical Datum of 1929.

PERIOD OF RECORD.--11-01-1976 to 09-30-1994. *

EXTREME VALUES.--Maximum observed, $71.52 \mathrm{ft}$. (02-08-1977); minimum observed, $57.77 \mathrm{ft}$. (02-07-1979).

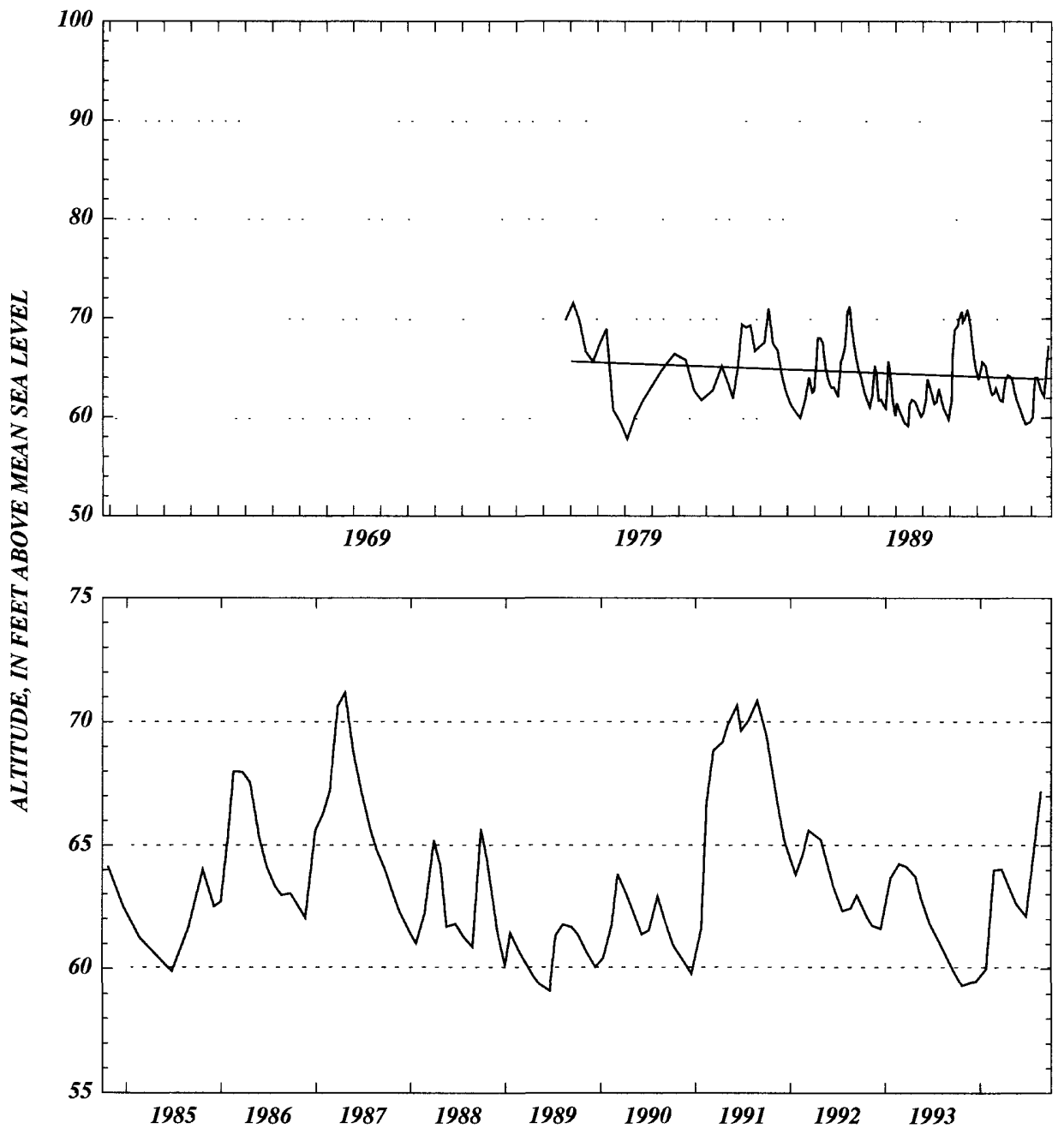



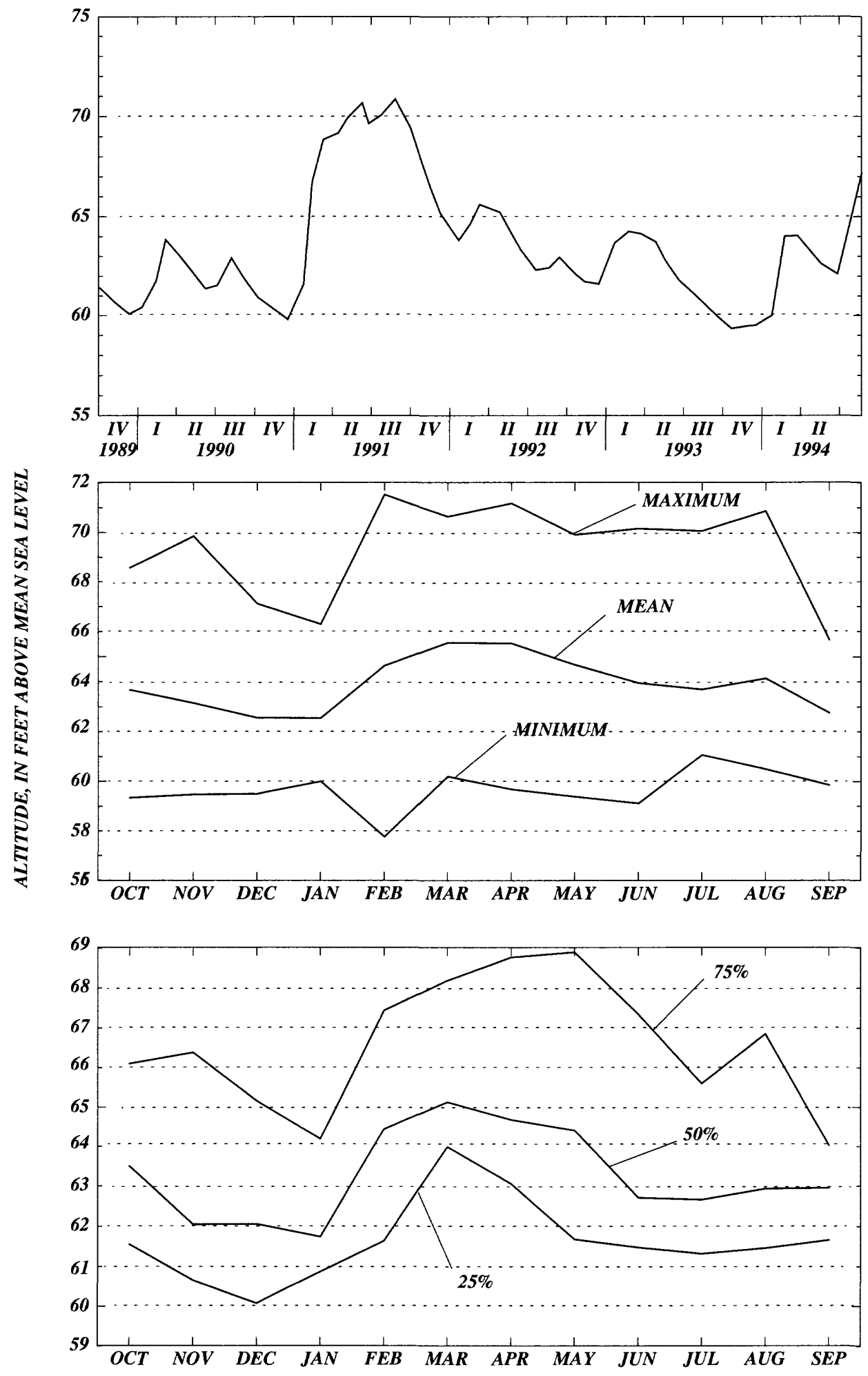


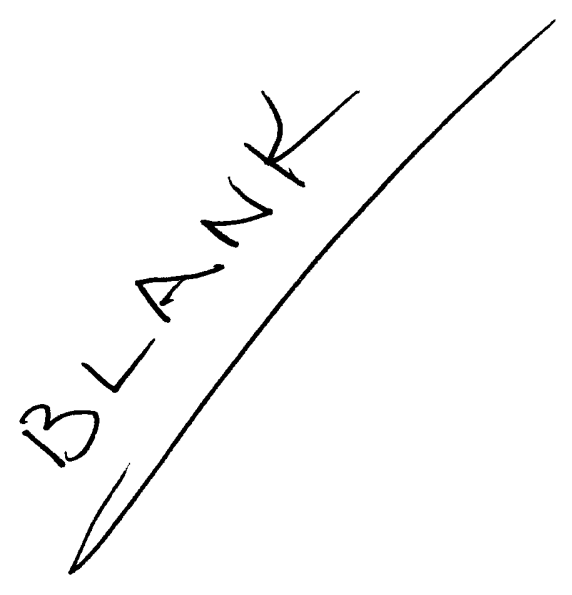




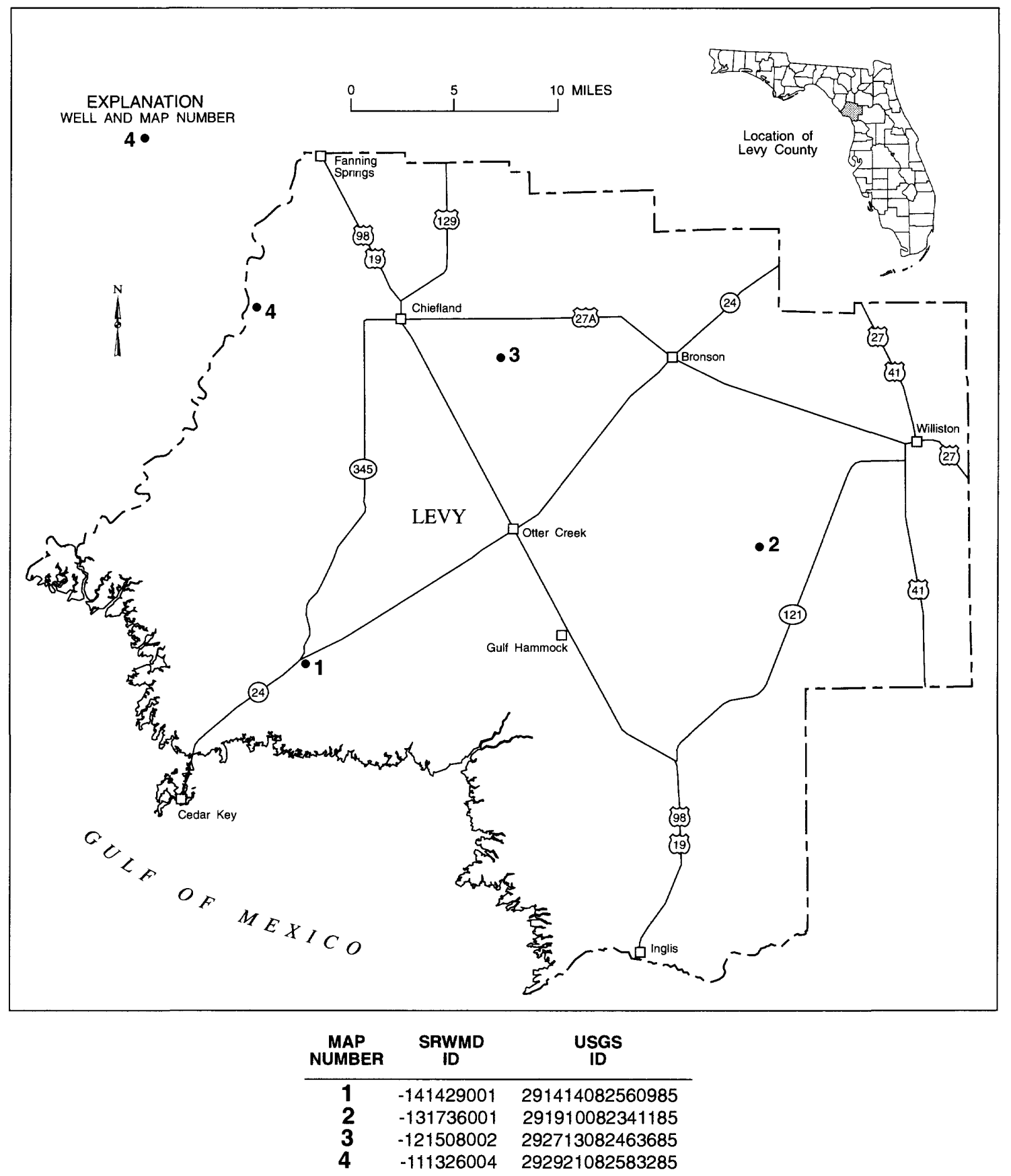

Figure 12. Location of wells in Levy County. 


\section{Levy County}

WELL NUMBER.--291414082560985. DOF - Cedar Key Tower. -141429001.

LOCATION.--Lat 29¹4'14', long 8256'09”, Hydrologic Unit Code 03110101.

AQUIFER.--Upper Floridan aquifer of the Tertiary system, Geologic Unit Code 120FLRD.

WELL CHARACTERISTICS.--Casing diameter 6 in., Casing depth $422 \mathrm{ft}$., Total depth $442 \mathrm{ft}$.

INSTRUMENTATION.--Recorder, set to elevation of Measuring Point $19.45 \mathrm{ft}$., NGVD.

DATUM.--The National Geodetic Vertical Datum of 1929.

PERIOD OF RECORD.--10-24-1975 to 09-30-94. *

EXTREME VALUES.--Maximum, 11.78 ft. (12-07-1981); minimum 8.59 ft. (07-19-1981).

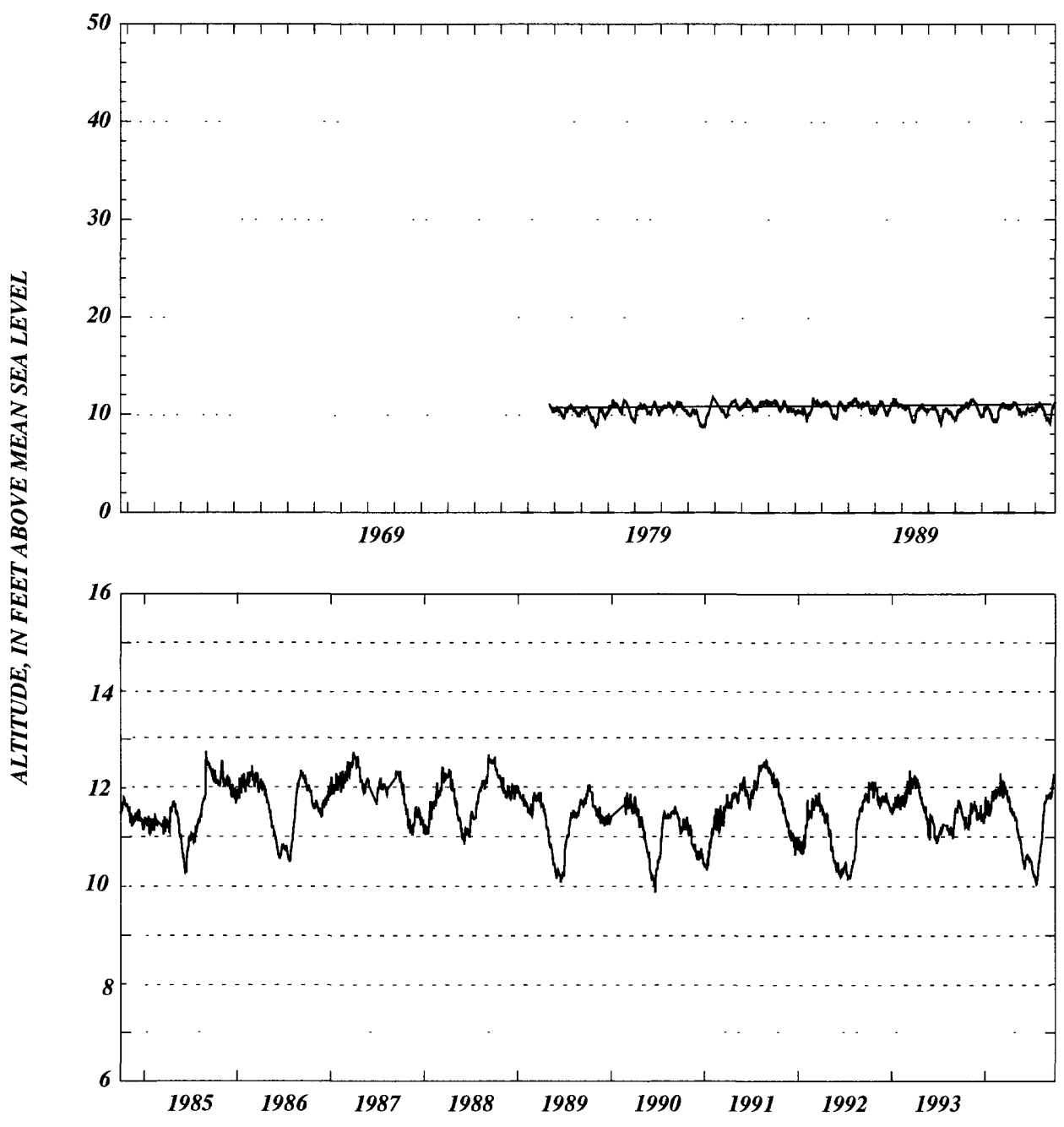



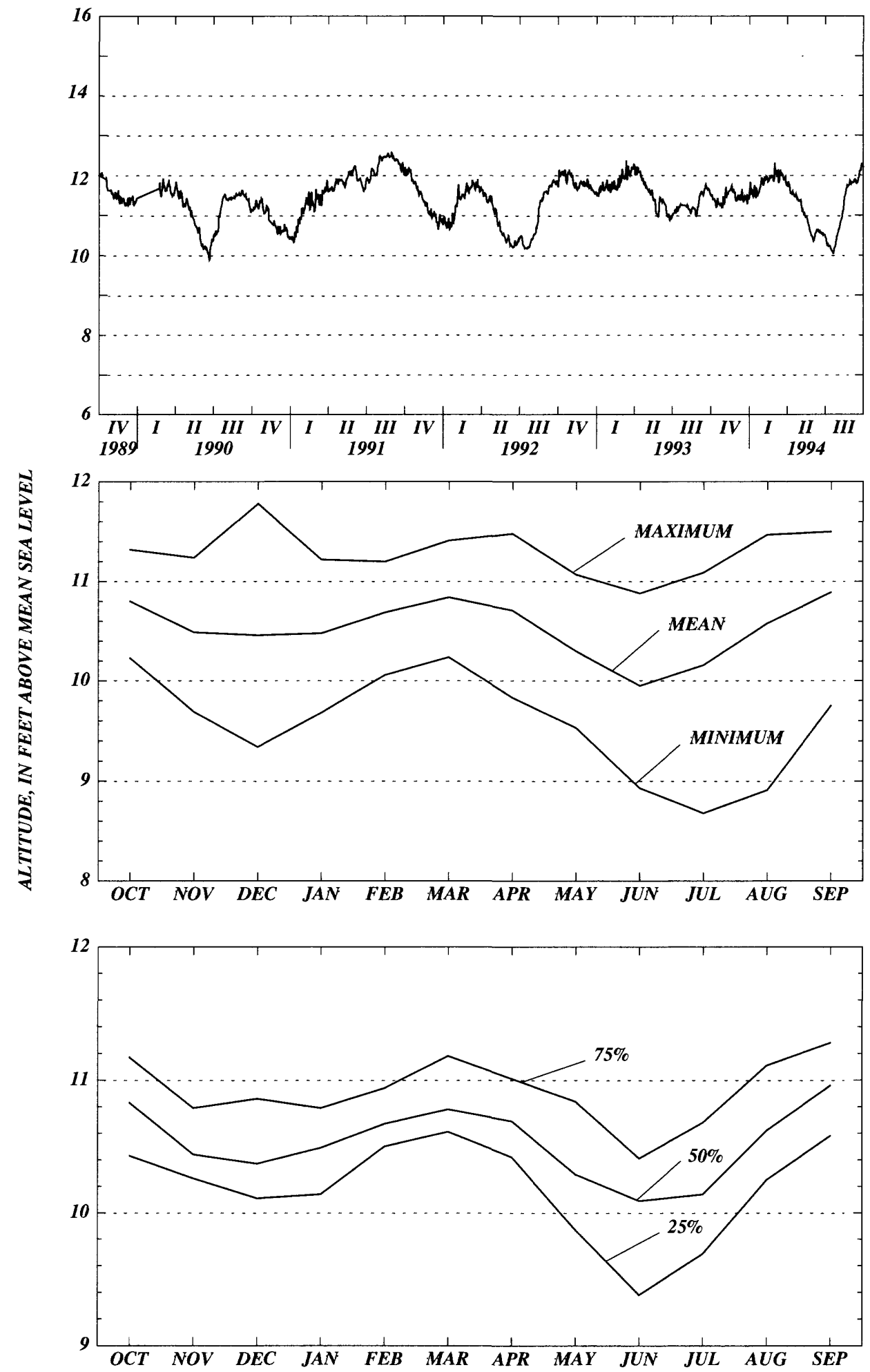


\section{Levy County}

WELL NUMBER.--291910082341185. USGS - near Bronson. -131736001.

LOCATION.--Lat 29¹9'10", long 82³4'11”, Hydrologic Unit Code 03080102.

AQUIFER.--Upper Floridan aquifer of the Tertiary system, Geologic Unit Code 120FLRD.

WELL CHARACTERISTICS.--Casing diameter 4 in., Casing depth $69 \mathrm{ft}$., Total depth $86 \mathrm{ft}$.

INSTRUMENTATION.--Recorder from 01-31-1977 to 07-01-1979; no record from 07-02-1979 to 10-07-1981; miscellaneous from 10-08-1981 to 04-05-1982; recorder from 04-06-1982 to 09-20-1994; elevation of the Measuring Point $94.30 \mathrm{ft}$., NGVD.

DATUM.--The National Geodetic Vertical Datum of 1929.

PERIOD OF RECORD.--01-31-1977 to 09-30-1994. *

EXTREME VALUES.--Maximum, 53.82 ft. (09-27-1988); minimum, 40.82 ft. (02-27-1990).

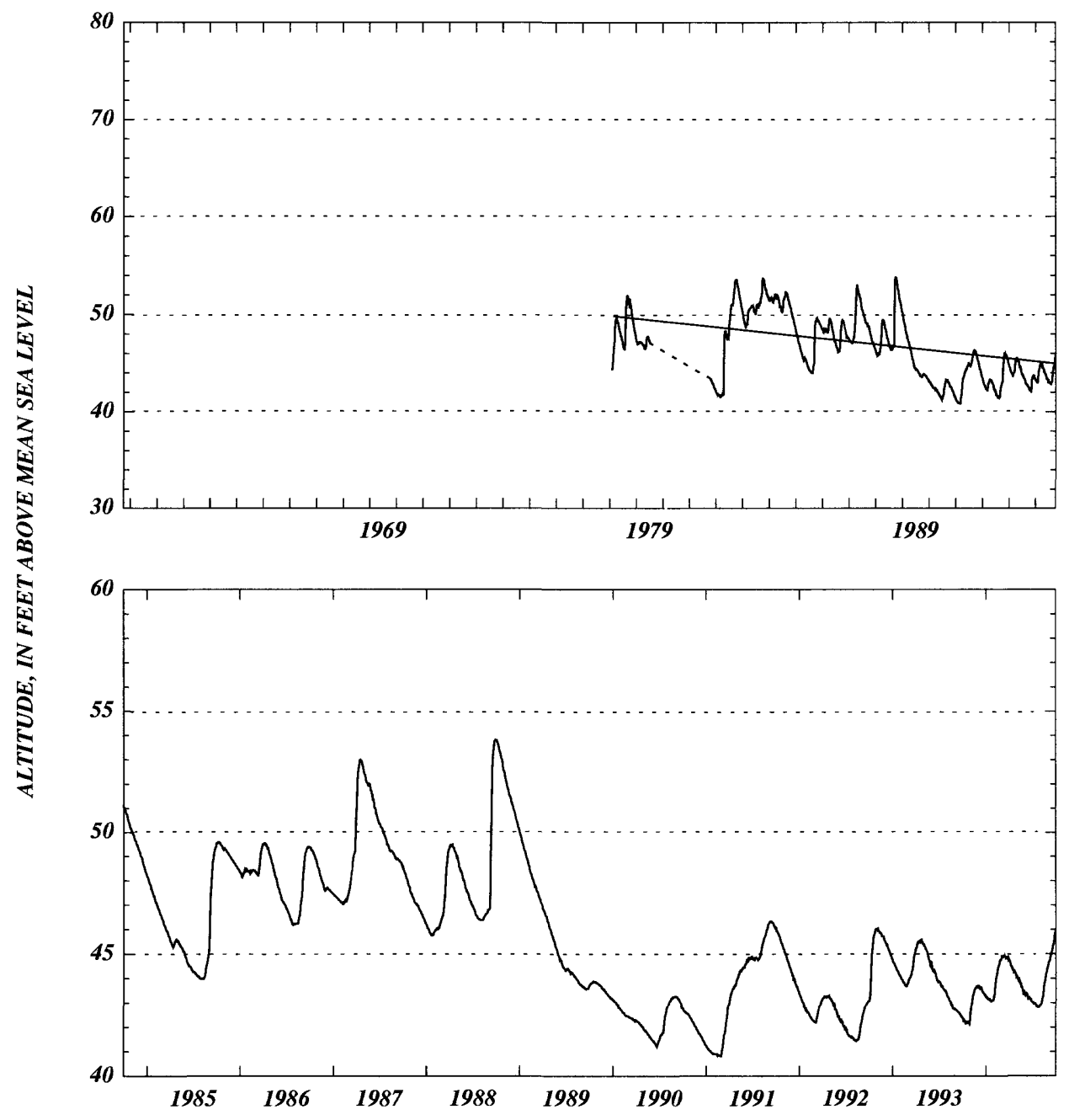



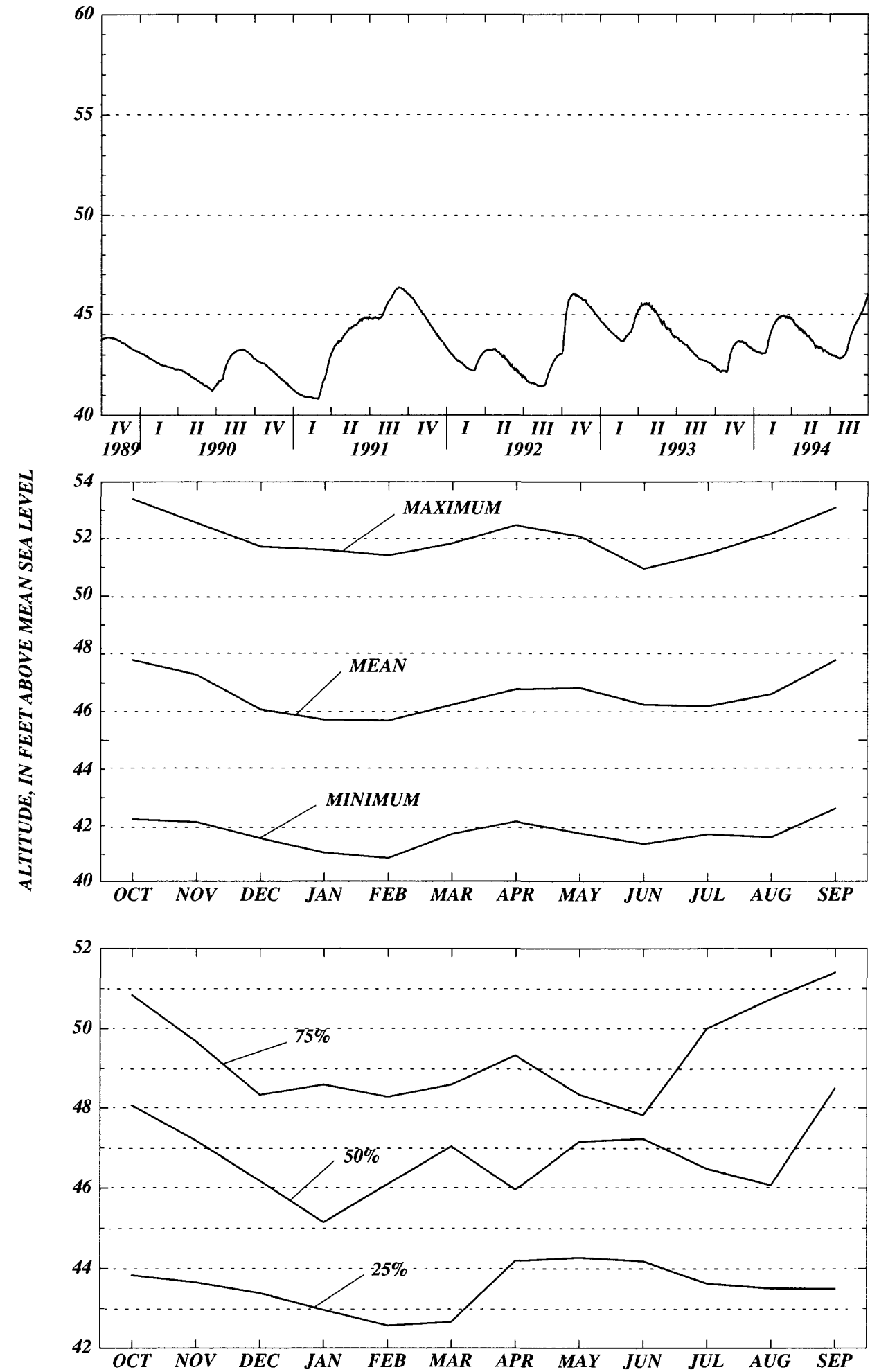
WELL NUMBER.--292713082493685. H.E. Mills. -121508002.

LOCATION.--Lat 29'27'13”, long 8249’36”, Hydrologic Unit Code 03110205.

AQUIFER.--Upper Floridan aquifer of the Tertiary system, Geologic Unit Code 120FLRD.

WELL CHARACTERISTICS.--Casing diameter 10 in., Casing depth $20 \mathrm{ft}$., Total depth $30 \mathrm{ft}$.

INSTRUMENTATION.--Recorder, set to elevation of the Measuring Point $34.93 \mathrm{ft}$., NGVD.

DATUM.--The National Geodetic Vertical Datum of 1929.

PERIOD OF RECORD.--10-02-1981 to 09-30-1994.

EXTREME VALUES.--Maximum, 34.21 ft. (03-30-1987); minimum, 20.88 ft. (01-24-1991).

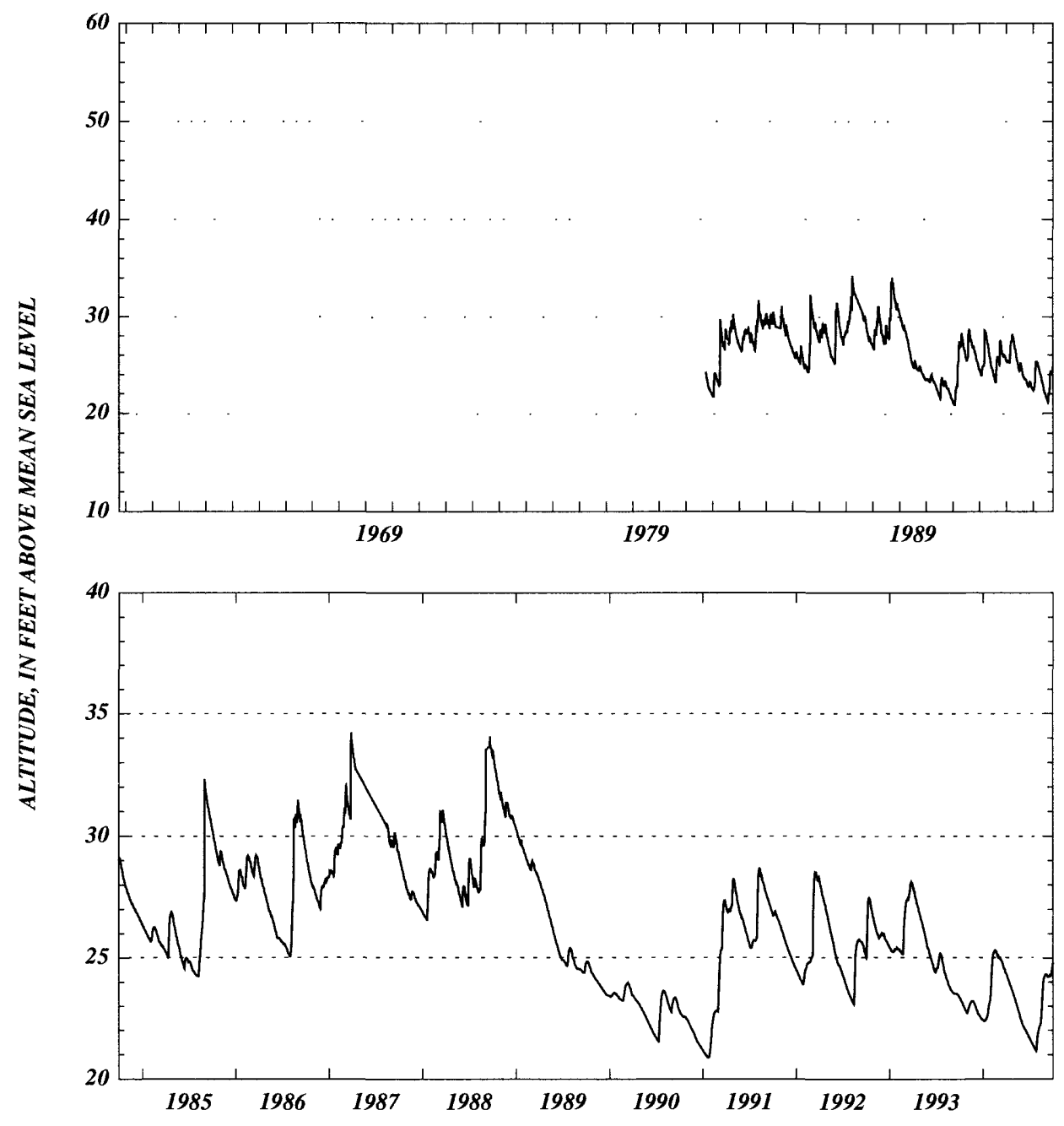




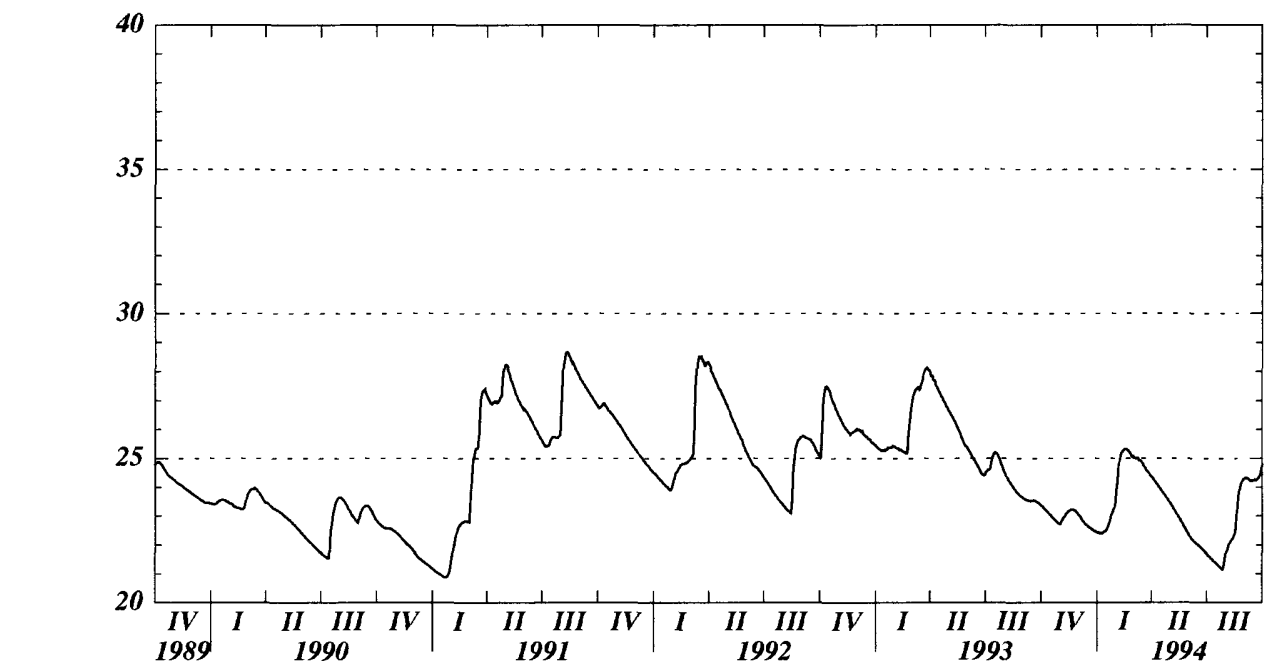


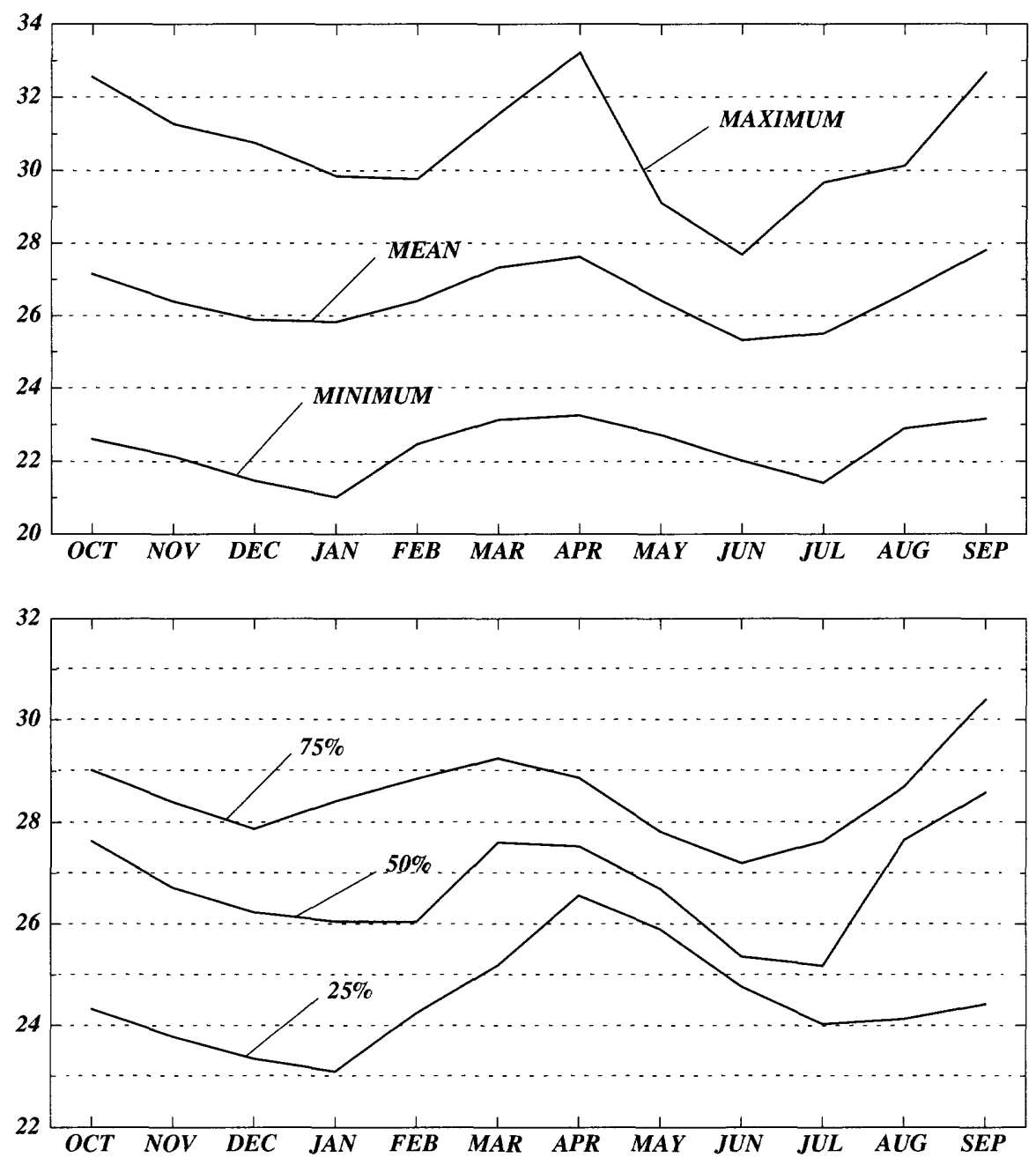
WELL NUMBER.--292921082583285. DNR - Manatee Springs State Park. -111326004.

LOCATION.--Lat 29²9'21”, long 8258'32”, Hydrologic Unit Code 03110205.

AQUIFER.--Upper Floridan aquifer of the Tertiary system, Geologic Unit Code 120FLRD. WELL CHARACTERISTICS.--Casing diameter 6 in., Casing depth $58 \mathrm{ft}$., Total depth $99 \mathrm{ft}$. INSTRUMENTATION.--Recorder, set to elevation of the Measuring Point $16.66 \mathrm{ft}$., NGVD. DATUM.--The National Geodetic Vertical Datum of 1929.

PERIOD OF RECORD.--10-01-1981 to 09-30-1994.

EXTREME VALUES.--Maximum, 12.69 ft. (04-17-1984); minimum, 1.26 ft. (12-25-1990).

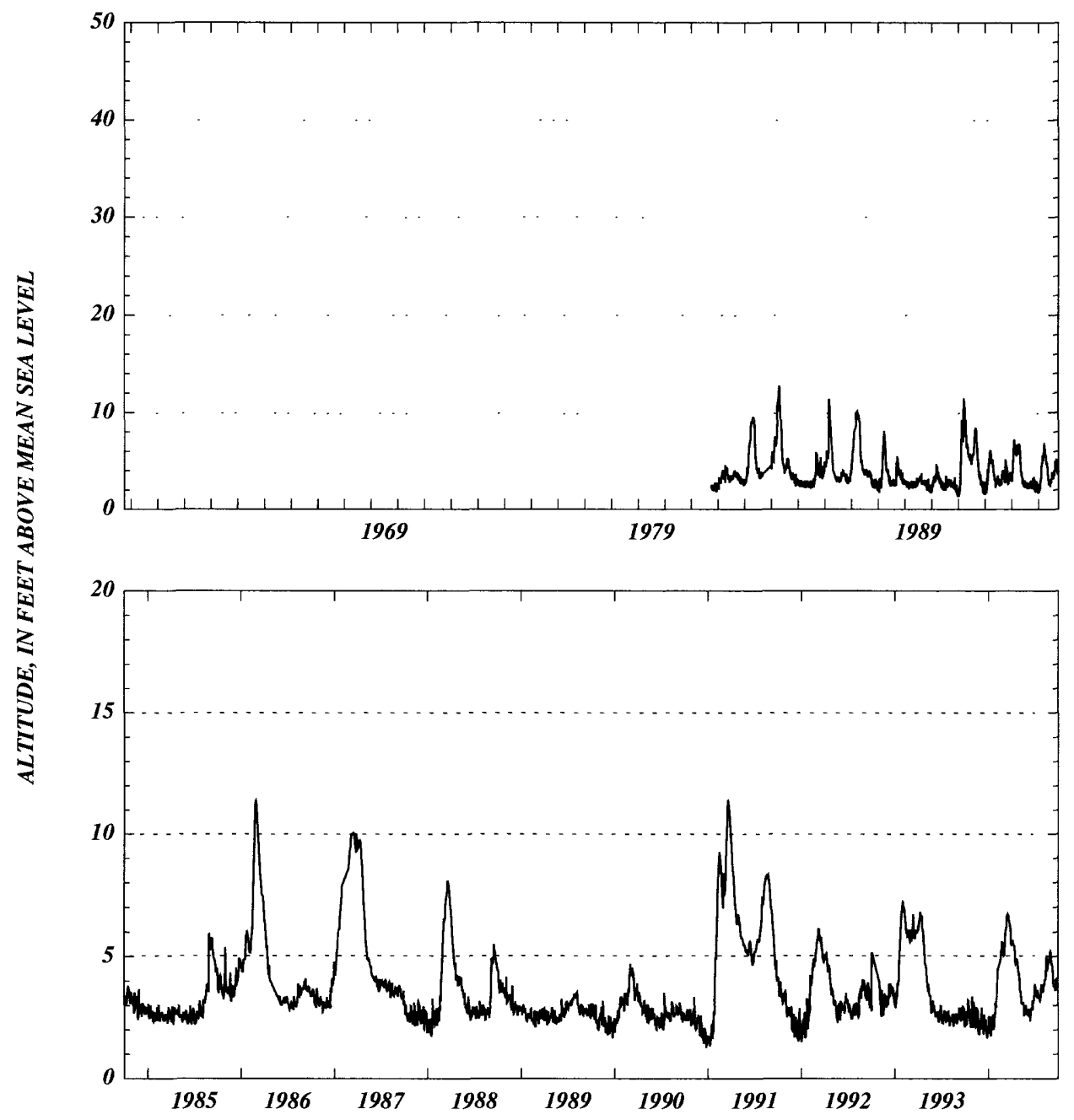




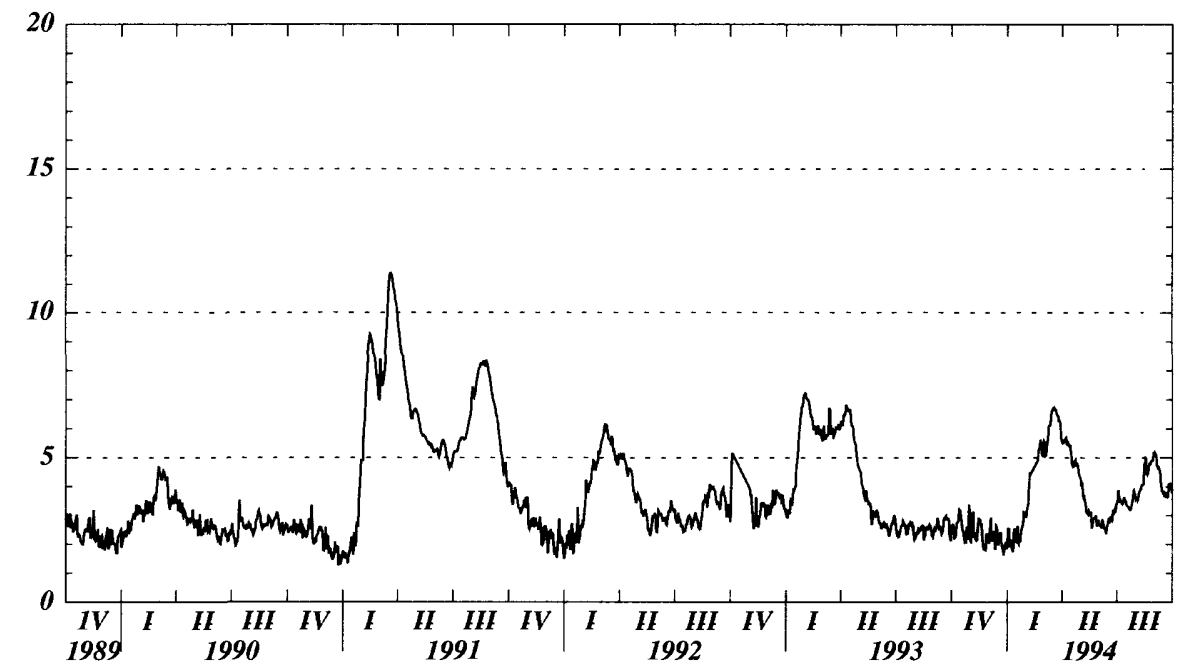


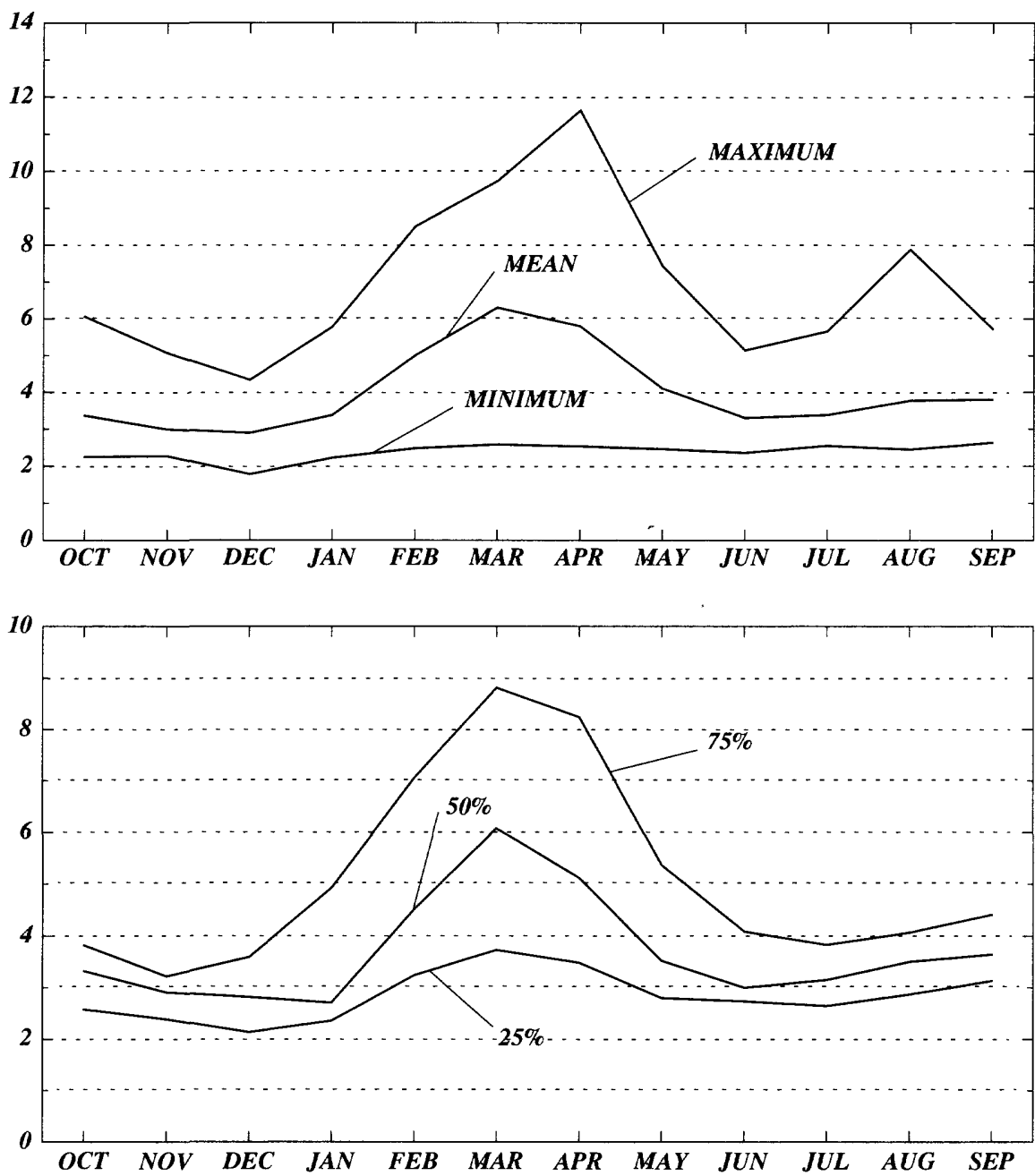


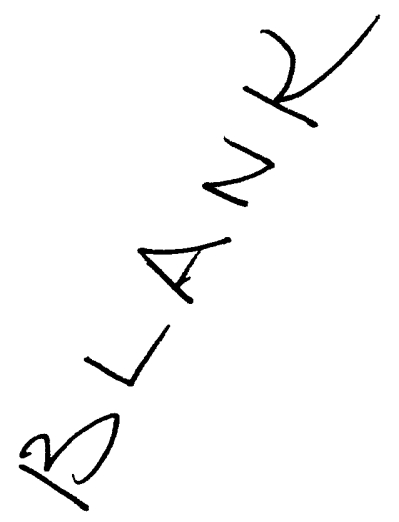




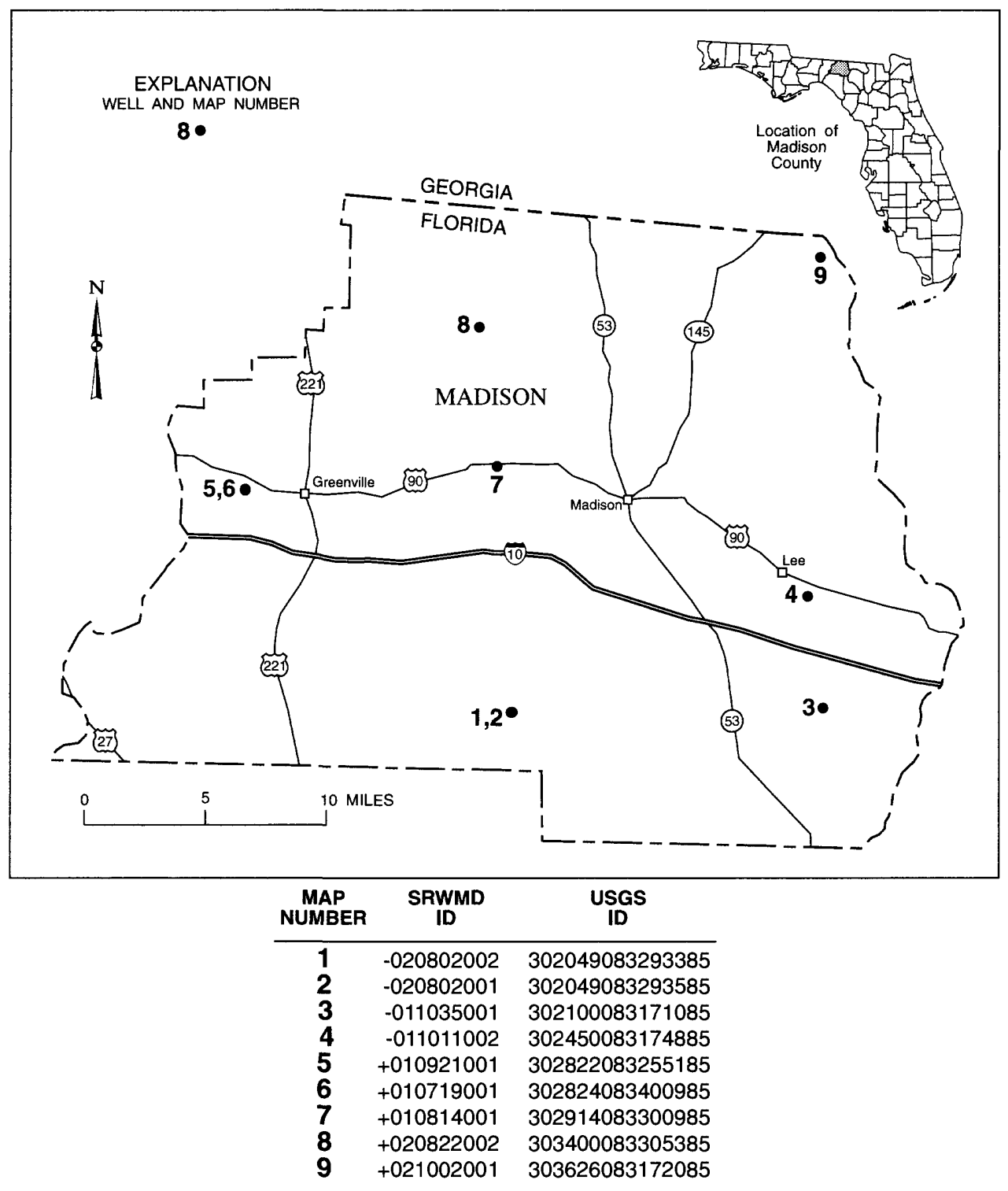

Figure 13. Location of wells in Madison County. 


\section{Madison County}

WELL NUMBER.--302049083293385. Procter and Gamble. -020802002.

LOCATION.--Lat 30²0'49”, long 83²9'33”, Hydrologic Unit Code 03110102.

AQUIFER.--Surficial aquifer, Geologic Unit Code 110NRSD.

WELL CHARACTERISTICS.--Casing diameter 3 in., Casing depth $2 \mathrm{ft}$., Total Depth $12 \mathrm{ft}$.

INSTRUMENTATION.--Elevation of Measuring Point $105.02 \mathrm{ft} .$, NGVD.

DATUM.--The National Geodetic Vertical Datum of 1929.

PERIOD OF RECORD.--04-15-1987 to 09-30-1994.

EXTREME VALUES.--Maximum observed, $101.82 \mathrm{ft}$, (03-13-1991); minimum observed, $92.25 \mathrm{ft}$. (11-12-1987).

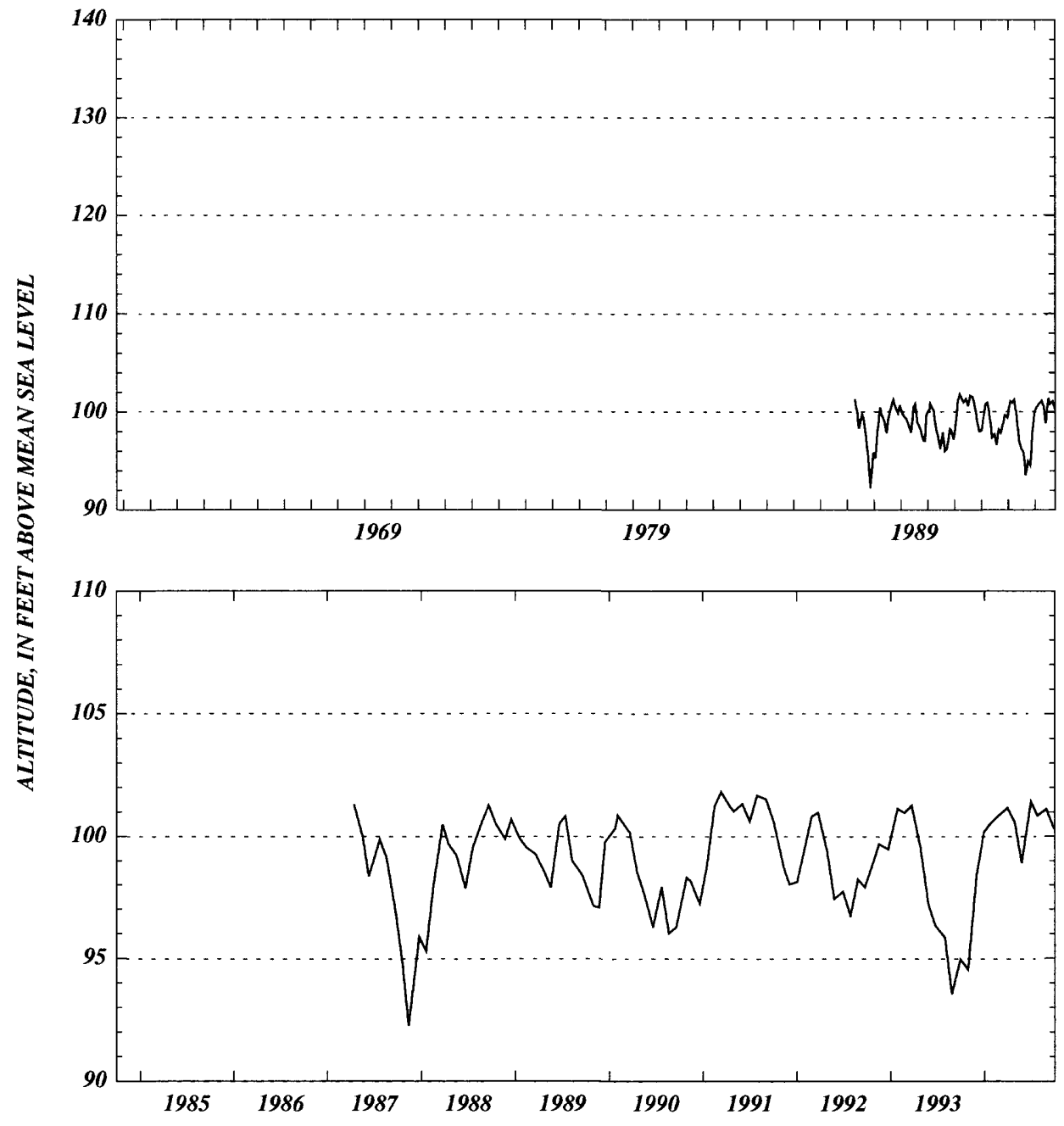



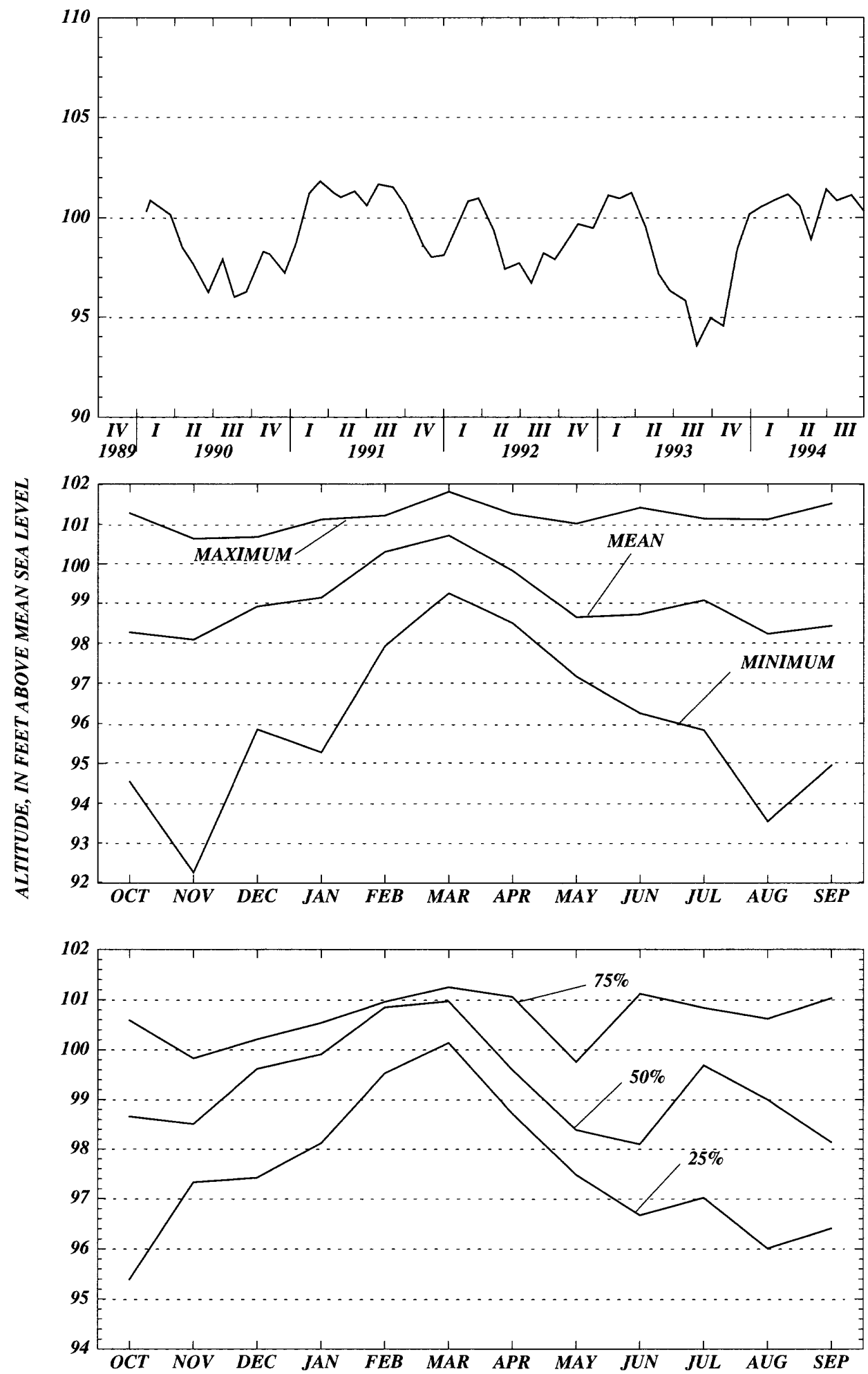


\section{Madison County}

WELL NUMBER.--302049083293585. Procter and Gamble. -020802001

LOCATION.--Lat 30²0’49”, long 83²9’35”, Hydrologic Unit Code 03110102.

AQUIFER.--Upper Floridan aquifer of the Tertiary system, Geologic Unit Code 120FLRD.

WELL CHARACTERISTICS.--Casing diameter 3 in., Casing depth $80 \mathrm{ft}$., Total depth $100 \mathrm{ft}$.

INSTRUMENTATION.--Elevation of Measuring Point $103.89 \mathrm{ft}$., NGVD.

DATUM.--The National Geodetic Vertical Datum of 1929.

PERIOD OF RECORD.--07-23-87 to 09-30-1994.

EXTREME VALUES.--Maximum observed, 94.29 ft. (09-03-1991); minimum observed, $81.33 \mathrm{ft}$. (10-28-1993).

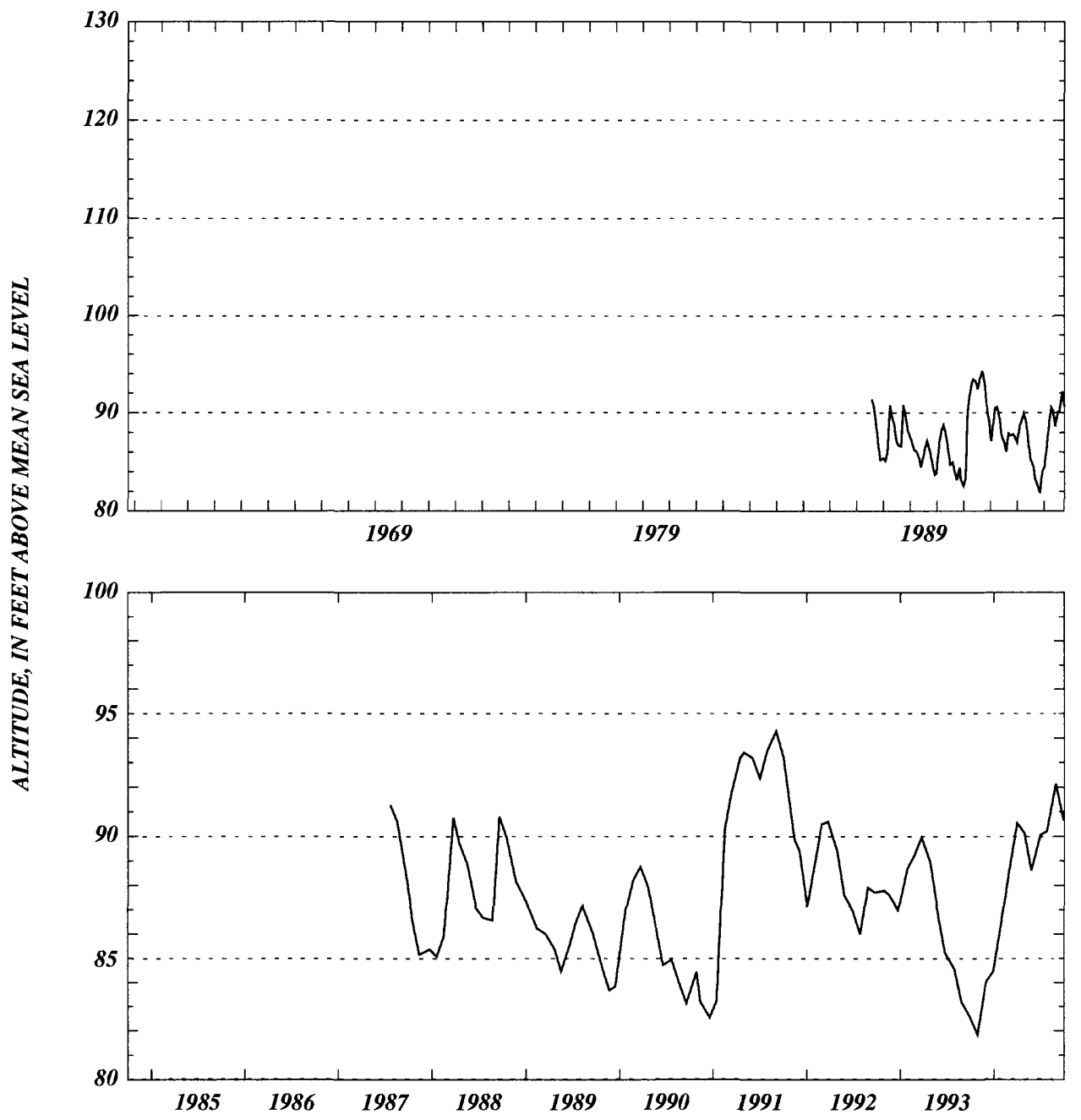



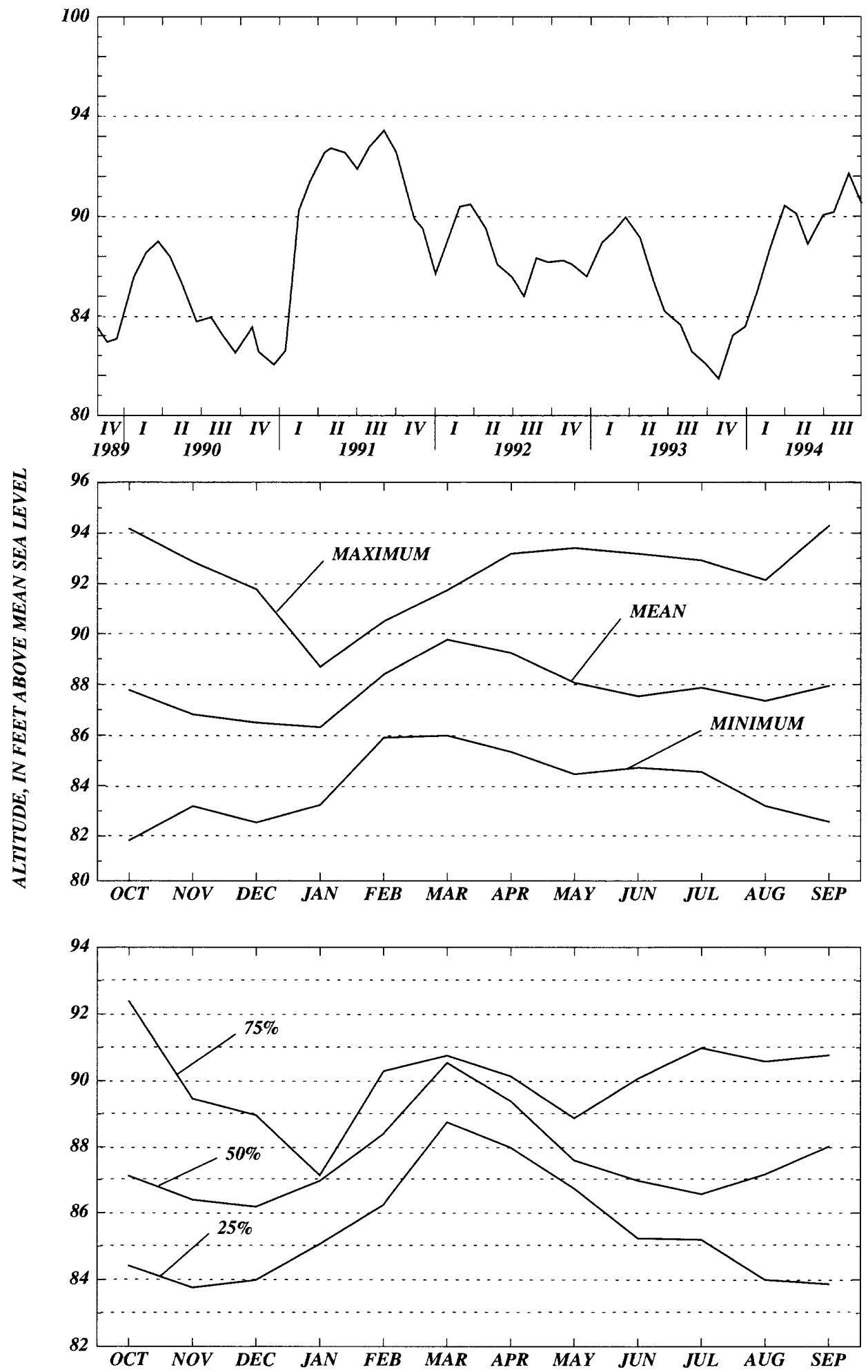


\section{Madison County}

WELL NUMBER.--302100083171085. Gene Norris. -011035001.

LOCATION.--Lat $30^{\circ} 21^{\prime} 00^{\prime \prime}$, long 8317'25', Hydrologic Unit Code 03110203.

AQUIFER.--Upper Floridan aquifer of the Tertiary system, Geologic Unit Code 120FLRD.

WELL CHARACTERISTICS.--Casing diameter 4 in., Casing depth $47 \mathrm{ft}$., Total depth $78 \mathrm{ft}$.

INSTRUMENTATION.--Elevation of Measuring Point $88.63 \mathrm{ft} .$, NGVD.

DATUM.--The National Geodetic Vertical Datum of 1929.

PERIOD OF RECORD.--11-01-1976 to 09-30-1994. *

EXTREME VALUES.--Maximum observed, 75.39 ft. (04-27-1987); minimum observed, $41.13 \mathrm{ft}$. (10-22-1990).

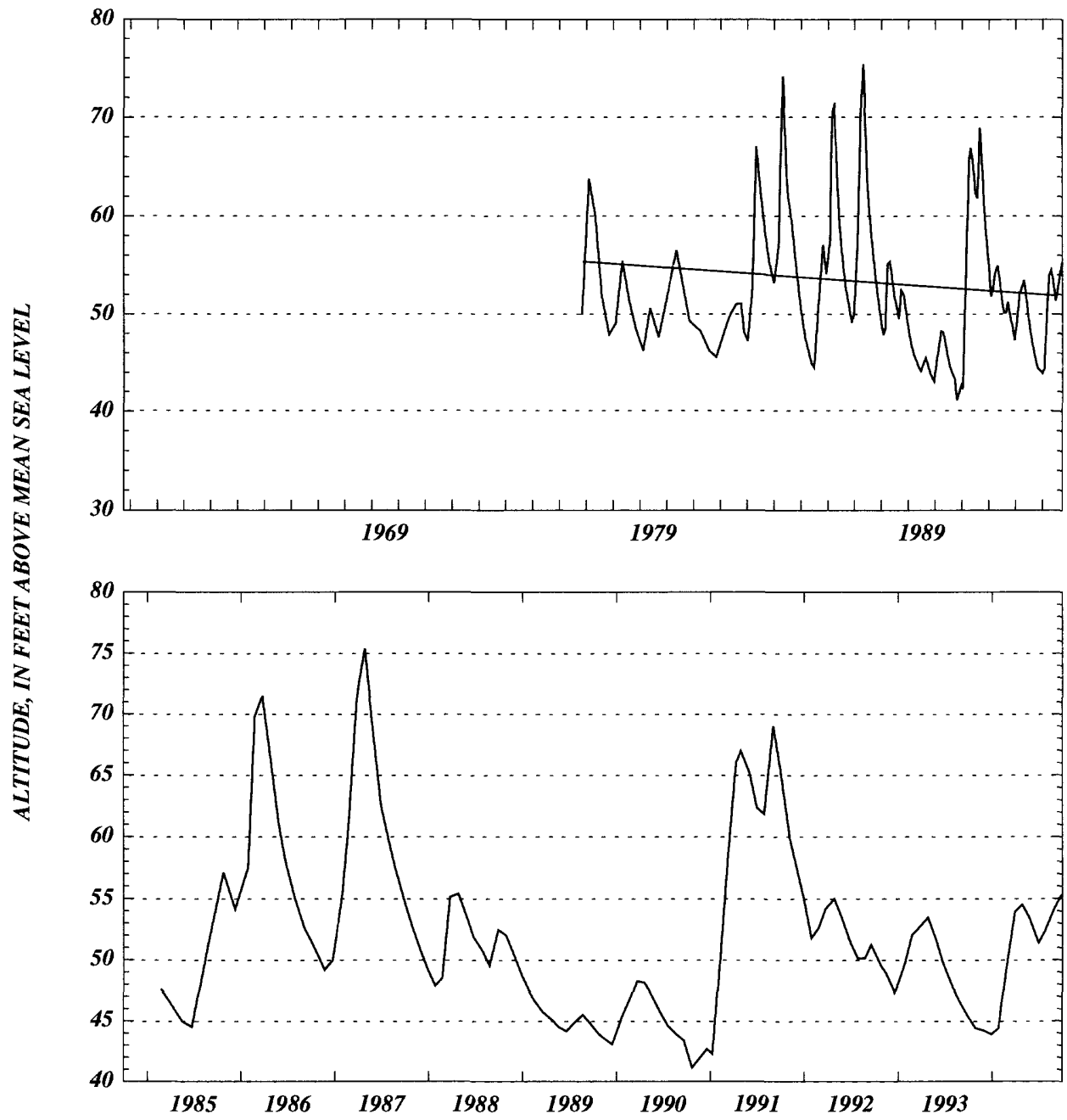



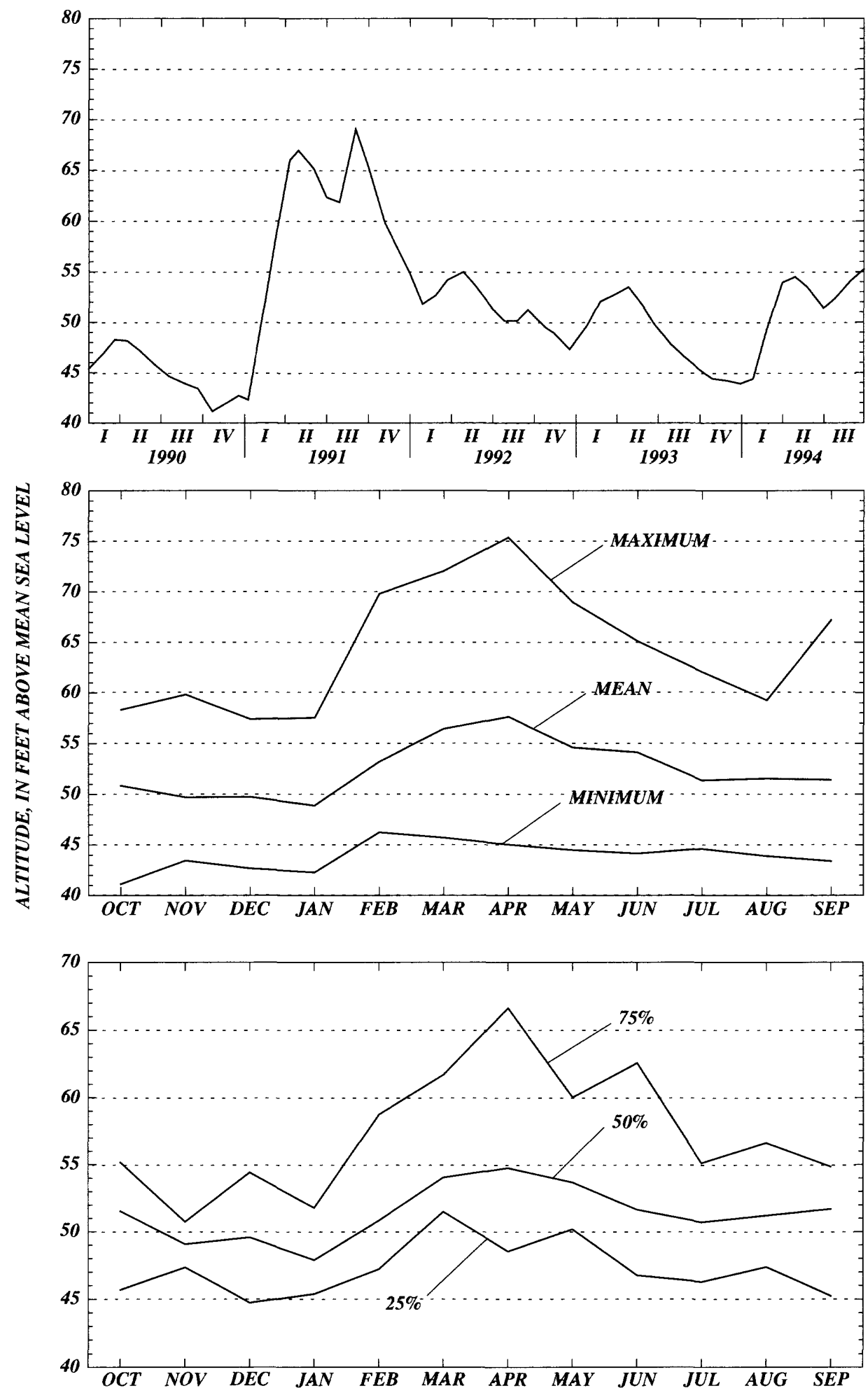


\section{Madison County}

WELL NUMBER.--302450083174885. Madison County School Board. -011011002.

LOCATION.--Lat 30²4'50”, long 8317’48”, Hydrologic Unit Code 03110203.

AQUIFER.--Upper Floridan aquifer of the Tertiary system, Geologic Unit Code 120FLRD.

WELL CHARACTERISTICS.--Casing diameter 3 in., Casing depth $58 \mathrm{ft}$., Total depth $78 \mathrm{ft}$.

INSTRUMENTATION.--Elevation of Measuring Point $80.49 \mathrm{ft}$., NGVD.

DATUM.--The National Geodetic Vertical Datum of 1929.

PERIOD OF RECORD.--03-21-1988 to 09-30-1994.

EXTREME VALUES.--Maximum observed, 69.21 ft. (09-04-1991); minimum observed $41.23 \mathrm{ft}$. (01-10-1991).

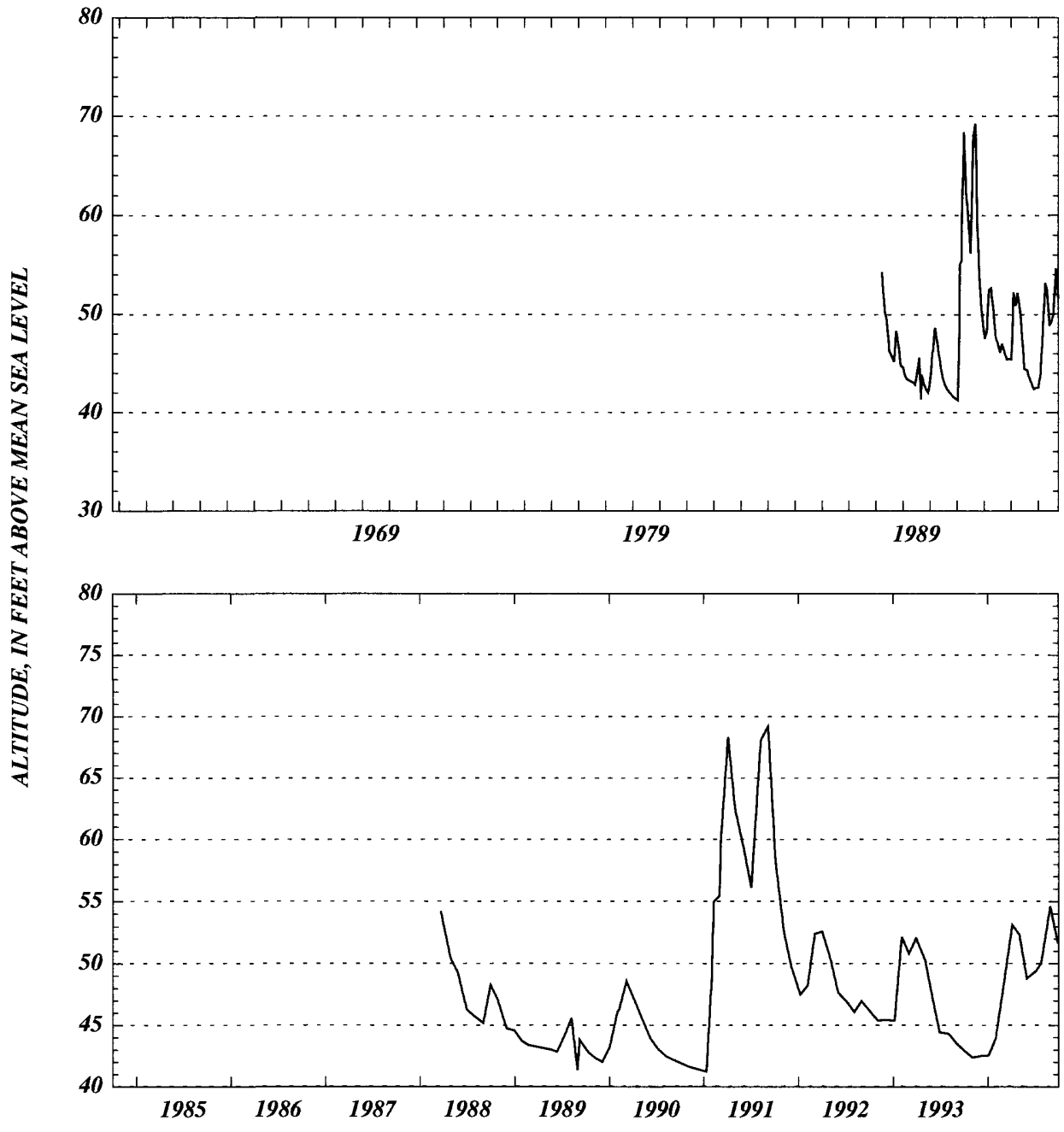



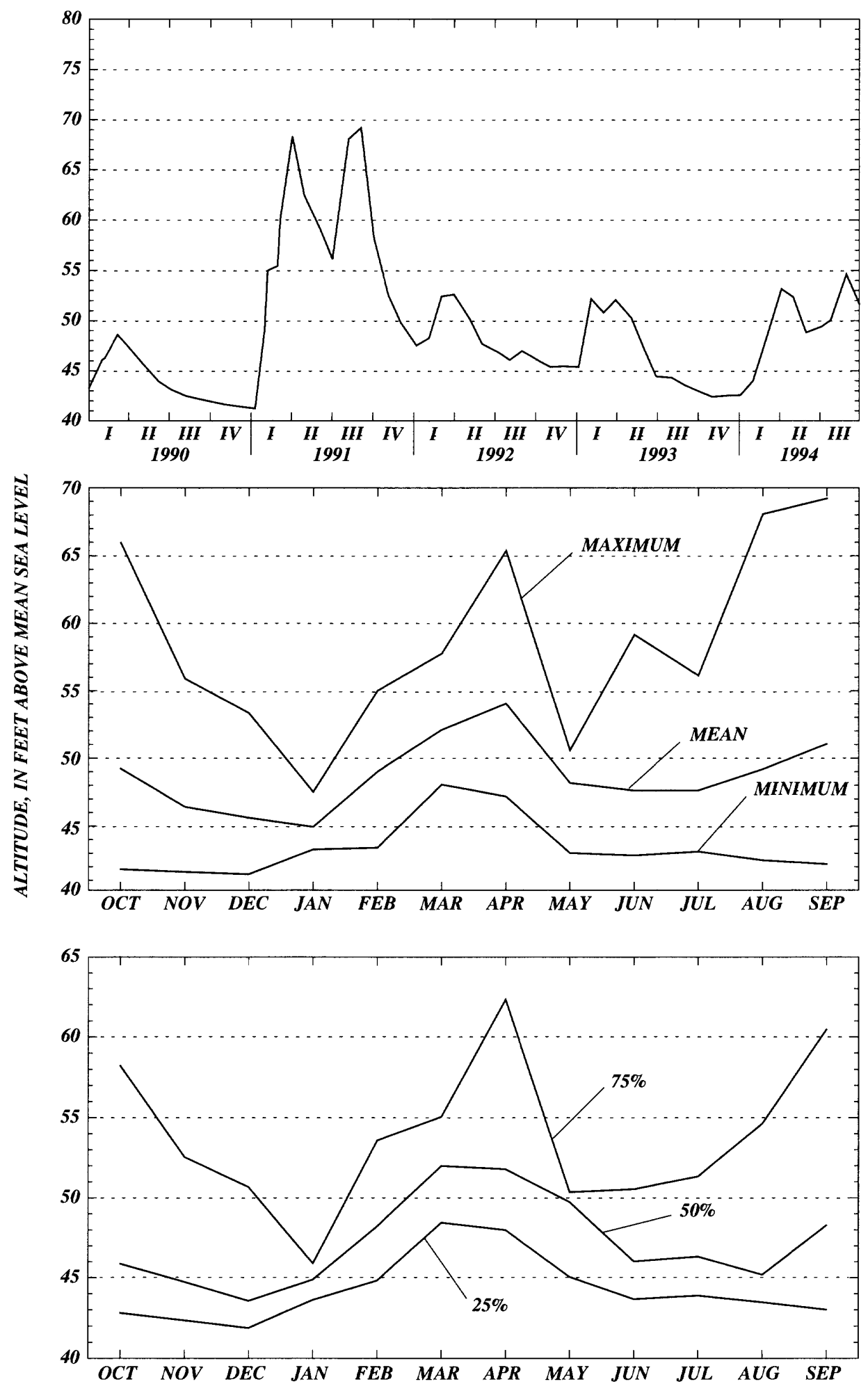


\section{Madison County}

WELL NUMBER.--302822083255585. DOT. +010921001.

LOCATION.--Lat 30²8'22”, long 83²5'55”, Hydrologic Unit Code 03110103.

AQUIFER.--Upper Floridan aquifer of the Tertiary system, Geologic Unit Code 120FLRD.

WELL CHARACTERISTICS.--Casing diameter 4 in., Casing depth $300 \mathrm{ft}$., Total depth $311 \mathrm{ft}$.

INSTRUMENTATION.--Miscellaneous from 11-06-1972 to 03-09-1981; then recorder, set to elevation of Measuring Point, $102.64 \mathrm{ft} .$, NGVD.

DATUM.--The National Geodetic Vertical Datum of 1929.

PERIOD OF RECORD.--04-17-1952 to 03-03-1991.

EXTREME VALUES.--Maximum, 90.21 ft. (04-16-1987); minimum, 67.27 ft. (01-09-1991).

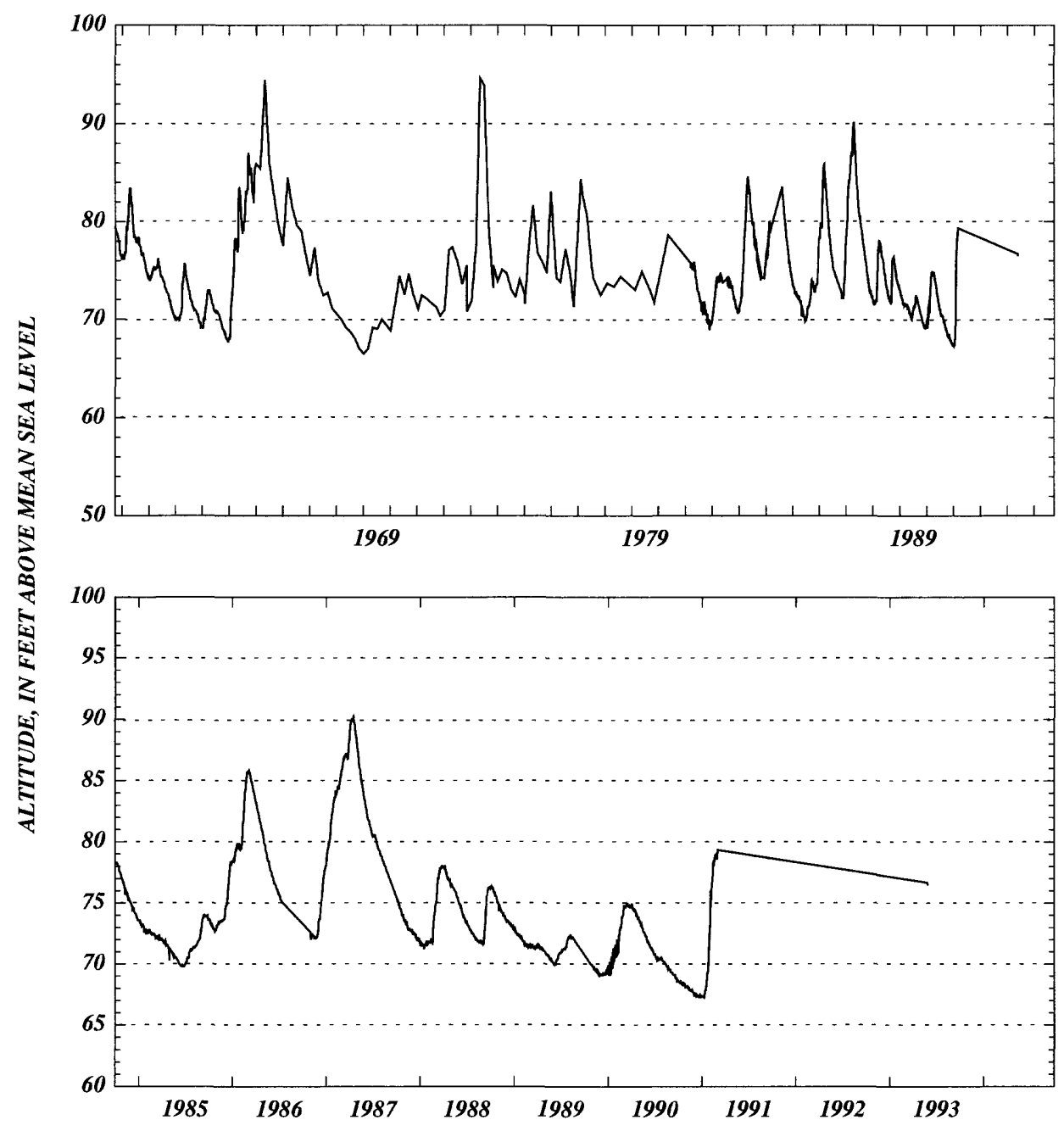



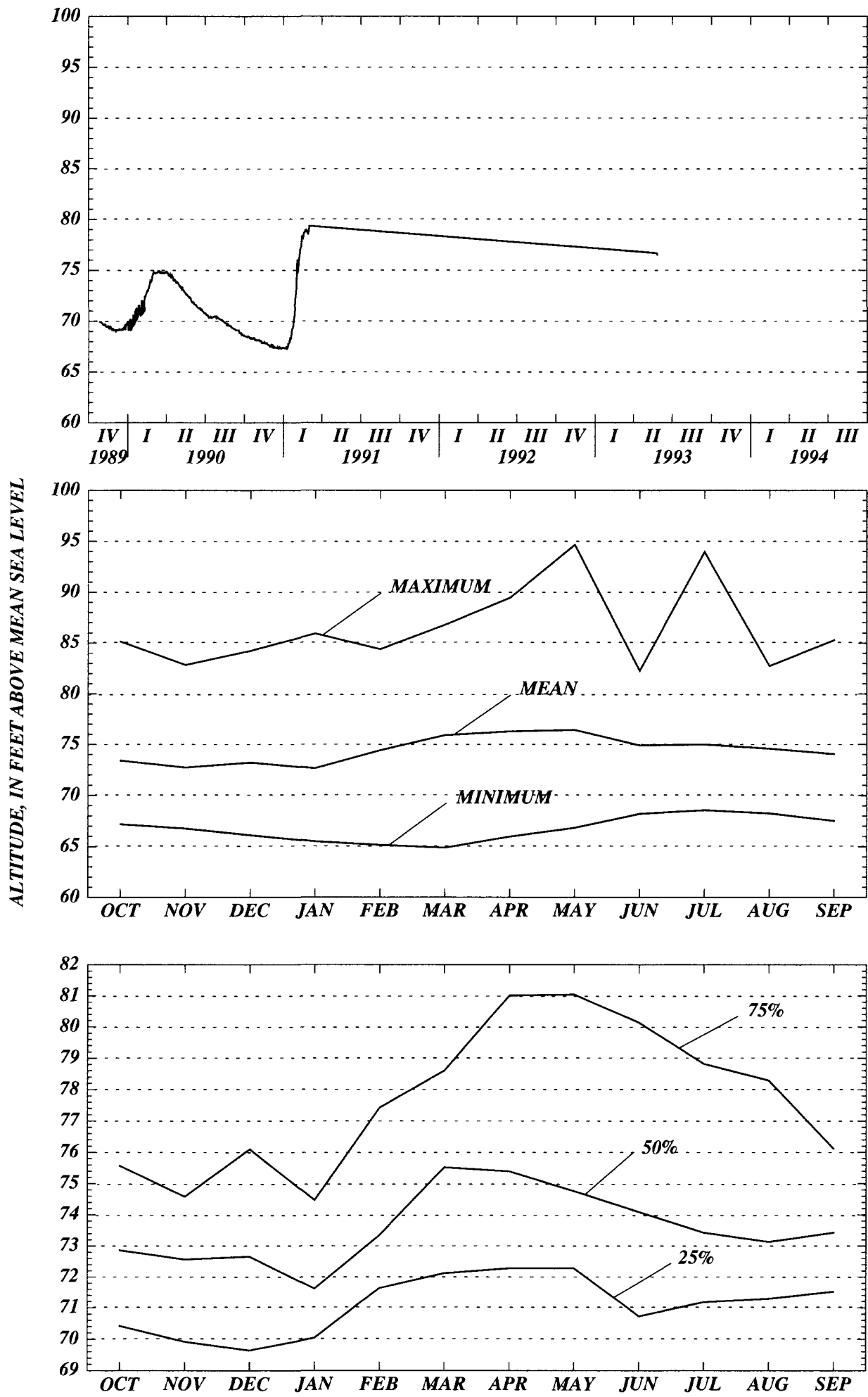


\section{Madison County}

WELL NUMBER.--302824083400985. Jerry Hall. +010719001.

LOCATION.--Lat 30²8'24”, long 8340'09”, Hydrologic Unit Code 03110103.

AQUIFER.--Upper Floridan aquifer of the Tertiary system, Geologic Unit Code 120FLRD.

WELL CHARACTERISTICS.--Casing diameter 6 in., Casing depth unknown, Total depth unknown ft.

INSTRUMENTATION.--Elevation of Measuring Point $96.38 \mathrm{ft} .$, NGVD.

DATUM.--The National Geodetic Vertical Datum of 1929.

PERIOD OF RECORD.--03-13-1961 to 09-30-1994. *

EXTREME VALUES.--Maximum observed, $85.08 \mathrm{ft}$. (10-02-1991); minimum observed, $70.18 \mathrm{ft}$. (12-11-1990).

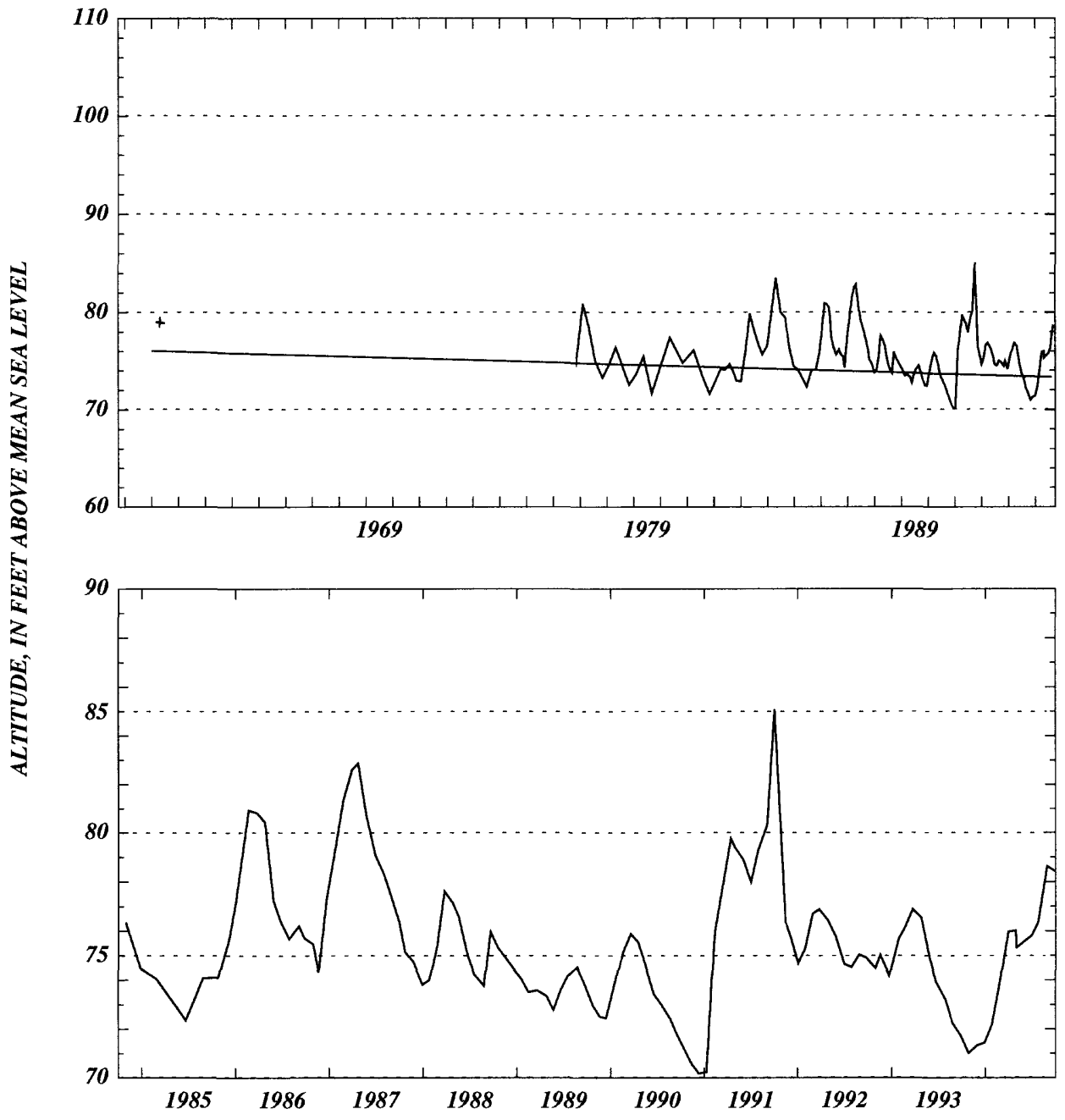



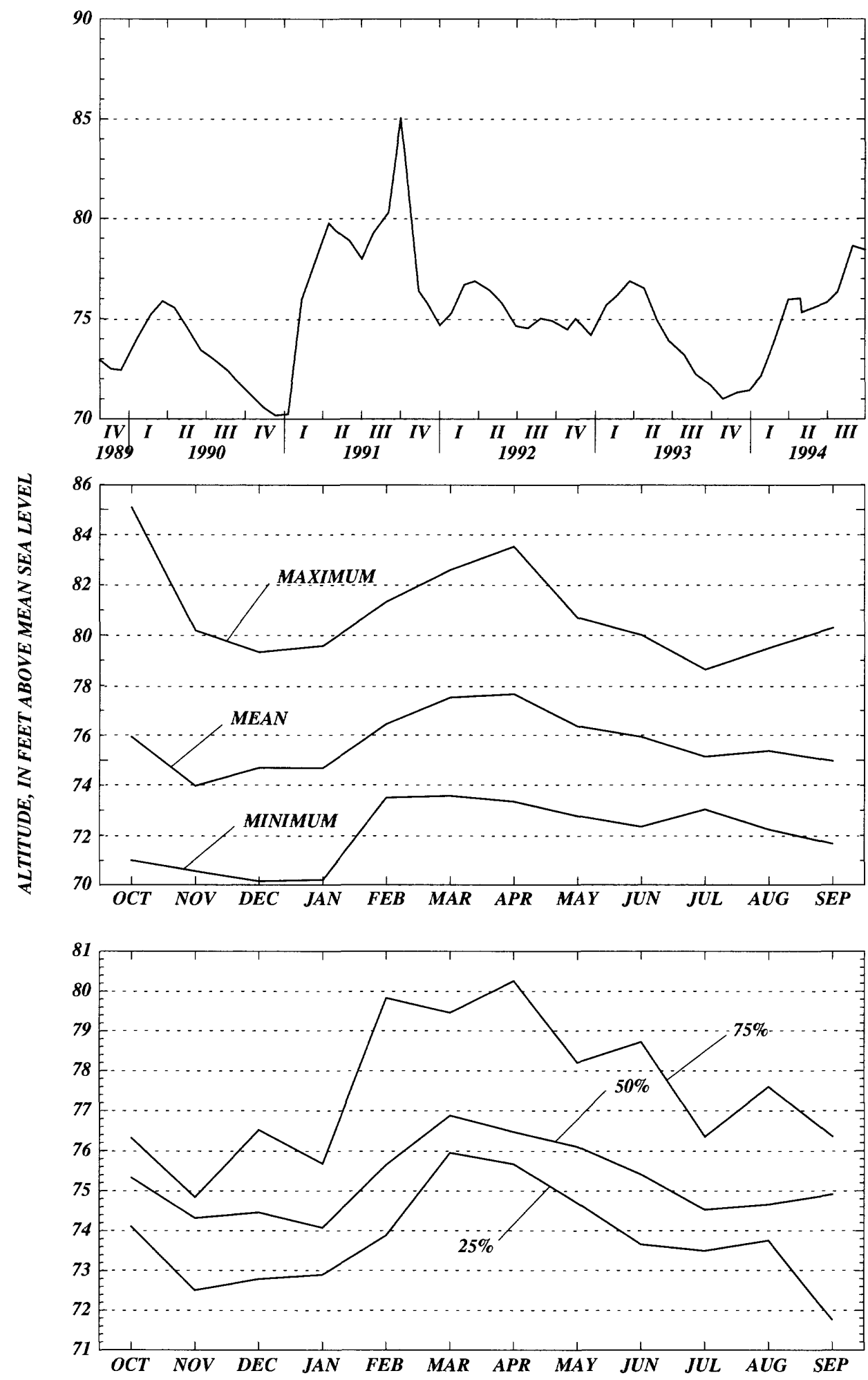


\section{Madison County}

WELL NUMBER.--302914083300985. Connecticut General Life. +010814001.

LOCATION.--Lat 30²9'14”, long 8330'09”, Hydrologic Unit Code 03110103.

AQUIFER.--Upper Floridan aquifer of the Tertiary system, Geologic Unit Code 120FLRD.

WELL CHARACTERISTICS.--Casing diameter 4 in., Casing depth $112 \mathrm{ft}$., Total depth $118 \mathrm{ft}$.

INSTRUMENTATION.--Recorder, set to elevation of Measuring Point, $118.13 \mathrm{ft}$., NGVD.

DATUM.--The National Geodetic Vertical Datum of 1929.

PERIOD OF RECORD.--08-02-1984 to 05-27-1993.

EXTREME VALUES.--Maximum observed, 89.39 ft. (04-25-1984) ‡; minimum, 71.04 ft. (12-20-1990).

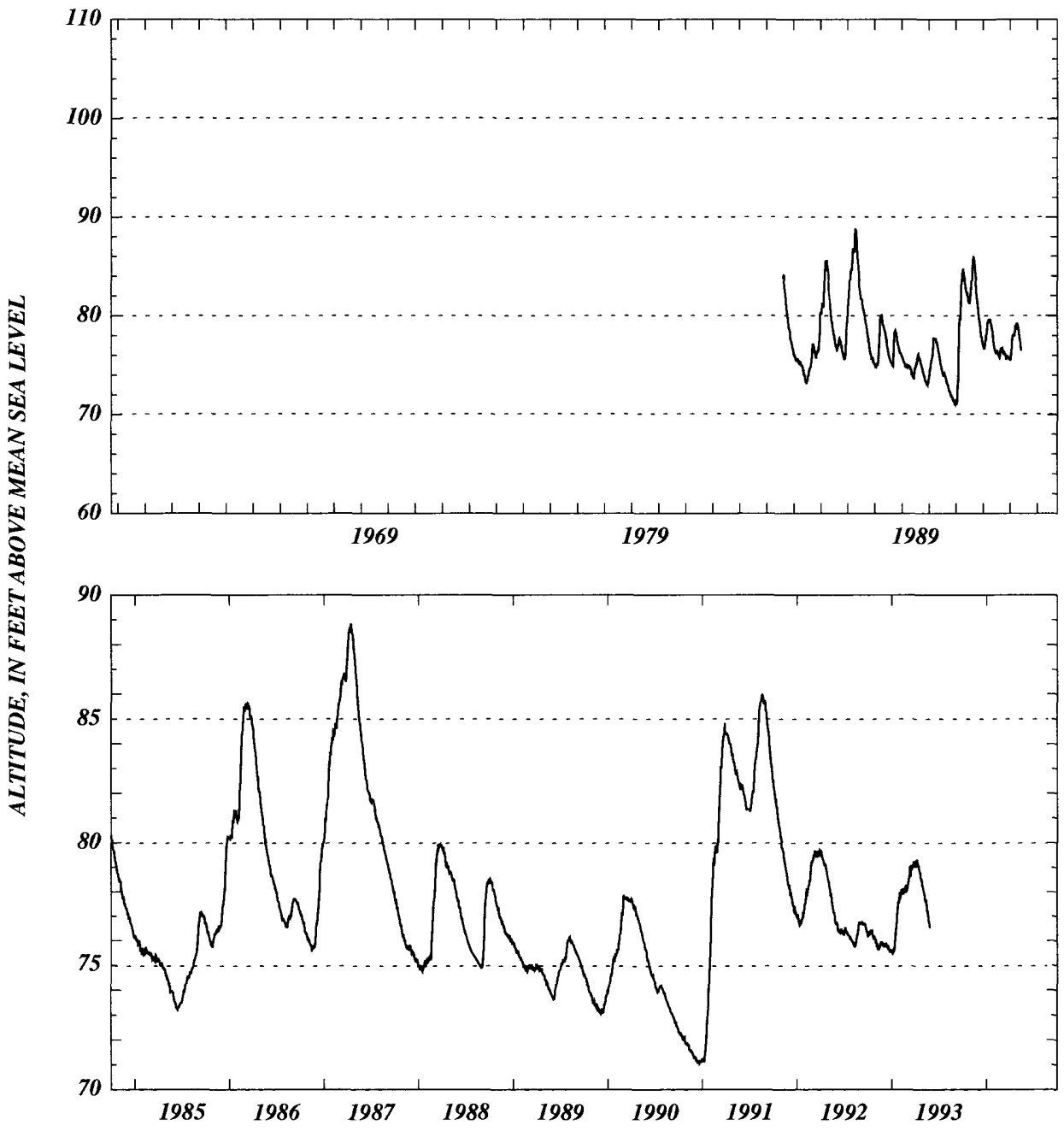



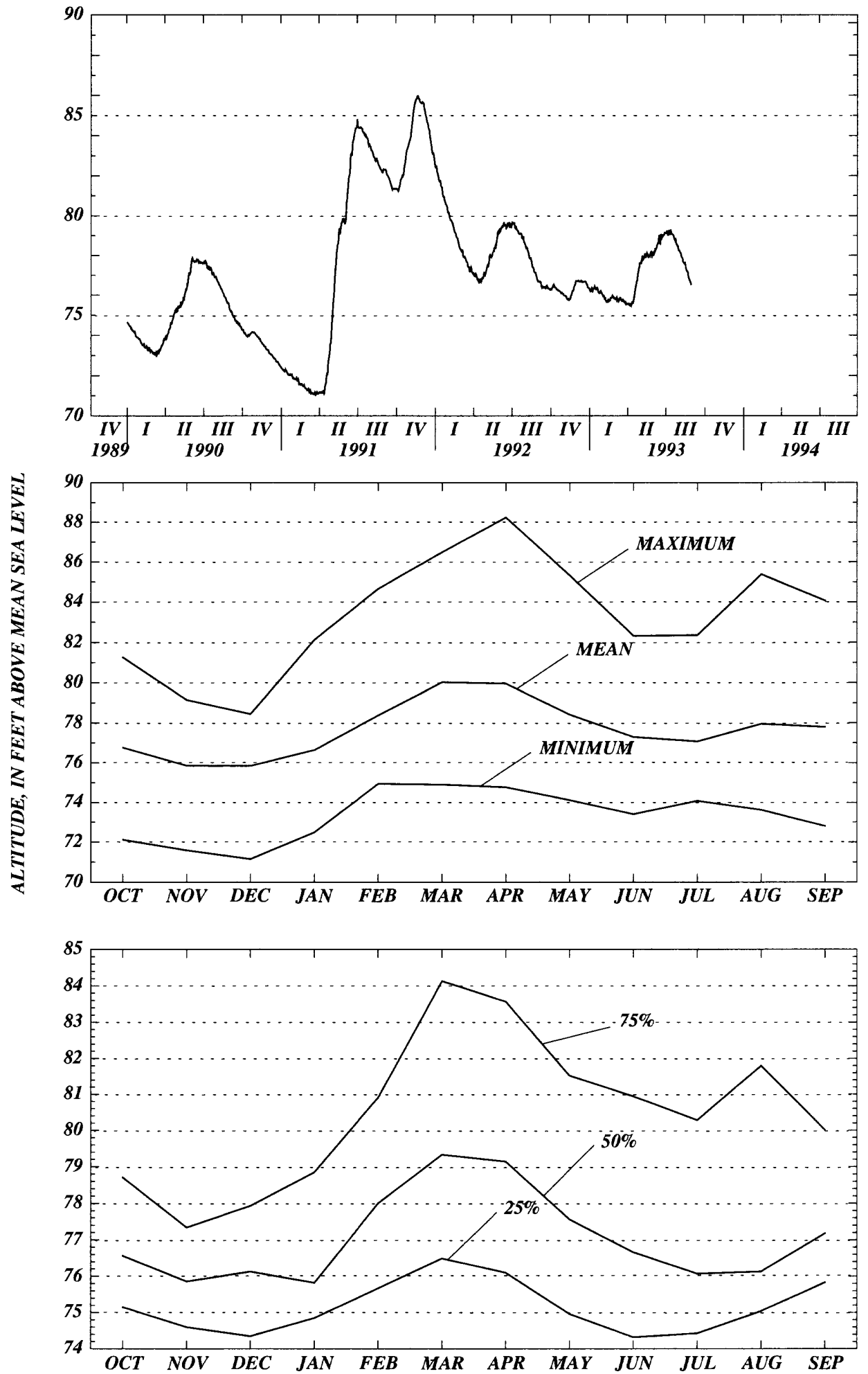


\section{Madison County}

WELL NUMBER.--303400083305385. DOF - Lovette Tower. +020822002.

LOCATION.--Lat 30³4’00”, long 83³0'53”, Hydrologic Unit Code 03110103.

AQUIFER.--Upper Floridan aquifer of the Tertiary system, Geologic Unit Code 120FLRD.

WELL CHARACTERISTICS.--Casing diameter 3 in., Casing depth $61 \mathrm{ft}$., Total depth $81 \mathrm{ft}$.

INSTRUMENTATION.--Elevation of Measuring Point 134.90 ft., NGVD.

DATUM.--The National Geodetic Vertical Datum of 1929.

PERIOD OF RECORD.--06-14-1989 to 09-30-1994.

EXTREME VALUES.--Maximum observed, 84.52 ft. (08-07-1991); minimum observed, $70.12 \mathrm{ft}$. (01-10-1991).

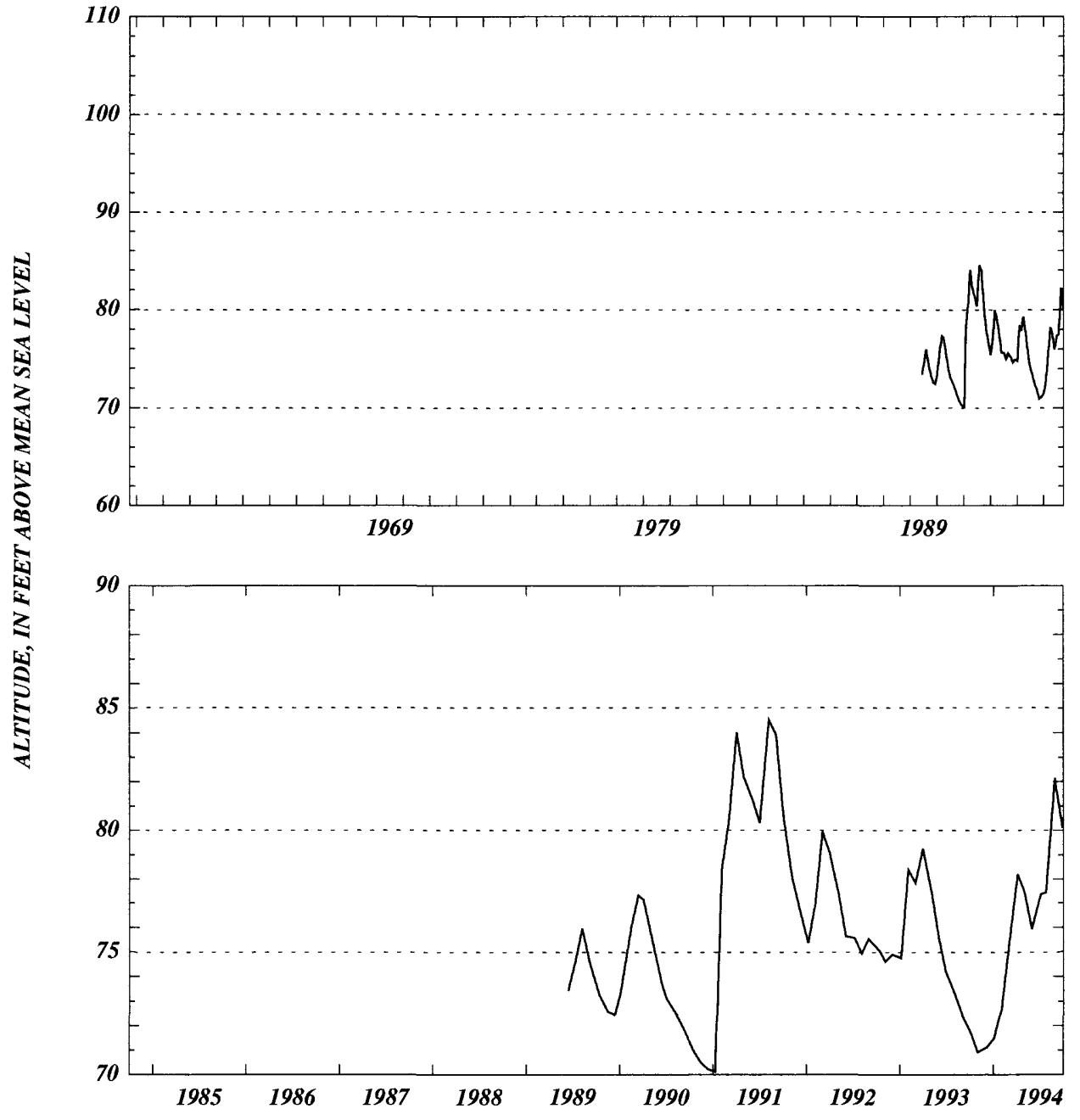



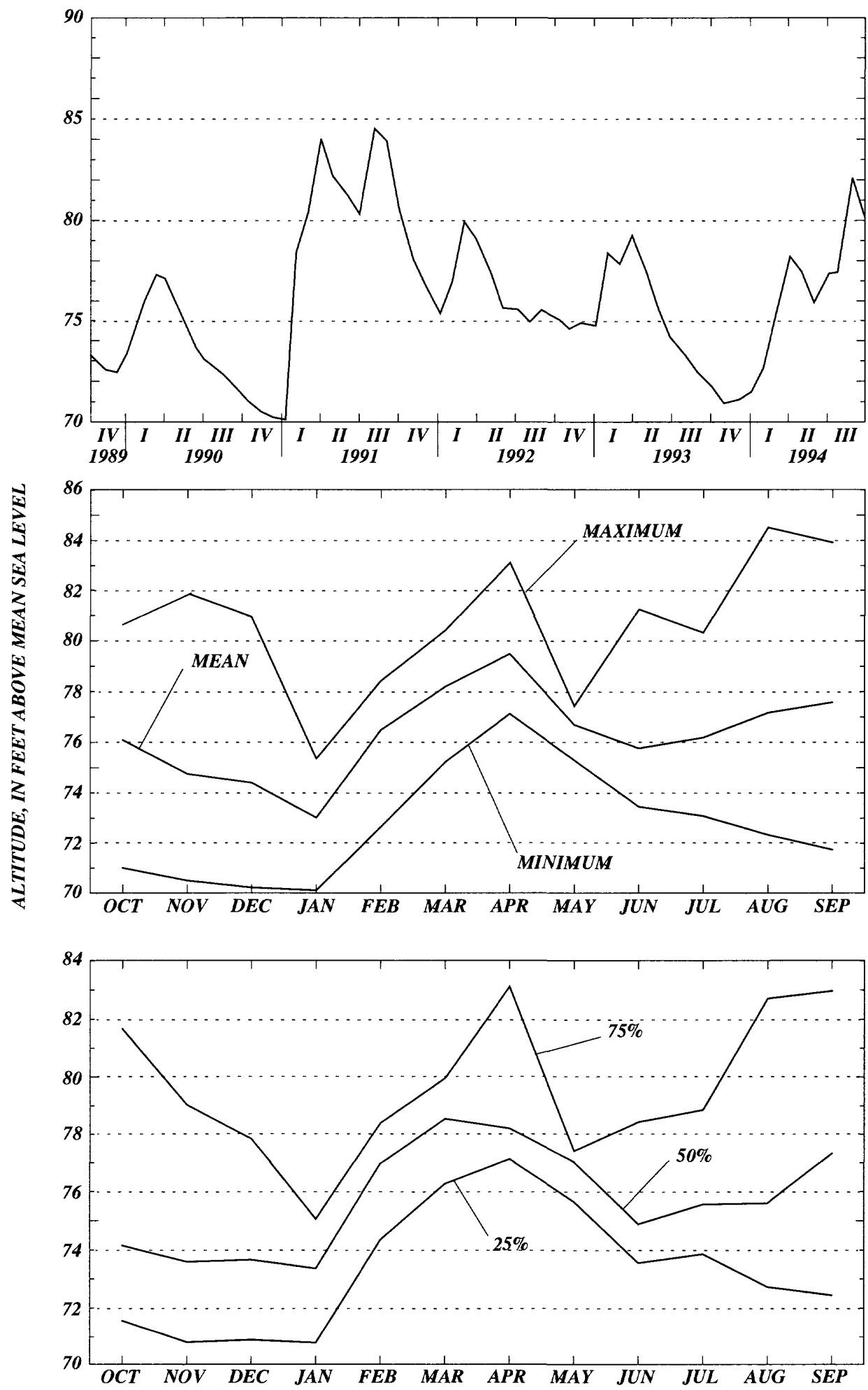


\section{Madison County}

WELL NUMBER.--3036260831720085. Jim Arnold. +021002001.

LOCATION.--Lat 30³6'26", long 8317'20", Hydrologic Unit Code 03110203.

AQUIFER.--Upper Floridan aquifer of the Tertiary system, Geologic Unit Code 120FLRD.

WELL CHARACTERISTICS.--Casing diameter 8 in., Casing depth $160 \mathrm{ft}$., Total depth $282 \mathrm{ft}$.

INSTRUMENTATION.--Elevation of Measuring Point $90.98 \mathrm{ft} .$, NGVD.

DATUM.--The National Geodetic Vertical Datum of 1929.

PERIOD OF RECORD.--11-01-1976 to 09-30-1994. *

EXTREME VALUES.--Maximum observed, 85.27 ft. (03-11-1991); minimum observed, $54.75 \mathrm{ft}$. (05-16-1985).

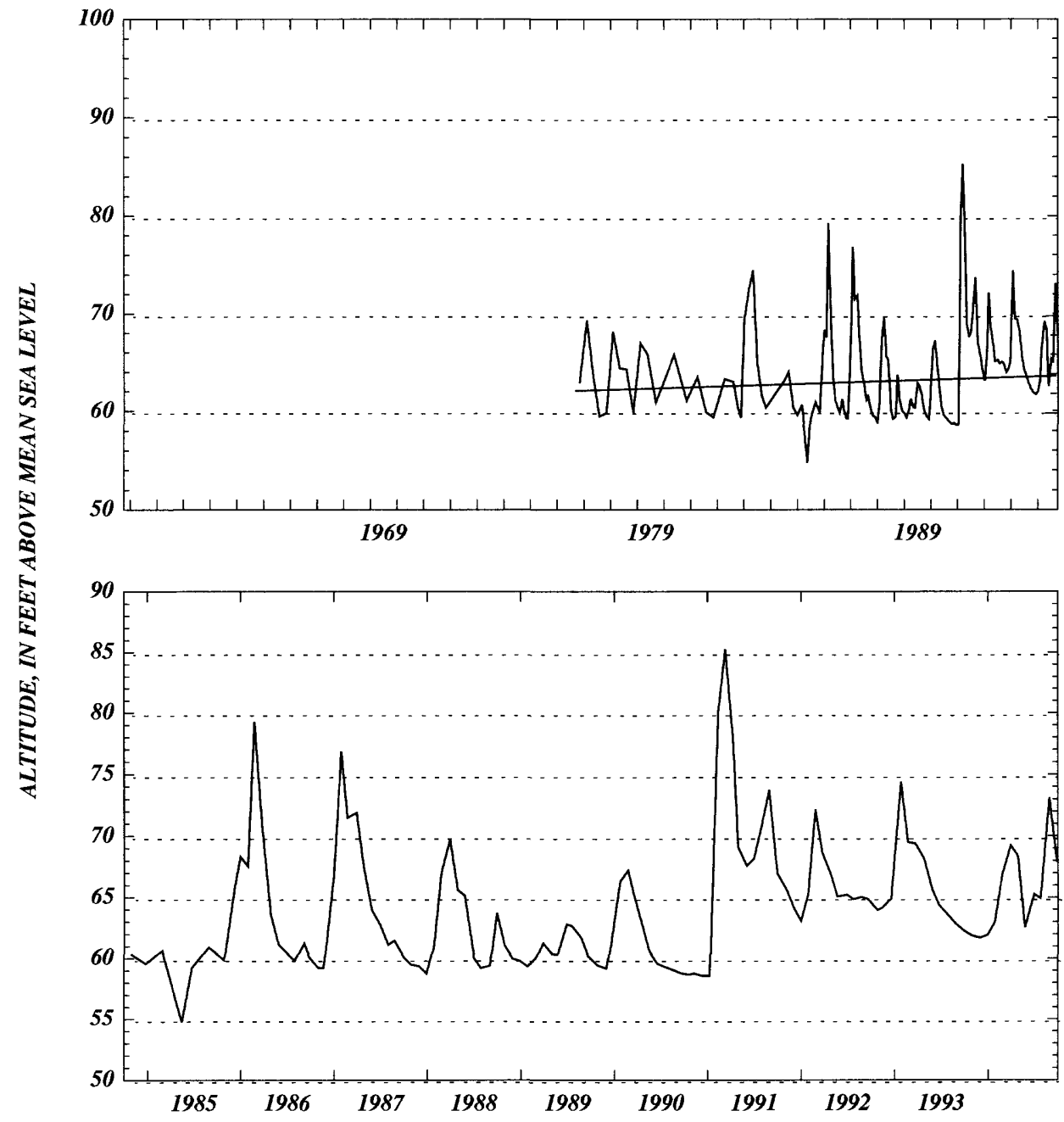



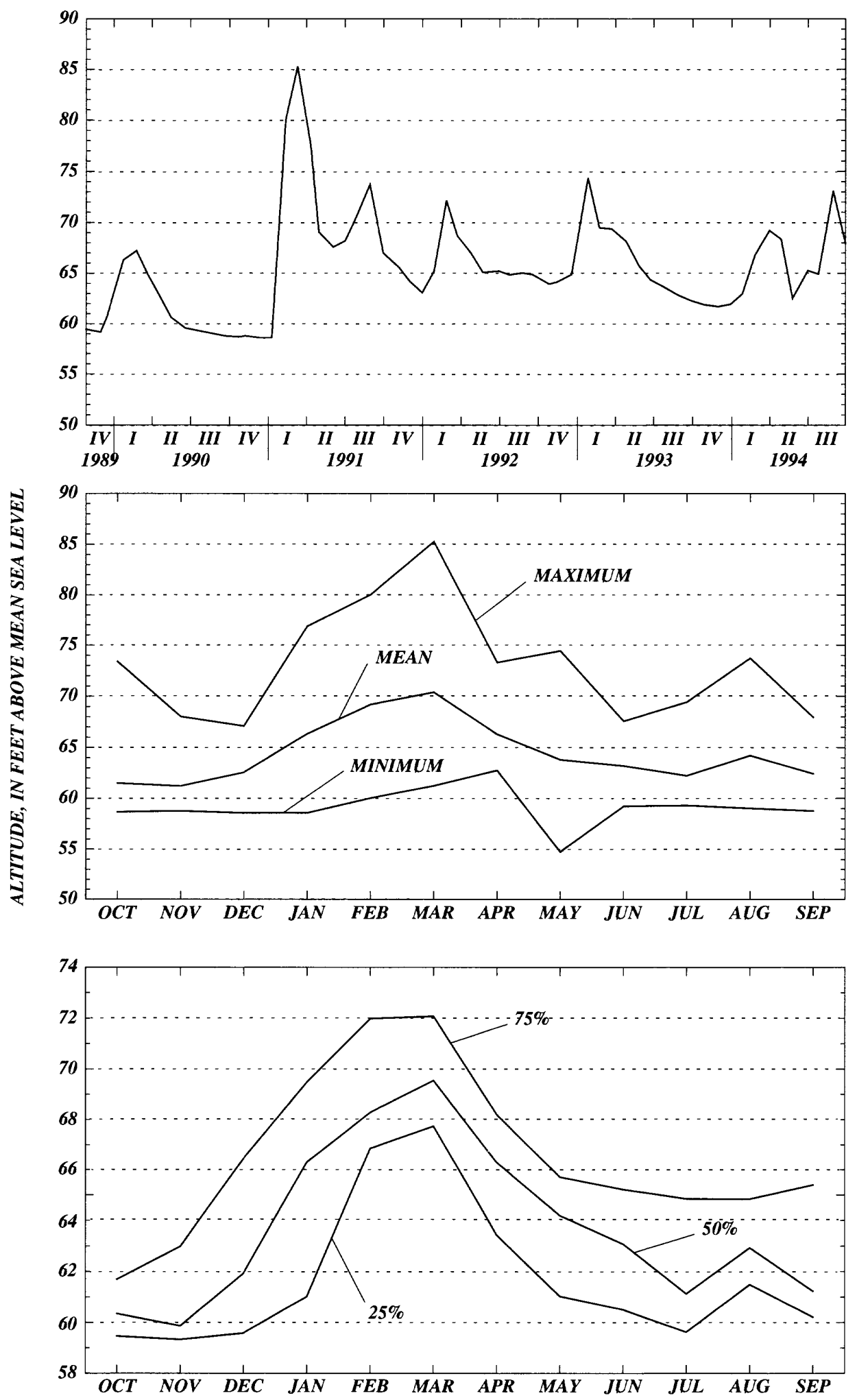


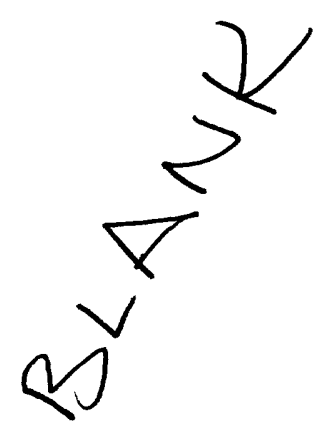

238 Statistical Summaries of Ground-Water Level Data Collected in the Suwannee River Water Management District, 1948-1994 


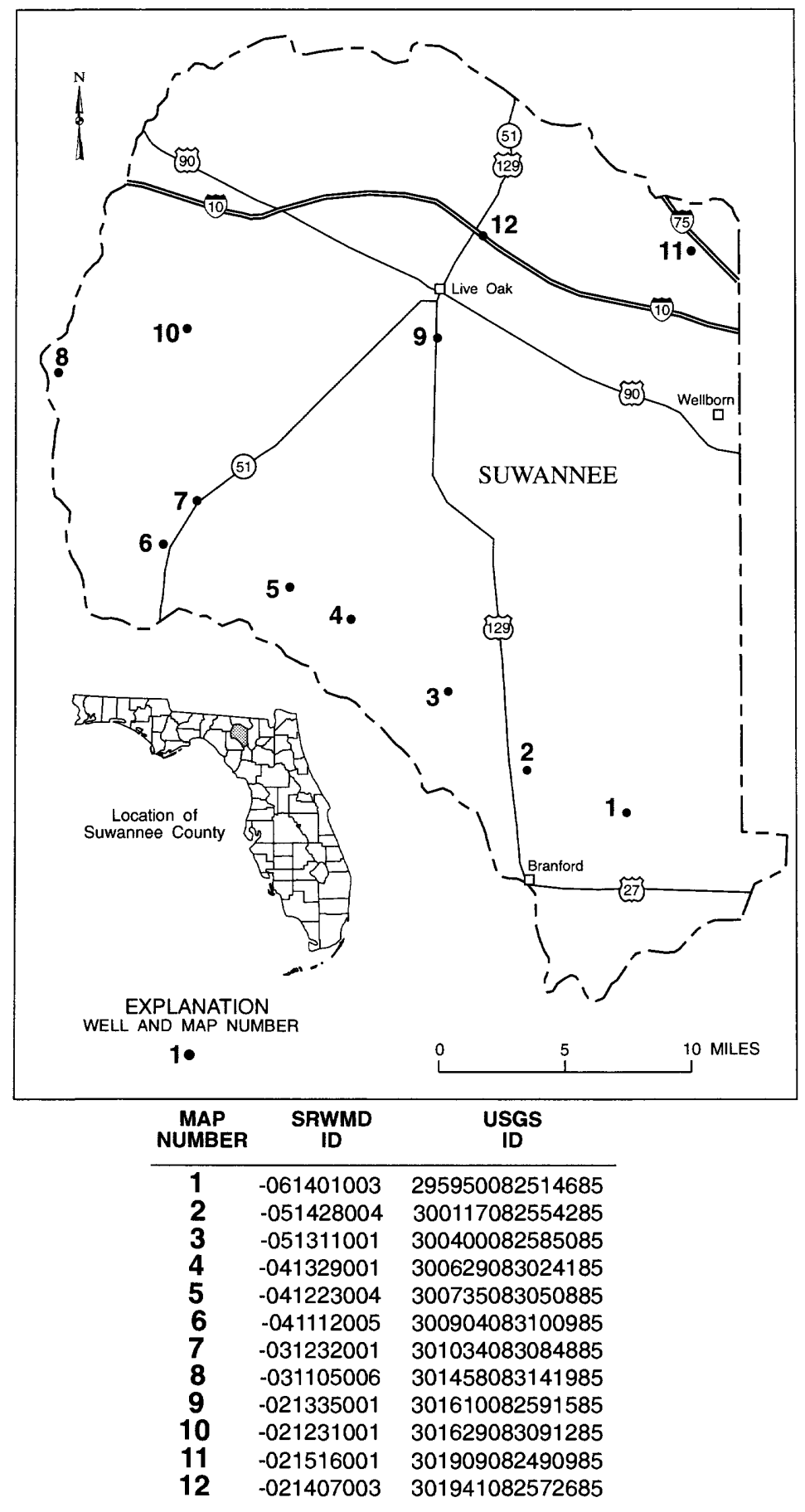

Figure 14. Location of wells in Suwannee County. 


\section{Suwannee County}

WELL NUMBER.--295950082514685. O.D. Beach. -061401003.

LOCATION.--Lat 29'59'50”, long 82 51'46”, Hydrologic Unit Code 03110205.

AQUIFER.--Upper Floridan aquifer of the Tertiary system, Geologic Unit Code 120FLRD.

WELL CHARACTERISTICS.--Casing diameter 3 in., Casing depth $18 \mathrm{ft}$., Total depth $48 \mathrm{ft}$.

INSTRUMENTATION.--Elevation of Measuring Point $58.72 \mathrm{ft}$., NGVD.

DATUM.--The National Geodetic Vertical Datum of 1929.

PERIOD OF RECORD.--06-07-1989 to 09-30-1994.

EXTREME VALUES.--Maximum observed, 36.37 ft. (09-03-1991); minimum observed, $25.39 \mathrm{ft}$. (10-17-1990).

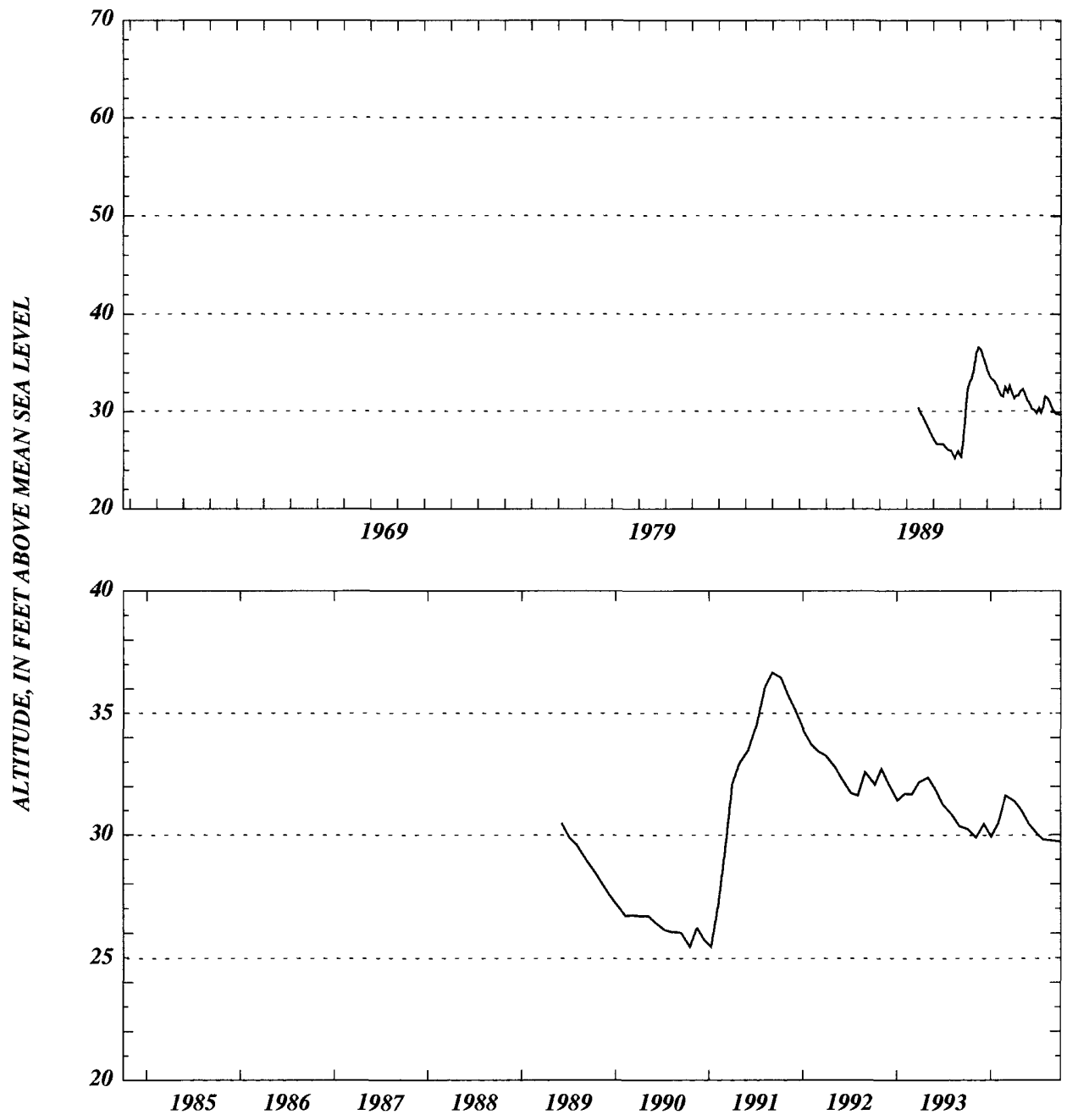



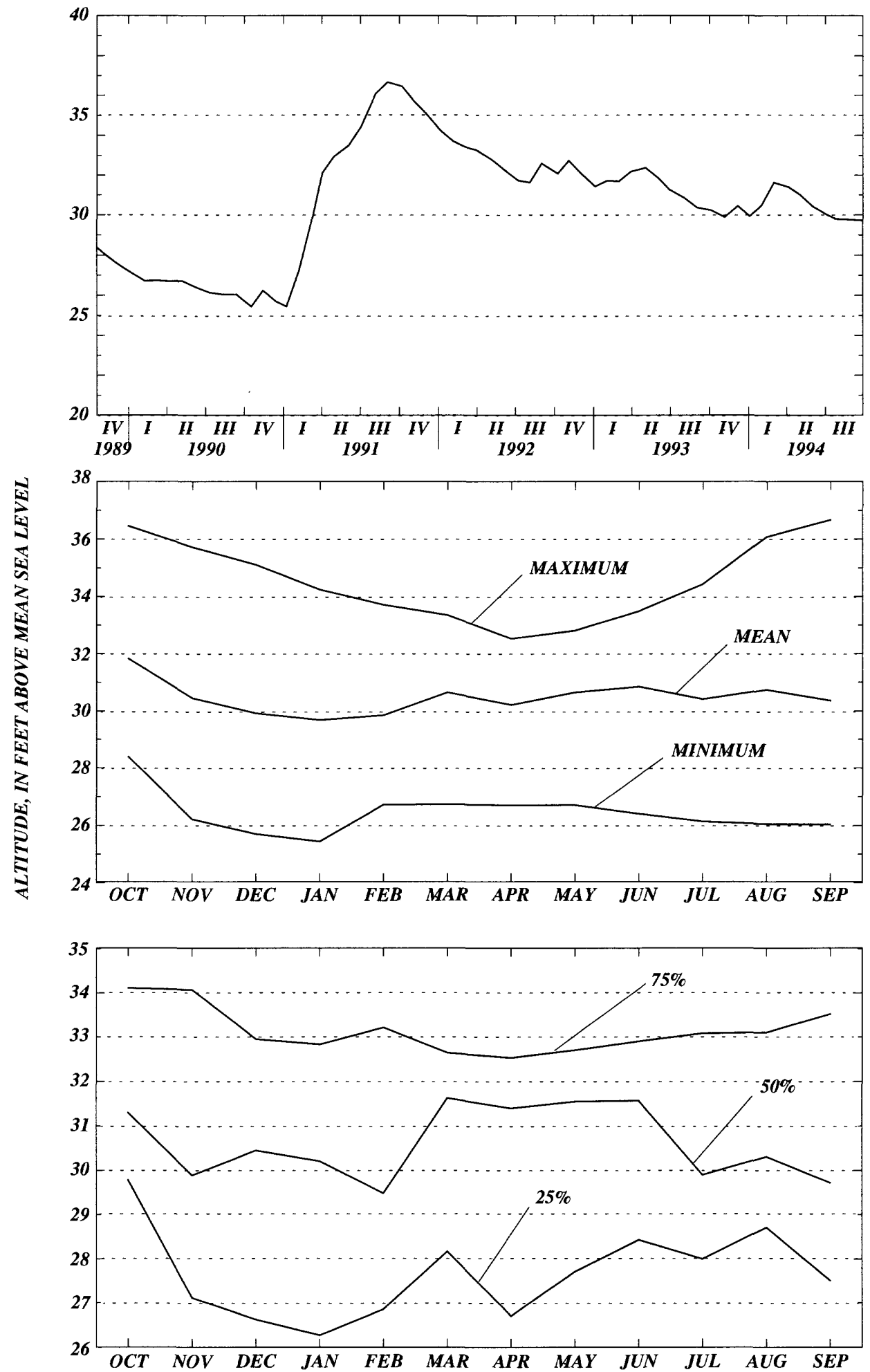


\section{Suwannee County}

WELL NUMBER.--300117082554285. Jimmy Daniel. -051428004.

LOCATION.--Lat 30 01'17', long 82 55'42”, Hydrologic Unit Code 03110205.

AQUIFER.--Upper Floridan aquifer of the Tertiary system, Geologic Unit Code 120FLRD.

WELL CHARACTERISTICS.--Casing diameter 4 in., Casing depth $42 \mathrm{ft}$., Total depth $50 \mathrm{ft}$.

INSTRUMENTATION.--Recorder, set to elevation of the Measuring Point, $53.81 \mathrm{ft}$., NGVD.

DATUM.--The National Geodetic Vertical Datum of 1929.

PERIOD OF RECORD.--03-23-1982 to 09-30-1994. *

EXTREME VALUES.--Maximum, 36.26 ft. (04-27-1984) †; minimum, 16.05 ft. (01-13-1991).

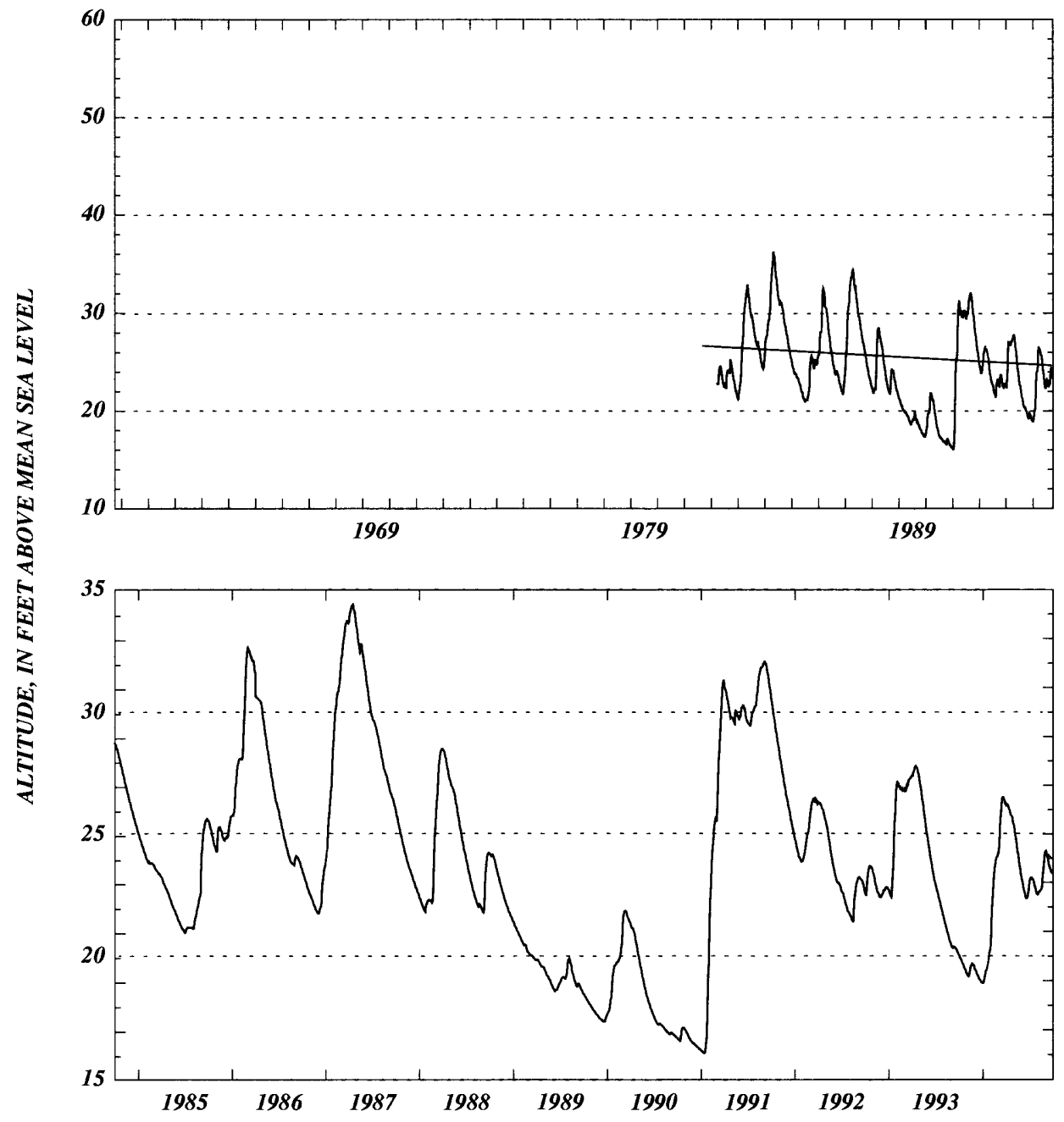



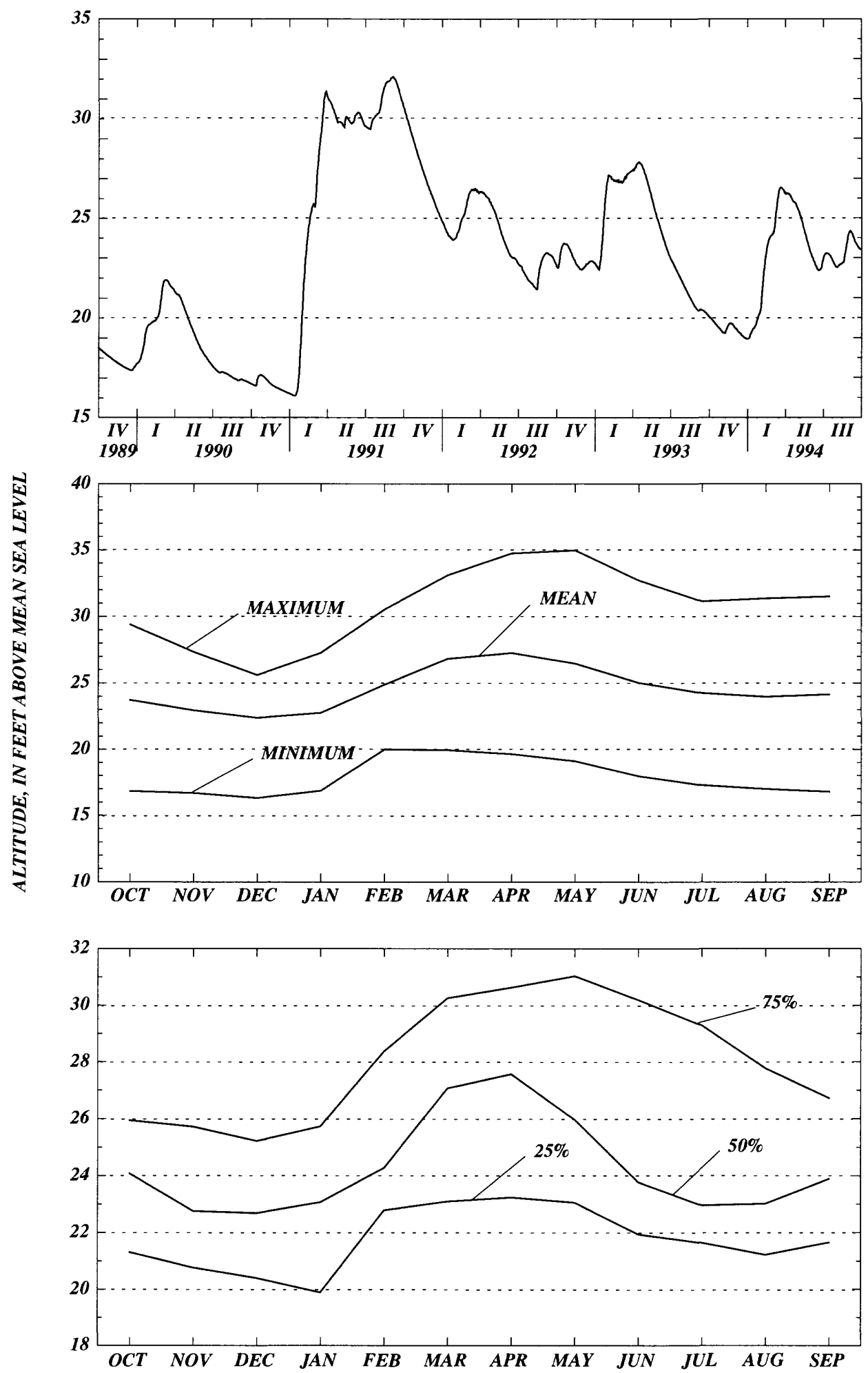
WELL NUMBER.--300400082585085. Valmont Farms. -051311001.

LOCATION.--Lat 3004'00”, long 82 58'50”, Hydrologic Unit Code 03110205.

AQUIFER.--Upper Floridan aquifer of the Tertiary system, Geologic Unit Code 120FLRD.

WELL CHARACTERISTICS.--Casing diameter 4 in., Casing depth $24 \mathrm{ft}$., Total depth $136 \mathrm{ft}$.

INSTRUMENTATION.--Elevation of Measuring Point $58.63 \mathrm{ft}$., NGVD.

DATUM.--The National Geodetic Vertical Datum of 1929.

PERIOD OF RECORD.--08-22-1968 to 09-30-1994.

EXTREME VALUES.--Maximum observed, $36.63 \mathrm{ft}$. (04-27-1984); minimum observed, $13.48 \mathrm{ft}$. (01-06-1969).

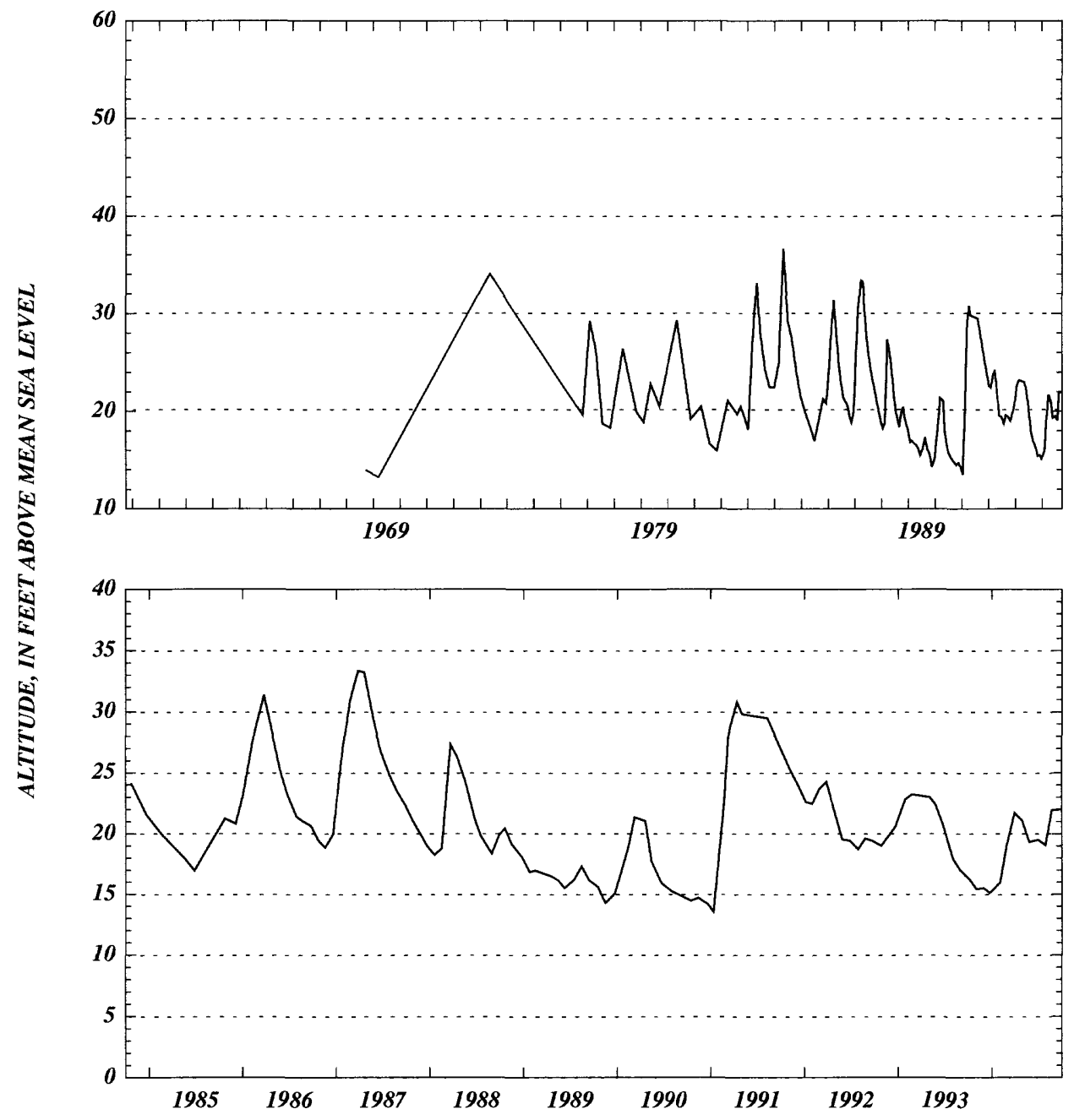




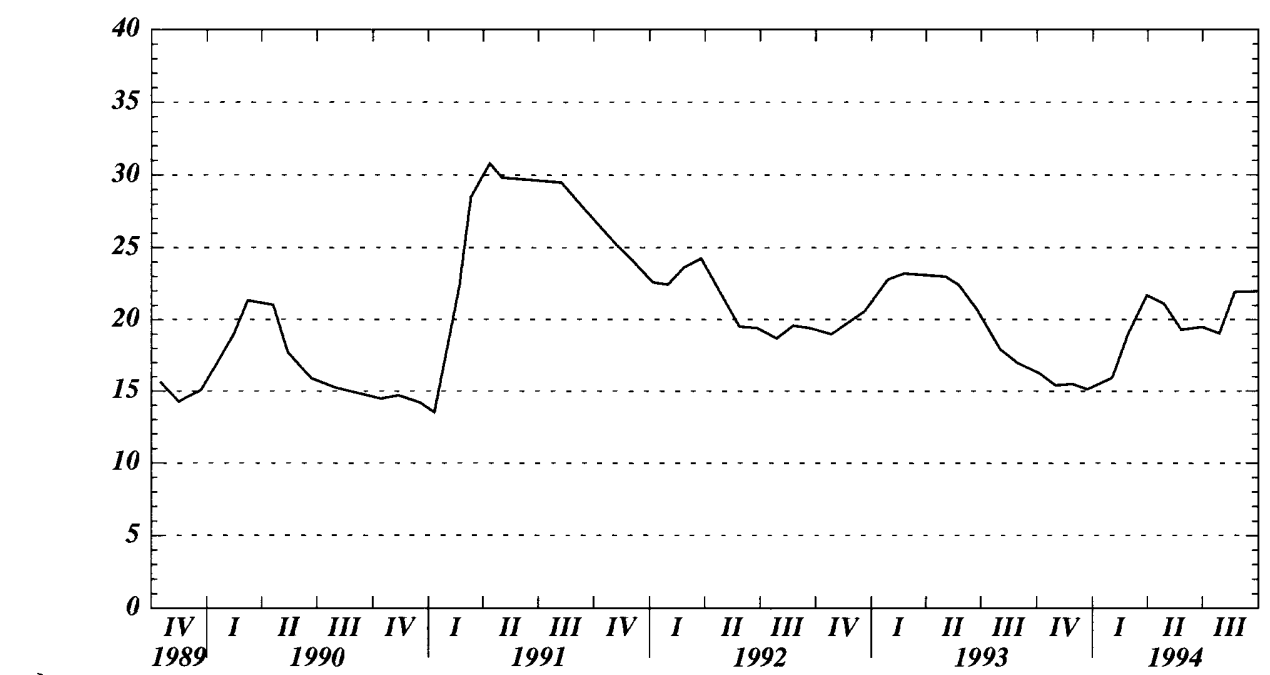


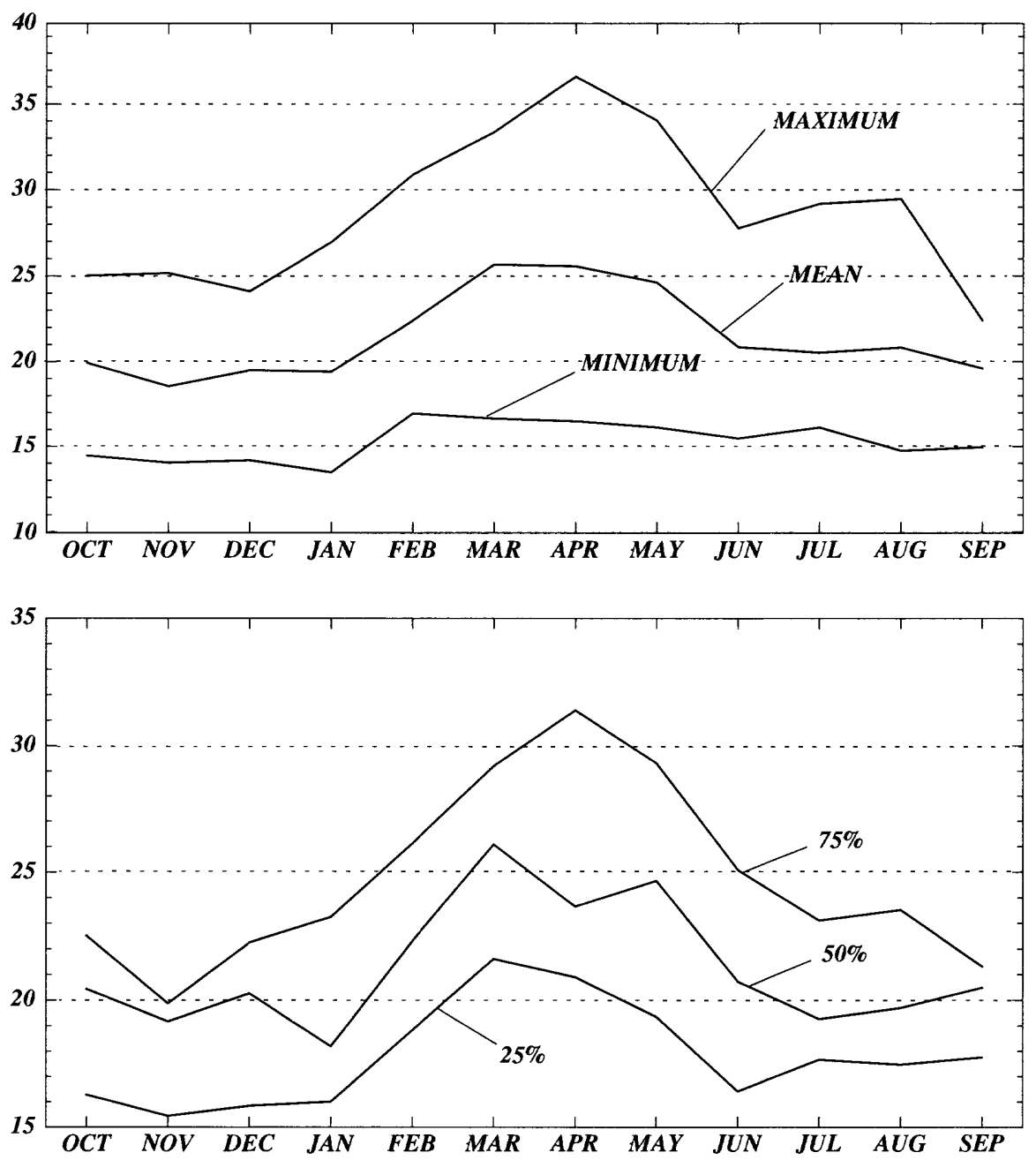


\section{Suwannee County}

WELL NUMBER.--300629083024185. Suwannee Farms. -041329001.

LOCATION.--Lat 3006'29”, long 8302'41”, Hydrologic Unit Code 03110205.

AQUIFER.--Upper Floridan aquifer of the Tertiary system, Geologic Unit Code 120FLRD.

WELL CHARACTERISTICS.--Casing diameter 6 in., Casing depth $94 \mathrm{ft}$., Total depth $247 \mathrm{ft}$.

INSTRUMENTATION.--Recorder, set to elevation of the Measuring Point, $72.83 \mathrm{ft}$., NGVD.

DATUM.--The National Geodetic Vertical Datum of 1929.

PERIOD OF RECORD.--01-10-1981 to 09-30-1994.

EXTREME VALUES.--Maximum, 39.81 ft. (04-18-1984); minimum, 19.24 ft. (01-11-1991)

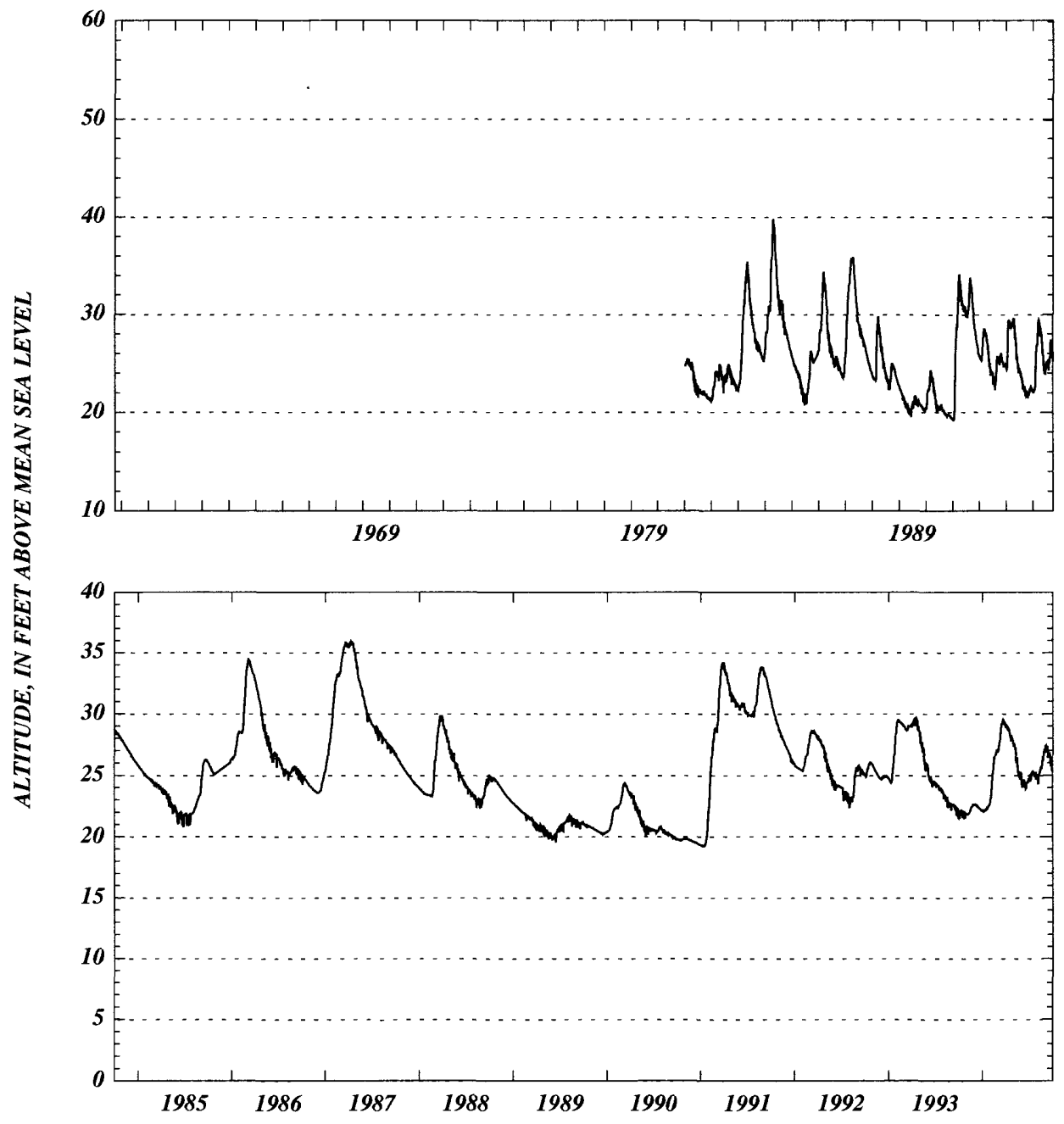



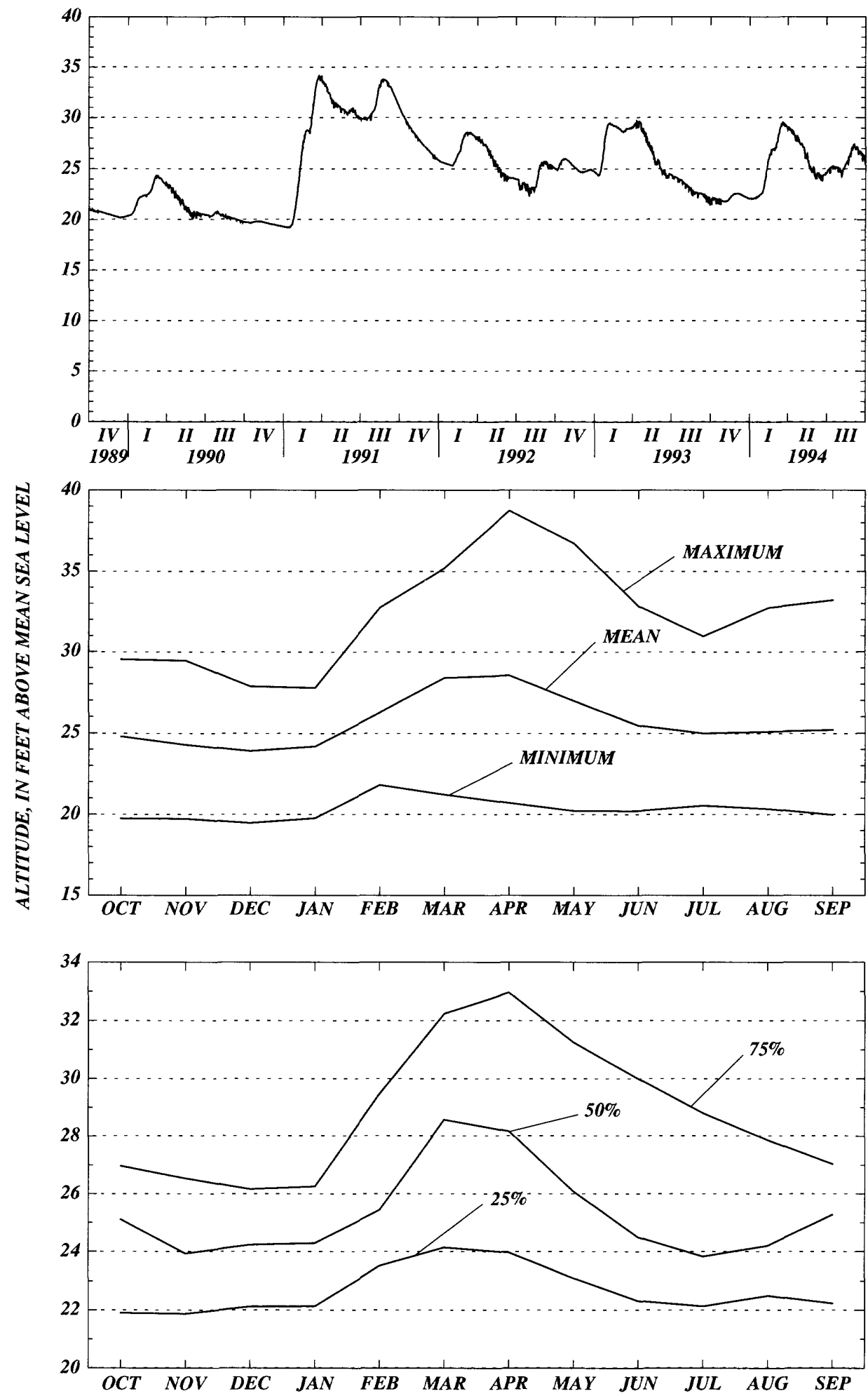


\section{Suwannee County}

WELL NUMBER.--300735083050885. Buddy Jackson. -041223004.

LOCATION.--Lat 3007'35', long 83 05'08', Hydrologic Unit Code 03110205.

AQUIFER.--Upper Floridan aquifer of the Tertiary system, Geologic Unit Code 120FLRD.

WELL CHARACTERISTICS.--Casing diameter 4 in., Casing depth $170 \mathrm{ft}$., Total depth $247 \mathrm{ft}$.

INSTRUMENTATION.--Recorder from 09-29-1981 to 01-15-1992; then miscellaneous from 01-29-1992 to 09-30-1994. Elevation of Measuring Point 62.22 ft., NGVD.

DATUM.--The National Geodetic Vertical Datum of 1929.

PERIOD OF RECORD.--09-29-1981 to 09-30-1994.

EXTREME VALUES.--Maximum, 40.21 ft. (04-27-1984) ‡; minimum, 20.74 ft. (01-11-1991).

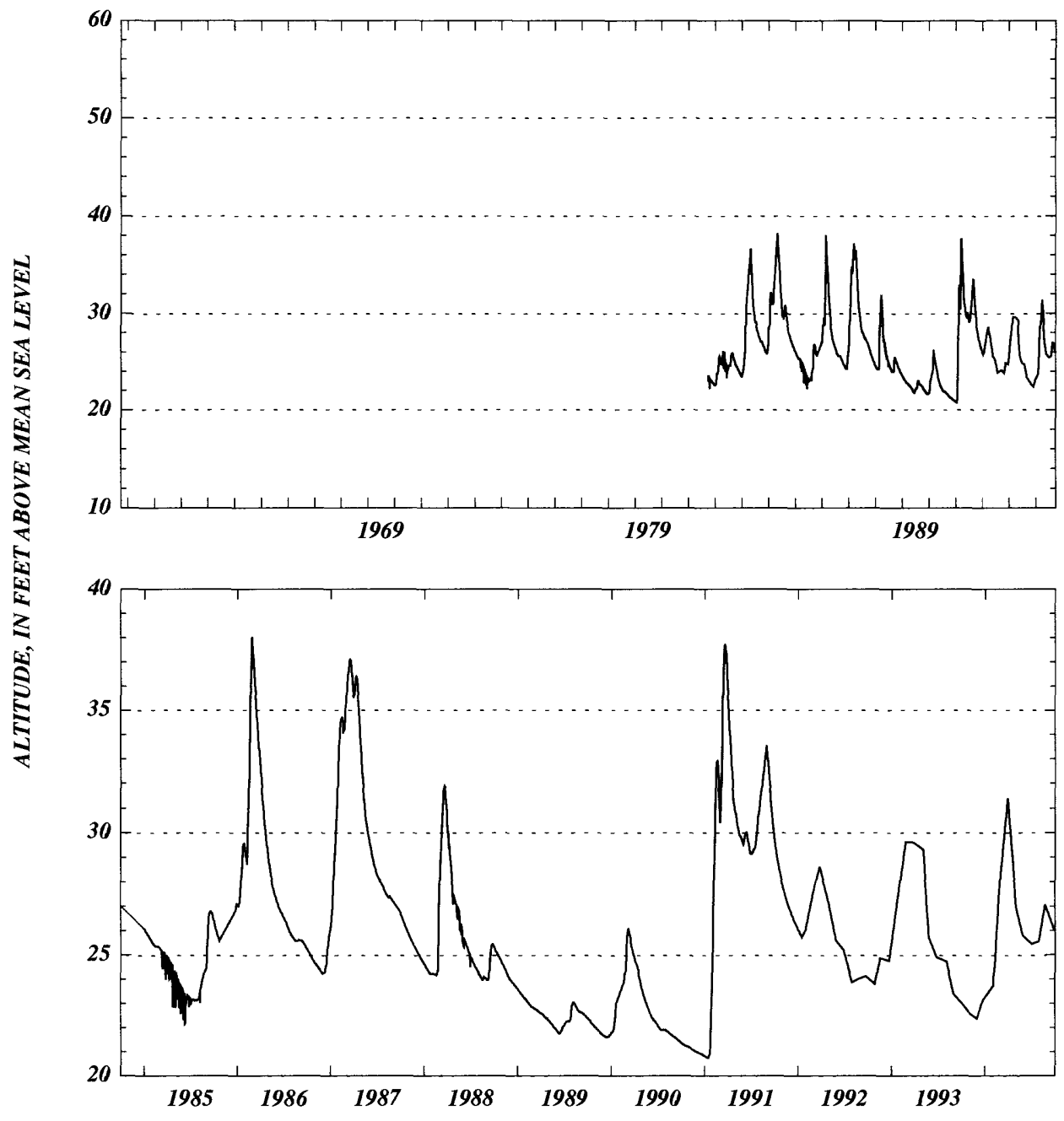



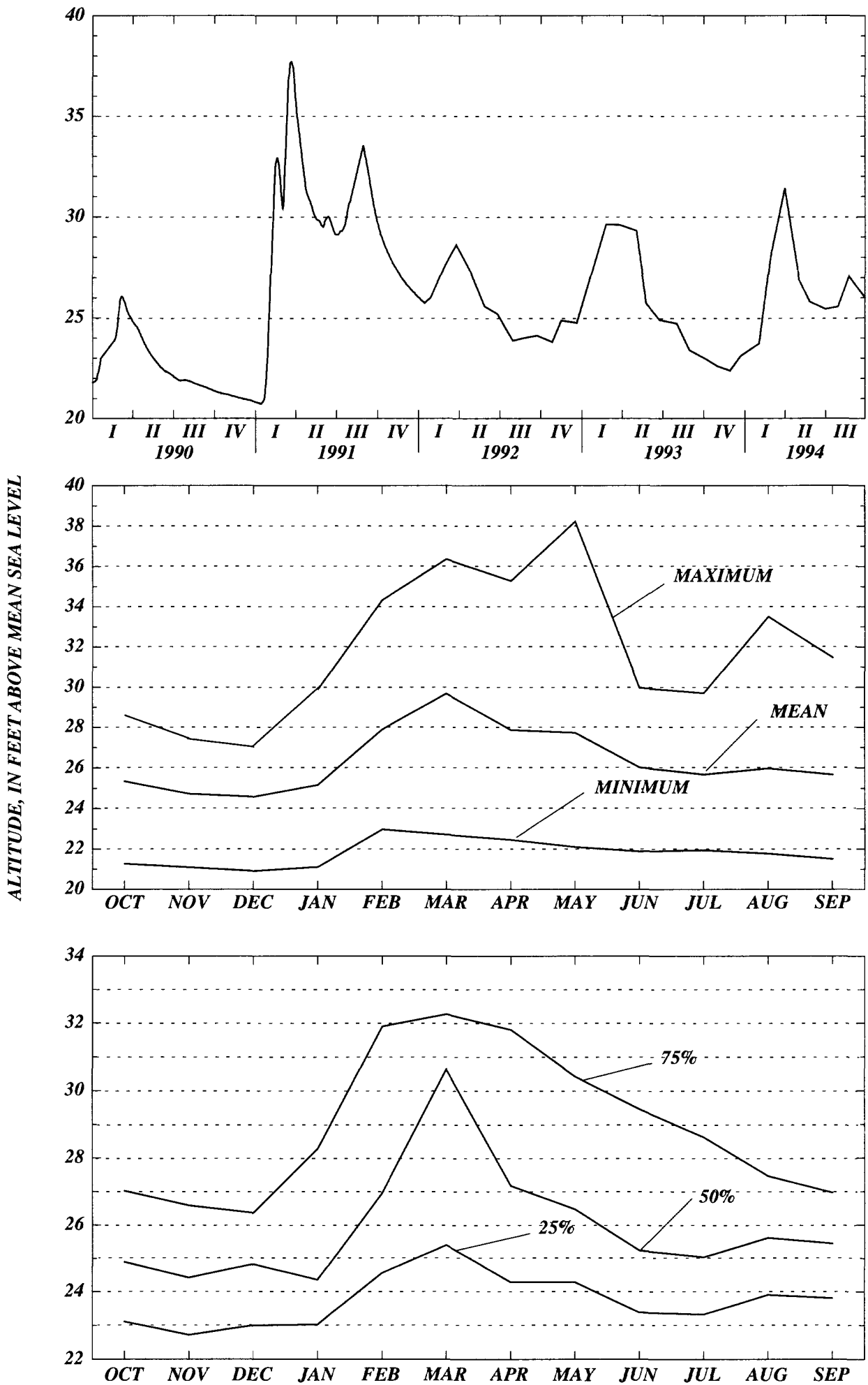


\section{Suwannee County}

WELL NUMBER.--300904083100985. Revis Moore. -041112005.

LOCATION.--Lat 30 09'04”, long 83¹0'09”, Hydrologic Unit Code 03110205.

AQUIFER.--Upper Floridan aquifer of the Tertiary system, Geologic Unit Code 120FLRD.

WELL CHARACTERISTICS.--Casing diameter 8 in., Casing depth $43 \mathrm{ft}$., Total depth $144 \mathrm{ft}$.

INSTRUMENTATION.--Recorder, set to elevation of the Measuring Point, $78.38 \mathrm{ft}$., NGVD.

DATUM.--The National Geodetic Vertical Datum of 1929.

PERIOD OF RECORD.--04-23-1985 to 09-30-1994.

EXTREME VALUES.--Maximum, 39.25 ft. (03-29-1991); minimum, 21.90 ft. (12-29-1990).

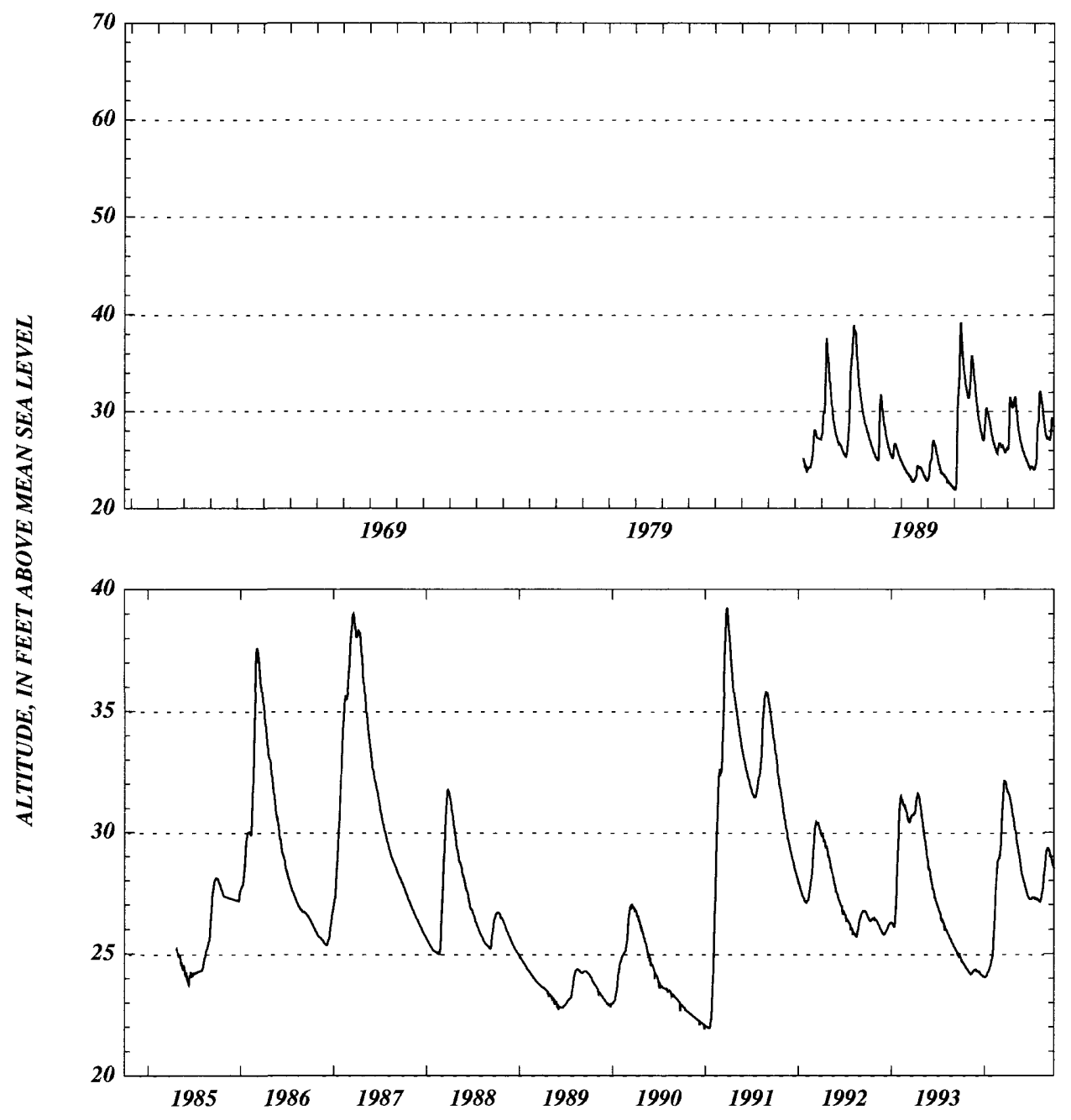



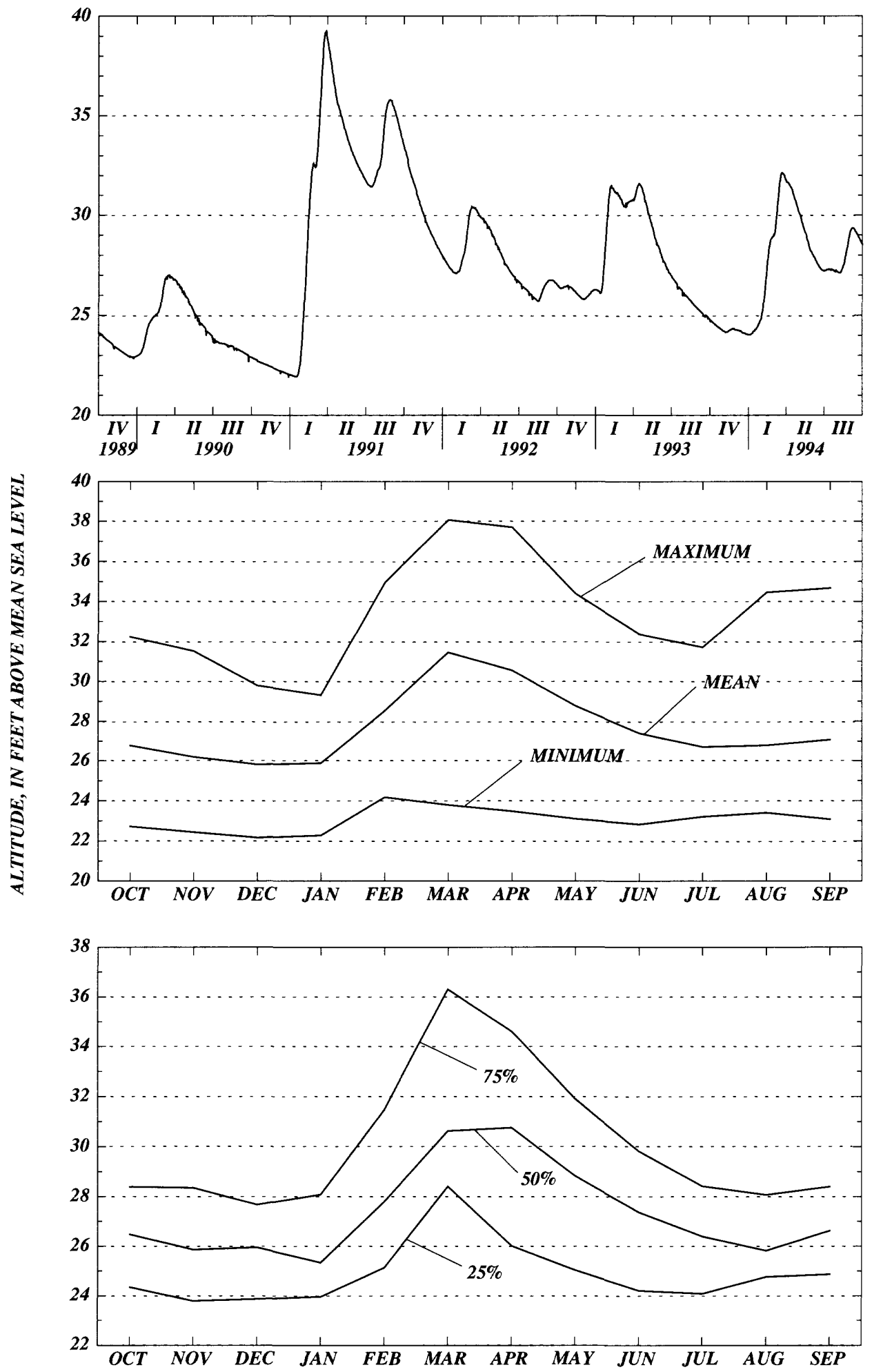


\section{Suwannee County}

WELL NUMBER.--301034083084885. Henery Ward. -031232001.

LOCATION.--Lat 30¹0'34”, long 8308'48”, Hydrologic Unit Code 03110205.

AQUIFER.--Upper Floridan aquifer of the Tertiary system, Geologic Unit Code 120FLRD.

WELL CHARACTERISTICS.--Casing diameter 4 in., Casing depth $100 \mathrm{ft}$., Total depth $124 \mathrm{ft}$.

INSTRUMENTATION.--Recorder from 01-16-1981 to 03-03-1985; then miscellaneous from 05-15-1985 to 12-30-1994. Elevation of the Measuring Point $79.83 \mathrm{ft}$., NGVD.

DATUM.--The National Geodetic Vertical Datum of 1929.

PERIOD OF RECORD.--01-16-1981 to 09-30-1994

EXTREME VALUES.--Maximum, 42.92 ft. (04-20-1984); minimum observed, 24.30 ft. (01-11-1991).

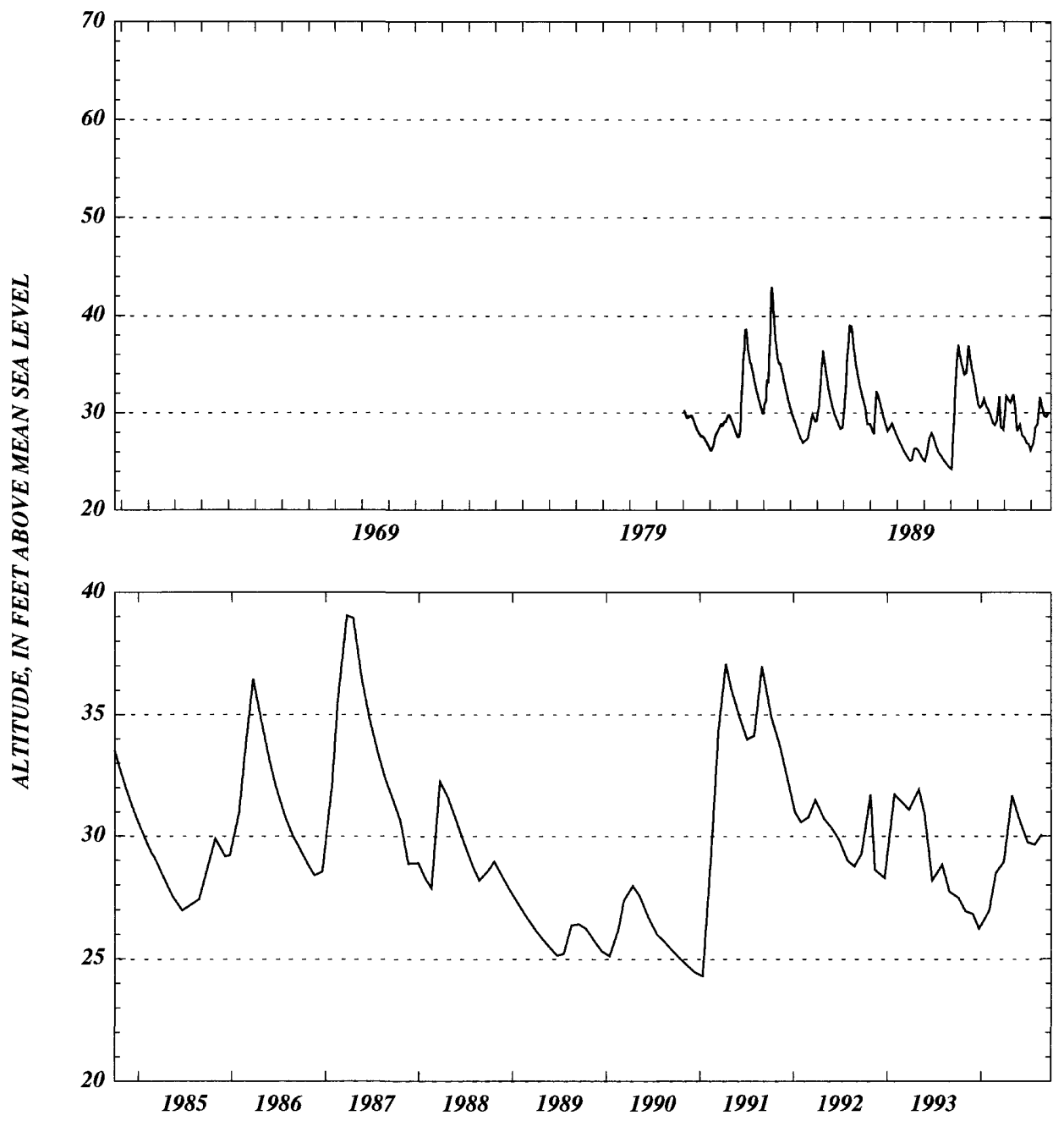



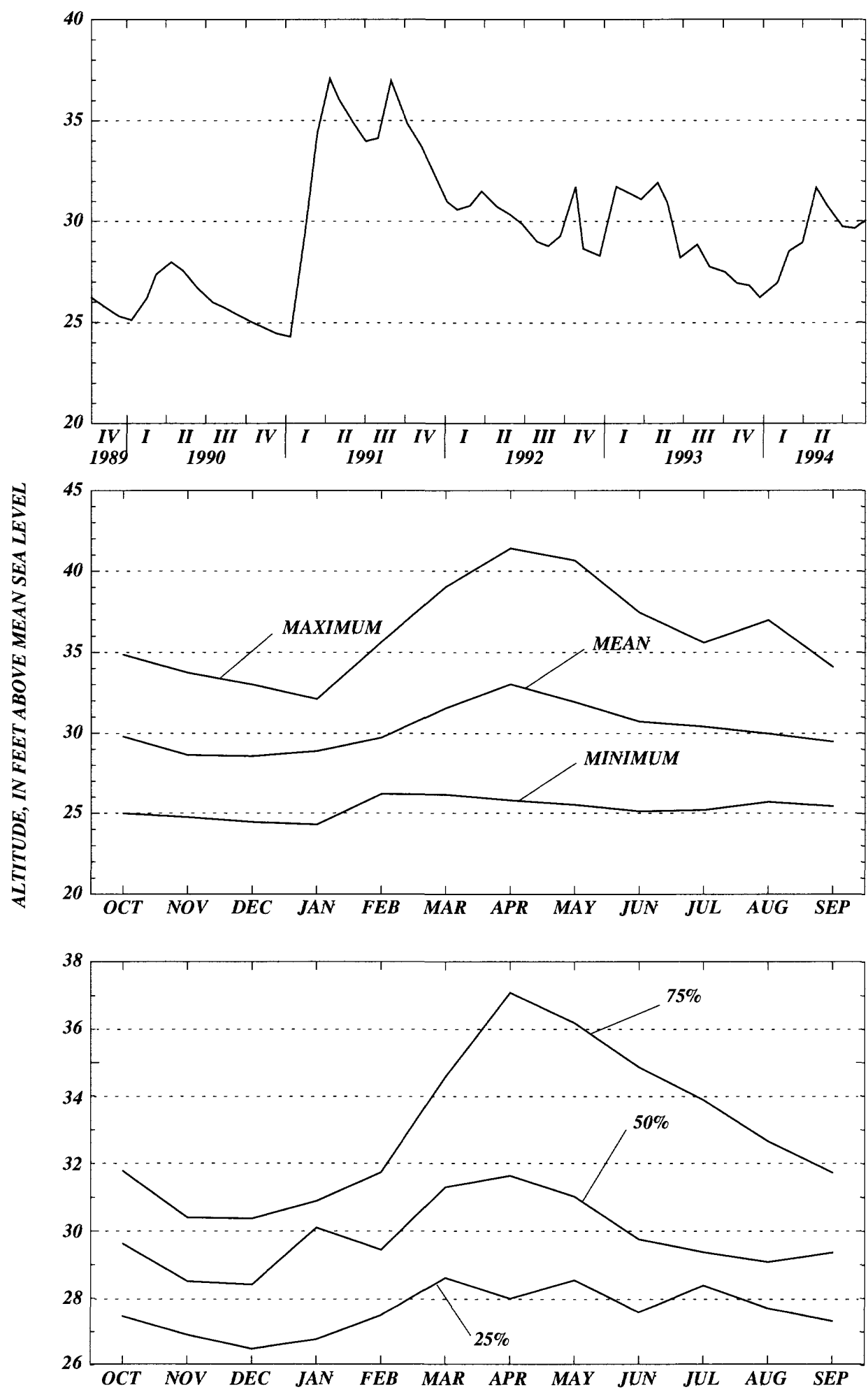
Suwannee County

WELL NUMBER.--301458083141985. Advent Christian Village. -031105006.

LOCATION.--Lat 30¹4'58”, long 8314'19”, Hydrologic Unit Code 03110205.

AQUIFER.--Upper Floridan aquifer of the Tertiary system, Geologic Unit Code 120FLRD.

WELL CHARACTERISTICS.--Casing diameter 4 in., Casing depth 60ft., Total depth 75ft.

INSTRUMENTATION.--Recorder, set to elevation of the Measuring Point, $60.40 \mathrm{ft}$., NGVD.

DATUM.--The National Geodetic Vertical Datum of 1929.

PERIOD OF RECORD.--08-28-1981 to 09-30-1994. *

EXTREME VALUES.--Maximum, 50.17 ft. (03-18-1991); minimum, 22.49 ft. (12-16-1990).

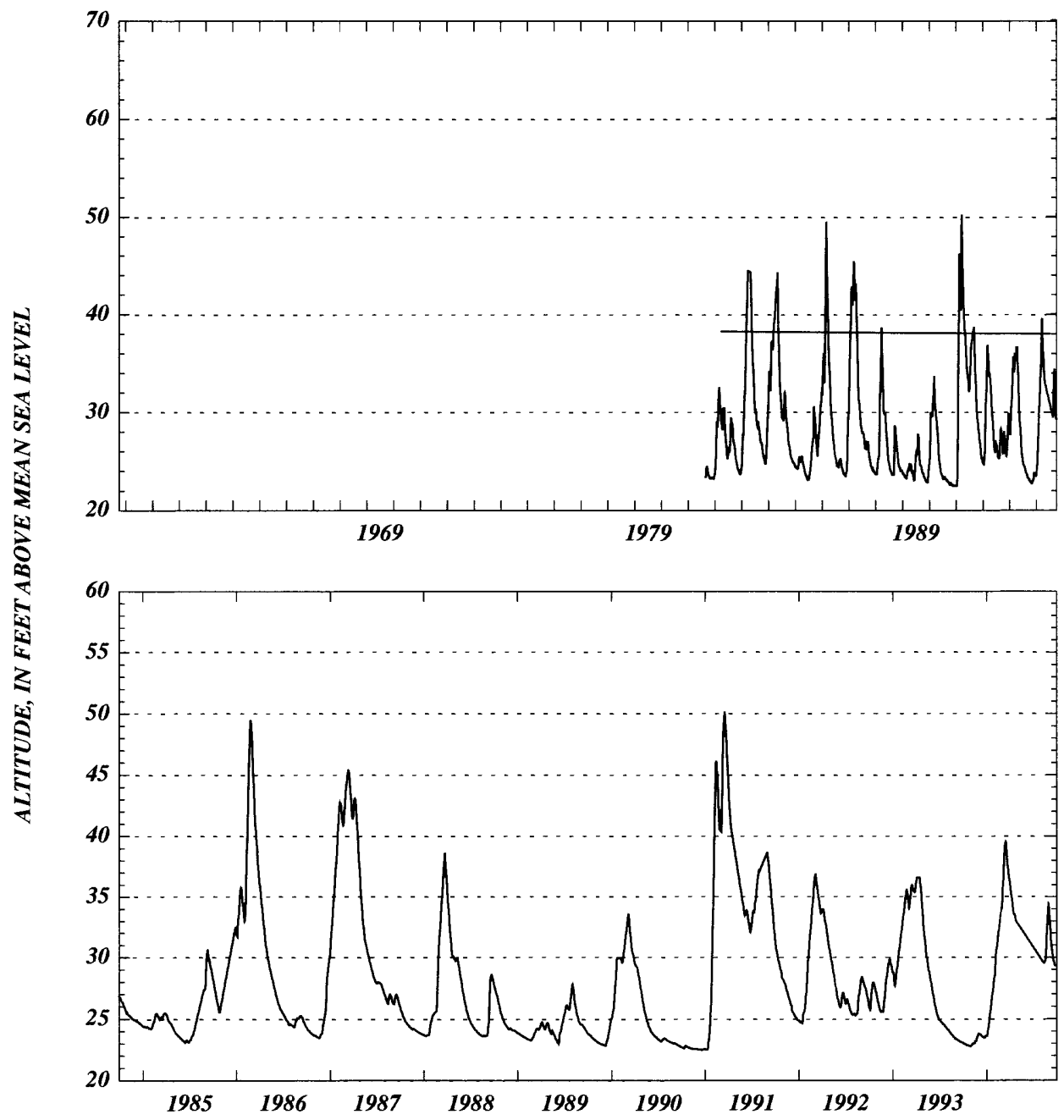



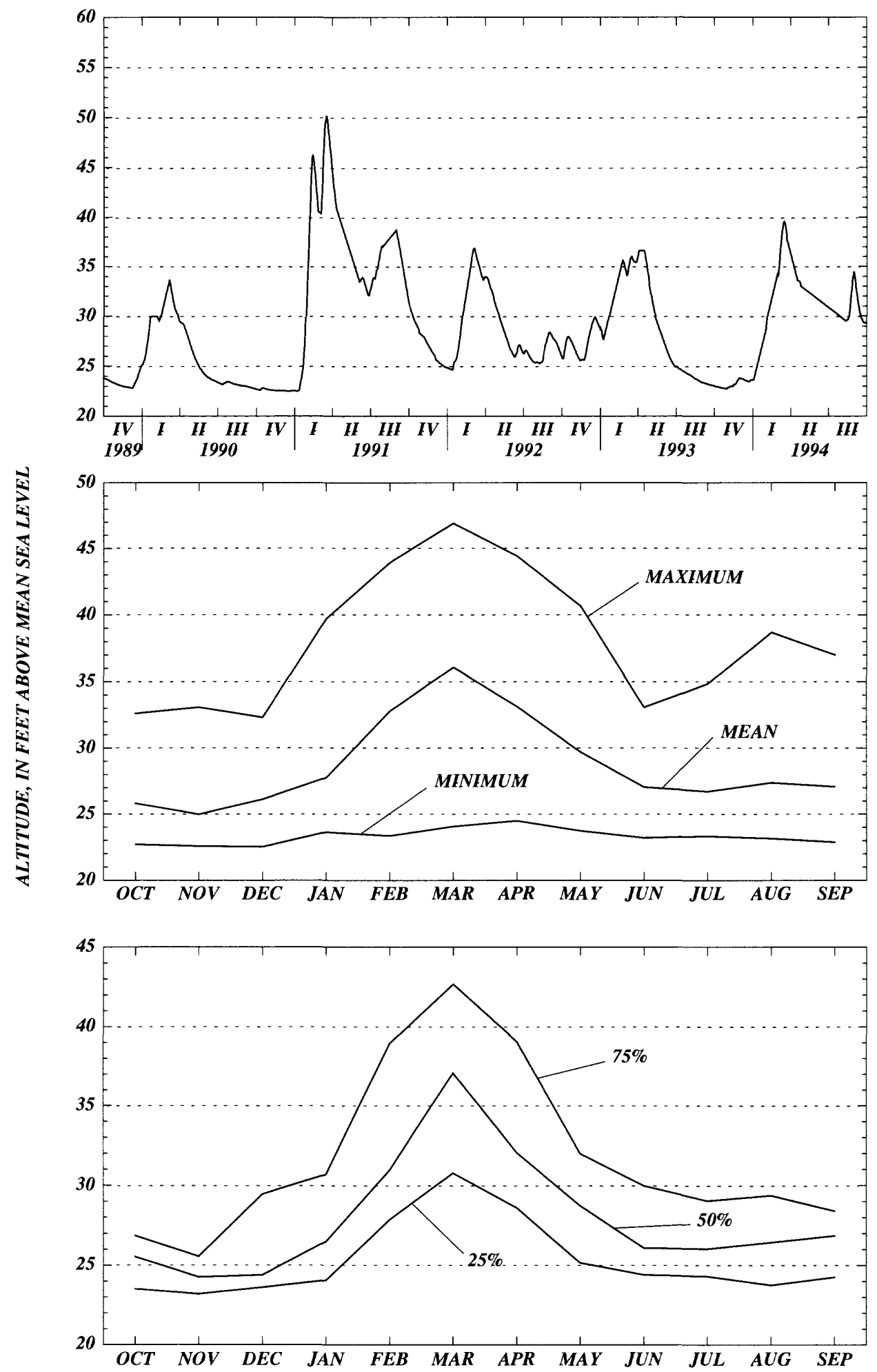


\section{Suwannee County}

WELL NUMBER.--301610082591585. Bobby Brickles. -021335001.

LOCATION.--Lat 30 16' 10”, long 82 59'15”, Hydrologic Unit Code 03110205.

AQUIFER.--Upper Floridan aquifer of the Tertiary system, Geologic Unit Code 120FLRD.

WELL CHARACTERISTICS.--Casing diameter 4 in., Casing depth $168 \mathrm{ft}$., Total depth $180 \mathrm{ft}$.

INSTRUMENTATION.--Miscellaneous from 11-01-1976 to 04-03-1981; then recorder, set to elevation of the Measuring Point, $105.12 \mathrm{ft}$., NGVD.

DATUM.--The National Geodetic Vertical Datum of 1929.

PERIOD OF RECORD.--11-01-1976 to 09-30-1994. *

EXTREME VALUES.--Maximum, 54.12 ft. (08-08-1984); minimum, 34.59 ft. (01-20-1991).

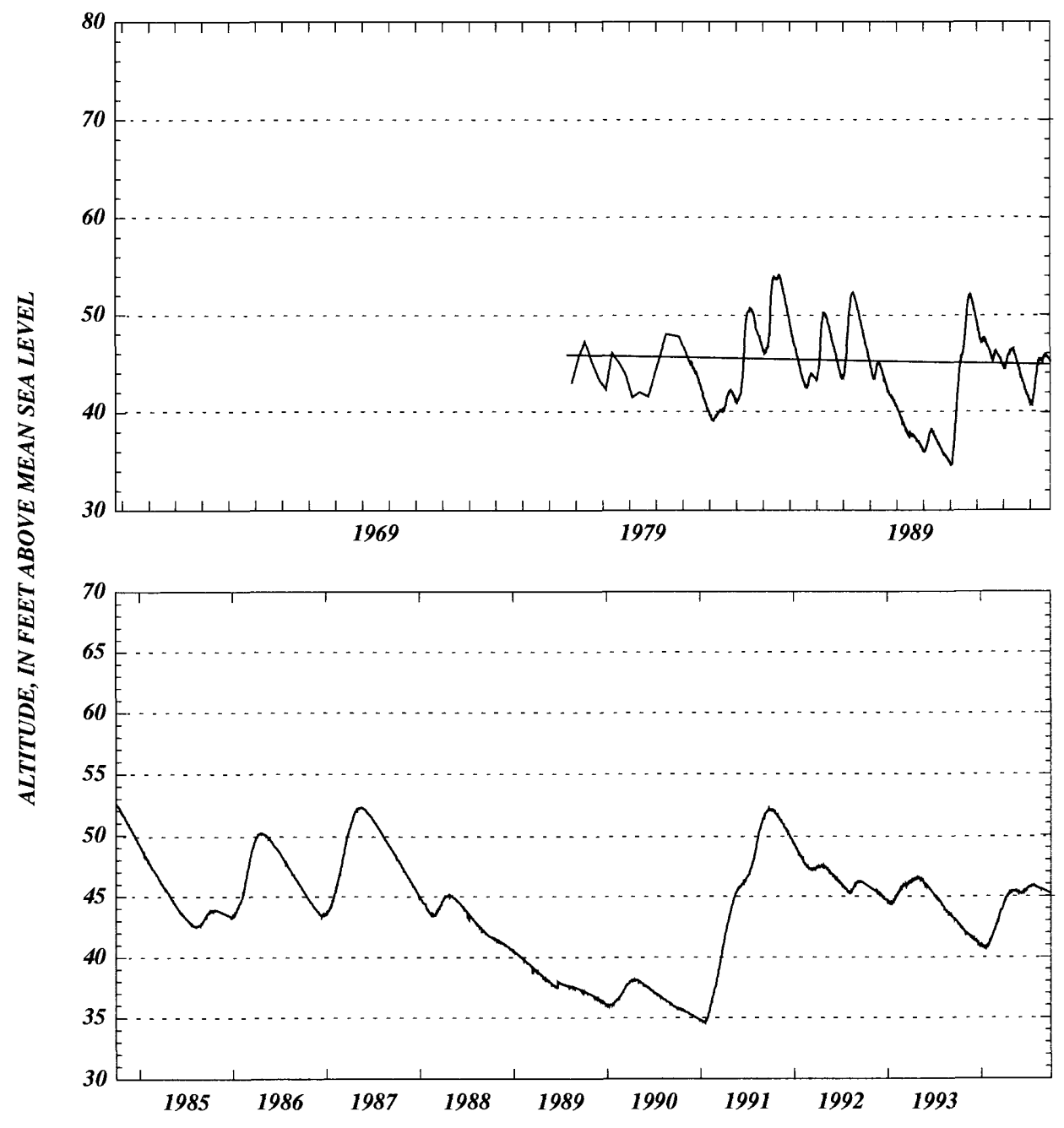



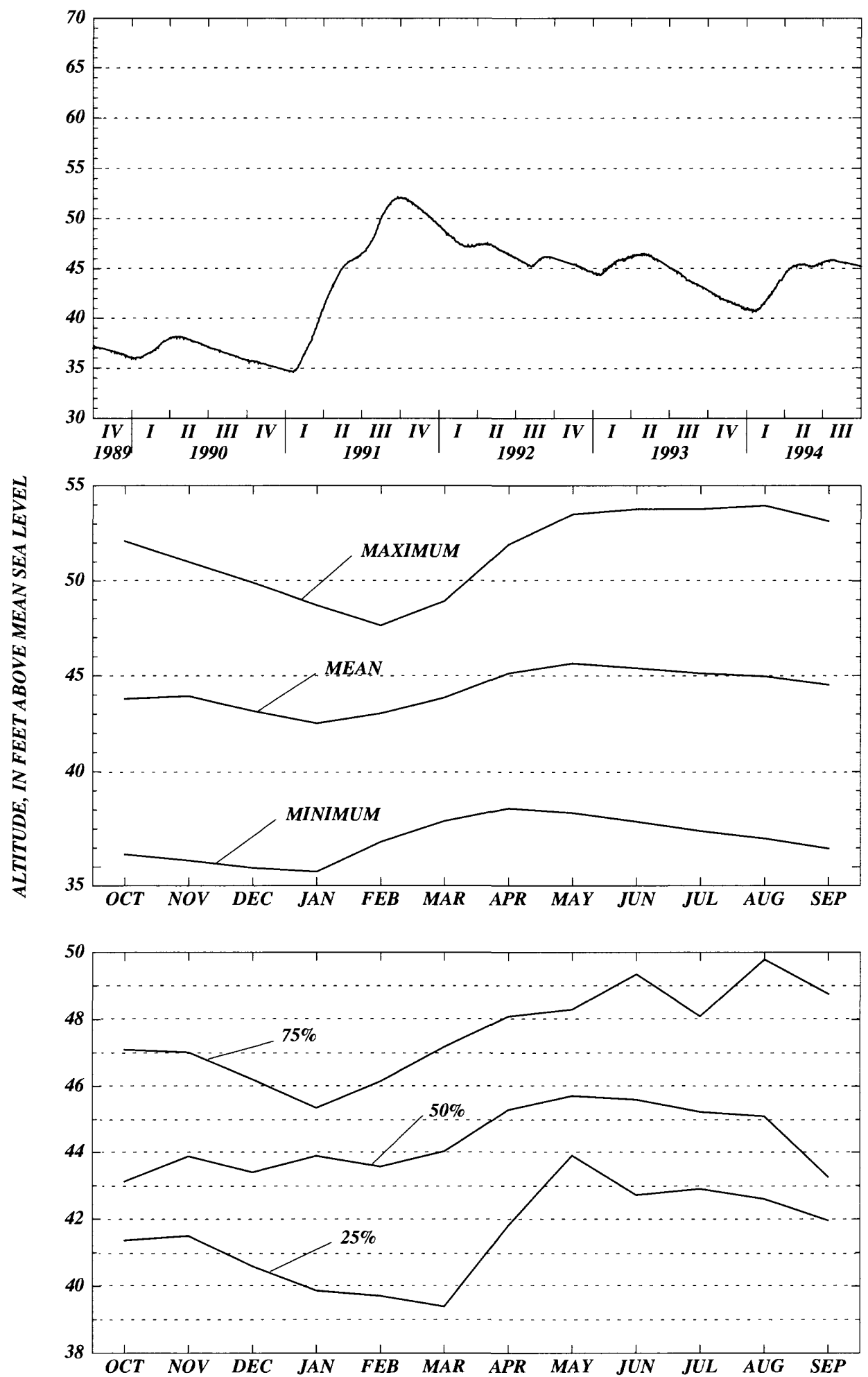


\section{Suwannee County}

WELL NUMBER.--301629083091285. Don Curtis. -021231001.

LOCATION.--Lat 30¹6’29”, long 8309'12', Hydrologic Unit Code 03110205.

AQUIFER.--Upper Floridan aquifer of the Tertiary system, Geologic Unit Code 120FLRD.

WELL CHARACTERISTICS.--Casing diameter 3 in., Casing depth $40 \mathrm{ft}$., Total Depth $80 \mathrm{ft}$.

INSTRUMENTATION.--Elevation of Measuring Point $88.04 \mathrm{ft} .$, NGVD.

DATUM.--The National Geodetic Vertical Datum of 1929.

PERIOD OF RECORD.--06-09-1989 to 09-30-1994.

EXTREME VALUES.--Maximum observed, $43.89 \mathrm{ft}$. (10-03-1991); minimum observed, $30.85 \mathrm{ft}$. (01-08-1991).

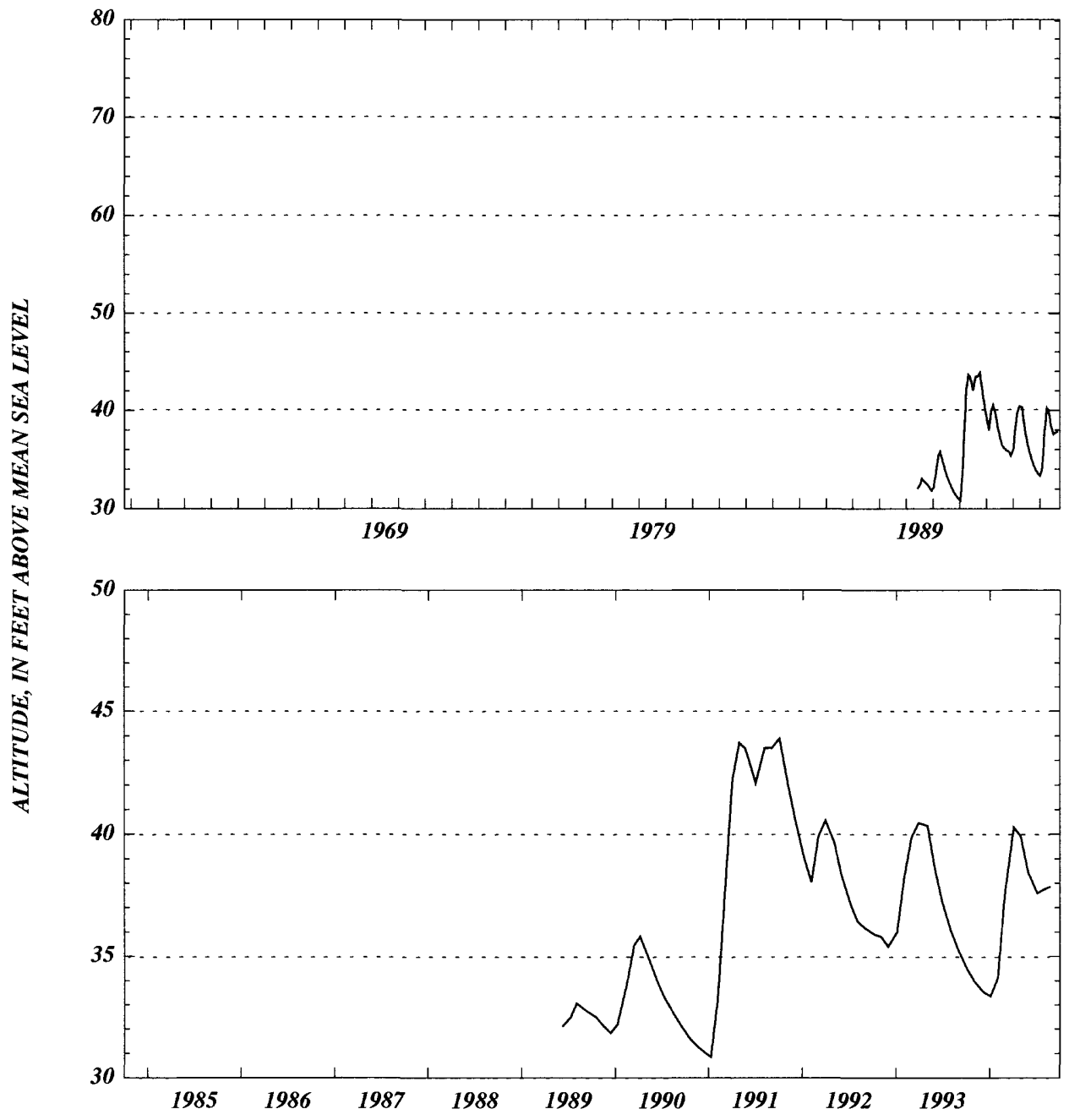




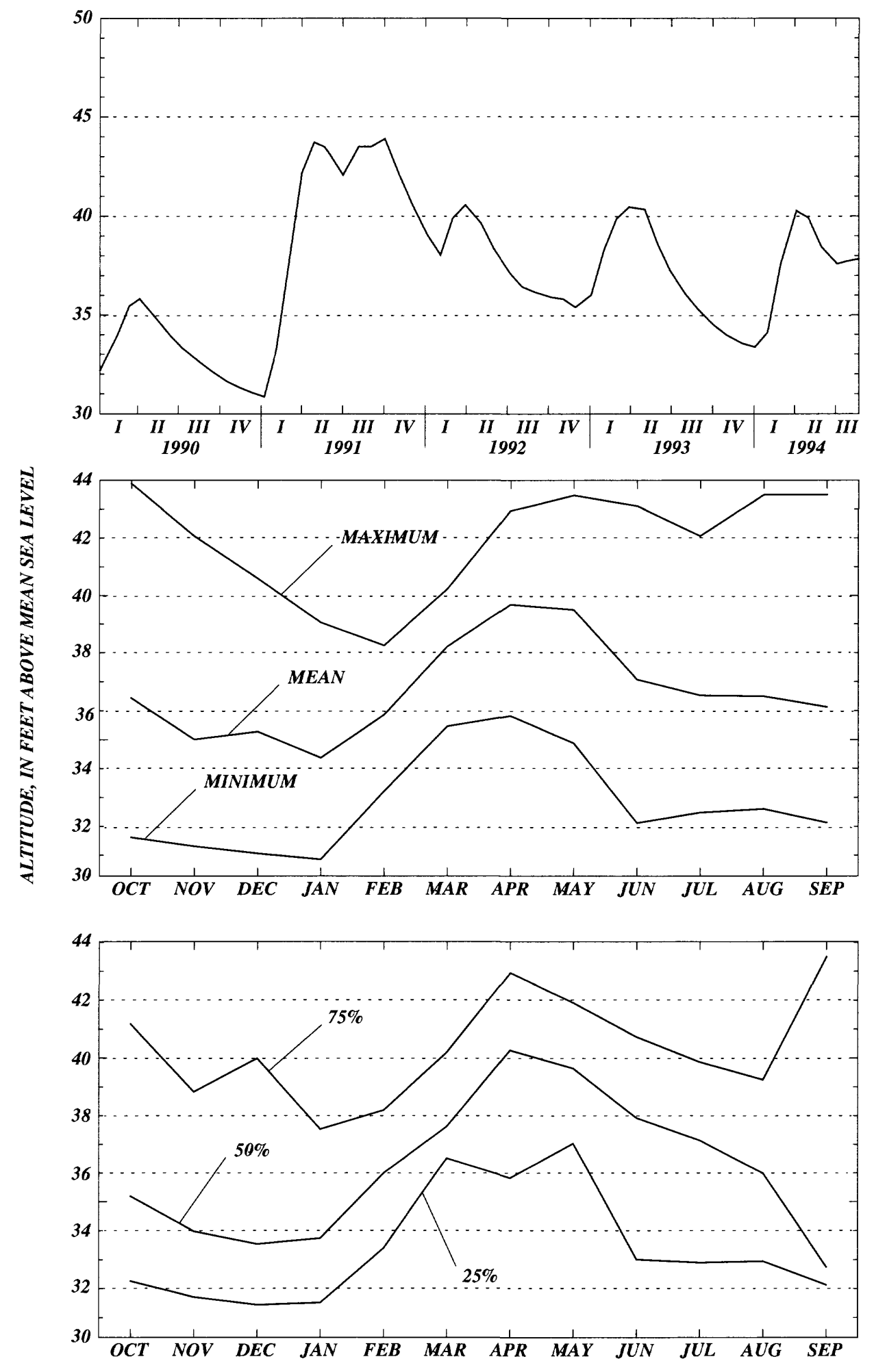


WELL NUMBER.--301909082490985. G.E. Poucher. -021516001.

LOCATION.--Lat 30¹9'09”, long 82 49'09”, Hydrologic Unit Code 03110201.

AQUIFER.--Upper Floridan aquifer of the Tertiary system, Geologic Unit Code 120FLRD.

WELL CHARACTERISTICS.--Casing diameter 4 in., Casing depth $135 \mathrm{ft}$., Total depth $138 \mathrm{ft}$.

INSTRUMENTATION.--Elevation of Measuring Point $90.49 \mathrm{ft}$., NGVD.

DATUM.--The National Geodetic Vertical Datum of 1929.

PERIOD OF RECORD.--01-20-1961 to 09-30-1994.

EXTREME VALUES.--Maximum observed, 75.39 ft. (04-24-1984); minimum observed, $46.14 \mathrm{ft}$. (01-04-1991).

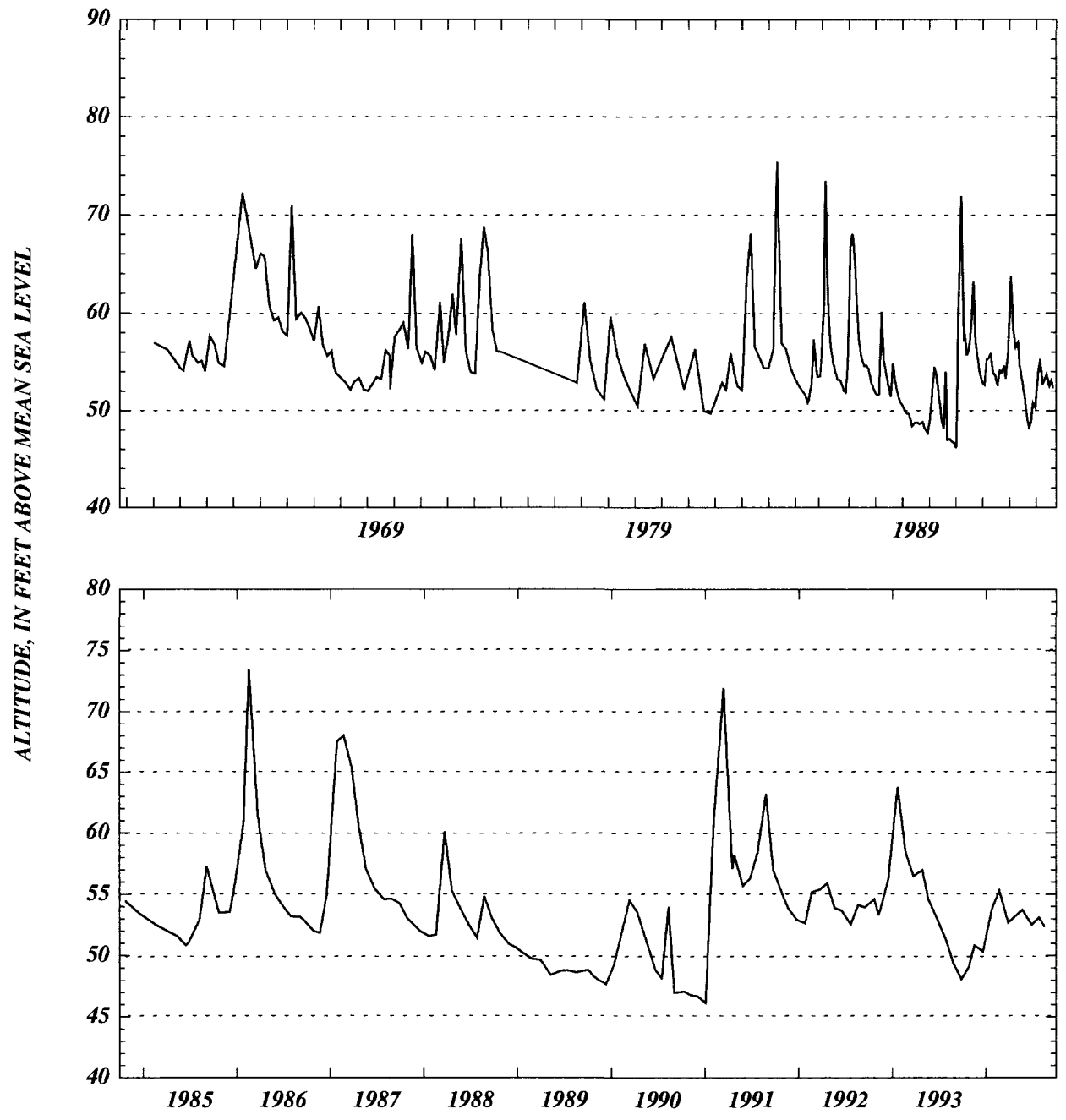



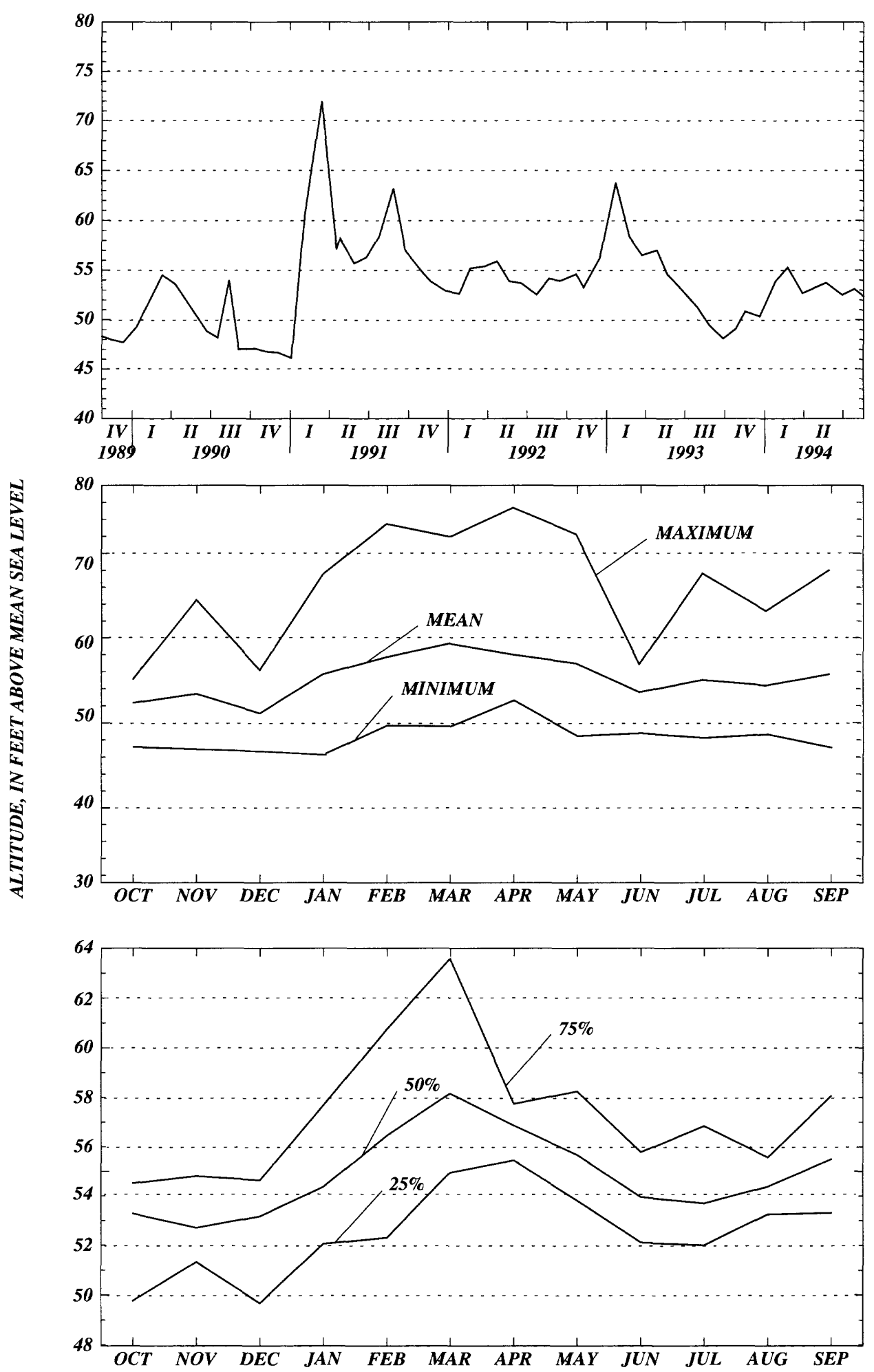
WELL NUMBER.--301941082572685. Rogers and Poole. -021407003.

LOCATION.--Lat 30'19'41”, long 82 57'26”, Hydrologic Unit Code 03110205.

AQUIFER.--Upper Floridan aquifer of the Tertiary system, Geologic Unit Code 120FLRD.

WELL CHARACTERISTICS.--Casing diameter 4 in., Casing depth unknown, Total depth $150 \mathrm{ft}$.

INSTRUMENTATION.--Elevation of the Measuring Point $166.37 \mathrm{ft}$., NGVD.

DATUM.--The National Geodetic Datum of 1929.

PERIOD OF RECORD.--06-27-1983 to 09-30-1994.

EXTREME VALUES.--Maximum observed, $61.53 \mathrm{ft}$. (04-24-1984); minimum observed, $36.85 \mathrm{ft}$. (11-01-1990).

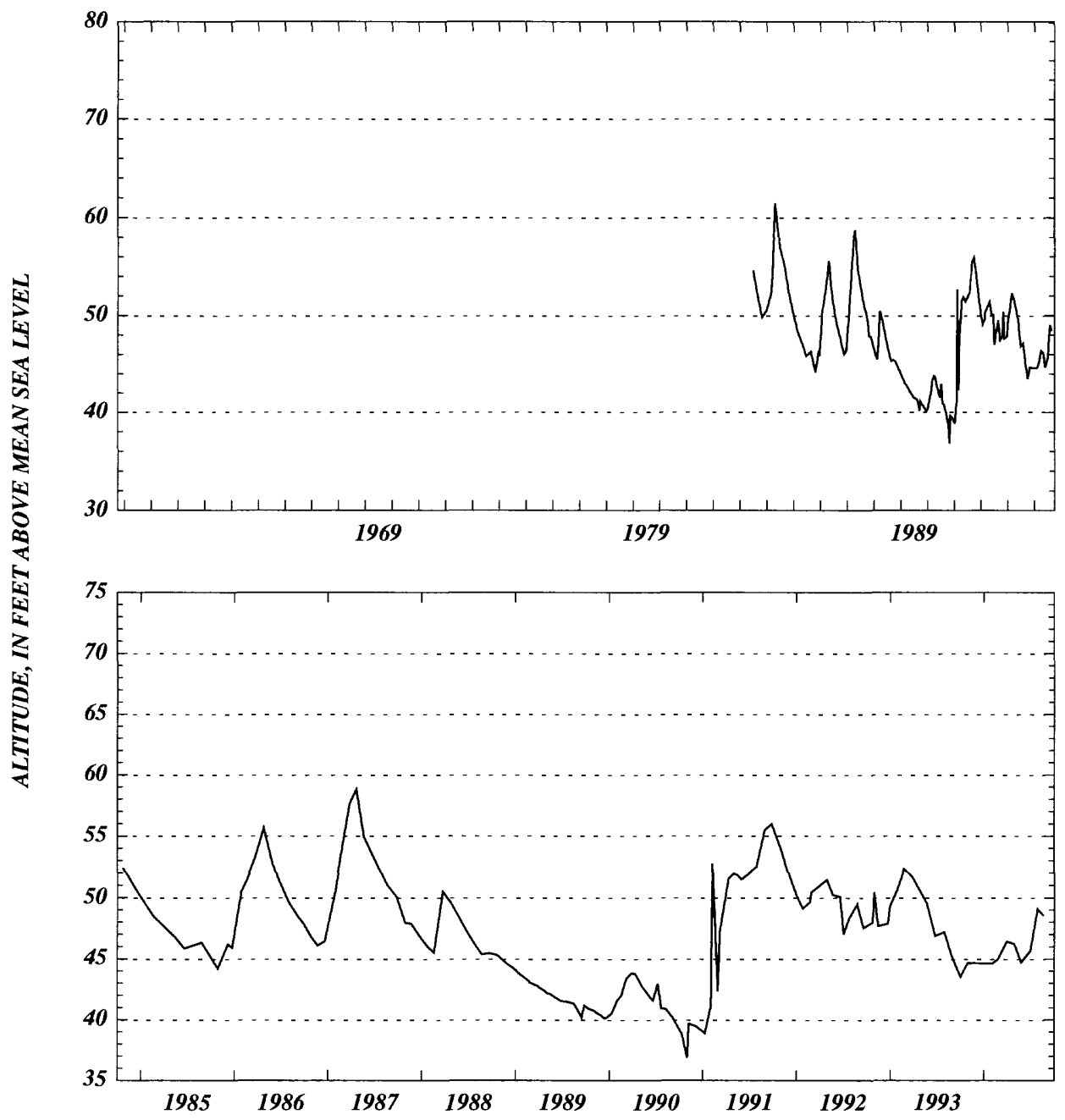



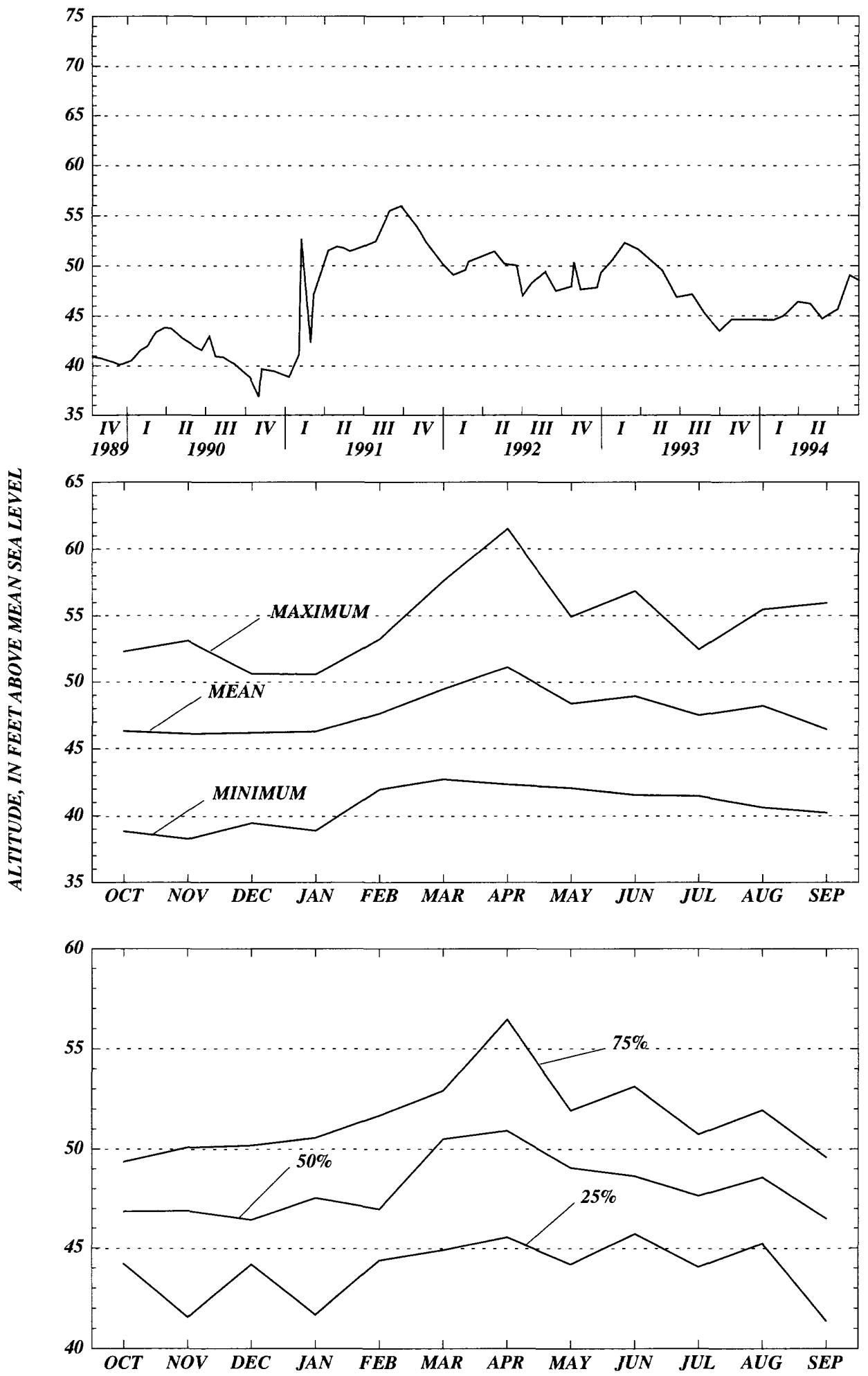


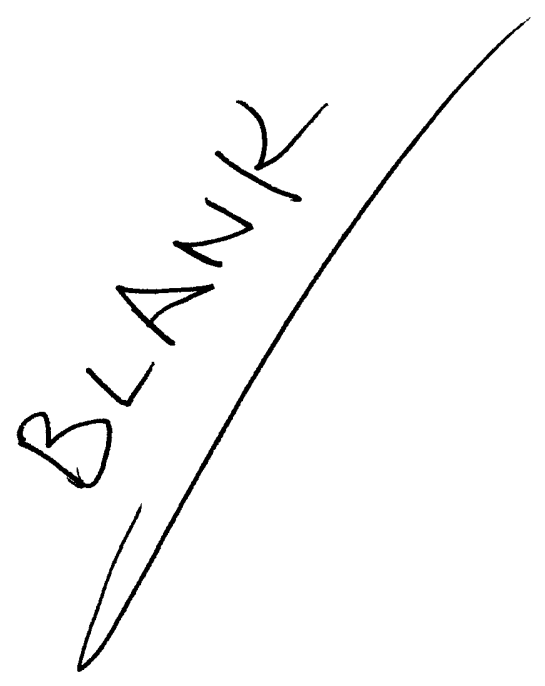




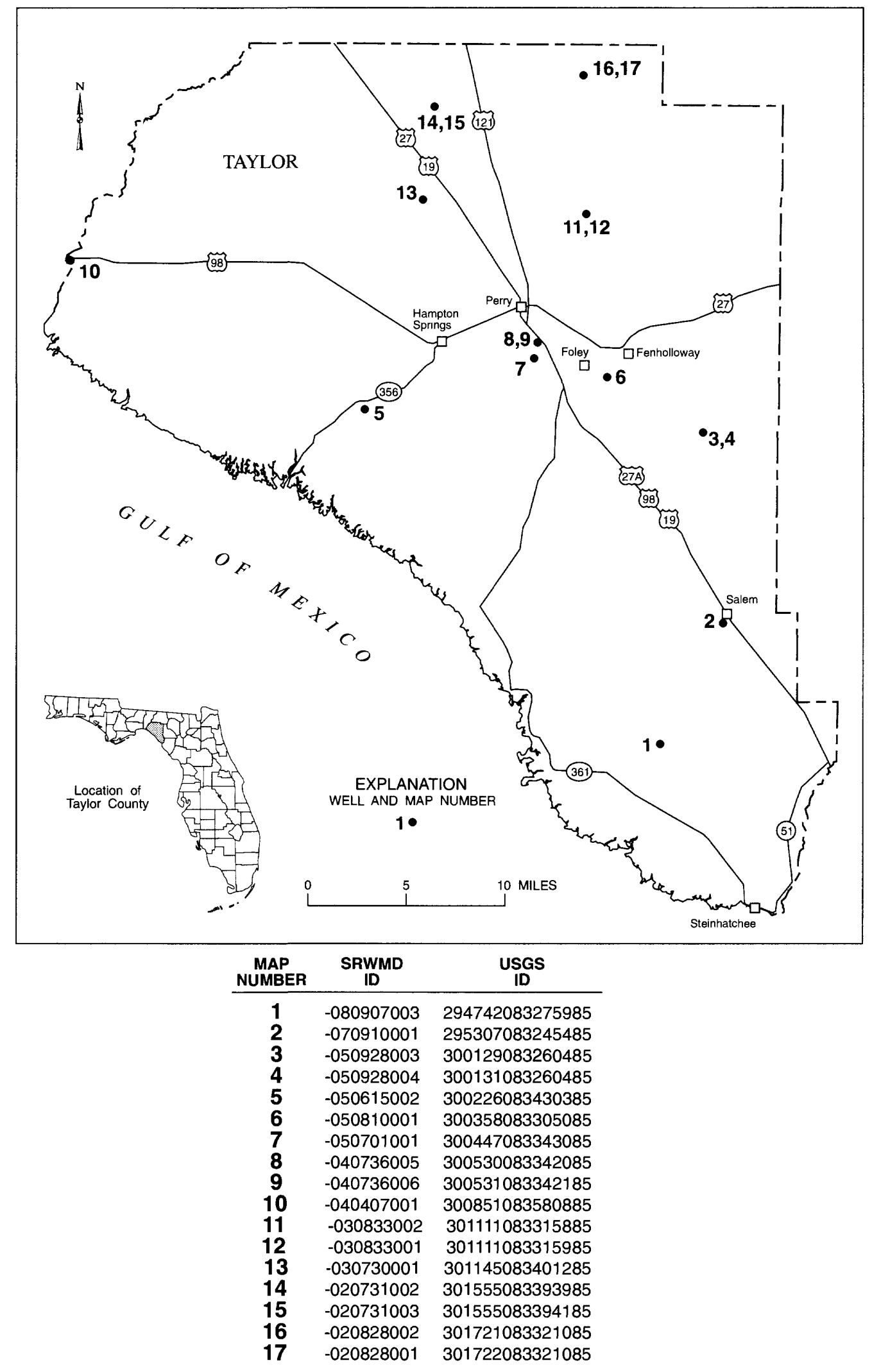

Figure 15. Location of wells in Taylor County. 


\section{Taylor County}

WELL NUMBER.--294742083275985. DOF - Salem Tower. -080907003.

LOCATION.--Lat 2947'42”, long 83²7'59”, Hydrologic Unit Code 03110102.

AQUIFER.--Upper Floridan aquifer of the Tertiary System, Geologic Unit Code 120FLRD.

WELL CHARACTERISTICS.--Casing diameter 3 in., Casing depth $7 \mathrm{ft}$., Total depth $37 \mathrm{ft}$.

INSTRUMENTATION.--Elevation of Measuring Point $38.66 \mathrm{ft}$., NGVD.

DATUM.--The National Geodetic Vertical Datum of 1929.

PERIOD OF RECORD.--06-12-1989 to 09-30-1994. *

EXTREME VALUES.--Maximum observed, $30.32 \mathrm{ft}$. (03-06-1991); minimum observed, $25.83 \mathrm{ft}$. (08-05-1992).

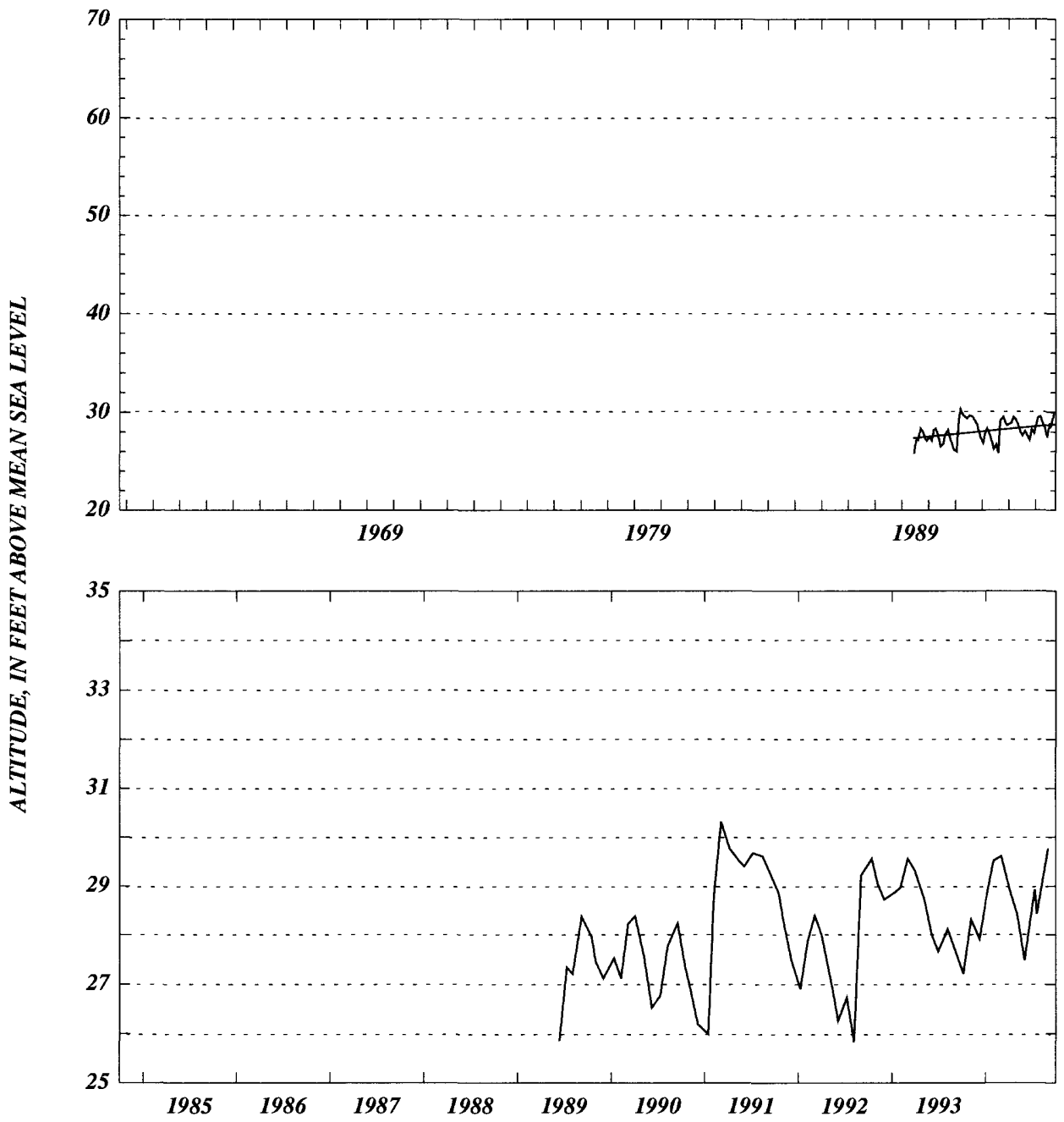



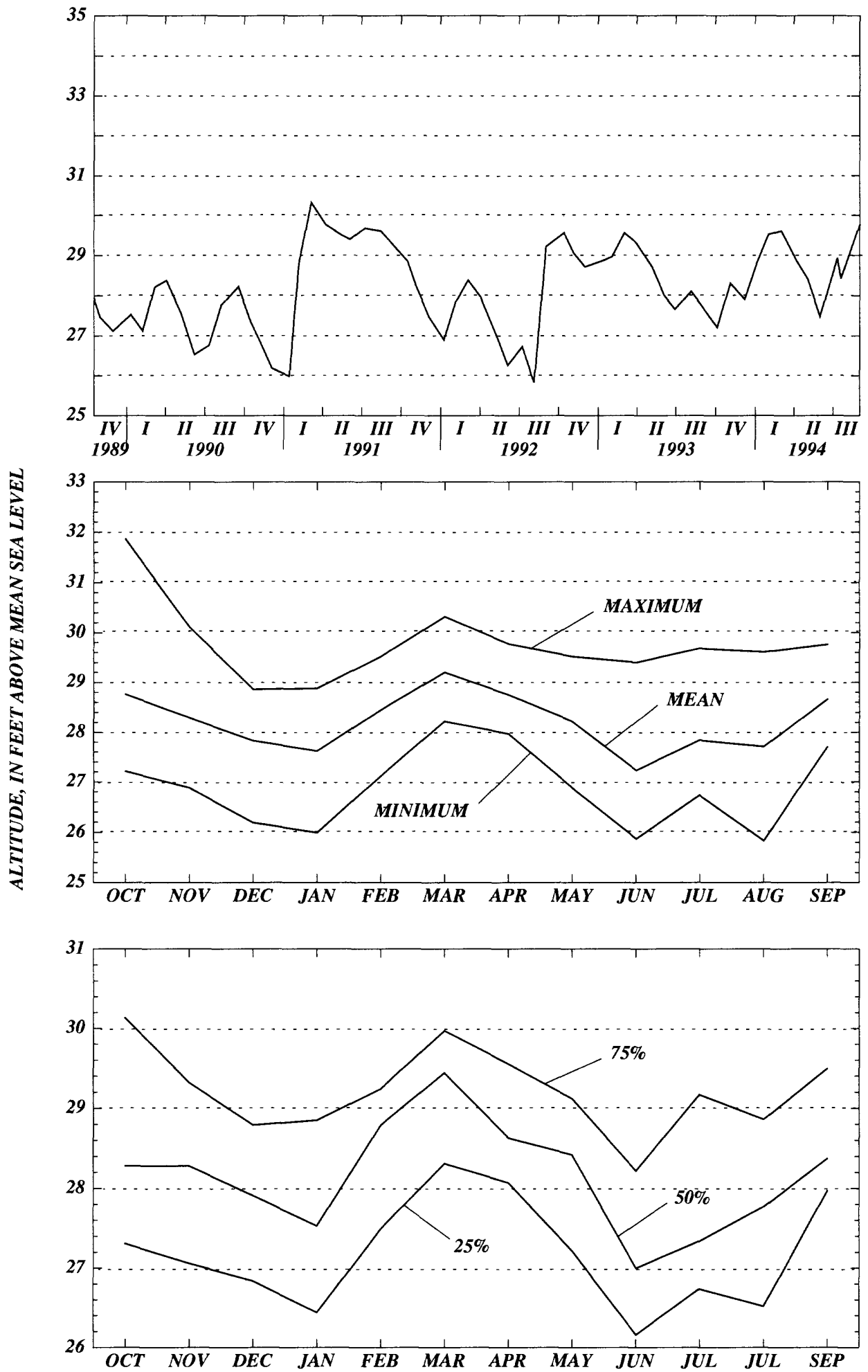


\section{Taylor County}

WELL NUMBER.--295307083245485. Danny Hudson. -070910001.

LOCATION.--Lat 2953'07', long 83²4'54”, Hydrologic Unit Code 03110102.

AQUIFER.--Upper Floridan aquifer of the Tertiary system, Geologic Unit Code 120FLRD.

WELL CHARACTERISTICS.--Casing diameter 2 in., Casing depth $28 \mathrm{ft}$., Total depth $32 \mathrm{ft}$.

INSTRUMENTATION.--Elevation of Measuring Point $40.16 \mathrm{ft}$., NGVD.

DATUM.The National Geodetic Vertical Datum of 1929.

PERIOD OF RECORD.--11-01-1976 to 09-30-1994.

EXTREME VALUES.--Maximum observed, 38.69 ft. (03-31-1987); minimum observed, $32.76 \mathrm{ft}$. (08-23-1993).

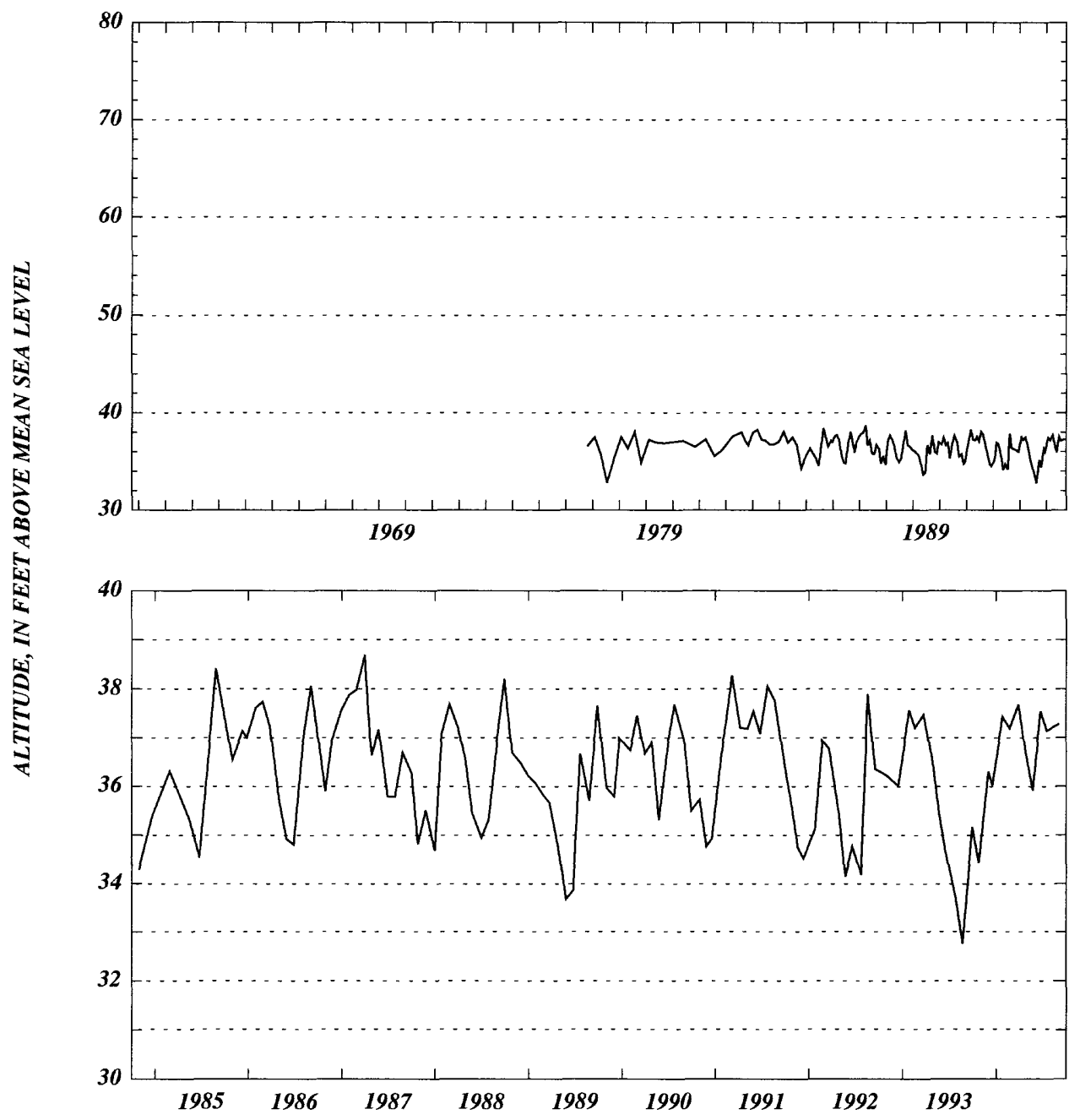



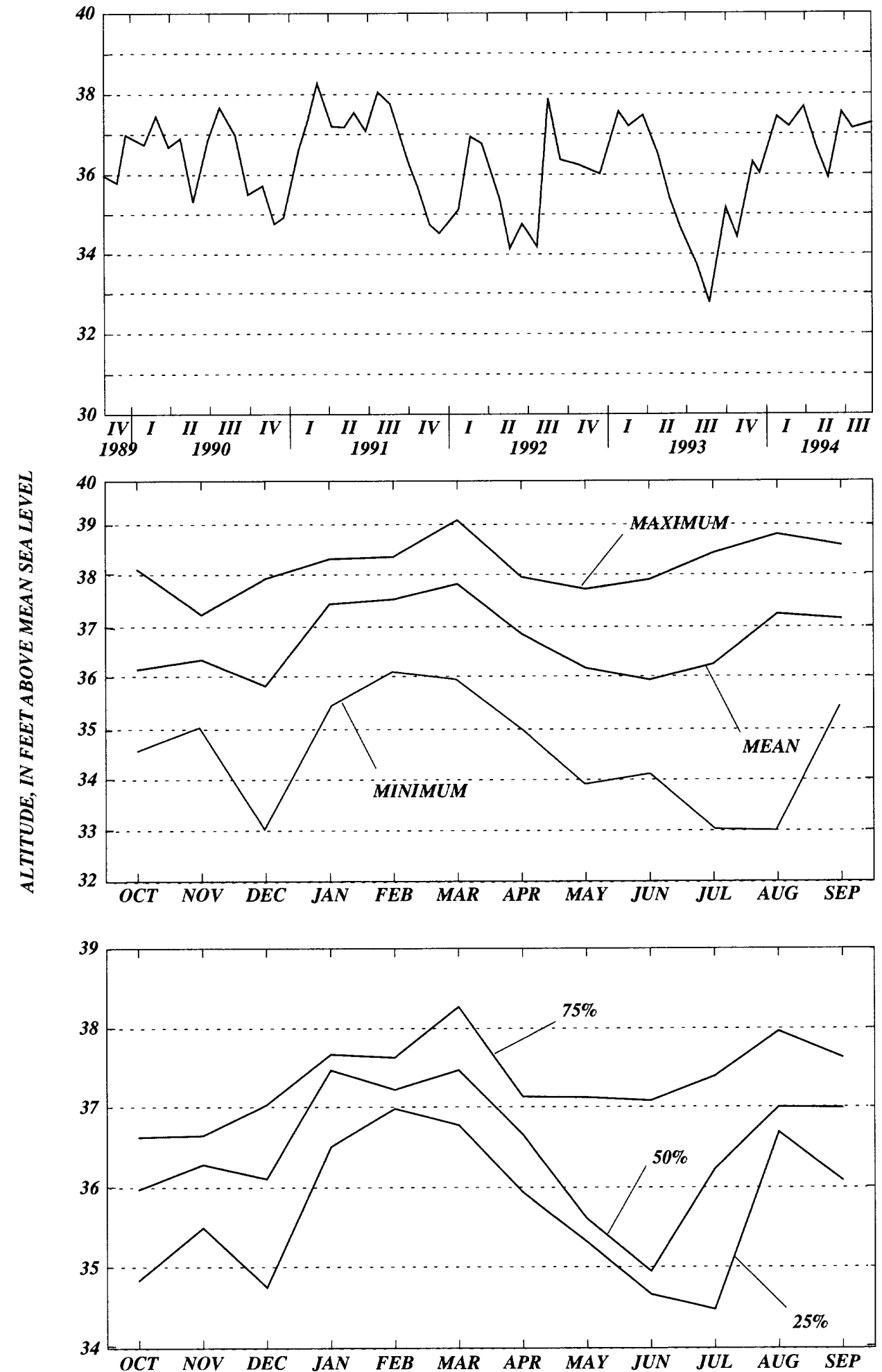


\section{Taylor County}

WELL NUMBER.--300129083260485. Procter and Gamble. -050928003.

LOCATION.--Lat 3001'29”, long 83²6'04", Hydrologic Unit Code 03110102.

AQUIFER.--Surificial aquifer, Geologic Unit Code 110NRSD.

WELL CHARACTERISTICS.--Casing diameter 3 in., Casing depth $3 \mathrm{ft}$., Total depth $13 \mathrm{ft}$.

INSTRUMENTATION.--Elevation of the Measuring Point $76.13 \mathrm{ft}$., NGVD.

DATUM.--The National Geodetic Vertical Datum of 1929.

PERIOD OF RECORD.--04-14-1987 to 09-30-1994. *

EXTREME VALUES.--Maximum observed, 72.03 ft. (04-14-1987); minimum observed, $64.89 \mathrm{ft}$. (09-03-1993).

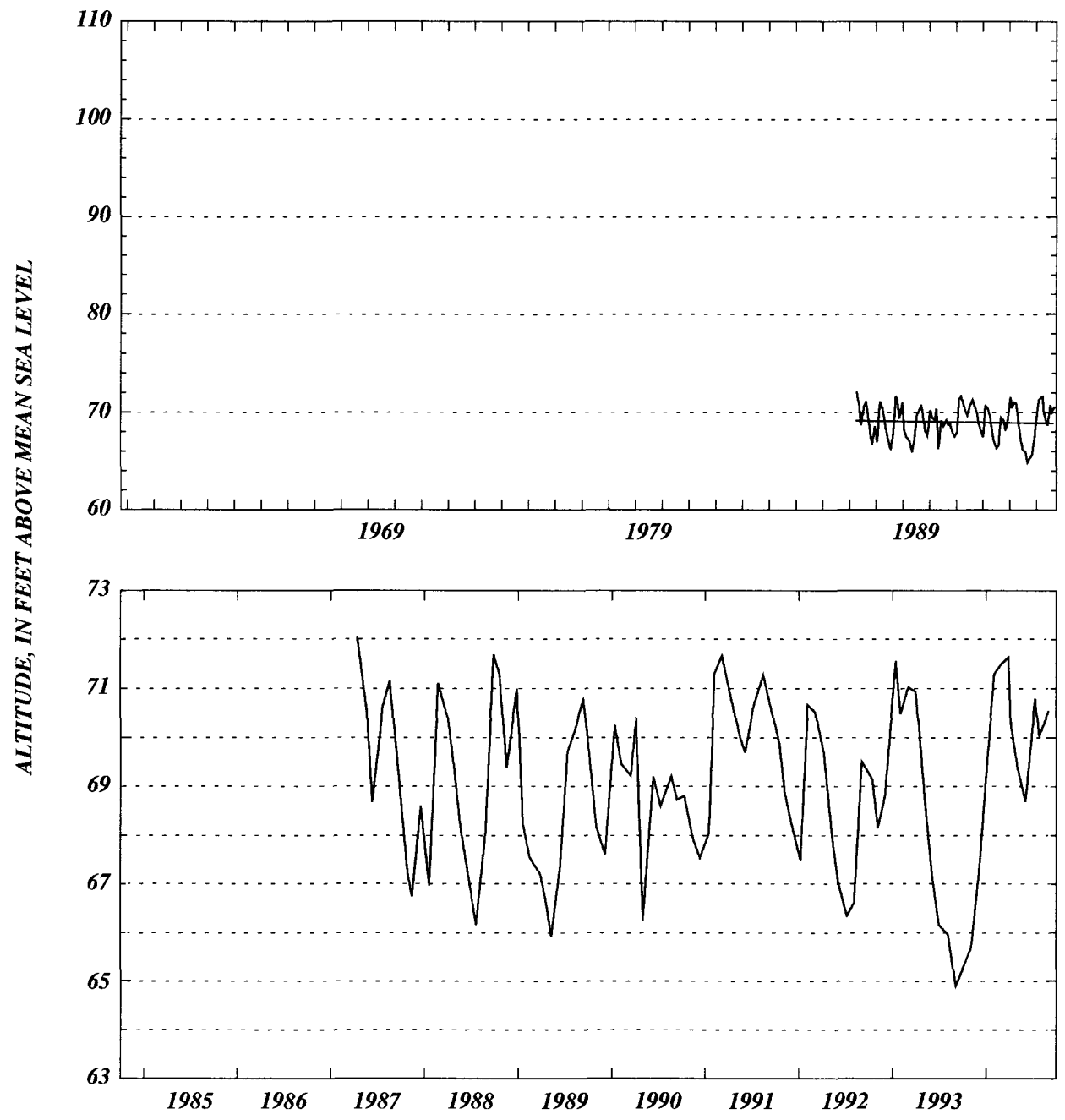



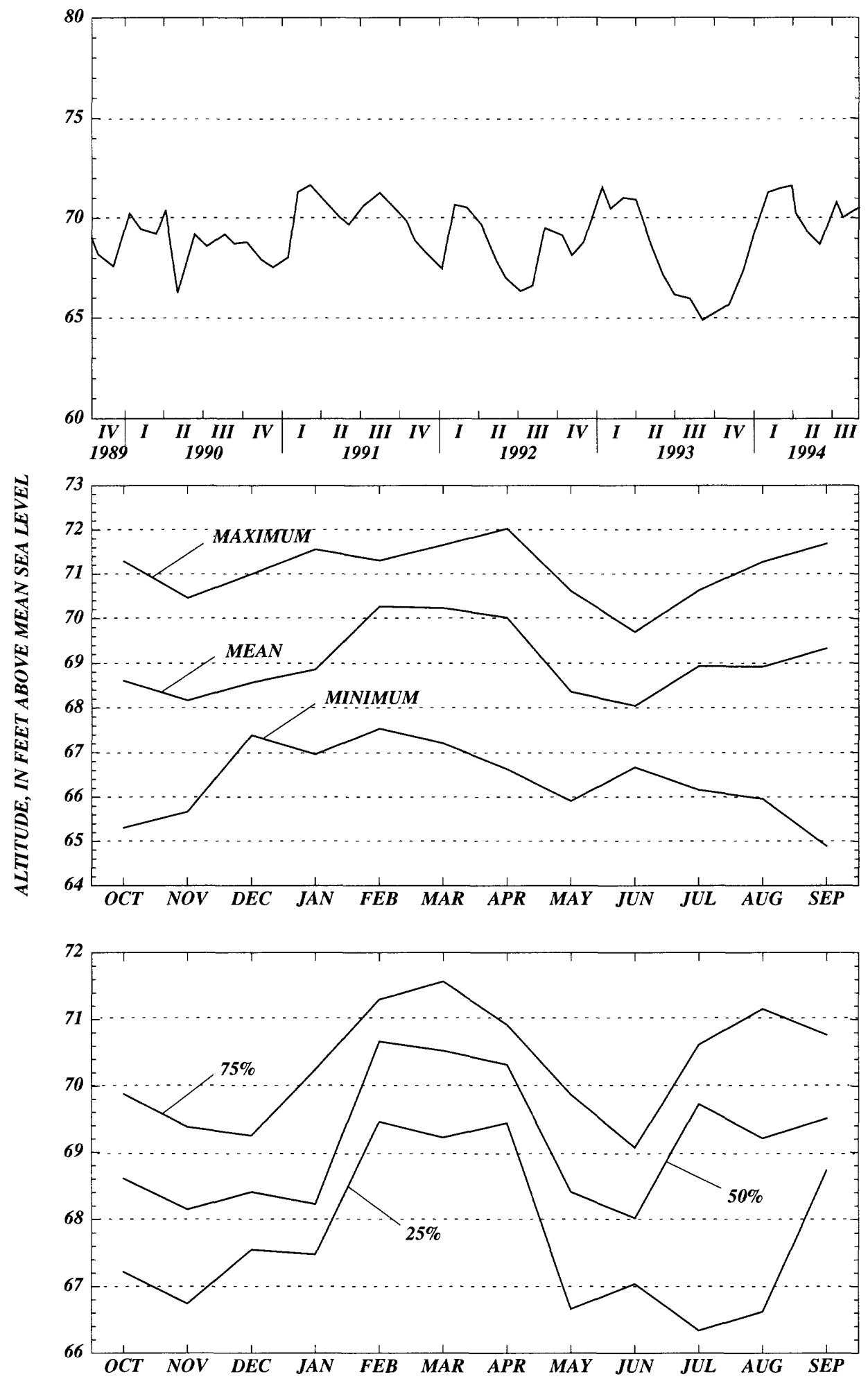


\section{Taylor County}

WELL NUMBER.--300131083260485. Procter and Gamble. -050928004.

LOCATION.--Lat 3001'31", long 83²6'04”, Hydrologic Unit Code 03110102.

AQUIFER.--Upper Floridan aquifer of the Tertiary system, Geologic Unit Code 120FLRD.

WELL CHARACTERISTICS.--Casing diameter 3 in., Casing depth $40 \mathrm{ft}$., Total depth $60 \mathrm{ft}$.

INSTRUMENTATION.--Elevation of Measuring Point $74.80 \mathrm{ft}$., NGVD.

DATUM.--The National Geodetic Vertical Datum of 1929.

PERIOD OF RECORD.--07-22-1987 to 09-30-1994. *

EXTREME VALUES.--Maximum observed, 71.80 ft. (09-11-1989); minimum observed, $64.72 \mathrm{ft}$. (09-03-1993).

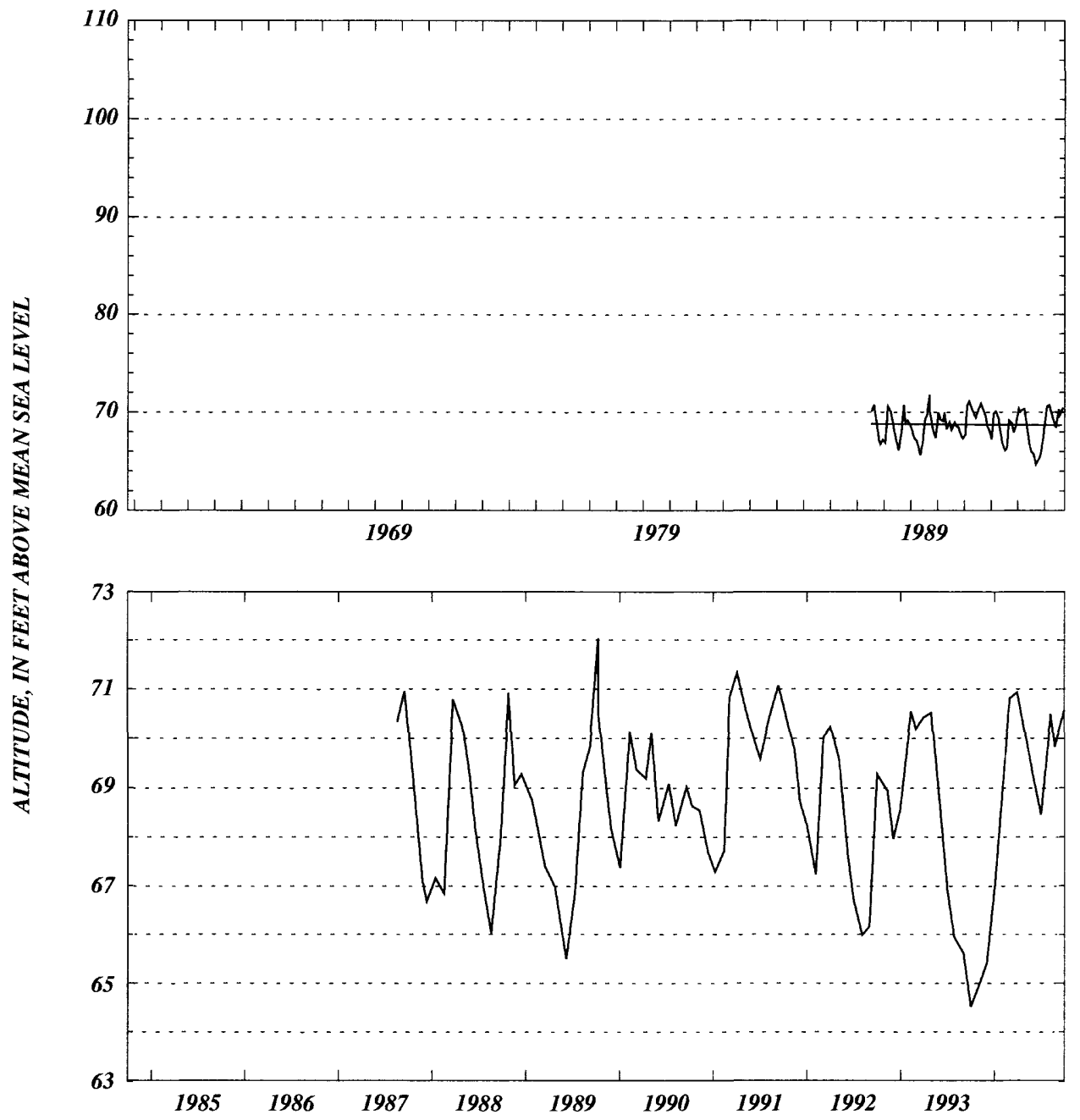



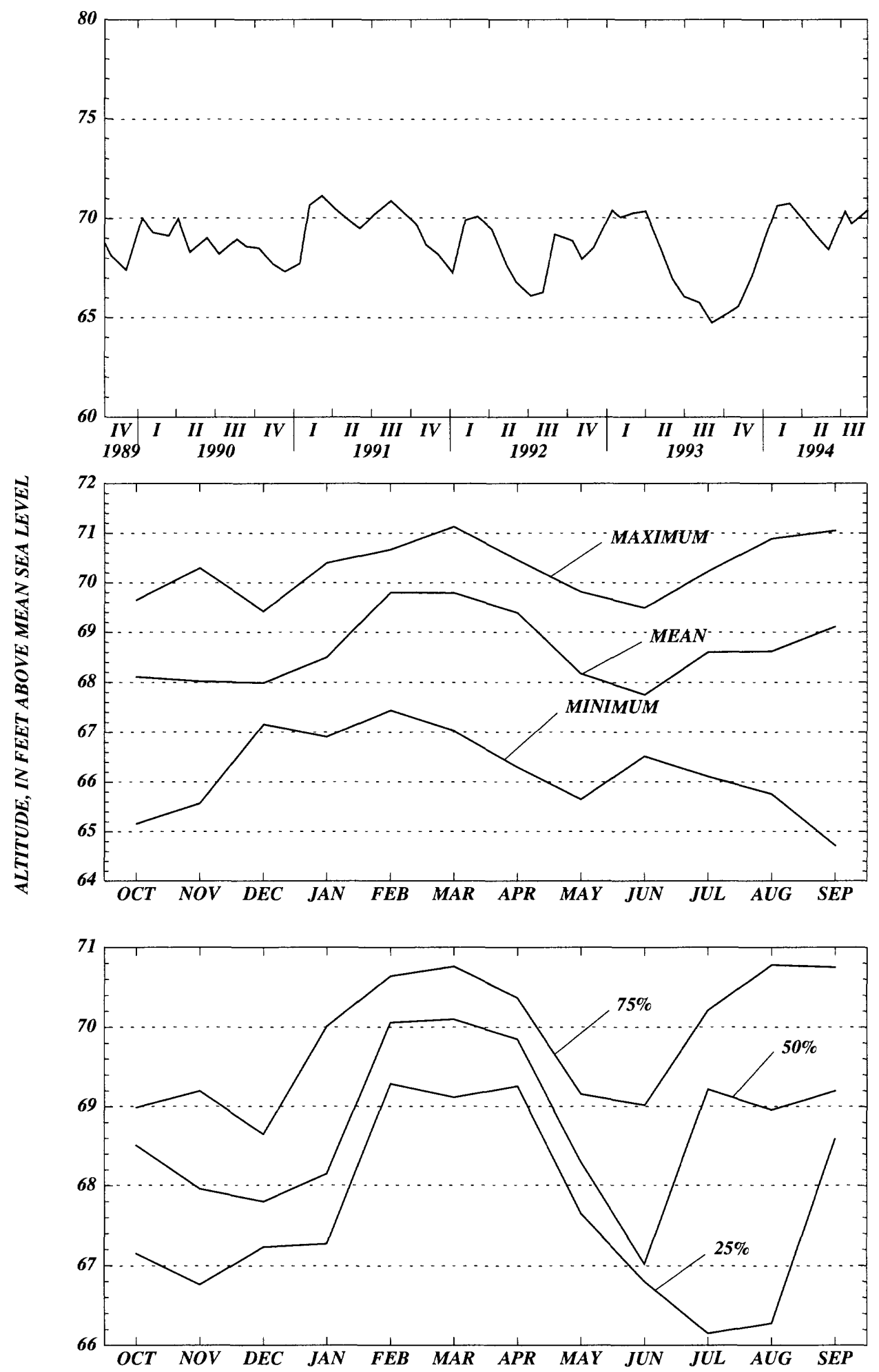


\section{Taylor County}

WELL NUMBER.--300226083430385. DOF - Hampton Springs Tower. -050615002.

LOCATION.--Lat $30^{\circ} 02^{\prime} 26^{\prime \prime}$, long 8343'03”, Hydrologic Unit Code 03110102.

AQUIFER.--Upper Floridan aquifer of the Tertiary system, Geologic Unit Code 120FLRD.

WELL CHARACTERISTICS.--Casing diameter 3 in., Casing depth $18 \mathrm{ft}$., Total depth $38 \mathrm{ft}$.

INSTRUMENTATION.--Elevation of Measuring Point $28.42 \mathrm{ft}$., NGVD.

DATUM.--The National Geodetic Vertical Datum of 1929.

PERIOD OF RECORD.--06-07-1989 to 09-30-1994.

EXTREME VALUES.--Maximum observed, $14.22 \mathrm{ft}$. (08-31-1994); minimum observed, $6.42 \mathrm{ft}$. (10-06-1993).

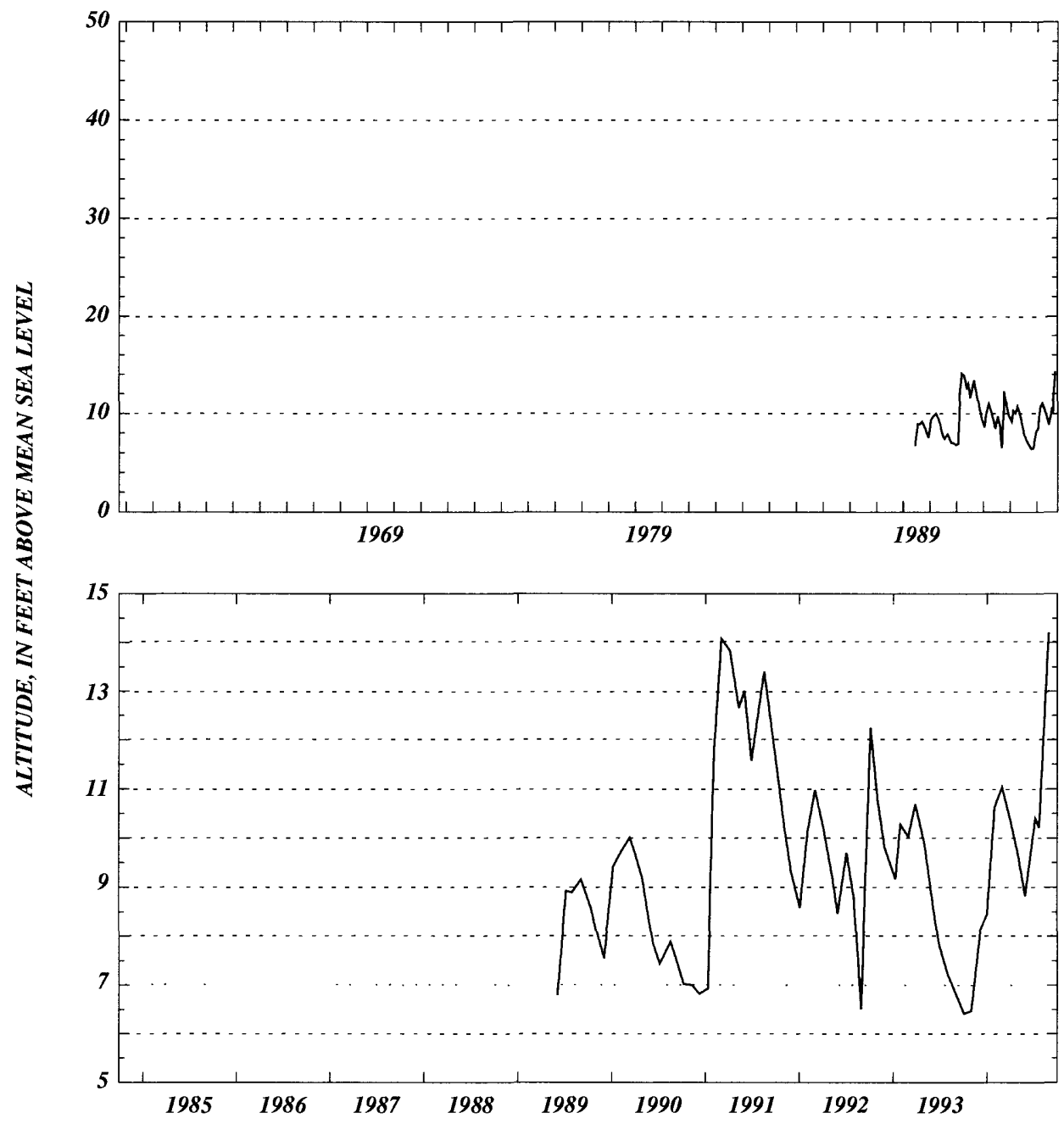



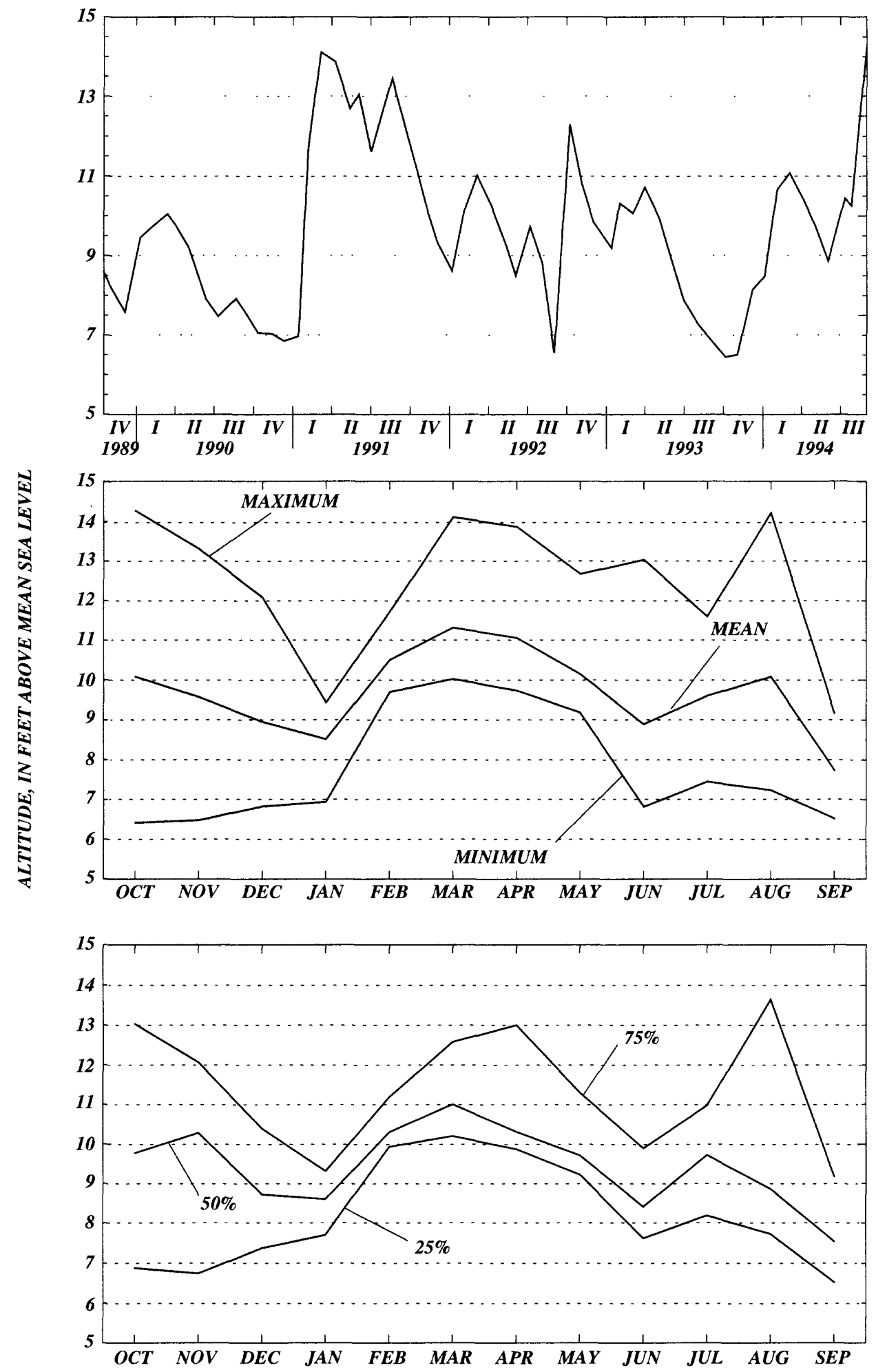
WELL NUMBER.--300358083305085. Procter and Gamble. -050810001.

LOCATION.--Lat 3003'58”, long 83³0'50”, Hydrologic Unit Code 03110102.

AQUIFER.--Upper Floridan aquifer of the Tertiary system, Geologic Unit Code 120FLRD.

WELL CHARACTERISTICS.--Casing diameter 17 in., Casing depth $191 \mathrm{ft}$., Total depth $230 \mathrm{ft}$.

INSTRUMENTATION.--Recorder from 07-03-1946 to 12-17-1949; no record from 12-18-1949 to 03-08-1954; recorder from 03-09-1954 to 12-31-1955; no record from 01-01-1956 to 01-04-1974; miscellaneous from 01-05-1974 to 10-31-1976; recorder from 11-01-1976 to 10-10-1994; miscellaneous from 10-17-1994 to 12-28-1994. Elevation of Measuring Point $57.09 \mathrm{ft} .$, NGVD.

DATUM.--The National Geodetic Vertical Datum of 1929.

PERIOD OF RECORD.--07-03-1946 to 09-30-1994.

EXTREME VALUES.--Maximum, 55.38 ft. (04-02-1948); minimum, 12.19 ft. (05-05-1974).

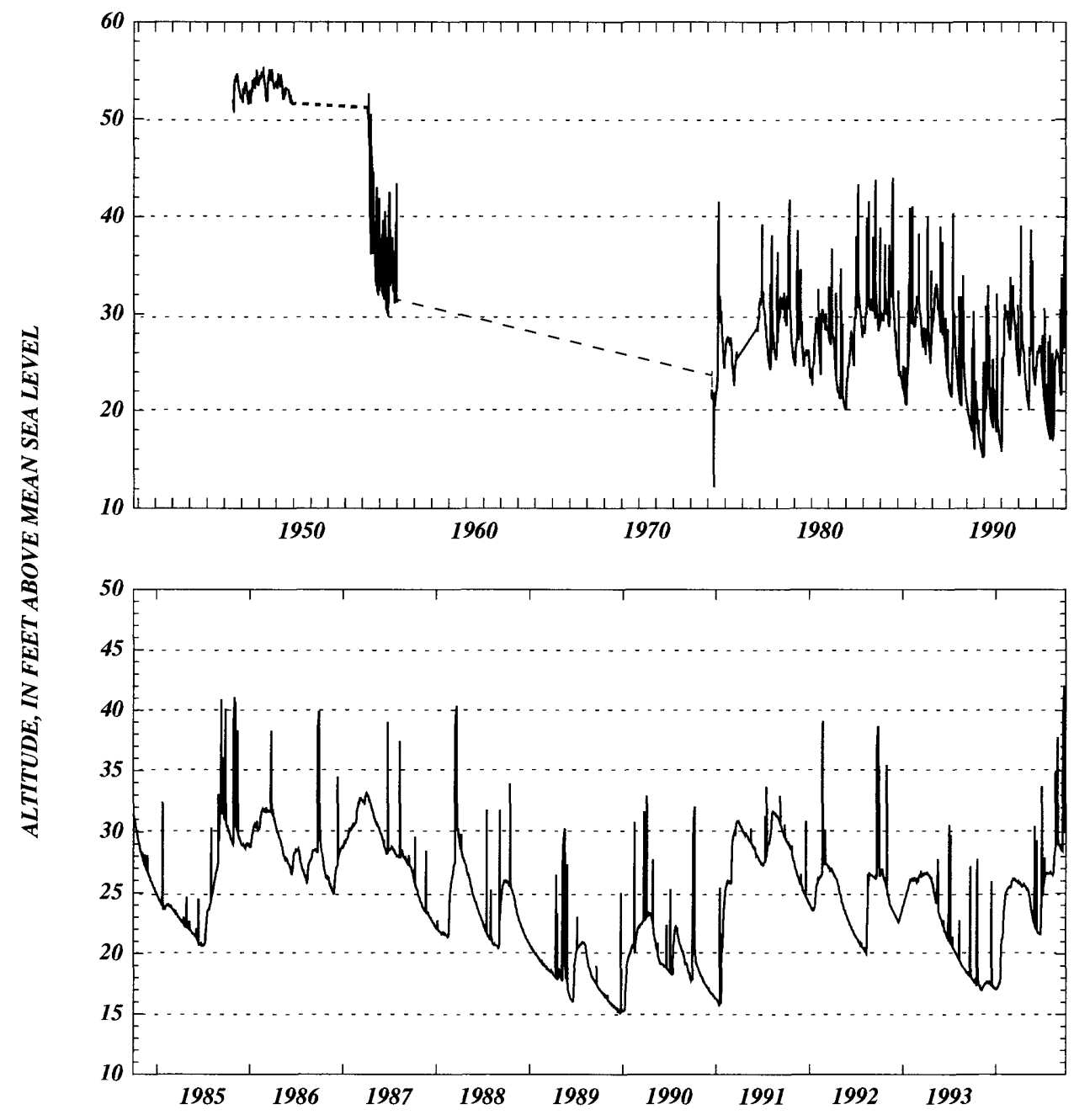




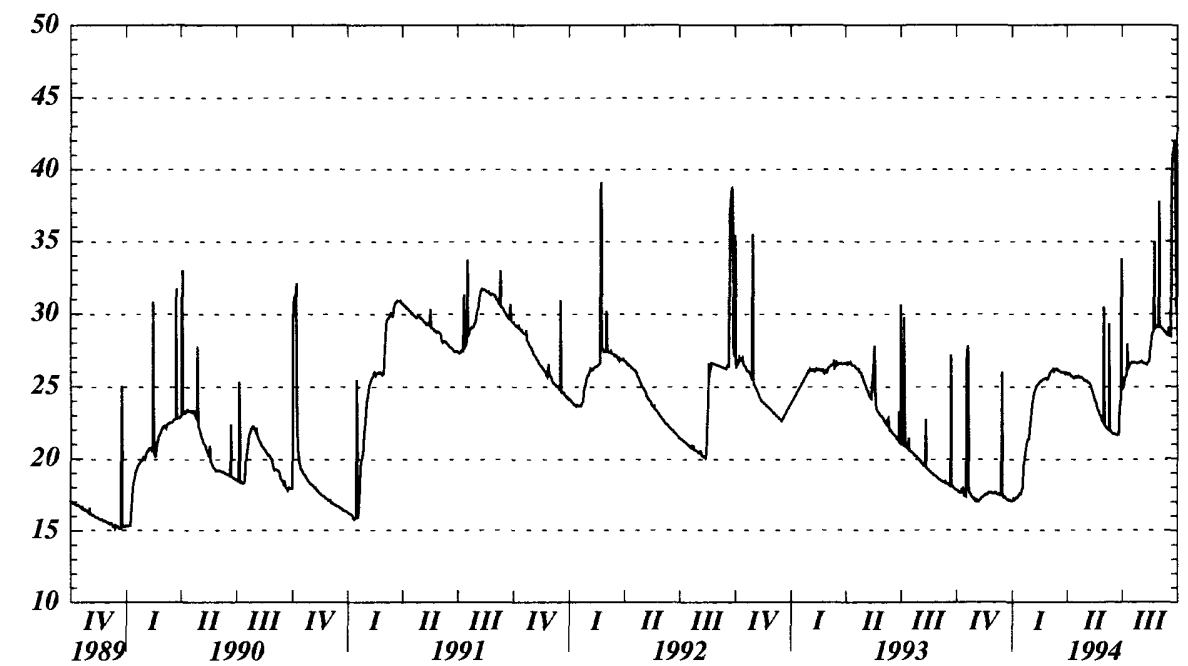

势
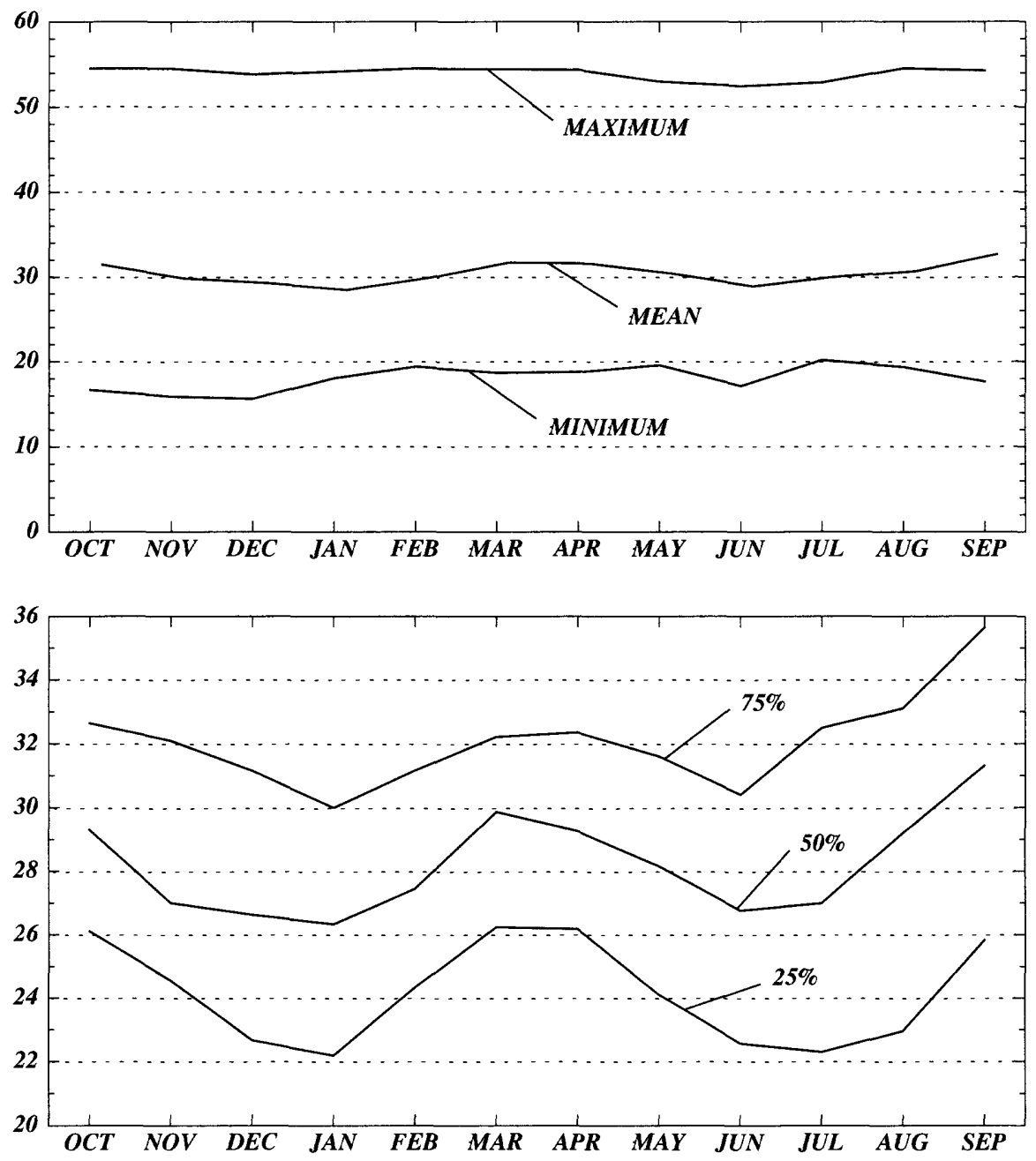


\section{Taylor County}

WELL NUMBER.--300447083343085. Aluminum Fab Products. -050701001.

LOCATION.--Lat 3004'47”, long 83³4'30', Hydrologic Unit Code 03110102.

AQUIFER.--Upper Floridan aquifer of the Tertiary system, Geologic Unit Code 120FLRD.

WELL CHARACTERISTICS.--Casing diameter 10 in., Casing depth $179 \mathrm{ft}$., Total depth $259 \mathrm{ft}$. INSTRUMENTATION.--Elevation of the Measuring Point $46.81 \mathrm{ft}$., NGVD.

DATUM.--The National Geodetic Vertical Datum of 1929.

PERIOD OF RECORD.--07-01-1975 to 09-30-1994.

EXTREME VALUES.--Maximum observed, 37.78 ft. (03-13-1991); minimum observed, $29.35 \mathrm{ft}$. (05-26-1989).

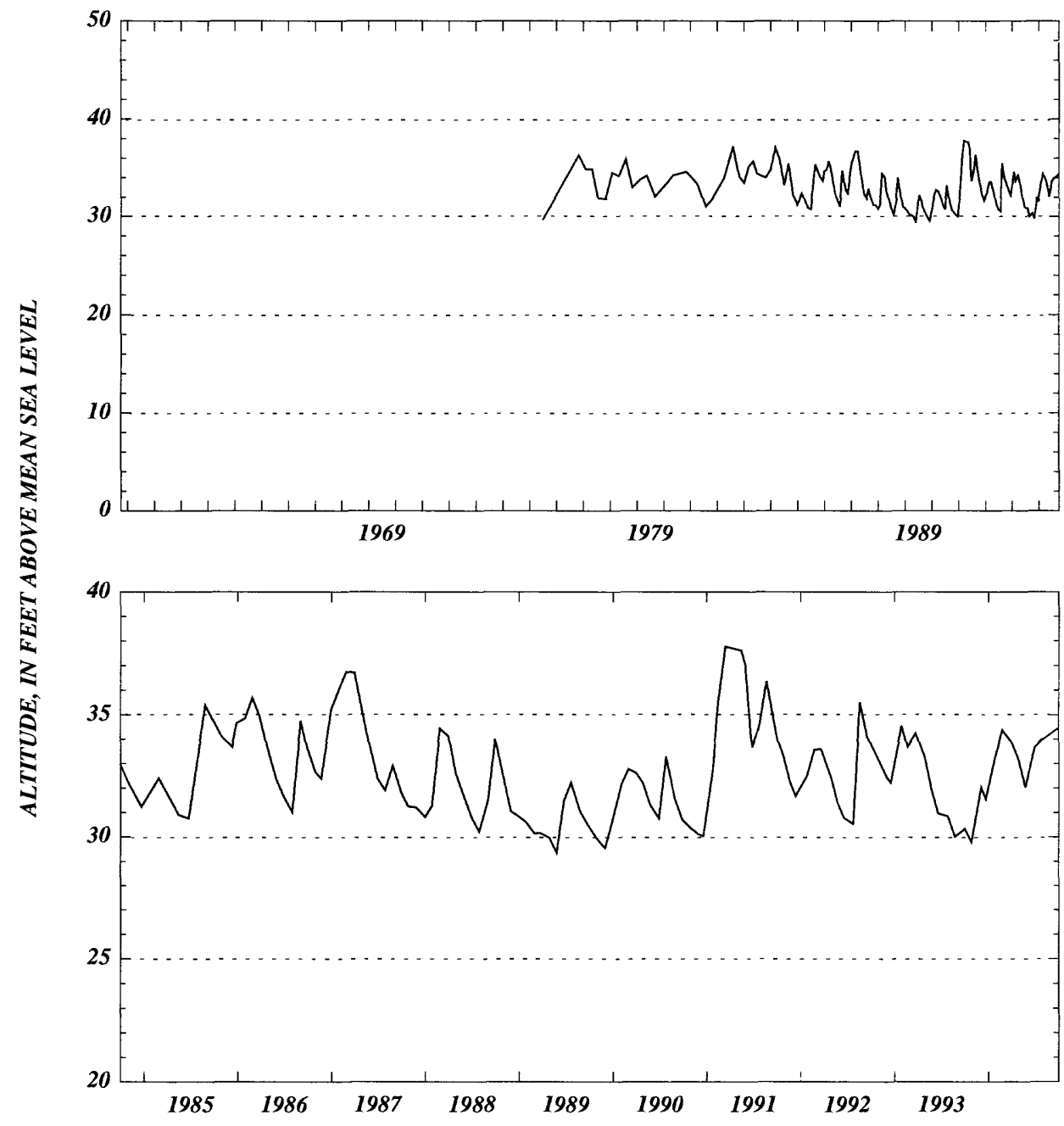



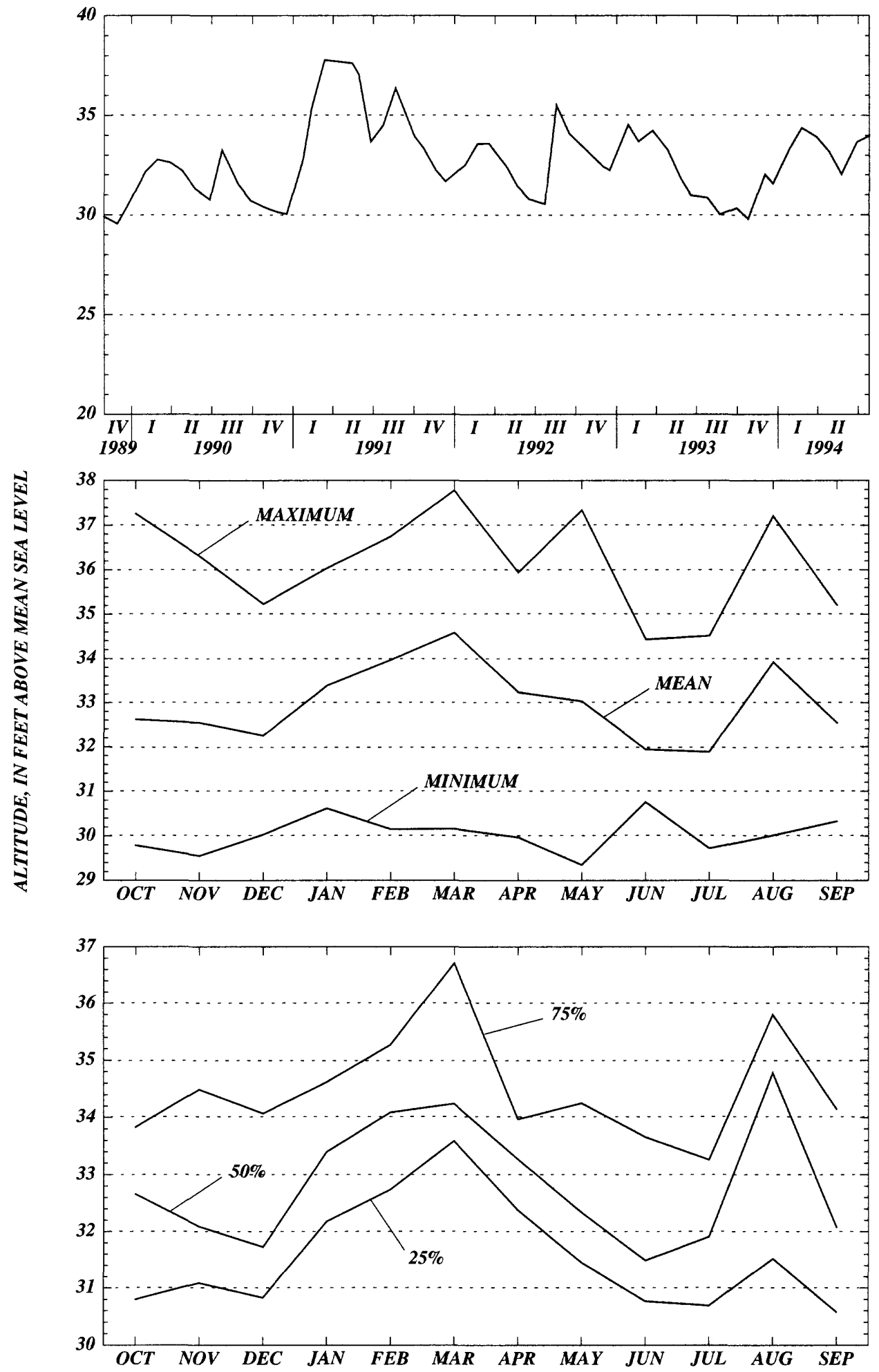
WELL NUMBER.--300530083342085. DOF - Perry HQ. -040736005.

LOCATION.--Lat $30^{\circ} 05^{\prime} 30^{\prime \prime}$, long 83³4'20”, Hydrologic Unit Code 03110102.

AQUIFER.--Upper Floridan aquifer of the Tertiary system, Geologic Unit Code 120FLRD.

WELL CHARACTERISTICS.--Casing diameter 3 in., Casing depth $24 \mathrm{ft}$,, Total depth $34 \mathrm{ft}$.

INSTRUMENTATION.--Elevation of Measuring Point $47.99 \mathrm{ft}$., NGVD.

DATUM.--The National Geodetic Vertical Datum of 1929.

PERIOD OF RECORD.--07-22-1987 to 09-30-1994.

EXTREME VALUES.--Maximum observed, $38.65 \mathrm{ft}$. (03-13-1990); minimum observed, $29.74 \mathrm{ft}$. (05-10-1989).

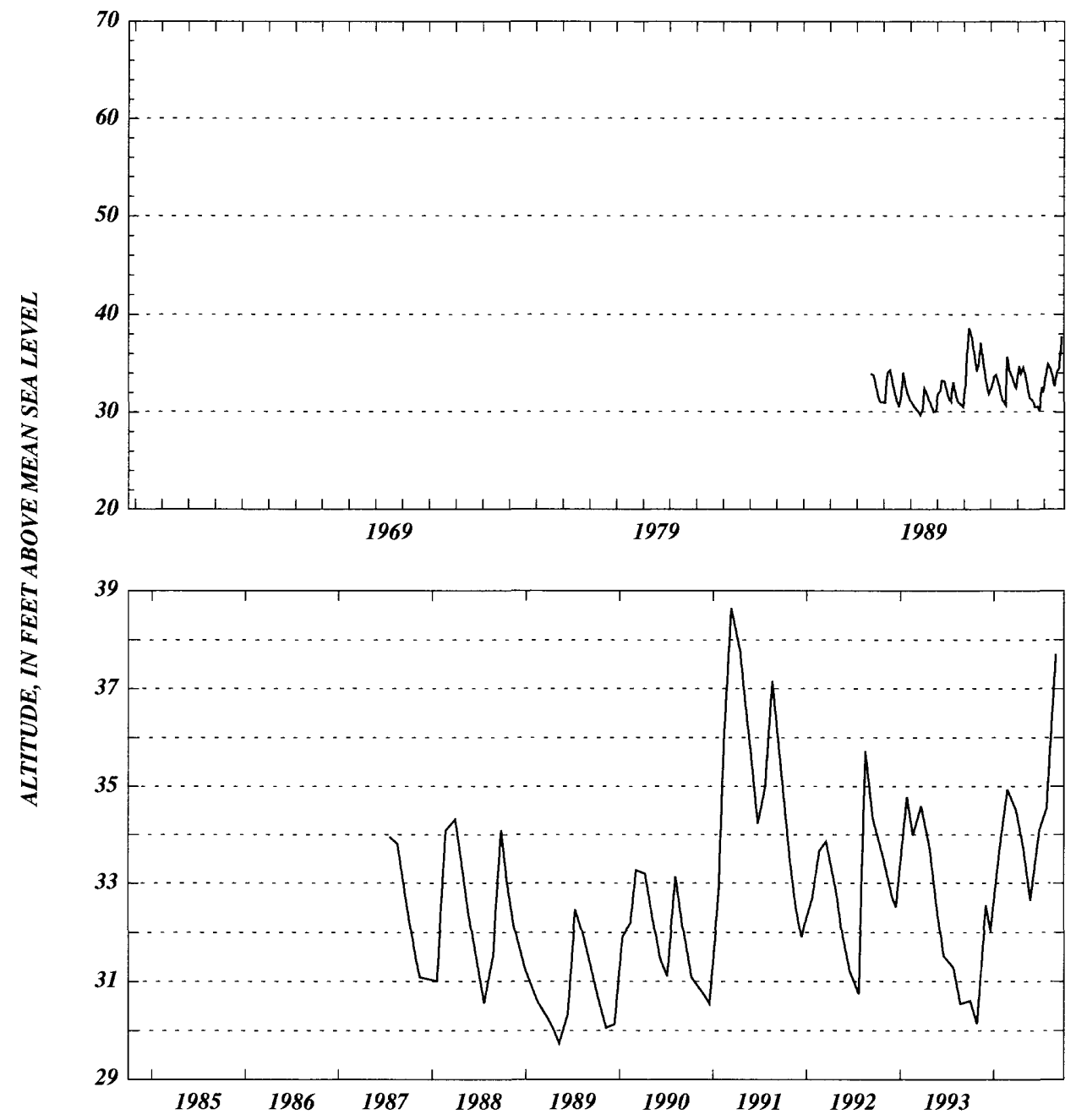



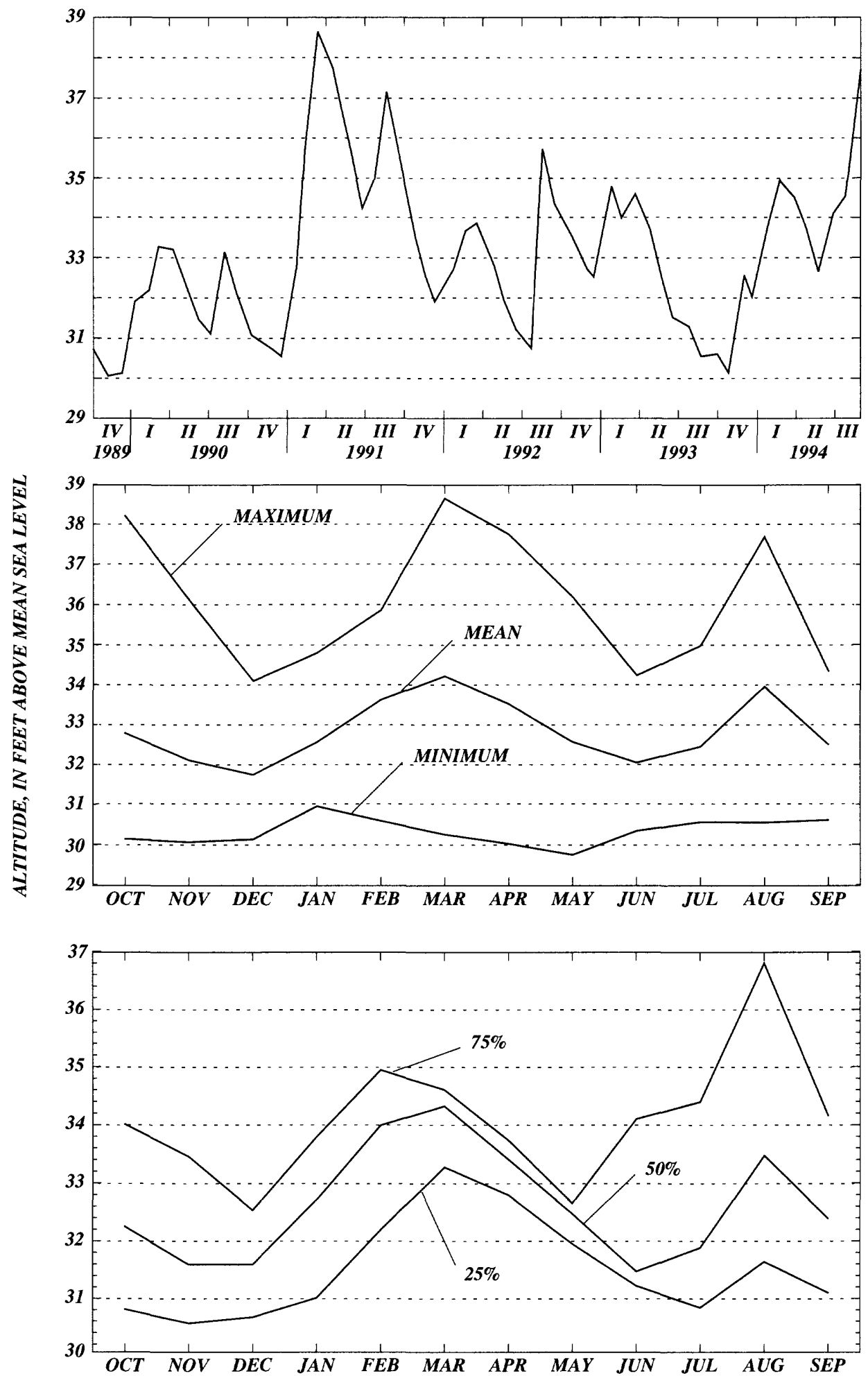
WELL NUMBER.--300531083342185. DOF - Perry HQ. -040736006.

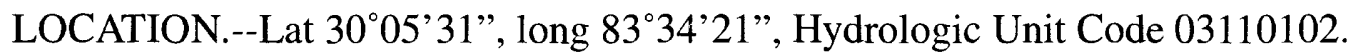

AQUIFER.--Surficial aquifer, Geologic Unit Code 110NRSD.

WELL CHARACTERISTICS.--Casing diameter 3 in., Casing depth $7 \mathrm{ft}$., Total depth $17 \mathrm{ft}$.

INSTRUMENTATION.--Elevation of Measuring Point $47.98 \mathrm{ft}$., NGVD.

DATUM.--The National Geodetic Vertical Datum of 1929.

PERIOD OF RECORD.--04-14-1987 to 09-30-1994.

EXTREME VALUES.--Maximum observed, $39.13 \mathrm{ft}$. (04-14-1987); minimum observed, $29.88 \mathrm{ft}$. (11-09-1989).

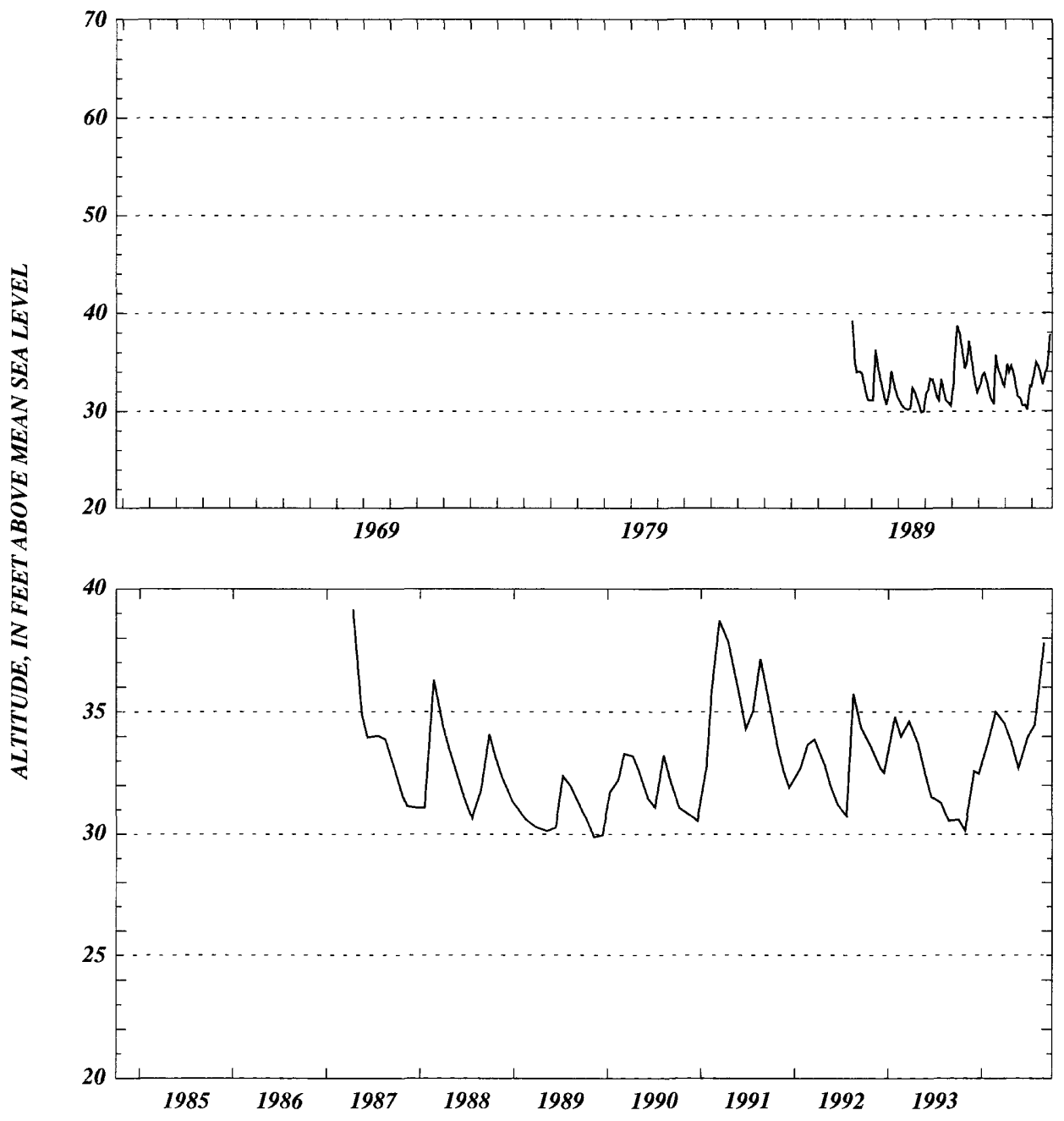



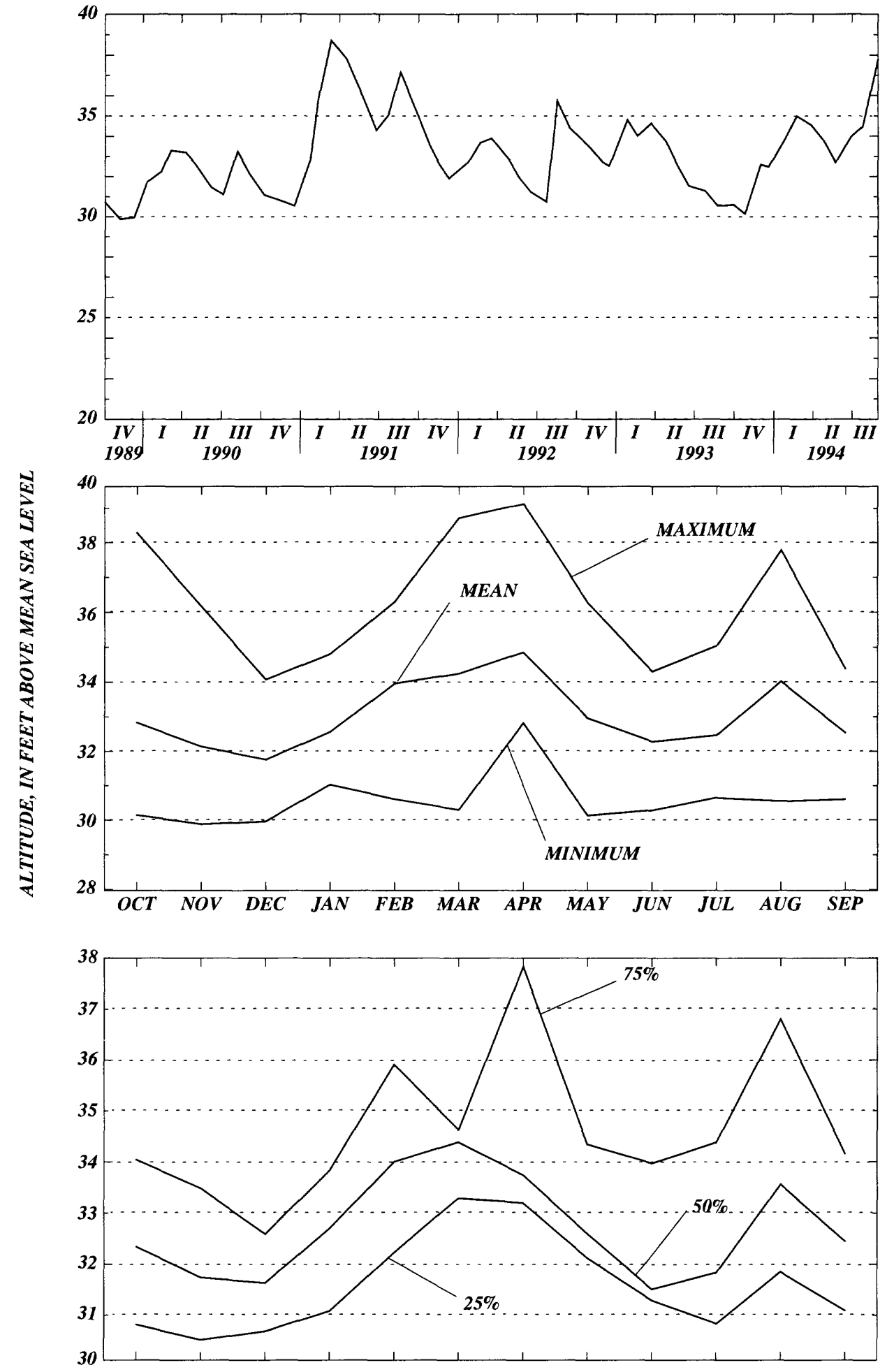


\section{Taylor County}

WELL NUMBER.--300851083580885. Floyd Sumner. -040407001.

LOCATION.--Lat 3008'51", long 8358'08', Hydrologic Unit Code 03110102.

AQUIFER.--Upper Floridan aquifer of the Tertiary System, Geodogic Unit Code 120FLRD.

WELL CHARACTERISTICS.--Casing diameter 2 in., Casing depth unknown, Total depth $12 \mathrm{ft}$.

INSTRUMENTATION.--Elevation of Measuring Point $6.00 \mathrm{ft}$. NGVD

DATUM.--The National Geodetic Vertical Datum of 1929.

PERIOD OF RECORD.--02-04-1977 to 09-30-1994. *

EXTREME VALUES.--Maximum observed, $5.45 \mathrm{ft}$. (03-06-1991); minimum observed, $0.04 \mathrm{ft}$. (10-31-1989).

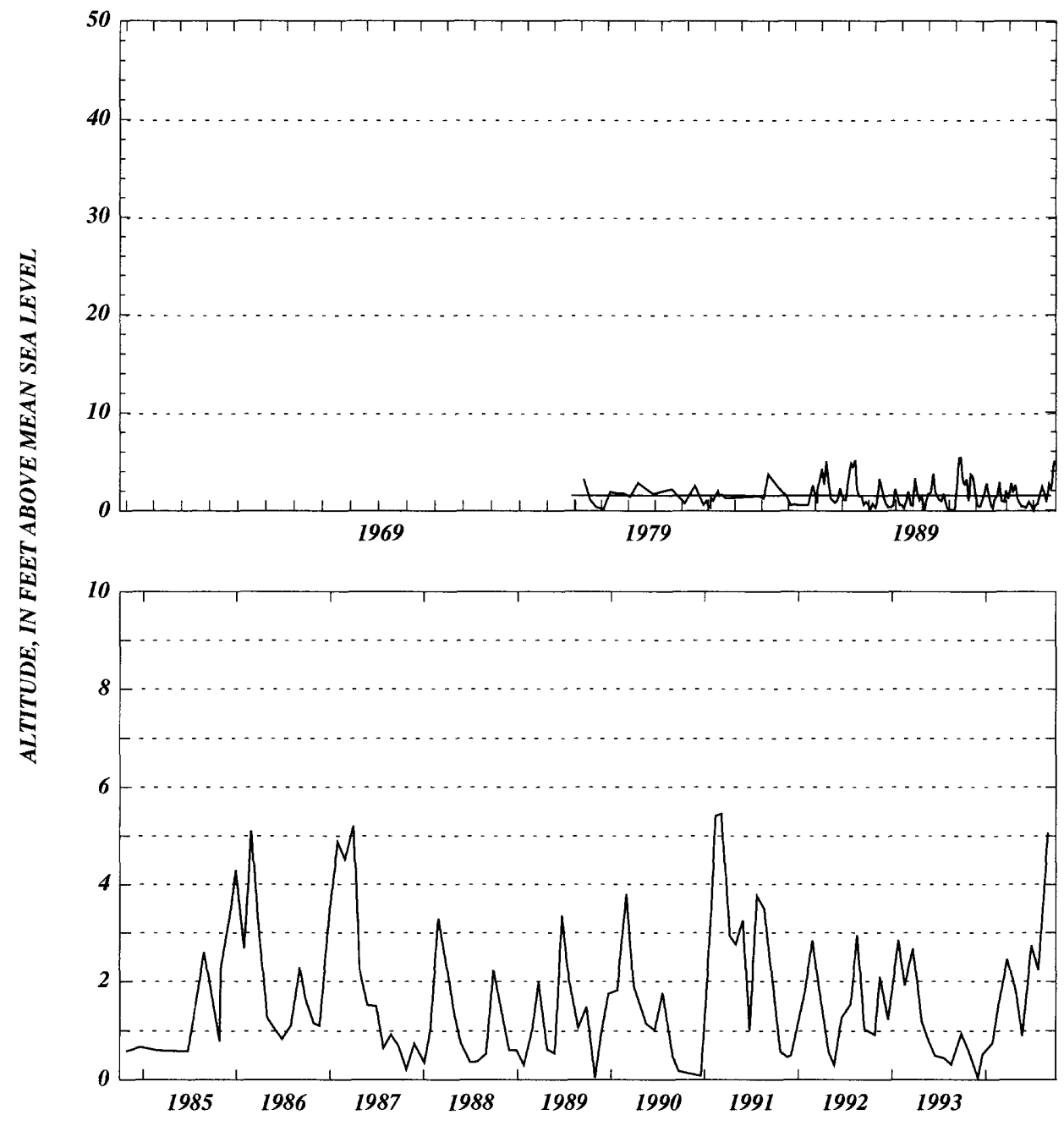



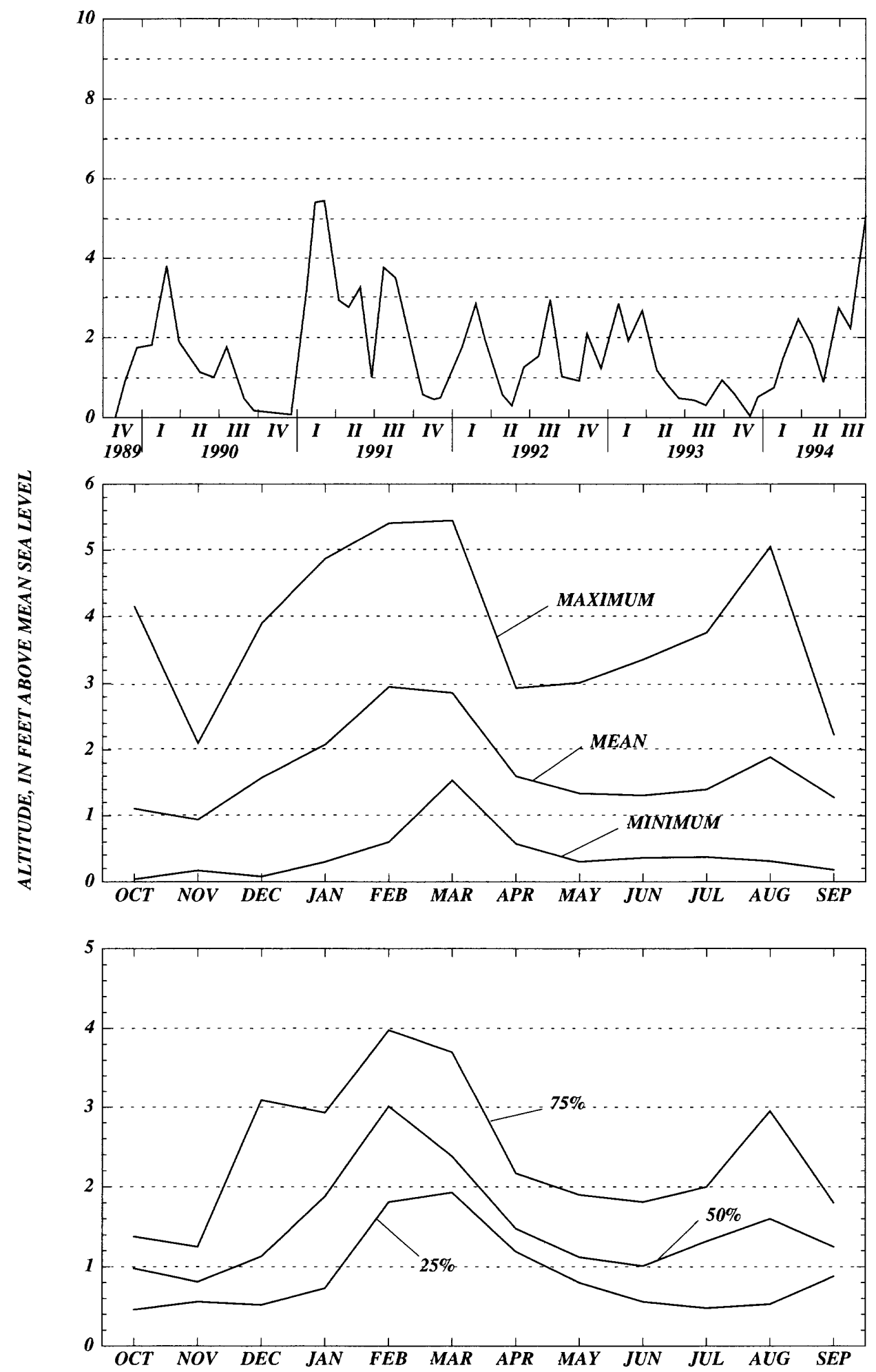


\section{Taylor County}

WELL NUMBER.--301111083315885. Procter and Gamble. -030833002.

LOCATION.--Lat 30¹1'11", long 8331'58”, Hydrologic Unit Code 03110102.

AQUIFER.--Surficial aquifer, Geologic Unit Code 110NRSD.

WELL CHARACTERISTICS.--Casing diameter 3 in., Casing depth $3 \mathrm{ft}$., Total depth $13 \mathrm{ft}$.

INSTRUMENTATION.--Elevation of Measuring Point $92.99 \mathrm{ft}$., NGVD.

DATUM.--The National Geodetic Vertical Datum of 1929.

PERIOD OF RECORD.--04-14-1987 to 09-30-1994.

EXTREME VALUES.--Maximum observed, $89.92 \mathrm{ft}$ (02-23-1988); minimum observed, $84.11 \mathrm{ft}$. (10-07-1993).

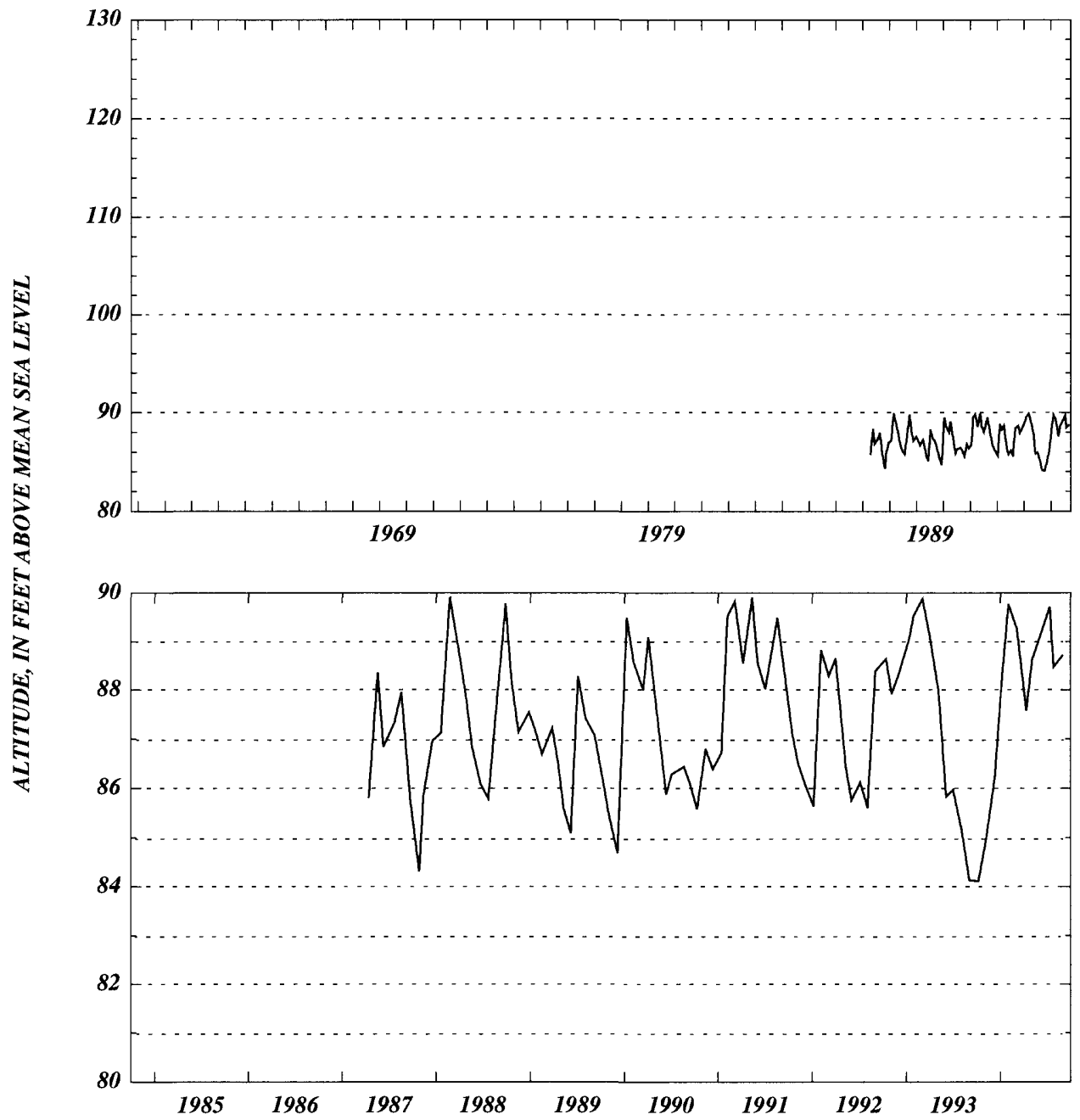




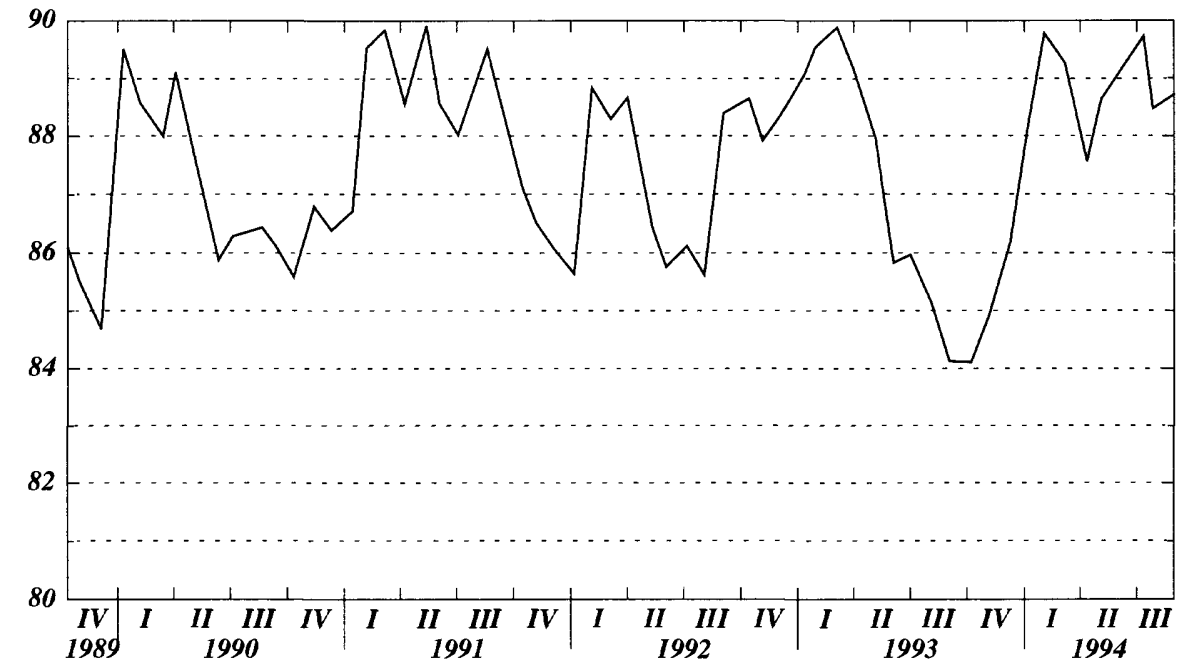

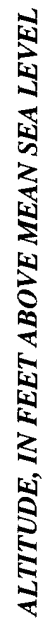
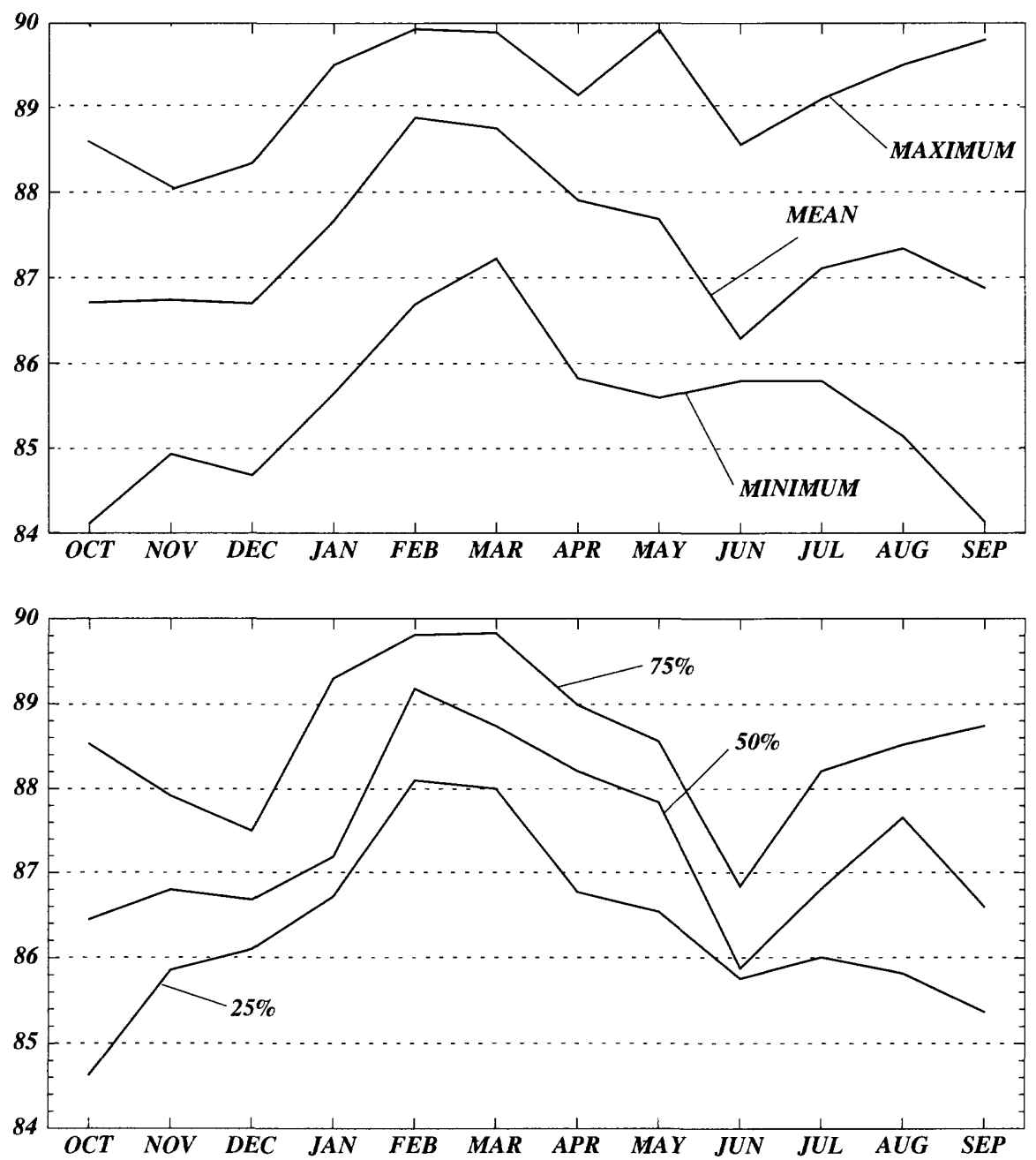


\section{Taylor County}

WELL NUMBER.--301111083315985. Procter and Gamble. -030833001.

LOCATION.--Lat 30¹1'11", long 83³1'59", Hydrologic Unit Code 03110102.

AQUIFER.--Upper Floridan aquifer of the Tertiary system, Geologic Unit Code 120FLRD.

WELL CHARACTERISTICS.--Casing diameter 3 in., Casing depth $48 \mathrm{ft}$., Total depth $68 \mathrm{ft}$.

INSTRUMENTATION.--Elevation of the Measuring Point $91.97 \mathrm{ft}$., NGVD.

DATUM.--The National Geodetic Vertical Datum of 1929.

PERIOD OF RECORD.--07-23-1987 to 09-30-1994.

EXTREME VALUES.--Maximum observed, 87.34 ft. (03-07-1991); minimum observed, $81.62 \mathrm{ft}$. (10-07-1993).

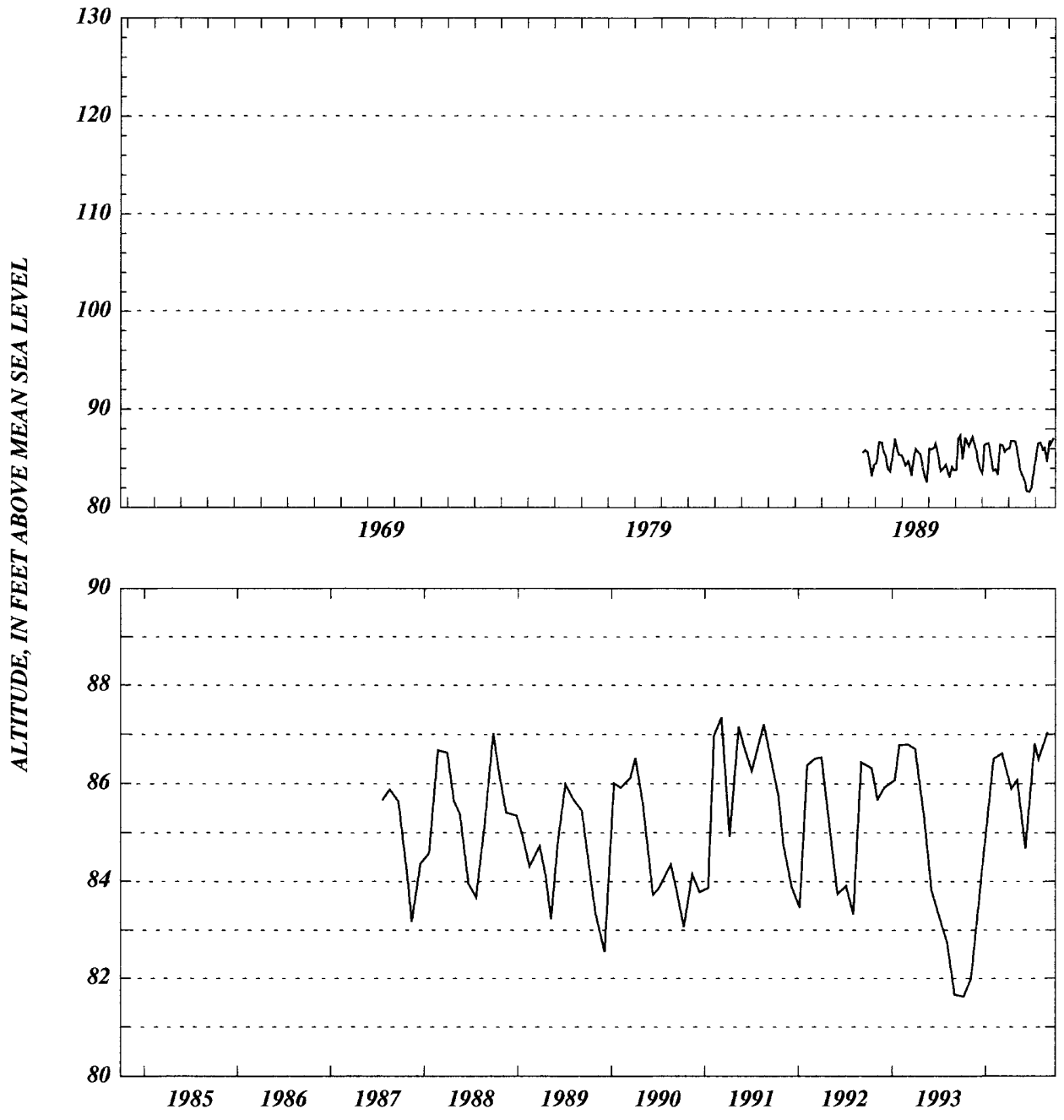



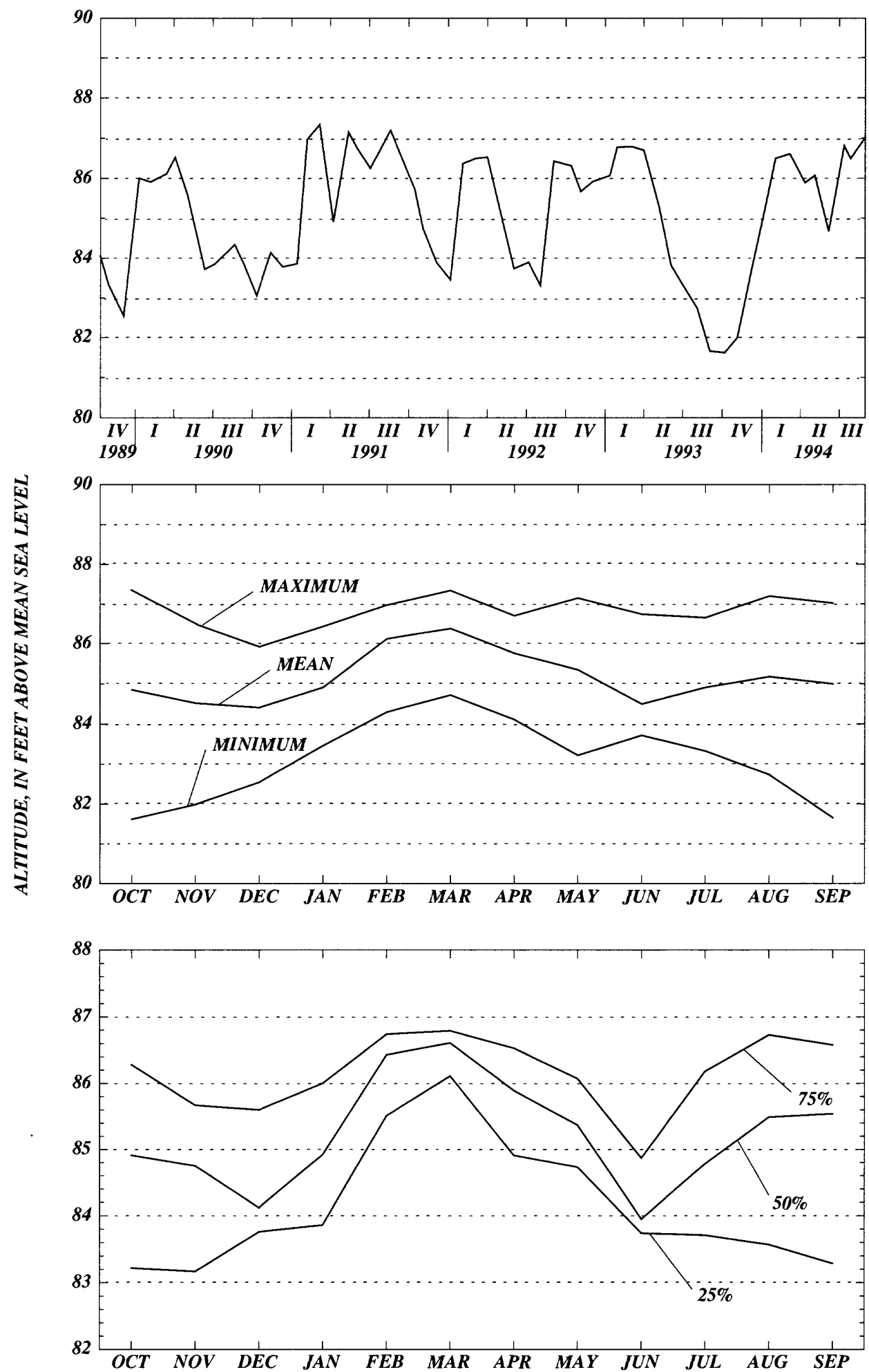
WELL NUMBER.--301145083401285. USGS - Old Gibson Still. -030730001.

LOCATION.--Lat 30¹1'45", long 8340'12”, Hydrologic Unit Code 03110102.

AQUIFER.--Upper Floridan aquifer of the Tertiary system, Geologic Unit Code 120FLRD.

WELL CHARACTERISTICS.--Casing diameter 6 in., Casing depth unknown, Total depth $142 \mathrm{ft}$.

INSTRUMENTATION.--Miscellaneous from 11-01-1976 to 06-01-1982; then recorder from 06-02-1982 to 08-03-1982; no record from 08-04-1982 to 09-10-1984; recorder from 09-11-1984 to 09-30-1994; elevation of Measuring Point, $48.40 \mathrm{ft}$, NGVD.

DATUM.--The National Geodetic Vertical Datum of 1929.

PERIOD OF RECORD.--11-01-1976 to 09-30-1994.

EXTREME VALUES.--Maximum, 45.19 ft. (03-03-1991); minimum, 35.10 ft. (10-31-1993).

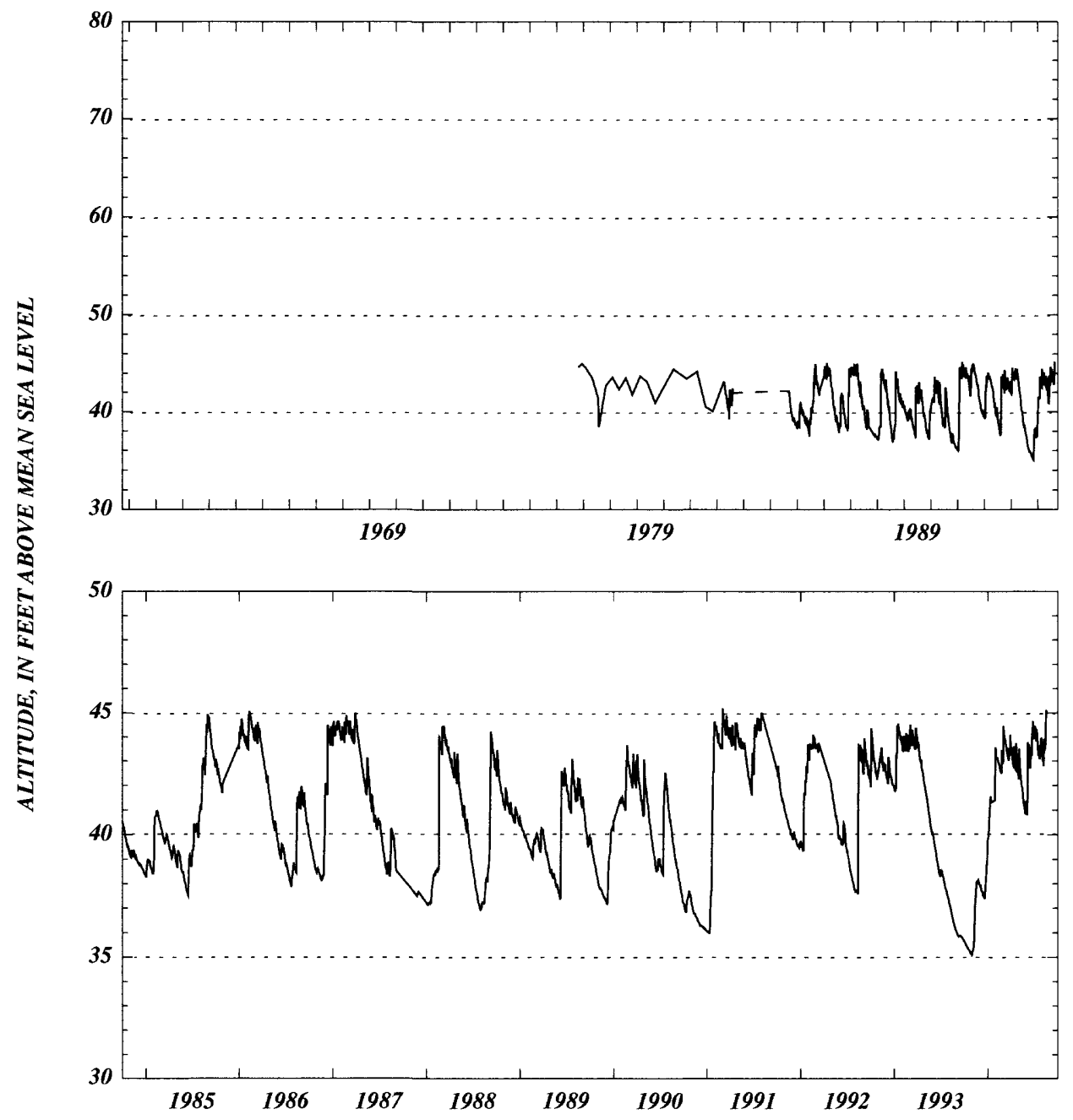



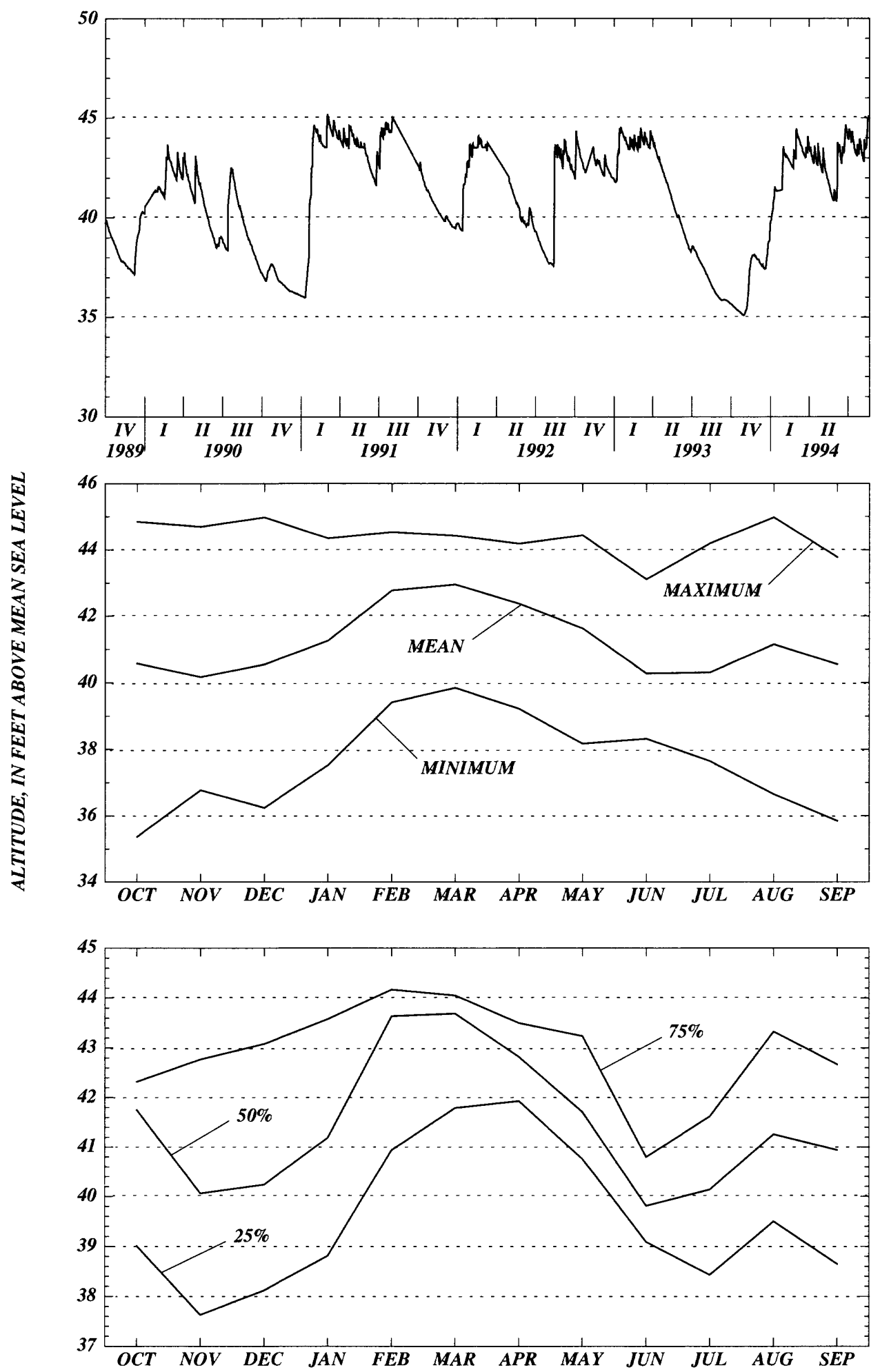


\section{Taylor County}

WELL NUMBER.--301555083393985. Procter and Gamble. -020731002.

LOCATION.--Lat 30¹5'55”, long 8339'39”, Hydrologic Unit Code 03110102.

AQUIFER.Upper Floridan aquifer of the Tertiary system, Geologic Unit Code 120FLRD.

WELL CHARACTERISTICS.--Casing diameter 3 in., Casing depth $37 \mathrm{ft}$., Total depth $57 \mathrm{ft}$.

INSTRUMENTATION.--Elevation of Measuring Point $68.98 \mathrm{ft} .$, NGVD.

DATUM.--The National Geodetic Datum of 1929.

PERIOD OF RECORD.--07-23-1987 to 09-30-1994.

EXTREME VALUES.--Maximum observed, 64.44 ft. (03-06-1991); minimum observed, $58.36 \mathrm{ft}$. (10-06-1993).

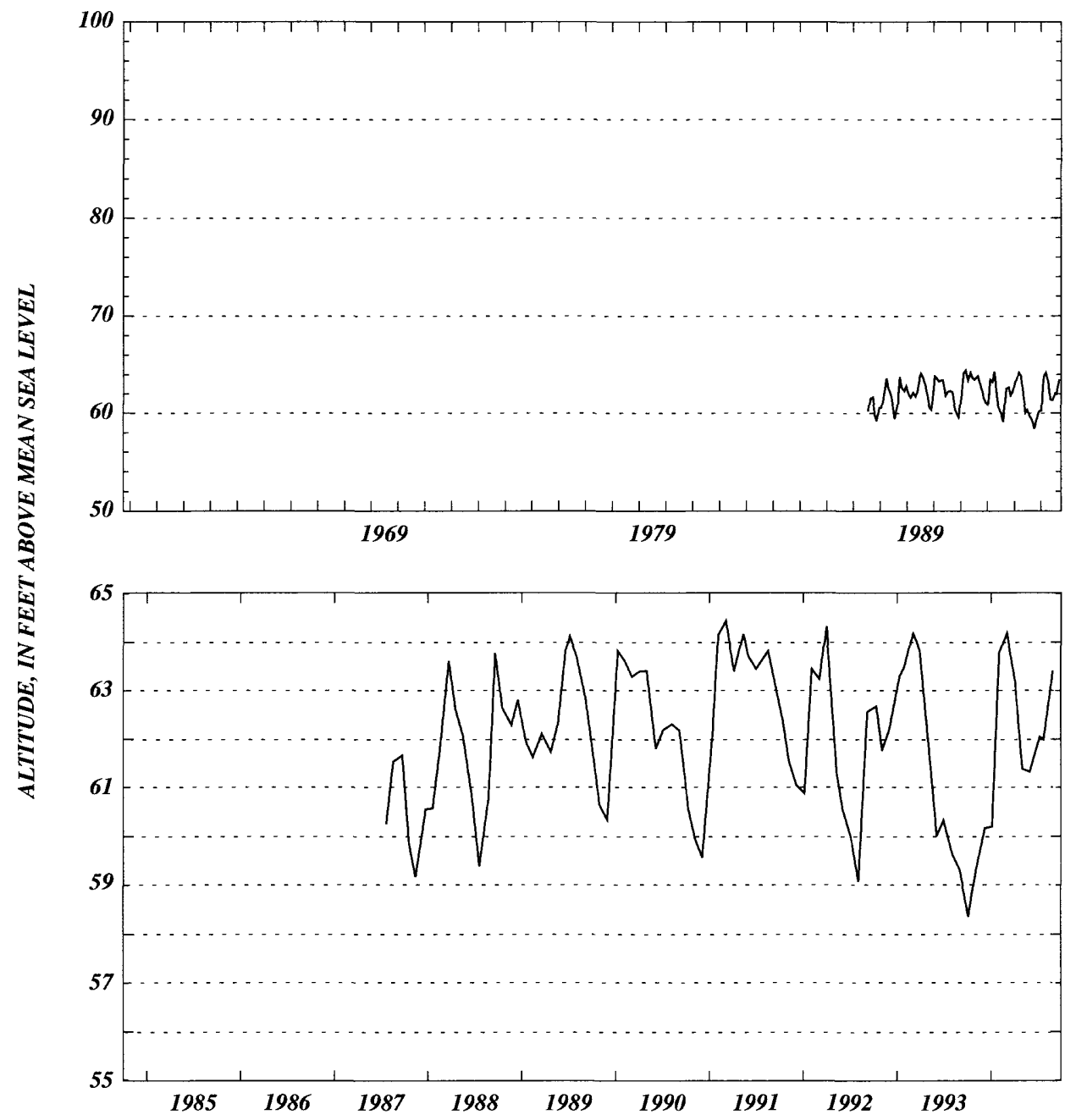



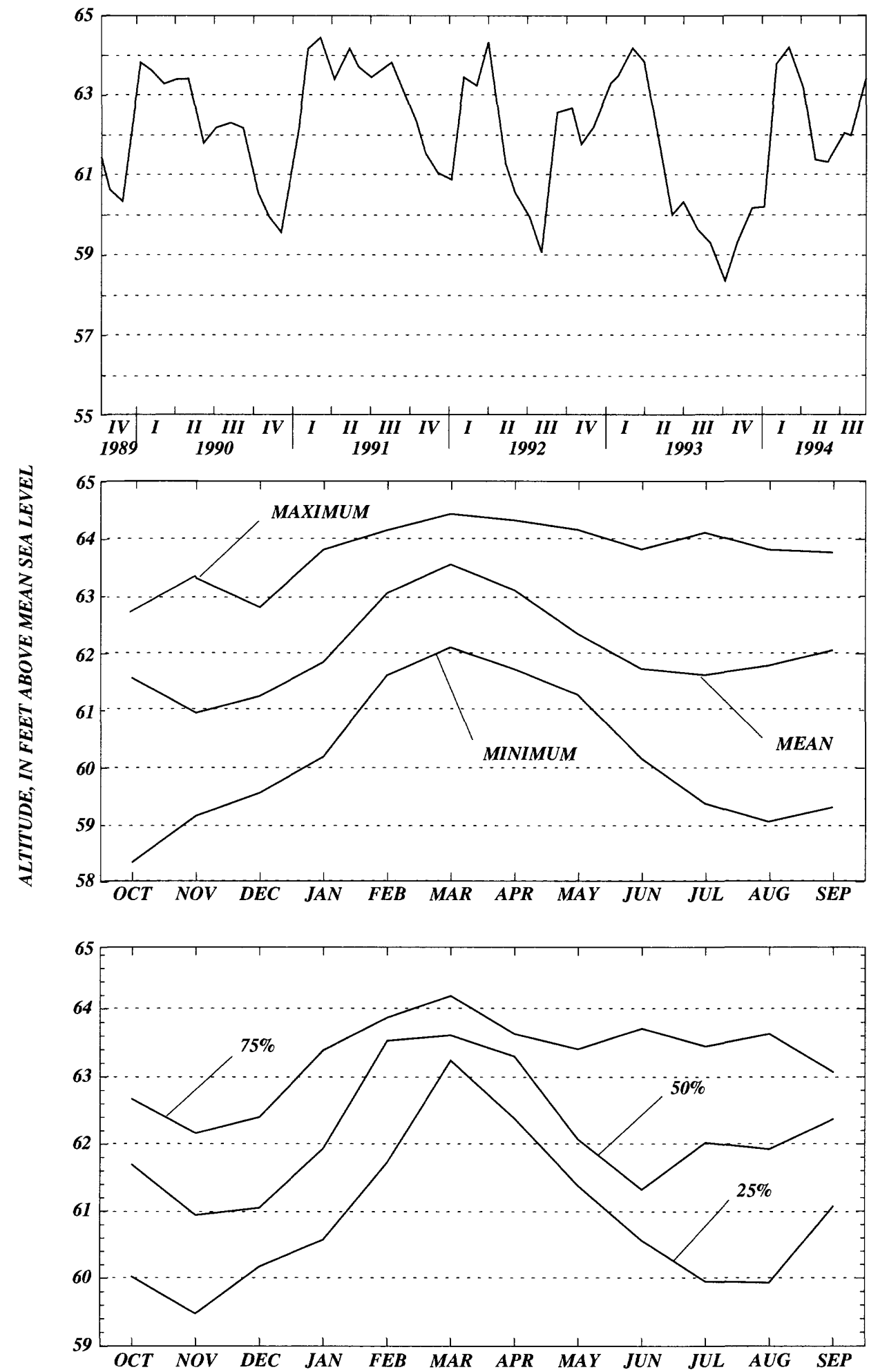


\section{Taylor County}

WELL NUMBER.--301555083394185. Procter and Gamble. -020731003.

LOCATION.--Lat 30¹5’55”, long 83³9'41”, Hydrologic Unit Code 03110102.

AQUIFER.--Surficial aquifer, Geologic Unit Code 110NRSD.

WELL CHARACTERISTICS.--Casing diameter 3 in., Casing depth $1 \mathrm{ft}$., Total depth $11 \mathrm{ft}$.

INSTRUMENTATION.--Elevation of Measuring Point $70.97 \mathrm{ft}$., NGVD.

DATUM.--The National Geodetic Vertical Datum of 1929.

PERIOD OF RECORD.--04-15-1987 to 09-30-1994.

EXTREME VALUES.--Maximum observed, 66.58 ft. (03-06-1991); minimum observed, $59.78 \mathrm{ft}$. (11-13-1987).

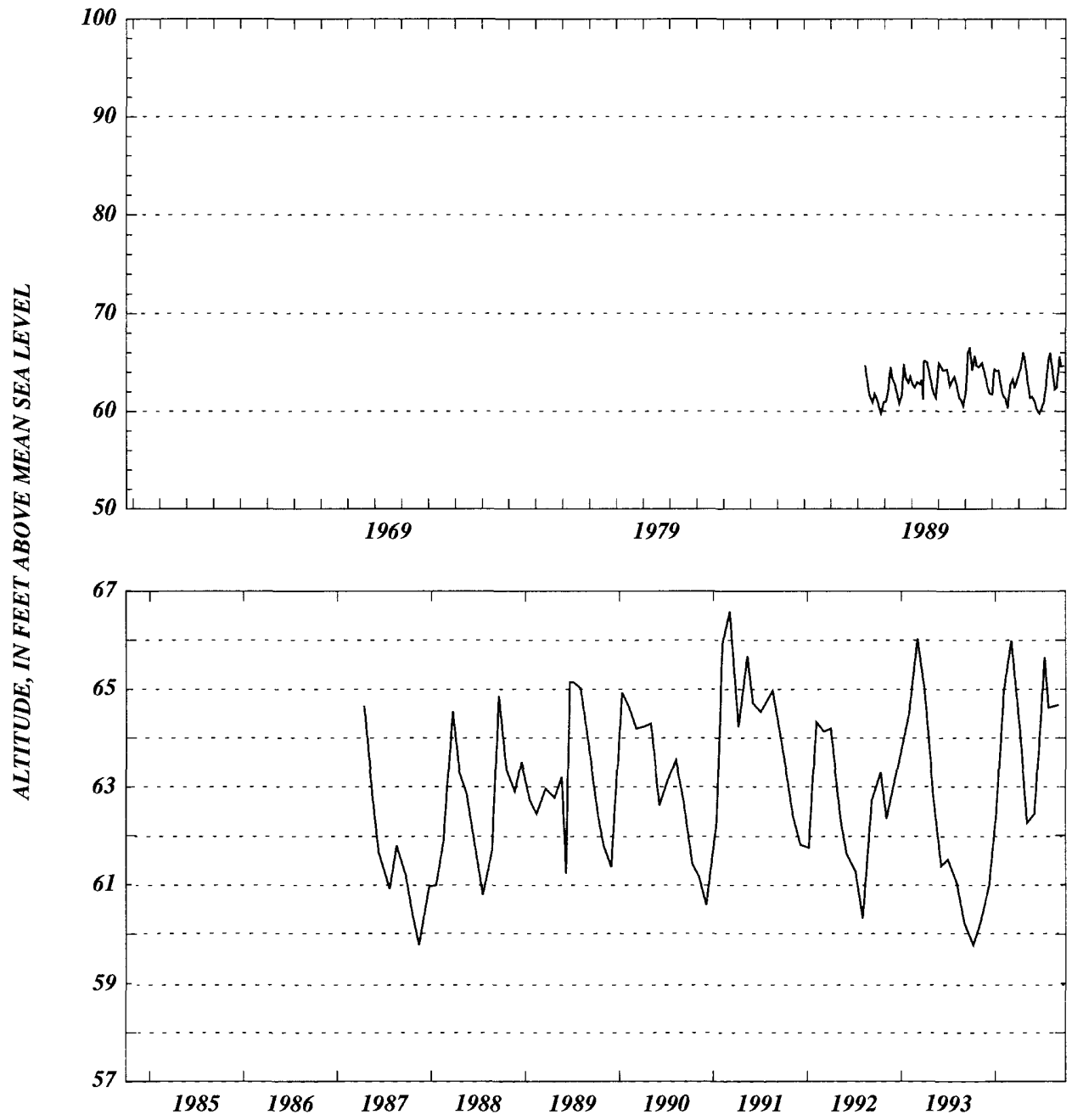



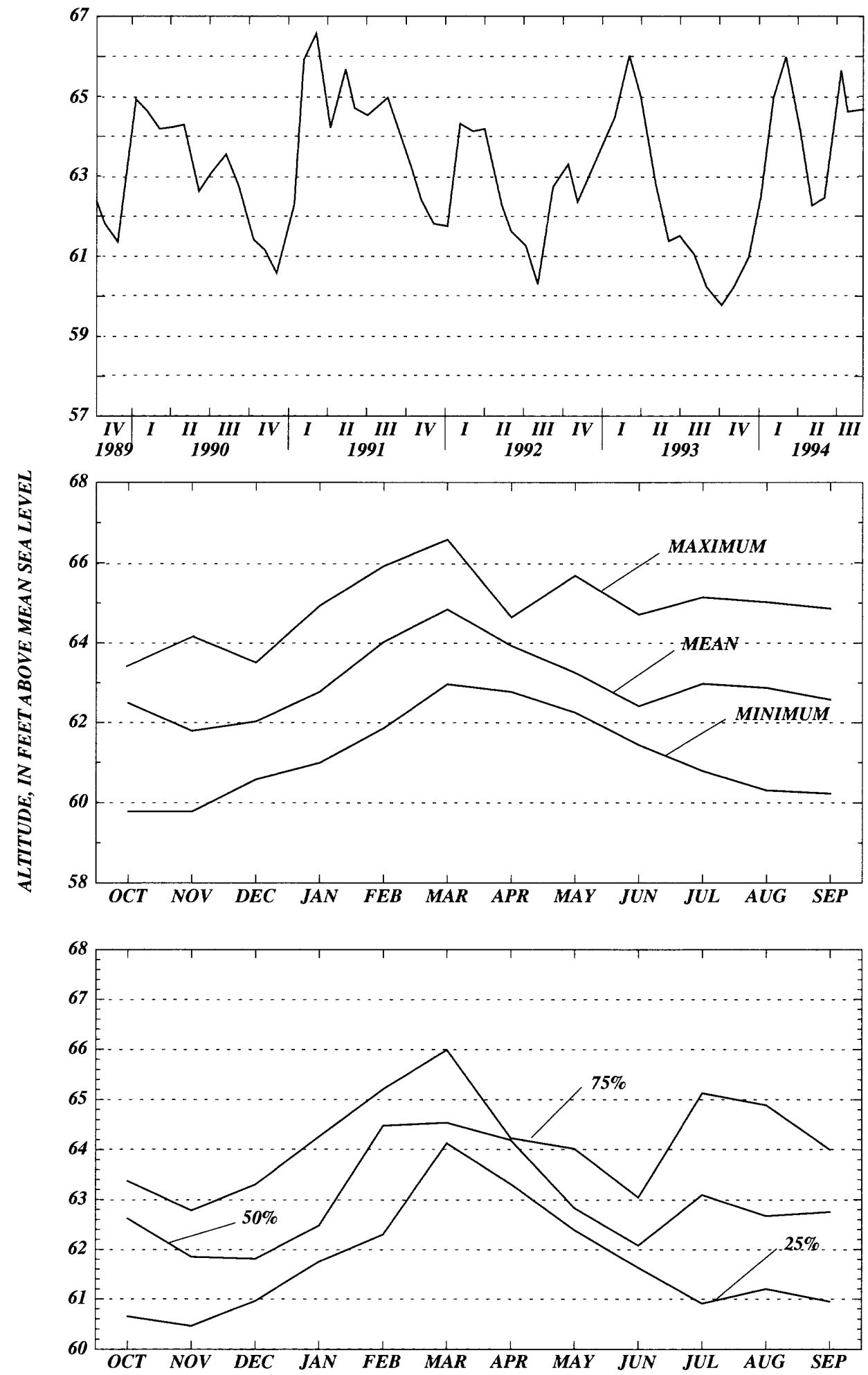


\section{Taylor County}

WELL NUMBER.--301721083321085. Procter and Gamble. -020828002.

LOCATION.--Lat 30¹7'21'”, long 83³2'10”, Hydrologic Unit Code 03110102

AQUIFER.--Surficial aquifer, Geologic Unit Code 110NRSD.

WELL CHARACTERISTICS.--Casing diameter 3 in., Casing depth $4 \mathrm{ft}$., Total depth $14 \mathrm{ft}$.

INSTRUMENTATION.--Miscellaneous from 04-30-1987 to 09-18-1988; then recorder, set to elevation of the Measuring Point, $96.29 \mathrm{ft}$., NGVD.

DATUM.--The National Geodetic Vertical Datum of 1929.

PERIOD OF RECORD.--04-30-1987 to 09-30-1994. *

EXTREME VALUES.--Maximum, 92.43 ft. (03-02-1991); minimum, 86.25 ft. (10-29-1993).

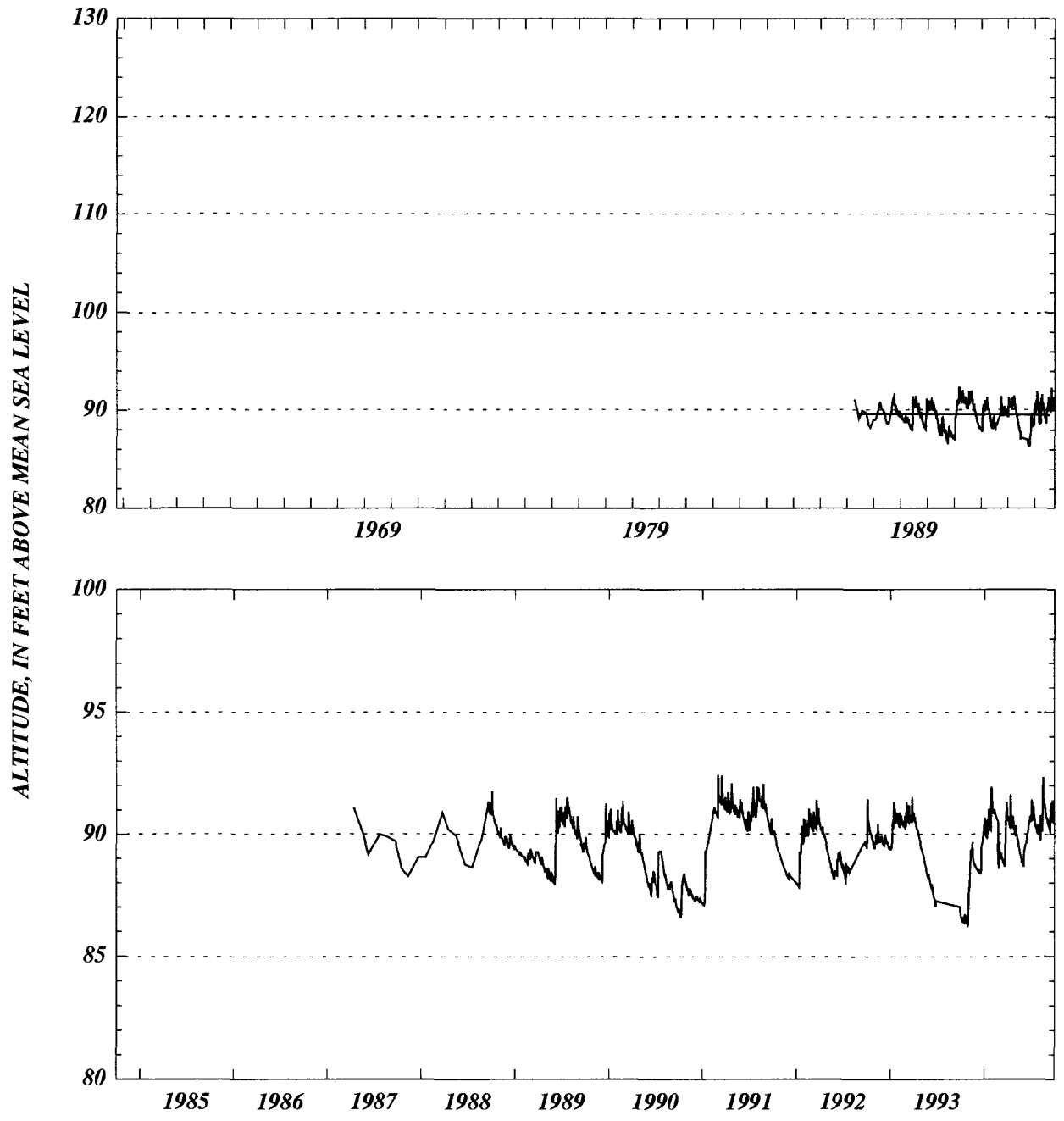



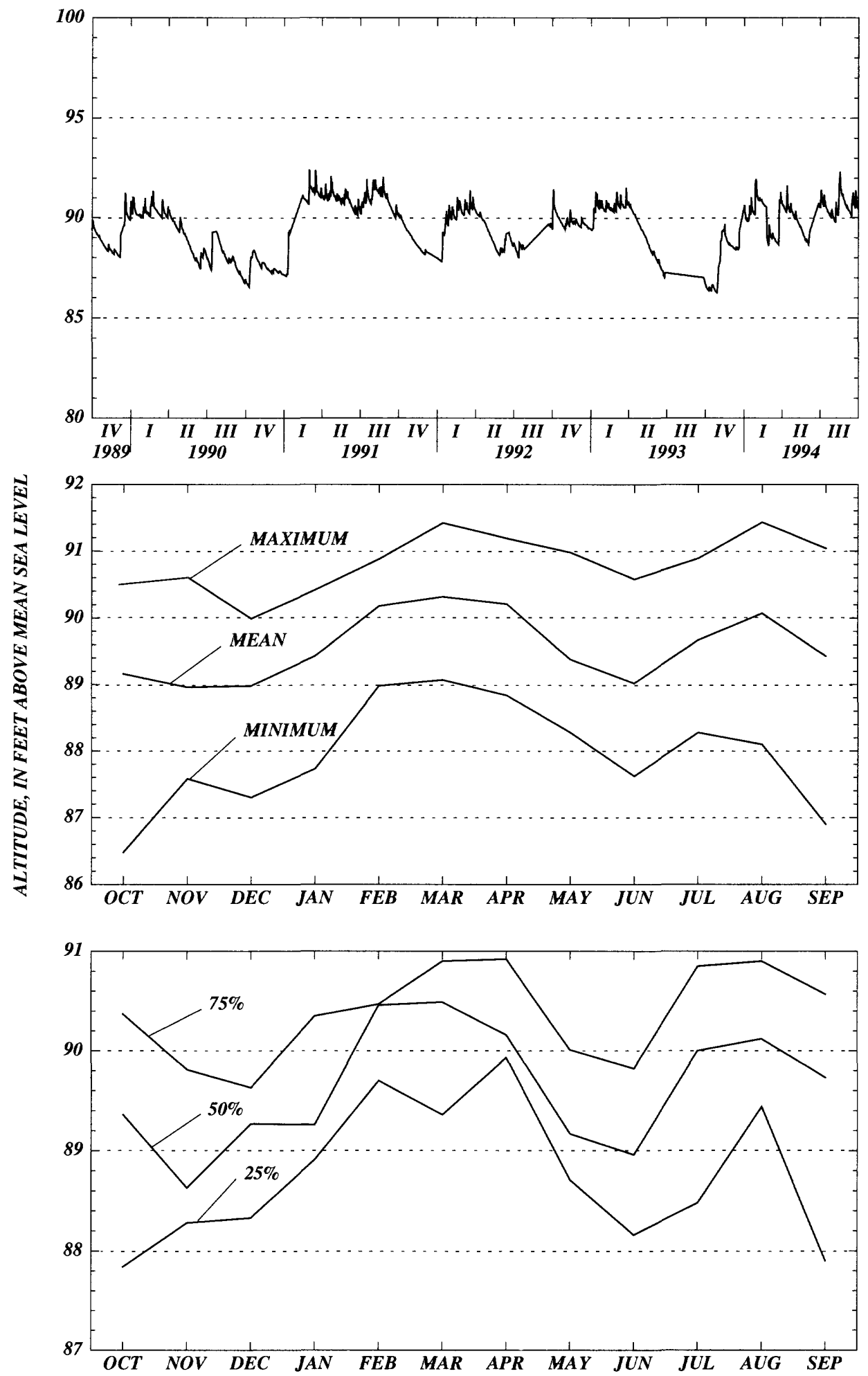


\section{Taylor County}

WELL NUMBER.--301722083321085. Procter and Gamble. -020828001.

LOCATION.--Lat 30¹7'22”, long 83³2'10’, Hydrologic Unit Code 03110102.

AQUIFER.--Upper Floridan aquifer of the Tertiary system, Geologic Unit Code 120FLRD.

WELL CHARACTERISTICS.--Casing diameter 3 in., Casing depth $49 \mathrm{ft}$., Total depth $69 \mathrm{ft}$.

INSTRUMENTATION.--Miscellaneous from 07-23-1987 to 08-09-1988; then recorder, set to elevation of the Measuring Point, $94.45 \mathrm{ft}$., NGVD.

DATUM.--The National Geodetic Vertical Datum of 1929.

PERIOD OF RECORD.--07-23-1987 to 09-30-1994. *

EXTREME VALUES.--Maximum, 91.54 ft. (08-10-1991); minimum, 82.00 ft. (10-29-1993).

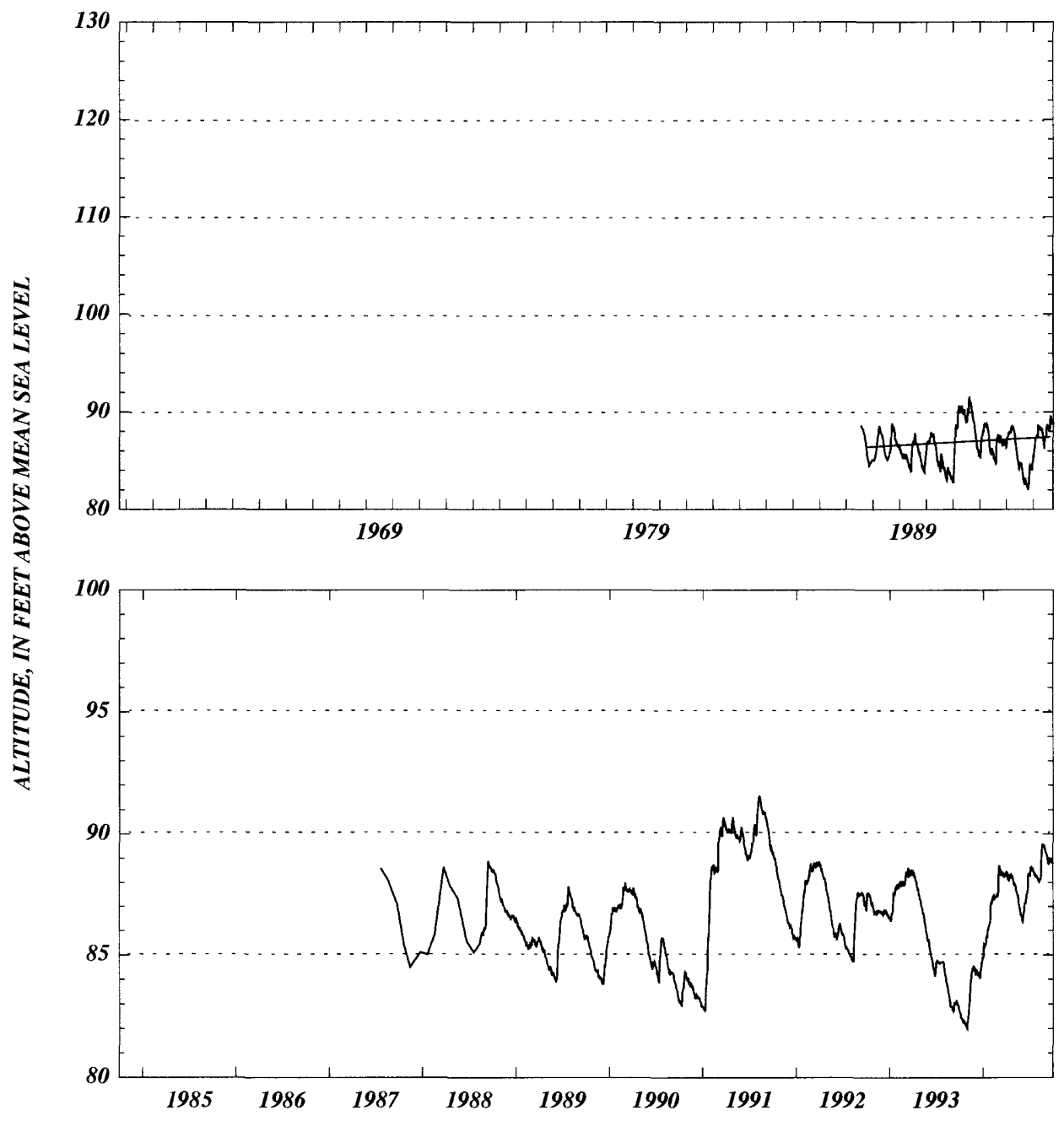



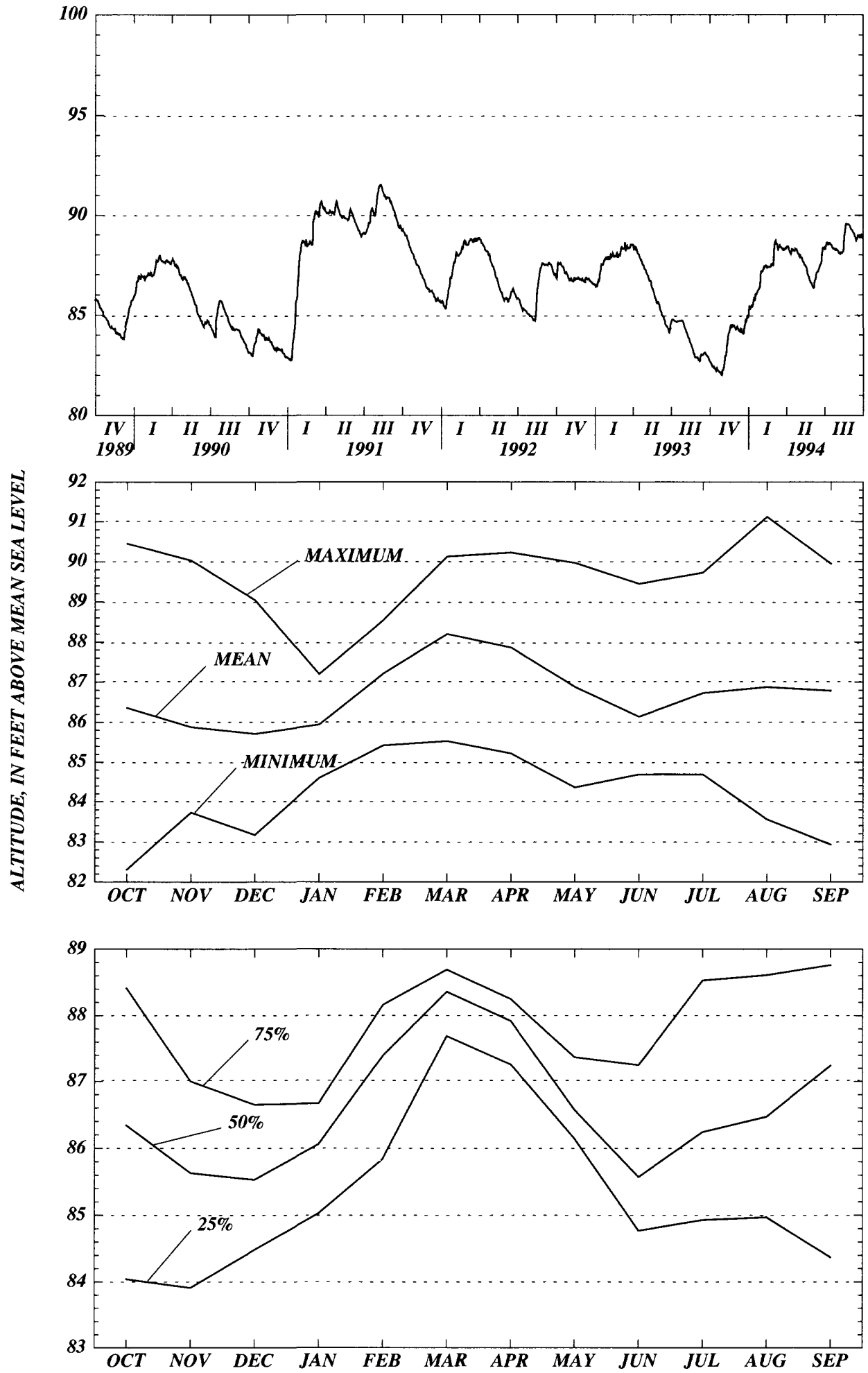


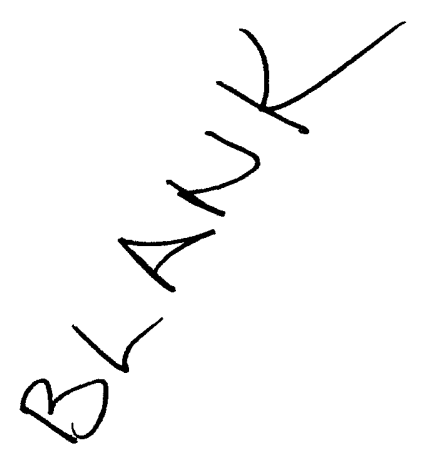

300 Statistical Summaries of Ground-Water Level Data Collected in the Suwannee River Water Management District, 1948-1994 


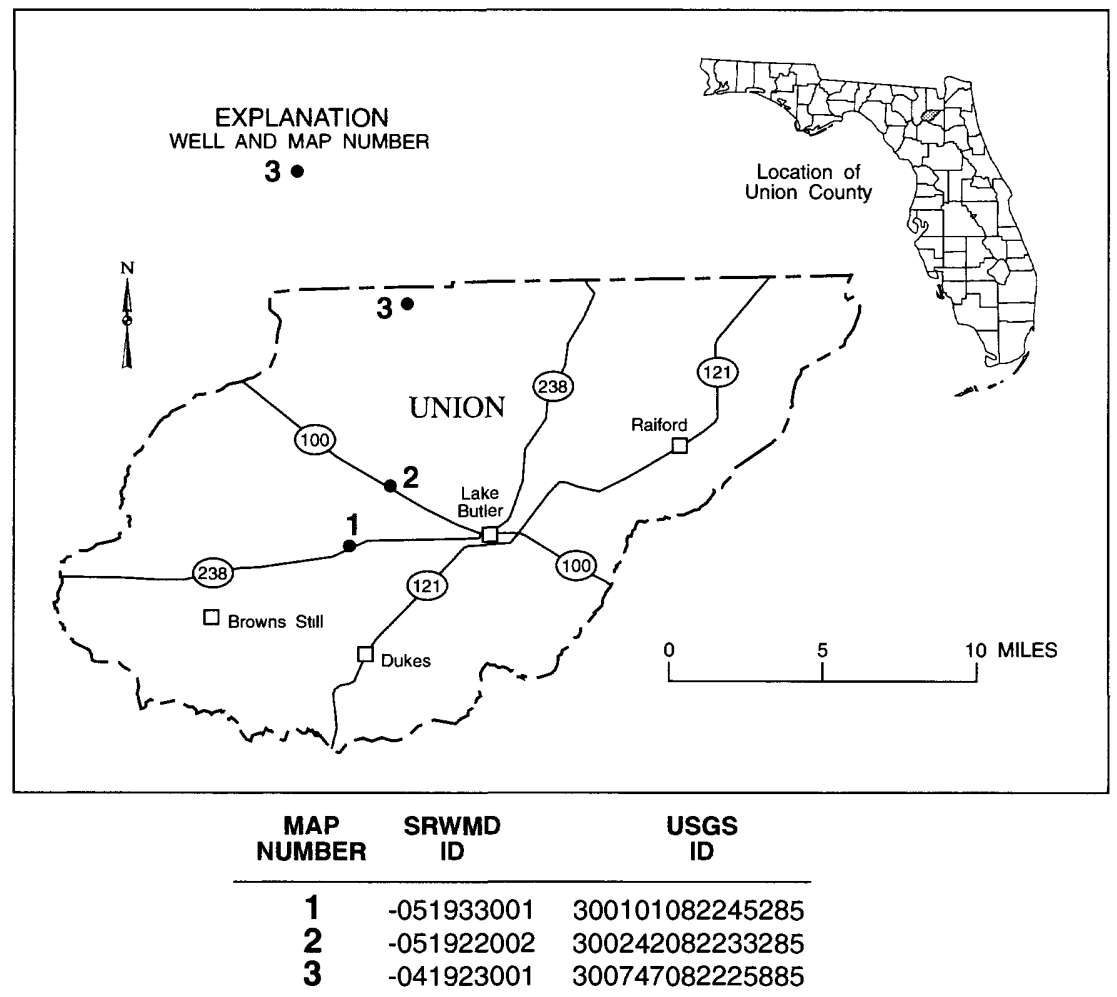

Figure 16. Location of wells in Union County. 


\section{Union County}

WELL NUMBER.--300101082245285. USGS - near Lake Butler. -051933001.

LOCATION.--Lat 3001'01”, long 82²4'52”, Hydrologic Unit Code 03110206.

AQUIFER.--Upper Floridan aquifer of the Tertiary system, Geologic Unit Code 120FLRD.

WELL CHARACTERISTICS.--Casing diameter 4 in., Casing depth $196 \mathrm{ft}$., Total depth $254 \mathrm{ft}$.

INSTRUMENTATION.--Recorder, set to elevation of the Measuring Point, $153.78 \mathrm{ft}$., NGVD.

DATUM.--The National Geodetic Vertical Datum of 1929.

PERIOD OF RECORD.--11-10-1958 to 09-30-1994. *†

EXTREME VALUES.--Maximum, 64.79 ft. (03-01-1964); minimum, 50.76 ft. (11-30-1990).

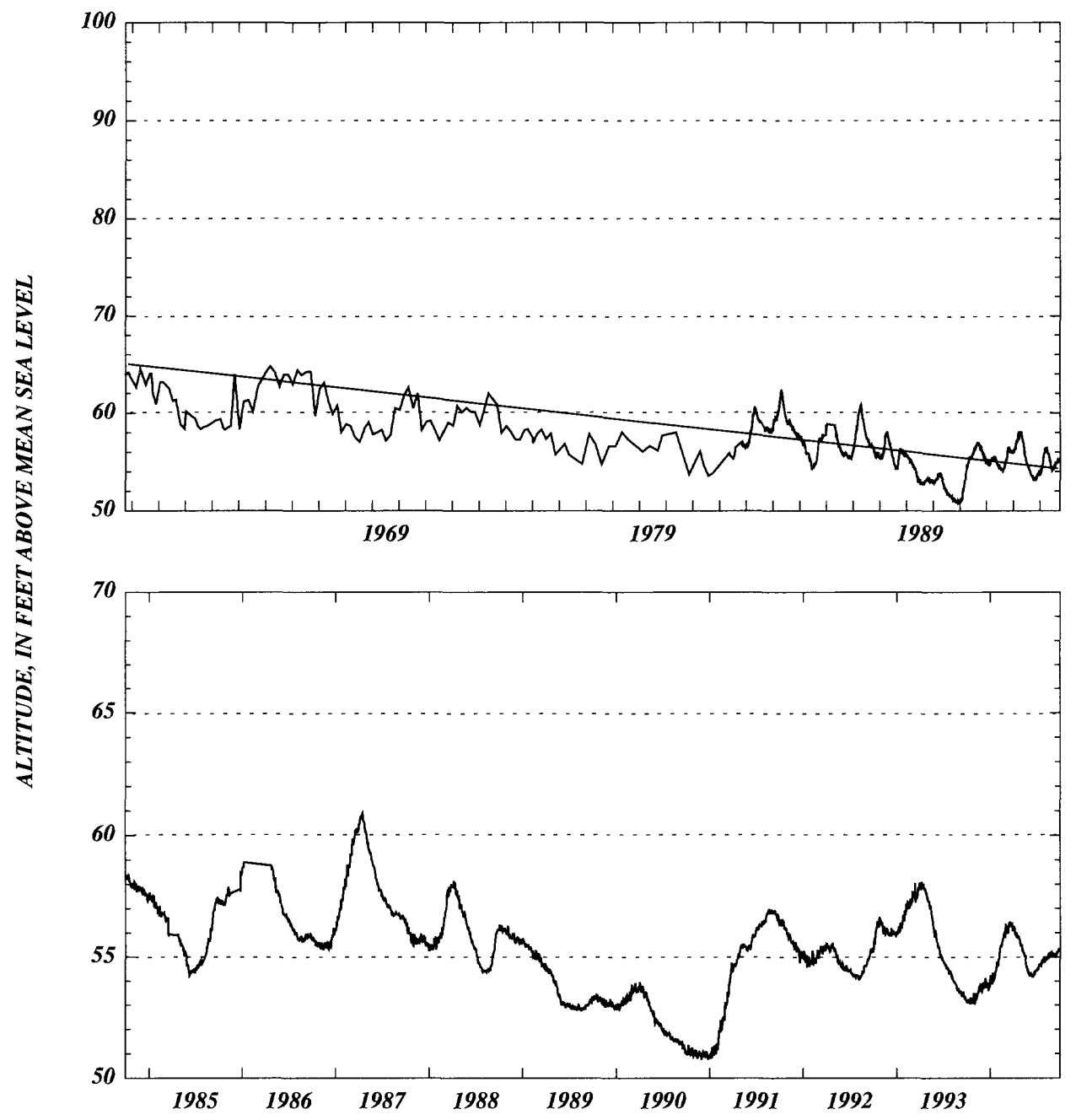



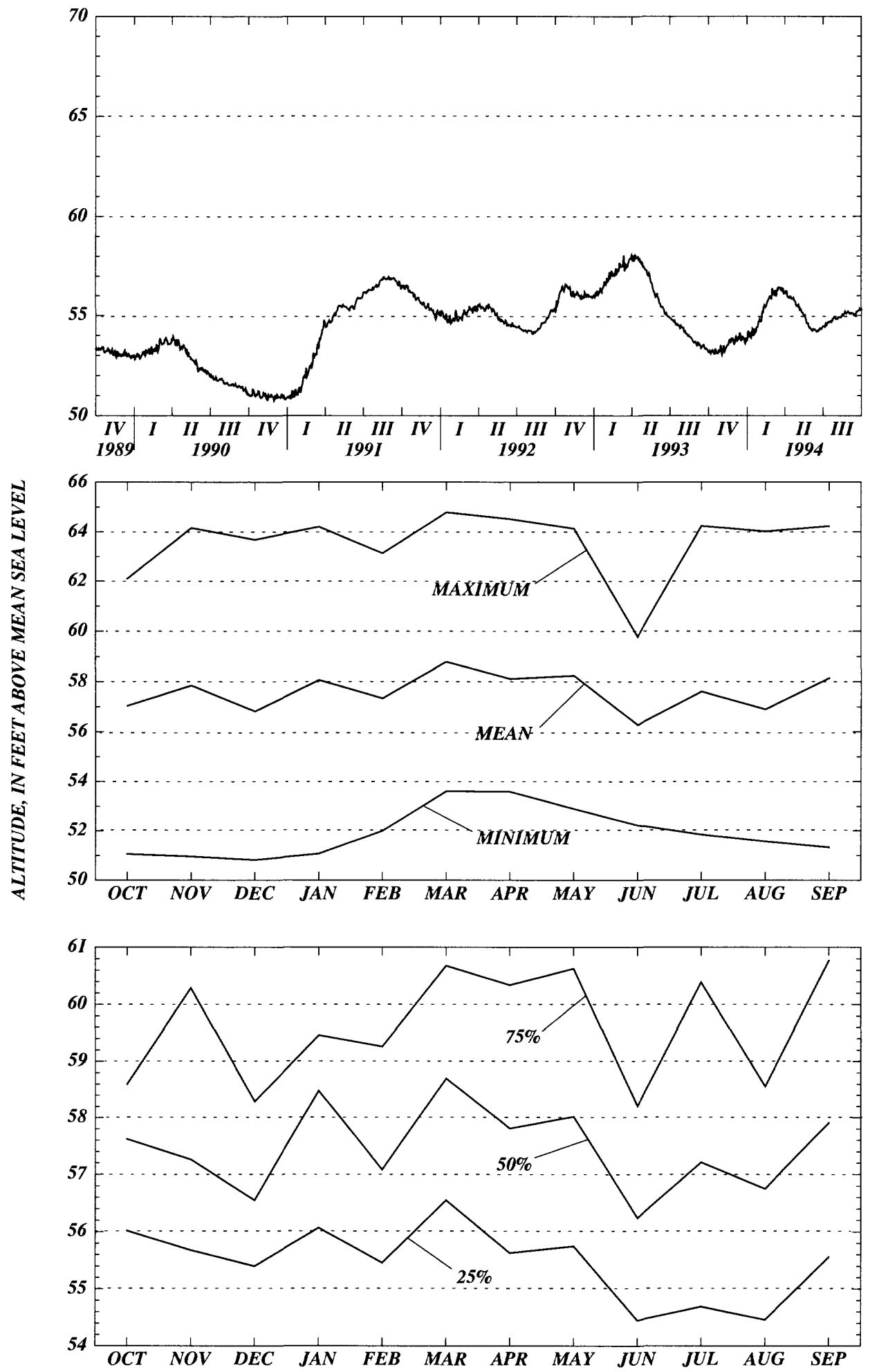


\section{Union County}

WELL NUMBER.--300242082233285. DOF - Union Tower. -051922002.

LOCATION.--Lat 3002’42”, long 82²3’32”, Hydrologic Unit Code 03110206.

AQUIFER.--Surficial aquifer, Geologic Unit Code 110NRSD.

WELL CHARACTERISTICS.--Casing diameter 3 in., Casing depth $7 \mathrm{ft}$., Total depth $27 \mathrm{ft}$.

INSTRUMENTATION.--Elevation of Measuring Point 144.64 ft., NGVD.

DATUM.--The National Geodetic Vertical Datum of 1929.

PERIOD OF RECORD.--06-05-1989 to 09-30-1994. *

EXTREME VALUES.--Maximum observed, 140.81 ft. (05-02-1991); minimum observed, $132.71 \mathrm{ft}$. (12-19-1990).

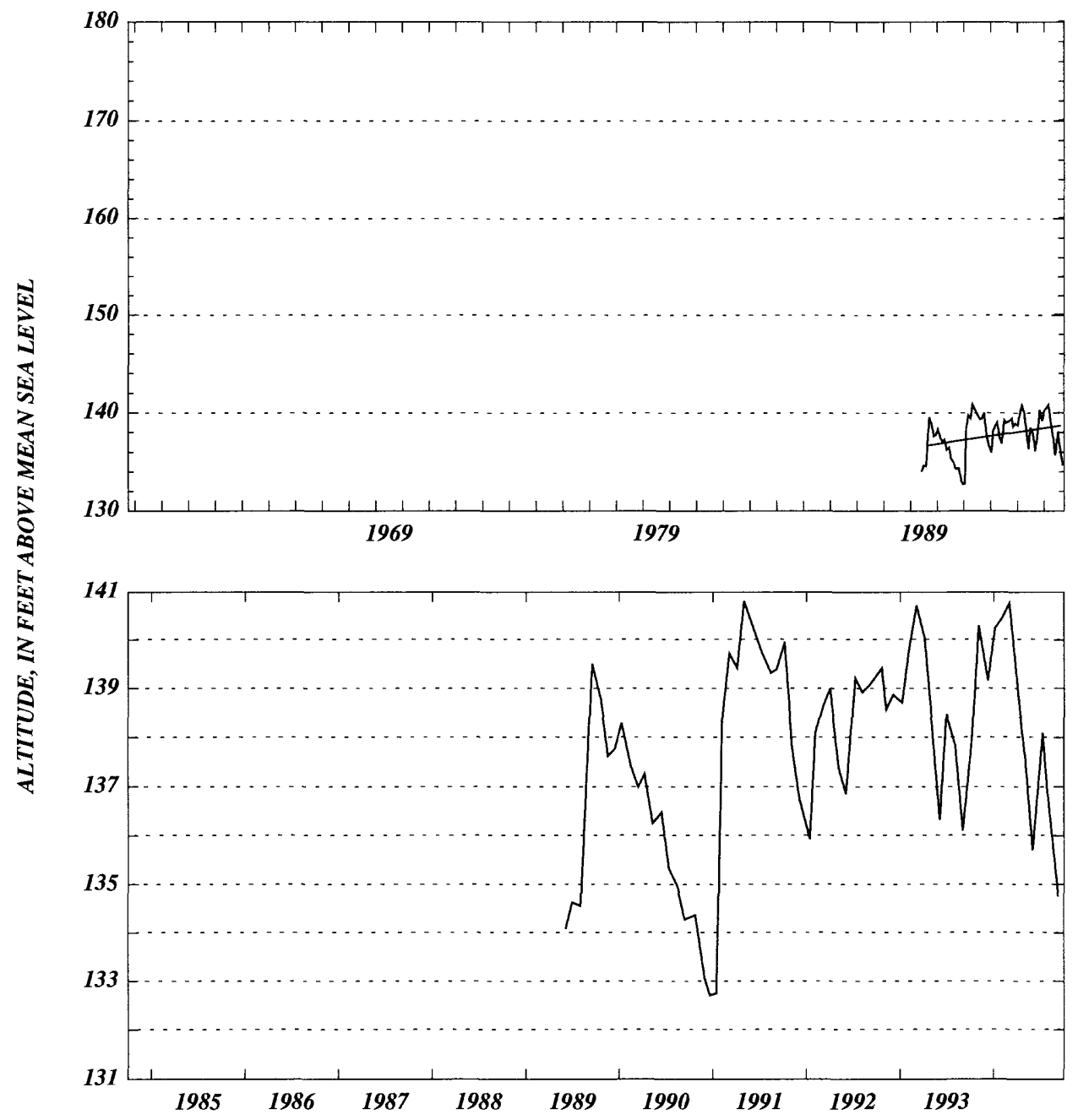



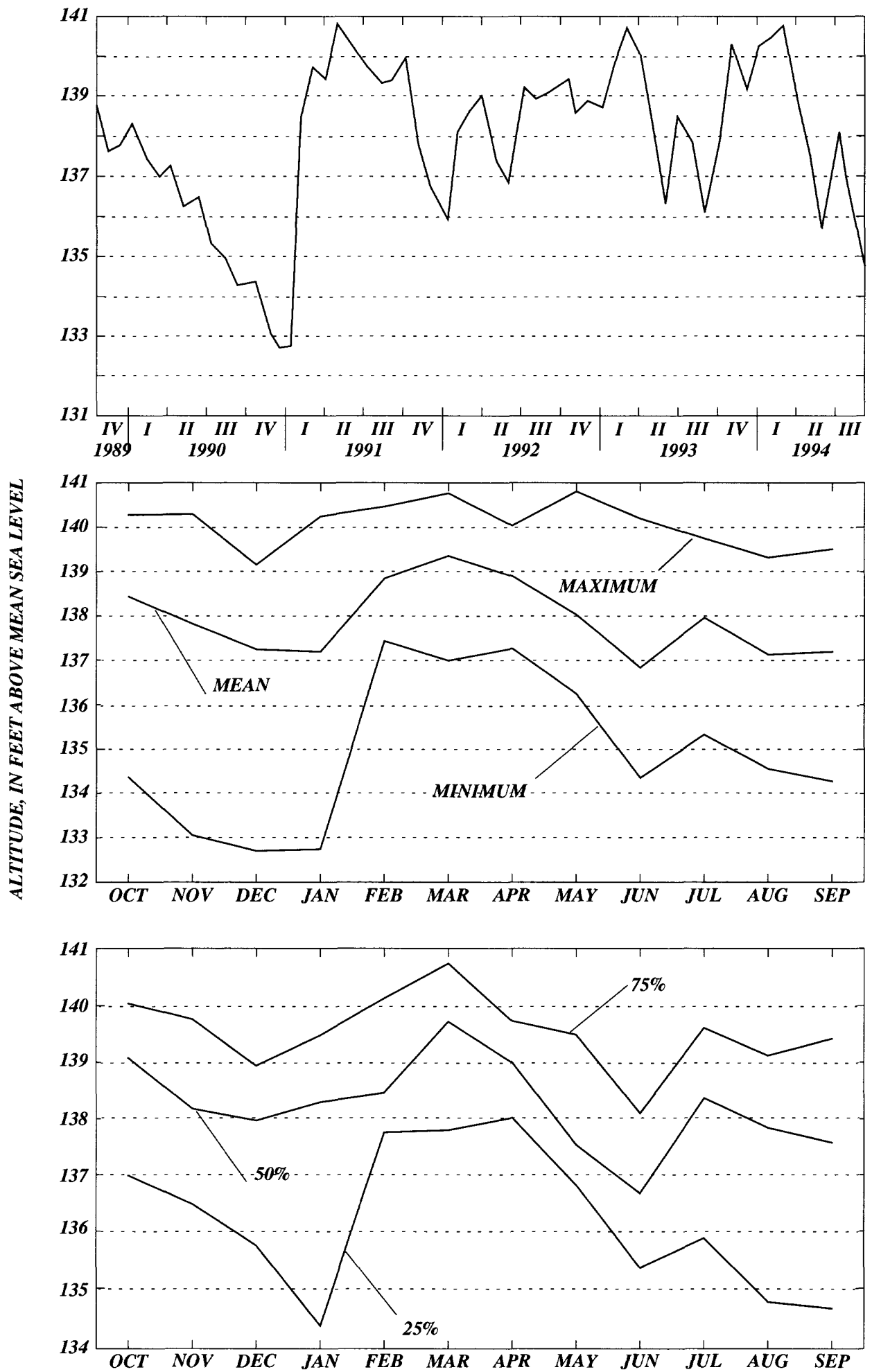


\section{Union County}

WELL NUMBER.--300747082225885. USGS - Lake Butler. -041923001.

LOCATION.--Lat 30 07'47”, long 82²2' 58', Hydrologic Unit Code 03110204.

AQUIFER.--Upper Floridan aquifer of the Tertiary system, Geologic Unit Code 120FLRD.

WELL CHARACTERISTICS.--Casing diameter 8 in., Casing depth $694 \mathrm{ft}$., Total depth $717 \mathrm{ft}$.

INSTRUMENTATION.--Miscellaneous from 11-20-1957 to 12-05-1957; no record 12-06-1957 to

11-01-1976; miscellaneous from 11-02-1976 to 04-30-1982; recorder from 05-01-1982 to 09-30-1994, set to elevation of Measuring Point, $155.75 \mathrm{ft}$., NGVD.

DATUM.--The National Geodetic Vertical Datum of 1929.

PERIOD OF RECORD.--11-20-1957 to 09-30-1994. †

EXTREME VALUES.--Maximum, 66.76 ft. (03-29-1965); minimum, 50.21 ft. (11-30-1990).

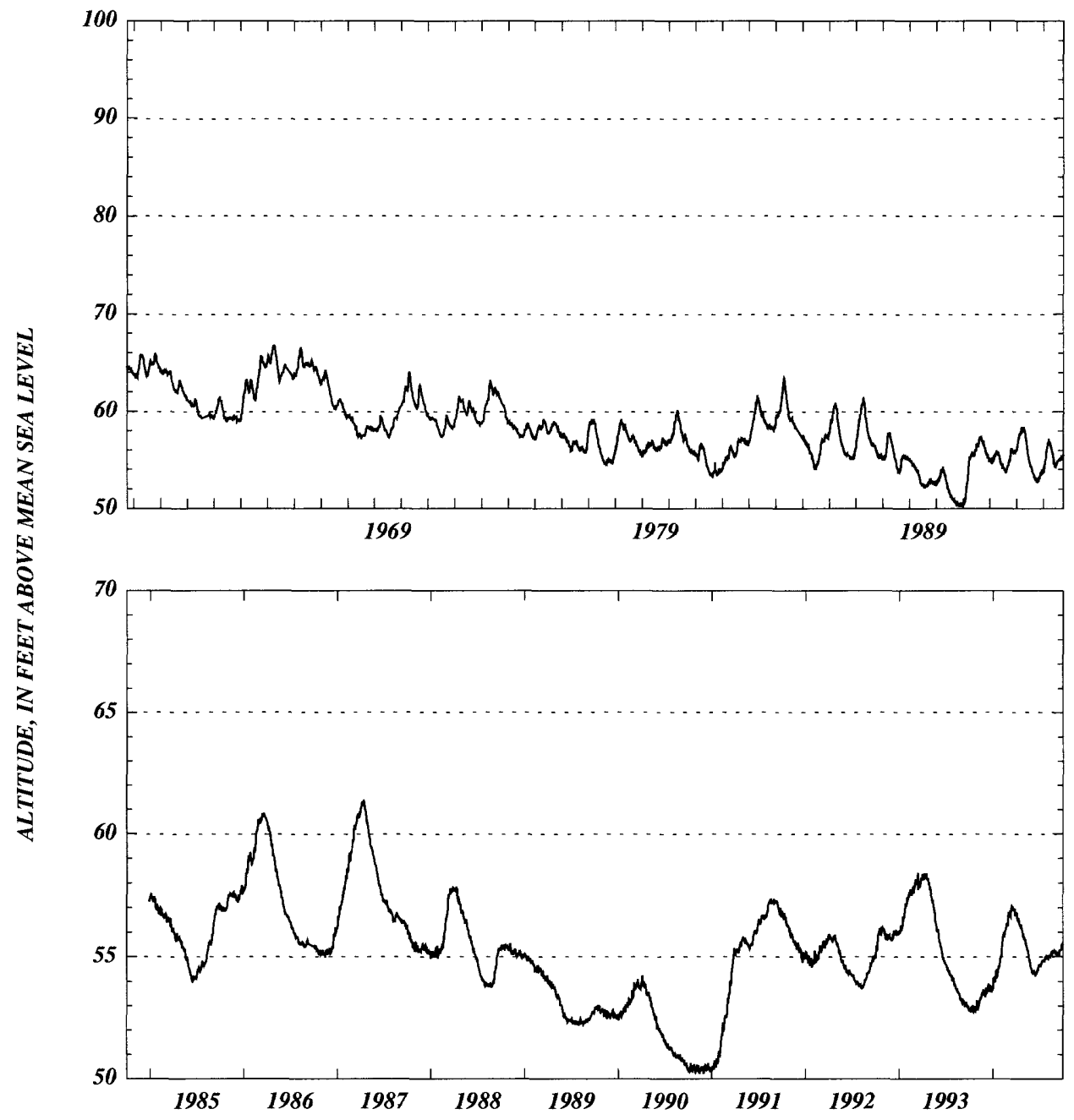



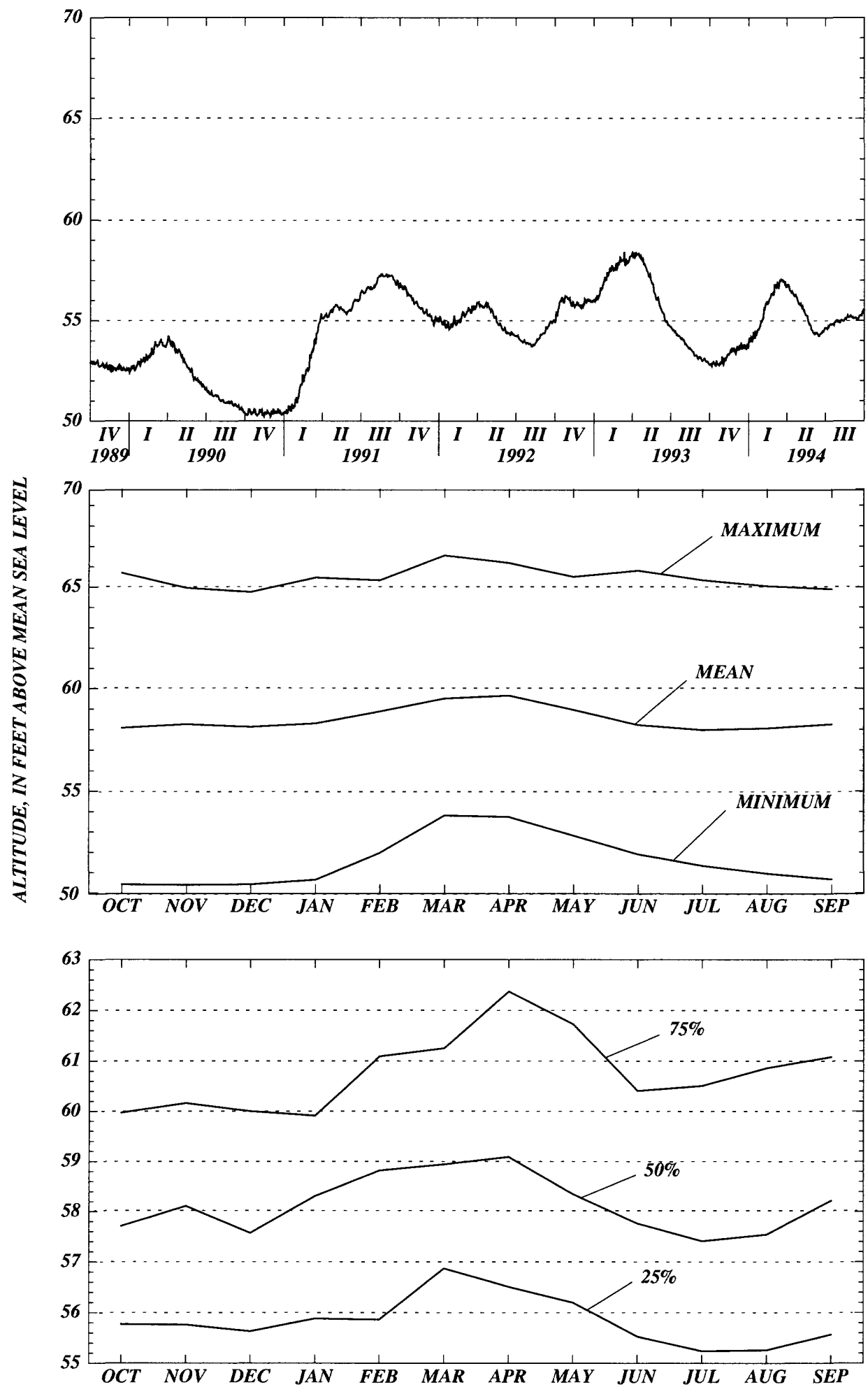


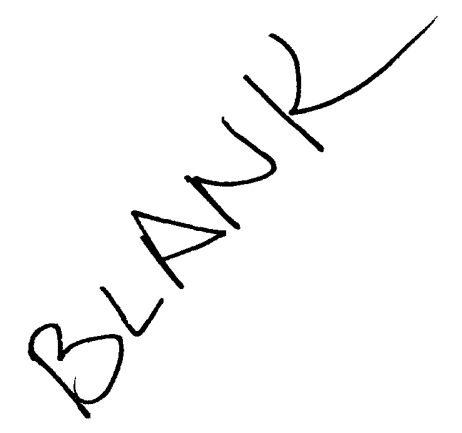




\section{APPENDIX I}

Location, Aquifer Monitored, and Frequency of Ground-Water

Level Measurements 


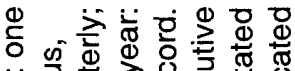

范 冞 ฮึ 春

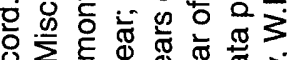

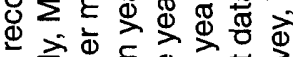

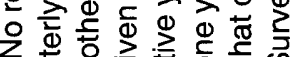

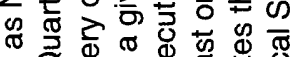

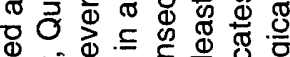

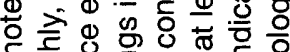

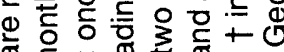

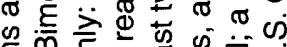

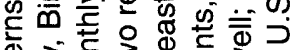
Ф

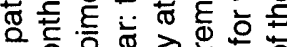
ه응 \& $\sum_{0}$ 㐫

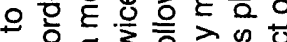
क 항 ธ。

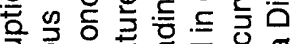

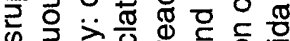

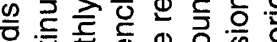

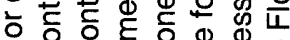
ซ $\sum \varepsilon$ g 帘

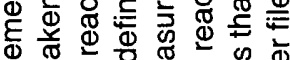
Ф

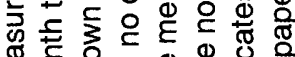

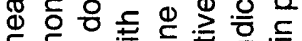
$\varepsilon \varepsilon \otimes$ 定.

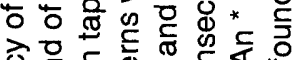

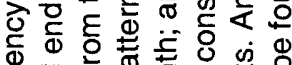

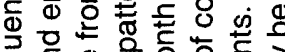

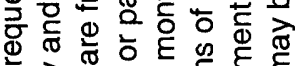

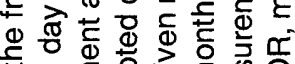

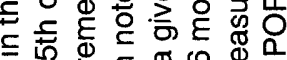

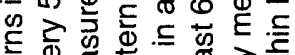
穴

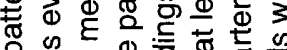

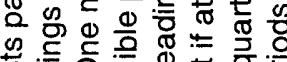
黑 đ है

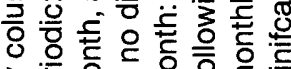

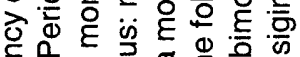

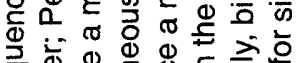

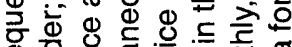

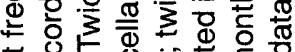
덩년.

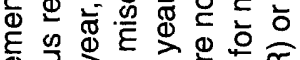
递

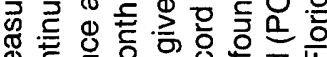
¿ ठํ ह

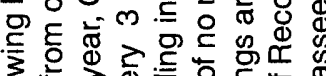
综 는

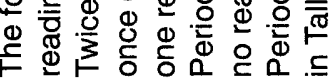

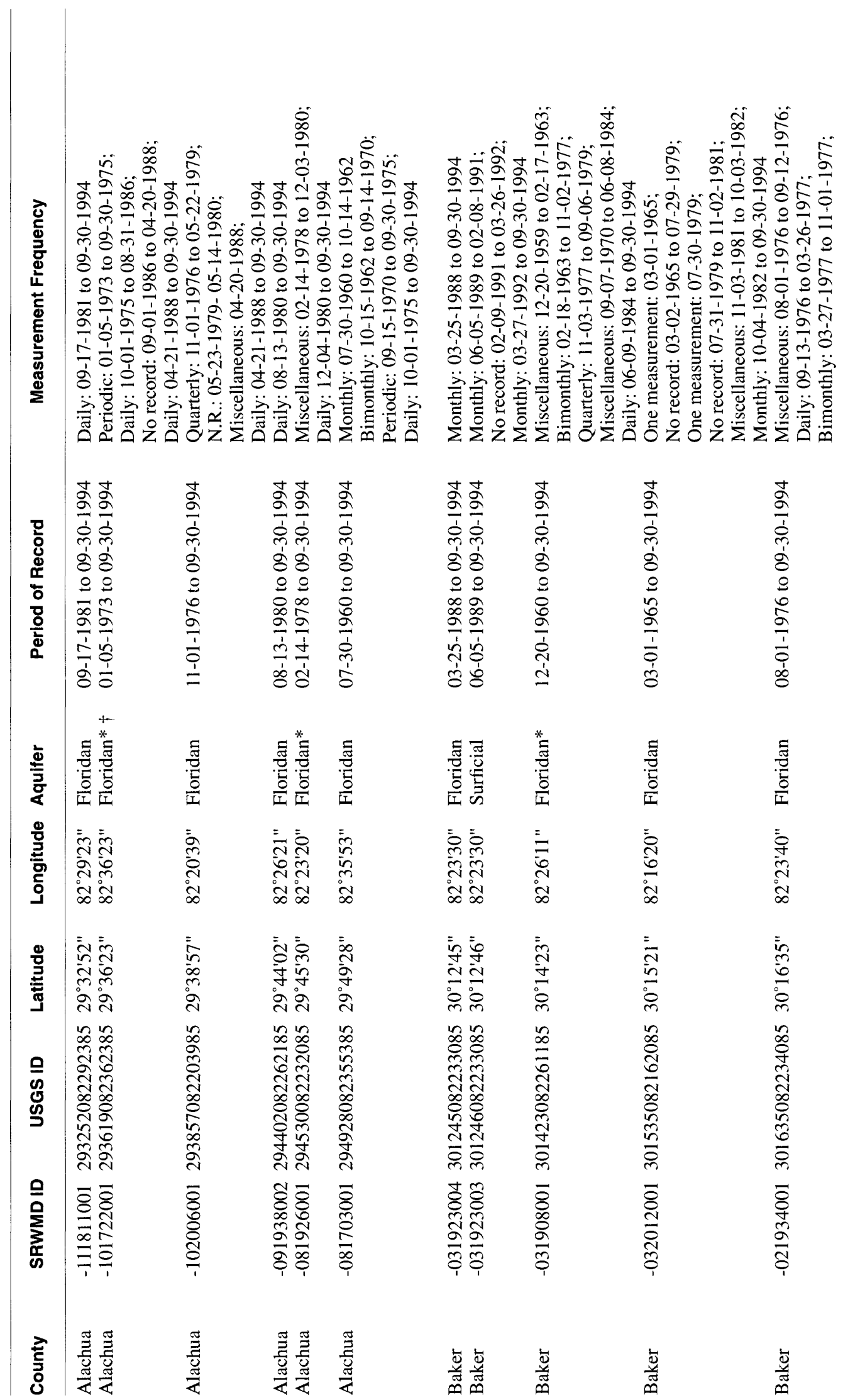




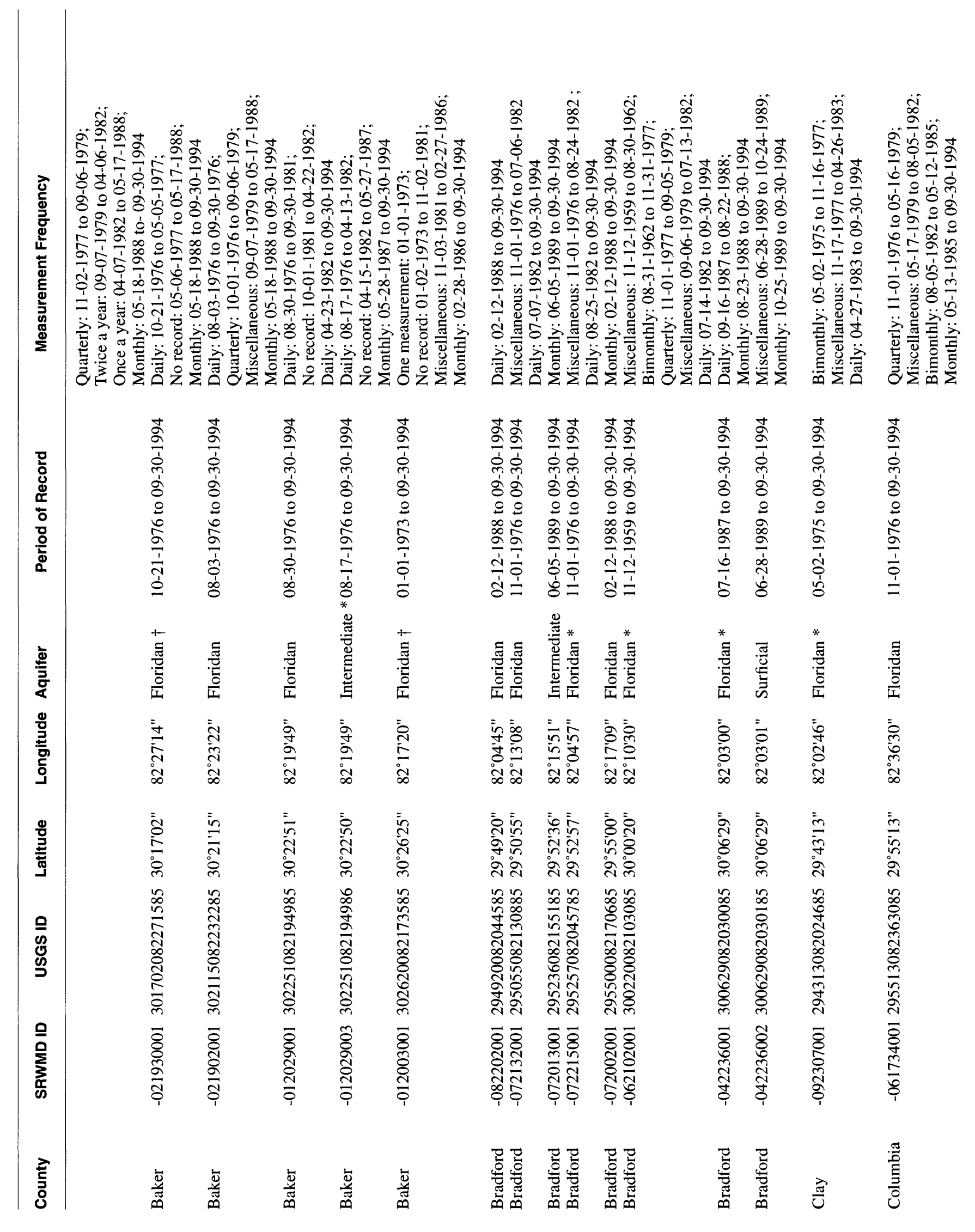




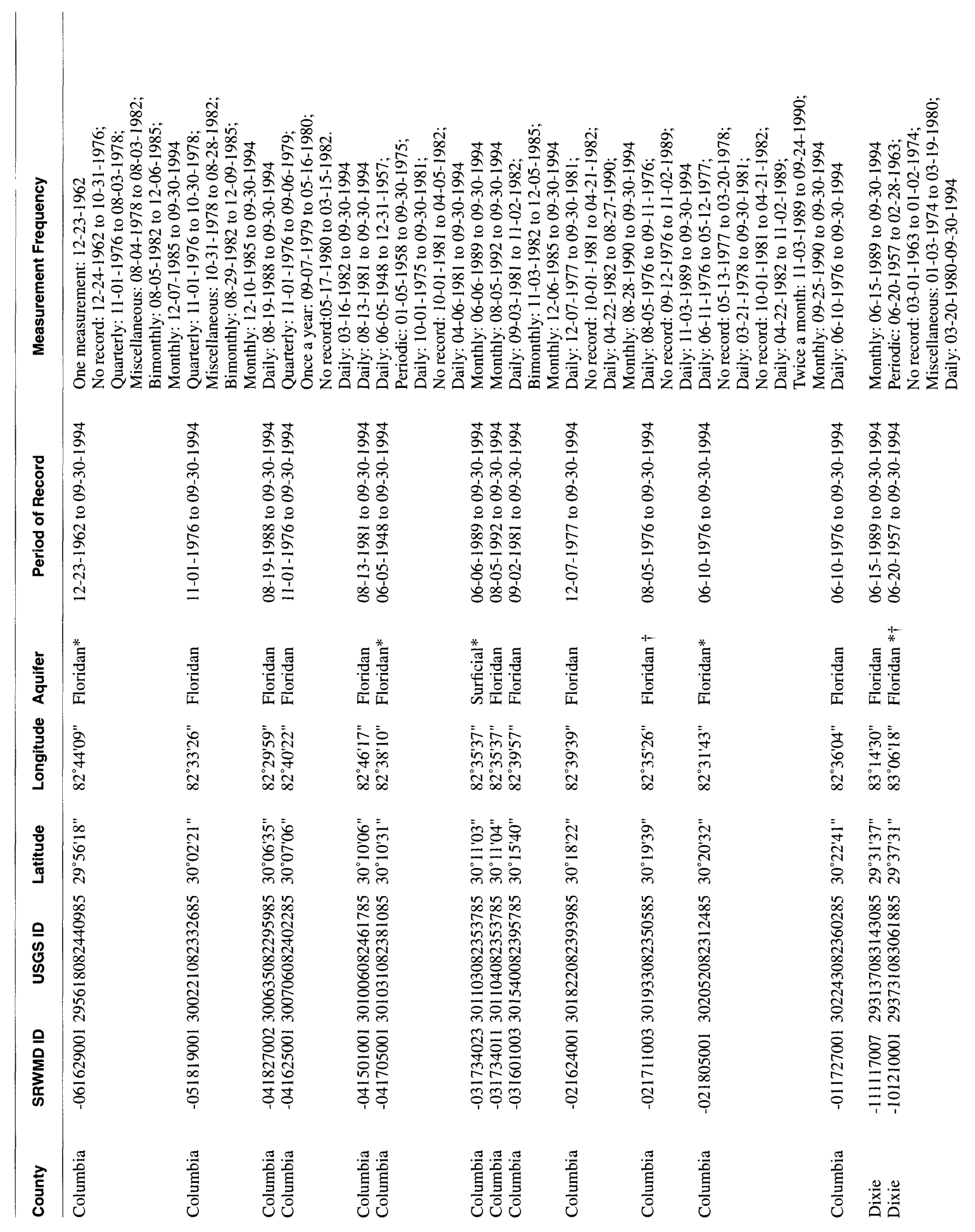




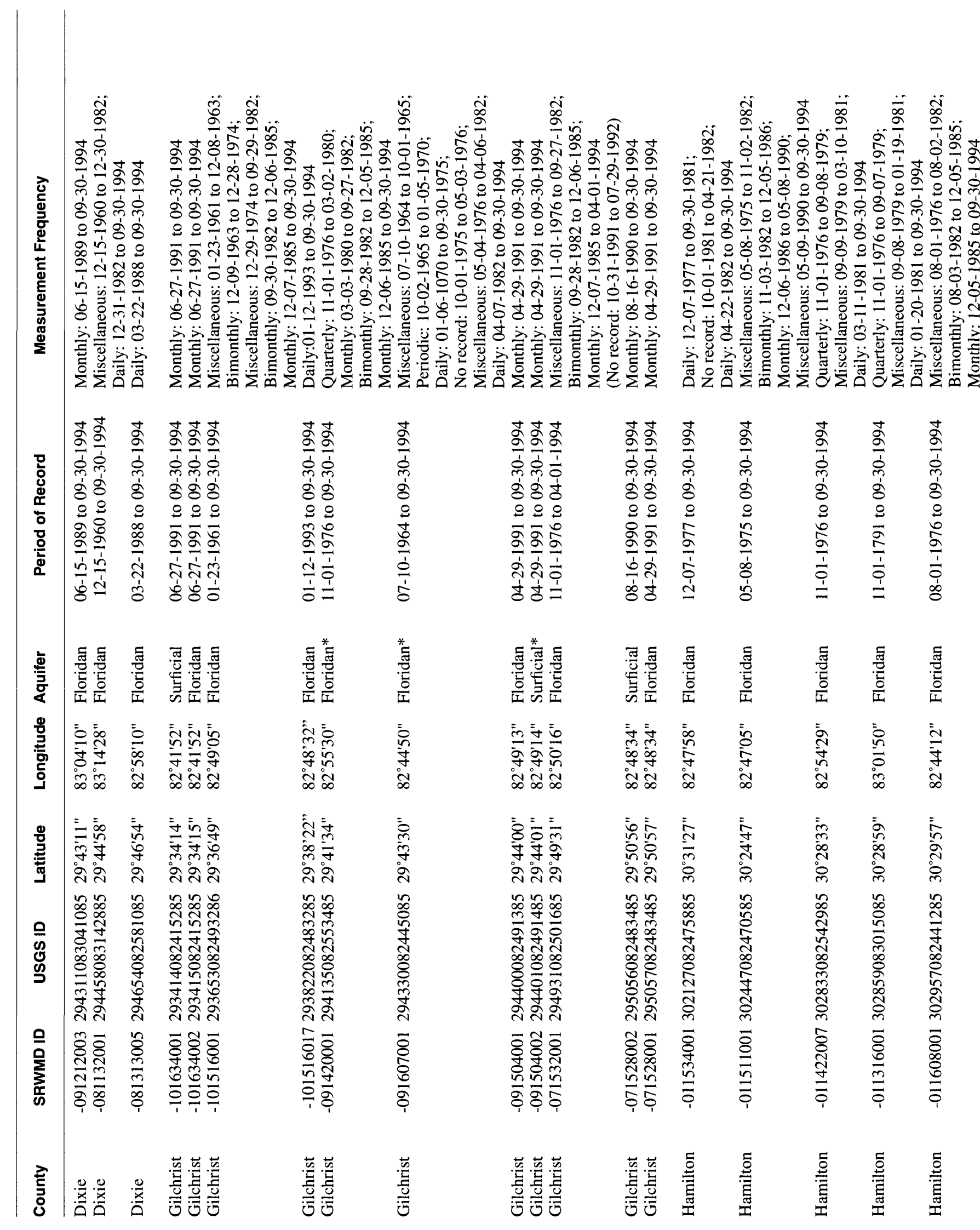




\begin{tabular}{|c|c|c|c|c|c|c|c|c|c|}
\hline 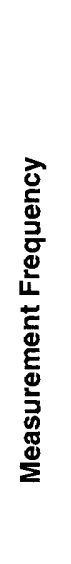 & \multicolumn{3}{|c|}{ 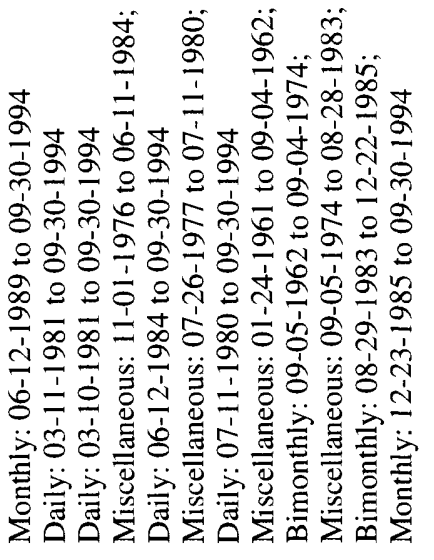 } & \multicolumn{4}{|c|}{ 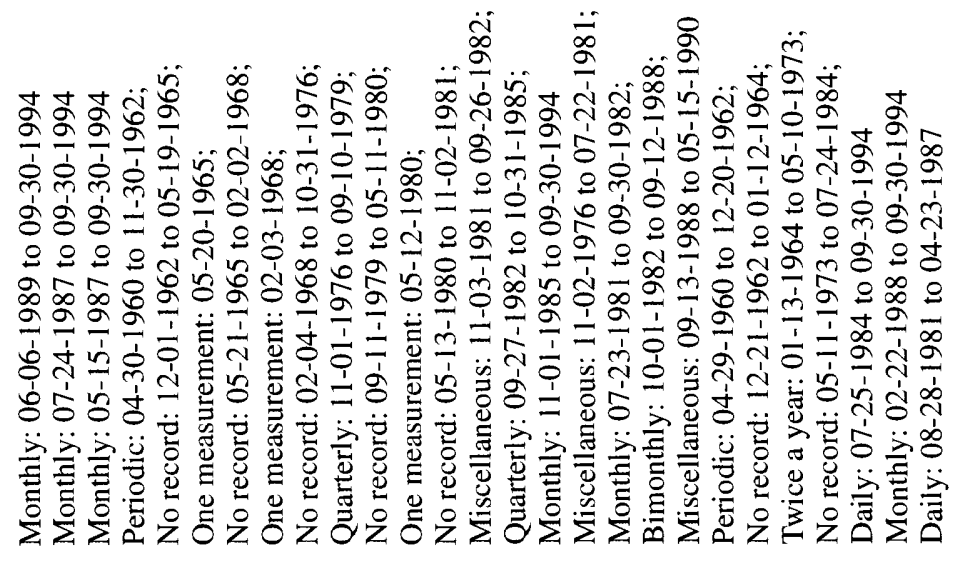 } & \multicolumn{2}{|c|}{ 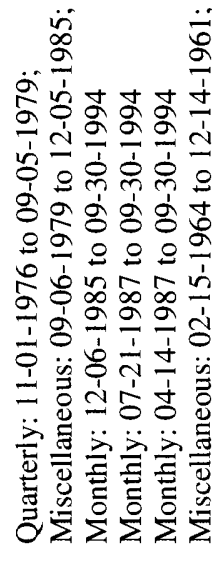 } \\
\hline 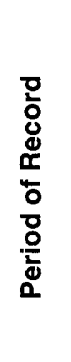 & 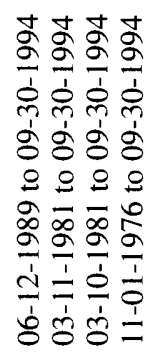 & 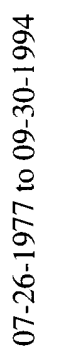 & 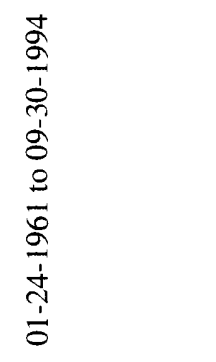 & 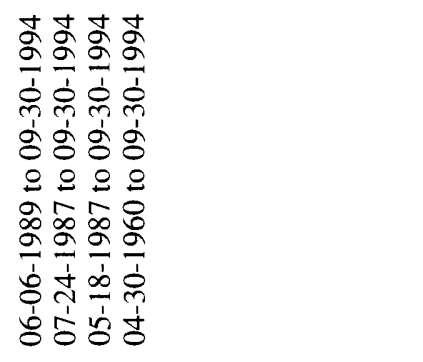 & 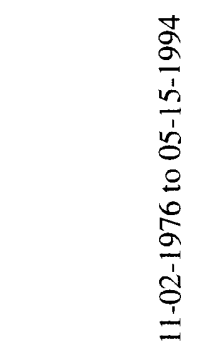 & 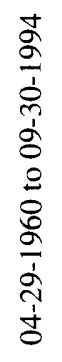 & 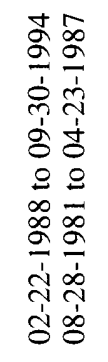 & 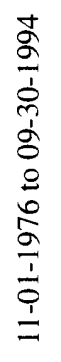 & 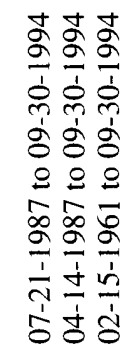 \\
\hline 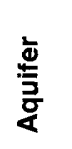 & 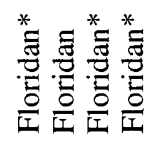 & 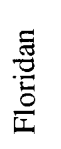 & $\begin{array}{l}\text { 胥 } \\
\text { 음 }\end{array}$ & 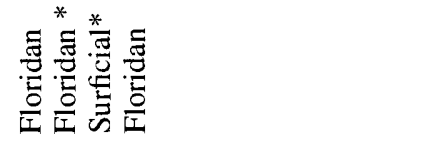 & $\begin{array}{l}\frac{5}{5} \\
\frac{D}{E} \\
\frac{0}{I}\end{array}$ & $\begin{array}{l}* \\
\stackrel{5}{0} \\
\frac{0}{0} \\
\frac{0}{I}\end{array}$ & 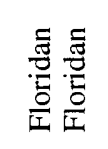 & $\frac{\sqrt[5]{0}}{\frac{0}{0}}$ & 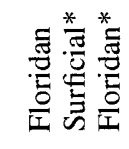 \\
\hline 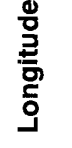 & 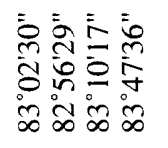 & $\begin{array}{l}\bar{y} \\
\dot{y} \\
i \\
0 \\
\infty \\
\infty\end{array}$ & $\begin{array}{l}\bar{b} \\
\dot{0} \\
b \\
0 \\
\infty \\
\infty\end{array}$ & 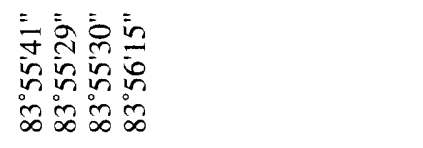 & $\begin{array}{l}\sum_{n}^{+} \\
m \\
n \\
\infty \\
\infty\end{array}$ & $\begin{array}{l}\stackrel{+}{N} \\
\stackrel{\infty}{0} \\
\infty \\
\infty\end{array}$ & 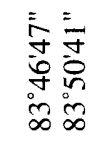 & $\begin{array}{l}\infty \\
\infty \\
\cdots \\
2 \\
\circ \\
\infty \\
\infty\end{array}$ & 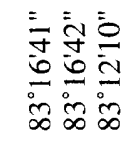 \\
\hline 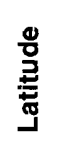 & 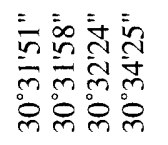 & $\begin{array}{l}\vdots \\
\vdots \\
i \\
\vdots \\
0 \\
\infty\end{array}$ & 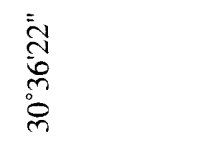 & 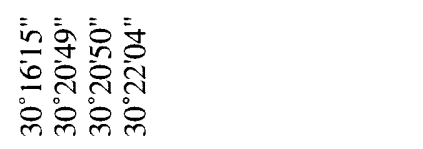 & 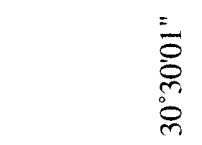 & $\begin{array}{l}\cdots \\
\bar{\infty} \\
\infty \\
0 \\
0\end{array}$ & 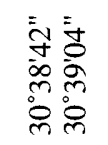 & $\begin{array}{l}\bar{j} \\
\stackrel{+}{\pi} \\
\text { ñ } \\
\text { ì }\end{array}$ & 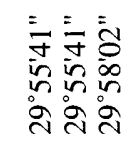 \\
\hline $\begin{array}{l}0 \\
0 \\
0 \\
9\end{array}$ & 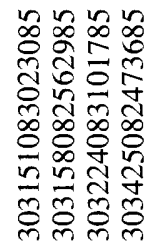 & 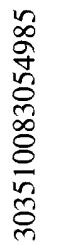 & 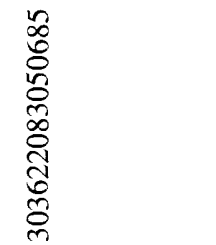 & 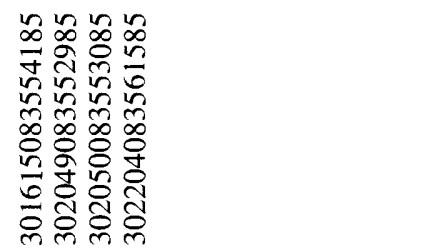 & 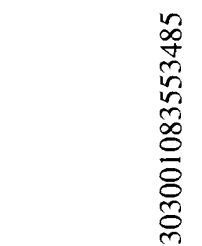 & 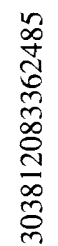 & 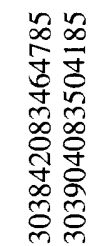 & 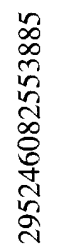 & 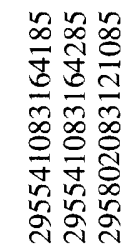 \\
\hline 足 & 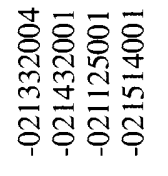 & $\begin{array}{l}\bar{\delta} \\
\frac{\bar{\alpha}}{1} \\
\frac{0}{1}\end{array}$ & 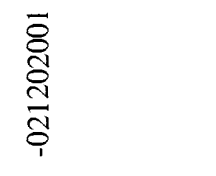 & 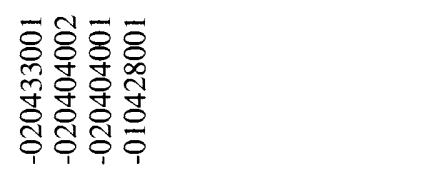 & 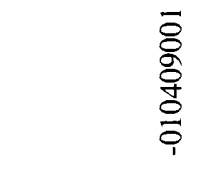 & 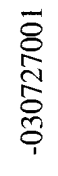 & 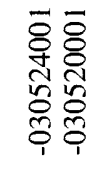 & $\frac{\overrightarrow{8}}{\frac{\sigma}{8}}$ & 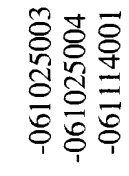 \\
\hline $\begin{array}{l}\vec{Z} \\
\stackrel{\Xi}{0} \\
\dot{0}\end{array}$ & 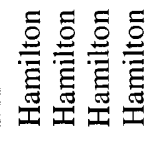 & 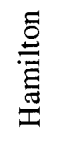 & 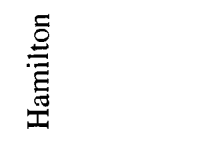 & 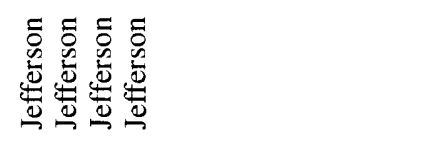 & 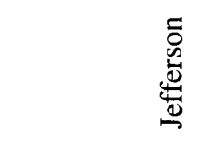 & 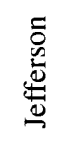 & 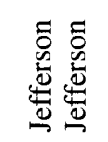 & 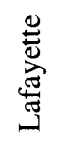 & 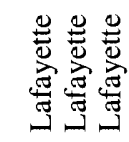 \\
\hline
\end{tabular}




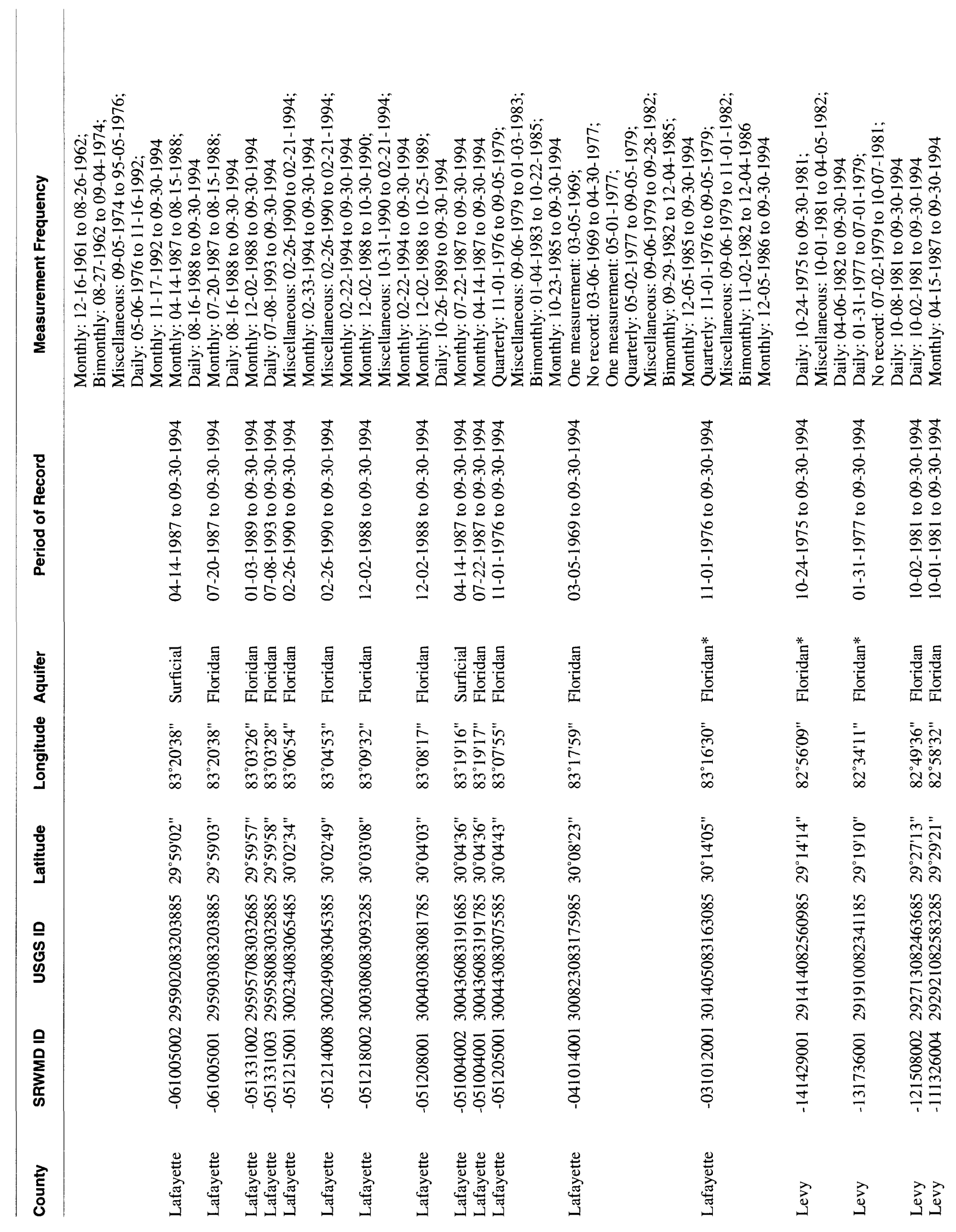




\begin{tabular}{|c|c|c|c|c|c|c|c|c|c|}
\hline 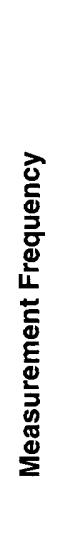 & \multicolumn{4}{|c|}{ 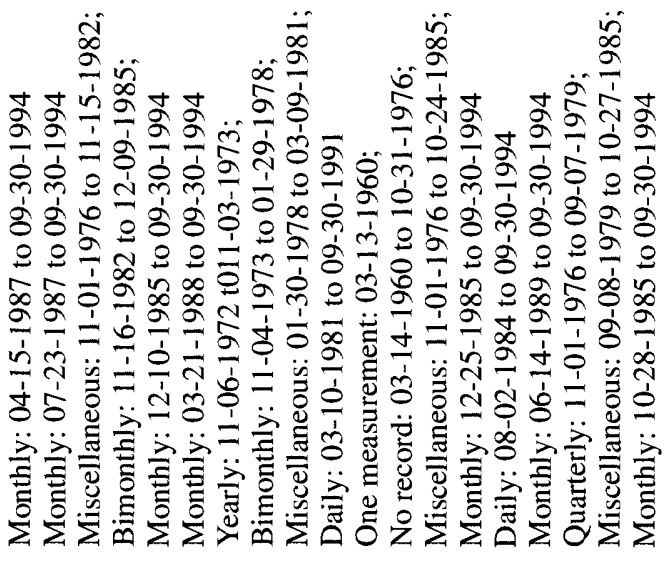 } & \multicolumn{5}{|c|}{ 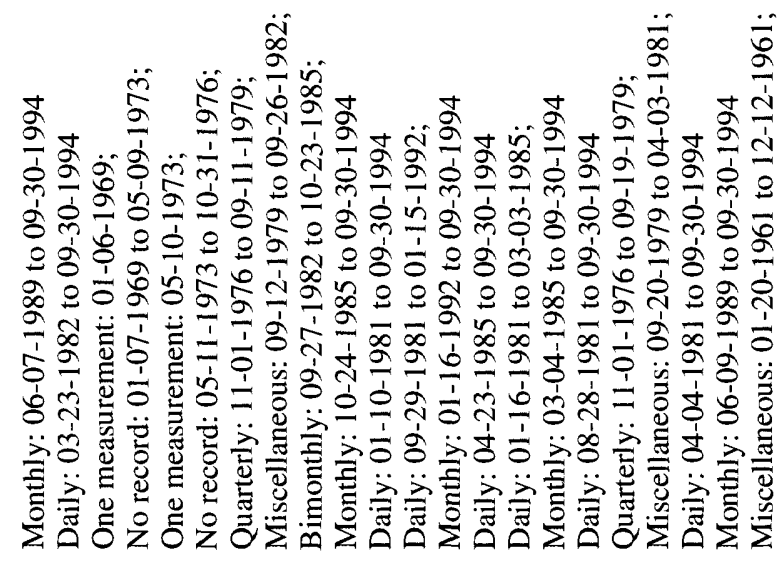 } \\
\hline 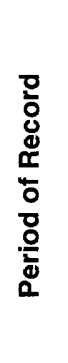 & 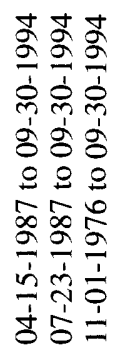 & 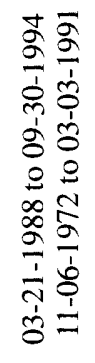 & 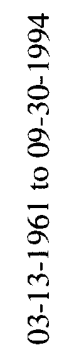 & 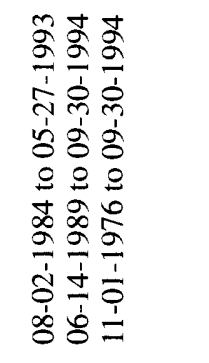 & 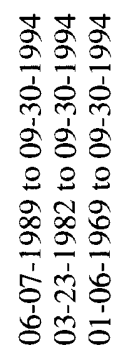 & 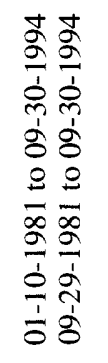 & 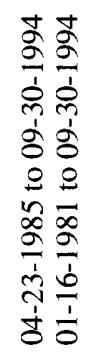 & 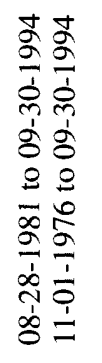 & 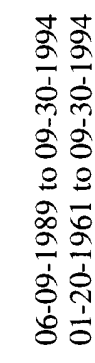 \\
\hline 嗃 & 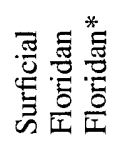 & 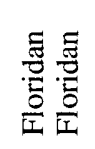 & 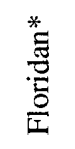 & 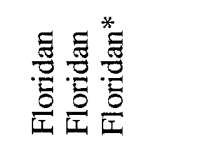 & 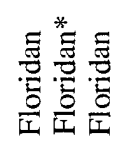 & 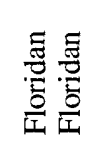 & 超 & 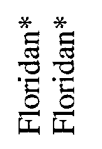 & $\frac{0}{I}$ \\
\hline 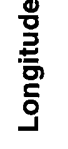 & 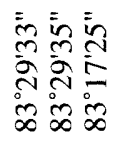 & 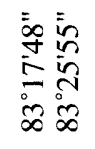 & $\begin{array}{l}\overline{0} \\
\dot{0} \\
\text { के } \\
\dot{\infty} \\
\infty\end{array}$ & 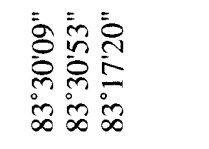 & 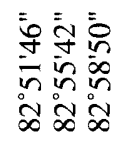 & 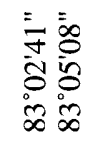 & 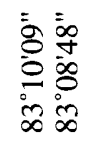 & $\begin{array}{l}\bar{a} \bar{n} \\
\bar{z} \bar{n} \\
i \stackrel{n}{\infty} \\
\infty \infty\end{array}$ & \\
\hline 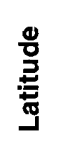 & 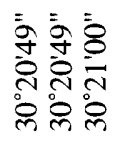 & 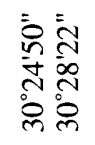 & 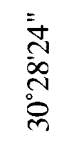 & 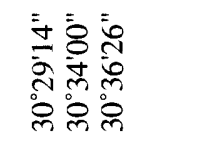 & 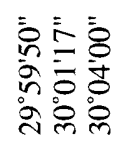 & 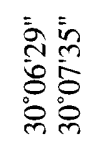 & $\begin{array}{l}\bar{y} \\
\dot{0}= \\
0 \\
0 \\
0 \\
0 \\
0 \\
0\end{array}$ & 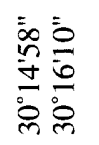 & \\
\hline 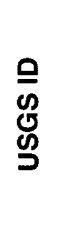 & 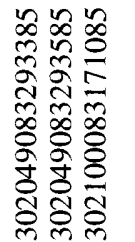 & 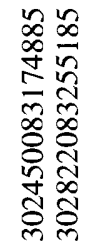 & 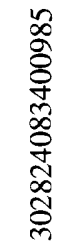 & 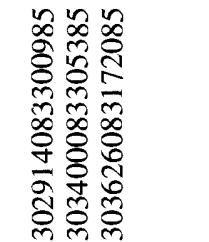 & 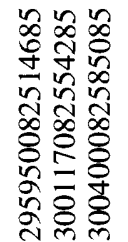 & 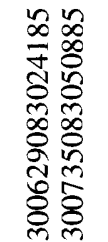 & 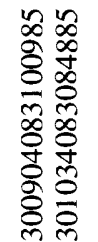 & 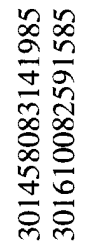 & \\
\hline 只 & 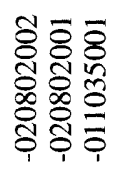 & 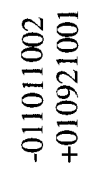 & $\frac{\bar{\delta}}{\frac{\delta}{5}}$ & 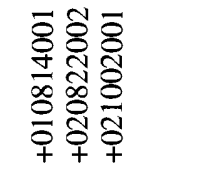 & 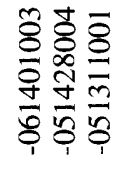 & 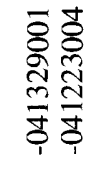 & 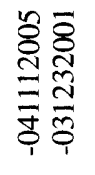 & 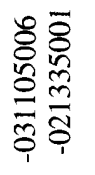 & \\
\hline 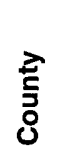 & 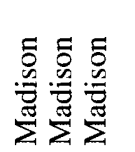 & 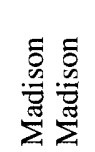 & 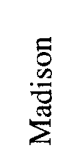 & 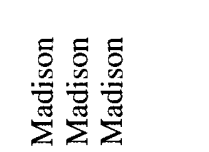 & 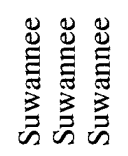 & 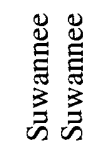 & 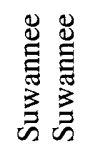 & 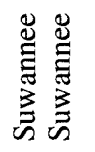 & $\vec{n}$ \\
\hline
\end{tabular}




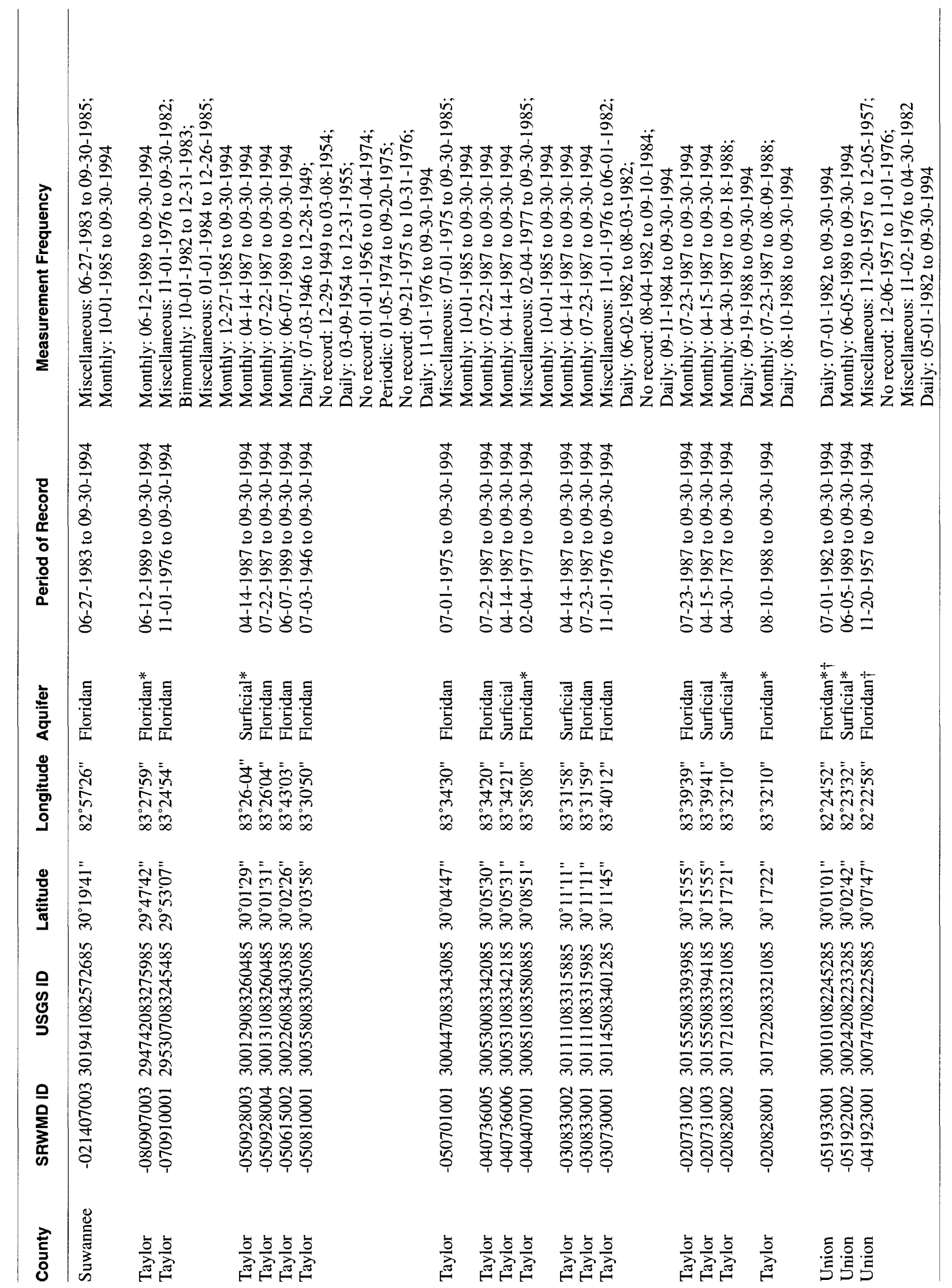




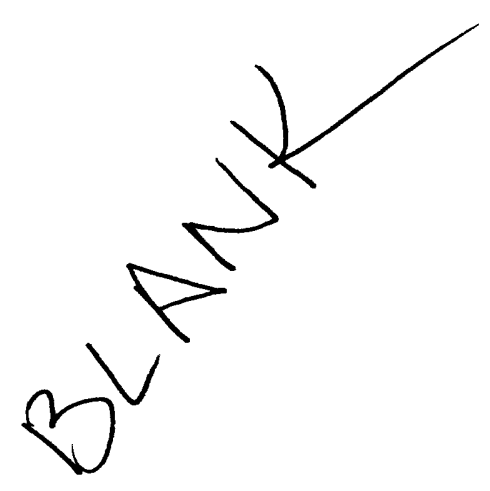




\section{APPENDIX II}

\section{Monthly Maximum, Mean, Minimum and 75-, 50-, and 25-Percent Quartile Values}

Data used for the graphs of the maximum, minimum, and mean monthly mean graphs and the quartile graphs for 125 wells are presented below. These maximum and minimum values presented here are not necessarily those in the Extreme Values for Period of Record listed for each well, since these values in this table represent mean values. No data is available for the 10 wells that have less than 5 years of data. $A$ dash indicates that less than 2 data points were available for that month. These data are ordered on the USGS Site ID. 
USGS SITE 291414082560985 SRWMD ID -141429001 COUNTY LEVY

$\begin{array}{lrrrrrr}\text { MONTH } & \text { MAXIMUM } & \text { MINIMUM } & \text { MEAN } & 25 \% & 50 \% & 75 \% \\ \text { OCT } & 11.32 & 10.23 & 10.80 & 10.43 & 10.83 & 11.17 \\ \text { NOV } & 11.24 & 9.69 & 10.49 & 10.26 & 10.44 & 10.79 \\ \text { DEC } & 11.78 & 9.34 & 10.46 & 10.11 & 10.37 & 10.86 \\ \text { JAN } & 11.22 & 9.68 & 10.48 & 10.14 & 10.49 & 10.79 \\ \text { FEB } & 11.20 & 10.06 & 10.69 & 10.50 & 10.67 & 10.94 \\ \text { MAR } & 11.41 & 10.24 & 10.84 & 10.61 & 10.78 & 11.18 \\ \text { APR } & 11.48 & 9.83 & 10.71 & 10.42 & 10.69 & 11.01 \\ \text { MAY } & 11.07 & 9.53 & 10.30 & 9.87 & 10.29 & 10.84 \\ \text { JUN } & 10.88 & 8.93 & 9.95 & 9.38 & 10.09 & 10.41 \\ \text { JUL } & 11.09 & 8.68 & 10.16 & 9.69 & 10.14 & 10.68 \\ \text { AUG } & 11.47 & 8.91 & 10.58 & 10.25 & 10.62 & 11.11 \\ \text { SEP } & 11.50 & 9.75 & 10.89 & 10.58 & 10.96 & 11.28\end{array}$

USGS SITE 291910082341185 SRWMD ID -131736001 COUNTY LeVY

$\begin{array}{lrrrrrr}\text { MONTH } & \text { MAXIMUM } & \text { MINIMUM } & \text { MEAN } & 25 \% & 50 \% & 75 \% \\ \text { OCT } & 53.40 & 42.23 & 47.79 & 43.83 & 48.06 & 50.84 \\ \text { NOV } & 52.56 & 42.13 & 47.28 & 43.65 & 47.18 & 49.68 \\ \text { DEC } & 51.72 & 41.56 & 46.08 & 43.38 & 46.18 & 48.33 \\ \text { JAN } & 51.61 & 41.06 & 45.72 & 42.96 & 45.15 & 48.59 \\ \text { FEB } & 51.41 & 40.87 & 45.69 & 42.57 & 46.10 & 48.28 \\ \text { MAR } & 51.83 & 41.71 & 46.24 & 42.66 & 47.03 & 48.59 \\ \text { APR } & 52.48 & 42.15 & 46.78 & 44.19 & 45.96 & 49.33 \\ \text { MAY } & 52.08 & 41.74 & 46.83 & 44.27 & 47.15 & 48.34 \\ \text { JUN } & 50.95 & 41.37 & 46.25 & 44.18 & 47.22 & 47.82 \\ \text { JUL } & 51.48 & 41.70 & 46.19 & 43.62 & 46.48 & 50.00 \\ \text { AUG } & 52.18 & 41.60 & 46.61 & 43.50 & 46.07 & 50.74 \\ \text { SEP } & 53.09 & 42.61 & 47.78 & 43.49 & 48.49 & 51.40\end{array}$

USGS SITE 292713082463985 SRWMD ID -121508002 COUNTY LEVY

$\begin{array}{lrrrrrr}\text { MONTH } & \text { MAXIMUM } & \text { MINIMUM } & \text { MEAN } & 25 \% & 50 \% & 75 \% \\ \text { OCT } & 32.56 & 22.60 & 27.15 & 24.33 & 27.63 & 29.02 \\ \text { NOV } & 31.27 & 22.13 & 26.39 & 23.78 & 26.72 & 28.40 \\ \text { DEC } & 30.75 & 21.46 & 25.88 & 23.34 & 26.23 & 27.87 \\ \text { JAN } & 29.84 & 21.01 & 25.83 & 23.09 & 26.05 & 28.42 \\ \text { FEB } & 29.76 & 22.46 & 26.40 & 24.25 & 26.04 & 28.85 \\ \text { MAR } & 31.55 & 23.13 & 27.33 & 25.19 & 27.61 & 29.25 \\ \text { APR } & 33.22 & 23.25 & 27.62 & 26.56 & 27.53 & 28.87 \\ \text { MAY } & 29.11 & 22.72 & 26.42 & 25.90 & 26.70 & 27.82 \\ \text { JUN } & 27.68 & 22.01 & 25.31 & 24.77 & 25.36 & 27.20 \\ \text { JUL } & 29.67 & 21.41 & 25.50 & 24.03 & 25.18 & 27.63 \\ \text { AUG } & 30.12 & 22.89 & 26.61 & 24.13 & 27.65 & 28.69 \\ \text { SEP } & 32.68 & 23.16 & 27.81 & 24.42 & 28.58 & 30.40\end{array}$

USGS SITE 292921082583285 SRWMD ID -111326004 COUNTY LevY

$\begin{array}{lrrrrrr}\text { MONTH } & \text { MAXIMUM } & \text { MINIMUM } & \text { MEAN } & 25 \% & 50 \% & 75 \% \\ \text { OCT } & 6.06 & 2.25 & 3.36 & 2.58 & 3.32 & 3.82 \\ \text { NOV } & 5.07 & 2.27 & 2.99 & 2.39 & 2.91 & 3.22 \\ \text { DEC } & 4.33 & 1.78 & 2.89 & 2.14 & 2.82 & 3.59 \\ \text { JAN } & 5.78 & 2.22 & 3.37 & 2.36 & 2.71 & 4.93 \\ \text { FEB } & 8.50 & 2.48 & 5.00 & 3.24 & 4.52 & 7.05 \\ \text { MAR } & 9.74 & 2.58 & 6.30 & 3.73 & 6.08 & 8.81 \\ \text { APR } & 11.64 & 2.53 & 5.80 & 3.48 & 5.12 & 8.24 \\ \text { MAY } & 7.43 & 2.46 & 4.10 & 2.80 & 3.52 & 5.37 \\ \text { JUN } & 5.14 & 2.36 & 3.30 & 2.74 & 3.00 & 4.09 \\ \text { JUL } & 5.66 & 2.55 & 3.38 & 2.65 & 3.15 & 3.83 \\ \text { AUG } & 7.88 & 2.45 & 3.77 & 2.87 & 3.50 & 4.07 \\ \text { SEP } & 5.73 & 2.63 & 3.80 & 3.13 & 3.64 & 4.41\end{array}$


USGS SITE 293137083143085 SRWMD ID -111117007 COUNTY Dixie

$\begin{array}{lrrrrrr}\text { MONTH } & \text { MAXIMUM } & \text { MINIMUM } & \text { MEAN } & 25 \% & 50 \% & 75 \% \\ \text { OCT } & 15.50 & 12.69 & 13.74 & 12.82 & 13.43 & 14.79 \\ \text { NOV } & 15.01 & 12.17 & 13.30 & 12.36 & 13.31 & 13.94 \\ \text { DEC } & 12.93 & 12.00 & 12.52 & 12.25 & 12.51 & 12.84 \\ \text { JAN } & 13.50 & 11.84 & 12.80 & 12.22 & 12.83 & 13.37 \\ \text { FEB } & 15.08 & 13.04 & 13.98 & 13.26 & 13.51 & 14.94 \\ \text { MAR } & 15.46 & 13.41 & 14.21 & 13.64 & 14.02 & 14.88 \\ \text { APR } & 14.53 & 13.14 & 13.75 & 13.14 & 13.66 & 14.44 \\ \text { MAY } & 14.10 & 12.50 & 12.96 & 12.56 & 12.77 & 13.44 \\ \text { JUN } & 14.31 & 11.42 & 12.34 & 11.66 & 12.06 & 12.92 \\ \text { JUL } & 13.61 & 11.81 & 12.78 & 12.03 & 12.81 & 13.50 \\ \text { AUG } & 16.38 & 11.92 & 13.61 & 12.04 & 12.64 & 16.12 \\ \text { SEP } & 15.85 & 12.88 & 14.26 & 13.18 & 14.15 & 15.44\end{array}$

USGS SITE 293252082292385 SRWMD ID -111811001 COUNTY Alachua

$\begin{array}{lrrrrrr}\text { MONTH } & \text { MAXIMUM } & \text { MINIMUM } & \text { MEAN } & 25 \% & 50 \% & 75 \% \\ \text { OCT } & 51.85 & 41.14 & 46.38 & 42.91 & 46.29 & 49.54 \\ \text { NOV } & 51.31 & 40.82 & 46.12 & 43.07 & 46.31 & 49.10 \\ \text { DEC } & 50.78 & 40.50 & 45.68 & 42.80 & 45.81 & 48.44 \\ \text { JAN } & 51.43 & 40.34 & 45.39 & 42.20 & 46.45 & 47.91 \\ \text { FEB } & 51.33 & 40.45 & 45.27 & 42.40 & 46.34 & 48.02 \\ \text { MAR } & 51.74 & 40.73 & 45.70 & 42.37 & 46.25 & 48.28 \\ \text { APR } & 53.00 & 42.22 & 46.37 & 42.72 & 45.62 & 49.15 \\ \text { MAY } & 53.11 & 41.98 & 46.54 & 43.56 & 45.18 & 49.94 \\ \text { JUN } & 52.35 & 41.64 & 46.13 & 43.50 & 44.92 & 49.49 \\ \text { JUL } & 51.35 & 41.71 & 45.97 & 43.14 & 44.51 & 49.17 \\ \text { AUG } & 51.34 & 41.53 & 45.96 & 43.20 & 44.63 & 49.15 \\ \text { SEP } & 50.89 & 41.39 & 46.15 & 42.69 & 45.78 & 49.90\end{array}$

USGS SITE 293619082362385 SRWMD ID -101722001 COUNTY Alachua

$\begin{array}{lrrrrrr}\text { MONTH } & \text { MAXIMUM } & \text { MINIMUM } & \text { MEAN } & 25 \% & 50 \% & 75 \% \\ \text { OCT } & 54.63 & 38.84 & 43.94 & 41.12 & 44.32 & 46.18 \\ \text { NOV } & 47.72 & 38.59 & 43.27 & 41.20 & 43.97 & 45.36 \\ \text { DEC } & 47.17 & 38.28 & 42.86 & 40.88 & 43.27 & 44.81 \\ \text { JAN } & 47.55 & 38.09 & 42.53 & 40.83 & 42.67 & 44.33 \\ \text { FEB } & 47.78 & 38.28 & 42.45 & 40.45 & 42.04 & 44.25 \\ \text { MAR } & 47.80 & 38.41 & 42.64 & 40.68 & 41.90 & 44.49 \\ \text { APR } & 48.76 & 39.56 & 43.04 & 40.96 & 42.21 & 45.12 \\ \text { MAY } & 49.49 & 40.03 & 43.20 & 40.65 & 42.47 & 45.97 \\ \text { JUN } & 49.06 & 39.78 & 43.04 & 40.23 & 42.43 & 45.31 \\ \text { JUL } & 48.42 & 39.69 & 42.84 & 40.08 & 42.28 & 44.65 \\ \text { AUG } & 48.30 & 39.28 & 42.99 & 40.42 & 42.82 & 44.63 \\ \text { SEP } & 48.20 & 39.03 & 43.21 & 40.72 & 43.15 & 45.25\end{array}$

USGS SITE 293653082493286 SRWMD ID -101516001 COUNTY Gilchrist

$\begin{array}{lrrrrrr}\text { MONTH } & \text { MAXIMUM } & \text { MINIMUM } & \text { MEAN } & 25 \% & 50 \% & 75 \% \\ \text { OCT } & 24.13 & 7.79 & 15.62 & 11.68 & 15.63 & 18.66 \\ \text { NOV } & 32.97 & 7.55 & 16.04 & 11.09 & 14.63 & 18.23 \\ \text { DEC } & 28.44 & 7.28 & 16.37 & 13.11 & 16.94 & 18.29 \\ \text { JAN } & 30.24 & 7.91 & 17.58 & 13.81 & 17.17 & 20.05 \\ \text { FEB } & 24.63 & 7.34 & 15.00 & 10.91 & 15.71 & 17.71 \\ \text { MAR } & 30.21 & 7.71 & 17.35 & 13.57 & 16.31 & 19.77 \\ \text { APR } & 24.45 & 7.95 & 14.94 & 9.88 & 13.24 & 20.05 \\ \text { MAY } & 28.88 & 9.23 & 17.60 & 14.67 & 17.58 & 19.76 \\ \text { JUN } & 29.27 & 8.30 & 16.65 & 13.17 & 13.25 & 21.85 \\ \text { JUL } & 30.13 & 8.26 & 16.07 & 12.35 & 15.42 & 18.71 \\ \text { AUG } & 33.39 & 9.97 & 16.77 & 12.45 & 15.04 & 21.34 \\ \text { SEP } & 30.94 & 9.44 & 17.50 & 13.97 & 16.56 & 19.66\end{array}$


USGS SITE 293731083061885 SRWMD ID -101210001 COUNTY Dixie

$\begin{array}{lrrrrrr}\text { MONTH } & \text { MAXIMUM } & \text { MINIMUM } & \text { MEAN } & 25 \% & 50 \% & 75 \% \\ \text { OCT } & 36.53 & 32.09 & 34.96 & 33.91 & 34.92 & 36.07 \\ \text { NOV } & 36.20 & 31.33 & 34.16 & 33.07 & 34.70 & 35.23 \\ \text { DEC } & 36.33 & 31.38 & 34.03 & 33.04 & 34.30 & 34.85 \\ \text { JAN } & 36.95 & 32.71 & 34.39 & 33.35 & 34.21 & 35.42 \\ \text { FEB } & 37.15 & 30.00 & 34.60 & 34.01 & 34.58 & 35.68 \\ \text { MAR } & 37.43 & 31.98 & 34.94 & 33.99 & 34.82 & 36.25 \\ \text { APR } & 37.09 & 32.29 & 34.82 & 33.65 & 34.94 & 36.22 \\ \text { MAY } & 36.43 & 31.44 & 34.11 & 32.73 & 34.16 & 35.53 \\ \text { JUN } & 36.28 & 30.58 & 33.83 & 32.60 & 34.03 & 35.10 \\ \text { JUL } & 36.99 & 30.42 & 34.13 & 32.87 & 34.33 & 35.46 \\ \text { AUG } & 39.31 & 32.03 & 35.26 & 34.12 & 35.32 & 36.33 \\ \text { SEP } & 38.88 & 32.39 & 35.40 & 34.24 & 35.28 & 36.21\end{array}$

USGS SITE 293857082203985 SRWMD ID -102006001 COUNTY Alachua

$\begin{array}{lrrrrrr}\text { MONTH } & \text { MAXIMUM } & \text { MINIMUM } & \text { MEAN } & 25 \% & 50 \% & 75 \% \\ \text { OCT } & 52.24 & 43.72 & 47.24 & 44.62 & 46.91 & 49.38 \\ \text { NOV } & 52.43 & 43.81 & 47.07 & 45.40 & 46.43 & 48.67 \\ \text { DEC } & 52.38 & 43.45 & 46.73 & 44.97 & 46.23 & 48.05 \\ \text { JAN } & 51.94 & 42.31 & 46.06 & 44.37 & 45.24 & 47.93 \\ \text { FEB } & 51.52 & 42.56 & 46.44 & 44.31 & 46.31 & 48.14 \\ \text { MAR } & 51.14 & 43.98 & 46.76 & 44.68 & 46.38 & 48.64 \\ \text { APR } & 50.24 & 44.32 & 46.95 & 44.66 & 46.75 & 50.03 \\ \text { MAY } & 49.94 & 43.93 & 46.47 & 44.71 & 46.26 & 48.37 \\ \text { JUN } & 48.73 & 43.56 & 45.89 & 44.74 & 45.57 & 47.30 \\ \text { JUL } & 48.00 & 44.57 & 45.86 & 44.59 & 45.41 & 47.02 \\ \text { AUG } & 49.29 & 44.47 & 46.33 & 44.85 & 46.11 & 47.57 \\ \text { SEP } & 50.93 & 44.20 & 46.34 & 44.54 & 45.10 & 48.05\end{array}$

USGS SITE 294135082553485 SRWMD ID -091420001 COUNTY Gilchrist

$\begin{array}{lrrrrrr}\text { MONTH } & \text { MAXIMUM } & \text { MINIMUM } & \text { MEAN } & 25 \% & 50 \% & 75 \% \\ \text { OCT } & 10.98 & 4.52 & 7.34 & 5.73 & 7.24 & 8.63 \\ \text { NOV } & 10.11 & 4.26 & 6.66 & 5.55 & 6.46 & 7.22 \\ \text { DEC } & 9.81 & 4.25 & 6.87 & 5.41 & 6.49 & 8.40 \\ \text { JAN } & 13.92 & 5.46 & 8.02 & 5.65 & 6.26 & 11.39 \\ \text { FEB } & 15.59 & 5.68 & 9.43 & 6.90 & 8.48 & 12.32 \\ \text { MAR } & 16.76 & 6.03 & 11.55 & 8.52 & 11.76 & 14.60 \\ \text { APR } & 19.69 & 5.89 & 11.47 & 8.30 & 11.04 & 13.90 \\ \text { MAY } & 17.37 & 5.58 & 9.12 & 7.40 & 8.69 & 10.48 \\ \text { JUN } & 11.61 & 5.33 & 7.69 & 5.43 & 7.41 & 9.64 \\ \text { JUL } & 12.01 & 5.05 & 7.50 & 6.44 & 6.92 & 8.92 \\ \text { AUG } & 14.60 & 4.75 & 7.89 & 6.12 & 7.68 & 8.84 \\ \text { SEP } & 9.66 & 4.58 & 7.12 & 5.86 & 7.44 & 8.17\end{array}$

USGS SITE 294311083041085 SRWMD ID -091212003 COUNTY Dixie

$\begin{array}{lrrrrrr}\text { MONTH } & \text { MAXIMUM } & \text { MINIMUM } & \text { MEAN } & 25 \% & 50 \% & 75 \% \\ \text { OCT } & 48.60 & 45.57 & 47.40 & 46.57 & 47.61 & 48.22 \\ \text { NOV } & 48.27 & 45.42 & 47.09 & 46.51 & 47.22 & 47.73 \\ \text { DEC } & 47.54 & 44.86 & 46.78 & 45.89 & 47.07 & 47.53 \\ \text { JAN } & 47.48 & 44.97 & 46.58 & 45.73 & 46.71 & 47.36 \\ \text { FEB } & 47.80 & 46.83 & 47.24 & 46.86 & 47.17 & 47.69 \\ \text { MAR } & 49.20 & 47.17 & 47.94 & 47.37 & 47.69 & 48.63 \\ \text { APR } & 48.79 & 47.24 & 47.69 & 47.25 & 47.37 & 48.45 \\ \text { MAY } & 48.56 & 46.11 & 47.18 & 46.15 & 47.11 & 48.24 \\ \text { JUN } & 48.16 & 45.27 & 46.42 & 45.59 & 46.17 & 47.31 \\ \text { JUL } & 47.48 & 45.61 & 46.34 & 45.76 & 46.24 & 46.96 \\ \text { AUG } & 49.36 & 44.93 & 46.79 & 45.06 & 46.16 & 49.10 \\ \text { SEP } & 48.70 & 45.09 & 47.15 & 45.64 & 47.41 & 48.40\end{array}$




$\begin{array}{lrrrrrr}\text { USGS SITE } & 294313082024685 & \text { SRWMD ID } & -092307001 & \text { COUNTY } & \text { ClaY } \\ \text { MONTH } & \text { MAXIMUM } & \text { MINIMUM } & \text { MEAN } & 25 \% & 50 \% & 75 \% \\ \text { OCT } & 87.87 & 78.90 & 83.93 & 81.42 & 84.47 & 86.67 \\ \text { NOV } & 87.68 & 78.71 & 83.77 & 81.38 & 83.94 & 86.23 \\ \text { DEC } & 87.67 & 78.48 & 83.21 & 80.67 & 83.67 & 85.20 \\ \text { JAN } & 88.07 & 78.33 & 83.47 & 80.79 & 84.36 & 85.88 \\ \text { FEB } & 88.17 & 78.30 & 83.44 & 81.22 & 84.08 & 85.74 \\ \text { MAR } & 88.50 & 78.92 & 83.66 & 81.12 & 83.89 & 86.00 \\ \text { APR } & 88.79 & 79.81 & 83.95 & 81.00 & 84.11 & 86.56 \\ \text { MAY } & 88.37 & 79.50 & 84.10 & 81.25 & 84.77 & 86.30 \\ \text { JUN } & 87.87 & 79.22 & 82.95 & 80.78 & 82.33 & 85.58 \\ \text { JUL } & 87.93 & 78.99 & 83.37 & 81.44 & 82.96 & 85.22 \\ \text { AUG } & 87.85 & 79.32 & 83.47 & 81.13 & 83.48 & 86.02 \\ \text { SEP } & 87.91 & 79.03 & 83.86 & 81.54 & 84.54 & 85.88\end{array}$

USGS SITE 294330082445085 SRWMD ID -091607001 COUNTY Gilchrist

$\begin{array}{lrrrrrr}\text { MONTH } & \text { MAXIMUM } & \text { MINIMUM } & \text { MEAN } & 25 \% & 50 \% & 75 \% \\ \text { OCT } & 74.17 & 45.69 & 57.65 & 51.20 & 57.49 & 62.25 \\ \text { NOV } & 72.28 & 45.20 & 55.74 & 50.18 & 55.40 & 59.31 \\ \text { DEC } & 70.74 & 44.71 & 54.88 & 49.49 & 54.15 & 57.49 \\ \text { JAN } & 69.85 & 44.42 & 54.26 & 48.52 & 53.02 & 56.13 \\ \text { FEB } & 67.41 & 45.28 & 53.32 & 48.12 & 53.23 & 56.09 \\ \text { MAR } & 73.28 & 46.75 & 56.18 & 50.74 & 53.37 & 61.72 \\ \text { APR } & 71.71 & 45.99 & 56.34 & 50.53 & 53.65 & 61.44 \\ \text { MAY } & 70.42 & 43.87 & 54.86 & 49.48 & 52.78 & 59.82 \\ \text { JUN } & 63.75 & 44.64 & 53.69 & 49.01 & 51.83 & 57.08 \\ \text { JUL } & 71.05 & 44.46 & 52.93 & 48.31 & 51.05 & 55.73 \\ \text { AUG } & 72.98 & 44.56 & 54.70 & 48.64 & 54.25 & 58.21 \\ \text { SEP } & 71.63 & 45.15 & 56.97 & 50.21 & 58.14 & 61.42\end{array}$

USGS SITE 294402082262185 SRWMD ID -091938002 COUNTY Alachua

$\begin{array}{lrrrrrr}\text { MONTH } & \text { MAXIMUM } & \text { MINIMUM } & \text { MEAN } & 25 \% & 50 \% & 75 \% \\ \text { OCT } & 65.59 & 46.26 & 59.00 & 53.80 & 62.14 & 64.09 \\ \text { NOV } & 65.15 & 44.12 & 57.62 & 52.98 & 60.06 & 62.05 \\ \text { DEC } & 71.52 & 43.78 & 57.55 & 49.10 & 58.90 & 62.45 \\ \text { JAN } & 68.44 & 47.77 & 60.37 & 54.99 & 62.34 & 65.51 \\ \text { FEB } & 68.78 & 47.47 & 62.66 & 61.66 & 63.80 & 65.62 \\ \text { MAR } & 69.20 & 47.52 & 64.08 & 62.33 & 65.24 & 67.92 \\ \text { APR } & 74.75 & 49.56 & 63.41 & 60.74 & 63.93 & 67.60 \\ \text { MAY } & 66.24 & 49.56 & 59.18 & 54.14 & 61.42 & 63.77 \\ \text { JUN } & 66.70 & 48.14 & 57.58 & 51.25 & 56.62 & 63.93 \\ \text { JUL } & 65.41 & 46.39 & 58.88 & 54.61 & 60.25 & 63.10 \\ \text { AUG } & 66.20 & 49.53 & 59.91 & 55.04 & 61.51 & 63.40 \\ \text { SEP } & 69.82 & 52.99 & 60.23 & 56.07 & 60.84 & 62.87\end{array}$

USGS SITE 294458083142885 SRWMD ID -081132001 COUNTY Dixie

$\begin{array}{lrrrrrr}\text { MONTH } & \text { MAXIMUM } & \text { MINIMUM } & \text { MEAN } & 25 \% & 50 \% & 75 \% \\ \text { OCT } & 39.09 & 35.77 & 37.77 & 37.03 & 38.05 & 38.54 \\ \text { NOV } & 38.96 & 33.70 & 37.10 & 35.77 & 37.48 & 38.28 \\ \text { DEC } & 39.16 & 35.36 & 37.66 & 36.82 & 37.88 & 38.62 \\ \text { JAN } & 39.49 & 36.03 & 38.25 & 37.63 & 38.56 & 39.05 \\ \text { FEB } & 39.35 & 36.72 & 38.56 & 38.17 & 38.95 & 39.10 \\ \text { MAR } & 39.36 & 36.68 & 38.52 & 38.18 & 38.93 & 39.09 \\ \text { APR } & 39.04 & 36.22 & 37.99 & 37.21 & 38.20 & 38.74 \\ \text { MAY } & 39.24 & 35.34 & 37.01 & 36.25 & 37.03 & 37.75 \\ \text { JUN } & 38.07 & 34.97 & 36.84 & 36.04 & 36.79 & 37.85 \\ \text { JUL } & 39.13 & 34.52 & 37.55 & 36.53 & 37.69 & 38.81 \\ \text { AUG } & 39.30 & 35.22 & 38.30 & 37.89 & 38.66 & 39.18 \\ \text { SEP } & 39.28 & 36.30 & 38.29 & 37.57 & 38.81 & 39.00\end{array}$


USGS SITE 294530082232085 SRWMD ID -081926001 COUNTY Alachua

$\begin{array}{lrrrrrr}\text { MONTH } & \text { MAXIMUM } & \text { MINIMUM } & \text { MEAN } & 25 \% & 50 \% & 75 \% \\ \text { OCT } & 46.04 & 40.44 & 43.12 & 41.40 & 42.85 & 45.01 \\ \text { NOV } & 45.95 & 40.51 & 43.22 & 41.54 & 42.69 & 45.07 \\ \text { DEC } & 45.74 & 40.01 & 43.12 & 41.58 & 43.01 & 45.05 \\ \text { JAN } & 45.79 & 40.15 & 43.10 & 41.57 & 43.04 & 45.10 \\ \text { FEB } & 46.24 & 40.10 & 43.18 & 41.69 & 42.94 & 44.96 \\ \text { MAR } & 46.29 & 40.42 & 43.35 & 41.85 & 43.01 & 45.22 \\ \text { APR } & 46.84 & 40.80 & 43.59 & 41.92 & 43.15 & 45.41 \\ \text { MAY } & 46.96 & 40.62 & 43.32 & 41.47 & 43.28 & 44.57 \\ \text { JUN } & 47.20 & 40.76 & 43.21 & 41.02 & 43.10 & 44.60 \\ \text { JUL } & 46.83 & 40.63 & 42.94 & 40.96 & 42.73 & 44.34 \\ \text { AUG } & 46.67 & 40.77 & 42.86 & 41.09 & 42.47 & 44.31 \\ \text { SEP } & 46.65 & 40.64 & 42.93 & 41.44 & 42.43 & 44.31\end{array}$

USGS SITE 294654082581085 SRWMD ID -081313005 COUNTY Dixie

$\begin{array}{lrrrrrr}\text { MONTH } & \text { MAXIMUM } & \text { MINIMUM } & \text { MEAN } & 25 \% & 50 \% & 75 \% \\ \text { OCT } & 29.91 & 20.05 & 24.01 & 20.71 & 23.33 & 27.13 \\ \text { NOV } & 25.54 & 19.87 & 23.02 & 20.87 & 22.99 & 25.34 \\ \text { DEC } & 24.40 & 19.60 & 22.34 & 20.64 & 22.44 & 24.29 \\ \text { JAN } & 23.68 & 19.60 & 21.65 & 20.31 & 21.45 & 23.32 \\ \text { FEB } & 23.07 & 20.74 & 22.01 & 21.16 & 21.99 & 22.97 \\ \text { MAR } & 30.45 & 21.23 & 24.20 & 21.90 & 23.40 & 25.65 \\ \text { APR } & 27.67 & 21.64 & 24.28 & 22.14 & 23.42 & 27.51 \\ \text { MAY } & 27.12 & 20.99 & 23.49 & 21.53 & 22.70 & 25.37 \\ \text { JUN } & 26.13 & 20.35 & 22.58 & 20.94 & 21.99 & 23.98 \\ \text { JUL } & 25.65 & 20.20 & 22.30 & 21.35 & 21.80 & 23.29 \\ \text { AUG } & 29.77 & 20.34 & 23.02 & 21.57 & 21.94 & 23.04 \\ \text { SEP } & 31.22 & 20.33 & 24.26 & 20.99 & 22.54 & 28.42\end{array}$

USGS SITE 294742083275985 SRWMD ID -080907003 COUNTY Taylor

$\begin{array}{lrrrrrr}\text { MONTH } & \text { MAXIMUM } & \text { MINIMUM } & \text { MEAN } & 25 \% & 50 \% & 75 \% \\ \text { OCT } & 31.86 & 27.21 & 28.76 & 27.31 & 28.28 & 30.13 \\ \text { NOV } & 30.11 & 26.88 & 28.29 & 27.06 & 28.28 & 29.32 \\ \text { DEC } & 28.86 & 26.19 & 27.83 & 26.84 & 27.91 & 28.79 \\ \text { JAN } & 28.88 & 25.99 & 27.62 & 26.44 & 27.53 & 28.85 \\ \text { FEB } & 29.52 & 27.12 & 28.45 & 27.49 & 28.79 & 29.24 \\ \text { MAR } & 30.32 & 28.22 & 29.20 & 28.31 & 29.44 & 29.97 \\ \text { APR } & 29.77 & 27.97 & 28.75 & 28.07 & 28.63 & 29.55 \\ \text { MAY } & 29.52 & 26.88 & 28.22 & 27.22 & 28.42 & 29.12 \\ \text { JUN } & 29.40 & 25.87 & 27.23 & 26.16 & 27.00 & 28.22 \\ \text { JUL } & 29.68 & 26.73 & 27.84 & 26.74 & 27.34 & 29.17 \\ \text { AUG } & 29.61 & 25.83 & 27.71 & 26.52 & 27.77 & 28.86 \\ \text { SEP } & 29.76 & 27.70 & 28.66 & 27.97 & 28.37 & 29.49\end{array}$

USGS SITE 294920082044585 SRWMD ID -082202001 COUNTY Bradford

$\begin{array}{lrrrrrr}\text { MONTH } & \text { MAXIMUM } & \text { MINIMUM } & \text { MEAN } & 25 \% & 50 \% & 75 \% \\ \text { OCT } & 78.85 & 72.68 & 75.82 & 73.62 & 75.74 & 78.27 \\ \text { NOV } & 78.90 & 72.51 & 75.88 & 74.35 & 75.64 & 78.65 \\ \text { DEC } & 78.96 & 72.34 & 75.79 & 74.63 & 75.19 & 78.58 \\ \text { JAN } & 78.31 & 72.24 & 75.17 & 74.13 & 74.89 & 76.51 \\ \text { FEB } & 77.81 & 72.36 & 75.67 & 74.78 & 76.04 & 77.48 \\ \text { MAR } & 78.38 & 73.19 & 76.05 & 74.86 & 76.49 & 77.46 \\ \text { APR } & 78.56 & 74.19 & 76.02 & 74.52 & 75.94 & 77.16 \\ \text { MAY } & 77.83 & 74.03 & 75.41 & 74.24 & 75.02 & 76.13 \\ \text { JUN } & 77.09 & 73.54 & 75.04 & 73.85 & 74.98 & 75.51 \\ \text { JUL } & 76.49 & 73.50 & 75.12 & 73.55 & 75.36 & 76.42 \\ \text { AUG } & 77.20 & 73.19 & 75.18 & 73.67 & 75.21 & 76.58 \\ \text { SEP } & 77.91 & 72.77 & 75.45 & 73.72 & 75.41 & 77.41\end{array}$


USGS SITE 294928082355385 SRWMD ID -081703001 COUNTY Alachua

$\begin{array}{lrrrrrr}\text { MONTH } & \text { MAXIMUM } & \text { MINIMUM } & \text { MEAN } & 25 \% & 50 \% & 75 \% \\ \text { OCT } & 36.68 & 32.55 & 34.47 & 33.69 & 34.60 & 35.38 \\ \text { NOV } & 36.33 & 31.60 & 34.22 & 33.51 & 34.53 & 35.10 \\ \text { DEC } & 35.58 & 32.25 & 34.05 & 33.25 & 34.11 & 34.78 \\ \text { JAN } & 37.20 & 31.41 & 34.16 & 33.31 & 34.18 & 34.79 \\ \text { FEB } & 35.61 & 32.56 & 34.15 & 33.58 & 34.03 & 34.68 \\ \text { MAR } & 39.14 & 31.13 & 34.72 & 33.66 & 34.32 & 35.71 \\ \text { APR } & 37.40 & 33.01 & 34.50 & 33.49 & 34.23 & 35.39 \\ \text { MAY } & 36.19 & 28.07 & 34.20 & 33.37 & 34.12 & 35.21 \\ \text { JUN } & 37.68 & 32.72 & 34.14 & 33.15 & 33.88 & 34.96 \\ \text { JUL } & 36.41 & 32.72 & 34.22 & 33.34 & 34.06 & 34.86 \\ \text { AUG } & 36.89 & 30.35 & 34.17 & 33.44 & 34.32 & 35.10 \\ \text { SEP } & 43.42 & 32.61 & 34.84 & 33.54 & 34.64 & 35.43\end{array}$

USGS SITE 294931082501685 SRWMD ID -071532001 COUNTY Gilchrist

$\begin{array}{lrrrrrr}\text { MONTH } & \text { MAXIMUM } & \text { MINIMUM } & \text { MEAN } & 25 \% & 50 \% & 75 \% \\ \text { OCT } & 37.49 & 25.71 & 32.64 & 29.49 & 33.62 & 35.46 \\ \text { NOV } & 34.53 & 27.49 & 31.09 & 28.56 & 31.93 & 32.82 \\ \text { DEC } & 37.01 & 26.03 & 31.73 & 26.91 & 32.90 & 35.72 \\ \text { JAN } & 38.03 & 26.83 & 31.71 & 29.18 & 31.50 & 33.28 \\ \text { FEB } & 36.18 & 26.39 & 31.21 & 27.28 & 31.13 & 34.86 \\ \text { MAR } & 37.13 & 25.99 & 31.16 & 27.18 & 29.26 & 36.75 \\ \text { APR } & 38.35 & 25.59 & 31.77 & 29.18 & 30.28 & 37.10 \\ \text { MAY } & 38.12 & 25.43 & 31.86 & 29.90 & 31.53 & 34.29 \\ \text { JUN } & 37.49 & 25.73 & 32.45 & 29.49 & 32.75 & 36.30 \\ \text { JUL } & 36.95 & 25.76 & 31.07 & 28.38 & 30.83 & 34.13 \\ \text { AUG } & 40.00 & 29.76 & 33.35 & 30.20 & 33.25 & 34.78 \\ \text { SEP } & 35.63 & 26.28 & 31.46 & 29.06 & 31.40 & 34.14\end{array}$

USGS SITE 295055082130885 SRWMD ID -072132001 COUNTY Bradford

$\begin{array}{lrrrrrr}\text { MONTH } & \text { MAXIMUM } & \text { MINIMUM } & \text { MEAN } & 25 \% & 50 \% & 75 \% \\ \text { OCT } & 65.75 & 57.82 & 62.53 & 82.12 & 83.74 & 85.19 \\ \text { NOV } & 65.62 & 57.75 & 62.55 & 82.13 & 83.68 & 85.30 \\ \text { DEC } & 65.65 & 57.52 & 62.50 & 81.93 & 83.68 & 85.26 \\ \text { JAN } & 66.39 & 57.80 & 62.52 & 81.88 & 83.41 & 85.27 \\ \text { FEB } & 66.76 & 58.34 & 62.91 & 81.87 & 83.35 & 84.74 \\ \text { MAR } & 67.32 & 59.62 & 63.53 & 82.05 & 83.93 & 86.21 \\ \text { APR } & 68.39 & 60.23 & 63.81 & 82.15 & 84.12 & 86.62 \\ \text { MAY } & 67.87 & 59.54 & 63.16 & 81.60 & 83.63 & 86.15 \\ \text { JUN } & 66.67 & 58.83 & 62.36 & 81.26 & 82.60 & 85.38 \\ \text { JUL } & 66.02 & 58.66 & 62.16 & 81.74 & 82.53 & 84.50 \\ \text { AUG } & 65.92 & 58.36 & 62.18 & 81.35 & 82.94 & 84.86 \\ \text { SEP } & 65.57 & 58.06 & 62.39 & 81.55 & 83.15 & 84.81\end{array}$

USGS SITE 295236082155185 SRWMD ID -072013001 COUNTY Bradford

$\begin{array}{lrrrrrr}\text { MONTH } & \text { MAXIMUM } & \text { MINIMUM } & \text { MEAN } & 25 \% & 50 \% & 75 \% \\ \text { OCT } & 140.09 & 133.34 & 136.40 & 134.58 & 136.01 & 138.50 \\ \text { NOV } & 139.32 & 134.56 & 136.61 & 135.24 & 136.16 & 138.34 \\ \text { DEC } & 138.97 & 133.94 & 136.08 & 134.65 & 135.94 & 137.33 \\ \text { JAN } & 138.41 & 133.73 & 135.70 & 133.89 & 135.44 & 137.52 \\ \text { FEB } & 138.66 & 134.42 & 137.11 & 135.77 & 137.14 & 138.42 \\ \text { MAR } & 139.48 & 136.28 & 137.80 & 136.54 & 137.86 & 139.02 \\ \text { APR } & 139.86 & 136.87 & 138.24 & 136.97 & 138.11 & 139.63 \\ \text { MAY } & 138.54 & 135.66 & 137.10 & 135.86 & 137.10 & 138.33 \\ \text { JUN } & 139.14 & 134.53 & 136.30 & 134.64 & 136.10 & 137.74 \\ \text { JUL } & 138.57 & 135.61 & 137.15 & 135.72 & 137.67 & 138.32 \\ \text { AUG } & 137.96 & 134.52 & 136.49 & 134.80 & 137.19 & 137.82 \\ \text { SEP } & 138.83 & 133.79 & 136.65 & 135.23 & 136.89 & 137.96\end{array}$


USGS SITE 295246082553885 SRWMD ID -071417001 COUNTY Lafayette

$\begin{array}{lrrrrrr}\text { MONTH } & \text { MAXIMUM } & \text { MINIMUM } & \text { MEAN } & 25 \% & 50 \% & 75 \% \\ \text { OCT } & 23.51 & 15.56 & 19.87 & 16.68 & 21.31 & 21.72 \\ \text { NOV } & 22.13 & 14.90 & 18.67 & 16.41 & 18.86 & 20.85 \\ \text { DEC } & 22.15 & 14.68 & 19.02 & 17.30 & 19.45 & 20.49 \\ \text { JAN } & 21.75 & 14.27 & 18.36 & 15.68 & 19.06 & 20.27 \\ \text { FEB } & 24.84 & 14.62 & 19.74 & 18.31 & 19.46 & 22.05 \\ \text { MAR } & 26.21 & 15.24 & 21.34 & 18.59 & 20.83 & 25.59 \\ \text { APR } & 26.15 & 15.91 & 20.45 & 16.91 & 19.49 & 23.97 \\ \text { MAY } & 26.23 & 15.89 & 20.53 & 18.54 & 20.50 & 22.09 \\ \text { JUN } & 24.85 & 14.88 & 19.91 & 16.65 & 19.30 & 24.08 \\ \text { JUL } & 24.50 & 14.50 & 18.79 & 16.51 & 18.25 & 21.19 \\ \text { AUG } & 25.09 & 16.44 & 19.81 & 16.95 & 19.29 & 22.88 \\ \text { SEP } & 23.13 & 16.26 & 19.48 & 17.50 & 19.19 & 21.62\end{array}$

USGS SITE 295257082045785 SRWMD ID -072215001 COUNTY Bradford

$\begin{array}{lrrrrrr}\text { MONTH } & \text { MAXIMUM } & \text { MINIMUM } & \text { MEAN } & 25 \% & 50 \% & 75 \% \\ \text { OCT } & 86.94 & 79.49 & 83.49 & 82.12 & 83.74 & 85.19 \\ \text { NOV } & 86.88 & 79.37 & 83.53 & 82.13 & 83.68 & 85.30 \\ \text { DEC } & 86.82 & 79.23 & 83.48 & 81.93 & 83.68 & 85.26 \\ \text { JAN } & 87.03 & 79.23 & 83.43 & 81.88 & 83.41 & 85.27 \\ \text { FEB } & 87.37 & 79.39 & 83.43 & 81.87 & 83.35 & 84.74 \\ \text { MAR } & 87.66 & 80.07 & 83.82 & 82.05 & 83.93 & 86.21 \\ \text { APR } & 88.21 & 81.02 & 84.20 & 82.15 & 84.12 & 86.62 \\ \text { MAY } & 88.09 & 80.99 & 83.87 & 81.60 & 83.63 & 86.15 \\ \text { JUN } & 87.26 & 80.45 & 83.29 & 81.26 & 82.60 & 85.38 \\ \text { JUL } & 86.72 & 80.28 & 82.92 & 81.74 & 82.53 & 84.50 \\ \text { AUG } & 86.75 & 79.99 & 83.20 & 81.35 & 82.94 & 84.86 \\ \text { SEP } & 86.83 & 79.67 & 83.29 & 81.55 & 83.15 & 84.81\end{array}$

USGS SITE 295307083245485 SRWMD ID -070910001 COUNTY Taylor

$\begin{array}{lrrrrrr}\text { MONTH } & \text { MAXIMUM } & \text { MINIMUM } & \text { MEAN } & 25 \% & 50 \% & 75 \% \\ \text { OCT } & 37.74 & 34.30 & 35.84 & 34.83 & 35.97 & 36.62 \\ \text { NOV } & 36.88 & 34.74 & 36.02 & 35.49 & 36.28 & 36.64 \\ \text { DEC } & 37.56 & 29.63 & 35.52 & 34.74 & 36.10 & 37.03 \\ \text { JAN } & 37.94 & 35.11 & 37.08 & 36.50 & 37.47 & 37.67 \\ \text { FEB } & 37.98 & 35.81 & 37.17 & 36.98 & 37.22 & 37.63 \\ \text { MAR } & 38.69 & 35.66 & 37.46 & 36.77 & 37.47 & 38.27 \\ \text { APR } & 37.59 & 34.73 & 36.51 & 35.93 & 36.65 & 37.13 \\ \text { MAY } & 37.36 & 33.66 & 35.86 & 35.31 & 35.60 & 37.12 \\ \text { JUN } & 37.54 & 33.86 & 35.63 & 34.65 & 34.94 & 37.08 \\ \text { JUL } & 38.05 & 32.80 & 35.93 & 34.46 & 36.22 & 37.39 \\ \text { AUG } & 38.41 & 32.76 & 36.89 & 36.68 & 37.00 & 37.96 \\ \text { SEP } & 38.20 & 35.16 & 36.80 & 36.08 & 36.99 & 37.63\end{array}$

USGS SITE 295500082170685 SRWMD ID -072002001 COUNTY Bradford

$\begin{array}{lrrrrrr}\text { MONTH } & \text { MAXIMUM } & \text { MINIMUM } & \text { MEAN } & 25 \% & 50 \% & 75 \% \\ \text { OCT } & 59.19 & 54.21 & 56.97 & 55.04 & 56.71 & 59.04 \\ \text { NOV } & 59.90 & 54.00 & 57.61 & 56.28 & 58.58 & 59.11 \\ \text { DEC } & 60.12 & 54.07 & 57.41 & 55.88 & 57.39 & 59.28 \\ \text { JAN } & 60.14 & 54.09 & 57.65 & 55.66 & 58.24 & 59.30 \\ \text { FEB } & 59.82 & 54.97 & 57.79 & 56.38 & 57.92 & 59.21 \\ \text { MAR } & 61.05 & 56.69 & 58.61 & 56.89 & 58.17 & 60.59 \\ \text { APR } & 60.79 & 56.89 & 58.46 & 57.24 & 57.76 & 60.02 \\ \text { MAY } & 60.29 & 56.20 & 58.30 & 56.82 & 58.23 & 59.81 \\ \text { JUN } & 59.38 & 55.29 & 57.41 & 56.19 & 57.28 & 58.42 \\ \text { JUL } & 59.82 & 54.86 & 57.45 & 55.44 & 57.61 & 59.37 \\ \text { AUG } & 59.16 & 54.57 & 57.13 & 56.02 & 57.17 & 58.26 \\ \text { SEP } & 59.59 & 54.56 & 57.38 & 55.81 & 57.28 & 59.38\end{array}$


USGS SITE 295513082363085 SRWMD ID -061734001 COUNTY COIumbia

\begin{tabular}{|c|c|c|c|c|c|c|}
\hline MONTH & MAXIMUM & MINIMUM & MEAN & $25 \%$ & $50 \%$ & $75 \%$ \\
\hline OCT & 40.36 & 31.62 & 34.59 & 33.31 & 34.31 & 35.58 \\
\hline NOV & 36.24 & 31.49 & 33.32 & 32.54 & 33.23 & 34.10 \\
\hline DEC & 36.31 & 31.44 & 33.58 & 32.59 & 33.66 & 34.15 \\
\hline JAN & 36.78 & 31.41 & 33.75 & 32.75 & 33.47 & 34.47 \\
\hline FEB & 38.46 & 32.70 & 34.95 & 33.21 & 34.84 & 35.82 \\
\hline MAR & 39.10 & 32.98 & 35.43 & 33.27 & 35.32 & 37.23 \\
\hline APR & 39.45 & 32.34 & 34.85 & 32.89 & 34.42 & 35.75 \\
\hline MAY & 40.22 & 32.24 & 34.54 & 33.15 & 34.41 & 35.32 \\
\hline JUN & 36.16 & 31.98 & 33.57 & 32.58 & 33.13 & 34.78 \\
\hline JUL & 35.46 & 31.86 & 33.11 & 32.26 & 33.14 & 33.47 \\
\hline AUG & 36.11 & 30.54 & 33.97 & 33.06 & 34.04 & 35.24 \\
\hline SEP & 39.41 & 31.73 & 34.55 & 33.35 & 34.31 & 35.13 \\
\hline USGS SITE & 29590308 & 203885 & SRWMD ID & -061025003 & COUNTY & Lafayett \\
\hline MONTH & MAXIMUM & MINIMUM & MEAN & $25 \%$ & $50 \%$ & $75 \%$ \\
\hline OCT & 69.54 & 66.83 & 68.37 & 68.08 & 68.29 & 69.20 \\
\hline NOV & 68.71 & 67.21 & 68.03 & 67.39 & 68.00 & 68.61 \\
\hline $\mathrm{DEC}$ & 68.34 & 66.11 & 67.63 & 66.98 & 67.92 & 68.23 \\
\hline JAN & 69.31 & 66.30 & 68.10 & 67.07 & 68.37 & 69.03 \\
\hline FEB & 69.28 & 66.73 & 68.55 & 67.81 & 68.98 & 69.19 \\
\hline MAR & 69.72 & 66.58 & 68.59 & 67.89 & 68.87 & 69.30 \\
\hline APR & 69.19 & 65.53 & 67.94 & 66.95 & 68.47 & 68.72 \\
\hline MAY & 68.91 & 64.76 & 66.98 & 65.61 & 67.25 & 68.11 \\
\hline JUN & 68.59 & 64.95 & 66.72 & 65.36 & 66.55 & 68.30 \\
\hline JUL & 69.17 & 64.94 & 67.71 & 66.57 & 67.97 & 69.12 \\
\hline AUG & 69.60 & 65.44 & 68.33 & 67.64 & 68.64 & 69.44 \\
\hline SEP & 69.86 & 67.05 & 68.58 & 68.09 & 68.51 & 69.32 \\
\hline
\end{tabular}

USGS SITE 295541083164285 SRWMD ID -061025004 COUNTY Lafayette

$\begin{array}{lrrrrrr}\text { MONTH } & \text { MAXIMUM } & \text { MINIMUM } & \text { MEAN } & 25 \% & 50 \% & 75 \% \\ \text { OCT } & 51.55 & 47.44 & 49.41 & 48.17 & 49.07 & 50.78 \\ \text { NOV } & 50.51 & 47.09 & 49.18 & 48.04 & 49.38 & 50.38 \\ \text { DEC } & 49.65 & 46.98 & 48.60 & 47.38 & 49.08 & 49.59 \\ \text { JAN } & 51.47 & 49.01 & 50.26 & 49.18 & 50.36 & 51.29 \\ \text { FEB } & 51.58 & 48.58 & 50.43 & 49.17 & 50.89 & 51.46 \\ \text { MAR } & 51.22 & 48.51 & 50.43 & 49.53 & 50.91 & 51.09 \\ \text { APR } & 51.21 & 47.88 & 49.88 & 48.98 & 50.12 & 50.79 \\ \text { MAY } & 50.11 & 46.93 & 48.58 & 47.49 & 48.65 & 49.45 \\ \text { JUN } & 51.29 & 47.13 & 48.26 & 47.20 & 47.94 & 48.49 \\ \text { JUL } & 50.29 & 46.78 & 48.35 & 47.15 & 48.12 & 49.39 \\ \text { AUG } & 51.30 & 45.62 & 49.10 & 47.50 & 49.54 & 50.69 \\ \text { SEP } & 51.62 & 48.39 & 49.94 & 48.83 & 49.75 & 50.78\end{array}$

USGS SITE 295618082440985 SRWMD ID -061629001 COUNTY Columbia

$\begin{array}{lrrrrrr}\text { MONTH } & \text { MAXIMUM } & \text { MINIMUM } & \text { MEAN } & 25 \% & 50 \% & 75 \% \\ \text { OCT } & 24.32 & 19.56 & 22.74 & 21.31 & 23.31 & 24.05 \\ \text { NOV } & 23.85 & 18.80 & 21.71 & 20.43 & 21.42 & 22.97 \\ \text { DEC } & 44.87 & 19.40 & 24.21 & 21.73 & 22.41 & 23.02 \\ \text { JAN } & 24.47 & 19.32 & 21.89 & 20.17 & 21.73 & 24.05 \\ \text { FEB } & 27.18 & 20.78 & 23.14 & 21.83 & 22.28 & 24.61 \\ \text { MAR } & 29.82 & 21.18 & 24.68 & 22.28 & 24.45 & 26.60 \\ \text { APR } & 32.24 & 20.65 & 24.83 & 22.20 & 24.16 & 26.58 \\ \text { MAY } & 29.26 & 20.06 & 23.50 & 21.74 & 22.81 & 25.33 \\ \text { JUN } & 25.59 & 19.76 & 22.76 & 21.00 & 22.81 & 24.60 \\ \text { JUL } & 23.70 & 19.96 & 21.48 & 20.63 & 21.46 & 22.10 \\ \text { AUG } & 25.09 & 19.86 & 22.40 & 20.74 & 22.25 & 24.04 \\ \text { SEP } & 25.76 & 18.76 & 22.55 & 21.15 & 22.38 & 24.35\end{array}$


USGS SITE 295802083121085 SRWMD ID -061114001 COUNTY Lafayette

$\begin{array}{lrrrrrr}\text { MONTH } & \text { MAXIMUM } & \text { MINIMUM } & \text { MEAN } & 25 \% & 50 \% & 75 \% \\ \text { OCT } & 69.40 & 61.14 & 66.74 & 65.84 & 66.73 & 68.10 \\ \text { NOV } & 69.19 & 62.13 & 66.32 & 64.94 & 66.82 & 67.29 \\ \text { DEC } & 69.63 & 63.86 & 67.02 & 66.09 & 67.10 & 68.47 \\ \text { JAN } & 70.25 & 64.13 & 68.18 & 67.11 & 68.57 & 69.57 \\ \text { FEB } & 70.10 & 65.54 & 68.82 & 68.13 & 69.29 & 69.69 \\ \text { MAR } & 70.36 & 65.75 & 68.89 & 68.19 & 69.18 & 69.72 \\ \text { APR } & 69.84 & 64.77 & 67.81 & 66.93 & 67.91 & 68.90 \\ \text { MAY } & 69.62 & 63.30 & 66.57 & 65.31 & 66.52 & 67.88 \\ \text { JUN } & 69.01 & 62.46 & 65.77 & 63.78 & 66.08 & 67.28 \\ \text { JUL } & 69.45 & 62.27 & 66.22 & 64.65 & 66.75 & 67.86 \\ \text { AUG } & 69.62 & 61.19 & 67.43 & 66.32 & 67.41 & 68.90 \\ \text { SEP } & 69.95 & 62.04 & 67.84 & 67.36 & 68.29 & 68.60\end{array}$

USGS SITE 295902083203885 SRWMD ID -061005002 COUNTY Lafayette

$\begin{array}{lrrrrrr}\text { MONTH } & \text { MAXIMUM } & \text { MINIMUM } & \text { MEAN } & 25 \% & 50 \% & 75 \% \\ \text { OCT } & 69.99 & 66.76 & 68.59 & 68.15 & 68.45 & 69.46 \\ \text { NOV } & 68.98 & 66.84 & 68.21 & 67.30 & 68.40 & 68.97 \\ \text { DEC } & 68.44 & 66.29 & 67.88 & 67.17 & 68.29 & 68.40 \\ \text { JAN } & 69.76 & 66.64 & 68.26 & 66.94 & 68.39 & 69.44 \\ \text { FEB } & 69.65 & 66.90 & 68.89 & 68.33 & 69.17 & 69.63 \\ \text { MAR } & 69.80 & 66.77 & 68.91 & 67.80 & 69.45 & 69.74 \\ \text { APR } & 69.10 & 65.85 & 68.16 & 67.24 & 68.72 & 68.90 \\ \text { MAY } & 68.81 & 64.88 & 67.07 & 65.26 & 67.72 & 68.12 \\ \text { JUN } & 68.77 & 64.98 & 66.89 & 65.18 & 66.91 & 68.60 \\ \text { JUL } & 69.68 & 64.61 & 68.07 & 66.04 & 69.29 & 69.49 \\ \text { AUG } & 69.89 & 65.72 & 68.95 & 69.17 & 69.38 & 69.76 \\ \text { SEP } & 69.88 & 67.38 & 68.94 & 68.42 & 69.07 & 69.67\end{array}$

USGS SITE 295903083203885 SRWMD ID -061005001 COUNTY Lafayette

$\begin{array}{lrrrrrr}\text { MONTH } & \text { MAXIMUM } & \text { MINIMUM } & \text { MEAN } & 25 \% & 50 \% & 75 \% \\ \text { OCT } & 69.54 & 65.51 & 68.01 & 67.14 & 68.27 & 69.00 \\ \text { NOV } & 68.71 & 65.11 & 67.66 & 67.26 & 67.93 & 68.56 \\ \text { DEC } & 68.34 & 65.73 & 67.39 & 66.33 & 67.87 & 68.17 \\ \text { JAN } & 69.31 & 66.22 & 67.83 & 66.30 & 67.85 & 68.94 \\ \text { FEB } & 69.39 & 66.73 & 68.67 & 68.17 & 69.07 & 69.28 \\ \text { MAR } & 69.72 & 66.58 & 68.62 & 68.33 & 68.78 & 69.16 \\ \text { APR } & 69.19 & 65.53 & 67.96 & 67.43 & 68.46 & 68.56 \\ \text { MAY } & 68.91 & 64.76 & 66.99 & 65.90 & 67.03 & 67.84 \\ \text { JUN } & 68.59 & 64.95 & 66.58 & 65.50 & 66.40 & 68.21 \\ \text { JUL } & 69.17 & 64.94 & 67.61 & 66.35 & 67.90 & 69.01 \\ \text { AUG } & 69.60 & 65.44 & 68.39 & 67.88 & 68.72 & 69.32 \\ \text { SEP } & 69.86 & 67.05 & 68.43 & 67.56 & 68.45 & 69.20\end{array}$

USGS SITE 295950082514685 SRWMD ID -061401003 COUNTY Suwannee

$\begin{array}{lrrrrrr}\text { MONTH } & \text { MAXIMUM } & \text { MINIMUM } & \text { MEAN } & 25 \% & 50 \% & 75 \% \\ \text { OCT } & 36.46 & 28.38 & 31.83 & 29.78 & 31.30 & 34.11 \\ \text { NOV } & 35.72 & 26.22 & 30.45 & 27.11 & 29.89 & 34.07 \\ \text { DEC } & 35.11 & 25.70 & 29.92 & 26.62 & 30.45 & 32.95 \\ \text { JAN } & 34.24 & 25.44 & 29.68 & 26.27 & 30.21 & 32.83 \\ \text { FEB } & 33.71 & 26.72 & 29.85 & 26.85 & 29.48 & 33.21 \\ \text { MAR } & 33.35 & 26.74 & 30.65 & 28.17 & 31.63 & 32.64 \\ \text { APR } & 32.53 & 26.70 & 30.21 & 26.70 & 31.40 & 32.53 \\ \text { MAY } & 32.81 & 26.71 & 30.65 & 27.71 & 31.55 & 32.70 \\ \text { JUN } & 33.49 & 26.41 & 30.85 & 28.43 & 31.57 & 32.90 \\ \text { JUL } & 34.43 & 26.14 & 30.41 & 28.00 & 29.90 & 33.08 \\ \text { AUG } & 36.08 & 26.05 & 30.74 & 28.71 & 30.31 & 33.10 \\ \text { SEP } & 36.67 & 26.04 & 30.36 & 27.51 & 29.72 & 33.52\end{array}$


USGS SITE 295957083032685 SRWMD ID -051331002 COUNTY Lafayette

$\begin{array}{lrrrrrr}\text { MONTH } & \text { MAXIMUM } & \text { MINIMUM } & \text { MEAN } & 25 \% & 50 \% & 75 \% \\ \text { OCT } & 51.72 & 37.96 & 43.91 & 39.45 & 42.27 & 49.91 \\ \text { NOV } & 50.75 & 37.87 & 43.62 & 39.47 & 41.56 & 50.16 \\ \text { DEC } & 49.23 & 37.57 & 43.55 & 39.86 & 42.01 & 49.19 \\ \text { JAN } & 47.44 & 36.99 & 41.75 & 38.71 & 40.44 & 46.31 \\ \text { FEB } & 46.17 & 38.93 & 41.96 & 39.02 & 41.53 & 44.97 \\ \text { MAR } & 45.68 & 39.35 & 42.07 & 40.05 & 41.85 & 43.99 \\ \text { APR } & 44.66 & 39.57 & 42.51 & 39.99 & 42.90 & 44.63 \\ \text { MAY } & 48.22 & 39.33 & 43.11 & 40.62 & 42.81 & 45.39 \\ \text { JUN } & 42.82 & 38.81 & 40.75 & 39.23 & 40.69 & 42.34 \\ \text { JUL } & 50.96 & 38.63 & 42.55 & 40.07 & 41.15 & 44.91 \\ \text { AUG } & 52.38 & 38.75 & 43.01 & 39.66 & 41.65 & 47.05 \\ \text { SEP } & 52.86 & 38.57 & 43.75 & 40.06 & 42.36 & 47.57\end{array}$

USGS SITE 300101082245285 SRWMD ID -051933001 COUNTY Union

$\begin{array}{lrrrrrr}\text { MONTH } & \text { MAXIMUM } & \text { MINIMUM } & \text { MEAN } & 25 \% & 50 \% & 75 \% \\ \text { OCT } & 62.10 & 51.06 & 57.04 & 56.02 & 57.62 & 58.60 \\ \text { NOV } & 64.16 & 50.96 & 57.85 & 55.68 & 57.26 & 60.29 \\ \text { DEC } & 63.69 & 50.82 & 56.82 & 55.40 & 56.55 & 58.29 \\ \text { JAN } & 64.21 & 51.07 & 58.06 & 56.07 & 58.48 & 59.46 \\ \text { FEB } & 63.14 & 52.00 & 57.34 & 55.46 & 57.08 & 59.26 \\ \text { MAR } & 64.79 & 53.61 & 58.79 & 56.55 & 58.70 & 60.68 \\ \text { APR } & 64.52 & 53.59 & 58.11 & 55.63 & 57.81 & 60.34 \\ \text { MAY } & 64.14 & 52.90 & 58.24 & 55.75 & 58.02 & 60.63 \\ \text { JUN } & 59.78 & 52.23 & 56.28 & 54.45 & 56.24 & 58.21 \\ \text { JUL } & 64.24 & 51.85 & 57.61 & 54.69 & 57.21 & 60.39 \\ \text { AUG } & 64.02 & 51.57 & 56.90 & 54.46 & 56.75 & 58.56 \\ \text { SEP } & 64.23 & 51.33 & 58.14 & 55.56 & 57.91 & 60.77\end{array}$

USGS SITE 300117082554285 SRWMD ID -051428004 COUNTY Suwannee

$\begin{array}{lrrrrrr}\text { MONTH } & \text { MAXIMUM } & \text { MINIMUM } & \text { MEAN } & 25 \% & 50 \% & 75 \% \\ \text { OCT } & 29.41 & 16.84 & 23.73 & 21.31 & 24.08 & 25.94 \\ \text { NOV } & 27.35 & 16.69 & 22.96 & 20.77 & 22.76 & 25.72 \\ \text { DEC } & 25.60 & 16.31 & 22.38 & 20.40 & 22.69 & 25.22 \\ \text { JAN } & 27.28 & 16.87 & 22.76 & 19.89 & 23.07 & 25.73 \\ \text { FEB } & 30.54 & 20.01 & 24.88 & 22.79 & 24.28 & 28.37 \\ \text { MAR } & 33.13 & 19.96 & 26.84 & 23.10 & 27.07 & 30.26 \\ \text { APR } & 34.76 & 19.66 & 27.28 & 23.24 & 27.56 & 30.63 \\ \text { MAY } & 34.99 & 19.12 & 26.48 & 23.06 & 25.97 & 31.03 \\ \text { JUN } & 32.73 & 17.97 & 25.03 & 21.94 & 23.78 & 30.19 \\ \text { JUL } & 31.15 & 17.29 & 24.26 & 21.64 & 22.96 & 29.29 \\ \text { AUG } & 31.37 & 16.99 & 23.98 & 21.22 & 23.02 & 27.76 \\ \text { SEP } & 31.51 & 16.79 & 24.15 & 21.65 & 23.89 & 26.72\end{array}$

USGS SITE 300129083260485 SRWMD ID -050928003 COUNTY Taylor

$\begin{array}{lrrrrrr}\text { MONTH } & \text { MAXIMUM } & \text { MINIMUM } & \text { MEAN } & 25 \% & 50 \% & 75 \% \\ \text { OCT } & 71.29 & 65.31 & 68.61 & 67.22 & 68.61 & 69.88 \\ \text { NOV } & 70.46 & 65.67 & 68.17 & 66.74 & 68.15 & 69.38 \\ \text { DEC } & 71.00 & 67.39 & 68.57 & 67.55 & 68.41 & 69.25 \\ \text { JAN } & 71.56 & 66.96 & 68.86 & 67.48 & 68.23 & 70.25 \\ \text { FEB } & 71.31 & 67.54 & 70.27 & 69.46 & 70.67 & 71.30 \\ \text { MAR } & 71.66 & 67.21 & 70.23 & 69.22 & 70.53 & 71.57 \\ \text { APR } & 72.03 & 66.63 & 70.02 & 69.44 & 70.32 & 70.92 \\ \text { MAY } & 70.61 & 65.91 & 68.36 & 66.66 & 68.41 & 69.87 \\ \text { JUN } & 69.70 & 66.67 & 68.05 & 67.04 & 68.02 & 69.07 \\ \text { JUL } & 70.63 & 66.16 & 68.93 & 66.34 & 69.73 & 70.62 \\ \text { AUG } & 71.28 & 65.96 & 68.92 & 66.62 & 69.21 & 71.16 \\ \text { SEP } & 71.69 & 64.89 & 69.33 & 68.73 & 69.51 & 70.77\end{array}$


USGS SITE 300131083260485 SRWMD ID -050928004 COUNTY TaYlor

$\begin{array}{lrrrrrr}\text { MONTH } & \text { MAXIMUM } & \text { MINIMUM } & \text { MEAN } & 25 \% & 50 \% & 75 \% \\ \text { OCT } & 69.65 & 65.16 & 68.11 & 67.15 & 68.51 & 68.99 \\ \text { NOV } & 70.30 & 65.57 & 68.02 & 66.76 & 67.96 & 69.20 \\ \text { DEC } & 69.42 & 67.16 & 67.99 & 67.23 & 67.80 & 68.65 \\ \text { JAN } & 70.40 & 66.91 & 68.50 & 67.27 & 68.15 & 70.01 \\ \text { FEB } & 70.67 & 67.44 & 69.80 & 69.29 & 70.06 & 70.64 \\ \text { MAR } & 71.13 & 67.03 & 69.79 & 69.12 & 70.10 & 70.76 \\ \text { APR } & 70.46 & 66.30 & 69.39 & 69.26 & 69.85 & 70.37 \\ \text { MAY } & 69.81 & 65.65 & 68.17 & 67.65 & 68.30 & 69.16 \\ \text { JUN } & 69.49 & 66.52 & 67.75 & 66.80 & 67.02 & 69.02 \\ \text { JUL } & 70.23 & 66.11 & 68.60 & 66.15 & 69.22 & 70.21 \\ \text { AUG } & 70.89 & 65.76 & 68.62 & 66.28 & 68.96 & 70.78 \\ \text { SEP } & 71.05 & 64.72 & 69.11 & 68.59 & 69.20 & 70.75\end{array}$

USGS SITE 300220082103085 SRWMD ID -062102001 COUNTY Bradford

$\begin{array}{lrrrrrr}\text { MONTH } & \text { MAXIMUM } & \text { MINIMUM } & \text { MEAN } & 25 \% & 50 \% & 75 \% \\ \text { OCT } & 63.29 & 54.11 & 59.65 & 58.78 & 59.80 & 61.40 \\ \text { NOV } & 68.35 & 54.12 & 61.10 & 58.59 & 60.37 & 64.07 \\ \text { DEC } & 67.45 & 54.11 & 59.94 & 58.47 & 59.40 & 60.87 \\ \text { JAN } & 67.16 & 54.29 & 61.16 & 58.71 & 61.20 & 62.53 \\ \text { FEB } & 66.91 & 55.06 & 60.52 & 58.71 & 60.23 & 62.28 \\ \text { MAR } & 67.64 & 56.61 & 61.84 & 59.82 & 61.60 & 63.81 \\ \text { APR } & 67.94 & 56.93 & 61.06 & 58.57 & 60.78 & 63.02 \\ \text { MAY } & 67.16 & 56.11 & 61.08 & 58.34 & 60.58 & 62.56 \\ \text { JUN } & 66.24 & 55.32 & 59.68 & 57.56 & 60.06 & 61.14 \\ \text { JUL } & 66.98 & 54.90 & 60.12 & 57.47 & 60.19 & 63.00 \\ \text { AUG } & 65.06 & 54.56 & 59.36 & 57.22 & 59.37 & 60.65 \\ \text { SEP } & 67.53 & 54.29 & 60.72 & 58.42 & 59.95 & 63.14\end{array}$

USGS SITE 300221082332685 SRWMD ID -051819001 COUNTY Columbia

$\begin{array}{lrrrrrr}\text { MONTH } & \text { MAXIMUM } & \text { MINIMUM } & \text { MEAN } & 25 \% & 50 \% & 75 \% \\ \text { OCT } & 45.47 & 38.78 & 43.08 & 41.13 & 44.00 & 44.51 \\ \text { NOV } & 44.08 & 38.40 & 41.72 & 40.62 & 41.40 & 43.35 \\ \text { DEC } & 44.70 & 38.17 & 42.05 & 40.38 & 42.32 & 43.88 \\ \text { JAN } & 44.26 & 38.32 & 42.02 & 41.06 & 42.17 & 43.36 \\ \text { FEB } & 45.15 & 38.63 & 42.60 & 41.95 & 42.83 & 43.28 \\ \text { MAR } & 46.56 & 39.06 & 43.75 & 42.05 & 44.49 & 45.31 \\ \text { APR } & 48.11 & 39.88 & 43.30 & 41.41 & 42.44 & 45.23 \\ \text { MAY } & 46.37 & 39.76 & 43.03 & 41.81 & 42.77 & 44.78 \\ \text { JUN } & 46.85 & 39.56 & 43.12 & 41.49 & 43.04 & 44.85 \\ \text { JUL } & 44.83 & 39.50 & 42.13 & 41.18 & 41.86 & 43.44 \\ \text { AUG } & 46.79 & 39.14 & 42.83 & 41.11 & 42.75 & 44.52 \\ \text { SEP } & 44.74 & 40.41 & 42.80 & 41.35 & 42.72 & 44.37\end{array}$

USGS SITE 300226083430385 SRWMD ID -050615002 COUNTY Taylor

$\begin{array}{lrrrrrr}\text { MONTH } & \text { MAXIMUM } & \text { MINIMUM } & \text { MEAN } & 25 \% & 50 \% & 75 \% \\ \text { OCT } & 15.28 & 6.42 & 10.09 & 6.88 & 9.77 & 13.03 \\ \text { NOV } & 13.31 & 6.48 & 9.58 & 6.74 & 10.28 & 12.00 \\ \text { DEC } & 12.09 & 6.83 & 8.96 & 7.38 & 8.72 & 10.39 \\ \text { JAN } & 9.44 & 6.94 & 8.52 & 7.70 & 8.60 & 9.31 \\ \text { FEB } & 11.72 & 9.71 & 10.51 & 9.93 & 10.30 & 11.10 \\ \text { MAR } & 14.11 & 10.03 & 11.32 & 10.20 & 11.00 & 12.00 \\ \text { APR } & 13.87 & 9.74 & 11.06 & 9.87 & 10.31 & 13.00 \\ \text { MAY } & 12.68 & 9.19 & 10.15 & 9.22 & 9.71 & 11.30 \\ \text { JUN } & 13.04 & 6.82 & 8.90 & 7.62 & 8.41 & 9.89 \\ \text { JUL } & 11.60 & 7.45 & 9.61 & 8.19 & 9.72 & 10.90 \\ \text { AUG } & 14.22 & 7.24 & 10.09 & 7.73 & 8.86 & 13.60 \\ \text { SEP } & 9.17 & 6.52 & 7.74 & 6.52 & 7.54 & 9.17\end{array}$


USGS SITE 300242082233285 SRWMD ID -051922002 COUNTY Union

$\begin{array}{lrrrrrr}\text { MONTH } & \text { MAXIMUM } & \text { MINIMUM } & \text { MEAN } & 25 \% & 50 \% & 75 \% \\ \text { OCT } & 140.28 & 134.37 & 138.44 & 136.99 & 139.08 & 140.04 \\ \text { NOV } & 140.30 & 133.06 & 137.82 & 136.48 & 138.18 & 139.76 \\ \text { DEC } & 139.16 & 132.71 & 137.24 & 135.75 & 137.97 & 138.94 \\ \text { JAN } & 140.25 & 132.75 & 137.19 & 134.34 & 138.30 & 139.48 \\ \text { FEB } & 140.47 & 137.43 & 138.85 & 137.76 & 138.46 & 140.13 \\ \text { MAR } & 140.77 & 136.99 & 139.36 & 137.80 & 139.72 & 140.74 \\ \text { APR } & 140.04 & 137.26 & 138.90 & 138.02 & 139.00 & 139.73 \\ \text { MAY } & 140.81 & 136.25 & 138.03 & 136.82 & 137.54 & 139.49 \\ \text { JUN } & 140.20 & 134.36 & 136.83 & 135.36 & 136.67 & 138.10 \\ \text { JUL } & 139.75 & 135.33 & 137.96 & 135.88 & 138.37 & 139.61 \\ \text { AUG } & 139.32 & 134.56 & 137.12 & 134.76 & 137.84 & 139.12 \\ \text { SEP } & 139.51 & 134.28 & 137.19 & 134.65 & 137.58 & 139.42\end{array}$

USGS SITE 300308083093285 SRWMD ID -051218002 COUNTY Lafayette

$\begin{array}{lrrrrrr}\text { MONTH } & \text { MAXIMUM } & \text { MINIMUM } & \text { MEAN } & 25 \% & 50 \% & 75 \% \\ \text { OCT } & 56.22 & 47.76 & 51.61 & 48.56 & 49.88 & 55.53 \\ \text { NOV } & 55.39 & 49.19 & 53.29 & 49.19 & 55.29 & 55.39 \\ \text { DEC } & 54.60 & 50.65 & 52.96 & 50.65 & 53.63 & 54.60 \\ \text { JAN } & 51.77 & 47.41 & 49.31 & 47.72 & 49.03 & 51.18 \\ \text { FEB } & 50.87 & 47.65 & 48.86 & 47.83 & 48.47 & 50.30 \\ \text { MAR } & 49.11 & 48.00 & 48.74 & 48.22 & 48.93 & 49.08 \\ \text { APR } & 49.20 & 47.07 & 48.42 & 47.07 & 49.00 & 49.20 \\ \text { MAY } & 54.29 & 47.17 & 49.85 & 47.52 & 48.98 & 53.06 \\ \text { JUN } & 48.38 & 46.72 & 47.93 & 47.11 & 48.31 & 48.37 \\ \text { JUL } & 48.38 & 46.64 & 47.77 & 46.64 & 48.30 & 48.38 \\ \text { AUG } & 51.37 & 48.07 & 49.00 & 48.08 & 48.27 & 50.63 \\ \text { SEP } & 56.34 & 48.87 & 52.60 & -- & -- & --\end{array}$

USGS SITE 300358083305085 SRWMD ID -050810001 COUNTY Taylor

$\begin{array}{lrrrrrr}\text { MONTH } & \text { MAXIMUM } & \text { MINIMUM } & \text { MEAN } & 25 \% & 50 \% & 75 \% \\ \text { OCT } & 54.53 & 16.67 & 31.75 & 26.11 & 29.31 & 32.64 \\ \text { NOV } & 54.52 & 15.90 & 30.14 & 24.56 & 27.00 & 32.09 \\ \text { DEC } & 53.84 & 15.64 & 29.60 & 22.66 & 26.63 & 31.15 \\ \text { JAN } & 54.16 & 18.04 & 28.76 & 22.18 & 26.33 & 29.99 \\ \text { FEB } & 54.51 & 19.40 & 30.17 & 24.33 & 27.44 & 31.16 \\ \text { MAR } & 54.43 & 18.68 & 31.98 & 26.24 & 29.86 & 32.21 \\ \text { APR } & 54.35 & 18.76 & 31.86 & 26.18 & 29.26 & 32.35 \\ \text { MAY } & 53.00 & 19.56 & 30.70 & 24.11 & 28.15 & 31.60 \\ \text { JUN } & 52.48 & 17.12 & 29.19 & 22.56 & 26.76 & 30.40 \\ \text { JUL } & 52.90 & 20.18 & 30.30 & 22.29 & 26.99 & 32.49 \\ \text { AUG } & 54.54 & 19.35 & 30.98 & 22.95 & 29.20 & 33.10 \\ \text { SEP } & 54.27 & 17.64 & 32.99 & 25.83 & 31.31 & 35.65\end{array}$

USGS SITE 300400082585085 SRWMD ID -051311001 COUNTY Suwannee

$\begin{array}{lrrrrrr}\text { MONTH } & \text { MAXIMUM } & \text { MINIMUM } & \text { MEAN } & 25 \% & 50 \% & 75 \% \\ \text { OCT } & 25.01 & 14.46 & 19.92 & 16.28 & 20.43 & 22.51 \\ \text { NOV } & 25.16 & 14.04 & 18.55 & 15.45 & 19.17 & 19.87 \\ \text { DEC } & 24.10 & 14.18 & 19.49 & 15.85 & 20.27 & 22.25 \\ \text { JAN } & 26.95 & 13.48 & 19.40 & 16.01 & 18.19 & 23.25 \\ \text { FEB } & 30.88 & 16.96 & 22.40 & 18.83 & 22.31 & 26.12 \\ \text { MAR } & 33.35 & 16.66 & 25.66 & 21.61 & 26.08 & 29.20 \\ \text { APR } & 36.63 & 16.50 & 25.57 & 20.90 & 23.65 & 31.40 \\ \text { MAY } & 34.03 & 16.14 & 24.61 & 19.36 & 24.66 & 29.31 \\ \text { JUN } & 27.77 & 15.49 & 20.85 & 16.42 & 20.73 & 25.08 \\ \text { JUL } & 29.20 & 16.13 & 20.52 & 17.67 & 19.27 & 23.11 \\ \text { AUG } & 29.48 & 14.75 & 20.82 & 17.47 & 19.70 & 23.52 \\ \text { SEP } & 22.41 & 14.96 & 19.60 & 17.76 & 20.49 & 21.32\end{array}$


USGS SITE 300403083081785 SRWMD ID -051208001 COUNTY Lafayette

$\begin{array}{lrrrrrr}\text { MONTH } & \text { MAXIMUM } & \text { MINIMUM } & \text { MEAN } & 25 \% & 50 \% & 75 \% \\ \text { OCT } & 35.05 & 26.59 & 30.74 & 27.32 & 30.16 & 34.94 \\ \text { NOV } & 35.40 & 26.29 & 30.39 & 27.15 & 30.08 & 33.64 \\ \text { DEC } & 34.08 & 26.56 & 29.68 & 27.03 & 29.36 & 32.14 \\ \text { JAN } & 30.10 & 26.75 & 28.39 & 26.82 & 28.29 & 30.02 \\ \text { FEB } & 32.40 & 29.08 & 30.33 & 29.17 & 29.44 & 31.94 \\ \text { MAR } & 37.72 & 29.79 & 32.61 & 30.19 & 32.32 & 35.17 \\ \text { APR } & 40.98 & 29.86 & 33.40 & 30.12 & 32.72 & 37.03 \\ \text { MAY } & 38.44 & 29.41 & 32.17 & 29.49 & 31.61 & 35.14 \\ \text { JUN } & 36.17 & 28.46 & 30.72 & 28.60 & 29.94 & 33.22 \\ \text { JUL } & 34.70 & 27.82 & 29.75 & 27.94 & 29.07 & 31.90 \\ \text { AUG } & 36.38 & 27.92 & 30.44 & 27.97 & 28.05 & 34.09 \\ \text { SEP } & 37.14 & 27.22 & 31.73 & 27.53 & 30.61 & 36.49\end{array}$

USGS SITE 300436083191685 SRWMD ID -051004001 COUNTY Lafayette

$\begin{array}{lrrrrrr}\text { MONTH } & \text { MAXIMUM } & \text { MINIMUM } & \text { MEAN } & 25 \% & 50 \% & 75 \% \\ \text { OCT } & 84.47 & 80.67 & 82.93 & 81.37 & 83.01 & 84.01 \\ \text { NOV } & 84.29 & 80.64 & 82.30 & 81.49 & 82.39 & 82.74 \\ \text { DEC } & 83.53 & 80.98 & 82.37 & 81.40 & 82.51 & 83.23 \\ \text { JAN } & 84.29 & 81.45 & 82.91 & 81.89 & 82.63 & 84.14 \\ \text { FEB } & 84.84 & 82.14 & 83.93 & 83.26 & 84.16 & 84.71 \\ \text { MAR } & 85.04 & 82.19 & 83.93 & 83.57 & 84.10 & 84.35 \\ \text { APR } & 84.74 & 81.26 & 82.60 & 82.94 & 83.89 & 84.43 \\ \text { MAY } & 83.86 & 80.62 & 82.68 & 81.90 & 82.94 & 83.54 \\ \text { JUN } & 83.59 & 81.01 & 82.18 & 81.38 & 82.09 & 83.02 \\ \text { JUL } & 84.38 & 80.25 & 83.00 & 81.98 & 84.00 & 84.32 \\ \text { AUG } & 84.77 & 79.80 & 82.80 & 80.23 & 83.66 & 84.29 \\ \text { SEP } & 84.82 & 79.92 & 83.08 & 81.88 & 83.67 & 84.64\end{array}$

USGS SITE 300436083191785 SRWMD ID -051004002 COUNTY Lafayette

$\begin{array}{lrrrrrr}\text { MONTH } & \text { MAXIMUM } & \text { MINIMUM } & \text { MEAN } & 25 \% & 50 \% & 75 \% \\ \text { OCT } & 84.24 & 81.49 & 83.22 & 81.89 & 82.88 & 84.28 \\ \text { NOV } & 84.25 & 80.73 & 82.62 & 81.94 & 82.71 & 83.32 \\ \text { DEC } & 83.80 & 81.50 & 82.53 & 81.71 & 82.11 & 83.70 \\ \text { JAN } & 85.22 & 81.63 & 83.32 & 82.18 & 82.36 & 85.06 \\ \text { FEB } & 85.64 & 82.31 & 84.30 & 83.65 & 83.98 & 85.49 \\ \text { MAR } & 85.47 & 82.64 & 84.23 & 83.42 & 84.52 & 84.85 \\ \text { APR } & 85.36 & 82.27 & 84.09 & 83.49 & 84.24 & 84.79 \\ \text { MAY } & 84.31 & 81.74 & 82.99 & 82.34 & 83.07 & 83.48 \\ \text { JUN } & 84.18 & 81.48 & 82.75 & 82.05 & 82.57 & 83.71 \\ \text { JUL } & 85.25 & 80.87 & 83.59 & 82.63 & 84.07 & 84.69 \\ \text { AUG } & 85.36 & 80.44 & 83.35 & 81.26 & 84.13 & 85.12 \\ \text { SEP } & 85.42 & 80.80 & 83.40 & 82.08 & 84.06 & 84.75\end{array}$

USGS SITE 300443083075585 SRWMD ID -051205001 COUNTY Lafayette

$\begin{array}{lrrrrrr}\text { MONTH } & \text { MAXIMUM } & \text { MINIMUM } & \text { MEAN } & 25 \% & 50 \% & 75 \% \\ \text { OCT } & 30.36 & 16.13 & 21.17 & 19.44 & 20.84 & 21.90 \\ \text { NOV } & 26.42 & 15.63 & 19.98 & 18.54 & 19.96 & 20.94 \\ \text { DEC } & 25.03 & 17.08 & 20.74 & 19.03 & 20.18 & 23.22 \\ \text { JAN } & 32.69 & 18.56 & 22.59 & 18.99 & 20.06 & 25.98 \\ \text { FEB } & 35.19 & 18.62 & 25.74 & 19.99 & 26.47 & 28.91 \\ \text { MAR } & 35.14 & 19.02 & 28.69 & 26.70 & 29.31 & 31.80 \\ \text { APR } & 41.92 & 19.17 & 26.87 & 22.71 & 25.79 & 30.81 \\ \text { MAY } & 37.48 & 18.74 & 24.10 & 21.95 & 23.33 & 25.26 \\ \text { JUN } & 25.81 & 16.76 & 21.30 & 19.45 & 20.72 & 24.30 \\ \text { JUL } & 28.74 & 18.29 & 20.35 & 18.65 & 19.42 & 20.25 \\ \text { AUG } & 24.91 & 16.61 & 20.57 & 18.62 & 20.14 & 22.23 \\ \text { SEP } & 30.72 & 18.02 & 22.15 & 19.07 & 20.80 & 24.72\end{array}$


USGS SITE 300447083343085 SRWMD ID -050701001 COUNTY Taylor

$\begin{array}{lrrrrrr}\text { MONTH } & \text { MAXIMUM } & \text { MINIMUM } & \text { MEAN } & 25 \% & 50 \% & 75 \% \\ \text { OCT } & 37.26 & 29.79 & 32.62 & 30.80 & 32.66 & 33.83 \\ \text { NOV } & 36.31 & 29.55 & 32.54 & 31.09 & 32.09 & 34.49 \\ \text { DEC } & 35.23 & 30.03 & 32.25 & 30.83 & 31.73 & 34.07 \\ \text { JAN } & 36.04 & 30.62 & 33.39 & 32.18 & 33.40 & 34.62 \\ \text { FEB } & 36.75 & 30.15 & 33.97 & 32.74 & 34.09 & 35.27 \\ \text { MAR } & 37.78 & 30.16 & 34.58 & 33.59 & 34.24 & 36.71 \\ \text { APR } & 35.94 & 29.97 & 33.24 & 32.38 & 33.27 & 33.97 \\ \text { MAY } & 37.34 & 29.35 & 33.03 & 31.45 & 32.34 & 34.25 \\ \text { JUN } & 34.43 & 30.76 & 31.94 & 30.77 & 31.49 & 33.66 \\ \text { JUL } & 34.51 & 29.72 & 31.88 & 30.69 & 31.91 & 33.26 \\ \text { AUG } & 37.21 & 30.01 & 33.92 & 31.52 & 34.78 & 35.80 \\ \text { SEP } & 35.21 & 30.33 & 32.54 & 30.58 & 32.08 & 34.15\end{array}$

USGS SITE 300530083342085 SRWMD ID -040736005 COUNTY Taylor

$\begin{array}{lrrrrrr}\text { MONTH } & \text { MAXIMUM } & \text { MINIMUM } & \text { MEAN } & 25 \% & 50 \% & 75 \% \\ \text { OCT } & 38.21 & 30.14 & 32.79 & 30.81 & 32.25 & 34.01 \\ \text { NOV } & 36.12 & 30.06 & 32.11 & 30.56 & 31.59 & 33.45 \\ \text { DEC } & 34.09 & 30.13 & 31.74 & 30.67 & 31.59 & 32.53 \\ \text { JAN } & 34.79 & 30.95 & 32.56 & 31.01 & 32.71 & 33.79 \\ \text { FEB } & 35.86 & 30.59 & 33.62 & 32.19 & 33.99 & 34.94 \\ \text { MAR } & 38.65 & 30.25 & 34.21 & 33.27 & 34.32 & 34.60 \\ \text { APR } & 37.75 & 30.02 & 33.52 & 32.79 & 33.40 & 33.73 \\ \text { MAY } & 36.19 & 29.74 & 32.57 & 31.95 & 32.47 & 32.65 \\ \text { JUN } & 34.23 & 30.34 & 32.05 & 31.22 & 31.47 & 34.10 \\ \text { JUL } & 34.97 & 30.56 & 32.45 & 30.84 & 31.88 & 34.39 \\ \text { AUG } & 37.69 & 30.55 & 33.95 & 31.64 & 33.47 & 36.80 \\ \text { SEP } & 34.34 & 30.61 & 32.51 & 31.10 & 32.39 & 34.16\end{array}$

USGS SITE 300531083342185 SRWMD ID -040736006 COUNTY Taylor

$\begin{array}{lrrrrrr}\text { MONTH } & \text { MAXIMUM } & \text { MINIMUM } & \text { MEAN } & 25 \% & 50 \% & 75 \% \\ \text { OCT } & 38.28 & 30.14 & 32.83 & 30.81 & 32.34 & 34.04 \\ \text { NOV } & 36.17 & 29.88 & 32.14 & 30.51 & 31.74 & 33.48 \\ \text { DEC } & 34.07 & 29.96 & 31.76 & 30.68 & 31.63 & 32.59 \\ \text { JAN } & 34.80 & 31.03 & 32.56 & 31.08 & 32.70 & 33.83 \\ \text { FEB } & 36.30 & 30.61 & 33.96 & 32.23 & 34.00 & 35.91 \\ \text { MAR } & 38.71 & 30.29 & 34.24 & 33.29 & 34.38 & 34.62 \\ \text { APR } & 39.13 & 32.82 & 34.85 & 33.20 & 33.74 & 37.83 \\ \text { MAY } & 36.27 & 30.13 & 32.96 & 32.12 & 32.60 & 34.34 \\ \text { JUN } & 34.30 & 30.28 & 32.28 & 31.29 & 31.51 & 33.97 \\ \text { JUL } & 35.03 & 30.65 & 32.46 & 30.83 & 31.83 & 34.37 \\ \text { AUG } & 37.78 & 30.55 & 34.02 & 31.85 & 33.56 & 36.80 \\ \text { SEP } & 34.38 & 30.60 & 32.54 & 31.09 & 32.45 & 34.16\end{array}$

USGS SITE 300629082030085 SRWMD ID -042236001 COUNTY Bradford

$\begin{array}{lrrrrrr}\text { MONTH } & \text { MAXIMUM } & \text { MINIMUM } & \text { MEAN } & 25 \% & 50 \% & 75 \% \\ \text { OCT } & 57.28 & 51.40 & 55.14 & 53.58 & 56.06 & 56.66 \\ \text { NOV } & 58.27 & 51.20 & 55.18 & 53.79 & 55.74 & 56.48 \\ \text { DEC } & 56.86 & 51.27 & 54.65 & 53.61 & 55.18 & 55.80 \\ \text { JAN } & 57.96 & 52.71 & 55.72 & 54.47 & 55.79 & 57.25 \\ \text { FEB } & 57.76 & 53.98 & 55.81 & 54.83 & 55.76 & 56.82 \\ \text { MAR } & 57.99 & 53.56 & 55.93 & 54.53 & 55.80 & 57.84 \\ \text { APR } & 58.66 & 54.09 & 56.17 & 54.61 & 56.31 & 57.68 \\ \text { MAY } & 57.60 & 53.23 & 55.55 & 54.03 & 55.71 & 56.76 \\ \text { JUN } & 56.21 & 52.28 & 54.80 & 52.97 & 55.74 & 55.96 \\ \text { JUL } & 58.07 & 51.40 & 54.99 & 51.92 & 55.10 & 57.17 \\ \text { AUG } & 60.03 & 51.63 & 55.30 & 53.96 & 54.46 & 56.73 \\ \text { SEP } & 57.86 & 51.20 & 54.80 & 53.20 & 55.14 & 56.50\end{array}$


USGS SITE 300629082030185 SRWMD ID -042236002 COUNTY Bradford

$\begin{array}{lrrrrrr}\text { MONTH } & \text { MAXIMUM } & \text { MINIMUM } & \text { MEAN } & 25 \% & 50 \% & 75 \% \\ \text { OCT } & 204.94 & 199.61 & 202.08 & 200.49 & 202.15 & 203.36 \\ \text { NOV } & 204.86 & 198.72 & 201.92 & 200.51 & 202.08 & 203.22 \\ \text { DEC } & 202.14 & 198.35 & 200.69 & 199.99 & 200.83 & 201.62 \\ \text { JAN } & 203.50 & 200.40 & 201.65 & 200.45 & 201.35 & 203.15 \\ \text { FEB } & 202.24 & 200.54 & 201.71 & 200.90 & 202.04 & 202.20 \\ \text { MAR } & 202.80 & 200.74 & 202.21 & 201.54 & 202.40 & 202.79 \\ \text { APR } & 203.64 & 199.84 & 201.30 & 200.14 & 201.19 & 202.52 \\ \text { MAY } & 202.84 & 199.01 & 200.36 & 199.14 & 200.29 & 201.62 \\ \text { JUN } & 203.79 & 198.13 & 200.75 & 199.13 & 200.20 & 202.96 \\ \text { JUL } & 204.31 & 197.95 & 201.56 & 200.08 & 201.24 & 203.93 \\ \text { AUG } & 203.15 & 198.63 & 200.90 & 198.76 & 201.19 & 202.90 \\ \text { SEP } & 201.89 & 197.96 & 200.16 & 198.28 & 200.39201 .80\end{array}$

USGS SITE 300629083024185 SRWMD ID -041329001 COUNTY Suwannee

$\begin{array}{lrrrrrr}\text { MONTH } & \text { MAXIMUM } & \text { MINIMUM } & \text { MEAN } & 25 \% & 50 \% & 75 \% \\ \text { OCT } & 29.52 & 19.75 & 24.79 & 21.90 & 25.11 & 26.97 \\ \text { NOV } & 29.44 & 19.73 & 24.27 & 21.87 & 23.93 & 26.54 \\ \text { DEC } & 27.85 & 19.47 & 23.89 & 22.12 & 24.23 & 26.16 \\ \text { JAN } & 27.76 & 19.77 & 24.18 & 22.13 & 24.29 & 26.26 \\ \text { FEB } & 32.75 & 21.81 & 26.25 & 23.51 & 25.43 & 29.47 \\ \text { MAR } & 35.20 & 21.22 & 28.38 & 24.14 & 28.58 & 32.24 \\ \text { APR } & 38.74 & 20.71 & 28.54 & 23.97 & 28.18 & 32.96 \\ \text { MAY } & 36.73 & 20.22 & 26.97 & 23.10 & 26.08 & 31.25 \\ \text { JUN } & 32.83 & 20.21 & 25.45 & 22.31 & 24.49 & 30.00 \\ \text { JUL } & 30.96 & 20.54 & 24.98 & 22.13 & 23.83 & 28.81 \\ \text { AUG } & 32.74 & 20.34 & 25.08 & 22.49 & 24.20 & 27.87 \\ \text { SEP } & 33.21 & 19.97 & 25.19 & 22.23 & 25.27 & 27.04\end{array}$

USGS SITE 300635082295985 SRWMD ID -041827002 COUNTY Columbia

$\begin{array}{lrrrrrr}\text { MONTH } & \text { MAXIMUM } & \text { MINIMUM } & \text { MEAN } & 25 \% & 50 \% & 75 \% \\ \text { OCT } & 53.15 & 46.77 & 50.74 & 48.99 & 52.18 & 52.29 \\ \text { NOV } & 52.60 & 46.59 & 50.49 & 48.64 & 51.73 & 52.15 \\ \text { DEC } & 52.26 & 46.54 & 50.31 & 48.50 & 51.41 & 52.04 \\ \text { JAN } & 52.51 & 46.58 & 50.08 & 48.10 & 50.74 & 51.60 \\ \text { FEB } & 53.33 & 47.87 & 50.70 & 48.67 & 51.17 & 52.12 \\ \text { MAR } & 53.82 & 49.40 & 51.33 & 49.82 & 51.22 & 52.71 \\ \text { APR } & 53.88 & 49.50 & 51.39 & 50.11 & 51.37 & 52.39 \\ \text { MAY } & 52.91 & 48.79 & 50.92 & 49.52 & 51.24 & 51.92 \\ \text { JUN } & 52.11 & 48.08 & 50.44 & 48.91 & 50.78 & 51.81 \\ \text { JUL } & 53.07 & 47.69 & 50.34 & 48.61 & 50.71 & 51.49 \\ \text { AUG } & 53.77 & 47.35 & 50.38 & 48.82 & 50.58 & 51.01 \\ \text { SEP } & 53.67 & 47.11 & 50.52 & 48.87 & 50.80 & 52.19\end{array}$

USGS SITE 300706082402285 SRWMD ID -041625001 COUNTY Columbia

$\begin{array}{lrrrrrr}\text { MONTH } & \text { MAXIMUM } & \text { MINIMUM } & \text { MEAN } & 25 \% & 50 \% & 75 \% \\ \text { OCT } & 45.78 & 32.63 & 40.04 & 37.63 & 40.28 & 42.71 \\ \text { NOV } & 45.06 & 32.42 & 39.11 & 36.97 & 38.63 & 41.73 \\ \text { DEC } & 44.31 & 32.22 & 39.26 & 37.27 & 40.17 & 41.77 \\ \text { JAN } & 43.52 & 32.10 & 39.31 & 37.06 & 40.52 & 41.65 \\ \text { FEB } & 42.81 & 32.13 & 39.57 & 38.88 & 40.09 & 41.92 \\ \text { MAR } & 44.41 & 34.14 & 39.76 & 36.30 & 40.13 & 42.98 \\ \text { APR } & 47.75 & 34.05 & 40.17 & 36.74 & 39.64 & 42.96 \\ \text { MAY } & 48.08 & 33.77 & 40.24 & 38.25 & 40.20 & 42.08 \\ \text { JUN } & 47.32 & 33.53 & 40.11 & 37.22 & 39.99 & 42.41 \\ \text { JUL } & 47.10 & 33.32 & 39.91 & 37.28 & 39.25 & 42.34 \\ \text { AUG } & 47.20 & 33.08 & 40.37 & 37.79 & 40.25 & 43.34 \\ \text { SEP } & 46.43 & 32.86 & 39.94 & 37.42 & 39.64 & 42.44\end{array}$


USGS SITE 300735083050885 SRWMD ID -041223004 COUNTY Suwannee

$\begin{array}{lrrrrrr}\text { MONTH } & \text { MAXIMUM } & \text { MINIMUM } & \text { MEAN } & 25 \% & 50 \% & 75 \% \\ \text { OCT } & 31.72 & 21.27 & 25.35 & 23.11 & 24.89 & 27.02 \\ \text { NOV } & 29.42 & 21.09 & 24.73 & 22.72 & 24.42 & 26.58 \\ \text { DEC } & 27.77 & 20.91 & 24.58 & 23.00 & 24.83 & 26.36 \\ \text { JAN } & 29.87 & 21.11 & 25.17 & 23.03 & 24.36 & 28.27 \\ \text { FEB } & 34.33 & 22.98 & 27.89 & 24.56 & 26.95 & 31.90 \\ \text { MAR } & 36.37 & 22.72 & 29.68 & 25.40 & 30.63 & 32.26 \\ \text { APR } & 35.29 & 22.46 & 27.87 & 24.29 & 27.17 & 31.80 \\ \text { MAY } & 38.23 & 22.10 & 27.73 & 24.29 & 26.47 & 30.42 \\ \text { JUN } & 29.97 & 21.88 & 26.02 & 23.38 & 25.24 & 29.45 \\ \text { JUL } & 29.70 & 21.94 & 25.68 & 23.32 & 25.04 & 28.62 \\ \text { AUG } & 33.50 & 21.77 & 25.97 & 23.91 & 25.62 & 27.46 \\ \text { SEP } & 31.47 & 21.51 & 25.67 & 23.81 & 25.45 & 26.97 \\ & & & & & & \\ \text { USGS } & 5 I T E & 300747082225885 & \text { SRWMD } 1 D & -041923001 & \text { COUNTY } & \text { Union } \\ & & & & & & \\ \text { MONTH } & \text { MAXIMUM } & \text { MINIMUM } & \text { MEAN } & 25 \% & 50 \% & 75 \% \\ \text { OCT } & 65.69 & 50.41 & 58.08 & 55.77 & 57.71 & 59.97 \\ \text { NOV } & 64.95 & 50.39 & 58.26 & 55.76 & 58.11 & 60.16 \\ \text { DEC } & 64.75 & 50.42 & 58.13 & 55.63 & 57.57 & 60.00 \\ \text { JAN } & 65.46 & 50.65 & 58.30 & 55.88 & 58.31 & 59.91 \\ \text { FEB } & 65.33 & 51.96 & 58.88 & 55.86 & 58.82 & 61.09 \\ \text { MAR } & 66.55 & 53.81 & 59.51 & 56.87 & 58.94 & 61.25 \\ \text { APR } & 66.18 & 53.74 & 59.65 & 56.51 & 59.09 & 62.37 \\ \text { MAY } & 65.50 & 52.82 & 58.96 & 56.20 & 58.35 & 61.73 \\ \text { JUN } & 65.81 & 51.90 & 58.23 & 55.53 & 57.76 & 60.41 \\ \text { JUL } & 65.34 & 51.34 & 57.98 & 55.24 & 57.41 & 60.51 \\ \text { AUG } & 65.04 & 50.95 & 58.06 & 55.26 & 57.54 & 60.86 \\ \text { SEP } & 64.89 & 50.67 & 58.26 & 55.57 & 58.22 & 61.08\end{array}$

USGS SITE 300823083175985 SRWMD ID -041014001 COUNTY Lafayette

$\begin{array}{lrrrrrr}\text { MONTH } & \text { MAXIMUM } & \text { MINIMUM } & \text { MEAN } & 25 \% & 50 \% & 75 \% \\ \text { OCT } & 51.28 & 37.96 & 44.03 & 38.66 & 43.99 & 48.32 \\ \text { NOV } & 66.87 & 37.41 & 44.39 & 39.66 & 43.56 & 46.52 \\ \text { DEC } & 49.18 & 37.17 & 43.01 & 37.86 & 43.99 & 46.07 \\ \text { JAN } & 45.36 & 36.73 & 40.95 & 37.09 & 42.25 & 44.04 \\ \text { FEB } & 50.23 & 38.39 & 42.68 & 39.00 & 41.79 & 45.99 \\ \text { MAR } & 52.99 & 35.44 & 42.85 & 40.41 & 42.01 & 44.17 \\ \text { APR } & 55.79 & 37.59 & 45.17 & 40.23 & 43.92 & 50.33 \\ \text { MAY } & 54.59 & 38.01 & 45.14 & 41.25 & 43.52 & 49.31 \\ \text { JUN } & 52.67 & 37.54 & 44.96 & 40.08 & 42.75 & 51.27 \\ \text { JUL } & 50.52 & 37.24 & 42.92 & 39.96 & 41.67 & 47.37 \\ \text { AUG } & 52.23 & 37.62 & 43.94 & 40.34 & 41.56 & 50.27 \\ \text { SEP } & 49.34 & 37.89 & 42.04 & 38.43 & 41.54 & 45.04\end{array}$

USGS SITE 300851083580885 SRWMD ID -040407001 COUNTY Taylor

$\begin{array}{lrrrrrr}\text { MONTH } & \text { MAXIMUM } & \text { MINIMUM } & \text { MEAN } & 25 \% & 50 \% & 75 \% \\ \text { OCT } & 4.15 & .04 & 1.11 & .46 & .98 & 1.38 \\ \text { NOV } & 2.10 & .17 & .94 & .56 & .81 & 1.25 \\ \text { DEC } & 3.90 & .08 & 1.58 & .52 & 1.13 & 3.09 \\ \text { JAN } & 4.87 & .30 & 2.08 & .73 & 1.88 & 2.93 \\ \text { FEB } & 5.41 & .60 & 2.95 & 1.81 & 3.01 & 3.98 \\ \text { MAR } & 5.45 & 1.54 & 2.86 & 1.93 & 2.38 & 3.70 \\ \text { APR } & 2.93 & .57 & 1.60 & 1.19 & 1.48 & 2.17 \\ \text { MAY } & 3.01 & .30 & 1.34 & .80 & 1.12 & 1.90 \\ \text { JUN } & 3.36 & .36 & 1.31 & .56 & 1.01 & 1.81 \\ \text { JUL } & 3.76 & .37 & 1.40 & .48 & 1.32 & 2.00 \\ \text { AUG } & 5.05 & .31 & 1.89 & .53 & 1.60 & 2.95 \\ \text { SEP } & 2.23 & .18 & 1.28 & .88 & 1.25 & 1.80\end{array}$


USGS SITE 300904083100985 SRWMD ID -041112005 COUNTY Suwannee

$\begin{array}{lrccrrr}\text { MONTH } & \text { MAXIMUM } & \text { MINIMUM } & \text { MEAN } & 25 \% & 50 \% & 75 \% \\ \text { OCT } & 32.24 & 22.72 & 26.78 & 24.35 & 26.47 & 28.39 \\ \text { NOV } & 31.52 & 22.44 & 26.20 & 23.79 & 25.86 & 28.35 \\ \text { DEC } & 29.79 & 22.17 & 25.82 & 23.87 & 25.95 & 27.67 \\ \text { JAN } & 29.31 & 22.28 & 25.89 & 23.96 & 25.34 & 28.08 \\ \text { FEB } & 34.96 & 24.18 & 28.53 & 25.14 & 27.80 & 31.48 \\ \text { MAR } & 38.07 & 23.79 & 31.45 & 28.41 & 30.63 & 36.31 \\ \text { APR } & 37.70 & 23.48 & 30.55 & 26.01 & 30.76 & 34.61 \\ \text { MAY } & 34.38 & 23.10 & 28.77 & 25.04 & 28.83 & 31.91 \\ \text { JUN } & 32.37 & 22.83 & 27.40 & 24.21 & 27.37 & 29.82 \\ \text { JUL } & 31.71 & 23.21 & 26.71 & 24.09 & 26.39 & 28.42 \\ \text { AUG } & 34.46 & 23.41 & 26.79 & 24.77 & 25.82 & 28.07 \\ \text { SEP } & 34.67 & 23.08 & 27.08 & 24.87 & 26.62 & 28.40\end{array}$

USGS SITE 301006082461785 SRWMD ID -041501001 COUNTY Columbia

$\begin{array}{lrrrrrr}\text { MONTH } & \text { MAXIMUM } & \text { MINIMUM } & \text { MEAN } & 25 \% & 50 \% & 75 \% \\ \text { OCT } & 45.19 & 30.62 & 37.98 & 35.33 & 38.08 & 40.92 \\ \text { NOV } & 44.51 & 30.40 & 37.70 & 35.03 & 37.40 & 40.65 \\ \text { DEC } & 43.72 & 30.22 & 37.36 & 34.57 & 37.29 & 40.20 \\ \text { JAN } & 42.93 & 30.00 & 37.08 & 34.14 & 37.71 & 39.88 \\ \text { FEB } & 42.09 & 30.10 & 37.38 & 34.14 & 37.93 & 40.97 \\ \text { MAR } & 42.72 & 31.12 & 37.69 & 34.33 & 37.66 & 41.60 \\ \text { APR } & 44.51 & 31.67 & 38.27 & 34.57 & 37.75 & 42.18 \\ \text { MAY } & 46.15 & 31.49 & 38.71 & 35.09 & 37.74 & 41.73 \\ \text { JUN } & 46.34 & 31.31 & 38.93 & 35.80 & 38.32 & 41.99 \\ \text { JUL } & 45.95 & 31.15 & 38.68 & 35.38 & 38.26 & 41.56 \\ \text { AUG } & 45.98 & 31.00 & 38.31 & 35.34 & 38.22 & 41.18 \\ \text { SEP } & 45.78 & 30.83 & 38.16 & 35.24 & 38.39 & 40.86\end{array}$

USGS SITE 301031082381085 SRWMD ID -041705001 COUNTY Columbia

$\begin{array}{lrrrrrr}\text { MONTH } & \text { MAXIMUM } & \text { MINIMUM } & \text { MEAN } & 25 \% & 50 \% & 75 \% \\ \text { OCT } & 60.79 & 43.78 & 51.38 & 48.84 & 50.89 & 53.09 \\ \text { NOV } & 60.50 & 43.45 & 51.21 & 48.79 & 50.73 & 52.94 \\ \text { DEC } & 59.93 & 43.20 & 50.95 & 48.73 & 50.25 & 52.74 \\ \text { JAN } & 59.53 & 43.06 & 50.92 & 48.96 & 50.31 & 52.40 \\ \text { FEB } & 59.56 & 43.63 & 51.03 & 48.84 & 50.85 & 52.10 \\ \text { MAR } & 59.65 & 44.76 & 51.36 & 49.38 & 51.09 & 52.49 \\ \text { APR } & 59.43 & 45.79 & 51.63 & 49.31 & 51.10 & 53.86 \\ \text { MAY } & 59.05 & 45.70 & 51.75 & 49.18 & 51.04 & 54.13 \\ \text { JUN } & 63.60 & 45.26 & 51.75 & 48.86 & 51.04 & 53.87 \\ \text { JUL } & 62.65 & 44.96 & 51.51 & 48.83 & 50.83 & 53.65 \\ \text { AUG } & 61.80 & 44.53 & 51.33 & 48.58 & 50.68 & 53.45 \\ \text { SEP } & 61.21 & 44.10 & 51.34 & 48.88 & 50.57 & 53.60\end{array}$

USGS SITE 301034083084885 SRWMD ID -031232001 COUNTY Suwannee

$\begin{array}{lrrrrrr}\text { MONTH } & \text { MAXIMUM } & \text { MINIMUM } & \text { MEAN } & 25 \% & 50 \% & 75 \% \\ \text { OCT } & 34.85 & 25.00 & 29.78 & 27.46 & 29.62 & 31.78 \\ \text { NOV } & 33.73 & 24.76 & 28.64 & 26.91 & 28.51 & 30.40 \\ \text { DEC } & 33.00 & 24.46 & 28.57 & 26.48 & 28.41 & 30.37 \\ \text { JAN } & 32.10 & 24.30 & 28.88 & 26.77 & 30.10 & 30.89 \\ \text { FEB } & 35.64 & 26.20 & 29.72 & 27.49 & 29.44 & 31.74 \\ \text { MAR } & 39.04 & 26.16 & 31.55 & 28.61 & 31.30 & 34.57 \\ \text { APR } & 41.41 & 25.81 & 33.02 & 27.99 & 31.64 & 37.09 \\ \text { MAY } & 40.67 & 25.53 & 31.93 & 28.54 & 31.02 & 36.19 \\ \text { JUN } & 37.46 & 25.13 & 30.72 & 27.58 & 29.75 & 34.86 \\ \text { JUL } & 35.59 & 25.20 & 30.40 & 28.38 & 29.37 & 33.88 \\ \text { AUG } & 36.98 & 25.71 & 29.97 & 27.70 & 29.08 & 32.66 \\ \text { SEP } & 34.10 & 25.44 & 29.47 & 27.32 & 29.36 & 31.73\end{array}$


USGS SITE 301103082353785 SRWMD ID -031734023 COUNTY Columbia

$\begin{array}{lrrrrrr}\text { MONTH } & \text { MAXIMUM } & \text { MINIMUM } & \text { MEAN } & 25 \% & 50 \% & 75 \% \\ \text { OCT } & 194.04 & 190.43 & 192.22 & 190.45 & 192.26 & 193.92 \\ \text { NOV } & 192.41 & 189.52 & 191.52 & 190.95 & 191.73 & 192.33 \\ \text { DEC } & 191.98 & 189.21 & 191.18 & 190.73 & 191.46 & 191.79 \\ \text { JAN } & 192.94 & 190.10 & 192.03 & 190.93 & 192.50 & 192.88 \\ \text { FEB } & 193.88 & 192.09 & 192.81 & 192.36 & 192.70 & 193.31 \\ \text { MAR } & 194.18 & 191.77 & 193.00 & 191.89 & 193.36 & 193.93 \\ \text { APR } & 193.08 & 192.21 & 192.50 & 192.23 & 192.41 & 192.82 \\ \text { MAY } & 193.99 & 191.38 & 191.94 & 191.39 & 191.44 & 192.73 \\ \text { JUN } & 194.15 & 190.47 & 191.69 & 190.73 & 191.32 & 192.60 \\ \text { JUL } & 194.98 & 191.53 & 192.34 & 191.53 & 191.66 & 193.28 \\ \text { AUG } & 192.96 & 190.74 & 191.75 & 190.84 & 191.65 & 192.76 \\ \text { SEP } & 193.30 & 186.60 & 190.77 & 189.04 & 191.24 & 192.59\end{array}$

USGS SITE 301111083315885 SRWMD ID -030833002 COUNTY Taylor

$\begin{array}{lrrrrrr}\text { MONTH } & \text { MAXIMUM } & \text { MINIMUM } & \text { MEAN } & 25 \% & 50 \% & 75 \% \\ \text { OCT } & 89.97 & 84.11 & 86.71 & 84.63 & 86.45 & 88.53 \\ \text { NOV } & 88.03 & 84.93 & 86.74 & 85.86 & 86.80 & 87.92 \\ \text { DEC } & 88.34 & 84.68 & 86.70 & 86.10 & 86.68 & 87.50 \\ \text { JAN } & 89.50 & 85.64 & 87.66 & 86.72 & 87.19 & 89.30 \\ \text { FEB } & 89.92 & 86.69 & 88.88 & 88.10 & 89.18 & 89.81 \\ \text { MAR } & 89.88 & 87.22 & 88.75 & 88.00 & 88.74 & 89.83 \\ \text { APR } & 89.14 & 85.82 & 87.90 & 86.77 & 88.21 & 88.99 \\ \text { MAY } & 89.91 & 85.59 & 87.68 & 86.54 & 87.84 & 88.56 \\ \text { JUN } & 88.56 & 85.09 & 86.29 & 85.76 & 85.88 & 86.84 \\ \text { JUL } & 89.10 & 85.79 & 87.11 & 86.01 & 86.81 & 88.21 \\ \text { AUG } & 89.50 & 85.14 & 87.34 & 85.82 & 87.66 & 88.52 \\ \text { SEP } & 89.79 & 84.13 & 86.88 & 85.37 & 86.60 & 88.74\end{array}$

USGS SITE 301111083315985 SRWMD ID -030833001 COUNTY Taylor

$\begin{array}{lrrrrrr}\text { MONTH } & \text { MAXIMUM } & \text { MINIMUM } & \text { MEAN } & 25 \% & 50 \% & 75 \% \\ \text { OCT } & 88.20 & 81.62 & 84.85 & 83.22 & 84.91 & 86.28 \\ \text { NOV } & 86.49 & 81.99 & 84.52 & 83.17 & 84.75 & 85.67 \\ \text { DEC } & 85.92 & 82.55 & 84.41 & 83.76 & 84.12 & 85.60 \\ \text { JAN } & 86.43 & 83.46 & 84.91 & 83.86 & 84.92 & 86.00 \\ \text { FEB } & 86.97 & 84.30 & 86.12 & 85.51 & 86.43 & 86.74 \\ \text { MAR } & 87.34 & 84.72 & 86.38 & 86.11 & 86.61 & 86.79 \\ \text { APR } & 86.70 & 84.11 & 85.76 & 84.91 & 85.89 & 86.53 \\ \text { MAY } & 87.15 & 83.22 & 85.35 & 84.73 & 85.37 & 86.07 \\ \text { JUN } & 86.74 & 83.72 & 84.50 & 83.74 & 83.95 & 84.87 \\ \text { JUL } & 86.65 & 83.33 & 84.91 & 83.71 & 84.78 & 86.18 \\ \text { AUG } & 87.20 & 82.74 & 85.18 & 83.57 & 85.49 & 86.73 \\ \text { SEP } & 87.02 & 81.66 & 85.00 & 83.29 & 85.54 & 86.58\end{array}$

USGS SITE 301145083401285 SRWMD ID -030730001 COUNTY Taylor

$\begin{array}{lrrrrrr}\text { MONTH } & \text { MAXIMUM } & \text { MINIMUM } & \text { MEAN } & 25 \% & 50 \% & 75 \% \\ \text { OCT } & 44.85 & 35.37 & 40.58 & 39.01 & 41.75 & 42.32 \\ \text { NOV } & 44.70 & 36.77 & 40.17 & 37.63 & 40.06 & 42.77 \\ \text { DEC } & 44.98 & 36.24 & 40.55 & 38.12 & 40.24 & 43.08 \\ \text { JAN } & 44.35 & 37.53 & 41.26 & 38.81 & 41.19 & 43.58 \\ \text { FEB } & 44.54 & 39.42 & 42.78 & 40.94 & 43.64 & 44.17 \\ \text { MAR } & 44.43 & 39.85 & 42.96 & 41.79 & 43.69 & 44.05 \\ \text { APR } & 44.19 & 39.22 & 42.38 & 41.93 & 42.82 & 43.50 \\ \text { MAY } & 44.44 & 38.17 & 41.63 & 40.76 & 41.71 & 43.24 \\ \text { JUN } & 43.12 & 38.32 & 40.28 & 39.09 & 39.81 & 40.80 \\ \text { JUI } & 44.20 & 37.65 & 40.31 & 38.43 & 40.14 & 41.62 \\ \text { AUG } & 44.98 & 36.65 & 41.15 & 39.50 & 41.26 & 43.33 \\ \text { SEP } & 43.78 & 35.85 & 40.55 & 38.65 & 40.94 & 42.67\end{array}$


USGS SITE 301245082233085 SRWMD ID -031923004 COUNTY Baker

$\begin{array}{lrrrrrr}\text { MONTH } & \text { MAXIMUM } & \text { MINIMUM } & \text { MEAN } & 25 \% & 50 \% & 75 \% \\ \text { OCT } & 57.08 & 49.28 & 53.75 & 51.60 & 54.32 & 56.36 \\ \text { NOV } & 56.43 & 49.10 & 53.34 & 51.41 & 54.22 & 55.18 \\ \text { DEC } & 56.24 & 49.12 & 53.30 & 51.38 & 53.85 & 55.21 \\ \text { JAN } & 56.21 & 49.34 & 53.17 & 51.12 & 53.76 & 54.74 \\ \text { FEB } & 57.45 & 51.73 & 54.19 & 52.25 & 53.99 & 56.00 \\ \text { MAR } & 57.94 & 52.97 & 55.31 & 53.05 & 55.12 & 57.50 \\ \text { APR } & 57.56 & 52.60 & 55.23 & 53.07 & 55.56 & 56.47 \\ \text { MAY } & 56.28 & 51.97 & 54.49 & 52.08 & 55.05 & 55.78 \\ \text { JUN } & 55.44 & 51.00 & 53.50 & 51.45 & 54.04 & 54.56 \\ \text { JUL } & 56.25 & 50.30 & 53.15 & 51.13 & 53.30 & 54.23 \\ \text { AUG } & 57.09 & 49.87 & 53.14 & 51.14 & 53.23 & 54.47 \\ \text { SEP } & 57.22 & 49.51 & 53.43 & 51.24 & 54.05 & 55.06\end{array}$

USGS SITE 301246082233085 SRWMD ID -031923003 COUNTY Baker

$\begin{array}{lrrrrrr}\text { MONTH } & \text { MAXIMUM } & \text { MINIMUM } & \text { MEAN } & 25 \% & 50 \% & 75 \% \\ \text { OCT } & 176.00 & 171.82 & 174.14 & 172.37 & 174.91 & 175.52 \\ \text { NOV } & 175.19 & 171.54 & 173.95 & 172.20 & 174.54 & 175.12 \\ \text { DEC } & 174.68 & 171.13 & 173.57 & 172.39 & 174.16 & 174.45 \\ \text { JAN } & 175.89 & 170.89 & 174.10 & 171.79 & 174.81 & 175.70 \\ \text { FEB } & 176.55 & 173.64 & 174.85 & 173.66 & 174.60 & 176.28 \\ \text { MAR } & 176.97 & 174.01 & 175.38 & 174.01 & 175.17 & 176.97 \\ \text { APR } & 174.98 & 173.91 & 174.43 & 174.01 & 174.42 & 174.86 \\ \text { MAY } & 173.51 & 172.97 & 173.22 & 172.97 & 173.19 & 173.51 \\ \text { JUN } & 173.14 & 172.36 & 172.72 & 172.42 & 172.70 & 173.05 \\ \text { JUL } & 173.97 & 171.79 & 173.35 & 172.65 & 173.67 & 173.89 \\ \text { AUG } & 174.20 & 171.70 & 173.18 & 172.13 & 173.28 & 174.17 \\ \text { SEP } & 174.91 & 172.38 & 173.74 & 172.54 & 174.35 & 174.64\end{array}$

USGS SITE 301405083163085 SRWMD ID -031012001 COUNTY Lafayette

$\begin{array}{lrrrrrr}\text { MONTH } & \text { MAXIMUM } & \text { MINIMUM } & \text { MEAN } & 25 \% & 50 \% & 75 \% \\ \text { OCT } & 68.57 & 59.34 & 63.67 & 61.55 & 63.50 & 66.10 \\ \text { NOV } & 69.85 & 59.47 & 63.15 & 60.65 & 62.05 & 66.38 \\ \text { DEC } & 67.12 & 59.50 & 62.56 & 60.08 & 62.06 & 65.16 \\ \text { JAN } & 66.29 & 60.00 & 62.55 & 60.87 & 61.74 & 64.19 \\ \text { FEB } & 71.52 & 57.77 & 64.64 & 61.64 & 64.44 & 67.44 \\ \text { MAR } & 70.64 & 60.20 & 65.56 & 63.99 & 65.13 & 68.19 \\ \text { APR } & 71.18 & 59.68 & 65.53 & 63.06 & 64.68 & 68.77 \\ \text { MAY } & 69.91 & 59.39 & 64.68 & 61.68 & 64.41 & 68.90 \\ \text { JUN } & 70.16 & 59.12 & 63.95 & 61.48 & 62.72 & 67.35 \\ \text { JUL } & 70.06 & 61.07 & 63.69 & 61.32 & 62.67 & 65.60 \\ \text { AUG } & 70.86 & 60.49 & 64.13 & 61.46 & 62.94 & 66.85 \\ \text { SEP } & 65.67 & 59.85 & 62.76 & 61.66 & 62.96 & 64.03\end{array}$

USGS SITE 301423082261185 SRWMD ID -031908001 COUNTY Baker

$\begin{array}{lrrrrrr}\text { MONTH } & \text { MAXIMUM } & \text { MINIMUM } & \text { MEAN } & 25 \% & 50 \% & 75 \% \\ \text { OCT } & 59.54 & 52.03 & 56.62 & 55.18 & 56.93 & 58.14 \\ \text { NOV } & 65.50 & 52.02 & 57.25 & 55.08 & 57.16 & 58.40 \\ \text { DEC } & 62.98 & 52.19 & 56.72 & 55.03 & 56.98 & 57.92 \\ \text { JAN } & 67.20 & 52.73 & 58.15 & 56.11 & 57.64 & 59.38 \\ \text { FEB } & 62.84 & 54.35 & 57.90 & 54.92 & 57.95 & 60.25 \\ \text { MAR } & 67.42 & 54.29 & 59.48 & 56.90 & 58.59 & 62.03 \\ \text { APR } & 66.15 & 53.99 & 58.98 & 55.52 & 58.82 & 61.32 \\ \text { MAY } & 65.46 & 53.53 & 58.21 & 56.38 & 57.43 & 59.41 \\ \text { JUN } & 60.34 & 53.20 & 56.85 & 55.20 & 57.15 & 58.43 \\ \text { JUL } & 65.51 & 52.54 & 57.99 & 56.07 & 57.26 & 60.46 \\ \text { AUG } & 59.56 & 51.92 & 56.08 & 54.80 & 56.14 & 57.77 \\ \text { SEP } & 65.04 & 51.90 & 57.90 & 55.68 & 57.82 & 59.27\end{array}$




$\begin{array}{lrrrrrr}\text { USGS SITE } & 301458083141985 & \text { SRIMD ID } & -031105006 & \text { COUNTY } & \text { Lafayet } \\ \text { MONTH } & \text { MAXIMUM } & \text { MINIMUM } & \text { MEAN } & 25 \% & 50 \% & 75 \% \\ \text { OCT } & 32.61 & 22.70 & 25.82 & 23.51 & 25.54 & 26.86 \\ \text { NOV } & 33.08 & 22.57 & 24.97 & 23.19 & 24.26 & 25.56 \\ \text { DEC } & 32.31 & 22.52 & 26.13 & 23.62 & 24.39 & 29.45 \\ \text { JAN } & 39.73 & 23.63 & 27.76 & 24.06 & 26.49 & 30.68 \\ \text { FEB } & 43.95 & 23.35 & 32.79 & 27.86 & 30.96 & 38.95 \\ \text { MAR } & 46.92 & 24.06 & 36.08 & 30.77 & 37.07 & 42.68 \\ \text { APR } & 44.43 & 24.49 & 33.14 & 28.60 & 32.04 & 39.07 \\ \text { MAY } & 40.67 & 23.73 & 29.72 & 25.16 & 28.73 & 31.98 \\ \text { JUN } & 33.08 & 23.20 & 27.06 & 24.41 & 26.09 & 29.98 \\ \text { JUL } & 34.83 & 23.32 & 26.72 & 24.31 & 26.03 & 29.03 \\ \text { AUG } & 38.70 & 23.15 & 27.39 & 23.76 & 26.44 & 29.37 \\ \text { SEP } & 37.01 & 22.88 & 27.09 & 24.26 & 26.86 & 28.40\end{array}$

USGS SITE 301535082162085 SRWMD ID -032012001 COUNTY Baker

$\begin{array}{lrrrrrr}\text { MONTH } & \text { MAXIMUM } & \text { MINIMUM } & \text { MEAN } & 25 \% & 50 \% & 75 \% \\ \text { OCT } & 55.75 & 48.17 & 53.33 & 51.31 & 54.31 & 55.14 \\ \text { NOV } & 55.52 & 47.97 & 52.78 & 51.08 & 52.90 & 54.68 \\ \text { DEC } & 55.99 & 48.07 & 53.12 & 51.69 & 53.55 & 55.03 \\ \text { JAN } & 56.85 & 48.52 & 53.37 & 52.39 & 53.11 & 55.35 \\ \text { FEB } & 58.48 & 51.02 & 54.77 & 51.74 & 54.46 & 57.57 \\ \text { MAR } & 64.05 & 51.71 & 56.48 & 53.78 & 56.30 & 58.84 \\ \text { APR } & 61.27 & 51.40 & 55.25 & 53.06 & 54.81 & 57.24 \\ \text { MAY } & 59.75 & 50.64 & 54.37 & 52.92 & 53.98 & 56.04 \\ \text { JUN } & 57.10 & 49.51 & 53.30 & 51.80 & 52.74 & 55.14 \\ \text { JUL } & 56.75 & 48.57 & 52.25 & 49.96 & 52.33 & 54.39 \\ \text { AUG } & 54.85 & 48.64 & 52.44 & 51.18 & 52.51 & 54.34 \\ \text { SEP } & 56.16 & 48.18 & 52.91 & 50.62 & 53.06 & 55.48\end{array}$

USGS SITE 301540082395785 SRWMD ID -031601003 COUNTY Columbia

$\begin{array}{lrrrrrr}\text { MONTH } & \text { MAXIMUM } & \text { MINIMUM } & \text { MEAN } & 25 \% & 50 \% & 75 \% \\ \text { OCT } & 68.71 & 51.14 & 56.88 & 54.40 & 56.60 & 58.42 \\ \text { NOV } & 58.71 & 49.23 & 54.53 & 51.82 & 54.97 & 56.64 \\ \text { DEC } & 62.03 & 48.90 & 55.73 & 52.98 & 56.11 & 57.82 \\ \text { JAN } & 78.85 & 48.60 & 58.88 & 53.93 & 55.92 & 66.37 \\ \text { FEB } & 81.50 & 51.90 & 61.02 & 54.47 & 58.47 & 64.51 \\ \text { MAR } & 83.30 & 53.10 & 75.44 & 56.52 & 59.90 & 69.15 \\ \text { APR } & 74.71 & 52.67 & 60.23 & 55.74 & 59.50 & 62.10 \\ \text { MAY } & 67.26 & 52.23 & 57.62 & 54.16 & 57.09 & 60.63 \\ \text { JUN } & 74.54 & 51.21 & 58.40 & 54.17 & 56.10 & 62.17 \\ \text { JUL } & 64.30 & 50.88 & 55.94 & 53.95 & 55.17 & 57.81 \\ \text { AUG } & 63.72 & 50.07 & 57.43 & 54.89 & 57.90 & 60.37 \\ \text { SEP } & 62.50 & 49.54 & 56.01 & 53.00 & 56.57 & 59.37\end{array}$

USGS SITE 301555083393985 SRWMD ID -020731002 COUNTY Taylor

$\begin{array}{lrrrrrr}\text { MONTH } & \text { MAXIMUM } & \text { MINIMUM } & \text { MEAN } & 25 \% & 50 \% & 75 \% \\ \text { OCT } & 65.08 & 58.36 & 61.57 & 60.02 & 61.69 & 62.67 \\ \text { NOV } & 63.32 & 59.17 & 60.96 & 59.47 & 60.94 & 62.16 \\ \text { DEC } & 62.81 & 59.57 & 61.25 & 60.17 & 61.05 & 62.40 \\ \text { JAN } & 63.82 & 60.20 & 61.85 & 60.57 & 61.93 & 63.39 \\ \text { FEB } & 64.16 & 61.62 & 63.06 & 61.72 & 63.53 & 63.87 \\ \text { MAR } & 64.44 & 62.11 & 63.56 & 63.24 & 63.61 & 64.19 \\ \text { APR } & 64.33 & 61.73 & 63.11 & 62.38 & 63.30 & 63.63 \\ \text { MAY } & 64.17 & 61.28 & 62.35 & 61.38 & 62.07 & 63.41 \\ \text { JUN } & 63.83 & 60.17 & 61.74 & 60.56 & 61.32 & 63.71 \\ \text { JUL } & 64.12 & 59.39 & 61.63 & 59.95 & 62.02 & 63.45 \\ \text { AUG } & 63.82 & 59.07 & 61.79 & 59.93 & 61.92 & 63.63 \\ \text { SEP } & 63.77 & 59.32 & 62.06 & 61.07 & 62.37 & 63.07\end{array}$


USGS SITE 301555083394185 SRWMD ID -020731003 COUNTY TaYlor

$\begin{array}{lrrrrrr}\text { MONTH } & \text { MAXIMUM } & \text { MINIMUM } & \text { MEAN } & 25 \% & 50 \% & 75 \% \\ \text { OCT } & 66.42 & 59.78 & 62.50 & 60.65 & 62.62 & 63.37 \\ \text { NOV } & 64.17 & 59.78 & 61.79 & 60.46 & 61.85 & 62.78 \\ \text { DEC } & 63.51 & 60.58 & 62.03 & 60.96 & 61.81 & 63.30 \\ \text { JAN } & 64.93 & 60.99 & 62.78 & 61.75 & 62.48 & 64.26 \\ \text { FEB } & 65.92 & 61.86 & 64.03 & 62.30 & 64.48 & 65.21 \\ \text { MAR } & 66.58 & 62.97 & 64.84 & 64.13 & 64.54 & 65.99 \\ \text { APR } & 64.64 & 62.78 & 63.93 & 63.31 & 64.19 & 64.23 \\ \text { MAY } & 65.68 & 62.26 & 63.26 & 62.39 & 62.83 & 64.02 \\ \text { JUN } & 64.71 & 61.44 & 62.42 & 61.63 & 62.08 & 63.04 \\ \text { JUL } & 65.14 & 60.79 & 62.98 & 60.91 & 63.09 & 65.13 \\ \text { AUG } & 65.02 & 60.31 & 62.88 & 61.20 & 62.67 & 64.89 \\ \text { SEP } & 64.86 & 60.23 & 62.58 & 60.95 & 62.75 & 64.00\end{array}$

USGS SITE 301610082591585 SRWMD ID -021335001 COUNTY Suwannee

$\begin{array}{lrrrrrr}\text { MONTH } & \text { MAXIMUM } & \text { MINIMUM } & \text { MEAN } & 25 \% & 50 \% & 75 \% \\ \text { OCT } & 52.10 & 35.66 & 43.80 & 41.37 & 43.12 & 47.10 \\ \text { NOV } & 51.01 & 35.34 & 43.78 & 40.94 & 44.08 & 47.02 \\ \text { DEC } & 49.92 & 34.95 & 43.17 & 40.60 & 43.40 & 46.21 \\ \text { JAN } & 48.71 & 34.74 & 42.52 & 39.87 & 43.89 & 45.35 \\ \text { FEB } & 47.64 & 36.32 & 42.99 & 39.32 & 44.45 & 46.32 \\ \text { MAR } & 48.93 & 37.42 & 43.86 & 39.40 & 44.03 & 47.18 \\ \text { APR } & 51.92 & 38.08 & 45.13 & 41.81 & 45.29 & 48.09 \\ \text { MAY } & 53.50 & 37.84 & 45.59 & 43.41 & 45.15 & 49.37 \\ \text { JUN } & 53.77 & 37.39 & 45.40 & 42.72 & 45.60 & 49.35 \\ \text { JUL } & 53.78 & 36.89 & 45.12 & 42.27 & 45.24 & 48.72 \\ \text { AUG } & 53.96 & 36.50 & 44.96 & 42.25 & 44.71 & 49.81 \\ \text { SEP } & 53.14 & 35.97 & 44.74 & 41.99 & 44.25 & 48.91\end{array}$

USGS SITE 301615083554185 SRWMD ID -020433001 COUNTY Jefferson

$\begin{array}{lrrrrrr}\text { MONTH } & \text { MAXIMUM } & \text { MINIMUM } & \text { MEAN } & 25 \% & 50 \% & 75 \% \\ \text { OCT } & 27.97 & 23.65 & 25.65 & 23.96 & 26.10 & 27.11 \\ \text { NOV } & 27.39 & 23.62 & 25.93 & 24.73 & 26.19 & 27.16 \\ \text { DEC } & 27.82 & 24.01 & 26.07 & 24.77 & 25.55 & 27.63 \\ \text { JAN } & 28.81 & 25.82 & 27.91 & 26.74 & 28.52 & 28.77 \\ \text { FEB } & 28.51 & 28.15 & 28.32 & 28.17 & 28.31 & 28.48 \\ \text { MAR } & 28.96 & 28.03 & 28.44 & 28.05 & 28.40 & 28.89 \\ \text { APR } & 28.41 & 27.63 & 28.14 & 27.77 & 28.26 & 28.39 \\ \text { MAY } & 28.38 & 26.10 & 26.92 & 26.18 & 26.59 & 27.97 \\ \text { JUN } & 26.25 & 25.05 & 25.57 & 25.15 & 25.50 & 26.03 \\ \text { JUL } & 29.25 & 24.28 & 26.97 & 24.76 & 27.17 & 28.97 \\ \text { AUG } & 28.50 & 24.43 & 25.83 & 24.43 & 25.19 & 27.86 \\ \text { SEP } & 27.70 & 24.50 & 26.32 & 24.75 & 26.54 & 27.67\end{array}$

USGS SITE 301629083091285 SRWMD ID -021231001 COUNTY Suwannee

$\begin{array}{lrrrrrr}\text { MONTH } & \text { MAXIMUM } & \text { MINIMUM } & \text { MEAN } & 25 \% & 50 \% & 75 \% \\ \text { OCT } & 43.89 & 31.62 & 36.44 & 32.26 & 35.19 & 41.18 \\ \text { NOV } & 42.07 & 31.31 & 35.01 & 31.71 & 33.98 & 38.83 \\ \text { DEC } & 40.60 & 31.06 & 35.28 & 31.44 & 33.54 & 39.99 \\ \text { JAN } & 39.05 & 30.85 & 34.37 & 31.51 & 33.74 & 37.53 \\ \text { FEB } & 38.25 & 33.22 & 35.86 & 33.40 & 35.99 & 38.19 \\ \text { MAR } & 40.22 & 35.46 & 38.21 & 36.51 & 37.62 & 40.19 \\ \text { APR } & 42.94 & 35.82 & 39.68 & 35.82 & 40.27 & 42.94 \\ \text { MAY } & 43.48 & 34.88 & 39.50 & 37.03 & 39.64 & 41.91 \\ \text { JUN } & 43.11 & 32.12 & 37.08 & 33.01 & 37.92 & 40.73 \\ \text { JUL } & 42.07 & 32.48 & 36.53 & 32.90 & 37.14 & 39.86 \\ \text { AUG } & 43.50 & 32.61 & 36.50 & 32.95 & 35.99 & 39.25 \\ \text { SEP } & 43.50 & 32.13 & 36.13 & 32.13 & 32.75 & 43.50\end{array}$


USGS SITE 301635082234085 SRWMD ID -021934001 COUNTY Baker

$\begin{array}{lrrrrrr}\text { MONTH } & \text { MAXIMUM } & \text { MINIMUM } & \text { MEAN } & 25 \% & 50 \% & 75 \% \\ \text { OCT } & 56.22 & 48.38 & 53.03 & 50.76 & 53.87 & 55.29 \\ \text { NOV } & 56.34 & 48.13 & 53.17 & 51.38 & 54.04 & 54.36 \\ \text { DEC } & 55.93 & 48.21 & 52.83 & 50.71 & 53.25 & 55.15 \\ \text { JAN } & 58.01 & 48.59 & 53.31 & 50.99 & 53.30 & 56.25 \\ \text { FEB } & 58.22 & 51.72 & 54.55 & 52.04 & 54.39 & 56.79 \\ \text { MAR } & 58.06 & 51.99 & 54.81 & 52.13 & 54.82 & 57.28 \\ \text { APR } & 62.90 & 51.67 & 55.64 & 53.06 & 54.71 & 57.85 \\ \text { MAY } & 60.39 & 51.02 & 55.08 & 53.44 & 54.92 & 56.60 \\ \text { JUN } & 54.82 & 49.87 & 52.43 & 50.28 & 53.11 & 53.64 \\ \text { JUL } & 55.42 & 49.30 & 52.23 & 50.72 & 52.42 & 53.21 \\ \text { AUG } & 60.57 & 48.92 & 53.40 & 50.96 & 52.51 & 55.49 \\ \text { SEP } & 56.34 & 48.48 & 52.91 & 50.92 & 53.53 & 54.34\end{array}$

USGS SITE 301702082271585 SRWMD ID -021930001 COUNTY Baker

$\begin{array}{lrrrrrr}\text { MONTH } & \text { MAXIMUM } & \text { MINIMUM } & \text { MEAN } & 25 \% & 50 \% & 75 \% \\ \text { OCT } & 58.15 & 48.77 & 53.94 & 51.21 & 54.52 & 56.74 \\ \text { NOV } & 56.37 & 48.40 & 53.52 & 50.75 & 54.73 & 55.50 \\ \text { DEC } & 57.17 & 48.41 & 53.49 & 50.98 & 54.12 & 55.77 \\ \text { JAN } & 60.04 & 49.00 & 54.37 & 51.39 & 54.19 & 58.02 \\ \text { FEB } & 59.94 & 52.67 & 55.63 & 52.87 & 54.84 & 58.92 \\ \text { MAR } & 59.69 & 52.54 & 56.09 & 52.66 & 56.58 & 58.75 \\ \text { APR } & 57.75 & 52.15 & 55.40 & 52.52 & 56.06 & 57.74 \\ \text { MAY } & 57.14 & 51.58 & 54.72 & 51.63 & 55.61 & 56.74 \\ \text { JUN } & 57.34 & 50.49 & 53.56 & 50.89 & 54.10 & 55.09 \\ \text { JUL } & 57.59 & 49.90 & 53.32 & 50.85 & 53.49 & 54.50 \\ \text { AUG } & 58.69 & 49.46 & 53.32 & 50.77 & 53.51 & 54.49 \\ \text { SEP } & 58.31 & 48.97 & 53.66 & 51.32 & 54.14 & 55.64\end{array}$

USGS SITE 301721083321085 SRWMD ID -020828002 COUNTY TaYlor

$\begin{array}{lrrrrrr}\text { MONTH } & \text { MAXIMUM } & \text { MINIMUM } & \text { MEAN } & 25 \% & 50 \% & 75 \% \\ \text { OCT } & 91.41 & 86.48 & 89.25 & 87.60 & 89.62 & 90.49 \\ \text { NOV } & 90.61 & 87.58 & 89.06 & 88.35 & 88.67 & 89.81 \\ \text { DEC } & 89.99 & 87.30 & 88.97 & 88.27 & 89.48 & 89.64 \\ \text { JAN } & 90.42 & 87.73 & 89.50 & 88.61 & 89.78 & 90.37 \\ \text { FEB } & 90.88 & 88.98 & 90.26 & 89.98 & 90.46 & 90.57 \\ \text { MAR } & 91.42 & 89.07 & 90.22 & 89.29 & 90.37 & 90.89 \\ \text { APR } & 91.19 & 88.84 & 90.07 & 89.55 & 90.04 & 90.66 \\ \text { MAY } & 90.98 & 88.28 & 89.18 & 88.59 & 88.82 & 89.86 \\ \text { JUN } & 90.58 & 87.62 & 89.04 & 87.89 & 89.07 & 90.10 \\ \text { JUL } & 90.89 & 88.28 & 89.81 & 88.38 & 90.54 & 90.87 \\ \text { AUG } & 91.43 & 88.10 & 90.15 & 88.66 & 90.53 & 91.25 \\ \text { SEP } & 91.04 & 86.90 & 89.39 & 87.33 & 89.75 & 90.59\end{array}$

USGS SITE 301722083321085 SRWMD ID -020828001 COUNTY Taylor

$\begin{array}{lrrrrrr}\text { MONTH } & \text { MAXIMUM } & \text { MINIMUM } & \text { MEAN } & 25 \% & 50 \% & 75 \% \\ \text { OCt } & 90.45 & 82.31 & 86.36 & 84.04 & 86.34 & 88.41 \\ \text { NOV } & 90.03 & 83.73 & 85.88 & 83.91 & 85.63 & 87.00 \\ \text { DEC } & 89.04 & 83.17 & 85.71 & 84.48 & 85.53 & 86.65 \\ \text { JAN } & 87.20 & 84.60 & 85.94 & 85.03 & 86.06 & 86.67 \\ \text { FEB } & 88.54 & 85.42 & 87.21 & 85.84 & 87.39 & 88.16 \\ \text { MAR } & 90.13 & 85.53 & 88.20 & 87.69 & 88.36 & 88.69 \\ \text { APR } & 90.23 & 85.22 & 87.86 & 87.26 & 87.92 & 88.25 \\ \text { MAY } & 89.97 & 84.36 & 86.88 & 86.14 & 86.57 & 87.37 \\ \text { JUN } & 89.45 & 84.69 & 86.14 & 84.77 & 85.57 & 87.25 \\ \text { JUL } & 89.73 & 84.69 & 86.73 & 84.93 & 86.24 & 88.53 \\ \text { AUG } & 91.12 & 83.56 & 86.88 & 84.97 & 86.47 & 88.61 \\ \text { SEP } & 89.95 & 82.93 & 86.79 & 84.37 & 87.24 & 88.76\end{array}$


USGS SITE 301822082393985 SRWMD ID -021624001 COUNTY Columbia

$\begin{array}{lrrrrrr}\text { MONTH } & \text { MAXIMUM } & \text { MINIMUM } & \text { MEAN } & 25 \% & 50 \% & 75 \% \\ \text { OCT } & 63.42 & 51.20 & 55.84 & 54.41 & 55.70 & 57.07 \\ \text { NOV } & 60.94 & 50.32 & 54.86 & 53.74 & 54.70 & 56.51 \\ \text { DEC } & 58.44 & 50.28 & 58.73 & 53.35 & 54.91 & 57.30 \\ \text { JAN } & 63.57 & 50.61 & 56.53 & 53.35 & 55.33 & 60.88 \\ \text { FEB } & 67.51 & 51.76 & 58.29 & 53.96 & 57.35 & 61.43 \\ \text { MAR } & 69.80 & 52.37 & 60.56 & 54.96 & 61.21 & 65.04 \\ \text { APR } & 70.96 & 51.97 & 59.64 & 55.41 & 58.83 & 63.34 \\ \text { MAY } & 63.95 & 51.58 & 57.39 & 54.89 & 56.72 & 60.25 \\ \text { JUN } & 63.14 & 50.76 & 56.28 & 53.85 & 55.34 & 58.14 \\ \text { JUL } & 62.21 & 50.08 & 55.59 & 53.21 & 55.96 & 57.42 \\ \text { AUG } & 63.16 & 49.44 & 55.90 & 52.57 & 55.77 & 58.78 \\ \text { SEP } & 60.86 & 51.02 & 56.18 & 54.96 & 56.11 & 58.08\end{array}$

USGS SITE 301909082490985 SRWMD ID -021516001 COUNTY Suwannee

$\begin{array}{lrrrrrr}\text { MONTH } & \text { MAXIMUM } & \text { MINIMUM } & \text { MEAN } & 25 \% & 50 \% & 75 \% \\ \text { OCT } & 55.13 & 47.09 & 52.35 & 49.77 & 53.28 & 54.51 \\ \text { NOV } & 64.50 & 46.79 & 53.40 & 51.33 & 52.70 & 54.80 \\ \text { DEC } & 56.19 & 33.26 & 51.13 & 49.67 & 53.17 & 54.63 \\ \text { JAN } & 67.54 & 46.14 & 55.69 & 52.06 & 54.36 & 57.68 \\ \text { FEB } & 73.47 & 49.76 & 57.72 & 52.30 & 56.46 & 60.76 \\ \text { MAR } & 71.94 & 49.65 & 59.32 & 54.95 & 58.16 & 63.58 \\ \text { APR } & 75.39 & 52.90 & 58.02 & 55.45 & 56.86 & 57.74 \\ \text { MAY } & 72.25 & 48.44 & 56.99 & 53.81 & 55.67 & 58.25 \\ \text { JUN } & 56.87 & 48.79 & 53.59 & 52.11 & 53.95 & 55.78 \\ \text { JUL } & 67.62 & 48.19 & 55.03 & 52.00 & 53.69 & 56.84 \\ \text { AUG } & 63.21 & 48.64 & 54.38 & 53.25 & 54.37 & 55.57 \\ \text { SEP } & 68.00 & 46.99 & 55.68 & 53.30 & 55.49 & 58.05\end{array}$

USGS SITE 301933082350585 SRWMD ID -021711003 COUNTY Columbia

$\begin{array}{lrrrrrr}\text { MONTH } & \text { MAXIMUM } & \text { MINIMUM } & \text { MEAN } & 25 \% & 50 \% & 75 \% \\ \text { OCT } & 58.94 & 48.65 & 54.64 & 50.32 & 56.57 & 58.00 \\ \text { NOV } & 57.46 & 48.48 & 53.25 & 50.01 & 53.75 & 56.03 \\ \text { DEC } & 56.19 & 48.39 & 52.99 & 49.99 & 53.57 & 55.84 \\ \text { JAN } & 57.66 & 48.77 & 53.39 & 50.07 & 54.40 & 56.19 \\ \text { FEB } & 59.06 & 52.50 & 55.68 & 52.83 & 55.33 & 58.70 \\ \text { MAR } & 59.14 & 53.52 & 57.32 & 54.84 & 58.80 & 59.06 \\ \text { APR } & 58.85 & 53.66 & 56.78 & 55.11 & 56.84 & 58.42 \\ \text { MAY } & 56.85 & 51.86 & 55.07 & 53.40 & 55.16 & 56.70 \\ \text { JUN } & 58.11 & 50.78 & 54.47 & 52.44 & 54.44 & 56.50 \\ \text { JUL } & 59.23 & 50.06 & 54.34 & 51.89 & 53.96 & 56.97 \\ \text { AUG } & 60.37 & 49.45 & 54.41 & 51.27 & 54.06 & 57.42 \\ \text { SEP } & 58.79 & 49.04 & 53.94 & 50.71 & 54.63 & 56.75\end{array}$

USGS SITE 301941082572685 SRWMD ID -021407003 COUNTY Suwannee

$\begin{array}{lrrrrrr}\text { MONTH } & \text { MAXIMUM } & \text { MINIMUM } & \text { MEAN } & 25 \% & 50 \% & 75 \% \\ \text { OCT } & 52.33 & 38.83 & 46.32 & 44.21 & 46.85 & 49.36 \\ \text { NOV } & 53.13 & 38.26 & 46.12 & 41.56 & 46.88 & 50.07 \\ \text { DEC } & 50.61 & 39.46 & 46.20 & 44.18 & 46.42 & 50.17 \\ \text { JAN } & 50.57 & 38.87 & 46.28 & 41.68 & 47.53 & 50.55 \\ \text { FEB } & 53.26 & 41.97 & 47.63 & 44.38 & 46.97 & 51.67 \\ \text { MAR } & 57.62 & 42.72 & 49.47 & 44.89 & 50.49 & 52.90 \\ \text { APR } & 61.53 & 42.34 & 51.12 & 45.54 & 50.91 & 56.44 \\ \text { MAY } & 54.94 & 42.07 & 48.38 & 44.18 & 49.05 & 51.92 \\ \text { JUN } & 56.87 & 41.56 & 48.94 & 45.71 & 48.63 & 53.12 \\ \text { JUL } & 52.47 & 41.48 & 47.49 & 44.05 & 47.64 & 50.72 \\ \text { AUG } & 55.49 & 40.62 & 48.21 & 45.22 & 48.57 & 51.94 \\ \text { SEP } & 55.97 & 40.22 & 46.45 & 41.38 & 46.49 & 49.58\end{array}$


USGS SITE 302049083293385 SRWMD ID -020802002 COUNTY Madison

$\begin{array}{lrrrrrr}\text { MONTH } & \text { MAXIMUM } & \text { MINIMUM } & \text { MEAN } & 25 \% & 50 \% & 75 \% \\ \text { OCT } & 101.28 & 94.54 & 98.27 & 95.39 & 98.66 & 100.59 \\ \text { NOV } & 100.64 & 92.25 & 98.09 & 97.33 & 98.51 & 99.83 \\ \text { DEC } & 100.68 & 95.85 & 98.92 & 97.42 & 99.62 & 100.21 \\ \text { JAN } & 101.12 & 95.28 & 99.15 & 98.12 & 99.91 & 100.54 \\ \text { FEB } & 101.22 & 97.93 & 100.31 & 99.53 & 100.85 & 100.96 \\ \text { MAR } & 101.82 & 99.26 & 100.72 & 100.14 & 100.97 & 101.20 \\ \text { APR } & 101.26 & 98.50 & 99.83 & 98.72 & 99.60 & 101.06 \\ \text { MAY } & 101.02 & 97.17 & 98.65 & 97.48 & 98.39 & 99.76 \\ \text { JUN } & 101.42 & 96.25 & 98.72 & 96.67 & 98.10 & 101.12 \\ \text { JUL } & 101.14 & 95.83 & 99.08 & 97.02 & 99.69 & 100.84 \\ \text { AUG } & 101.12 & 93.54 & 98.23 & 96.01 & 99.00 & 100.62 \\ \text { SEP } & 101.52 & 94.95 & 98.43 & 96.41 & 98.14 & 101.03\end{array}$

USGS SITE 302049083293585 SRWMD ID -020802001 COUNTY Madison

$\begin{array}{lrrrrrr}\text { MONTH } & \text { MAXIMUM } & \text { MINIMUM } & \text { MEAN } & 25 \% & 50 \% & 75 \% \\ \text { OCT } & 94.18 & 81.83 & 87.78 & 84.42 & 87.11 & 92.39 \\ \text { NOV } & 92.87 & 83.19 & 86.82 & 83.76 & 86.39 & 89.46 \\ \text { DEC } & 91.77 & 82.54 & 86.50 & 83.99 & 86.18 & 88.96 \\ \text { JAN } & 88.69 & 83.24 & 86.32 & 85.07 & 86.96 & 87.13 \\ \text { FEB } & 90.49 & 85.91 & 88.39 & 86.24 & 88.40 & 90.29 \\ \text { MAR } & 91.74 & 85.99 & 89.76 & 88.75 & 90.54 & 90.76 \\ \text { APR } & 93.19 & 85.35 & 89.24 & 87.98 & 89.39 & 90.14 \\ \text { MAY } & 93.41 & 84.46 & 88.07 & 86.73 & 87.59 & 88.87 \\ \text { JUN } & 93.19 & 84.72 & 87.54 & 85.24 & 86.97 & 90.07 \\ \text { JUL } & 92.92 & 84.55 & 87.87 & 85.20 & 86.56 & 90.99 \\ \text { AUG } & 92.14 & 83.20 & 87.36 & 84.00 & 87.16 & 90.58 \\ \text { SEP } & 94.29 & 82.57 & 87.94 & 83.87 & 88.01 & 90.77\end{array}$

USGS SITE 302049083552985 SRWMD ID -020404002 COUNTY Jefferson

$\begin{array}{lrrrrrr}\text { MONTH } & \text { MAXIMUM } & \text { MINIMUM } & \text { MEAN } & 25 \% & 50 \% & 75 \% \\ \text { OCT } & 34.53 & 32.01 & 34.51 & 32.63 & 34.03 & 34.47 \\ \text { NOV } & 36.69 & 31.81 & 34.13 & 33.70 & 34.01 & 34.50 \\ \text { DEC } & 36.40 & 31.79 & 34.02 & 32.58 & 33.84 & 35.42 \\ \text { JAN } & 35.75 & 32.19 & 34.15 & 33.46 & 34.25 & 35.13 \\ \text { FEB } & 36.93 & 33.23 & 35.70 & 34.65 & 36.12 & 36.84 \\ \text { MAR } & 38.57 & 33.37 & 35.96 & 35.40 & 36.00 & 36.32 \\ \text { APR } & 37.41 & 33.47 & 35.21 & 34.69 & 34.97 & 35.51 \\ \text { MAY } & 37.12 & 33.09 & 34.53 & 33.91 & 34.13 & 35.05 \\ \text { JUN } & 36.55 & 33.33 & 34.87 & 33.51 & 34.95 & 35.95 \\ \text { JUL } & 36.54 & 33.12 & 34.85 & 33.31 & 34.93 & 36.31 \\ \text { AUG } & 38.50 & 32.57 & 35.05 & 32.97 & 35.19 & 36.46 \\ \text { SEP } & 35.30 & 32.27 & 33.94 & 32.49 & 34.33 & 34.95\end{array}$

USGS SITE 302050083553085 SRWMD ID -020404001 COUNTY Jefferson

$\begin{array}{lrrrrrr}\text { MONTH } & \text { MAXIMUM } & \text { MINIMUM } & \text { MEAN } & 25 \% & 50 \% & 75 \% \\ \text { OCT } & 41.14 & 34.36 & 37.60 & 34.97 & 37.00 & 40.13 \\ \text { NOV } & 41.40 & 33.70 & 38.85 & 35.61 & 39.80 & 41.37 \\ \text { DEC } & 42.78 & 32.70 & 37.69 & 35.17 & 36.94 & 40.58 \\ \text { JAN } & 42.22 & 33.23 & 39.30 & 36.22 & 40.75 & 42.03 \\ \text { FEB } & 43.41 & 35.94 & 41.66 & 41.80 & 42.50 & 43.25 \\ \text { MAR } & 43.48 & 38.32 & 41.61 & 41.56 & 41.79 & 42.43 \\ \text { APR } & 42.07 & 40.31 & 41.08 & 40.77 & 40.86 & 41.86 \\ \text { MAY } & 42.57 & 36.36 & 39.68 & 39.20 & 39.53 & 40.76 \\ \text { JUN } & 43.14 & 35.87 & 39.79 & 36.70 & 40.50 & 42.34 \\ \text { JUL } & 42.24 & 35.48 & 39.41 & 35.86 & 40.94 & 41.90 \\ \text { AUG } & 45.00 & 34.89 & 39.76 & 35.72 & 40.77 & 42.60 \\ \text { SEP } & 41.96 & 35.07 & 38.68 & 35.10 & 39.59 & 41.06\end{array}$


USGS SITE 302052082312485 SRWMD ID -021805001 COUNTY Columbia

$\begin{array}{lrrrrrr}\text { MONTH } & \text { MAXIMUM } & \text { MINIMUM } & \text { MEAN } & 25 \% & 50 \% & 75 \% \\ \text { OCT } & 55.75 & 47.01 & 52.62 & 51.80 & 53.16 & 54.22 \\ \text { NOV } & 57.64 & 46.80 & 52.43 & 51.74 & 52.85 & 53.22 \\ \text { DEC } & 55.46 & 46.96 & 52.39 & 51.43 & 52.79 & 53.96 \\ \text { JAN } & 57.74 & 47.41 & 53.21 & 51.80 & 52.81 & 55.84 \\ \text { FEB } & 58.63 & 50.60 & 54.39 & 52.02 & 53.83 & 57.13 \\ \text { MAR } & 59.90 & 50.46 & 55.70 & 53.29 & 55.81 & 57.94 \\ \text { APR } & 62.96 & 50.16 & 55.43 & 53.25 & 54.52 & 57.70 \\ \text { MAY } & 59.56 & 49.73 & 54.23 & 52.27 & 53.75 & 56.18 \\ \text { JUN } & 57.09 & 48.81 & 53.05 & 51.51 & 53.00 & 54.77 \\ \text { JUL } & 56.29 & 47.94 & 52.57 & 51.11 & 52.65 & 54.21 \\ \text { AUG } & 56.11 & 47.43 & 52.51 & 50.46 & 52.78 & 54.03 \\ \text { SEP } & 55.92 & 47.10 & 52.52 & 51.48 & 53.00 & 53.81\end{array}$

USGS SITE 302100083171085 SRWMD ID -011035001 COUNTY Madison

$\begin{array}{lrrrrrc}\text { MONTH } & \text { MAXIMUM } & \text { MINIMUM } & \text { MEAN } & 25 \% & 50 \% & 75 \% \\ \text { OCT } & 58.32 & 41.13 & 50.85 & 45.68 & 51.53 & 55.16 \\ \text { NOV } & 59.83 & 43.45 & 49.71 & 47.34 & 49.06 & 50.74 \\ \text { DEC } & 57.39 & 42.68 & 49.75 & 44.75 & 49.57 & 54.42 \\ \text { JAN } & 57.53 & 42.28 & 48.90 & 45.38 & 47.88 & 51.78 \\ \text { FEB } & 69.81 & 46.26 & 53.21 & 47.21 & 50.83 & 58.75 \\ \text { MAR } & 72.07 & 45.72 & 56.44 & 51.48 & 54.04 & 61.70 \\ \text { APR } & 75.39 & 45.04 & 57.64 & 48.53 & 54.74 & 66.62 \\ \text { MAY } & 68.97 & 44.50 & 54.62 & 50.18 & 53.68 & 60.02 \\ \text { JUN } & 65.13 & 44.15 & 54.15 & 46.75 & 51.64 & 62.56 \\ \text { JUL } & 62.08 & 44.62 & 51.39 & 46.26 & 50.71 & 55.11 \\ \text { AUG } & 59.27 & 43.91 & 51.56 & 47.37 & 51.21 & 56.62 \\ \text { SEP } & 67.22 & 43.40 & 51.43 & 45.24 & 51.69 & 54.85\end{array}$

USGS SITE 302115082232285 SRWMD ID -021902001 COUNTY Baker

$\begin{array}{lrrrrrr}\text { MONTH } & \text { MAXIMUM } & \text { MINIMUM } & \text { MEAN } & 25 \% & 50 \% & 75 \% \\ \text { OCT } & 53.77 & 46.15 & 50.40 & 48.37 & 50.51 & 52.99 \\ \text { NOV } & 53.21 & 45.98 & 50.99 & 48.94 & 51.49 & 52.51 \\ \text { DEC } & 53.98 & 46.12 & 50.12 & 48.21 & 50.11 & 52.34 \\ \text { JAN } & 55.99 & 46.67 & 50.34 & 48.42 & 50.56 & 51.86 \\ \text { FEB } & 55.97 & 49.84 & 52.72 & 49.94 & 52.12 & 54.54 \\ \text { MAR } & 55.69 & 49.56 & 52.07 & 49.93 & 52.32 & 54.08 \\ \text { APR } & 60.49 & 49.34 & 53.35 & 50.85 & 52.43 & 55.54 \\ \text { MAY } & 58.12 & 48.72 & 52.68 & 51.19 & 52.41 & 53.81 \\ \text { JUN } & 52.34 & 47.64 & 50.06 & 47.95 & 50.64 & 51.36 \\ \text { JUL } & 52.87 & 46.94 & 49.81 & 48.27 & 49.97 & 50.89 \\ \text { AUG } & 53.46 & 46.59 & 50.38 & 48.62 & 50.24 & 52.66 \\ \text { SEP } & 53.99 & 46.18 & 50.48 & 48.56 & 50.89 & 52.03\end{array}$

USGS SITE 302127082475885 SRWMD ID -011534001 COUNTY Hamilton

$\begin{array}{lrrrrrr}\text { MONTH } & \text { MAXIMUM } & \text { MINIMUM } & \text { MEAN } & 25 \% & 50 \% & 75 \% \\ \text { OCT } & 58.91 & 47.10 & 52.95 & 51.83 & 52.95 & 55.08 \\ \text { NOV } & 56.76 & 46.84 & 52.00 & 50.97 & 52.09 & 53.67 \\ \text { DEC } & 56.32 & 46.64 & 52.17 & 50.69 & 52.24 & 53.78 \\ \text { JAN } & 60.60 & 47.22 & 53.51 & 50.65 & 52.40 & 58.02 \\ \text { FEB } & 67.03 & 49.78 & 57.28 & 52.30 & 56.53 & 61.66 \\ \text { MAR } & 69.20 & 49.60 & 59.76 & 54.12 & 59.72 & 65.06 \\ \text { APR } & 76.07 & 49.41 & 58.01 & 53.12 & 56.50 & 61.36 \\ \text { MAY } & 60.93 & 49.18 & 54.70 & 52.69 & 54.16 & 56.68 \\ \text { JUN } & 57.25 & 48.79 & 53.35 & 51.57 & 53.08 & 55.18 \\ \text { JUL } & 58.09 & 48.45 & 52.96 & 51.24 & 53.07 & 54.31 \\ \text { AUG } & 63.09 & 47.81 & 53.42 & 51.28 & 53.47 & 55.02 \\ \text { SEP } & 58.41 & 47.45 & 52.93 & 51.13 & 52.96 & 54.64\end{array}$


USGS SITE 302204083561585 SRWMD ID -010428001 COUNTY Jefferson

$\begin{array}{lrrrrrr}\text { MONTH } & \text { MAXIMUM } & \text { MINIMUM } & \text { MEAN } & 25 \% & 50 \% & 75 \% \\ \text { OCT } & 41.26 & 33.04 & 37.06 & 36.17 & 37.16 & 37.53 \\ \text { NOV } & 39.12 & 34.97 & 36.63 & 35.69 & 36.81 & 37.41 \\ \text { DEC } & 40.10 & 34.97 & 37.45 & 36.47 & 37.20 & 38.56 \\ \text { JAN } & 41.34 & 35.67 & 37.49 & 36.26 & 37.15 & 38.12 \\ \text { FEB } & 42.71 & 34.11 & 38.52 & 37.06 & 38.83 & 39.52 \\ \text { MAR } & 42.67 & 36.40 & 39.18 & 38.23 & 38.80 & 41.02 \\ \text { APR } & 40.11 & 36.04 & 38.21 & 37.65 & 38.09 & 38.98 \\ \text { MAY } & 41.34 & 35.84 & 38.16 & 37.01 & 37.86 & 39.86 \\ \text { JUN } & 39.95 & 36.12 & 37.81 & 36.86 & 37.69 & 38.52 \\ \text { JUL } & 39.58 & 35.73 & 37.42 & 36.44 & 37.34 & 38.32 \\ \text { AUG } & 39.44 & 35.56 & 37.28 & 36.62 & 37.04 & 38.19 \\ \text { SEP } & 40.35 & 35.70 & 37.19 & 35.98 & 37.22 & 37.87\end{array}$

USGS SITE 302243082360285 SRWMD ID -011727001 COUNTY Columbia

$\begin{array}{lrrrrrr}\text { MONTH } & \text { MAXIMUM } & \text { MINIMUM } & \text { MEAN } & 25 \% & 50 \% & 75 \% \\ \text { OCT } & 56.60 & 46.77 & 52.39 & 51.66 & 52.50 & 54.25 \\ \text { NOV } & 55.71 & 46.70 & 51.95 & 51.31 & 52.15 & 53.12 \\ \text { DEC } & 58.94 & 46.73 & 52.52 & 51.13 & 52.54 & 54.23 \\ \text { JAN } & 60.85 & 47.37 & 53.62 & 51.31 & 52.68 & 56.85 \\ \text { FEB } & 62.02 & 50.27 & 55.57 & 52.67 & 54.35 & 58.23 \\ \text { MAR } & 64.03 & 50.19 & 57.38 & 53.48 & 57.87 & 60.35 \\ \text { APR } & 67.75 & 49.99 & 56.51 & 53.32 & 55.60 & 58.06 \\ \text { MAY } & 59.78 & 49.70 & 54.30 & 52.68 & 54.04 & 55.78 \\ \text { JUN } & 56.73 & 48.94 & 53.12 & 52.08 & 52.88 & 54.78 \\ \text { JUL } & 56.61 & 48.13 & 52.71 & 51.70 & 52.59 & 54.09 \\ \text { AUG } & 58.86 & 47.49 & 52.55 & 50.86 & 52.75 & 53.60 \\ \text { SEP } & 56.70 & 47.14 & 52.49 & 51.44 & 52.74 & 54.00\end{array}$

USGS SITE 302251082194985 SRWMD ID -012029001 COUNTY Baker

$\begin{array}{lrrrrrr}\text { MONTH } & \text { MAXIMUM } & \text { MINIMUM } & \text { MEAN } & 25 \% & 50 \% & 75 \% \\ \text { OCT } & 53.33 & 45.89 & 51.11 & 50.48 & 51.61 & 52.48 \\ \text { NOV } & 53.30 & 45.98 & 51.01 & 50.39 & 51.33 & 52.14 \\ \text { DEC } & 53.66 & 46.09 & 51.19 & 50.38 & 51.43 & 52.75 \\ \text { JAN } & 55.56 & 46.51 & 51.71 & 50.43 & 52.18 & 53.04 \\ \text { FEB } & 55.86 & 49.06 & 52.53 & 50.94 & 52.26 & 54.99 \\ \text { MAR } & 57.15 & 49.48 & 53.79 & 51.95 & 53.84 & 55.92 \\ \text { APR } & 59.54 & 49.24 & 53.66 & 51.93 & 52.89 & 55.61 \\ \text { MAY } & 57.61 & 48.72 & 52.69 & 51.24 & 52.21 & 54.42 \\ \text { JUN } & 55.38 & 47.75 & 51.51 & 50.30 & 51.50 & 53.10 \\ \text { JUL } & 54.61 & 46.84 & 50.95 & 49.77 & 51.02 & 52.42 \\ \text { AUG } & 54.26 & 46.36 & 50.94 & 49.32 & 50.87 & 52.30 \\ \text { SEP } & 53.55 & 46.09 & 50.97 & 49.82 & 51.50 & 52.15\end{array}$

USGS SITE 302251082194986 SRWMD ID -012029003 COUNTY Baker

$\begin{array}{lrrrrrr}\text { MONTH } & \text { MAXIMUM } & \text { MINIMUM } & \text { MEAN } & 25 \% & 50 \% & 75 \% \\ \text { OCT } & 119.65 & 115.58 & 117.84 & 116.38 & 118.27 & 118.92 \\ \text { NOV } & 119.06 & 114.61 & 117.45 & 116.30 & 118.06 & 118.32 \\ \text { DEC } & 119.34 & 114.14 & 117.54 & 117.26 & 117.87 & 118.58 \\ \text { JAN } & 119.55 & 114.84 & 117.98 & 117.49 & 118.20 & 119.05 \\ \text { FEB } & 119.61 & 117.06 & 118.68 & 118.21 & 119.05 & 119.23 \\ \text { MAR } & 119.87 & 116.90 & 118.97 & 118.48 & 119.23 & 119.65 \\ \text { APR } & 119.98 & 116.47 & 118.75 & 118.42 & 118.81 & 119.15 \\ \text { MAY } & 119.60 & 116.56 & 118.25 & 117.47 & 118.03 & 119.21 \\ \text { JUN } & 119.84 & 115.75 & 117.69 & 116.73 & 117.52 & 118.87 \\ \text { JUL } & 119.42 & 115.71 & 117.58 & 116.69 & 117.67 & 118.60 \\ \text { AUG } & 119.94 & 116.08 & 118.09 & 116.74 & 118.35 & 119.07 \\ \text { SEP } & 119.70 & 115.37 & 118.18 & 117.54 & 118.56 & 119.23\end{array}$




$\begin{array}{lrrrrrr}\text { USGS SITE } & 302447082470585 & \text { SRWMD ID } & -011511001 & \text { COUNTY } & \text { Hamilton } \\ \text { MONTH } & \text { MAXIMUM } & \text { MINIMUM } & \text { MEAN } & 25 \% & 50 \% & 75 \% \\ \text { OCT } & 58.90 & 48.22 & 52.13 & 49.11 & 52.03 & 53.62 \\ \text { NOV } & 60.75 & 48.17 & 52.27 & 49.94 & 51.24 & 52.71 \\ \text { DEC } & 55.90 & 47.88 & 51.81 & 49.27 & 51.94 & 53.92 \\ \text { JAN } & 62.41 & 49.59 & 53.24 & 50.41 & 51.40 & 55.89 \\ \text { FEB } & 68.77 & 49.46 & 57.71 & 51.42 & 55.79 & 65.74 \\ \text { MAR } & 65.81 & 50.21 & 59.46 & 55.38 & 60.60 & 63.47 \\ \text { APR } & 71.54 & 48.68 & 58.31 & 52.33 & 57.66 & 63.46 \\ \text { MAY } & 64.98 & 48.66 & 54.72 & 51.83 & 53.50 & 56.63 \\ \text { JUN } & 55.91 & 48.09 & 52.64 & 50.73 & 52.57 & 55.35 \\ \text { JUL } & 53.36 & 48.20 & 50.86 & 49.71 & 50.60 & 52.49 \\ \text { AUG } & 60.21 & 48.42 & 53.09 & 49.99 & 53.44 & 54.97 \\ \text { SEP } & 55.49 & 48.71 & 51.83 & 49.46 & 53.47 & 61.92 \\ & & & & & & \\ \text { USGS } & \text { SITE } & 302450083174885 & \text { SRWMD ID } & -011011002 & \text { COUNTY } & \text { Madison } \\ & & & & & & \\ \text { MONTH } & \text { MAXIMUM } & \text { MINIMUM } & \text { MEAN } & 25 \% & 50 \% & 75 \% \\ \text { OCT } & 65.97 & 41.82 & 49.23 & 42.80 & 45.87 & 58.23 \\ \text { NOV } & 55.90 & 41.62 & 46.42 & 42.35 & 44.74 & 52.54 \\ \text { DEC } & 53.32 & 41.45 & 45.62 & 41.88 & 43.56 & 50.67 \\ \text { JAN } & 47.51 & 43.28 & 44.95 & 43.62 & 44.89 & 45.91 \\ \text { FEB } & 55.00 & 43.41 & 49.02 & 44.83 & 48.24 & 53.58 \\ \text { MAR } & 57.76 & 48.06 & 52.09 & 48.46 & 51.99 & 55.06 \\ \text { APR } & 65.39 & 47.19 & 54.04 & 48.00 & 51.79 & 62.33 \\ \text { MAY } & 50.58 & 43.02 & 48.18 & 45.05 & 49.74 & 50.36 \\ \text { JUN } & 59.16 & 42.85 & 47.62 & 43.67 & 46.03 & 50.55 \\ \text { JUL } & 56.13 & 43.13 & 47.63 & 43.89 & 46.33 & 51.34 \\ \text { AUG } & 58.07 & 42.48 & 49.19 & 43.47 & 45.19 & 54.63 \\ \text { SEP } & 69.21 & 42.20 & 51.05 & 43.01 & 48.29 & 60.46\end{array}$

USGS SITE 302620082173585 SRWMD ID -012003001 COUNTY Baker

$\begin{array}{lrrrrrr}\text { MONTH } & \text { MAXIMUM } & \text { MINIMUM } & \text { MEAN } & 25 \% & 50 \% & 75 \% \\ \text { OCT } & 53.00 & 45.58 & 50.58 & 49.04 & 51.42 & 52.37 \\ \text { NOV } & 52.56 & 45.40 & 50.04 & 48.25 & 50.13 & 51.76 \\ \text { DEC } & 54.97 & 45.59 & 50.67 & 49.06 & 51.03 & 52.35 \\ \text { JAN } & 62.50 & 46.15 & 51.88 & 49.64 & 51.06 & 53.51 \\ \text { FEB } & 56.60 & 49.22 & 52.53 & 49.36 & 52.37 & 55.28 \\ \text { MAR } & 57.14 & 48.93 & 53.53 & 51.23 & 53.62 & 56.34 \\ \text { APR } & 56.20 & 48.74 & 52.53 & 50.41 & 52.44 & 54.57 \\ \text { MAY } & 57.00 & 48.12 & 51.94 & 50.50 & 51.75 & 53.28 \\ \text { JUN } & 54.32 & 47.00 & 50.71 & 49.03 & 50.45 & 52.55 \\ \text { JUL } & 53.97 & 46.29 & 50.01 & 48.47 & 50.15 & 51.65 \\ \text { AUG } & 53.76 & 45.96 & 50.05 & 48.58 & 50.26 & 51.65 \\ \text { SEP } & 53.27 & 45.54 & 50.36 & 48.61 & 50.56 & 52.63\end{array}$

USGS SITE 302822083255185 SRWMD ID +010921001 COUNTY Madison

$\begin{array}{lrrrrrr}\text { MONTH } & \text { MAXIMUM } & \text { MINIMUM } & \text { MEAN } & 25 \% & 50 \% & 75 \% \\ \text { OCT } & 85.14 & 67.17 & 73.40 & 70.42 & 72.86 & 75.57 \\ \text { NOV } & 82.85 & 66.76 & 72.73 & 69.92 & 72.57 & 74.58 \\ \text { DEC } & 84.23 & 66.12 & 73.21 & 69.64 & 72.66 & 76.10 \\ \text { JAN } & 85.93 & 65.51 & 72.65 & 70.04 & 71.62 & 74.47 \\ \text { FEB } & 84.38 & 65.16 & 74.41 & 71.64 & 73.35 & 77.42 \\ \text { MAR } & 86.78 & 64.89 & 75.90 & 72.12 & 75.52 & 78.60 \\ \text { APR } & 89.45 & 65.98 & 76.28 & 72.28 & 75.39 & 81.01 \\ \text { MAY } & 94.66 & 66.83 & 76.43 & 72.28 & 74.76 & 81.04 \\ \text { JUN } & 82.26 & 68.20 & 74.90 & 70.73 & 74.09 & 80.13 \\ \text { JUL } & 93.96 & 68.56 & 74.99 & 71.18 & 73.43 & 78.82 \\ \text { AUG } & 82.74 & 68.25 & 74.58 & 71.29 & 73.13 & 78.29 \\ \text { SEP } & 85.29 & 67.52 & 74.05 & 71.52 & 73.43 & 76.12\end{array}$


USGS SITE 302824083400985 SRWMD ID +010719001 COUNTY Madison

$\begin{array}{lrrrrrr}\text { MONTH } & \text { MAXIMUM } & \text { MINIMUM } & \text { MEAN } & 25 \% & 50 \% & 75 \% \\ \text { OCT } & 85.08 & 71.01 & 75.95 & 74.11 & 75.33 & 76.32 \\ \text { NOV } & 80.19 & 70.58 & 73.98 & 72.51 & 74.32 & 74.84 \\ \text { DEC } & 79.32 & 70.18 & 74.70 & 72.79 & 74.46 & 76.52 \\ \text { JAN } & 79.58 & 70.24 & 74.69 & 72.90 & 74.08 & 75.68 \\ \text { FEB } & 81.33 & 73.51 & 76.46 & 73.88 & 75.65 & 79.83 \\ \text { MAR } & 82.60 & 73.58 & 77.52 & 75.95 & 76.88 & 79.46 \\ \text { APR } & 83.53 & 73.35 & 77.66 & 75.67 & 76.47 & 80.26 \\ \text { MAY } & 80.70 & 72.78 & 76.37 & 74.70 & 76.10 & 78.20 \\ \text { JUN } & 80.01 & 72.35 & 75.95 & 73.66 & 75.41 & 78.72 \\ \text { JUL } & 78.63 & 73.04 & 75.15 & 73.50 & 74.53 & 76.35 \\ \text { AUG } & 79.49 & 72.24 & 75.38 & 73.76 & 74.66 & 77.60 \\ \text { SEP } & 80.30 & 71.68 & 74.98 & 71.76 & 74.91 & 76.36\end{array}$

USGS SITE 302833082542985 SRWMD ID +011422007 COUNYY Hamilton

$\begin{array}{lrrrrrr}\text { MONTH } & \text { MAXIMUM } & \text { MINIMUM } & \text { MEAN } & 25 \% & 50 \% & 75 \% \\ \text { OCT } & 51.21 & 40.06 & 44.76 & 41.83 & 44.74 & 46.64 \\ \text { NOV } & 50.80 & 39.82 & 43.91 & 41.71 & 43.82 & 45.75 \\ \text { DEC } & 49.57 & 39.78 & 44.39 & 42.18 & 44.12 & 46.38 \\ \text { JAN } & 52.32 & 41.51 & 46.09 & 42.70 & 44.49 & 51.37 \\ \text { FEB } & 58.46 & 41.36 & 50.30 & 45.03 & 50.99 & 54.70 \\ \text { MAR } & 61.21 & 42.16 & 52.89 & 46.56 & 53.08 & 59.42 \\ \text { APR } & 67.10 & 42.39 & 52.11 & 46.50 & 51.56 & 56.92 \\ \text { MAY } & 57.79 & 42.02 & 48.59 & 43.94 & 47.83 & 51.82 \\ \text { JUN } & 52.35 & 41.55 & 46.24 & 42.68 & 45.83 & 49.18 \\ \text { JUL } & 52.97 & 41.00 & 45.76 & 43.23 & 45.29 & 47.83 \\ \text { AUG } & 57.02 & 40.68 & 45.93 & 42.64 & 46.02 & 47.58 \\ \text { SEP } & 53.97 & 40.31 & 45.51 & 42.61 & 45.92 & 47.31\end{array}$

USGS SITE 302859083015085 SRWMD ID +011316001 COUNTY Hamilton

$\begin{array}{lrrrrrr}\text { MONTH } & \text { MAXIMUM } & \text { MINIMUM } & \text { MEAN } & 25 \% & 50 \% & 75 \% \\ \text { OCT } & 50.89 & 33.03 & 36.70 & 33.90 & 35.74 & 37.92 \\ \text { NOV } & 44.57 & 32.93 & 35.99 & 34.24 & 35.28 & 36.62 \\ \text { DEC } & 46.98 & 33.47 & 37.91 & 35.01 & 35.58 & 41.57 \\ \text { JAN } & 52.20 & 34.44 & 41.53 & 35.23 & 40.47 & 48.33 \\ \text { FEB } & 60.71 & 34.40 & 48.18 & 42.13 & 49.90 & 53.43 \\ \text { MAR } & 62.19 & 36.99 & 49.97 & 43.13 & 51.29 & 55.40 \\ \text { APR } & 59.93 & 37.44 & 46.12 & 40.62 & 44.13 & 50.71 \\ \text { MAY } & 52.01 & 35.00 & 41.35 & 36.95 & 40.31 & 44.96 \\ \text { JUN } & 46.79 & 34.01 & 37.75 & 35.51 & 37.17 & 39.00 \\ \text { JUL } & 48.05 & 33.54 & 37.94 & 34.95 & 38.33 & 39.77 \\ \text { AUG } & 54.82 & 33.09 & 38.98 & 34.27 & 38.39 & 41.23 \\ \text { SEP } & 44.89 & 32.83 & 38.11 & 35.39 & 38.24 & 40.16\end{array}$

USGS SITE 302914083300985 SRWMD ID +010814001 COUNTY Madison

$\begin{array}{lrrrrrr}\text { MONTH } & \text { MAXIMUM } & \text { MINIMUM } & \text { MEAN } & 25 \% & 50 \% & 75 \% \\ \text { OCT } & 81.26 & 72.12 & 76.77 & 75.15 & 76.56 & 78.71 \\ \text { NOV } & 79.15 & 71.59 & 75.86 & 74.60 & 75.86 & 77.34 \\ \text { DEC } & 78.44 & 71.15 & 75.85 & 74.35 & 76.13 & 77.93 \\ \text { JAN } & 82.14 & 72.49 & 76.65 & 74.85 & 75.82 & 78.85 \\ \text { FEB } & 84.66 & 74.95 & 78.37 & 75.67 & 78.00 & 80.90 \\ \text { MAR } & 86.49 & 74.91 & 80.03 & 76.49 & 79.33 & 84.13 \\ \text { APR } & 88.24 & 74.78 & 79.96 & 76.10 & 79.14 & 83.57 \\ \text { MAY } & 85.32 & 74.13 & 78.41 & 74.96 & 77.56 & 81.52 \\ \text { JUN } & 82.32 & 73.40 & 77.29 & 74.32 & 76.66 & 80.94 \\ \text { JUL } & 82.36 & 74.09 & 77.07 & 74.43 & 76.07 & 80.28 \\ \text { AUG } & 85.38 & 73.62 & 77.95 & 75.04 & 76.13 & 81.80 \\ \text { SEP } & 84.07 & 72.80 & 77.79 & 75.83 & 77.18 & 80.01\end{array}$


USGS SITE 302957082441285 SRWMD ID +011608001 COUNTY Hamilton

$\begin{array}{lrrrrrr}\text { MONTH } & \text { MAXIMUM } & \text { MINIMUM } & \text { MEAN } & 25 \% & 50 \% & 75 \% \\ \text { OCT } & 65.88 & 53.98 & 59.74 & 57.85 & 59.52 & 61.37 \\ \text { NOV } & 63.67 & 53.72 & 58.70 & 57.63 & 58.74 & 60.53 \\ \text { DEC } & 62.45 & 53.70 & 59.10 & 58.23 & 59.63 & 60.44 \\ \text { JAN } & 67.13 & 52.85 & 60.74 & 57.85 & 59.69 & 65.87 \\ \text { FEB } & 72.32 & 57.55 & 63.27 & 59.03 & 62.70 & 67.20 \\ \text { MAR } & 70.75 & 57.44 & 65.09 & 62.65 & 65.34 & 68.42 \\ \text { APR } & 78.47 & 57.10 & 64.03 & 60.38 & 62.94 & 66.34 \\ \text { MAY } & 71.21 & 56.79 & 61.86 & 60.96 & 61.82 & 62.62 \\ \text { JUN } & 63.63 & 56.05 & 60.42 & 58.29 & 60.63 & 62.97 \\ \text { JUL } & 65.00 & 55.37 & 59.19 & 56.64 & 59.06 & 60.70 \\ \text { AUG } & 67.90 & 54.57 & 60.46 & 58.19 & 60.71 & 62.22 \\ \text { SEP } & 63.68 & 54.33 & 59.51 & 57.75 & 59.85 & 61.86\end{array}$

USGS SITE 303001083553485 SRWMD ID +010409001 COUNTY Jefferson

$\begin{array}{lrrrrrr}\text { MONTH } & \text { MAXIMUM } & \text { MINIMUM } & \text { MEAN } & 25 \% & 50 \% & 75 \% \\ \text { OCT } & 37.01 & 32.24 & 35.14 & 33.99 & 35.07 & 36.90 \\ \text { NOV } & 43.78 & 33.18 & 36.19 & 33.28 & 35.04 & 38.55 \\ \text { DEC } & 37.42 & 32.66 & 35.75 & 34.29 & 36.26 & 37.15 \\ \text { JAN } & 40.90 & 33.02 & 35.60 & 33.03 & 34.57 & 39.27 \\ \text { FEB } & 40.34 & 33.62 & 36.97 & 34.51 & 35.80 & 40.02 \\ \text { MAR } & 42.42 & 33.82 & 37.09 & 34.16 & 36.14 & 40.42 \\ \text { APR } & 43.56 & 33.97 & 39.78 & 35.52 & 40.79 & 43.03 \\ \text { MAY } & 41.95 & 33.70 & 37.66 & 35.35 & 37.56 & 39.51 \\ \text { JUN } & 39.52 & 33.42 & 37.27 & 34.45 & 38.45 & 39.49 \\ \text { JUL } & 36.45 & 30.10 & 34.03 & 32.72 & 34.14 & 35.92 \\ \text { AUG } & 39.72 & 33.82 & 36.43 & 34.11 & 36.17 & 38.30 \\ \text { SEP } & 36.24 & 33.38 & 34.43 & 33.38 & 33.67 & 36.24\end{array}$

USGS SITE 303151083023085 SRWMD ID +021332004 COUNTY Hamilton

$\begin{array}{lrrrrrr}\text { MONTH } & \text { MAXIMUM } & \text { MINIMUM } & \text { MEAN } & 25 \% & 50 \% & 75 \% \\ \text { OCT } & 66.66 & 33.02 & 41.51 & 33.17 & 36.90 & 48.45 \\ \text { NOV } & 55.14 & 32.40 & 38.14 & 32.95 & 34.75 & 42.80 \\ \text { DEC } & 43.42 & 32.72 & 36.92 & 32.92 & 34.82 & 42.92 \\ \text { JAN } & 46.40 & 33.90 & 39.39 & 34.38 & 39.00 & 44.21 \\ \text { FEB } & 72.12 & 54.96 & 61.72 & 56.74 & 59.68 & 67.73 \\ \text { MAR } & 71.85 & 57.81 & 61.80 & 57.94 & 59.03 & 67.05 \\ \text { APR } & 57.66 & 45.33 & 52.43 & 45.33 & 54.31 & 57.66 \\ \text { MAY } & 44.17 & 37.33 & 41.75 & 38.38 & 42.76 & 44.12 \\ \text { JUN } & 51.09 & 33.87 & 38.75 & 34.65 & 36.24 & 44.10 \\ \text { JUL } & 49.27 & 33.03 & 41.45 & 36.46 & 42.47 & 45.92 \\ \text { AUG } & 64.87 & 32.66 & 41.53 & 32.88 & 36.13 & 52.88 \\ \text { SEP } & 55.60 & 32.61 & 42.61 & 34.29 & 42.70 & 50.89\end{array}$

USGS SITE 303158082592985 SRWMD ID +021432001 COUNTY Hamilton

$\begin{array}{lrrrrrr}\text { MONTH } & \text { MAXIMUM } & \text { MINIMUM } & \text { MEAN } & 25 \% & 50 \% & 75 \% \\ \text { OCT } & 51.76 & 34.06 & 39.36 & 35.89 & 38.98 & 40.79 \\ \text { NOV } & 49.93 & 33.97 & 38.86 & 35.82 & 37.61 & 40.70 \\ \text { DEC } & 49.53 & 34.29 & 40.75 & 36.70 & 37.75 & 47.39 \\ \text { JAN } & 51.79 & 36.39 & 44.10 & 38.81 & 43.78 & 51.10 \\ \text { FEB } & 60.60 & 35.94 & 50.83 & 46.65 & 51.49 & 56.16 \\ \text { MAR } & 60.80 & 38.96 & 52.54 & 45.84 & 54.21 & 59.09 \\ \text { APR } & 54.55 & 40.23 & 51.11 & 45.57 & 50.57 & 56.44 \\ \text { MAY } & 56.67 & 37.43 & 46.73 & 41.48 & 46.22 & 51.39 \\ \text { JUN } & 51.50 & 36.02 & 41.88 & 38.26 & 40.40 & 45.19 \\ \text { JUL } & 53.24 & 35.56 & 41.47 & 37.35 & 41.26 & 44.31 \\ \text { AUG } & 57.03 & 34.78 & 41.91 & 37.00 & 41.20 & 44.09 \\ \text { SEP } & 51.39 & 34.28 & 41.18 & 37.30 & 41.59 & 43.45\end{array}$


USGS SITE 303224083101785 SRWMD ID +021125001 COUNTY Hamilton

$\begin{array}{lrrrrrr}\text { MONTH } & \text { MAXIMUM } & \text { MINIMUM } & \text { MEAN } & 25 \% & 50 \% & 75 \% \\ \text { OCT } & 52.17 & 40.42 & 43.75 & 41.71 & 43.05 & 44.49 \\ \text { NOV } & 52.68 & 40.35 & 43.01 & 41.12 & 42.20 & 43.56 \\ \text { DEC } & 49.25 & 40.25 & 43.68 & 41.53 & 42.45 & 46.34 \\ \text { JAN } & 51.02 & 41.41 & 45.03 & 41.96 & 43.57 & 49.18 \\ \text { FEB } & 58.43 & 41.55 & 49.14 & 43.47 & 48.02 & 54.15 \\ \text { MAR } & 63.46 & 42.08 & 52.94 & 48.05 & 52.69 & 59.14 \\ \text { APR } & 67.56 & 42.71 & 52.40 & 47.08 & 51.27 & 58.85 \\ \text { MAY } & 59.14 & 41.68 & 48.32 & 44.13 & 47.11 & 51.94 \\ \text { JUN } & 59.14 & 41.68 & 45.02 & 42.35 & 44.09 & 47.60 \\ \text { JUL } & 52.29 & 41.31 & 44.65 & 42.04 & 44.17 & 47.31 \\ \text { AUG } & 58.19 & 41.04 & 45.11 & 41.99 & 43.99 & 46.72 \\ \text { SEP } & 53.96 & 40.68 & 44.73 & 42.47 & 44.15 & 45.33\end{array}$

USGS SITE 303400083305385 SRWMD ID +020822002 COUNTY Madison

$\begin{array}{lrrrrrr}\text { MONTH } & \text { MAXIMUM } & \text { MINIMUM } & \text { MEAN } & 25 \% & 50 \% & 75 \% \\ \text { OCT } & 80.57 & 71.01 & 76.10 & 71.56 & 74.15 & 81.66 \\ \text { NOV } & 81.89 & 70.51 & 74.76 & 70.82 & 73.59 & 79.03 \\ \text { DEC } & 80.95 & 70.23 & 74.41 & 70.90 & 73.66 & 77.84 \\ \text { JAN } & 75.36 & 70.12 & 73.02 & 70.80 & 73.36 & 75.05 \\ \text { FEB } & 78.42 & 72.65 & 76.49 & 74.34 & 76.97 & 78.40 \\ \text { MAR } & 80.41 & 75.23 & 78.20 & 76.27 & 78.55 & 79.96 \\ \text { APR } & 83.12 & 77.13 & 79.49 & 77.13 & 78.21 & 83.12 \\ \text { MAY } & 77.44 & 75.30 & 76.70 & 75.65 & 77.03 & 77.42 \\ \text { JUN } & 81.25 & 73.46 & 75.77 & 73.55 & 74.88 & 78.44 \\ \text { JUL } & 80.32 & 73.09 & 76.20 & 73.86 & 75.56 & 78.86 \\ \text { AUG } & 84.52 & 72.34 & 77.17 & 72.73 & 75.60 & 82.71 \\ \text { SEP } & 83.92 & 71.75 & 77.58 & 72.44 & 77.33 & 82.97\end{array}$

USGS SITE 303425082473685 SRWMD ID +021514001 COUNTY Hamilton

$\begin{array}{lrrrrrr}\text { MONTH } & \text { MAXIMUM } & \text { MINIMUM } & \text { MEAN } & 25 \% & 50 \% & 75 \% \\ \text { OCT } & 58.45 & 49.45 & 54.62 & 52.02 & 54.71 & 56.51 \\ \text { NOV } & 59.56 & 49.52 & 55.21 & 53.62 & 55.18 & 57.99 \\ \text { DEC } & 58.78 & 49.73 & 54.71 & 52.88 & 54.50 & 57.17 \\ \text { JAN } & 60.13 & 50.00 & 55.31 & 53.75 & 54.64 & 57.49 \\ \text { FEB } & 66.06 & 52.90 & 59.15 & 55.89 & 58.35 & 63.17 \\ \text { MAR } & 64.70 & 53.44 & 60.02 & 56.65 & 60.42 & 63.87 \\ \text { APR } & 69.63 & 53.56 & 59.32 & 57.06 & 58.43 & 60.62 \\ \text { MAY } & 66.77 & 53.01 & 58.54 & 56.06 & 57.51 & 61.96 \\ \text { JUN } & 60.66 & 51.90 & 55.45 & 53.64 & 55.20 & 57.27 \\ \text { JUL } & 60.27 & 50.75 & 55.37 & 53.64 & 54.70 & 57.47 \\ \text { AUG } & 61.02 & 50.16 & 55.29 & 52.71 & 55.13 & 56.97 \\ \text { SEP } & 59.09 & 49.69 & 55.28 & 52.80 & 55.48 & 58.28\end{array}$

USGS SITE 303510083054985 SRWMD ID +021211001 COUNTY Hamilton

$\begin{array}{lrrrrrr}\text { MONTH } & \text { MAXIMUM } & \text { MINIMUM } & \text { MEAN } & 25 \% & 50 \% & 75 \% \\ \text { OCT } & 54.12 & 35.78 & 39.60 & 36.72 & 38.85 & 40.83 \\ \text { NOV } & 49.67 & 35.79 & 38.98 & 36.77 & 38.32 & 39.02 \\ \text { DEC } & 50.36 & 36.53 & 41.04 & 37.72 & 38.87 & 44.57 \\ \text { JAN } & 54.41 & 37.76 & 45.04 & 39.32 & 44.05 & 51.70 \\ \text { FEB } & 62.07 & 37.48 & 50.83 & 45.34 & 51.42 & 56.67 \\ \text { MAR } & 64.46 & 40.50 & 53.78 & 47.45 & 54.76 & 61.73 \\ \text { APR } & 63.72 & 40.49 & 50.47 & 45.82 & 48.78 & 55.27 \\ \text { MAY } & 54.34 & 37.76 & 45.03 & 40.03 & 44.42 & 49.13 \\ \text { JUN } & 50.01 & 36.78 & 41.30 & 38.36 & 40.37 & 43.37 \\ \text { JUL } & 50.82 & 36.48 & 41.31 & 37.68 & 42.11 & 43.75 \\ \text { AUG } & 57.20 & 35.97 & 42.12 & 37.11 & 41.55 & 44.67 \\ \text { SEP } & 49.24 & 35.61 & 41.41 & 38.07 & 41.69 & 43.44\end{array}$


USGS SITE 303622083050685 SRWMD ID +021202001 COUNTY Hamilton

$\begin{array}{lrrrrrr}\text { MONTH } & \text { MAXIMUM } & \text { MINIMUM } & \text { MEAN } & 25 \% & 50 \% & 75 \% \\ \text { OCT } & 55.28 & 34.91 & 40.82 & 38.57 & 40.10 & 40.69 \\ \text { NOV } & 58.30 & 35.69 & 42.56 & 38.73 & 41.49 & 44.86 \\ \text { DEC } & 49.71 & 36.18 & 41.42 & 37.10 & 39.58 & 44.71 \\ \text { JAN } & 63.05 & 36.64 & 46.92 & 42.09 & 44.72 & 49.36 \\ \text { FEB } & 69.81 & 42.68 & 55.90 & 49.89 & 55.50 & 63.38 \\ \text { MAR } & 66.15 & 42.39 & 55.14 & 50.28 & 55.10 & 60.25 \\ \text { APR } & 66.72 & 44.43 & 51.49 & 46.68 & 48.59 & 55.14 \\ \text { MAY } & 70.85 & 38.06 & 55.14 & 42.45 & 45.59 & 52.03 \\ \text { JUN } & 46.86 & 35.88 & 41.65 & 38.61 & 41.65 & 45.03 \\ \text { JUL } & 59.79 & 35.66 & 44.67 & 39.20 & 44.22 & 49.06 \\ \text { AUG } & 57.53 & 35.40 & 44.46 & 41.64 & 43.96 & 46.77 \\ \text { SEP } & 61.60 & 34.99 & 45.76 & 41.10 & 45.55 & 48.62\end{array}$

USGS SITE 303626083172085 SRWMD ID +021002001 COUNTY Madison

$\begin{array}{lrrrrrr}\text { MONTH } & \text { MAXIMUM } & \text { MINIMUM } & \text { MEAN } & 25 \% & 50 \% & 75 \% \\ \text { OCT } & 73.40 & 58.68 & 61.51 & 59.46 & 60.34 & 61.69 \\ \text { NOV } & 68.03 & 58.78 & 61.23 & 59.33 & 59.86 & 62.98 \\ \text { DEC } & 67.10 & 58.58 & 62.57 & 59.58 & 61.93 & 66.45 \\ \text { JAN } & 76.86 & 58.58 & 66.35 & 61.01 & 66.30 & 69.48 \\ \text { FEB } & 80.03 & 60.03 & 69.21 & 66.85 & 68.28 & 71.99 \\ \text { MAR } & 85.27 & 61.25 & 70.40 & 67.74 & 69.55 & 72.08 \\ \text { APR } & 73.30 & 62.76 & 66.30 & 63.43 & 66.29 & 68.20 \\ \text { MAY } & 74.44 & 54.75 & 63.82 & 61.03 & 64.19 & 65.71 \\ \text { JUN } & 67.58 & 59.24 & 63.21 & 60.50 & 63.08 & 65.22 \\ \text { JUL } & 69.43 & 59.31 & 62.24 & 59.62 & 61.13 & 64.85 \\ \text { AUG } & 73.72 & 59.03 & 64.22 & 61.49 & 62.93 & 64.84 \\ \text { SEP } & 67.96 & 58.78 & 62.44 & 60.21 & 61.23 & 65.40\end{array}$

USGS SITE 303812083362485 SRWMD ID +030727001 COUNTY Jefferson

$\begin{array}{lrrrrrr}\text { MONTH } & \text { MAXIMUM } & \text { MINIMUM } & \text { MEAN } & 25 \% & 50 \% & 75 \% \\ \text { OCT } & 80.06 & 70.05 & 74.38 & 72.78 & 74.10 & 75.71 \\ \text { NOV } & 81.08 & 69.38 & 73.81 & 71.95 & 73.72 & 74.89 \\ \text { DEC } & 80.33 & 68.87 & 73.78 & 71.90 & 74.15 & 75.06 \\ \text { JAN } & 80.83 & 66.47 & 72.34 & 69.14 & 72.25 & 74.32 \\ \text { FEB } & 80.36 & 71.38 & 74.47 & 72.66 & 73.71 & 74.95 \\ \text { MAR } & 81.87 & 72.17 & 76.01 & 73.56 & 75.80 & 77.14 \\ \text { APR } & 83.80 & 71.67 & 76.34 & 73.70 & 76.12 & 78.94 \\ \text { MAY } & 84.99 & 67.30 & 75.45 & 72.23 & 75.34 & 78.32 \\ \text { JUN } & 80.28 & 71.58 & 75.06 & 73.08 & 74.47 & 77.21 \\ \text { JUL } & 79.75 & 71.72 & 75.33 & 72.92 & 75.24 & 77.48 \\ \text { AUG } & 80.03 & 71.52 & 74.93 & 72.25 & 74.24 & 76.93 \\ \text { SEP } & 79.56 & 70.76 & 74.85 & 72.98 & 74.19 & 77.26\end{array}$

USGS SITE 303842083464785 SRWMD ID +030524001 COUNTY Jefferson

$\begin{array}{lrrrrrr}\text { MONTH } & \text { MAXIMUM } & \text { MINIMUM } & \text { MEAN } & 25 \% & 50 \% & 75 \% \\ \text { OCT } & 72.54 & 61.88 & 65.81 & 62.77 & 64.78 & 68.93 \\ \text { NOV } & 72.64 & 61.33 & 65.39 & 62.25 & 64.50 & 68.40 \\ \text { DEC } & 72.28 & 60.88 & 64.98 & 62.07 & 64.25 & 67.22 \\ \text { JAN } & 66.21 & 60.75 & 63.70 & 61.61 & 64.16 & 65.31 \\ \text { FEB } & 66.23 & 62.55 & 64.58 & 62.88 & 64.47 & 66.14 \\ \text { MAR } & 68.71 & 63.77 & 66.25 & 64.63 & 66.51 & 68.03 \\ \text { APR } & 69.81 & 63.55 & 66.69 & 65.27 & 66.88 & 68.60 \\ \text { MAY } & 68.46 & 63.13 & 66.12 & 65.46 & 66.00 & 67.98 \\ \text { JUN } & 68.48 & 63.66 & 65.92 & 64.69 & 65.71 & 67.34 \\ \text { JUL } & 68.12 & 64.02 & 65.69 & 64.04 & 65.10 & 66.86 \\ \text { AUG } & 69.11 & 63.39 & 65.42 & 63.97 & 64.90 & 66.83 \\ \text { SEP } & 69.98 & 62.65 & 65.78 & 63.35 & 65.25 & 68.73\end{array}$


USGS SITE 303904083504185 SRWMD ID +030520001 COUNTY Jefferson

\begin{tabular}{lrrrrrr} 
MONTH & MAXIMUM & MINIMUM & MEAN & $25 \%$ & $50 \%$ & $75 \%$ \\
OCT & 75.08 & 66.41 & 70.35 & 67.26 & 70.46 & 72.90 \\
NOV & 74.23 & 66.18 & 69.97 & 66.67 & 70.55 & 72.15 \\
DEC & 73.26 & 66.04 & 70.10 & 66.39 & 71.34 & 72.40 \\
JAN & 73.64 & 65.80 & 70.45 & 66.02 & 72.10 & 73.14 \\
FEB & 75.19 & 66.41 & 71.35 & 66.62 & 72.40 & 75.05 \\
MAR & 76.40 & 66.64 & 72.41 & 68.06 & 73.35 & 76.24 \\
APR & 77.51 & 67.06 & 73.28 & 69.77 & 73.60 & 77.31 \\
MAY & 77.62 & 67.08 & 72.61 & 68.71 & 72.04 & 76.81 \\
JUN & 77.13 & 66.96 & 72.18 & 68.26 & 72.22 & 76.08 \\
JUL & 76.30 & 66.75 & 71.70 & 67.93 & 72.22 & 75.19 \\
AUG & 76.32 & 66.71 & 70.93 & 67.62 & 70.68 & 74.01 \\
SEP & 76.02 & 66.65 & 70.80 & 67.60 & 70.76 & 73.51 \\
\hline
\end{tabular}

